PRELIMINARY INTERPRETIVE REPORT 2009-8

\title{
PRELIMINARY RESULTS OF RECENT GEOLOGIC INVESTIGATIONS IN THE HOMER-KACHEMAK BAY AREA, COOK INLET BASIN, ALASKA: PROGRESS DURING THE 2006-2007 FIELD SEASON
}

by

David L. LePain, editor

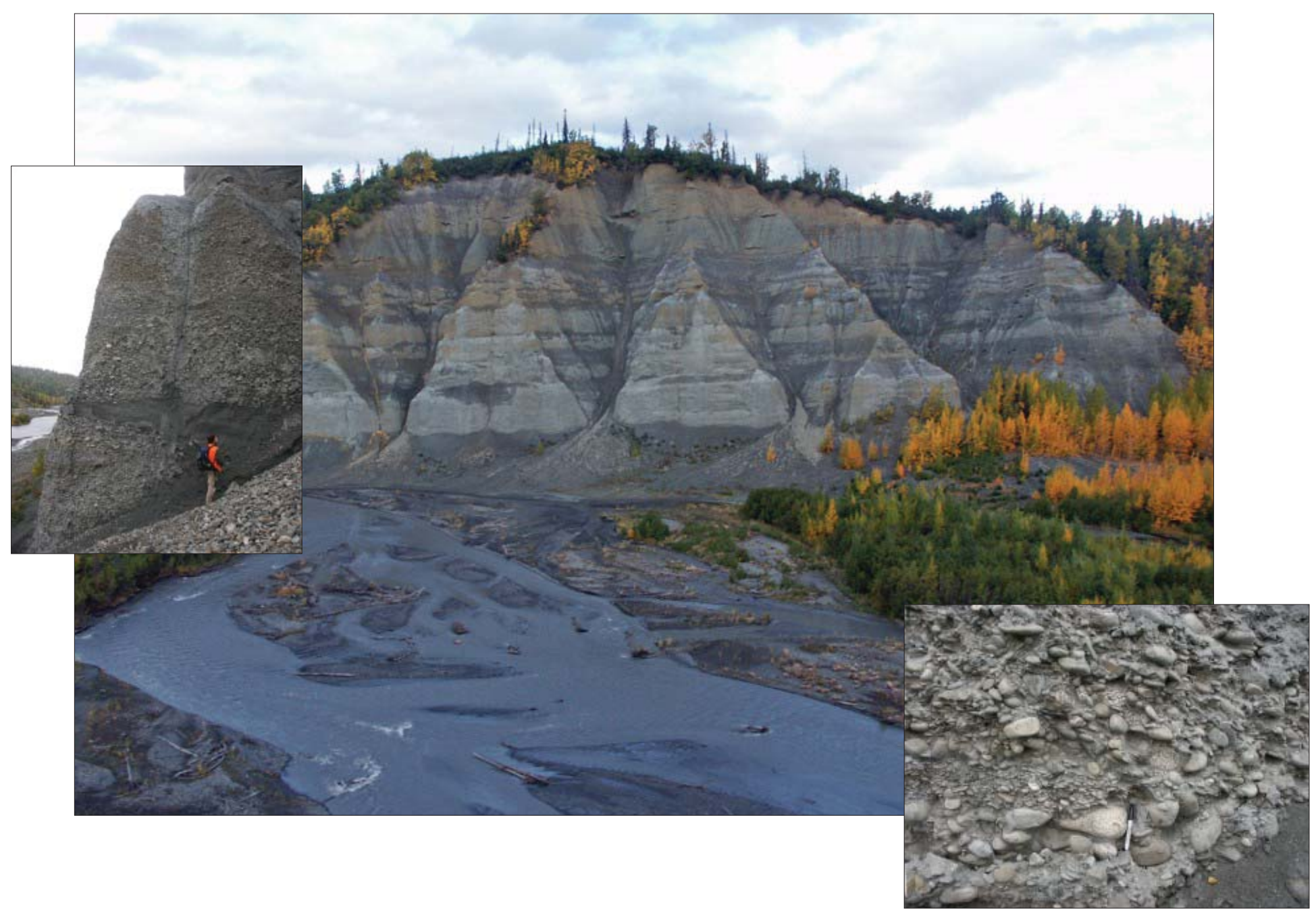

November 2009

Released by

STATE OF ALASKA

DEPARTMENT OF NATURAL RESOURCES

Division of Geological \& Geophysical Surveys

3354 College Rd.

Fairbanks, Alaska 99709-3707 



\section{CONTENTS}

Foreword

David L. Lepain

A Facies associations, sand body geometry, and depositional systems in Late Oligocene-Pliocene Strata, southern Kenai Peninsula, Cook Inlet, Alaska: Report on progress during the 2006-07 field season .......

David L. LePain, Marwan A. Wartes, Paul J. McCarthy, Richard Stanley, Laura J. Silliphant, Shaun Peterson, Diane P. Shellenbaum, Kenneth P. Helmold, Paul L. Decker, Jacob Mongrain, Robert J. Gillis

Appendix

B Sedimentology of an Oligocene-Miocene incised paleovalley, Tyonek Formation, Cook Inlet Basin, Alaska

Emily S. Finzel, Kenneth D. Ridgway, and David L. LePain

C Report on day trip (5/16/07) to visit Mesozoic rocks exposed in Port Graham and near Seldovia, southern Kenai Peninsula

Robert B. Blodgett

D Mercury injection capillary pressure results from outcrop samples in the Homer area of Cook Inlet 117

Andrea Loveland

Front cover. Outcrop of early Pliocene age conglomerate of the Sterling Formation along the west side of the Fox River, north of Kachemak Bay, in the Kenai National Wildlife Refuge. Approximately $45 \mathrm{~m}$ of conglomerate is shown; conglomerate is overlain by interbedded sandstone and siltstone in the upper third of the exposure. Conglomerates are interpreted as part of an alluvial fan, or fan complex, that prograded basinward (west) from sources in the western Chugach Mountains (McHugh Complex). View toward the west. Photograph by Marwan Wartes (DGGS).

Left inset. Clast-supported pebble and cobble conglomerate with lens of coarse-grained, poorly sorted sandstone. Photo was taken at an exposure of conglomerate approximately $0.5 \mathrm{~km}$ downstream from the conglomerate shown in the cover photo. Conglomerates were deposited during flood events in an alluvial fan, or associated proximal braided fluvial setting, possibly as hyperconcentrated flood flow deposits. Photograph by Marwan Wartes (DGGS).

Right inset. Close-up view showing the clast fabric in the conglomerate bed above the sand lens visible at geologist's head level in left inset photo. Note the poor sorting, sandy matrix, and distinct granitoid clasts. This fabric is typical of the conglomerates in these exposures. The granitoid clasts were probably derived from intrusive bodies in the accretionary wedge to the east (western Chugach Mountains). A 52.1 Ma $( \pm 0.2 \mathrm{Ma})^{40} \mathrm{Ar}{ }^{\beta 9} \mathrm{Ar}$ age on biotite from one of these granitoid clasts suggests derivation from near-trench intrusive bodies in the accretionary wedge. Photograph by Marwan Wartes (DGGS).

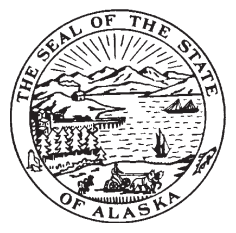

Alaska Division of Geological \& Geophysical Surveys 3354 College Rd., Fairbanks, AK 99709-3707

(907) 451-5020 (907)451-5050 fax email: dggspubs@alaska.gov http://www.dggs.dnr.state.ak.us

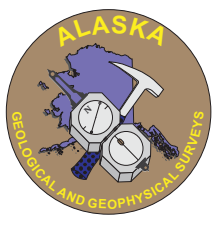





\title{
FOREWORD
}

\author{
Dave LePain
}

The Alaska Division of Geological \& Geophysical Surveys, in collaboration with the Alaska Division of Oil \& Gas, is engaged in a multi-year analysis of Cook Inlet basin that began in May 2006. This program is being implemented in two phases. The focus of Phase I is the stratigraphic trap potential of Tertiary strata in upper Cook Inlet; the focus of Phase II is the reservoir and source rock potential of middle Jurassic through Maastrichtian rocks of the Peninsular terrane. The chapters in the volume represent preliminary results from fieldwork conducted in September 2006 and May 2007 on the Kenai Peninsula.

- Chapter A by LePain and others presents a facies analysis of the Tyonek, Beluga, and Sterling Formations in exposures on the Kenai Lowland and between Seldovia and Coal Cove (Port Graham). This report includes detailed measured stratigraphic sections of these formations. Lateral facies changes are documented in incised valley-fill deposits of the Tyonek Formation between Barabara Point and Coal Cove. In this area the Tyonek Formation is limited to small paleovalleys that were eroded into older metamorphic rocks of an emergent accretionary wedge (McHugh Complex., Chugach terrane). Lateral facies changes in bluff exposures of the Beluga and Sterling Formations are also documented and used to highlight contrasting sand body geometries in these units. Includes Appendix A, pages 33-97.

- Chapter B by Finzel and others presents a more detailed facies analysis of the Tyonek Formation occupying a paleovalley cut into the Chugach terrane between Seldovia and Barabara points. This work documents a significant change in sediment composition up-section in the valley fill; near the base of the valley fill, sediment composition reflects derivation from local sources in the underlying Chugach terrane, whereas higher in the valley fill, sediment composition and textures suggest derivation from more regional sources and transport in a large drainage network. The latter part of the valley fill appears to represent the transition from valley-confined sedimentation to axial fluvial depositional systems located basinward of the incised valley network.

- Chapter C by Blodgett and others presents a brief description of a one-day field trip to exposures of Mesozoic strata in Port Graham and at Point Naskowhak. Preliminary fossil identifications are presented, along with their age significance. Well-preserved and lightly abraded bivalves in sandstones that include features suggestive of rapid deposition in relatively deep water indicate short transport paths between the shallow water source area for the fauna and the depositional site.

- Chapter D by Loveland presents mercury injection capillary pressure data generated by George Bolger at PetroTech Associates, Houston, TX, from outcrop samples collected from the Beluga and Sterling Formations. Nearly all samples are tied to measured stratigraphic sections, which provide facies context for the data. Most of our measured sections are presented in Appendix A of Chapter A (LePain and others, this volume). The sample number includes the measured section number and the stratigraphic position of the sample in the measured section. For example, sample 07JRM005-16.5 was collected $16.5 \mathrm{~m}$ above the base of measured section 07JRM005 (fig. A11, Appendix A, LePain and others, this volume).

\section{ACKNOWLEDGMENTS}

This work would not have been possible without generous funding from the State of Alaska, Benchmark Oil and Gas, Pioneer Natural Resources Alaska, Inc., and Chevron North America Exploration and Production Company. We gratefully thank the management of the Kenai National Wildlife Refuge for permitting access to exposures of the Sterling Formation in the Fox River drainage north of Kachemak Bay during the 2006 and 2007 seasons. 



\title{
FACIES ASSOCIATIONS, SAND BODY GEOMETRY, AND DEPOSITIONAL SYSTEMS IN LATE OLIGOCENE-PLIOCENE STRATA, SOUTHERN KENAI PENINSULA, COOK INLET, ALASKA: REPORT ON PROGRESS DURING THE 2006-07 FIELD SEASONS
}

\author{
by \\ David L. LePain ${ }^{1}$, Marwan A. Wartes ${ }^{1}$, Paul J. McCarthy², Richard Stanley ${ }^{3}$, Laura J. Silliphant ${ }^{4}$, \\ Shaun Peterson ${ }^{4}$, Diane P. Shellenbaum ${ }^{4}$, Kenneth P. Helmold ${ }^{4}$, Paul L. Decker ${ }^{4}$, \\ Jacob Mongrain ${ }^{2}$, Robert J. Gillis ${ }^{1}$
}

\section{INTRODUCTION}

This preliminary report is a summary of progress made during the 2006-07 field seasons reconstructing depositional systems in Tertiary strata exposed in the Homer-Kachemak Bay area (fig. 1). This work is part of a Cook Inlet basin-wide effort to reconstruct depositional systems for use as a predictive tool in oil and gas exploration. The resulting framework will provide the context for evaluating sand body geometries, their internal heterogeneities, and compositional parameters controlling reservoir quality. The study area addressed in this report extends from Clam Gulch in the north to Coal Cove in the south. Tertiary strata in this area are only mildly deformed and provide a relatively clear view of depositional systems and sand body geometries along the eastern basin edge and their change from basin edge to more basin axial positions.

Quaternary deposits blanket Tertiary strata throughout most of the Kenai lowland and exposures are limited to coastal bluffs and isolated river cuts (Magoon and others, 1976; Bradley and others, 1999; fig. 2). Oligocene to Pliocene age strata in the study area consist of the Tyonek, Beluga, and Sterling Formations (fig. 3). Rocks assigned to the Tyonek Formation are exposed in aerially restricted coastal exposures between Barabara Point (northeast of Seldovia Bay) and Coal Cove (north side of entrance to Port Graham, fig. 2). The Beluga Formation is present in bluff exposures northwest of Homer and along the northwest shore of Kachemak Bay. The Sterling Formation crops out along the northwest shore of Kachemak Bay, north of Kachemak Bay along the Fox River, along Deep Creek, and along the east shore of Cook Inlet.

Measured stratigraphic sections and stitched digital photos acquired by the Alaska Division of Geological \& Geophysical Surveys and the Alaska Division of Oil \& Gas during the 2006-07 field seasons form the dataset upon which the preliminary interpretations presented in this report are based. Selected measured stratigraphic sections are presented in page format in an appendix at the end of this chapter; locations of measured sections are summarized in Table A1. Outcrop spectral gamma data were acquired for most of these measured sections, but are not included here pending further analysis of their significance.

\section{REGIONAL GEOLOGY}

Cook Inlet basin is part of a northeast-trending collisional forearc basin that extends approximately from Shelikof Strait in the southwest to the Wrangell Mountains in the northeast (fig. 1). The basin is bounded on the west and north by granitic batholiths and volcanoes of the Aleutian volcanic arc and Alaska Range, respectively, and on the east and south by the Chugach and Kenai mountains, which represent the emergent portion of an enormous accretionary prism (Haeussler and others, 2000; Nokleberg and others, 1994). High-angle faults, including the Bruin Bay, Castle Mountain, and Capps Glacier faults modified the west and north sides of the forearc basin (fig. 1) and juxtapose different age Mesozoic and Cenozoic sedimentary formations against each other and against arc-intrusive bodies (for example, Barnes and Cobb, 1959; Magoon and others, 1976). The Border Ranges fault bounds the east side of the forearc basin (fig. 1) and juxtaposes Mesozoic sedimentary rocks of the Peninsular terrane against highly deformed and metamorphosed Mesozoic rocks of the accretionary prism, assigned to the Chugach terrane (for example, Magoon and others, 1976; Bradley and others, 1999).

\footnotetext{
${ }^{1}$ Alaska Division of Geological \& Geophysical Surveys, 3354 College Road, Fairbanks, Alaska 99709-3707; dave.lepain@alaska.gov ${ }^{2}$ Department of Geology and Geophysics, P.O. Box 757320, University of Alaska Fairbanks, Fairbanks, Alaska 99775-7320

${ }^{3}$ U.S. Geological Survey, 345 Middlefield Road, MS 969, Menlo Park, California 94025

${ }^{4}$ Alaska Division of Oil \& Gas, 550 West 7th Avenue, Suite 800, Anchorage, Alaska 99501
} 


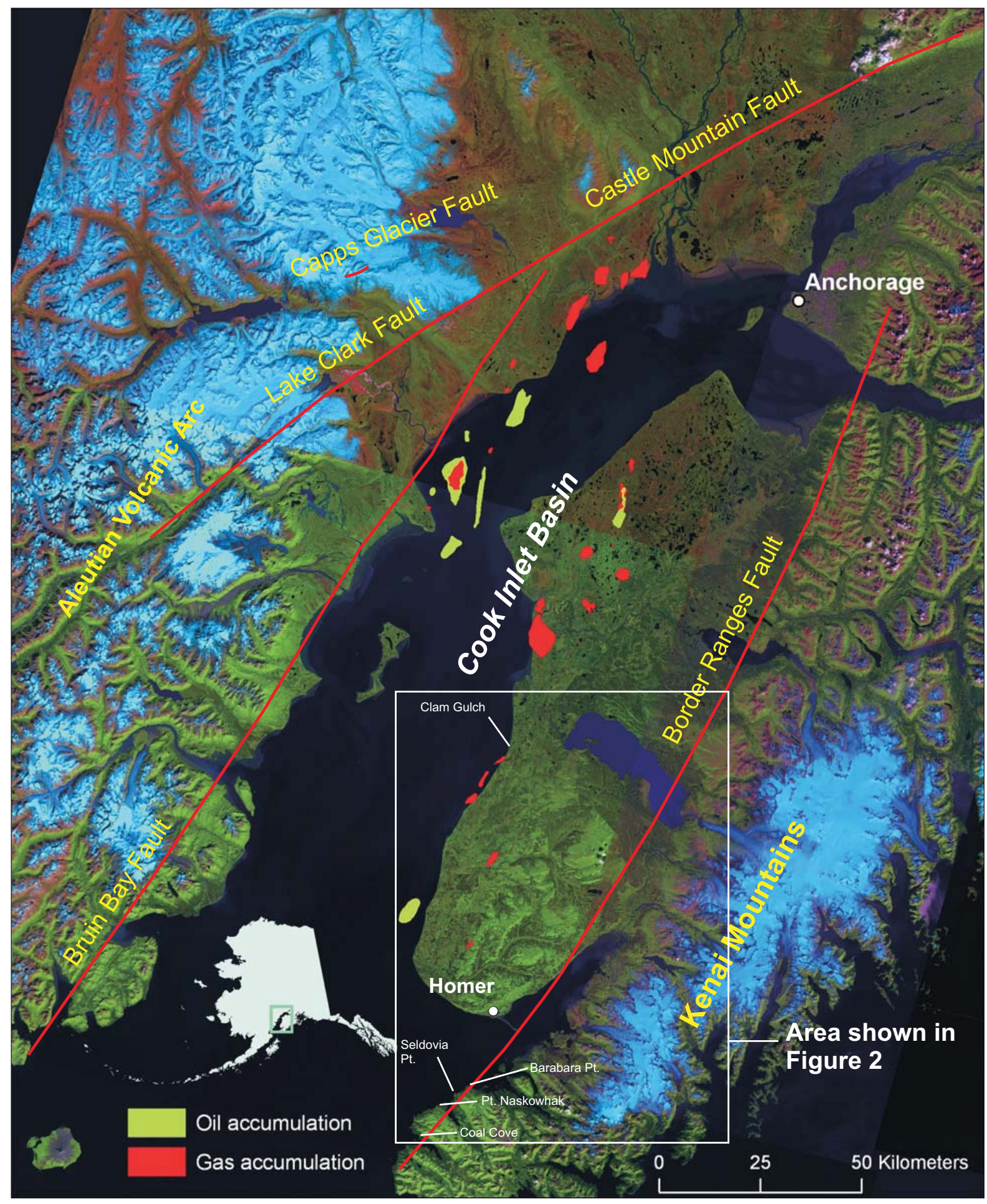

Figure 1. Landsat image showing Cook Inlet from just south of Augustine Island (lower left corner of image) to the southwestern corner of the Talkeetna Mountains (northeastern corner of image). Major faults that either bound the Tertiary basin and/or cut the Tertiary stratigraphy are shown in red with fault names in yellow. The white rectangle outlines the study area addressed in this report. 


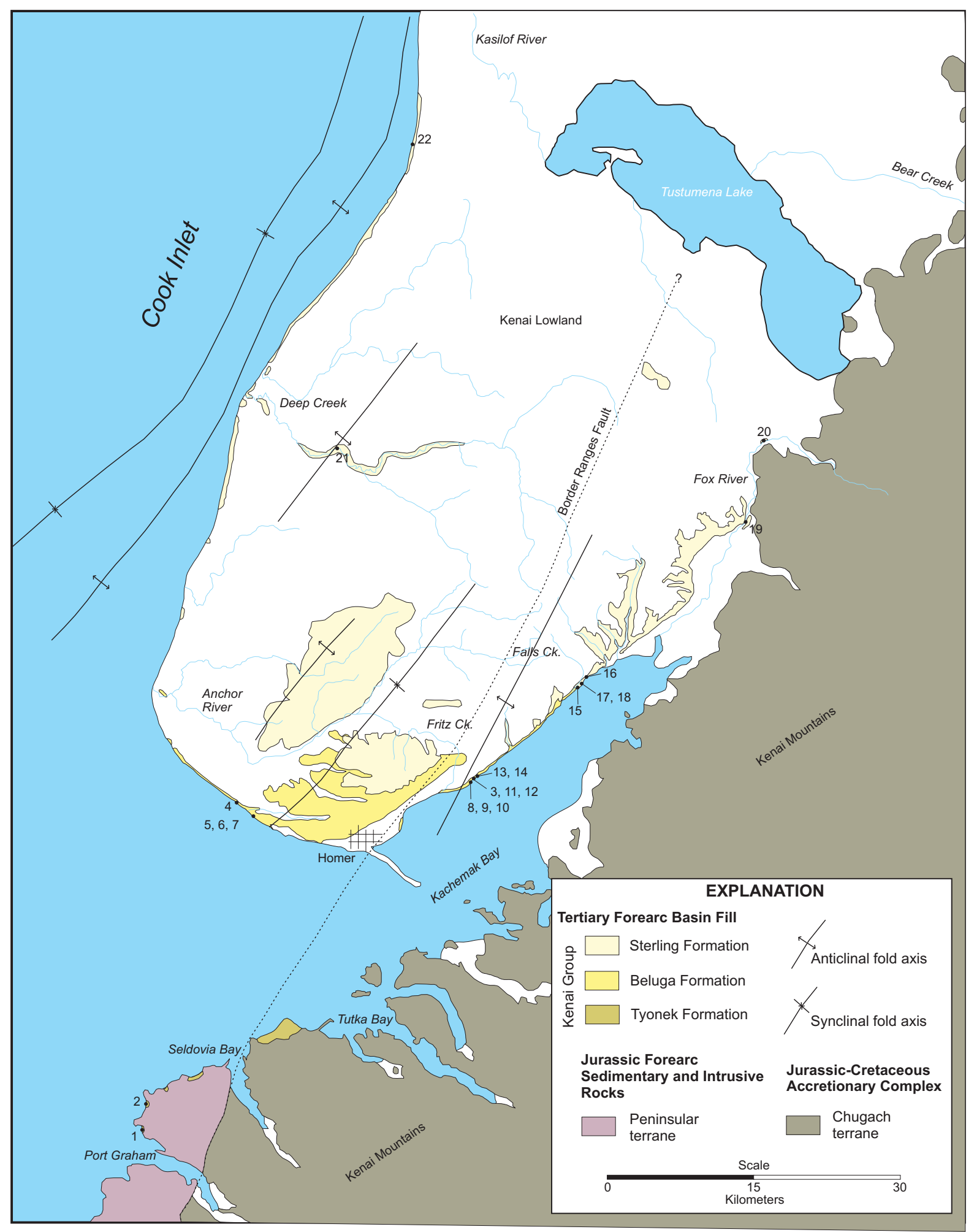

Figure 2. Map showing the generalized distribution of Tertiary formations in the study area and outcrop locations discussed in this report. The geology was taken from Magoon and others (1976). 
Mesozoic strata of the Peninsular terrane represent the foundation upon which the Cenozoic forearc basin developed. The Peninsular terrane has been interpreted as part of a microcontinent that accreted to inboard terranes during Cretaceous time (Nokleberg and others, 1994; Plafker and others, 1989, 1994). The terrane consists of late Paleozoic through Mesozoic rocks having a regional composite thickness of nearly 12,200 m (Kirschner and Lyon, 1973). Mesozoic strata extend continuously at depth under Tertiary nonmarine deposits and are exposed along the upturned western and eastern margins of the forearc basin (Fisher and Magoon, 1978; Magoon and Egbert, 1986). Mildly deformed late Cenozoic nonmarine strata unconformably overlie Mesozoic strata and depositionally onlap Mesozoic strata along the eastern margin of the basin (Swenson, 2002). Tertiary nonmarine strata, which are up to $7,620 \mathrm{~m}$ thick in the axial region of the basin (Boss and others, 1976), consist of a complex assemblage of alluvial fan, axial fluvial, and alluvial floodbasin depositional systems (fig. 3; Swenson, 2002).

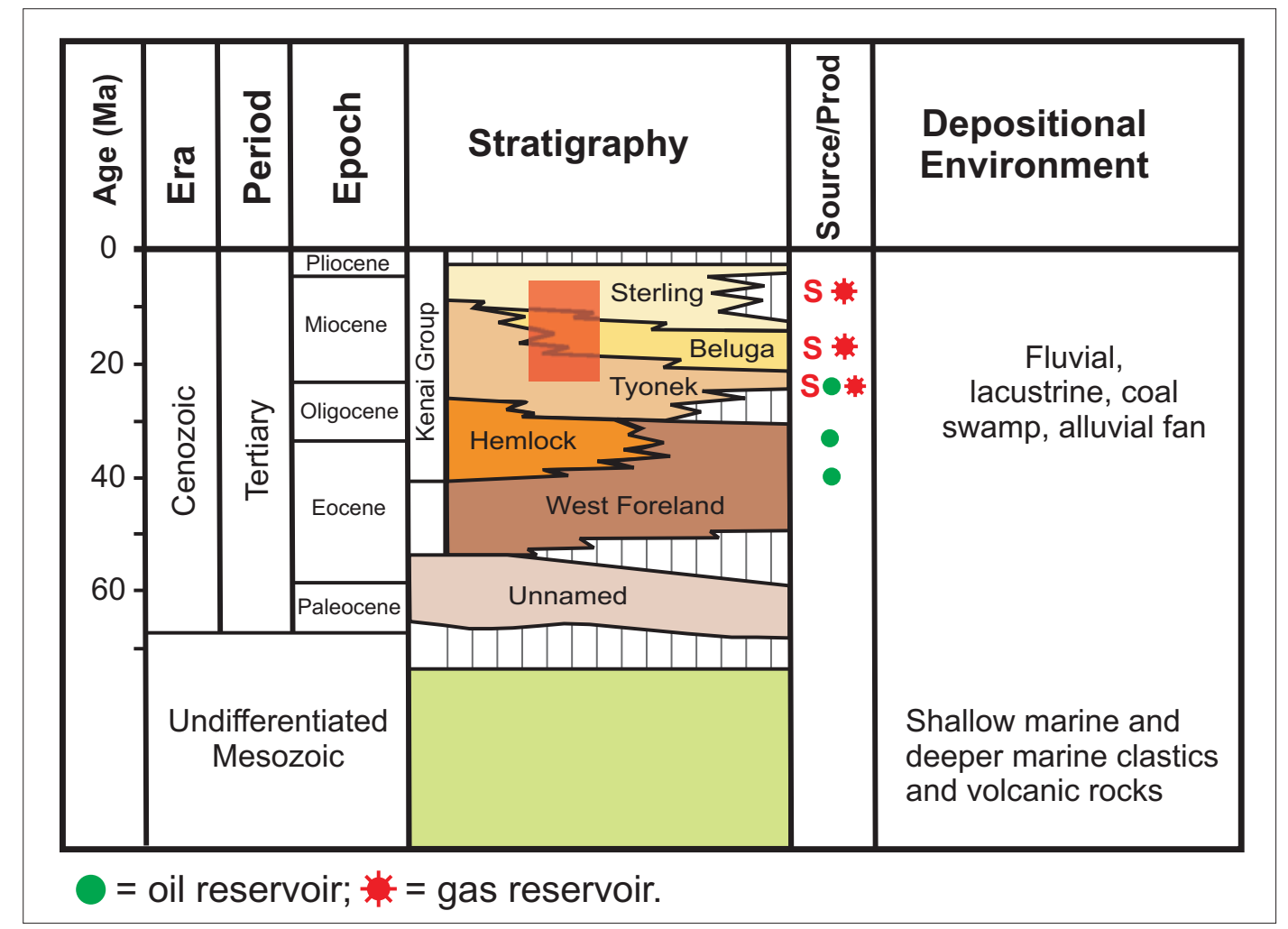

Figure 3. Simplified stratigraphic column showing Tertiary nonmarine formations in Cook Inlet basin. The vertical transparent red rectangle shows the stratigraphic focus of this report. Modified from Swenson (2002).

\section{PREVIOUS WORK ON TERTIARY STRATA}

\section{Stratigraphy}

Stratigraphic nomenclature applied to Tertiary strata in the Cook Inlet region has evolved since Dall and Harris (1892) first proposed the name Kenai Group for coal-bearing sediments exposed on the southern Kenai Peninsula. Dall (1898) subsequently extended the group to include similar strata from as far north as Norton Sound to as far south as British Columbia. Subsequent usage was more restrictive, including only the coal-bearing strata on the Kenai Peninsula (Calderwood and Fackler, 1972). Barnes and Cobb (1959) mapped and described coal-bearing strata in the Homer district and referred to these rocks as the Kenai Formation. Exploratory drilling for hydrocarbons in the 1950s and 1960s demonstrated that the thickness of Tertiary strata in the basin significantly exceeded the thickness of coal-bearing strata exposed on the Kenai Peninsula (Calderwood and Fackler, 1972). For this reason Calderwood and Fackler (1972) formally elevated the unit to group rank and defined five formations, each with subsurface type sections, as comprising the Kenai Group. From oldest to youngest these include the West Foreland Formation, Hemlock Conglomerate, Tyonek Formation, Beluga Formation, and Sterling Formation (fig. 3). 
Subsequent work led Boss and others (1976) to restrict the Kenai Group to three formations (Tyonek, Beluga, and Sterling) on the basis of an interpreted unconformable relation between the West Foreland and overlying Tyonek Formation. These authors considered the Hemlock Conglomerate to be a member of the Tyonek Formation.

Calderwood and Fackler (1972) correlated two subsurface formations to surface exposures on the Kenai Peninsula. They correlated the subsurface Beluga Formation with the type locality for Wolfe's (1966) Homerian floral stage, and correlated the subsurface Sterling Formation with the type locality for Wolfe's Clamgulchian floral stage. Kirschner and Lyon (1973, fig. 11, p. 403) show isopach maps with generalized locations where these formations crop out at the surface. A geologic map compiled by Magoon and others (1976) showed the distribution of the Beluga and Sterling in outcrop, as well as aerially restricted exposures of Tertiary rocks along the coastline southwest of Homer, between Barabara Point and Coal Cove. These exposures include reference localities for Wolfe's (1966) Seldovian floral stage and were mapped as Tyonek by Magoon and others (1976).

Many geologists have investigated the stratigraphy and environmental significance of parts of the Tertiary succession in outcrop around the basin. Barnes and Cobb (1959) mapped Tertiary rocks on the Kenai Peninsula as part of an effort to evaluate the coal resources of the region. Wolfe (1966) and Wolfe and others (1966) defined three provincial floral stages based on plant megafossils recovered from Tertiary exposures on the southern Kenai Peninsula. The Seldovian stage was based on plant megafossils collected in the vicinity of Capps Glacier on the northwest side of the basin and Seldovia Point on the southeast side of the basin. The Seldovia Point flora was interpreted by Wolfe and Tanai (1980) as an early to middle Miocene warm temperate assemblage. Wolfe and others (1966) noted that the Seldovian flora could extend back in time to late Oligocene. The Homerian stage was based on plant fossils collected from exposures along the west shore of Kachemak Bay and immediately west of Homer and was interpreted as a cool-temperate assemblage of late Miocene age. The Clamgulchian stage was based on fossils collected from bluff exposures at Clam Gulch, on the east shore of Cook Inlet, that Wolfe and others (1966) interpreted as a cool temperate assemblage of probable Pliocene age. These workers provide no information on the depositional systems responsible for depositing the Tertiary successions they studied.

Reinink-Smith $(1990,1995)$ used K-Ar techniques to date tephra layers in Tertiary strata along the east shore of Cook Inlet (Sterling Formation) and along the west shore of Kachemak Bay (Beluga and Sterling Formations). Reinink-Smith concluded that the lower Beluga and lower Sterling Formations were deposited during periods of increased volcanic activity in the basin more than 10.5 m.y. and approximately 7.5 m.y. ago, respectively. ReininkSmith's focus was to use tephra layers as correlation tools and her work did not address the depositional settings of the Beluga and Sterling Formations.

Dallegge and Layer (2004) used the ${ }^{40} \mathrm{Ar}^{39} \mathrm{Ar}$ method to date 37 tephra beds in the Beluga and Sterling Formations in outcrop on the Kenai Peninsula and a single altered tephra sample from the Tyonek Formation in core from well 14CC in the Pioneer Unit in the Matanuska Valley. Their work demonstrates the existence of numerous high-angle faults in outcrop, some with significant displacements, which would otherwise be difficult to recognize due to poor exposures. The single date they obtained from the Tyonek Formation yielded a weighted mean age of $48.65 \pm 2.31$ Ma (early Eocene).

\section{Depositional Systems and Provenance}

Flores and others (2004) examined the Tyonek Formation between Barabara Point and Seldovia Point. They recognized that Tyonek strata at the southwestern end of this exposure represented the fill of an incised paleovalley. Bradley and others (1999) also recognized the paleovalley-filling nature of these deposits. Stricker and Flores (1996) suggested a tidal influence on strata above the paleovalley fill succession (east of Seldovia Point), but did not explain the basis for their interpretation. Flores and others $(1994,1997)$ examined the Tyonek Formation in exposures on the northwest side of the basin, along Chuit Creek and the Chuitna River. In that area they interpreted Tyonek sand bodies as the product of braided streams that were flanked by floodplains and mires. They suggested a tidal influence on floodplain mudstones in this area and subsequently recognized several tide-influenced facies in cores from the Diamond-Chuitna project area (a few miles east of Chuit Creek), including tidal sand flat, tidal marsh, and tidal channel deposits (Flores and others, 1997). Hite (1976) provided a regional interpretation for the Tyonek as the product of alluvial fans, fan deltas, and estuarine processes, but did not discuss the Tyonek in the Seldovia-Coal Cove area.

Hayes and others (1976) examined exposures of the Beluga and Sterling Formations on the Kenai Peninsula. They interpreted the Beluga as the product of alluvial fans and braided fluvial streams that flowed westward from the Kenai-Chugach mountains. They interpreted the Sterling as the product of moderately large meandering streams that flowed south to southeastward in the area of the Kenai Peninsula. These authors noted that the Beluga was composed mainly of metasedimentary rock fragments from the Kenai-Chugach mountains and that Sterling 
sandstones were composed of quartz, plagioclase, and volcanic rock fragments derived from the Aleutian-Alaska ranges to the north and west.

Boss and others (1976), in a paper describing the Middle Ground Shoal oil field, noted the time-transgressive nature of the Beluga and Sterling Formations, interpreted the Beluga as a "waste basket" stratigraphic unit, and interpreted the Sterling as the product of braided streams possibly similar to present-day streams in the area. These authors described the Tyonek as consisting of massive fluvial sandstones, floodplain shales, and thick coals, but did not provide details on fluvial style (for example, braided or meandering). Interestingly, they claimed to recognize tillites in the Beluga and Sterling Formations that they infer were deposited by glaciers originating in the Kenai Mountains (their fig. 5).

Rawlinson (1984) examined exposures of the Beluga and Sterling Formations along the west shore of Kachemak Bay. He interpreted the Beluga (referred to as Homerian stage beds in his paper) as the product of braided and meandering streams flanked by natural levee, floodplain, and flood-basin deposits. Beluga streams flowed westward and northwestward from the Chugach-Kenai mountains. He interpreted the Sterling (Clamgulchian in his paper) as the product of meandering streams that were flanked by overbank deposits similar to those recognized in the Beluga. Sterling rivers flowed down the regional paleoslope toward the west-northwest. Rawlinson (1984) confirmed the conclusion of Hayes and others (1976) that the abundance of low-rank metamorphic rock fragments in the Beluga and abundant volcanic grains in the Sterling reflected sources in the Kenai-Chugach mountains and Alaska-Aleutian Range, respectively.

A group of geoscientists working for ARCO in the 1980s and 1990s developed a biostratigraphic and depositional systems framework for Cook Inlet basin. Limited elements of this framework have been published (Swenson, 2002) and include alluvial fans along the western and eastern basin margins that grade basinward to an axial fluvial system. By integrating depositional systems information with detailed palynological analyses they were able to demonstrate the time-transgressive nature of Tertiary lithostratigraphic units (Swenson, 2002, his figures 5 and 6).

Flores and Stricker (1992) interpreted the upper part of the Beluga Formation and lower and middle parts of the Sterling Formation along the west shore of Kachemak Bay as the products of suspended-load anastomosed streams and meandering streams, respectively. They attributed coal deposition to raised mires; they also inferred that the thicker coals in the Beluga were the result of vertical accretion typical of the anastomosed system, whereas thinner coals in the Sterling reflect lateral migration of fluvial channels and resulting interruption of peat deposition. Flores and Stricker (1993) interpreted the Sterling Formation exposures at Clam Gulch as the products of braided streams. They suggested that channel style in the Sterling evolved up-section from bedload-dominated low-sinuosity forms to mixed- and suspended-load forms, but did not mention changes in inferred plan-form geometry.

\section{FACIES ANALYSIS}

Twenty-one facies are recognized in exposures of the Kenai Group in outcrop on the southern Kenai Peninsula. These are summarized in table 1 and will not be addressed in more detail in this report. The facies occur in nine facies associations (table 2). A brief description and interpretation of each association is presented below.

\section{Facies Association 1 - Valley Margin Apron DESCRIPTION}

Facies association 1 consists largely of matrix-supported conglomerate $(\mathrm{Gmm})$ with subordinate interbedded clast-supported conglomerates of facies Gcm (tables 1 and 2; fig. 4a). Clasts range from granule size to approximately $100 \mathrm{~cm}$, are angular to sub-angular, equant shaped, and are supported by a maroon-colored, argillaceous, silty-sandy matrix (fig. 4b-d). This association is always in contact with underlying Mesozoic bedrock along steeply-dipping surfaces and extends up to $30 \mathrm{~m}$ away from this contact (fig. 4a). Clast compositions reflect derivation from nearby Mesozoic lithologies. At Point Naskowhak and Coal Cove clasts were derived from Jurassic volcanigenic rocks of the Talkeetna Formation (Peninsular terrane), whereas at Seldovia Point clasts were derived from sedimentary and volcanic rocks of the McHugh Complex (Chugach terrane).

\section{INTERPRETATION}

This association records deposition from cohesive debris flows on small alluvial fans located along steeply sloping margins of paleovalleys incised into underlying bedrock of the Peninsular and Chugach terranes. Angular and sub-angular clast shapes attest to limited transport. 
Table 1. Cook Inlet Facies. Facies codes and interpretations significantly modifed from Miall (1996).

\begin{tabular}{|c|c|c|c|}
\hline Lithofacies & Code & Description & Interpretation \\
\hline \multicolumn{4}{|l|}{ Gravel-Conglomerate } \\
\hline Matrix-supported conglomerate & Gmm & $\begin{array}{l}\text { Very poorly sorted granule to cobble } \\
\text { conglomerate, unstratified, clasts angular to } \\
\text { sub-round derived from subjacent bedrock } \\
\text { and supported by a clayey, silty, sandy } \\
\text { matrix }\end{array}$ & $\begin{array}{l}\text { Plastic to pseudoplastic debris flows } \\
\text { and hyperconcentrated flows } \\
\text { operating in areas of high relief, } \\
\text { typically near basin margin }\end{array}$ \\
\hline $\begin{array}{l}\text { Clast-supported massive } \\
\text { conglomerate }\end{array}$ & $\mathrm{Gcm}$ & $\begin{array}{l}\text { Poor to moderately sorted, disorganized } \\
\text { granule to boulder conglomerate, clasts sub- } \\
\text { angular to rounded, bedding up to } 3+\mathrm{m} \text {, } \\
\text { laterally continuous and discontinuous }\end{array}$ & $\begin{array}{l}\text { Pseudoplastic debris flows and } \\
\text { hyperconcentrated flows operating } i \\
\text { areas of high relief near basin marg }\end{array}$ \\
\hline $\begin{array}{l}\text { Clast-supported crudely bedded } \\
\text { conglomerate }\end{array}$ & Gch & $\begin{array}{l}\text { Poor to moderately sorted, disorganized to } \\
\text { moderately organized granule to boulder } \\
\text { conglomerate, clasts sub-angular to well- } \\
\text { rounded, crude horizontal bedding up to } 1.5 \\
\text { m thick and laterally discontinuous, locally } \\
\text { developed clast imbrication }\end{array}$ & Longitudinal barforms \\
\hline $\begin{array}{l}\text { Clast-supported planar cross- } \\
\text { bedded conglomerate }\end{array}$ & Gcp & $\begin{array}{l}\text { Poor to moderately sorted granule to cobble } \\
\text { conglomerate, clasts sub-angular to well- } \\
\text { rounded, planar-tangential foresets up to } 2.5 \\
m \text { thick and laterally discontinuous over tens }\end{array}$ & $\begin{array}{l}\text { Moderate to large two-dimensional } \\
\text { transverse bedforms and delta-like } \\
\text { growths on downstream ends of } \\
\text { composite bars }\end{array}$ \\
\hline
\end{tabular}

Clast-supported trough crossbedded conglomerate

Gct meters

Poor to moderately sorted granule to cobble conglomerate, trough cross-bedded in sets up to $2.5 \mathrm{~m}$ thick; log and large plant fragments present locally

Conglomeratic lag

$\mathrm{Gl}$

Granule and pebble lags up to $20 \mathrm{~cm}$ thick overlying scour surfaces at base of sand beds; equant to discoid-shaped extrabasinal clasts and discoid-shaped mudstone ripup clasts, locally consists of only mudstone ripup clasts

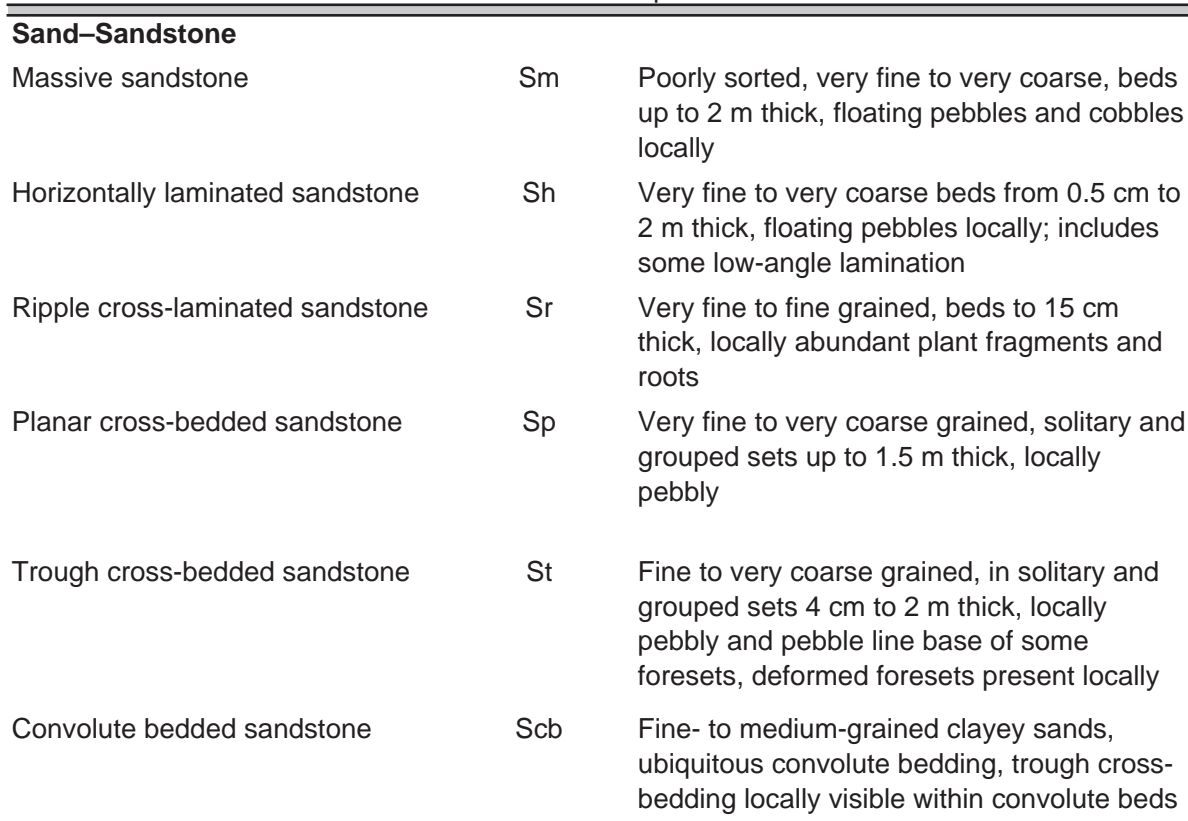

Sediment gravity flows, rapid deposition without tractive transport

Lower and upper flow-regime plane bed phase; correct choice depends on overall facies context

Lower flow regime, downstream migrating ripples

Lower flow regime two-dimensional bedforms with relatively straight crestline; includes delta-like growths along margins of barforms

Lower flow regime three-dimensional bedforms, sinuous to linguoid crestlines

Deformation resulting from low permeability and high fluid pressure resulting in fluidization and loss of strength; process may be associated with one or more of the following: high sedimentation rates, frictional drag at interface between larger bedforms and overlying moving fluid, deformation of oversteepened foreset laminae; origin may be a combination of the above factors locally 
Table 1. Cook Inlet Facies. Facies codes and interpretations significantly modifed from Miall (1996)—continued.

\begin{tabular}{lcll}
\hline \multicolumn{1}{c}{ Lithofacies } & Code & Description & Interpretation \\
\hline \hline Scour-fill sandstone & Ssf & $\begin{array}{l}\text { Very-fine- to fine-grained sand with } \\
\text { interlaminated mudstone, laminae as form- } \\
\text { concordant scour drape, plant fragments and } \\
\text { roots locally abundant }\end{array}$ & $\begin{array}{l}\text { Concave-up erosion surfaces cut } \\
\text { during flood events and subsequently } \\
\text { draped by fine-grained sediment } \\
\text { during low flow conditions }\end{array}$ \\
\hline \hline Clay/Silt/Mud & & during & \\
\hline
\end{tabular}

\begin{tabular}{ll}
\hline Clay/Silt/Mud & Fcl $\quad \begin{array}{l}\text { Light gray to dark brown claystone with } \\
\text { Laminated claystone } \\
\text { millimeter-scale lamination }\end{array}$
\end{tabular}

Massive claystone

$\mathrm{Fcm}$

Light to medium gray claystone, no visible lamination, minor scattered plant fragments, color mottling locally

Laminated mudstone

$\mathrm{Fml}$

Light gray to brown silt and silt-clay mixtures in undisturbed millimeter- to centimeter-scale laminae, darker laminae commonly finer grained; locally ripple cross-laminated

Thinly interbedded sandstone and siltstone

Interbedded very-fine-grained sandstone and siltstone, bed millimeter to multi-centimeters thick, locally ripple cross-laminated

Massive mudstone

Fmm

Light gray to brown massive silt, silt-clay, and silt-clay-sand mixtures, commonly micromicaceous, no visible internal structures, sideritic concretions locally abundant and commonly with preserved plant fragments, rooted horizons locally

Blocky mudstone $\mathrm{Fmb}$

Light gray to brown blocky mudstone, common sideritic concretions and rooted horizons; tree stumps in growth position locally

Carbonaceous mudstone

Fcb

Dark brown laminated claystone and mudstone, abundant terrestrial organic material typically preserved as comminuted plant fragments

Coal

C

Dark brown to black, blocky lignitic to subbituminous coal, dull and alternating bright and dull layers common, original plant material commonly recognizable; dispersed volcanigenic mineral crystals and disrupted ash layers common
Slow settling from suspension in quiet water setting removed from sources of coarser sediment; deposition in floodplain ponds, lakes, and abandoned fluvial channels; possible seasonal laminae

Rapid deposition during flood events on poorly drained floodplain distal to fluvial channels, poorly developed soils locally; locally developed marshes (paludal)

Alternating slow suspension settling and relatively rapid suspension settling during flood event in distal levee and proximal perennially flooded regions of floodplain

Upper flow regime plane bed and lower flow regime ripple bed conditions in waning flows depositing sand-silt couplets

Rapid deposition during flood events on poorly drained floodplain proximal to fluvial channels, poorly developed soils locally, sparse colonization of depositional surface by land plants

Relatively rapid deposition during flood events in seasonally flooded regions of floodplain, weak to moderate pedogenesis and colonization by land plants and trees

Alternating suspension settling of clay and fine silt and relatively rapid deposition admixed terrestrial organic material, clay, and silt during flood events affecting perennially flooded region of floodplains

Swamp; thick low-ash coals probably originated in raised mires, whereas high-ash coals originated in topographically low swamps that frequently received clastic sediment from nearby fluvial sources

Facies codes and interpretations significantly modifed from Miall (1996) 
Table 2. Cook Inlet Facies associations.

\begin{tabular}{|c|c|c|c|}
\hline Lithofacies Association & Lithofacies & Geometry & Interpretation \\
\hline 1 Valley margin apron & $\mathrm{Gmm}, \mathrm{Gcm}$ & Wedge & $\begin{array}{l}\text { Colluvial apron and regolith locally } \\
\text { at valley margin. }\end{array}$ \\
\hline $\begin{array}{l}2 \text { Disorganized gravelly braided } \\
\text { fluvial }\end{array}$ & $\begin{array}{l}\text { Gcm, Gch, } \\
\text { Gct/Gcp, } \\
\text { Gmm, Sm, } \\
\text { Sh, St., Fsb, } \\
\text { and minor } \\
\text { coal }\end{array}$ & Sheet & $\begin{array}{l}\text { Paleovalley-fill; hyperconcentrated } \\
\text { flow and normal, but flashy stream } \\
\text { flow, local sediment sources. }\end{array}$ \\
\hline $\begin{array}{l}3 \text { Sheetflood-dominated alluvial } \\
\text { fan }\end{array}$ & $\begin{array}{l}\text { Gcm, Gch, } \\
\text { Sm, Sh, St, } \\
\text { and possible } \\
\text { Gct or Gcp }\end{array}$ & Sheet & $\begin{array}{l}\text { Basin margin alluvial fans traversed } \\
\text { by braided streams flanked by } \\
\text { poorly drained floodplains, semi- } \\
\text { regional sources. }\end{array}$ \\
\hline 4 Sandy braided fluvial sheet & $\begin{array}{l}\text { Sm/St/Scb, } \\
\text { Sh, Sp, Sr, } \\
\text { Gl, and minor } \\
\text { Fssl }\end{array}$ & Sheet & $\begin{array}{l}\text { Low- to moderate-sinuosity sandy } \\
\text { braided streams distal to the basin } \\
\text { margin, regional sediment dispersal } \\
\text { systems and sources. Abundant } \\
\text { Scb at Clam Gulch attributed herein } \\
\text { to seismic shaking. }\end{array}$ \\
\hline $\begin{array}{l}5 \text { Meandering channel fluvial } \\
\text { sheet }\end{array}$ & $\begin{array}{l}\text { Sm/St, Sh, } \\
\text { Sp, Sr, Ssf, } \\
\text { Gl, minor Scb }\end{array}$ & $\begin{array}{l}\text { Broadly } \\
\text { lenticular }\end{array}$ & $\begin{array}{l}\text { Moderate- to high-sinuosity } \\
\text { meandering streams flanked by } \\
\text { prominent poorly drained } \\
\text { floodplains. }\end{array}$ \\
\hline 6 Overbank sheet & $\begin{array}{l}\text { Fmm/Fmb, } \\
\text { coal; minor } \\
\text { Fcm, Fml, } \\
\text { Fcl, and Fssl; } \\
\text { altered tephra } \\
\text { locally }\end{array}$ & Sheet & $\begin{array}{l}\text { Poorly drained floodplains with local } \\
\text { ponds and lakes; periodically } \\
\text { converted to vast raised mires. }\end{array}$ \\
\hline 7 Single-thread channel-fill & $\begin{array}{l}\text { Sm, St, and } \\
\text { Sr }\end{array}$ & Lenticular & $\begin{array}{l}\text { Single-thread, mixed- to suspended- } \\
\text { load fluvial channels, limited or no } \\
\text { lateral migration. }\end{array}$ \\
\hline 8 Crevasse channel & $\begin{array}{l}\text { Sm, Sh, St, } \\
\text { Sr, Ssf }\end{array}$ & Lenticular & $\begin{array}{l}\text { Small single-thread channels. } \\
\text { Distinction from association } 7 \text { may } \\
\text { be artificial. }\end{array}$ \\
\hline 9 Crevasse splay & $\begin{array}{l}\text { Sm, Sh, St, } \\
\text { Sr, Fssl, } \\
\text { Fmm }\end{array}$ & $\begin{array}{l}\text { Lobate and } \\
\text { sheet }\end{array}$ & $\begin{array}{l}\text { Crevasse splay lobes; most likely } \\
\text { includes some sheet-like levee } \\
\text { deposits. }\end{array}$ \\
\hline
\end{tabular}

*Splay assignment unless able to see channel margins.

**Single-thread and crevasse channels division based on arbitrary size cutoff. 

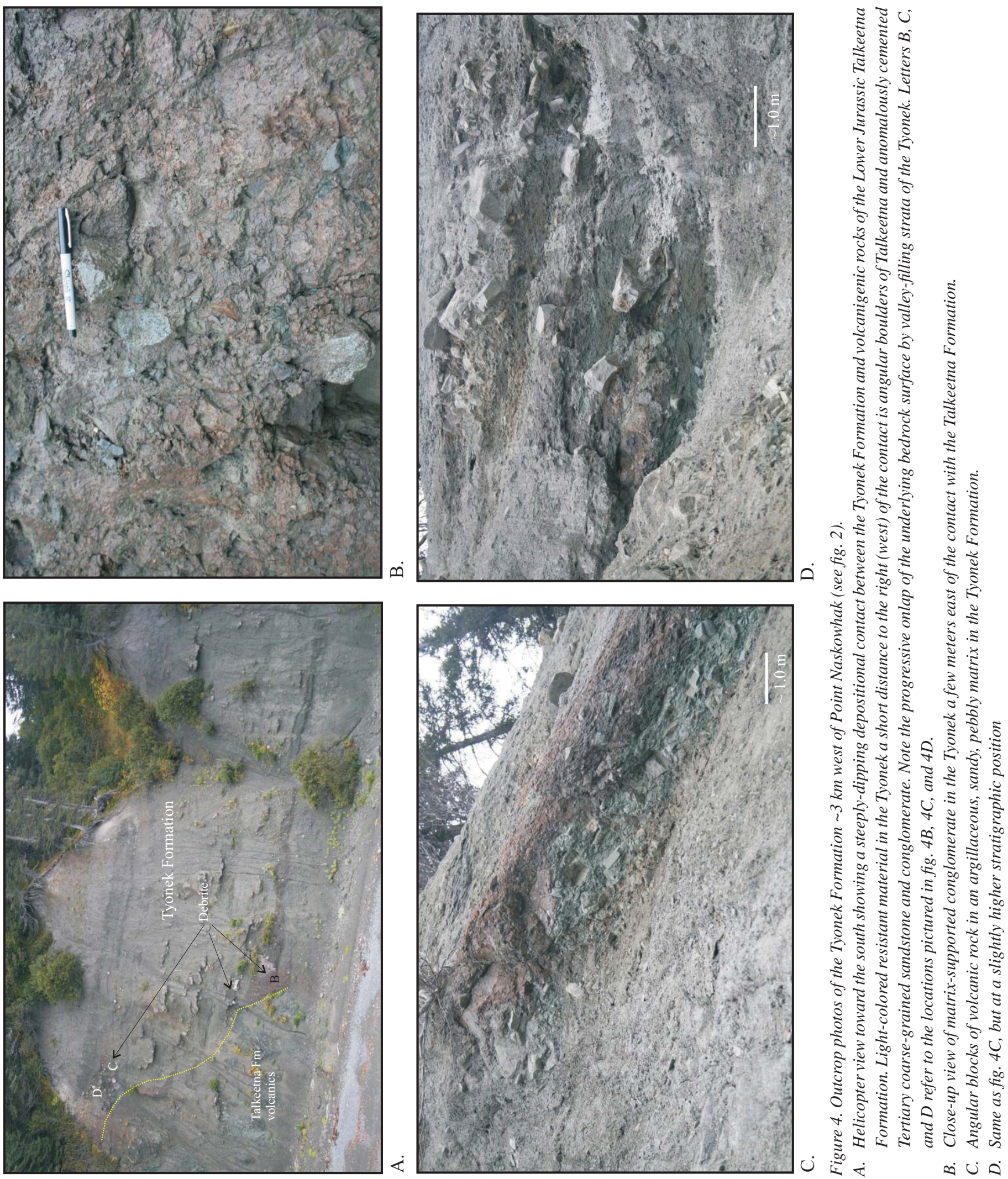


\section{Facies Association 2 - Disorganized Gravelly Braided Fluvial DESCRIPTION}

Facies association 2 consists dominantly of clast-supported massive conglomerate $(\mathrm{Gcm})$ and horizontally bedded conglomerate (Gch), with subordinate interbedded trough and planar cross-stratified conglomerate (Gct and Gcp), matrix-supported conglomerate (Gmm), massive sandstone (Sm), horizontally bedded sandstone (Sh), and trough cross-stratified sandstone (St), and minor locally developed blocky mudstone (Fmb) and coal (tables 1 and 2). Facies Gcm is most abundant, followed by Gch; both are present as tabular to broadly lenticular lithosomes up to $3 \mathrm{~m}$ thick (fig. 5a-b and 6a). Conglomerate beds extend laterally from a few meters to many tens of meters. Thin, laterally discontinuous channel fills of facies $\mathrm{Gcm}$, Gch, and Sm are present locally (fig. 6b). Clast size ranges from $0.3-15 \mathrm{~cm}$, clast shapes are equant to slightly discoidal, and sorting is very poor to poor (fig. $5 \mathrm{c}-\mathrm{d}$ ). Where enough disc-shaped clasts are present, weakly developed imbrication is recognizable locally, but clast fabric in most beds is disorganized. Low-angle sigmoidally cross-bedded gravel (Gcp) and low-angle planar bedded gravel are present locally and grade laterally to facies Gcm and Gch. Interbedded sandy facies are commonly well cemented and project out from outcrop surfaces (figs. 5b and 6a). Sandy facies are present as thin (few centimeters) discontinuous drapes separating conglomerate beds, as thin discontinuous beds up to $1 \mathrm{~m}$ thick blanketing conglomerate beds and filling depositional topography on conglomerate beds (fig. 5a, top right) and, less commonly, as laterally continuous sheets separating conglomerate beds (fig. 5a, at geologist's knee level). Amalgamated conglomerate beds are also common (fig. 5a, conglomerate body above thick sand). Poorly preserved plant material is common and well-preserved leaf fossils are present locally as are petrified logs and carbonized plant roots (fig. 5e). Mudstones are locally preserved as discontinuous drapes (fig. 5f).

\section{INTERPRETATION}

This association records deposition in low-sinuosity fluvial channels separated by low-relief longitudinal bar forms. Locally developed low-angle cross-bedded conglomerate (Gcp) records lateral or downstream accretion along the margins of larger bars. The disorganized appearance of many conglomerate beds $(\mathrm{Gcm})$ suggests deposition from sediment-laden hyperconcentrated flows (Pierson, 2005) generated during flood events. At Point Naskowhak conglomerates of this association interfinger along the margin of an incised paleovalley with debrites of the valley margin apron association. Minor coal indicates plant colonization or deposition of allochthonous plant matter in low-lying areas (topogenous mires) between active channels or in abandoned channels.

\section{Facies Association 3 - Sheetflood-dominated Alluvial Fan DESCRIPTION}

Facies association 3 consists dominantly of facies Gcm, Gch, Sm, Sh, and St. Possible cross-bedded conglomerates belonging to Gct or Gcp were observed in beds at least $2 \mathrm{~m}$ thick, but were inaccessible for further analysis. Individual conglomerate beds range from $2 \mathrm{~m}$ to at least $6 \mathrm{~m}$ thick and erosive bases are common (fig. 7a); thicker conglomerate bodies up to $15+\mathrm{m}$ probably represent amalgamated successions (fig. 7a). Conglomerate is clast supported, poorly to moderately sorted, with tightly packed poorly sorted sandy matrix. Clast sizes range from granule to $30 \mathrm{~cm}$ (fig. 7b). Imbricate clast fabrics are developed only locally (fig. 7c). Conglomerate is typically compact, but weakly cemented to uncemented; well-cemented masses occur widely scattered in most exposures and accumulate as float near the base of steep outcrops of this association. Sandstones are present as lenses up to $2 \mathrm{~m}$ thick that extend along local strike for many meters to many tens of meters (fig. 7a) and consist dominantly of facies Sm and Sh, with St locally developed. Sand lenses commonly include scattered floating pebbles and concentrated pebble accumulations 1-2 clasts thick above scour surfaces or along low-angle dipping laminae. In the study area addressed in this report, facies association 3 has only been recognized along the upper reaches of the Fox River (fig. 2), a short distance west of exposures of the Chugach terrane (McHugh Complex).

\section{INTERPRETATION}

This association is interpreted as the product of high-gradient, low-sinuosity gravelly braided streams and sheetflood processes. Crudely developed horizontal stratification resembles stratification associated with longitudinal and diagonal gravel bars in modern braided streams (Hein and Walker, 1977) and in gravelly sheetflood deposits (Blair and McPherson, 1994). Disorganized clast fabrics suggest relatively rapid deposition from flows with high sediment concentrations, and possibly from hyperconcentrated flows locally (for example, Pierson, 2005). The geometry of these deposits is unclear and hyperconcentrated flows may have been associated with channelized or un-channelized sheetfloods. Possible Gct or Gcp suggest the presence of large gravel bedforms that represent either in-channel structures or deposition along the slip face (downstream end or lateral margin) of large bar forms. 

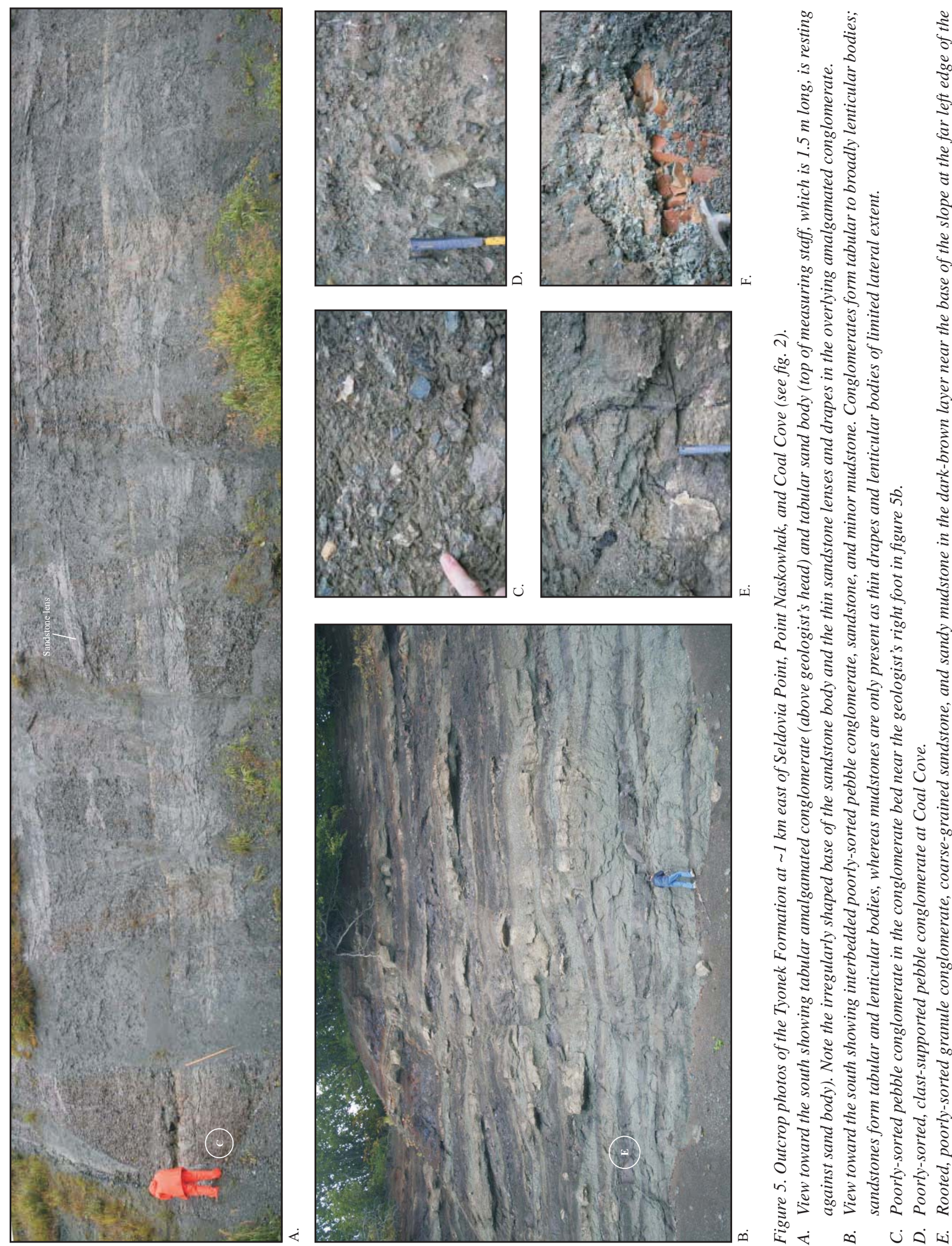

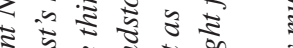

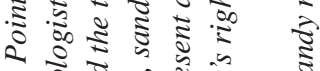

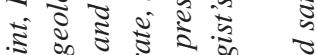

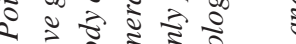

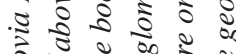

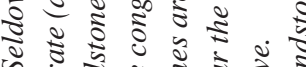

जั

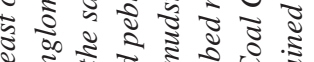

ई

ᄂ छ छ

ธ हิ ปे

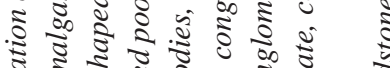

हิ जิ

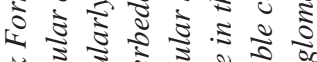

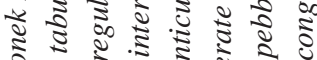

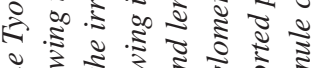

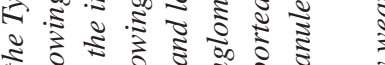

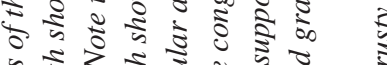

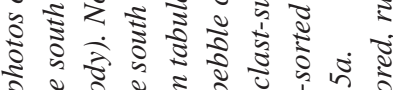

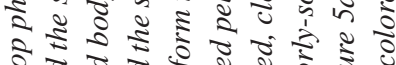

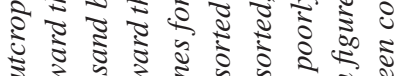

จ

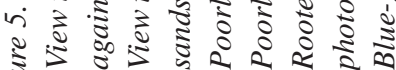

选花 


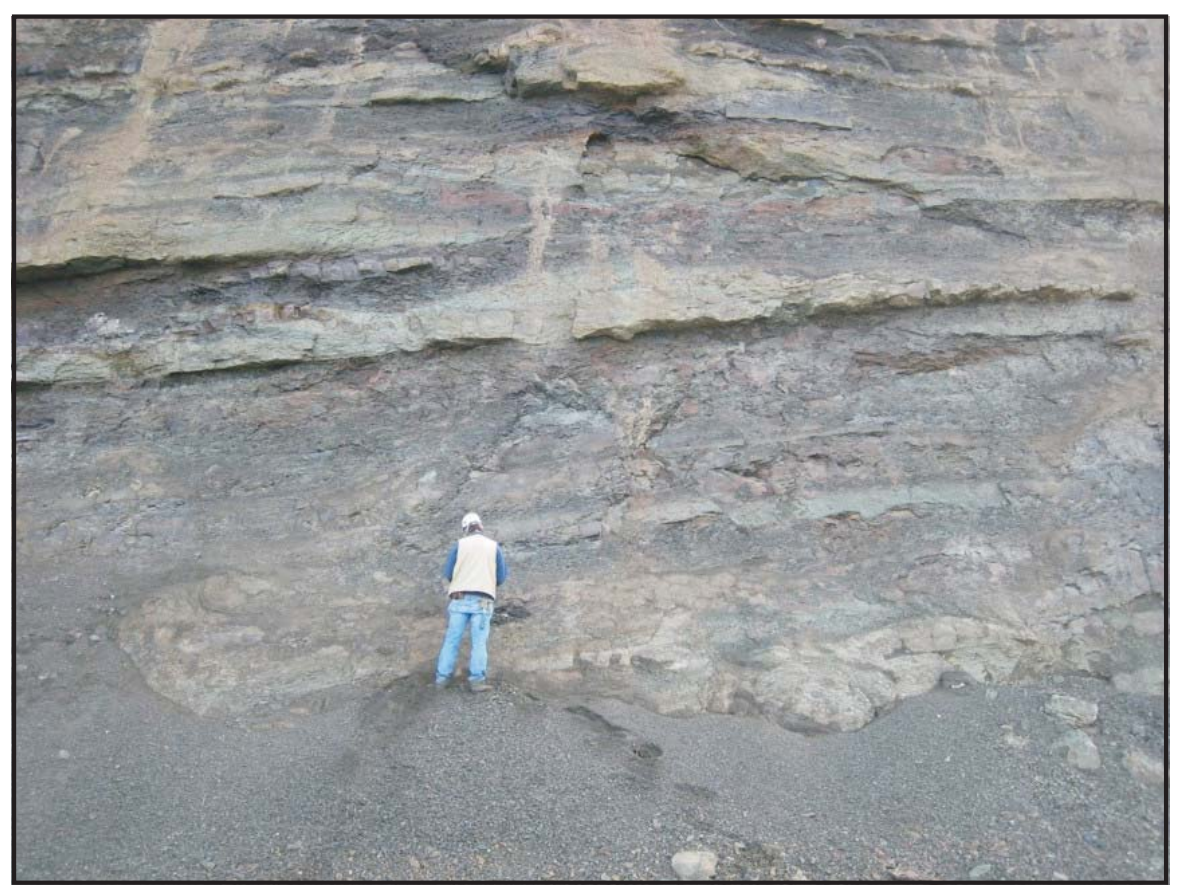

A.

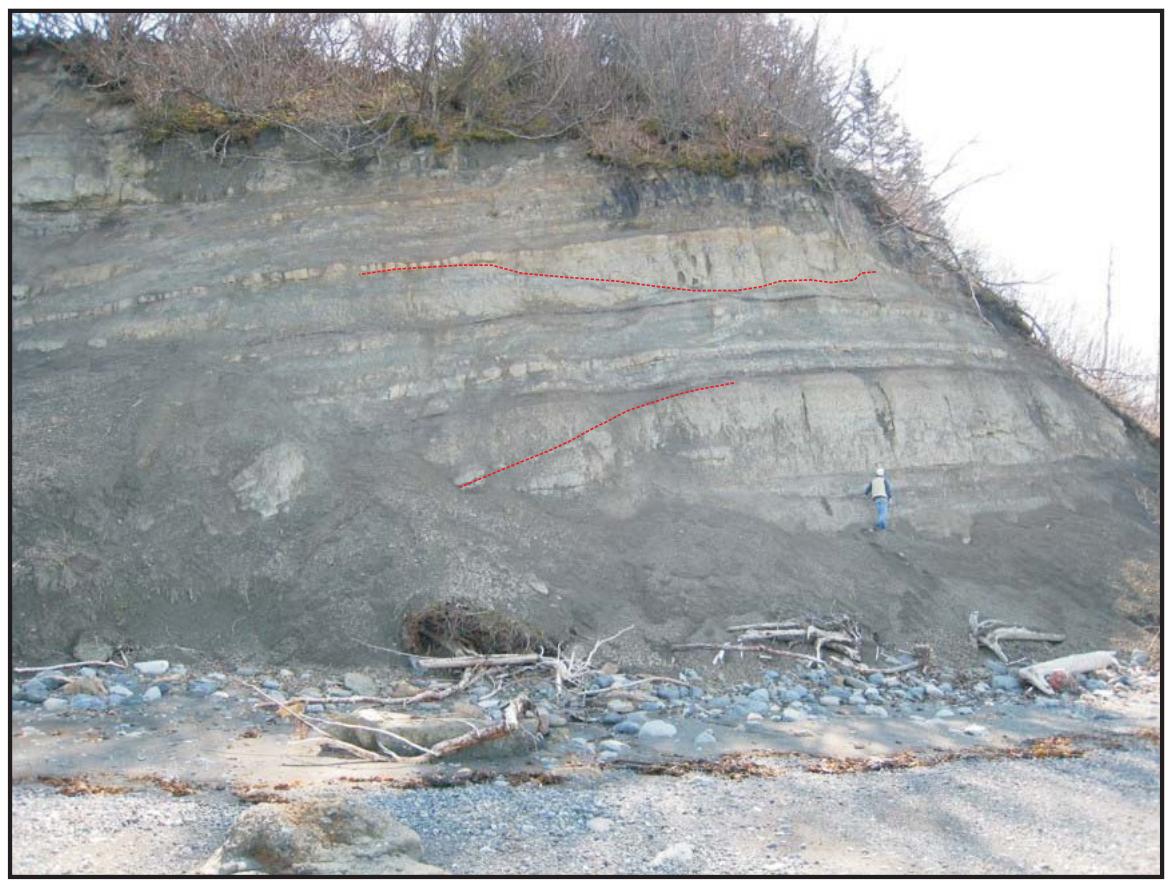

B.

Figure 6. Outcrop photos of the Tyonek Formation east of Seldovia Point (see fig. 2). Facies exposed near Seldovia Point fill a paleovalley incised into the underlying McHugh Complex.

A. Interbedded poorly-sorted pebble conglomerate and sandstone similar to the succession at Point Naskowhak (fig. 4a, right side of photo, and fig. 5a). This photograph was taken a few hundred meters east of the photo in figure $5 b$.

B. Pebble conglomerate and sandstone channel fills separated by thin tabular mudstones and sandstones east of Seldovia Point. The red lines show shallow channel scour surfaces. This photo was taken east of the location shown in figure $6 a$. 

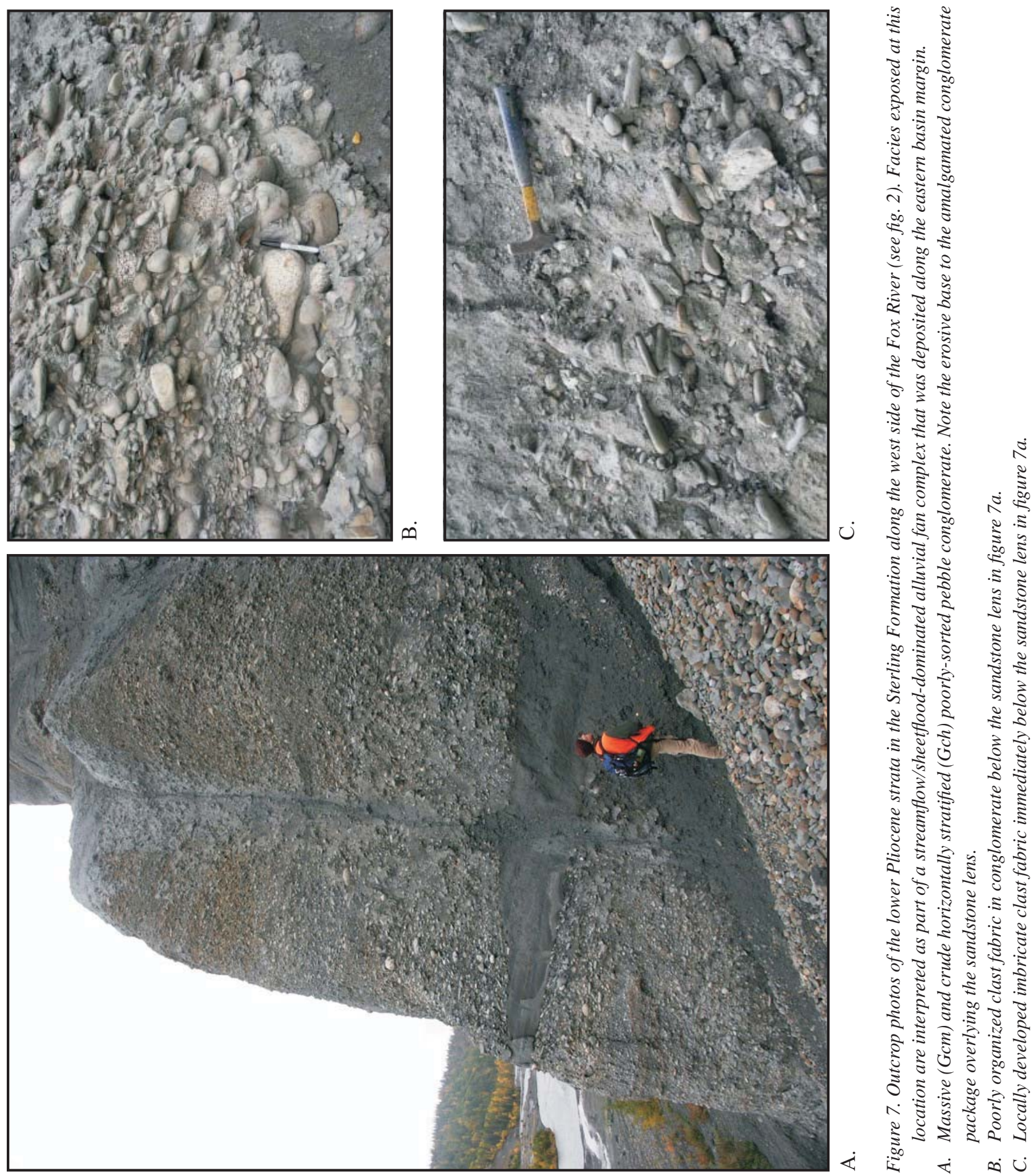
Facies Gcp/Gct demonstrates that some channels were relatively deep (>>2m). Sandstone lenses represent deposition during the waning stage of flood events as drapes in bar top positions and as minor channel fills (Miall, 1977; Rust, 1972, 1978). Characteristics of facies association 3 and its close proximity (within $0.5 \mathrm{~km}$ ) to exposures of the Chugach terrane and significant mountainous topography (at least present-day mountainous topography) suggest it represents part of a wet alluvial fan or fan complex.

\section{Facies Association 4 - Sandy, Braided Fluvial Sheet DESCRIPTION}

Facies association 4 consists dominantly of facies Sm, St, and Scb, followed in abundance by Sh, Sp, and Sr. Facies $\mathrm{Gl}$ is common and occurs in beds up to $30 \mathrm{~cm}$ thick. The facies composition of this association appears to differ across the study area. Along the west shore of Kachemak Bay, this association consists largely of subequal amounts of Sm and St, with subordinate Sp, Sh, and minor Scb (fig. 8a-d). In this area the association commonly weathers to form sheet-like sand bodies with a monotonous appearance. Along the east shore of Cook Inlet at Clam Gulch, the association consists predominantly of Scb (fig. 8e) followed in abundance by St, Sh, and Sp, all interbedded to form a complex facies mosaic of sheet-like sand bodies. Between Kachemak Bay and the east shore of Cook Inlet (Clam Gulch), along Deep Creek, the facies makeup of this association appears similar to that noted for Kachemak Bay except that convolute bedding appears more distinctive (greater abundance?; fig. 8d and 8f). In all of these areas facies Scb is made up of deformed versions of St, Sh, and Sp.

Internal low-relief scour surfaces are common and, in outcrops oriented at high angles to paleoflow, they create a complex series of intersecting surfaces, making the internal organization appear complex (fig. 9a). The presence of these surfaces allows sand bodies of this association to be distinguished from sand bodies of association 5 (meandering fluvial channel fill). Extrabasinal clasts from pebble to boulder size (up to $45 \mathrm{~cm}$ along the apparent long dimension) are widely scattered throughout this association and appear to "float" in a sandy matrix (fig. 8b). Mudstone rip-up clasts are locally abundant near the base of sand bodies assigned to this association.

Clear fining-upward grain size trends are typically only present in the uppermost few meters of the sandy braided fluvial association where they grade up-section to mudstones and coal of the overbank association. Scour at the base of sand bodies commonly resulted in sand-on-coal contacts. Prominent fining-upward successions are present only locally within some sand bodies where facies Sh, St, Sr, and Fssl overlie concave-upward scour surfaces (fig. 9b).

\section{INTERPRETATION}

This association is interpreted as the depositional record of low- to moderate-sinuosity sandy braided streams. The suite of facies recognized is similar to facies described along braided reaches of the modern sandy South Saskatchewan River (Cant and Walker, 1978). Complex internal scour surfaces recognized in some outcrops of this association are similar to surfaces recognized in sandy braided alluvium by Adams and Bhattacharya (2005) and Bristow (1993), and are discussed further in the section addressing stacking patterns and depositional systems. Association with coal and fine-grained overbank facies demonstrates that active channel tracts were flanked by aggrading floodplains. The occurrence of facies Sh, St, Sr, and Fssl above concave-upward scour surfaces are interpreted as the fill of abandoned channels.

Convolute bedding in this association warrants further discussion. Many fluvial systems documented in the literature include examples of soft-sediment deformation. In most systems these features are minor components of the total facies composition. Many examples are attributed to a combination of frictional drag at the sediment-water interface and liquefaction of over-steepened foresets. At Clam Gulch soft-sediment deformation features are ubiquitous and their abundance is not likely attributable to fluvial processes alone. We tentatively suggest that these features are related to liquefaction of clay-rich sands resulting from an external forcing mechanism. Given the Holocene record of repeated major earthquakes (Combellick, 1994), we favor a seismogenic origin for this fabric (for example, Ettensohn and others, 2002), but more work is required to test this hypothesis.

\section{Facies Association 5 - Meandering Channel Fluvial Sheet DESCRIPTION}

Facies association 5 consists of a suite of facies similar to those recognized in association 4 (Sm, St, Sh, with subordinate Sr, Ssf, Scb, and Fssl). This association is bounded below by an erosional contact with underlying overbank mudstones and above by a gradational contact with overlying overbank mudstones. The presence of lateral accretion surfaces within this association is the main characteristic that distinguishes it from the otherwise similar sandy braided fluvial association (fig. 9c). 


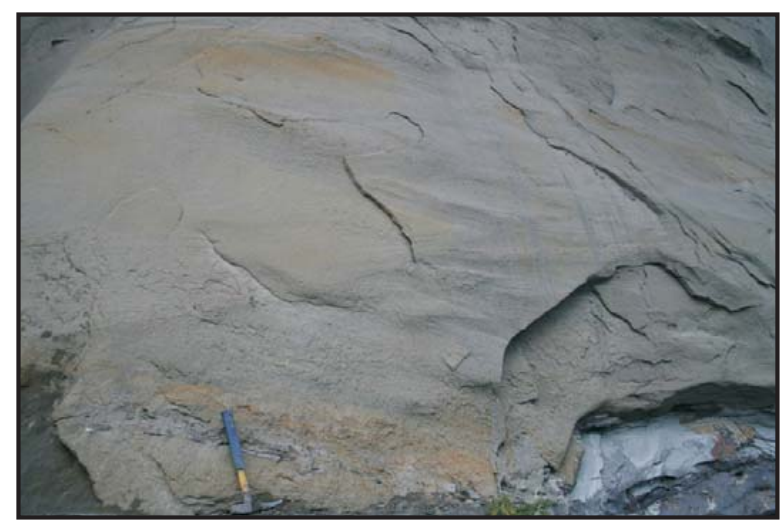

A.

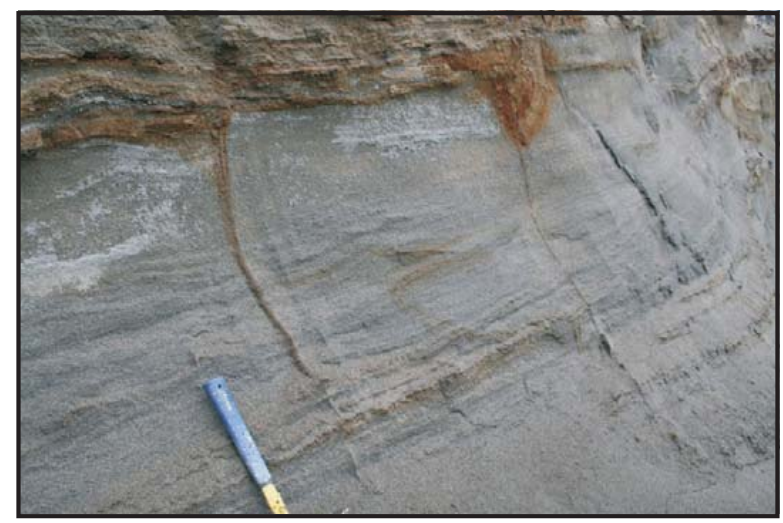

C.

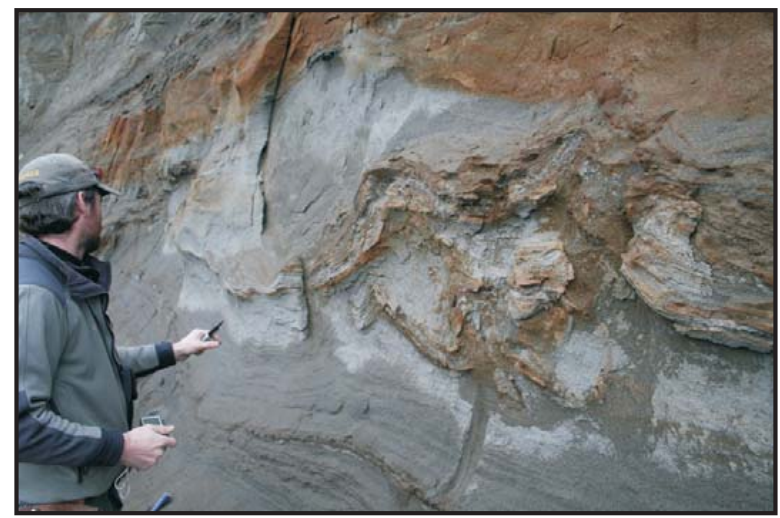

E.

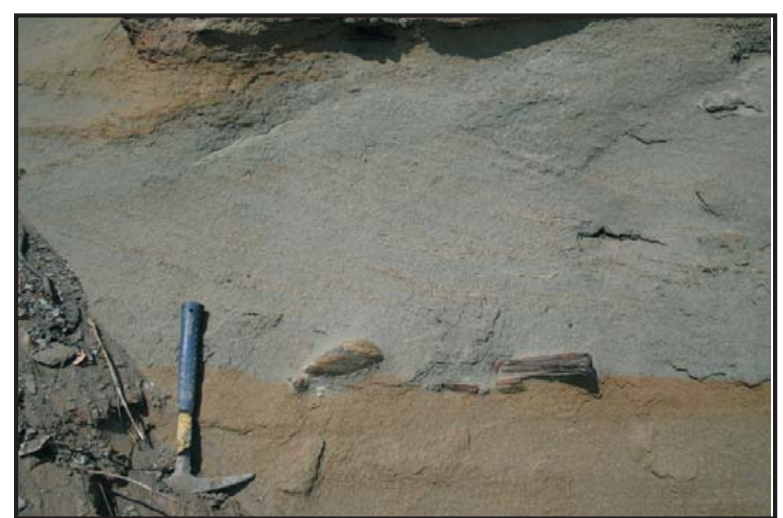

B.

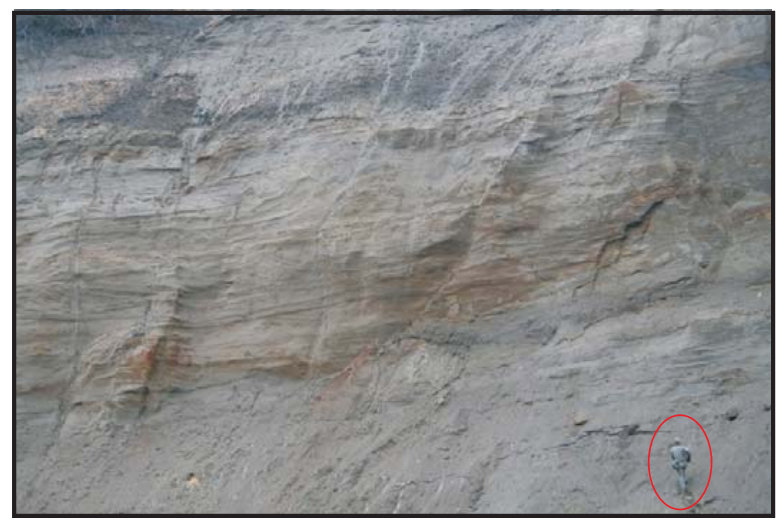

D.

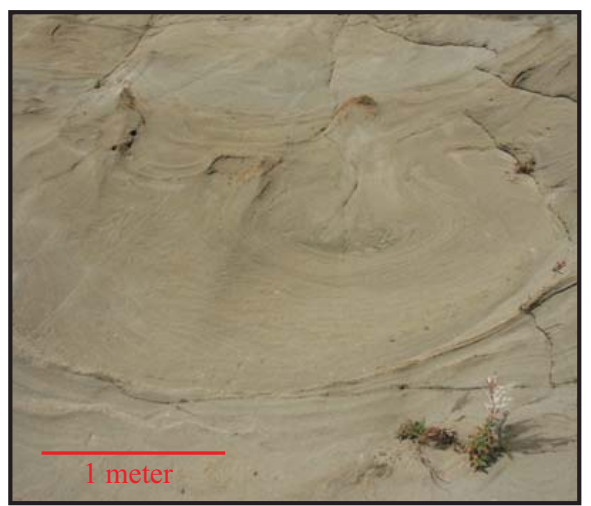

F.

Figure 8. Outcrop photos of the Sterling Formation along Deep Creek at location 07MAW03 and near Falls Creek (see fig. 2).

A. Trough cross-stratified sandstone (St) above thin, discontinuous lag of mudstone rip-up clasts (visible near top of hammer handle) near Falls Creek.

B. Trough cross-stratified sandstone (St) near the base of a tabular channel sand body near Falls Creek. Note the cobble of granitic/dioritic material and small log to the right of the hammer and immediately above the red-stained sandstone. The contact between the red-stained sandstone and the overlying sandstone corresponds to an erosion surface at the base of an amalgamated sand body.

C. Horizontally laminated sandstone (Sh) cut by thin, rusty-stained sand-filled dikes at 07 MAW03 (fig. 2).

D. Approximately $12 \mathrm{~m}$ of sandstone below an overbank mudstone package. Note the geologist in the lower right for scale. Also note several through-going surfaces that bound prominent sets of planar-tangential foresets (Sp, or St along a trough axis-parallel cut) and horizontally bedded sandstone.

E. Convolute bedded sandstone (Scb) along Deep Creek (07MAW03).

F. Convolute bedded sandstone (Scb) at Clam Gulch. 

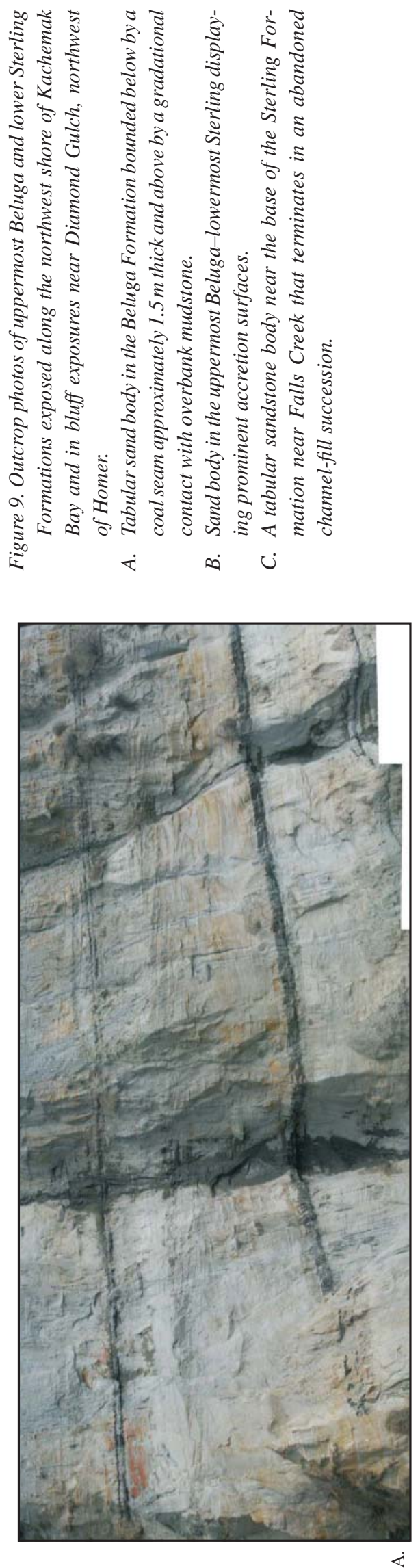

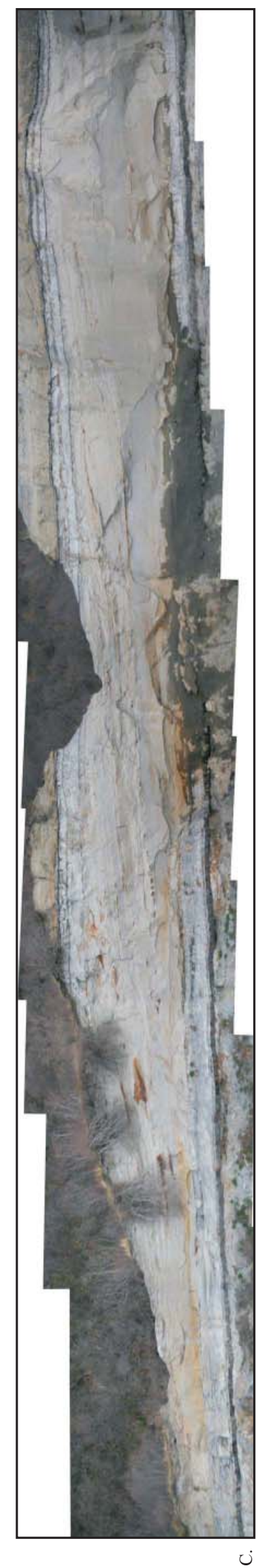




\section{INTERPRETATION}

This association is interpreted as the record of moderate- to high-sinuosity mixed-load meandering rivers. The close association with mudstones of the overbank association (above, below, and lateral to sand bodies) demonstrates that active channels were flanked by aggrading poorly-drained floodplains. Our interpretation of this facies association is tentative and based on only one location; this location also includes sand bodies assigned to facies association 4. The component facies and lateral accretion surfaces recognized in facies association 5 are not unique to meandering stream deposits, but are also common in sandy braided stream deposits. More work is required to determine if this association is truly different from facies association 4 (for example, includes point bar successions) and whether or not it is the record of high sinuosity streams.

\section{Facies Association 6 - Overbank Sheet DESCRIPTION}

Facies association 6 is prominent in most outcrops in the Kachemak Bay area, where it consists predominantly of facies Fmm, Fmb, and coal (fig. 10a-b), with locally important Fcm, Fml, Fcl, Fssl, and altered tephra (fig. 10c). Locally Fml, Fcl, and Fssl comprise facies successions up to a few meters thick in which millimeter-scale laminae are undisturbed by plant roots. The overbank association comprises tabular bodies that envelop several other facies associations, including the fluvial channel fill, crevasse channel fill, and crevasse splay associations.

Lignitic coal seams are a prominent component of this association and range from centimeters to several meters in thickness. Coals commonly include scattered yellow-white crystal clusters up to a few millimeters diameter. Coals appear to be laterally continuous over significant outcrop distances (many hundreds of meters).

\section{INTERPRETATION}

This association is interpreted to record deposition during floods beyond the confines of active fluvial channels. Deposition was largely from suspension and over time floodplains aggraded vertically. Facies Fmm and Fmb suggest a poorly-drained floodplain characterized by localized weak pedogenesis. Progradation/lateral migration and vertical accretion of related associations during flood events give the overbank association a more complex appearance. The occurrence of tephras indicates relatively common volcanic eruptions in the arc to the west. Thick, laterally continuous coal seams indicate that vast areas of the floodplain were colonized by dense vegetation, that a delicate balance between peat accumulation and subsidence was maintained for significant periods of time, and that these areas were isolated from clastic input. Scattered yellow-white crystal clusters represent fragments of tephras that were disrupted and dispersed by plant roots (Reinink-Smith, 1990; Dallegge and Layer, 2004).

The lateral continuity of coal seams bounding occurrences of the sandy braided fluvial and meandering fluvial associations suggest that catastrophic subsidence led to establishment of widespread floodplain mires. Alternatively, the lateral continuity of coals below most tabular sand bodies suggests that catastrophic and widespread subsidence shut down peat deposition, resulting in abrupt channel re-establishment (avulsion). We favor the latter interpretation.

Locally important occurrences of Fcl, Fml, and Fssl suggest deposition in floodplain ponds and lakes. Undisturbed millimeter-thick laminae typical of these occurrences suggest deposition from suspension in a low-energy environment in water deep enough to eliminate colonization from terrestrial vegetation. Local intercalations of Fssl and Fcm suggest transport in turbulent suspensions and traction transport of coarser material, possibly associated with small lacustrine deltas located near the margin of floodplain lakes.

\section{Facies Association 7 - Single Thread Channel Fill DESCRIPTION}

Facies association 7 consists of a suite of facies similar to those recognized in associations 4 and 5, but Sm, St, and $\mathrm{Sr}$ are most abundant (tables 1 and 2). The primary characteristic of this association is its lenticular ribbon to narrow sheet geometry; channel margins are commonly visible in outcrop. Many sand bodies preserve the crosssectional shape of the original channel (ribbon-like geometry), whereas other bodies record limited lateral channel migration (narrow sheet geometry). Sand bodies are up to $7 \mathrm{~m}$ thick and encased in mudstones of the overbank association. Examples of this association in laterally continuous exposures of the overbank association typically show overlapping channel fills at different stratigraphic levels (fig. 11). 


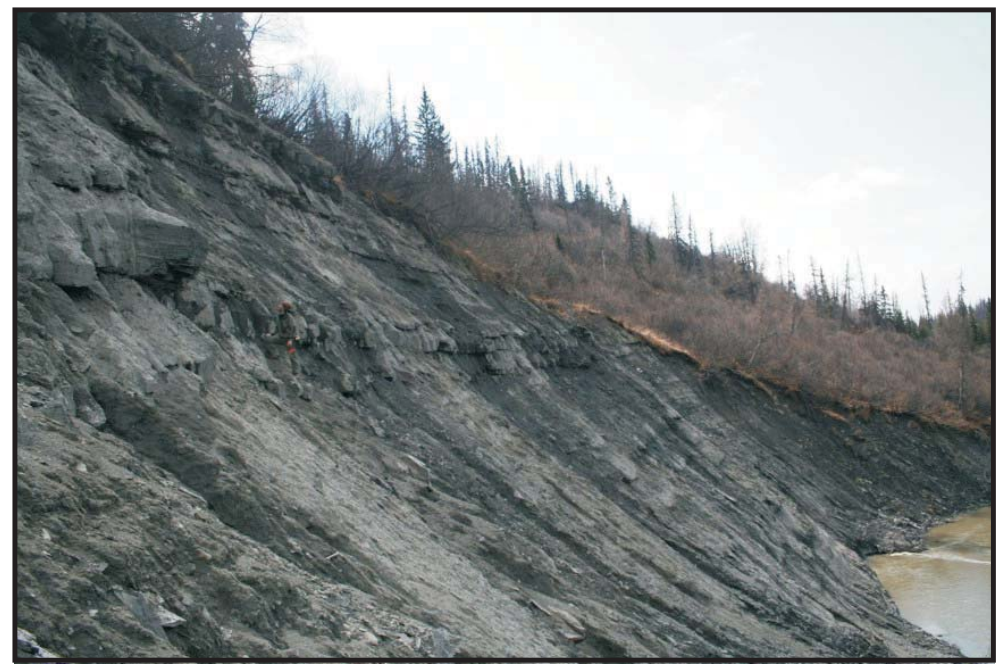

A.

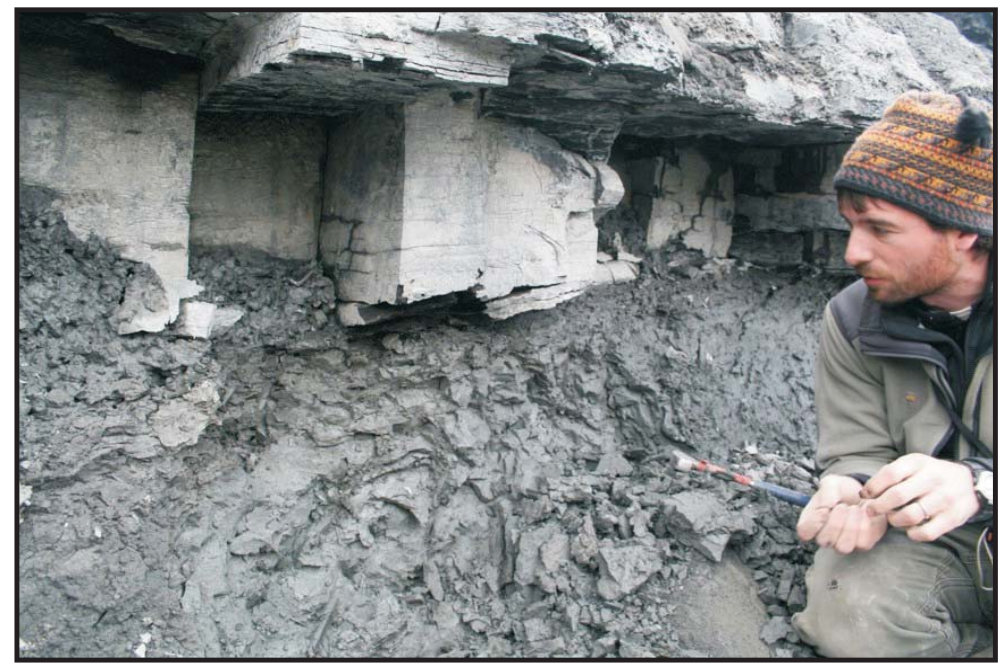

B.

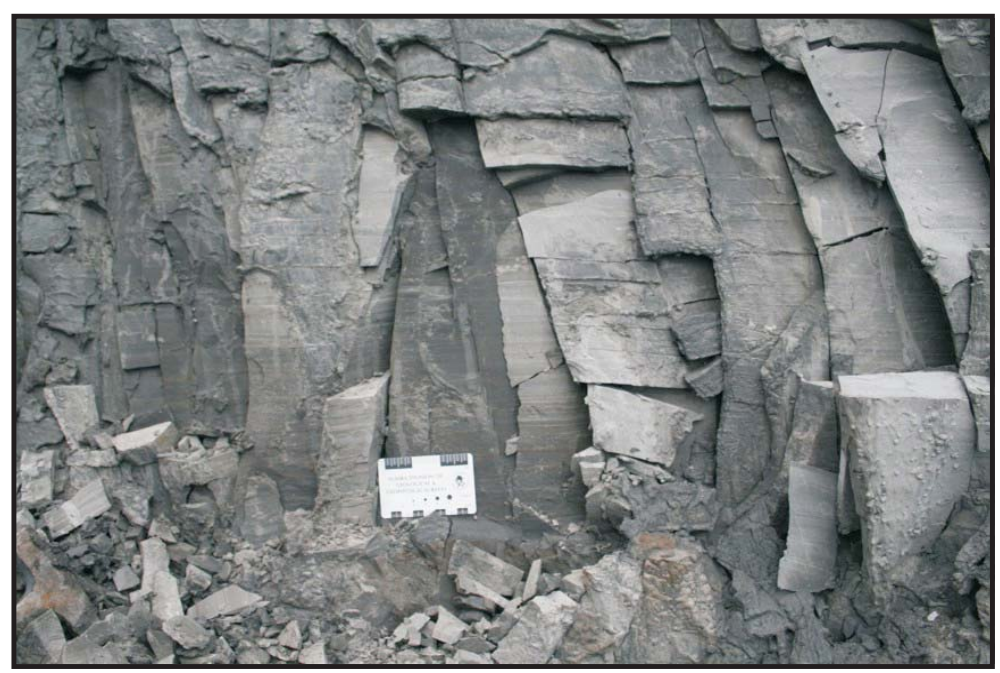

C.
Figure 10. Outcrop of an overbank succession exposed along the east shore of the Fox River (fig. 2). The age of this succession is unknown, but its location near exposures of the Sterling Formation suggest it is part of this unit.

A. View toward the south showing approximately 12 m of overbank mudstone and thin lignitic coal.

B. Contact between a lignitic coal (even with geologist's head) and an underlying mudstone.
C. Laminated argillaceous mudstone (Fml) shale from the Beluga Formation near Fritz Creek (06PJM04 at 9m). 

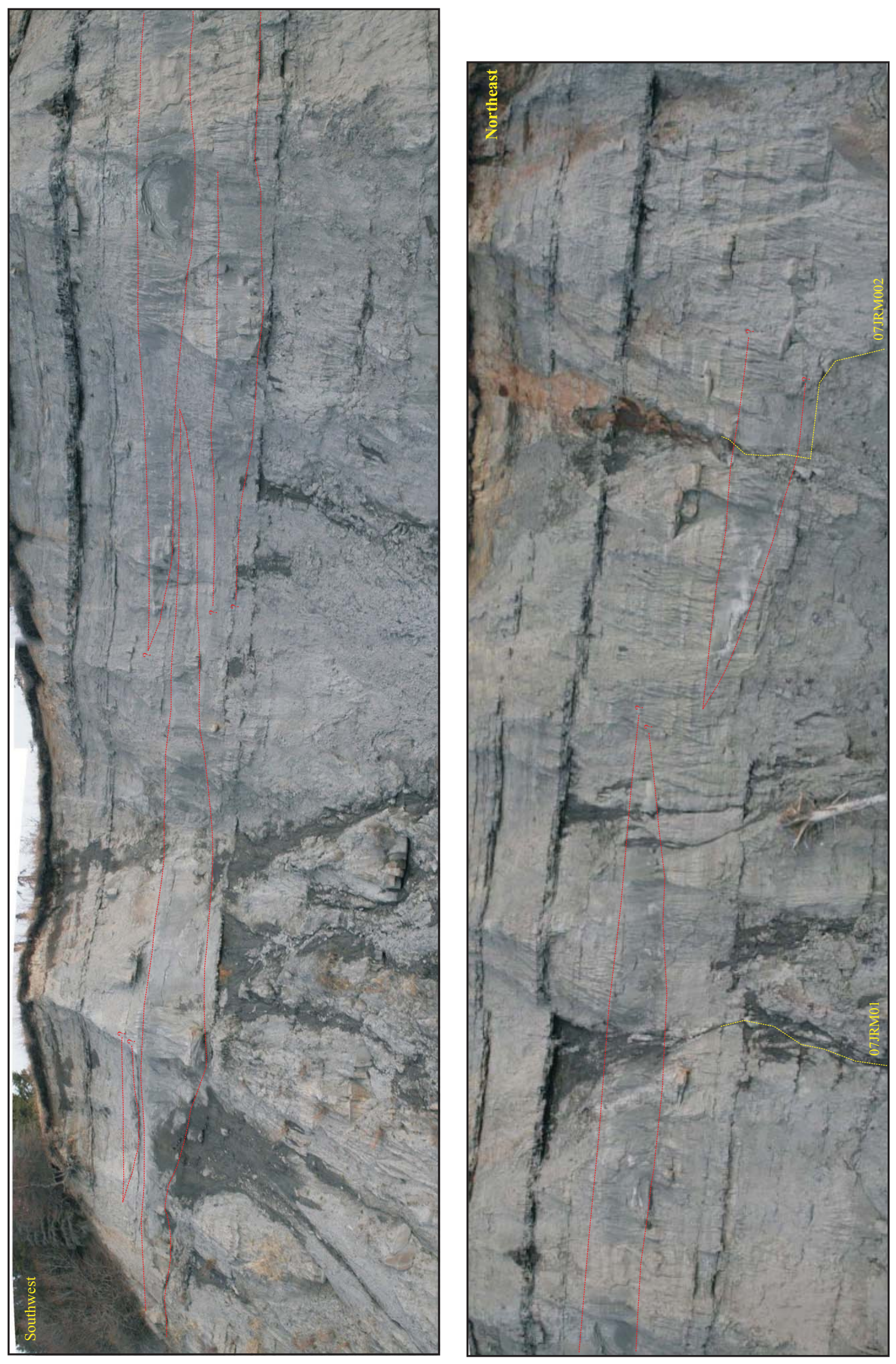

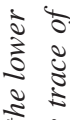

万ิ

:ั้

$\frac{\sigma}{2}$

ฐ $\Xi$

ป

ฐ ฐ

ฆे है

한

क्ष ई

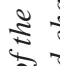

원

जิ

ฐิ

है ญ

จิ

के

ङँ

ฮั

$\mathcal{2} 0$

츠

s.

$\approx 5$

ป

है ธี

호 ㅎํㄴ

ริ ฐิ

के के

ป ฐ

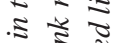

ป छ

ชั ปิ

옹

के छे

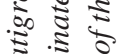

के

D.

उิ ริ

के

ป :

ปิ

ธิ ป

은

के ॠँ क्ष

ธี ธี

$\therefore \div$ ज

ปี ะ 


\section{INTERPRETATION}

Association 7 resembles anastomosed fluvial sand bodies described by Kirschbaum and McCabe (1992), Nadon (1994), and Rygel and Gibling (2006) in that it forms ribbon- and narrow sheet-like sand bodies. It differs from these published examples in that multiple sand bodies have not yet been recognized at the same stratigraphic level in the study area; outcrop examples of this association include overlapping channel sands at different stratigraphic levels. We interpret association 7 as the record of single-thread mixed- to suspended-load channels that experienced limited lateral migration. Our interpretation differs from Flores and Stricker (1992), who interpreted the same exposures as the record of anastomosed fluvial channel fills.

\section{Facies Association 8 - Crevasse Channel DESCRIPTION}

Facies association 8 consists of facies Sm, Sh, St, Sr, and minor Ssf. These facies comprise the fill of narrow channels that range from 1 to $3 \mathrm{~m}$ thick and $5 \mathrm{~m}$ to many tens of meters wide. Channels are encased in the tabular mudstone association. Channel fills of association 8 resemble association 7, but are significantly smaller.

\section{INTERPRETATION}

This association is interpreted as a crevasse channel-fill succession. Crevasse channels formed when levees bounding larger meandering(?) trunk channels were breached during flood events (high flow stage). Preliminary data suggest that crevasse channels are more common in overbank deposits that include larger channels of association 7.

\section{Facies Association 9 - Crevasse Splay DESCRIPTION}

Facies association 9 occurs encased within mudstones of the overbank association and consists of Sm, Sh, St, Sr, Fssl, and Fm. This association forms sheet-like bodies composed of sandstone-mudstone couplets that range from decimeters to approximately $2 \mathrm{~m}$ thick; locally this association consists of amalgamated sand beds, each up to a few decimeters thick. Facies Sm, Sh, and/or St form the base of these couplets; individual sheets can consist of a single couplet or multiple couplets. Plant roots are locally common.

\section{INTERPRETATION}

This association is interpreted to record deposition as channel levees and as crevasse splay sheets. Available data do not allow differentiation between splay sheets and levee deposits. We infer that splay sheets probably account for the bulk of this association. Single sand-mud couplets, stacked sand-mud couplets, and amalgamated multi-decimeter-thick sand-on-sand beds likely record distal to proximal variations in crevasse splay deposition.

\section{STACKING PATTERNS AND DEPOSITIONAL SYSTEMS}

In this section the facies associations presented above are placed in a depositional systems context. Associations in late Oligocene(?) to early Miocene strata between Barabara Point and Coal Cove are discussed first, followed by middle to upper Miocene strata near Homer, and ending with Pliocene strata along the northwest shore of Kachemak Bay, Deep Creek and Clam Gulch, and the Fox River. Facies and facies associations are identified on the measured sections at the end of this report. Figure 12 is a schematic representation of fluvial style interpreted for formations of the Kenai Group exposed in the study area and will be referred to throughout this section.

\section{Tyonek Formation-Barabara Point to Coal Cove}

Late Oligocene to early Miocene strata assigned to the Tyonek Formation fill paleotopographic depressions developed on Mesozoic rocks of the Talkeetna Formation and McHugh Complex between Barabara Point and Coal Cove (fig. 2). This is most clearly demonstrated at Coal Cove and Point Naskowhak, where the accumulations are interpreted as paleovalley fills (fig. 12). At the latter location the valley margin apron association (table 2) rests abruptly with angular discordance above dark green- and maroon-weathering volcanic rocks of the Lower Jurassic Talkeetna Formation (fig. 4a). Debrites of this association interfinger laterally over short distances (5-30 m) with conglomerates of the disorganized gravelly braided fluvial association. Stratigraphically higher debrites clearly backstep (shift away from the paleovalley axis) up the margin of the paleovalley and show an unequivocal onlap relation (fig. 4a). Clast and matrix compositions closely reflect the parent material in the subjacent Talkeetna Formation and were obviously locally sourced. The valley margin apron association represents talus aprons that 


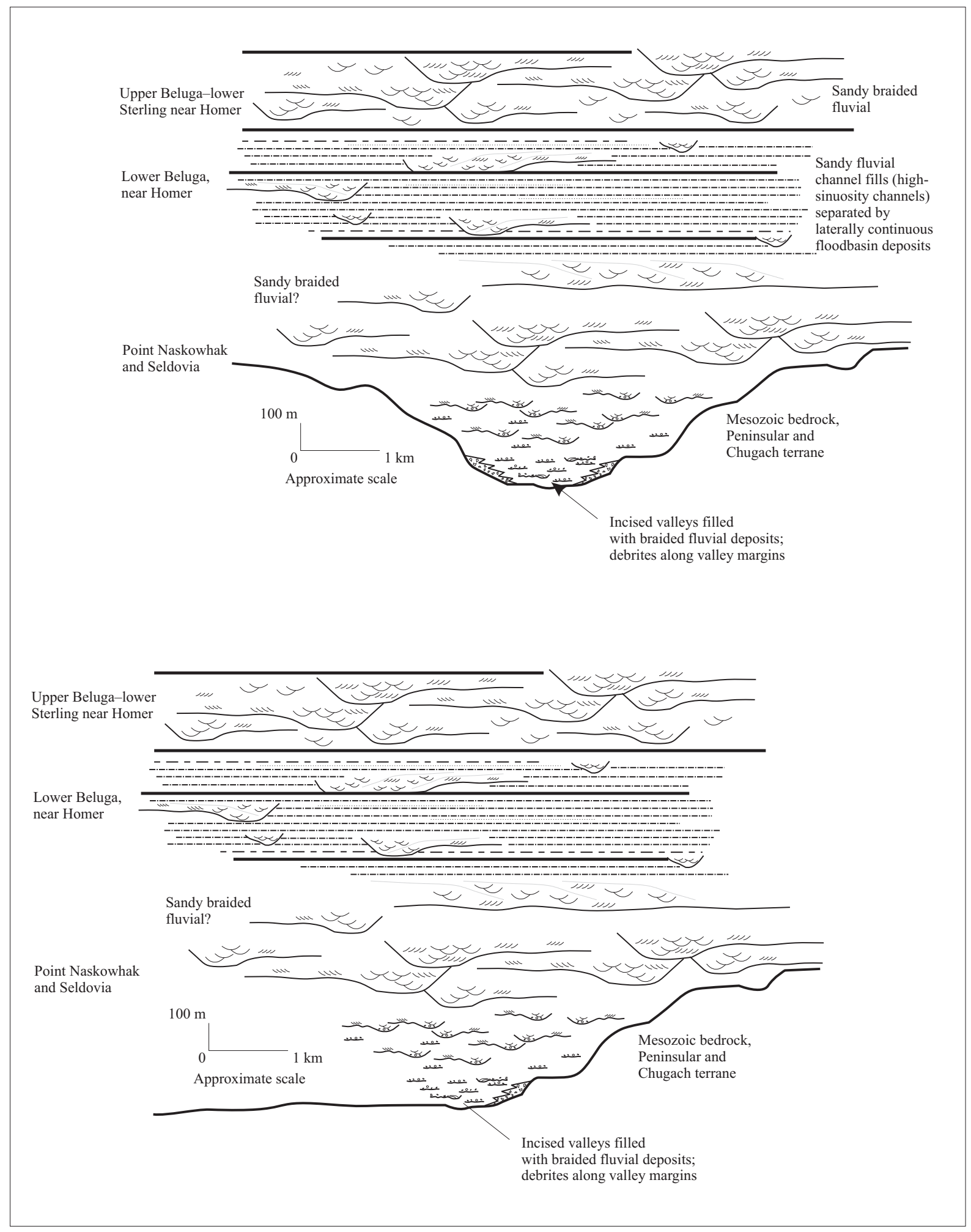

Figure. 12. Line drawing illustrating the evolution of fluvial style from late Oligocene through early Pliocene time in the Homer-Kachemak Bay area. Scale is approximate only. 
accumulated at the toe of exposed bedrock slopes. Angular clasts and clast-supported fabrics typical of these debrites suggest an origin whereby hill slope colluvium was mobilized during high rainfall events (or seasonal snowmelt) and transported downslope as debris flows. Debrites grade toward valley axes into the deposits of lowsinuosity braided streams responsible for depositing the disorganized gravelly braided fluvial association. The disorganized nature of these conglomerates suggests flashy streams that were prone toward hyperconcentrated flows (for example, Pierson, 2005). Sand lenses and sand drapes were deposited during waning flow stage and during low-flow periods. The paleovalley near Point Naskowhak has an apparent width parallel to the shoreline of $1.7 \mathrm{~km}$. Minimum estimates of the depth of incision are provided by the thickness of Tertiary strata preserved in these exposures: $15 \mathrm{~m}$ at Coal Cove (and Point Pogibshi) and at least $30 \mathrm{~m}$ at Point Naskowhak.

The succession at Coal Cove is similarly interpreted as a paleovalley-fill succession, but the actual valley walls are poorly exposed. At this location, an interfluve of Talkeetna volcanics separates what are thought to be two narrow paleovalleys, each probably less than $0.5 \mathrm{~km}$ in apparent width parallel to the shoreline.

A much thicker Tertiary succession is exposed between Seldovia Point and Barabara Point, east of Seldovia Bay, which is addressed in more detail by Finzel and others (this volume). The Tertiary succession at this location dips gently toward the east and the base is exposed near Seldovia Point where the entire bluff height of approximately $14 \mathrm{~m}$ consists of pebble conglomerate and lenticular sandstone of the disorganized gravelly braided fluvial association (fig. 6a). Lithologies present in nearby exposures of the Mesozoic McHugh Complex are recognized as clasts in conglomerate of this association. The contact between Tertiary deposits and underlying Mesozoic rocks is not exposed, but progressive overlap of Mesozoic rocks by Tertiary conglomerate and sandstone is apparent (fig.13a) and supports interpretation of this succession as the fill of an incised paleovalley. Valley margin alluvial apron deposits have not been recognized at this location. The gravelly braided fluvial deposits grade upsection to better organized sandstones and mudstones interpreted as distal sandy braided fluvial (association 4) and floodplain deposits (association 6) that reflect deposition beyond the confines of the paleovalley (Finzel and others, this volume).

In summary, Tertiary rocks mapped as Tyonek Formation include gravelly braided fluvial deposits that filled the axial region of incised paleovalleys that were cut into Mesozoic bedrock of the Peninsular and Chugach terranes. Debrites formed a discontinuous alluvial apron along the valley margin and represent slope colluvium. Between Barabara Point and Seldovia Point locally sourced incised paleovalley fill deposits grade up-section to mixed-load distal braided fluvial deposits that likely extended beyond the confines of incised paleovalleys. Distal braided alluvium near Barabara Point megascopically appears to record sediment derived from more regional sources. Flores and others (2004) reported the occurrence of tidally influenced deposits in the Tyonek between Barabara and Seldovia points but did elaborate. We did not find tide-influenced facies in Tyonek outcrops in this area.

\section{Lower Beluga Formation-Bluff Point to McNeil Creek}

Exposures of late Miocene strata in coastal bluffs northwest and northeast of Homer are thought to represent stratigraphic positions relatively low in the Beluga Formation (Adkison and others, 1975). These exposures consist largely of associations 6, 7, 8, and 9 (table 2). The overbank association envelops the fluvial channel fill, crevasse channel, and crevasse splay associations (associations 7, 8, and 9, respectively). Overbank deposits of association 6 dominate these exposures. Figure 11 shows a photomosaic of bluff exposures east of Fritz Creek, on the west shore of Kachemak Bay, that illustrates sand body geometry and the relative abundance of sandy versus muddy associations. Measured section 07JRM01 and 02 intersect relatively thick overbank successions (association 6) with thin crevasse splay sand sheets (association 9). Measured sections 06PM003 and 004 also intersect relatively thick overbank deposits with numerous crevasse splay sheets (association 9) and possible crevasse channel fills (association 8). The fluvial channel-fill association forms broad ribbons to narrow sheet sand bodies that cut into underlying mudstones of the overbank association (figs. 11 and 12). These sand bodies are interpreted as the product of single thread rivers that traversed poorly drained floodplains and did not migrate significant distances laterally. Our interpretations contrast with those of Flores and Stricker (1992), who interpreted the succession near McNeil Creek as the product of suspended-load anastomosed streams.

Bluff exposures northwest of Bluff Point closely resemble exposures of the lower Beluga Formation near Fritz Creek (fig. 14). Measured section 07MAW204 intersects a thick overbank succession (association 6) with numerous crevasse splay and probable crevasse channel sand bodies (associations 8 and 9). The lower Beluga at this location is similar to the succession exposed near Fritz Creek in that overbank deposits represent a prominent part of the depositional system.

In summary, the lower Beluga Formation in the vicinity of Homer and Kachemak Bay is characterized by broad ribbon-like and narrow sheet-like sand bodies bounded by thick, laterally continuous overbank mudstone 


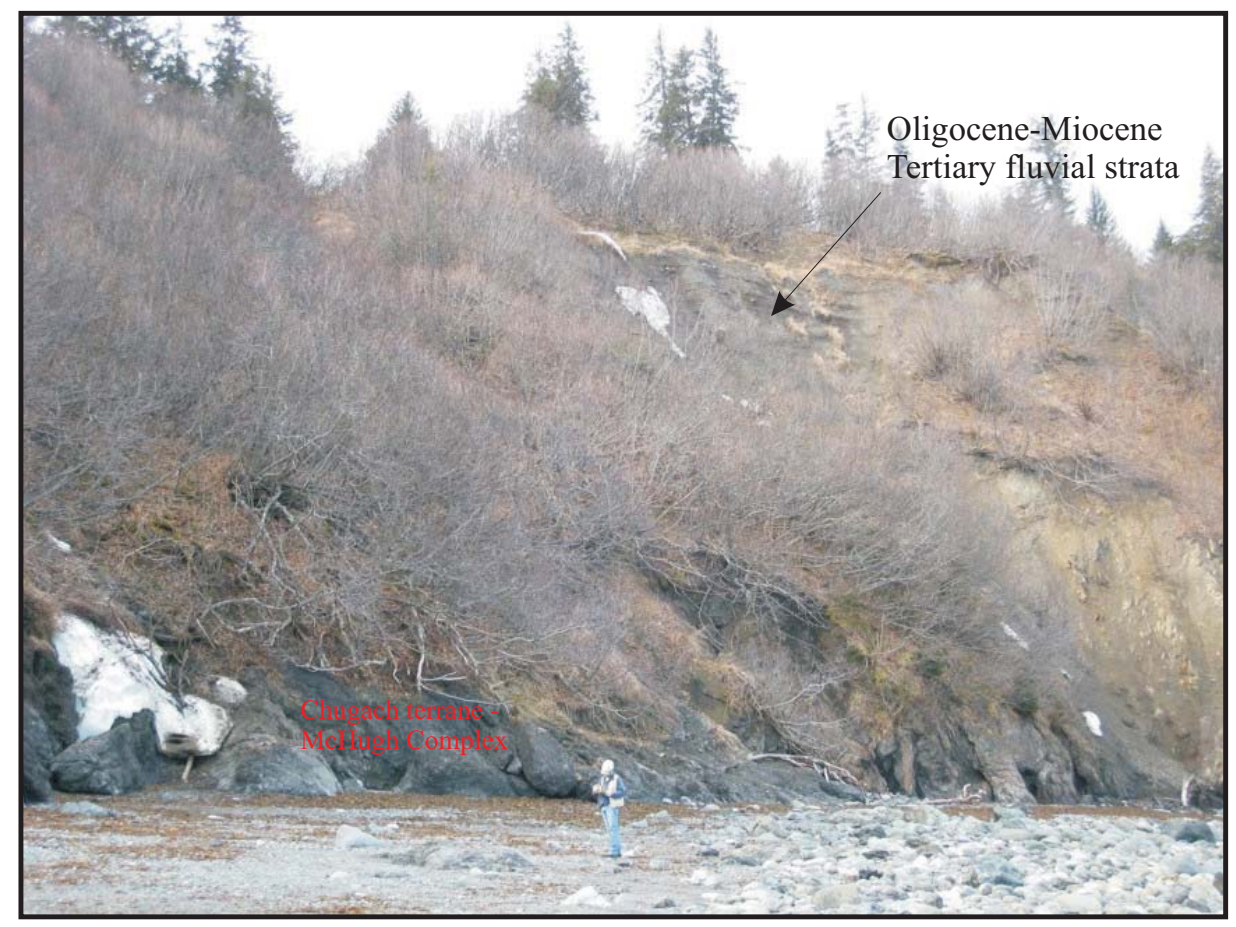

A.

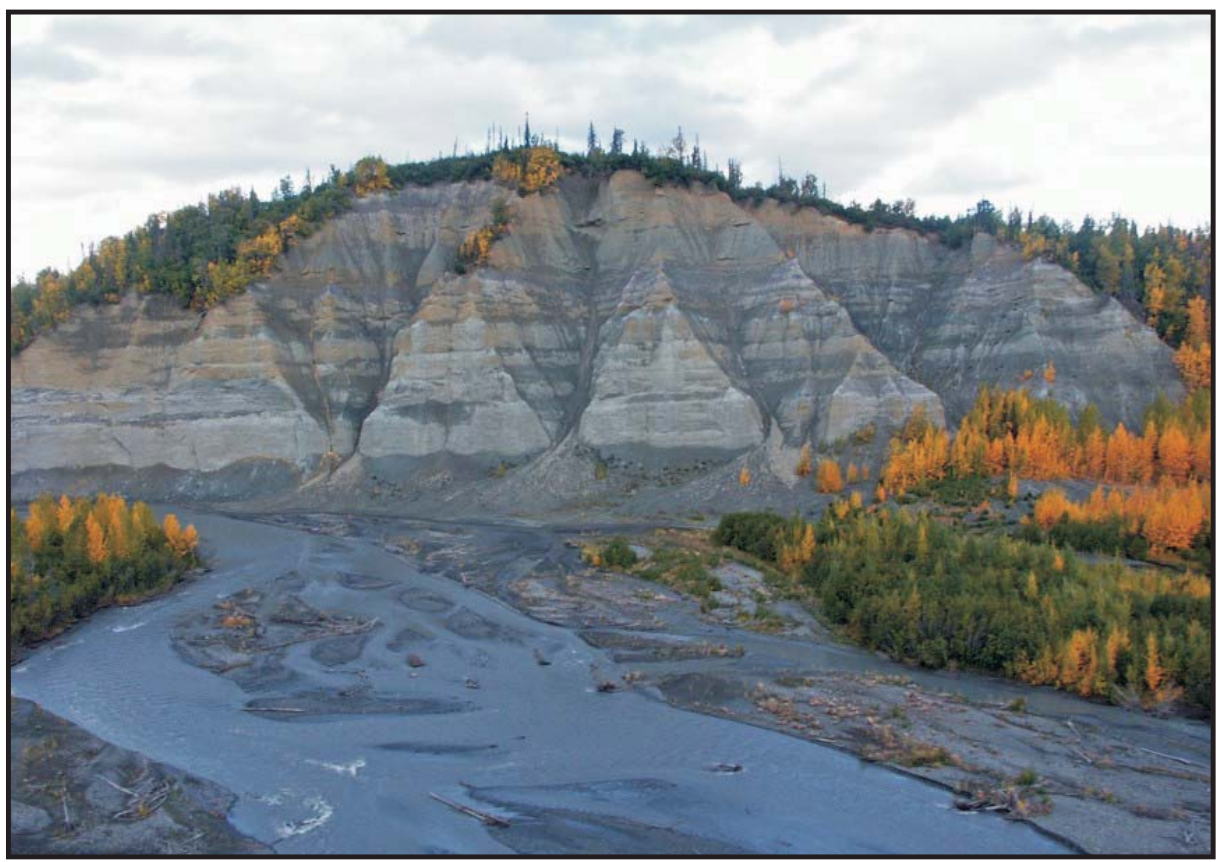

B.

Figure 13. Outcrop photos of Tertiary strata near Seldovia Point and along the upper Fox River (see fig. 2).

A. Exposures of the McHugh Complex at beach level overlain by poorly exposed valley-fill strata of the Tyonek Formation.

B. Helicopter view toward the west showing early Pliocene alluvial fan deposits of the Sterling Formation very close to the eastern basin margin. 


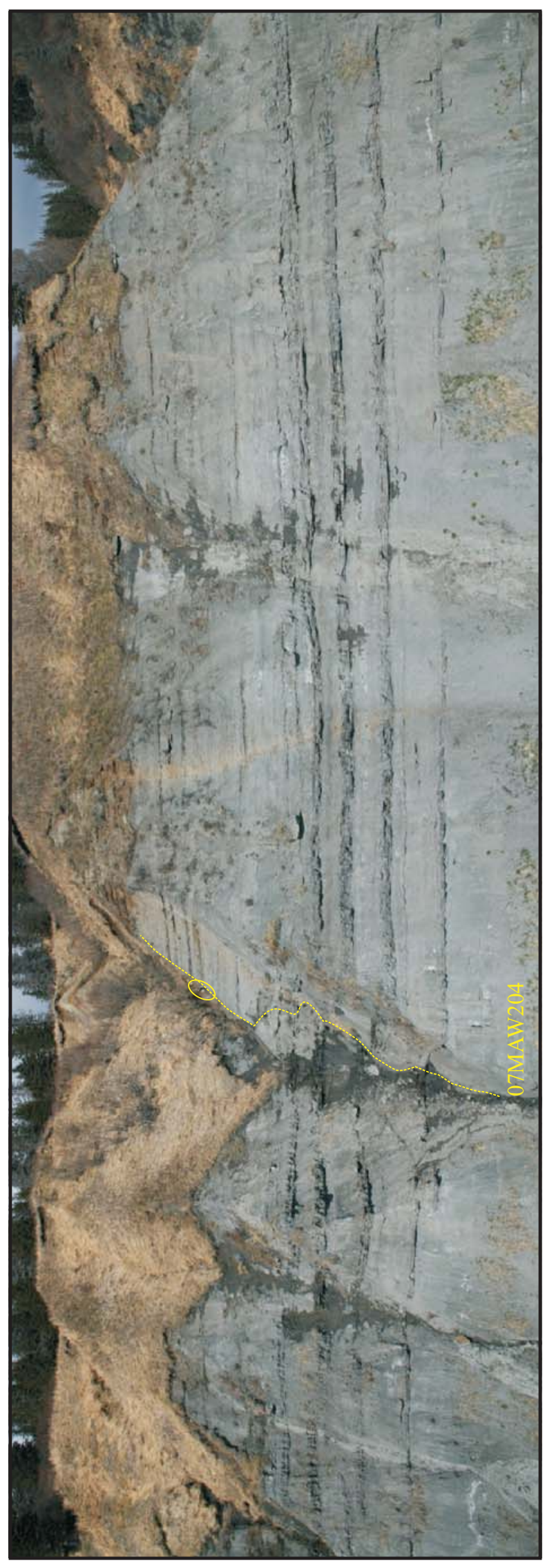

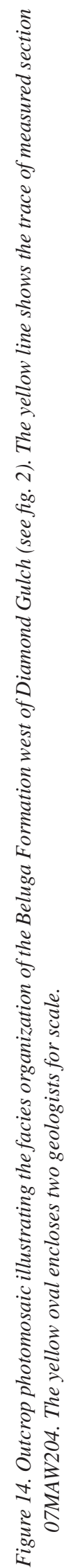


successions. These sand bodies are interpreted as the products of single-thread streams that carried a significant percentage of their total load in suspension. Frequent flood events led to accretion of significant thicknesses of overbank mudstones. Locally, numerous small channel fills and thin sheet-like sand bodies suggest that flow in the larger streams frequently broke through their levees to deposit crevasse channel and splay sand bodies. Thick, laterally continuous overbank deposits record deposition in a high accommodation setting.

\section{Upper Beluga Formation to Lower Sterling Formation-Falls Creek}

Exposures of latest Miocene to Pliocene strata near Falls Creek on the west shore of Kachemak Bay straddle the Beluga-Sterling formational boundary as placed by Adkison and others (1975). These workers placed the formation contact at the base of a channel sand body exposed just above the beach a short distance northeast of the mouth of Falls Creek (their measured section L5) and noted, "The position of the contact is broadly determined by an upward change in the heavy mineral suites...." Their measured sections are generalized and do not show a gross change in stratigraphy (for example, sand:mudstone) across the position of their contact. This is consistent with our observation that the Beluga-Sterling contact in this region appears gradational based on a gradual change in fluvial style. Related to this gradual change in fluvial style is a gradual up-section decline in the thickness of coal seams.

Exposures of the uppermost Beluga and lowermost Sterling near Falls Creek are characterized by laterally continuous sand bodies up to $12 \mathrm{~m}$ thick consisting of the sandy braided fluvial and meandering fluvial sheet associations (association 4 and 5). Overbank mudstones and lignitic coal seams of association 6 form laterally continuous caps (up to $5 \mathrm{~m}$ thick) to many sheet sand bodies. Although prominent in these bluff exposures, the overbank association is thinner than exposed in the lower Beluga. Many sand bodies of the sandy braided fluvial association are internally monotonous and consist largely of massive sandstone and trough cross-bedded sandstone (fig. 15). Some sand bodies assigned to association 4 include numerous large, overlapping concave-upward surfaces suggestive of multi-lateral scours typical of sandy braided fluvial deposits (fig. 9a). Sand bodies of the meandering fluvial sheet association include uniformly dipping surfaces indicative of lateral accretion (fig. 9c). The range of internal organization noted here suggests that upper Beluga-lower Sterling rivers included both braided and meandering channel geometries. Although thinner than in the lower Beluga, the presence of laterally continuous overbank deposits (association 6) suggests that rivers were still flanked by prominent floodplains. The reduced thickness of overbank deposits is probably the result of increased erosion from laterally migrating and avulsing river channels. Many thick sand bodies rest in erosional contact on lignite seams, demonstrating that channels scoured down to the level of underlying peat mats, but could not cut through them. Increased erosion and reduced thickness of overbank deposits are attributed to deposition in lower accommodation settings.

\section{Sterling Formation-Deep Creek}

Outcrops assigned to the Sterling Formation occur discontinuously along the valley of Deep Creek, west of the Fox River. The stratigraphic position of these exposures in the Sterling is unclear. Flores and Stricker (1993) note that exposures at Clam Gulch represent the upper Sterling Formation, but do not explain the basis for this interpretation. The exposures along Deep Creek are separated from Clam Gulch by at least one major northeasttrending fold and from exposures along the Fox River by at least two major folds (fig. 2; see Magoon and others, 1976). These structures complicate determination of the stratigraphic position of the Deep Creek exposures within the Sterling Formation.

Many exposures consist predominantly of sandstone of association 4 (figs. 15 and 16a) or a combination of association 4 (sandy braided fluvial) and mudstones of association 6 (fig. 16b). The laterally discontinuous nature of these exposures makes classifying sand body geometry and evaluating the lateral continuity of overbank deposits particularly difficult; we infer sheet-like geometries based on comparison with similar sand bodies in the lower Sterling along the west shore of Kachemak Bay.

Intersecting outcrop faces illustrate the internal organization of an amalgamated sand body at location 07MAW03 (fig. 2) and provide insights on fluvial channel style. The outcrop faces shown in figure 16a intersect at a high angle to provide nearly orthogonal views through a multistory and multilateral sand body at least $20 \mathrm{~m}$ thick. Three surfaces of different order are visible in both (fig. 16a). One class of surface can be traced across the exposure and correlated between the two faces; these surfaces bound individual stories. The second class of surface is internal to the individual stories and probably bounds bar and channel architectural elements (fig. 16a, left of bend; for example, Miall, 1995). The other class of surface is internal to these elements, cannot be traced significant distances, and probably records slipfaces with smaller-scale dunes that comprise the large bars and channel elements 


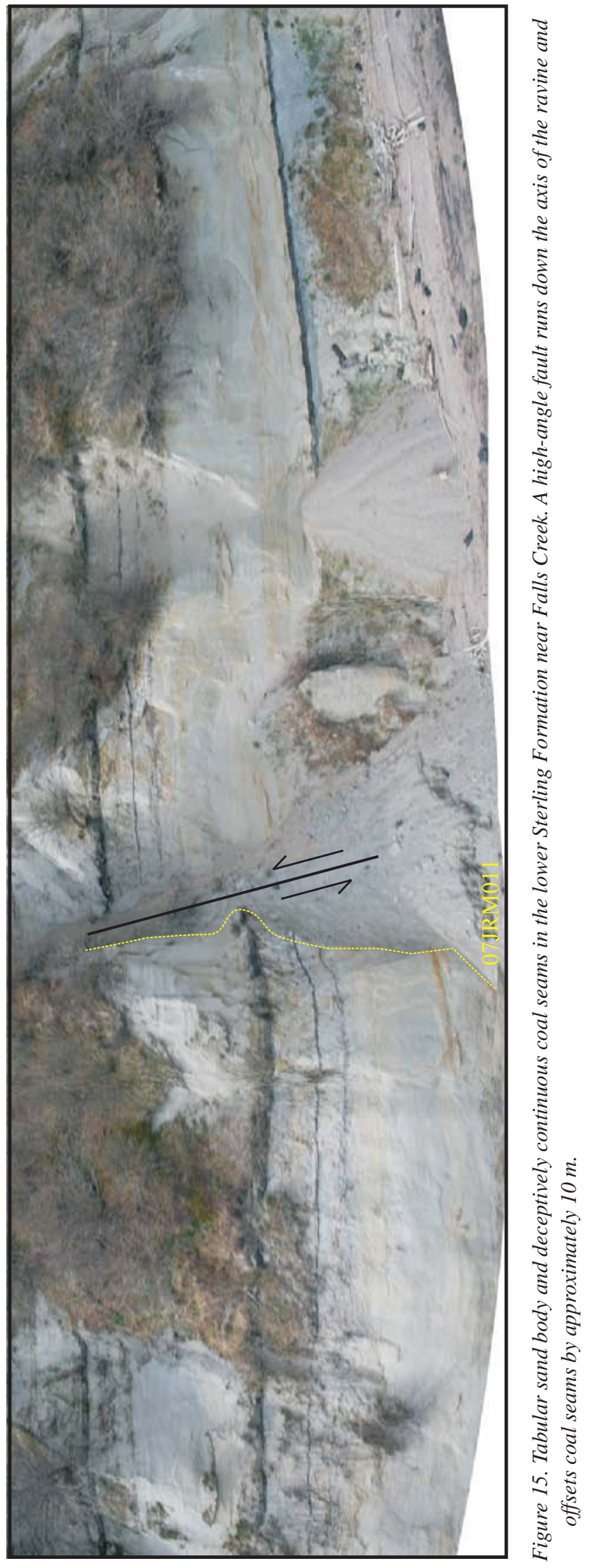



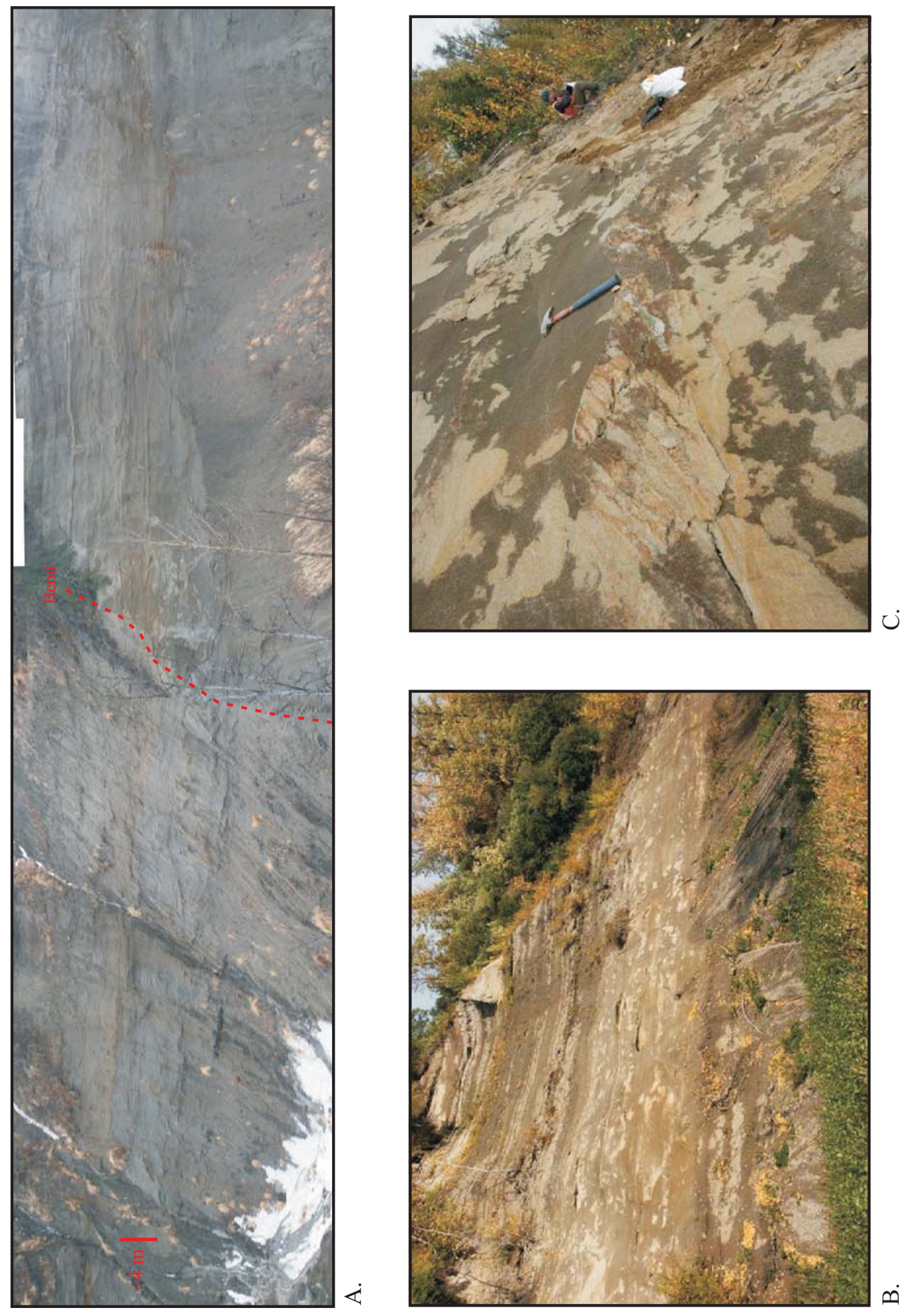

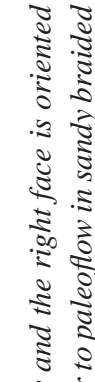

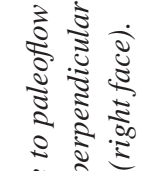

कั है

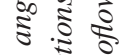

ฐ

व

z

密

:

วิ

\% ष 00

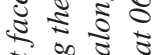

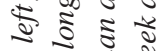

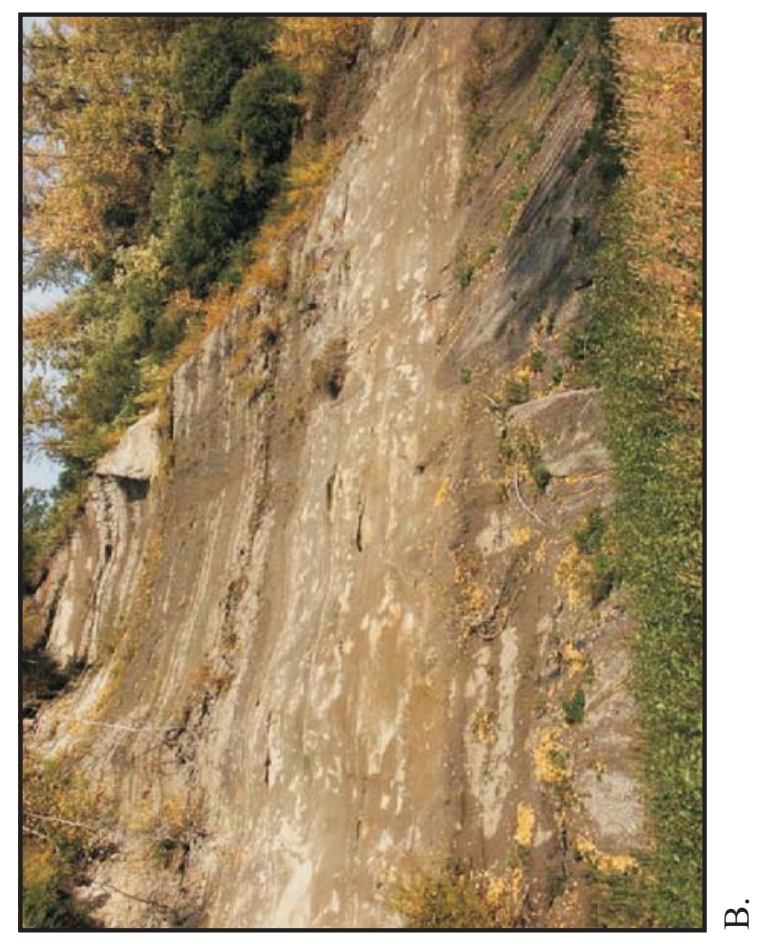

₹

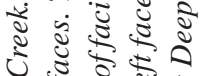

ن 0 过

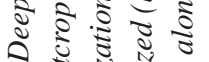

2)

응

ธิ์

ปั.

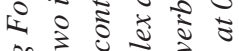

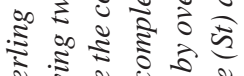

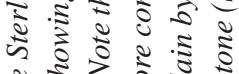

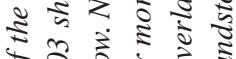

के

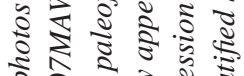

है ठิ

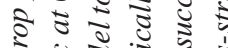

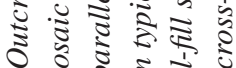

เ

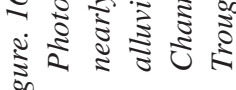

这 
(fig. 16a, right of bend). The latter two classes of surfaces are characterized by significant complexity: changes in concavity and dip direction over short distances make each story appear internally disorganized. In contrast, the intersecting outcrop face (fig. 16a, right of bend) includes the through-going surfaces that bound stories and surfaces internal to each story. These internal surfaces include relatively few concave-up scours and well-defined dune slip faces that dip consistently toward the right, imparting a more orderly, organized appearance for each story. Although this exposure is of limited extent, the complex surfaces seen on the left half of figure 16a suggest this orientation is close to depositional strike (perpendicular to paleoflow) for this river in this area, and that the right side of image is oriented close to depositional dip (nearly parallel to westerly paleoflow). Strike-oriented exposures through sandy braided alluvium are typically characterized by complex internal surfaces that dip in various directions and lack preferred orientations as expected in meandering streams (Bristow, 1993; Adams and Bhattacharya, 2005).

\section{Sterling Formation-Fox River}

Previously unmapped and undated (Cieutat and others, 1992) deposits along the Fox River in the Kenai National Wildlife Refuge consist of conglomerates and lenticular sandstones of association 3 (fig. 13b; wet alluvial fan association). Palynological samples collected during the 2006 field season yielded pollen of early Pliocene age that do not appear to be reworked (Pierre Zippi, unpublished report). These coarse-grained units represent very proximal deposits broadly correlative with the Sterling Formation. Facies recognized in this association (Gcm, Gch, Gcp/Gct, Sm, and Sh) are common in gravelly braided stream environments (tables 1 and 2). The proximity of this association to exposures of deformed and uplifted rocks of the McHugh Complex a few kilometers away suggest these braided streams were associated with a large alluvial fan, or complex of fans, deposited along the Kenai-Chugach Mountain front during Pliocene time. Though not recognized in outcrop in the study area, alluvial fans were probably present along this mountain front in Miocene time and possibly earlier. Clast composition reflects derivation from greywackes, argillites, and bedded cherts in the McHugh Complex to the east. ${ }^{40} \mathrm{Ar}{ }^{39} \mathrm{Ar}$ dates from volumetrically minor, but conspicuous, white and black diorite clasts obtained during the present study indicate they were derived from near-trench plutons in the accretionary prism (e.g. Bradley and others, 2003).

\section{DISCUSSION}

Outcrop data gathered during the 2006 and 2007 seasons provide insights on the nature of nonmarine depositional systems along the eastern margin of Cook Inlet basin. Late Oligocene to early Miocene strata exposed in coastal bluffs between Seldovia Point and Coal Cove, previously mapped as Tyonek Formation (Magoon and others, 1976; Bradley and others, 1999), record deposition in paleovalleys incised into deformed Mesozoic rocks of the McHugh Complex and Talkeetna Formation. These occurrences of the Tyonek are drastically different than the type Tyonek in the subsurface, or from the Tyonek in outcrop on the northwest side of the basin (see Calderwood and Fackler, 1972, and Flores and others, 1994). Braided streams occupying these valleys transported detritus derived from relatively small, locally sourced catchment areas, were prone to flashy discharge and hyperconcentrated flows, and graded to colluvial aprons comprised of debrites at valley margins. Valley-filling braided alluvium near Seldovia Point grades up-section to sandy braided alluvium attributed to a dispersal system of more regional extent, reflecting deposition more distal to the basin margin (Finzel and others, this volume).

Late Miocene strata exposed in coastal bluff exposures northwest of Homer and along the west shore of Kachemak Bay near Fritz Creek, mapped by Kirschner and Lyon (1973) and Magoon and others (1976) as Beluga Formation, record deposition from suspended-load to mixed-load, high-sinuosity single-thread (anastomosed) rivers. Sand bodies associated with these rivers are narrow sheets to broad ribbons up to $8 \mathrm{~m}$ thick encased in overbank mudstones. The high percentage of mudstone and coal in these exposures suggests deposition in highaccommodation settings.

Beluga exposures near Fritz Creek grade up-section over several kilometers of bluff exposures and several hundred meters of section to sheet-like sand bodies up to $15 \mathrm{~m}$ thick in the uppermost Beluga and lower Sterling Formations in the vicinity of Falls Creek. Overbank mudstones still form laterally continuous deposits in this area, but are significantly thinner than in the lower Beluga. Sheet-like sand bodies are attributed to low-sinuosity sandy braided rivers; locally visible, well-developed lateral accretion surfaces suggest that meandering streams were also present during this time or, alternatively, that some braid bars also migrated laterally or obliquely. The reduced thickness of overbank deposits is attributed to deposition in low accommodation settings during latest Miocene to Pliocene time in this part of the basin. 
Exposures of the Sterling Formation along Deep Creek appear similar to the upper Beluga and lower Sterling Formations along the west shore of Kachemak Bay, but their laterally discontinuous nature precludes more rigorous comparison. One exposure includes two outcrop faces that intersect at a high angle to provide nearly orthogonal cuts through an amalgamated sand body, the details of which suggest deposition in a sandy low-sinuosity fluvial system.

Previously unmapped exposures of conglomerate along the upper reaches of the Fox River contain un-reworked Pliocene palynomorphs. Facies suggest deposition from braided streams that are inferred to have flowed radially down the axis of large wet alluvial fans situated at the basin margin. Within the coarse constraints provided by limited age control, it is reasonable to suggest these fans represent the proximal equivalents to sandy braided alluvium recognized in Sterling Formation exposures along Kachemak Bay and Deep Creek.

\section{ACKNOWLEDGMENT}

Paige Delaney is gratefully acknowledged for reviewing a draft of this manuscript.

\section{REFERENCES CITED}

Adams, M.M, and Bhattacharya, J.P., 2005, No change in fluvial style across a sequence boundary, Cretaceous Blackhawk and Castlegate formations of central Utah, U.S.A.: Journal of Sedimentary Research, v. 75, p. $1,038-1,051$.

Adkison, W.L., Kelley, J.S., and Newman, K.R., 1975, Lithology and palynology of the Beluga and Sterling Formations exposed near Homer, Kenai Peninsula, Alaska: U.S. Geological Survey Open-file Report 75-383, $237 \mathrm{p}$.

Barnes, F.F., and Cobb, E.H., 1959, Geology and coal resources of the Homer District, Kenai coal field, Alaska: U.S. Geological Survey Bulletin 1058-F, p. 217-260, 12 plates.

Blair, T.C. and McPherson, J.G., 1994 Alluvial fans and their natural distinction from rivers based on morphology, hydraulic processes, sedimentary processes, and facies assemblages: Journal of Sedimentary Research, v. A64, p. 450-489.

Boss, R.F., Lennon, R.B., and Wilson, B.W., 1976, Middle Ground Shoal oil field, Alaska, in Braunstein, J., ed., North American oil and gas fields: American Association of Petroleum Geologists Memoir 24, p. 1-22.

Bradley, D.C., Kusky, T.M., Haeussler, P.J., Karl, S.M., and Donley, D.T., 1999, Geologic map of the Seldovia Quadrangle, south-central Alaska: U.S. Geological Survey Open-file Report 99-18, scale 1:250,000, http://pubs. usgs.gov/of/1999/of99-018/.

Bradley, D.C., Kusky, T., Hauessler, P., Goldfarb, R., Miller, M., Dumoulin, J., Nelson, S.W., and Karl, S., 2003, Geologic signature of early Tertiary ridge subduction in Alaska, in Sisson, V.B., Roeske, S.M., and Pavlis, T.L., eds., Geology of a transpressional orogen developed during ridge-trench interaction along the North Pacific Margin: Boulder, CO, Geological Society of America, Special Paper, v. 371, p. 19-49.

Bristow, C.S., 1993, Sedimentary structures exposed in bar tops in the Brahmaputra River, Bangladesh, in Best, J.L., and Bristow, C.S., eds., Braided rivers: Geological Society of London, Special Publication 75, p. 291-304.

Calderwood, K.H., and Fackler, W.C., 1972, Proposed stratigraphic nomenclature for Kenai Group, Cook Inlet basin, Alaska: American Association of Petroleum Geologists Bulletin, v. 56, p. 739-754.

Cant, D.J., and Walker, R.G., 1978, Fluvial processes and facies sequences in the sandy braided South Saskatchewan River, Canada: Sedimentology, v. 25, p. 625-648.

Cieutat, B.A., Goldfarb, R.J., Bradley, D.C., and Roushey, B.H., 1992, Placer gold of the Kenai lowland, in Bradley, D.C., and Dusel-Bacon, C., eds., Geologic studies in Alaska by the U.S. Geological Survey, 1991: U.S. Geological Survey Bulletin 2041, p. 23-29.

Combellick, R.A., 1994, Investigation of peat stratigraphy in tidal marshes along Cook Inlet, Alaska, to determine the frequency of 1964-style great earthquakes in the Anchorage region: Alaska Division of Geological \& Geophysical Surveys, Report of Investigations 94-7, 24 p.

Dall, W.H., 1898, A table of the North American Tertiary formations, correlated with one another and with those of western Europe: U.S. Geological Survey $18^{\text {th }}$ Annual Report, part 2, p. 323-348.

Dall, W.H., and Harris, G.D., 1892, Correlation papers-Neocene: U.S. Geological Survey Bulletin 84, p. 237-238.

Dallegge, T.A., and Layer, P.W., 2004, Revised chronostratigraphy of the Kenai Group from ${ }^{40} \mathrm{Ar} /{ }^{39} \mathrm{Ar}$ dating of low-potassium-bearing minerals, Cook Inlet basin, Alaska: Canadian Journal of Earth Science, v. 141, p $1,159-1,179$. 
Ettensoshn, F.R., Rast, N., and Brett, C.E., 2002, Ancient Seismites: Geological Society of America, Special Paper 359, $190 \mathrm{p}$.

Fisher, M.A., and Magoon, L.B., 1978, Geologic framework of lower Cook Inlet, Alaska: American Association of Petroleum Geologists Bulletin, v. 62, p. 373-402.

Flores, R.M., and Stricker, G.D., 1992, Some facies aspects of the upper part of the Kenai Group, southern Kenai Peninsula, Alaska, in Bradley, D.C., Dusel-Bacon, C., eds., Geologic studies in Alaska by the U.S. Geological Survey, 1991: U.S. Geological Survey Bulletin 2041, p. 160-170.

_ 1993, Reservoir framework architecture in the Clamgulchian type section (Pliocene) of the Sterling Formation, Kenai Peninsula, Alaska, in Dusel-Bacon, C., and Till, A.B., eds., Geologic studies in Alaska by the U.S. Geological Survey, 1992: U.S. Geological Survey Bulletin 2068, p. 118-129.

Flores, R.M., Stricker, G.D., and Roberts, S.B., 1994, Miocene coal-bearing strata of the Tyonek Formation: Braided-stream deposits in the Chuit Creek-Chuitna River drainage basin, southern Alaska, in Till, A.B., and Moore, T.E., eds., Geologic studies in Alaska by the U.S. Geological Survey, 1993: U.S. Geological Survey Bulletin 2107, p. 95-114.

Flores, R.M., Myers, M.D., Stricker, G.D., and Houle, J.A., 1997, Core lithofacies analysis and fluvio-tidal environments in the AK94 CBM-1 well, near Wasilla, Alaska, in Kelley, K.D., ed., Geologic studies in Alaska by the U.S. Geological Survey, 1997: U.S. Geological Survey Professional Paper 1614, p. 57-72.

Flores, R.M., Stricker, G.D., and Kinney, S.A., 2004, Alaska coal geology, resources, and coalbed methane potential: U.S. Geological Survey, DD-77, 140 p.

Haeussler, P.J., Bruhn, R.L., and Pratt, T.L., 2000, Potential seismic hazards and tectonics of the upper Cook Inlet basin, Alaska, based on analysis of Pliocene and younger deformation: Geological Society of America Bulletin, v. 112, p. 1,414-1,429.

Hayes, J.B., Harms, J.C., and Wilson, T., 1976, Contrasts between braided and meandering stream deposits, Beluga and Sterling Formations (Tertiary), Cook Inlet, Alaska, in Miller, T.P., ed., Recent and ancient sedimentary environments in Alaska: Proceedings of the Alaska Geological Society Symposium, April 2-4, 1975, Anchorage, Alaska, p. J1-J27.

Hein, F.J., and Walker, R.G., 1977, Bar evolution and development of stratification in the gravelly, braided, Kicking Horse River, British Columbia: Canadian Journal of Earth Sciences, v. 14, p. 562-570.

Hite, D.M., 1976, Some sedimentary aspects of the Kenai Group, Cook Inlet, Alaska, in Miller, T.P., ed., Recent and ancient sedimentary environments in Alaska: Proceedings of the Alaska Geological Society Symposium, April 2-4, 1975, Anchorage, Alaska, p. I1-I23.

Kirschbaum, M.A., and McCabe, P.J., 1992, Controls on the accumulation of coal and on the development of anastomosed fluvial systems in the Cretaceous Dakota Formation of southern Utah: Sedimentology, v. 39, p. 581-598.

Kirschner, C.E., and Lyon, C.A., 1973, Stratigraphic and tectonic development of Cook Inlet petroleum province, in Pitcher, M.G., ed., Arctic geology: American Association of Petroleum Geologists Memoir 19, p. 396-407.

Magoon, L.B., Adkison, W.L., and Egbert, R.M., 1976, Map showing geology, wildcat wells, Tertiary plant fossil localities, K-Ar age dates, and petroleum operations, Cook Inlet area, Alaska: U.S. Geological Survey Miscellaneous Investigations Series, Map I-1019, scale 1:250,000.

Magoon, L.B., and Egbert, R.M., 1986, Framework geology and sandstone composition, in Magoon, L.B., ed., Geologic studies of the ;ower Cook Inlet COST No. 1 well, Alaska Outer Continental Shelf: U.S. Geological Survey Bulletin 1596, p. 65-99.

Miall, A.D., 1977, A review of the braided-river depositional environment: Earth-Science Reviews, v. 13, p. $1-62$.

_ 1995, The geology of fluvial deposits: Sedimentary facies, basin analysis, and petroleum geology: SpringerVerlag, $582 \mathrm{p}$.

Nadon, G.C., 1994, The genesis and recognition of anastomosed fluvial deposits: Data from the St. Mary Formation, southwestern Alberta, Canada: Journal of Sedimentary Research, v. B64, p. 451-463.

Nokleberg, W.J., Plafker, G., and Wilson, F.H., 1994, Geology of south-central Alaska, in Plafker, G., and Berg, H.C., eds., The geology of Alaska: Boulder, Colorado, Geological Society of America, The Geology of North America, v. G-1, p. 311-366.

Pierson, T.C., 2005, Hyperconcentrated flow-Transitional process between water flow and debris flow, in Jakob, M., and Hungr, O., eds., Debris-flow hazards and related phenomena: Springer-Verlag, Berlin, p. 159-202. 
Plafker, G., Nokleberg, W.J., and Lull, J.S., 1989, Bedrock geology and tectonic evolution of the Wrangellia, Peninsular, and Chugach terranes along the Trans-Alaska Crustal Transect in the Chugach Mountains and southern Copper River basin, Alaska: Journal of Geophysical Research, v. 94, p. 4,255-4,295.

Plafker, G., Moore, J.C., and Winkler, G., 1994, Geology of the southern Alaska margin, in Plafker, G., and Berg, H.C., eds., The geology of Alaska: Boulder, Colorado, Geological Society of America, The Geology of North America, v. G-1, p. 389-449.

Rawlinson, S.E., 1984, Environments of deposition, paleocurrents, and provenance of Tertiary deposits along Kachemak Bay, Kenai Peninsula, Alaska: Sedimentary Geology, v. 38, p. 421-442.

Reinink-Smith, L.M., 1990, Relative frequency of Neogene volcanic events as recorded in coal partings from the Kenai lowland, Alaska: A comparison with deep-sea core data: Geological Society of America Bulletin, v. 102, p. 830-840.

1995, Tephra layers as correlation tools of Neogene coal-bearing strata from the Kenai lowland, Alaska: Geological Society of America Bulletin, v. 107, p. 340-353.

Rust, B.R., 1972, Structure and process in a braided river: Sedimentology, v. 18, p. 221-245.

1978, Depositional models for braided alluvium, in Miall, A.D., ed., Fluvial sedimentology: Canadian Society of Petroleum Geologists Memoir 5, p. 605-625.

Rygel, M.C., and Gibling, M.R., 2006, Natural geomorphic variability recorded in a high-accommodation setting: Fluvial architecture of the Pennsylvanian Joggins Formation of Atlantic Canada: Journal of Sedimentary Research, v. 76, p. 1,230-1,251.

Stricker, G.D., and Flores, R.M., 1996, Miocene fluvial-tidal sedimentation in a residual forearc basin of the northeastern Pacific rim; Cook Inlet, Alaska case study: American Association of Petroleum Geologists Annual Convention, Abstracts with Program, San Diego, CA, p. A-135.

Swenson, R., 2002, Introduction to Tertiary tectonics and sedimentation in the Cook Inlet basin, in Dallegge, T., compiler, Geology and hydrocarbon systems of the Cook Inlet basin, Alaska: American Association of Petroleum Geologists Pacific Section/Society of Petroleum Engineers Pacific Regional Conference, May 23-24, 2002, Anchorage, Alaska, p. 11-20.

Wolfe, J.A., 1966, Tertiary plants from the Cook Inlet region, Alaska: U.S. Geological Survey Professional Paper 398-B, 32 p., 8 plates.

Wolfe, J.A., Hopkins, D.M., and Leopold, E.B., 1966, Tertiary stratigraphy and paleobotany of the Cook Inlet region, Alaska: U.S. Geological Survey Professional Paper 398-A, 29 p., 2 plates.

Wolfe, J.A., and Tanai, T., 1980, The Miocene Seldovia Point flora from the Kenai Group, Alaska: U.S. Geological Survey Professional Paper 1105, 47 p., 25 plates. 


\section{APPENDIX A}

Table A1. Locations of measured sections illustrated in Appendix A.

\begin{tabular}{|c|c|c|c|c|c|}
\hline No. & Section Name & Location Name & Formation & Latitude & Longitude \\
\hline 1 & 06РМ001 & Coal Cove, Port Graham & Tyonek & N59.3942 & W151.8925 \\
\hline 2 & 06DL024 & Point Pogibshi, Kachemak Bay & Tyonek & N59.41695 & W151.88352 \\
\hline 3 & 06РM004 & Fritz Creek, Kachemak Bay & Beluga & N59.69571 & W151.30385 \\
\hline 4 & 07MAW004 & Bluff Point & Beluga & N59.67557 & W151.71409 \\
\hline 5 & 07DL002 & Bluff Point & Beluga & N59.65911 & W151.66521 \\
\hline 6 & 07DL003 & Bluff Point & Beluga & N59.65944 & W151.66624 \\
\hline 7 & 07DL004 & Diamond Gulch & Beluga & N59.65964 & W151.66736 \\
\hline 8 & 07JRM001 & Fritz Creek, Kachemak Bay & Beluga & N59.69343 & W151.31347 \\
\hline 9 & 07JRM002 & Fritz Creek, Kachemak Bay & Beluga & N55.69365 & W151.3128 \\
\hline 10 & 07JRM003 & Fritz Creek, Kachemak Bay & Beluga & N59.6938 & W151.31266 \\
\hline 11 & 07JRM005 & Fritz Creek, Kachemak Bay & Beluga & N59.69517 & W151.30707 \\
\hline 12 & 07JRM006 & Fritz Creek, Kachemak Bay & Beluga & N59.69522 & W151.30672 \\
\hline 13 & 07JRM008 & Fritz Creek, Kachemak Bay & Beluga & N59.6962 & W151.30368 \\
\hline 14 & 07JRM009 & Fritz Creek, Kachemak Bay & Beluga & N59.70012 & W151.29219 \\
\hline 15 & 07JRM010 & Falls Creek, Kachemak Bay & Beluga-Sterling & N59.69879 & W151.29545 \\
\hline 16 & 07JRM011 & Falls Creek, Kachemak Bay & Sterling & N59.77309 & W151.12128 \\
\hline 17 & 07JRM012 & Falls Creek, Kachemak Bay & Sterling & N59.78246 & W151.10204 \\
\hline 18 & 07JRM013 & Falls Creek, Kachemak Bay & Sterling & N59.77343 & W151.12043 \\
\hline 19 & 07JRM014 & Falls Creek, Kachemak Bay & Sterling & N59.77366 & W151.12004 \\
\hline 20 & $06 \mathrm{PD} 213$ & Fox River, Kenai NWR & Sterling? & N59.91270 & W150.82426 \\
\hline 21 & 06MAW203 & Fox River, Kenai NWR & Sterling & N59.98066 & W150.79642 \\
\hline 22 & 06PD244 & Deep Creek, southern Kenai Peninsula & Sterling & N59.98250 & W151.54721 \\
\hline 23 & 06PD220 & Clam Gulch, Cook Inlet & Sterling & N60.24970 & W151.39291 \\
\hline
\end{tabular}

Datum is NAD27 Alaska. 
06PM001

FIGURE A1

Coal Cove, Port Graham

N59.3942 W151.8925

Tyonek Formation

Page 1 of 2

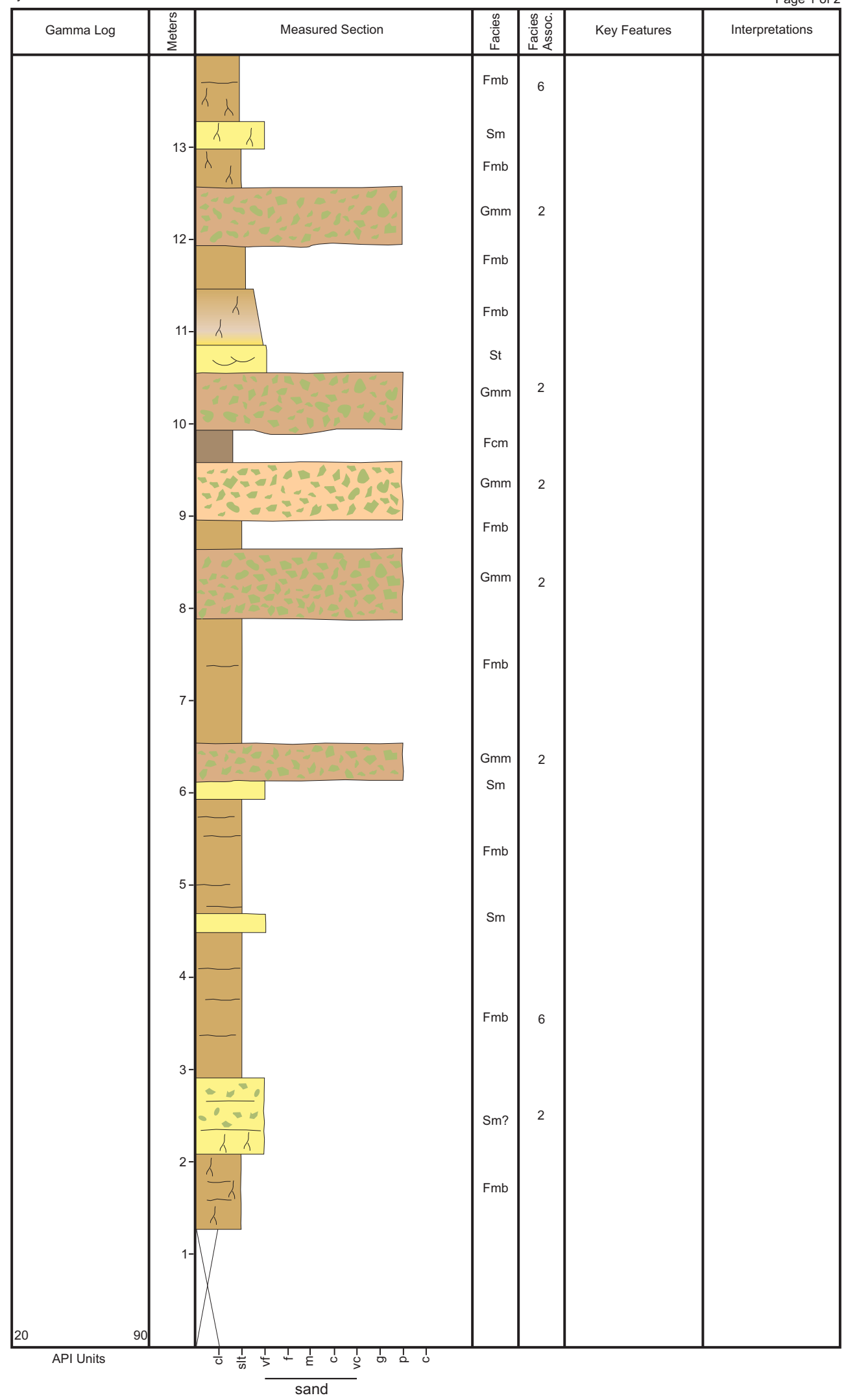


06PM001

Coal Cove, Port Graham
N59.3942 W151.8925

FIGURE A1

Tyonek Formation

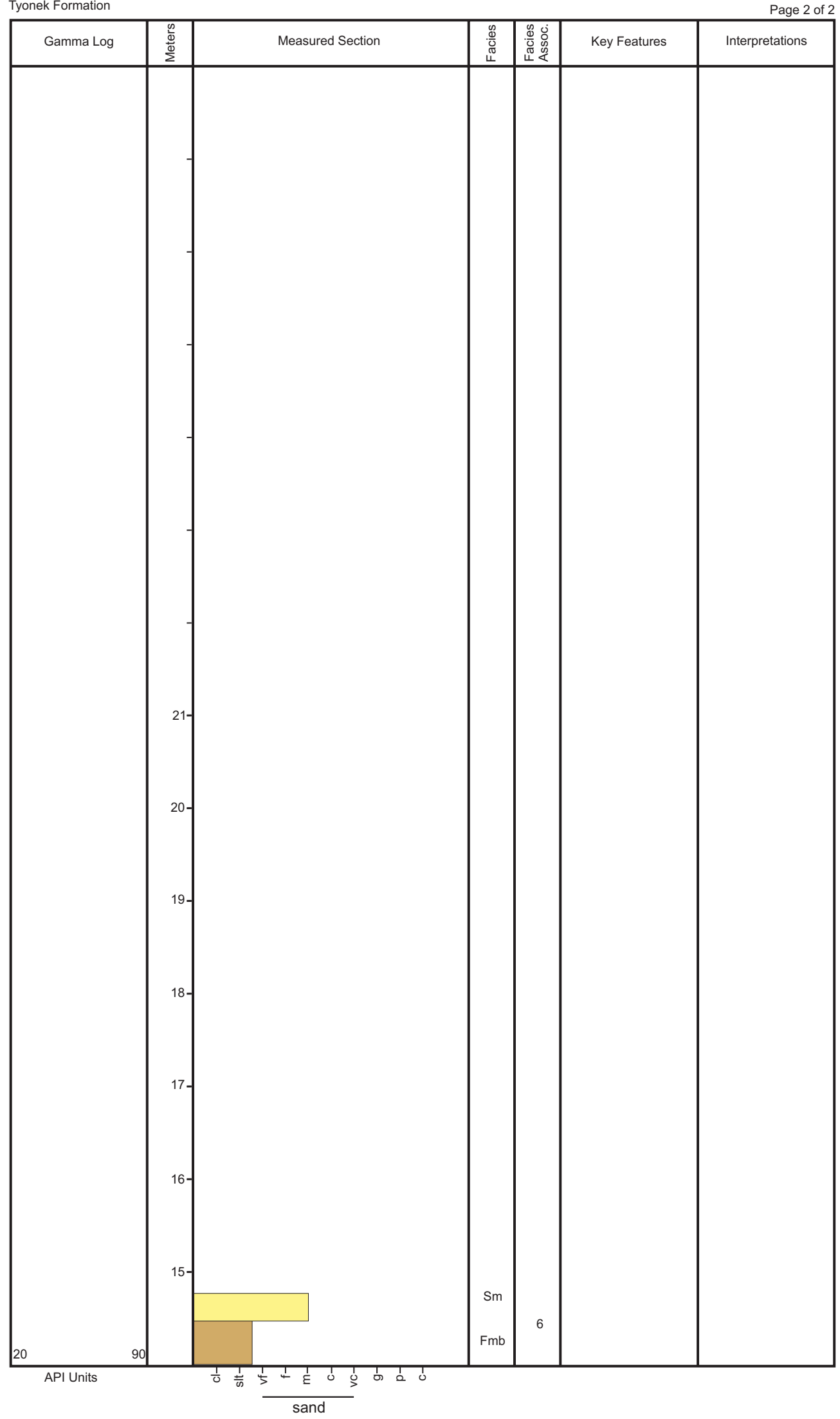


06DL024

Point Pogibshi, Kachemak Bay

FIGURE A2

N59.43726 W151.80049

Tyonek(?) Formation

Page 1 of 2

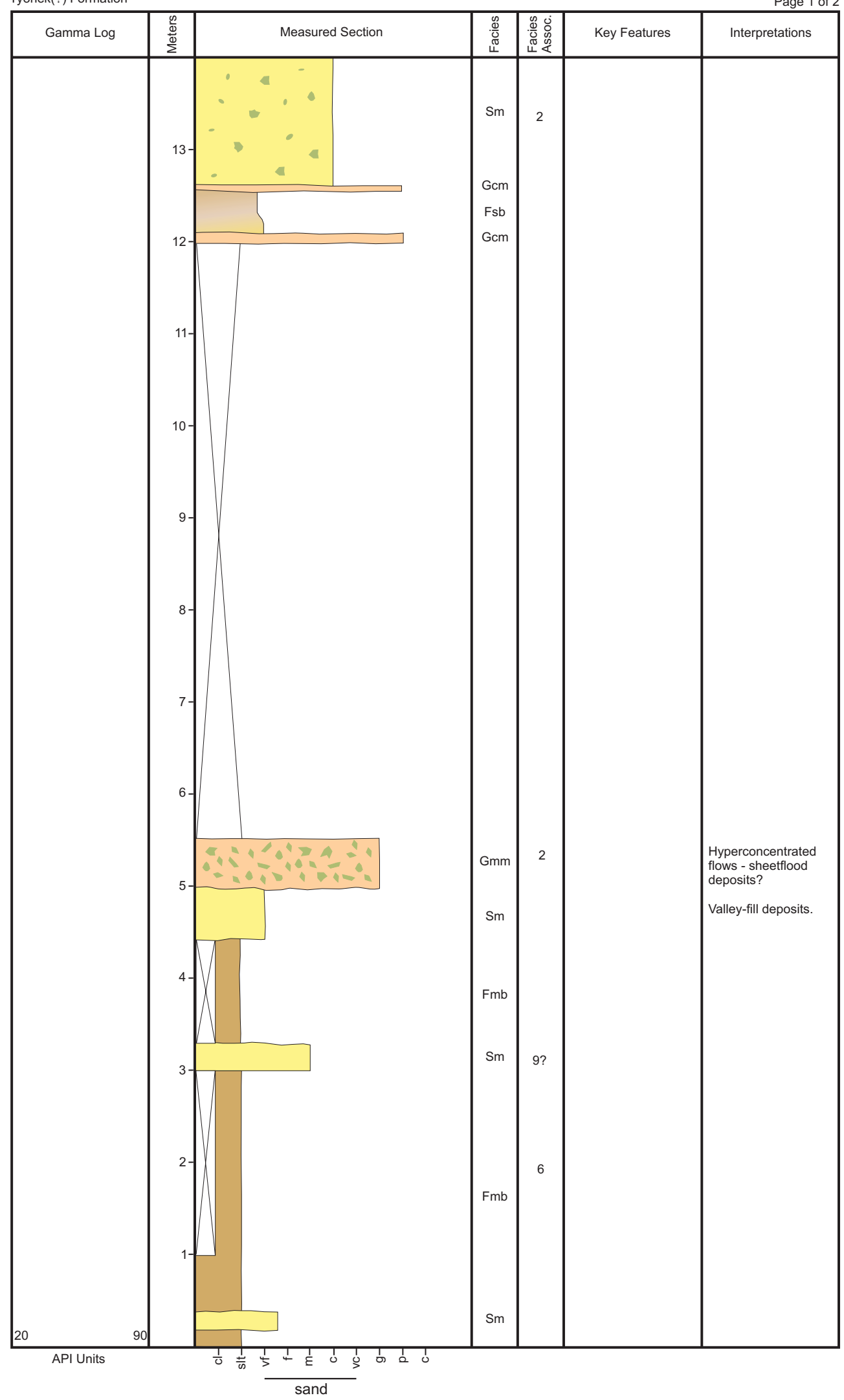


06DL024

Point Pogibshi, Kachemak Bay

N59.43726 W151.80049

Tyonek(?) Formation

FIGURE A2

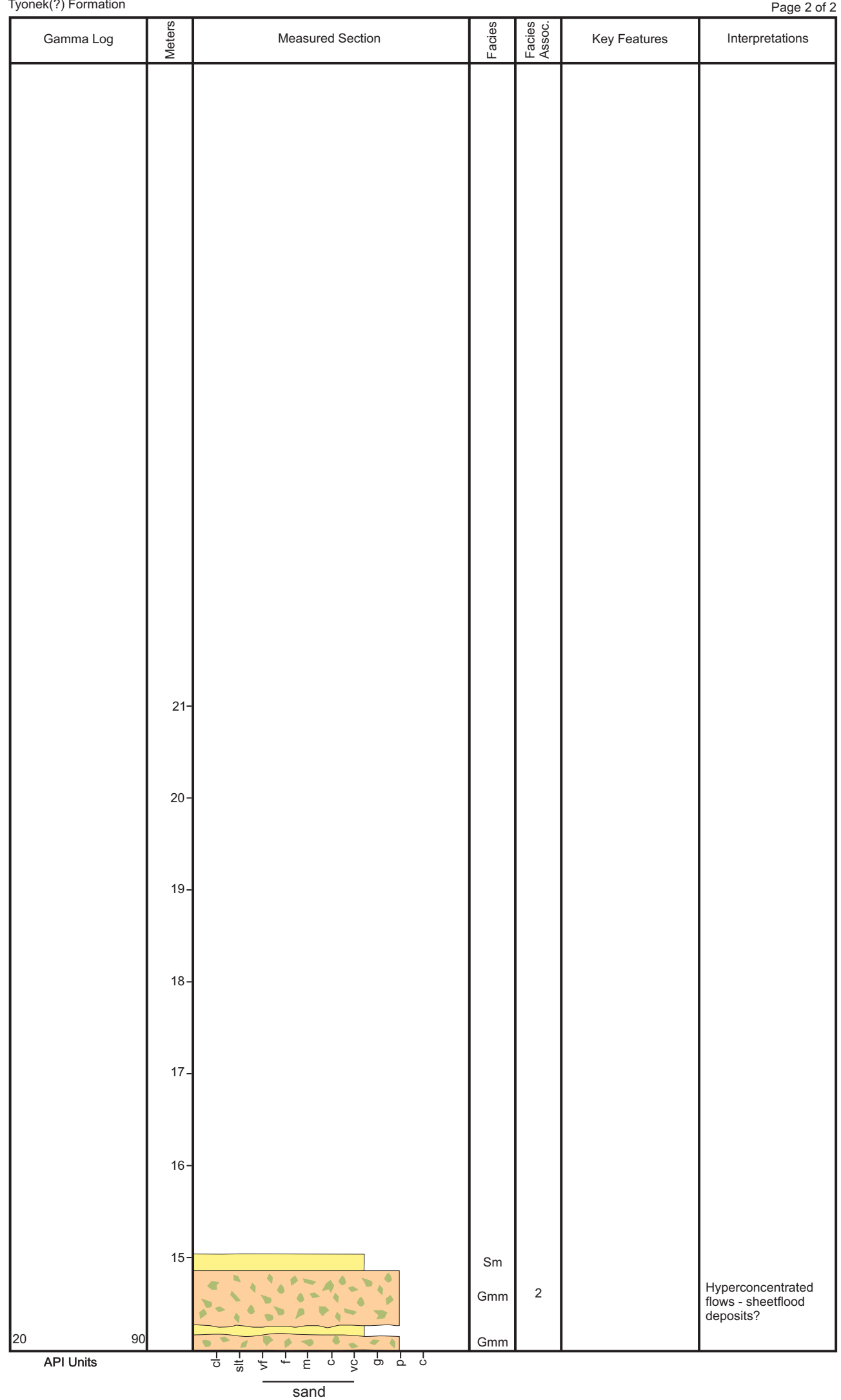


06PM004

Fritz Creek, Kachemak Bay

N59.69571 W151.30385

Beluga Formation

FIGURE A3

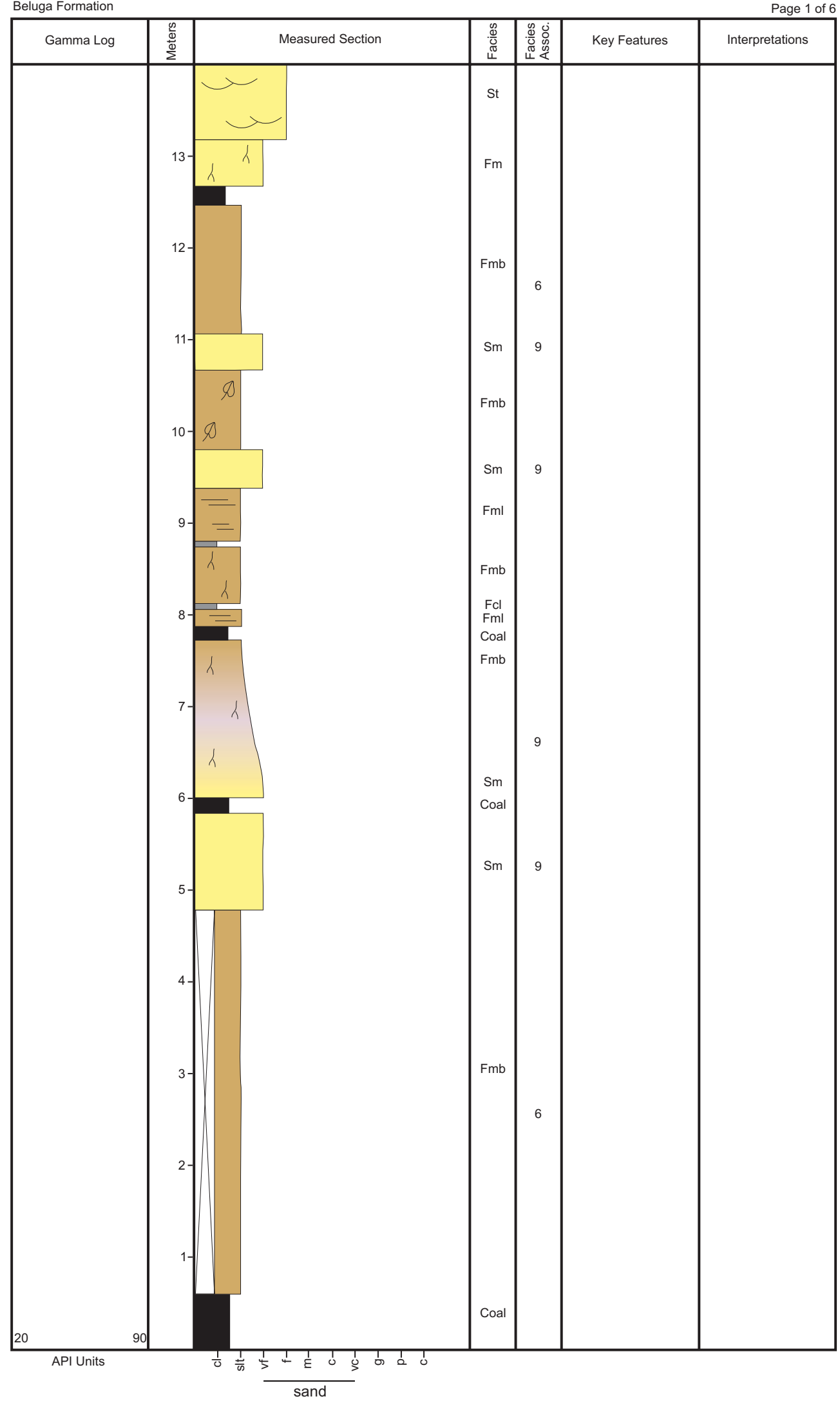


06PM004

Fritz Creek, Kachemak Bay

N59.69571 W151.30385

Beluga Formation

FIGURE A3

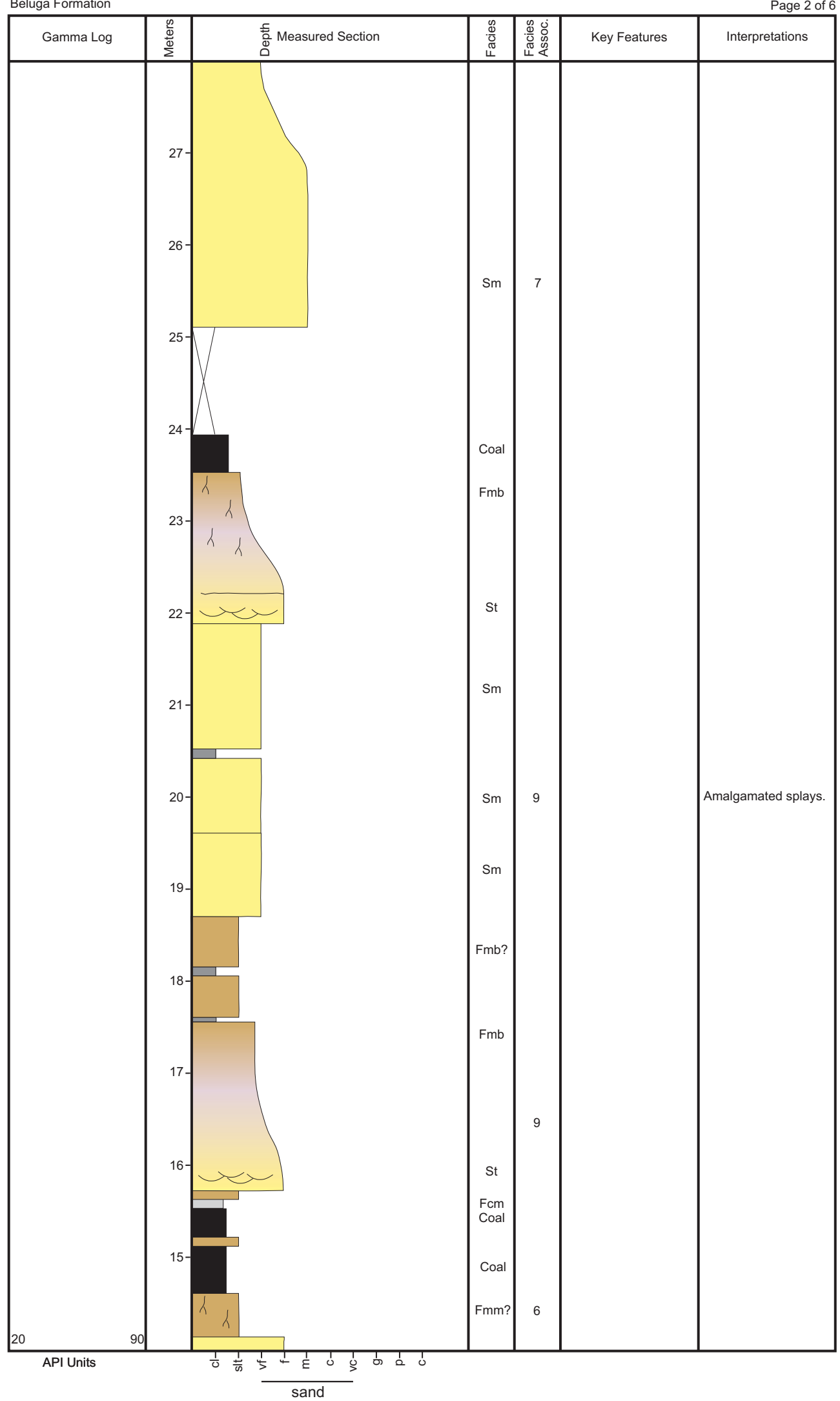


06PM004

Fritz Creek, Kachemak Bay

N59.69571 W151.30385

Beluga Formation

FIGURE A3

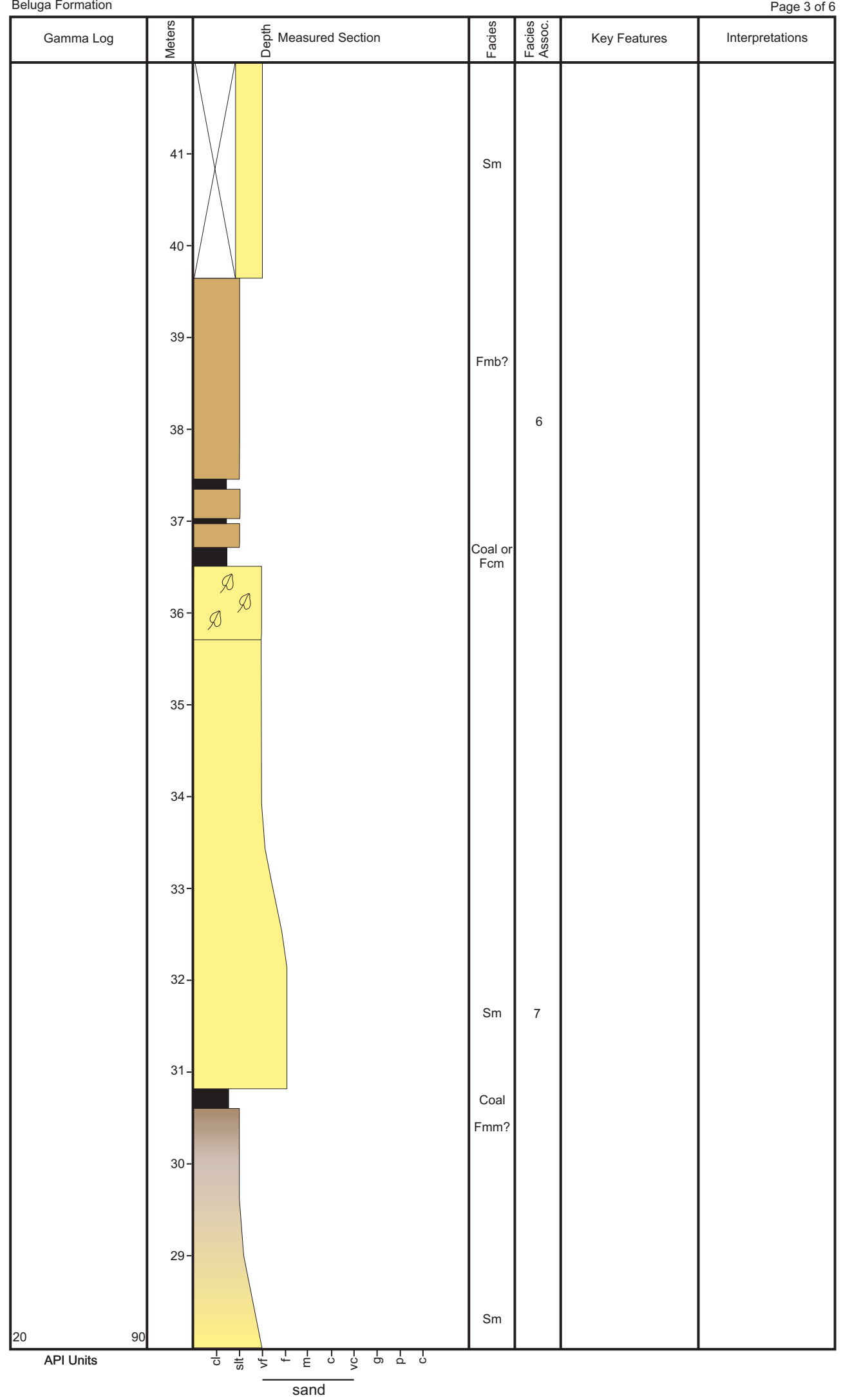


06PM004

Fritz Creek, Kachemak Bay

N59.69571 W151.30385

Beluga Formation

FIGURE A3

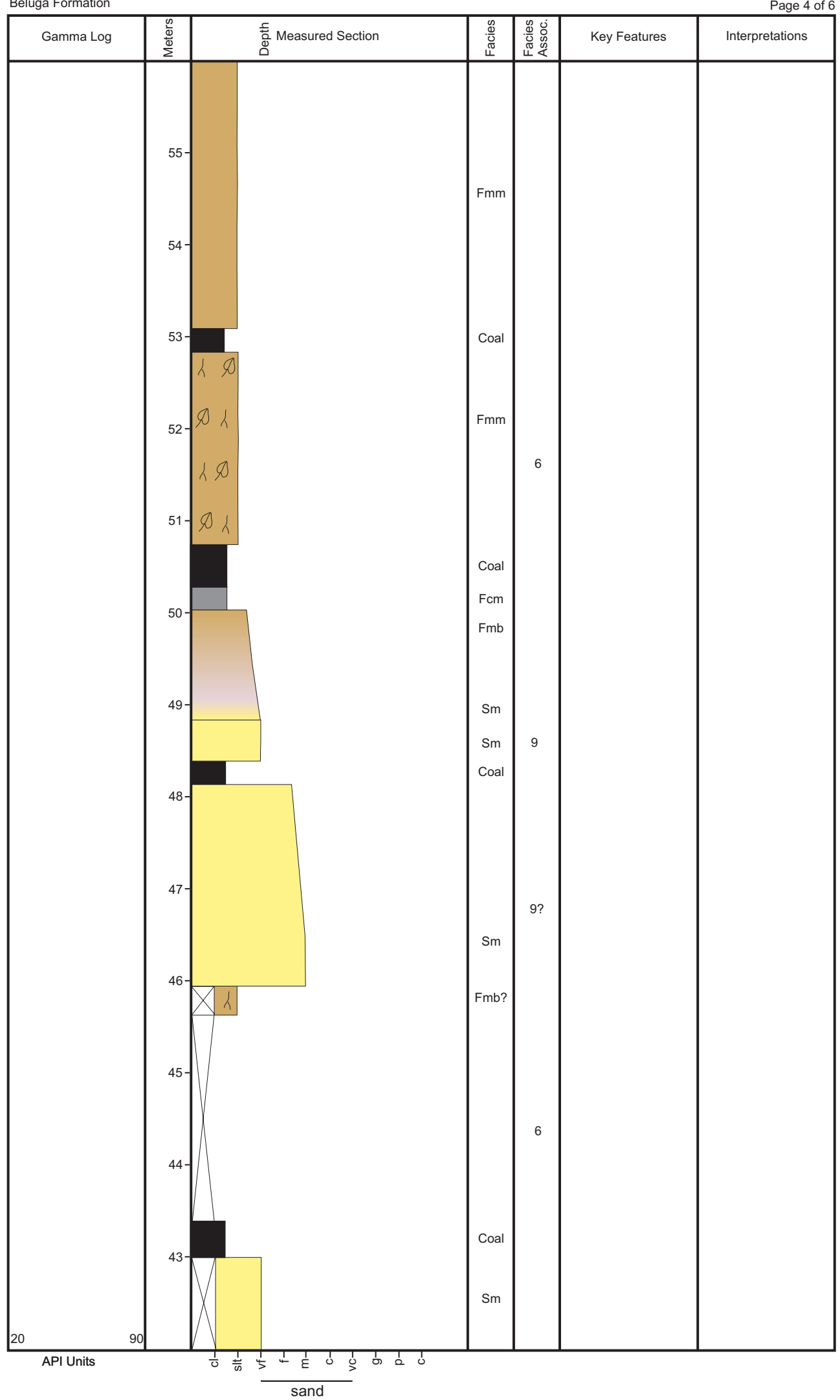


06PM004

Fritz Creek, Kachemak Bay

N59.69571 W151.30385

Beluga Formation

FIGURE A3

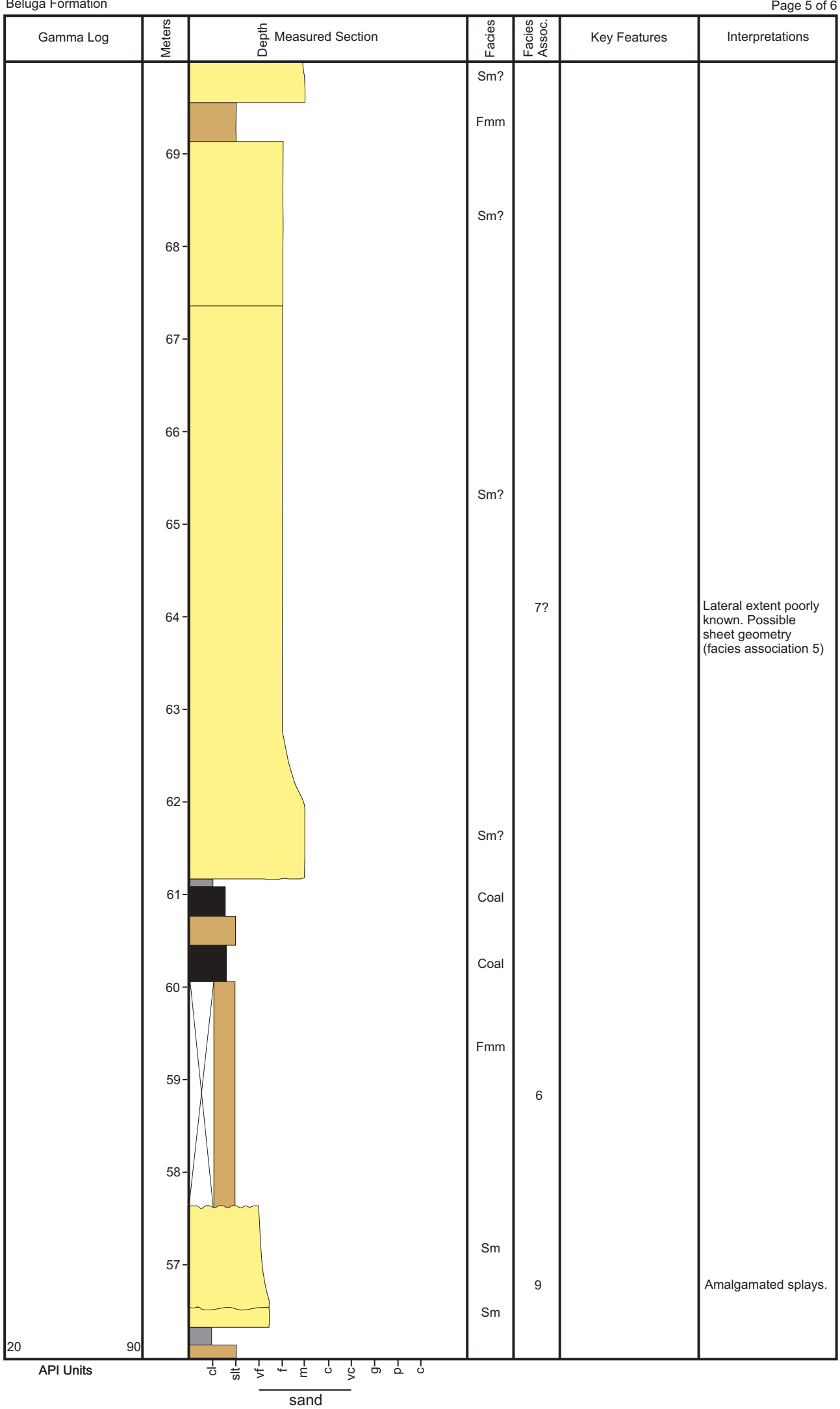


06PM004

Fritz Creek, Kachemak Bay

N59.69571 W151.30385

Beluga Formation

FIGURE A3

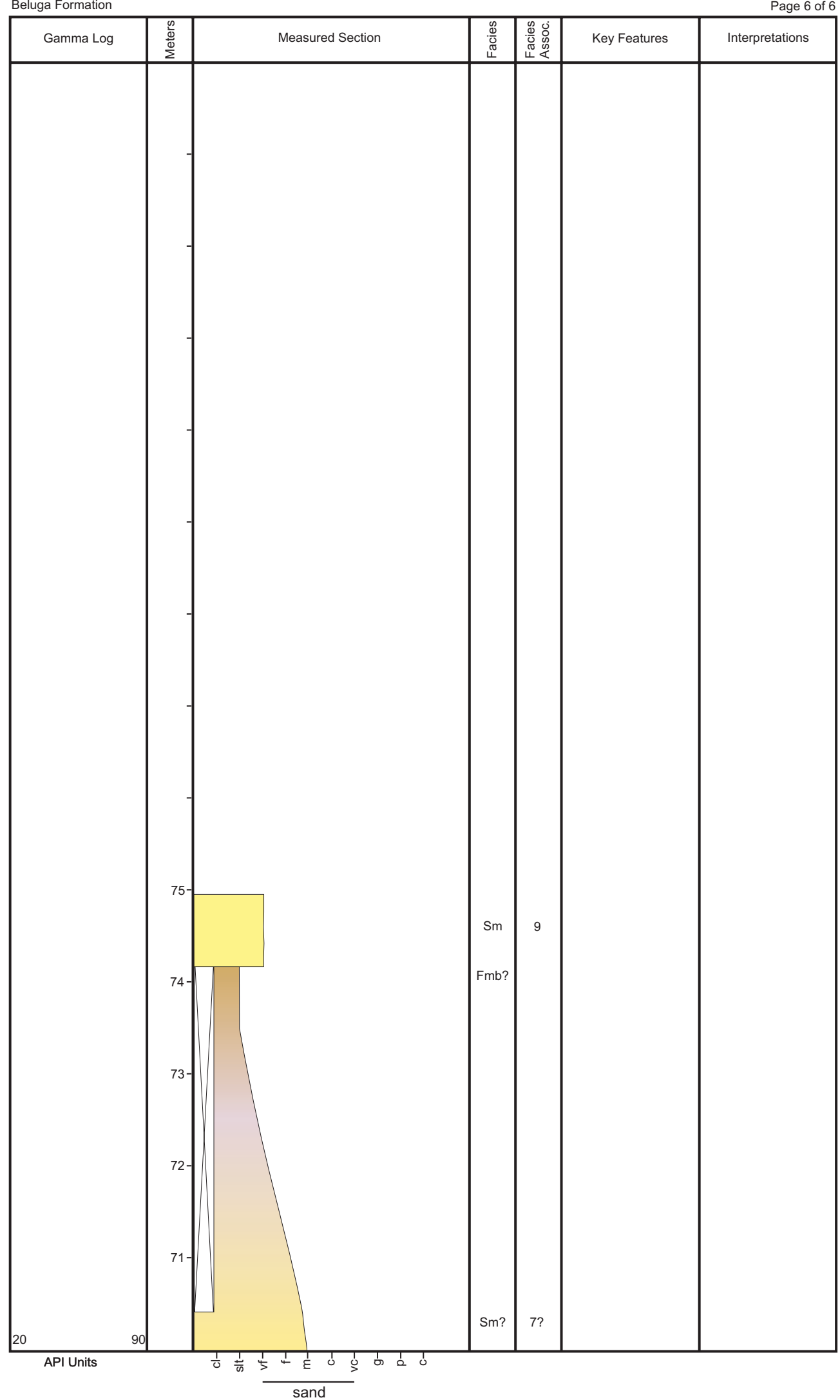


07MAW004

Bluff Point

FIGURE A4

N59.67557 W151.71409

Beluga Formation

Page 1 of 3

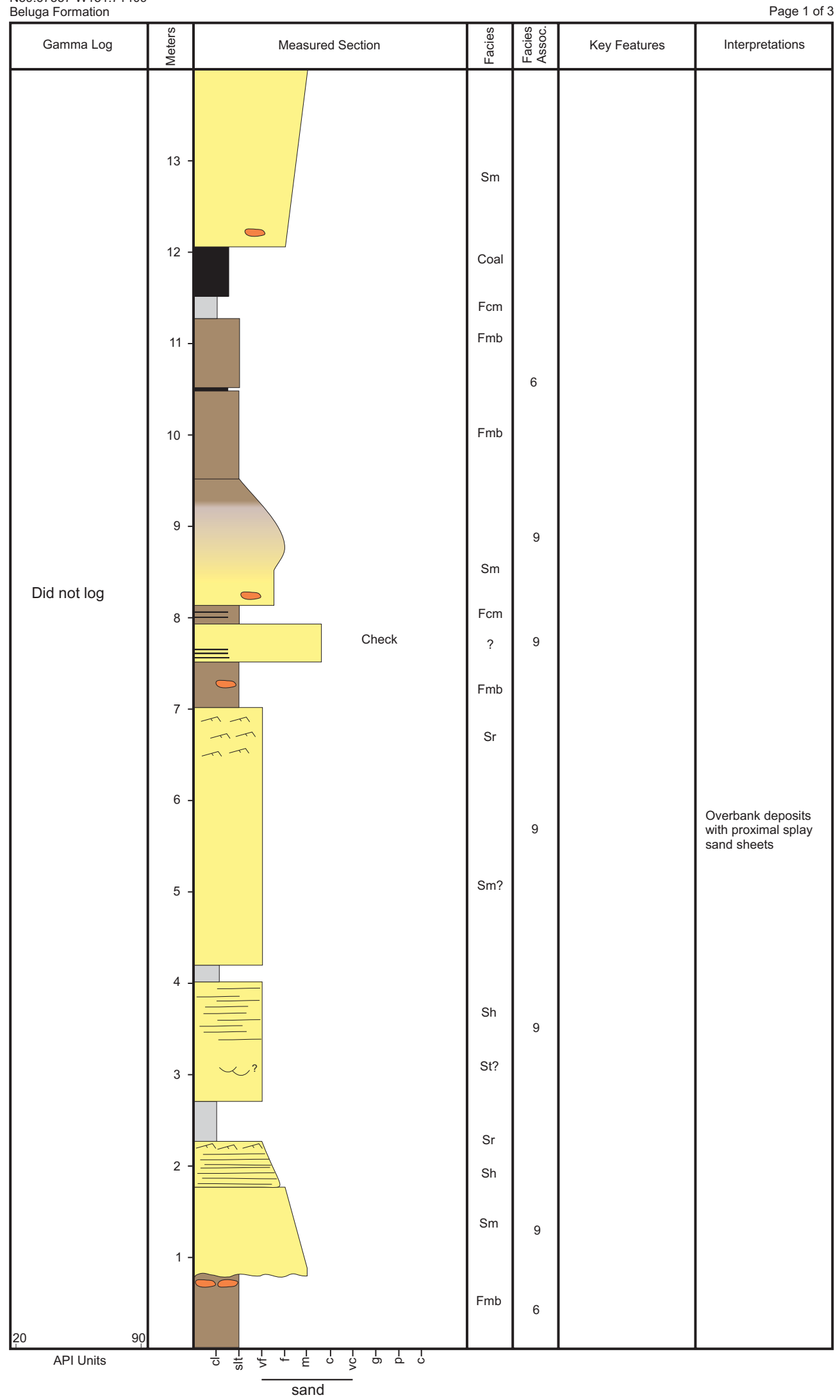


07MAW004

Bluff Point

FIGURE A4

N59.67557 W151.71409

Beluga Formation

Page 2 of 3

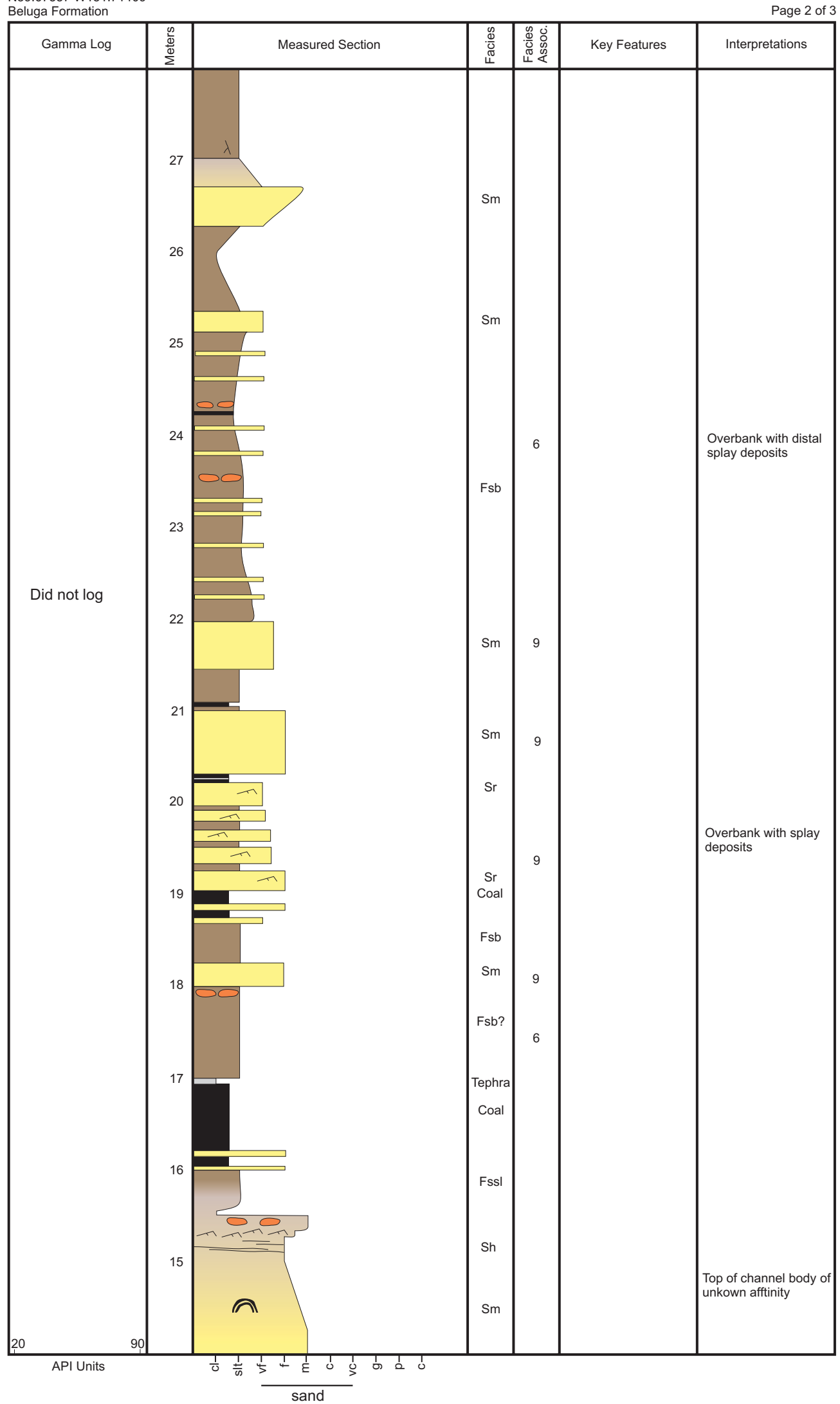


07MAW004

Bluff Point

FIGURE A4

N59.67557 W151.71409

Beluga Formation

Page 3 of 3

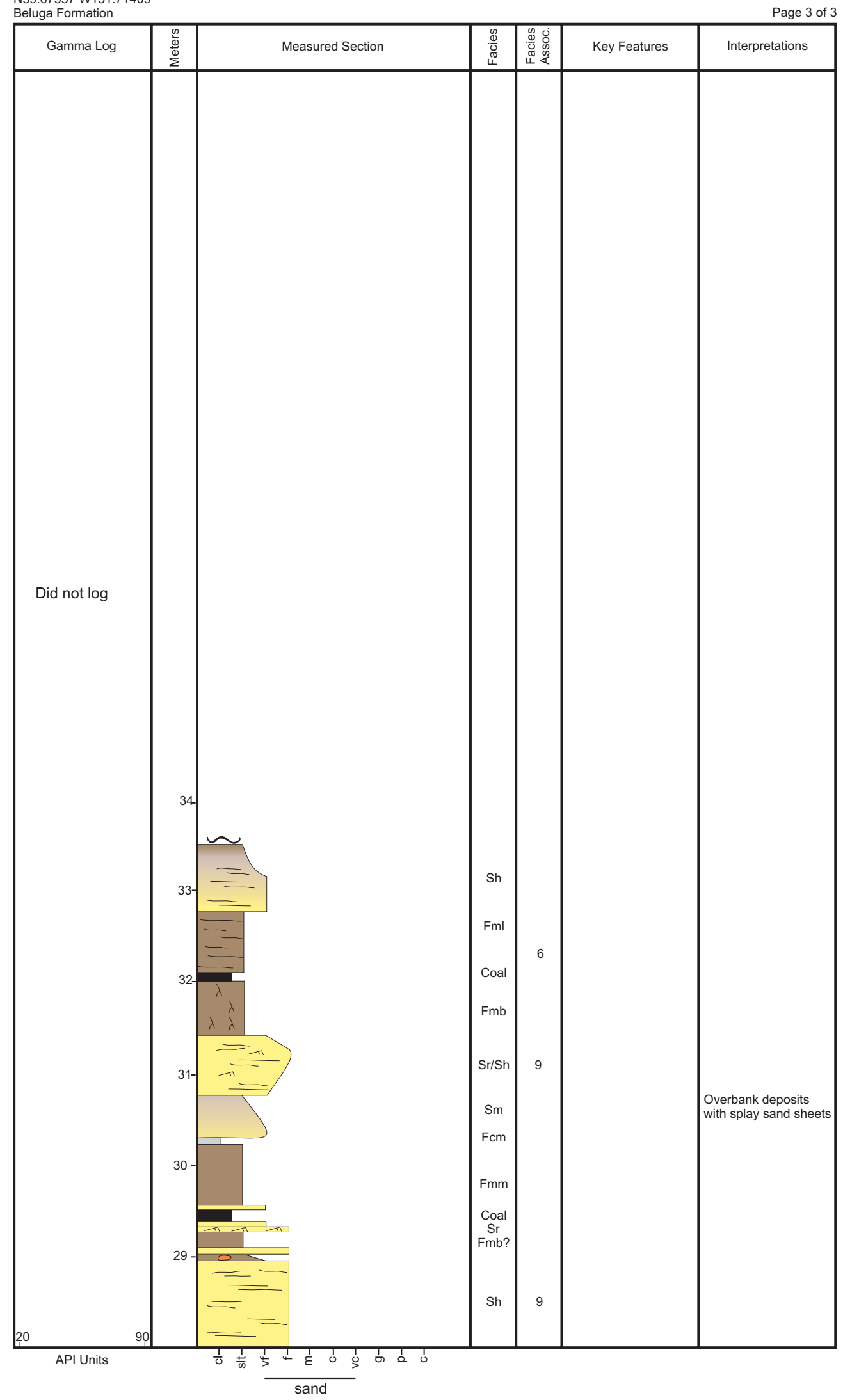


07DL002

Bluff Point

FIGURE A5

N59.65911 W151.66521

Beluga Formation

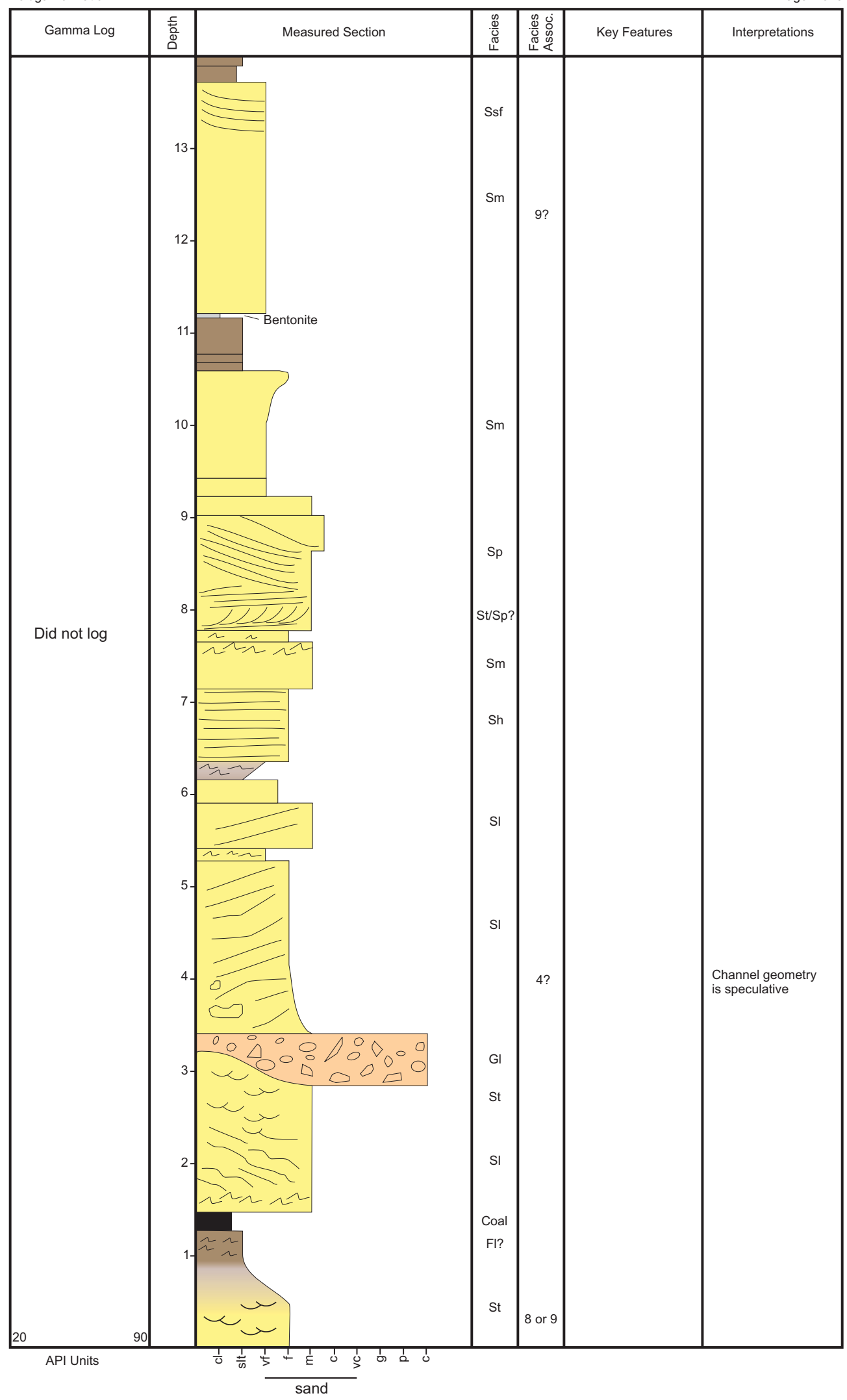


07DL002

FIGURE A5

N59.65911 W151.66521

Beluga Formation

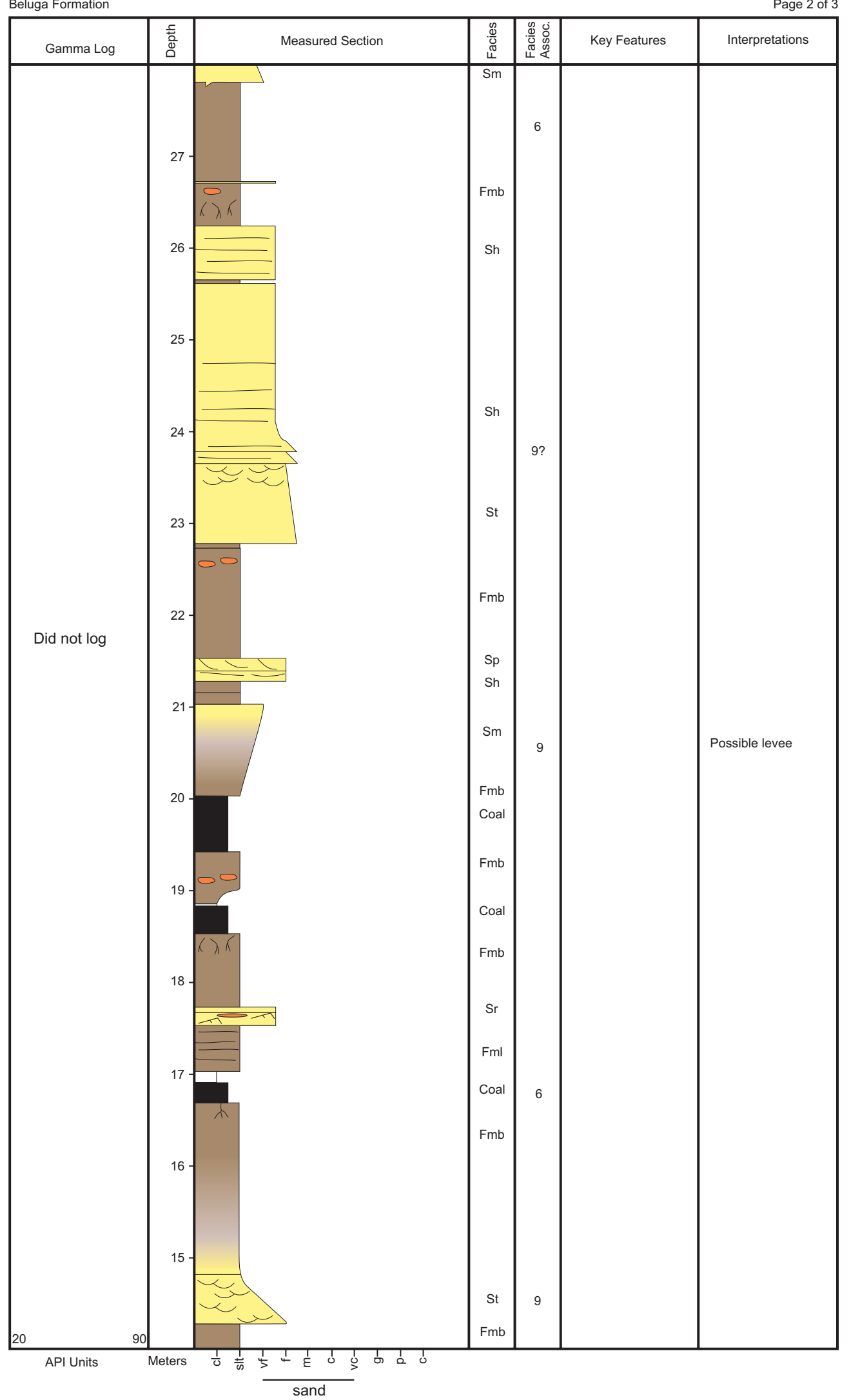


07DL002

Bluff Point

FIGURE A5

N59.65911 W151.66521

Beluga Formation

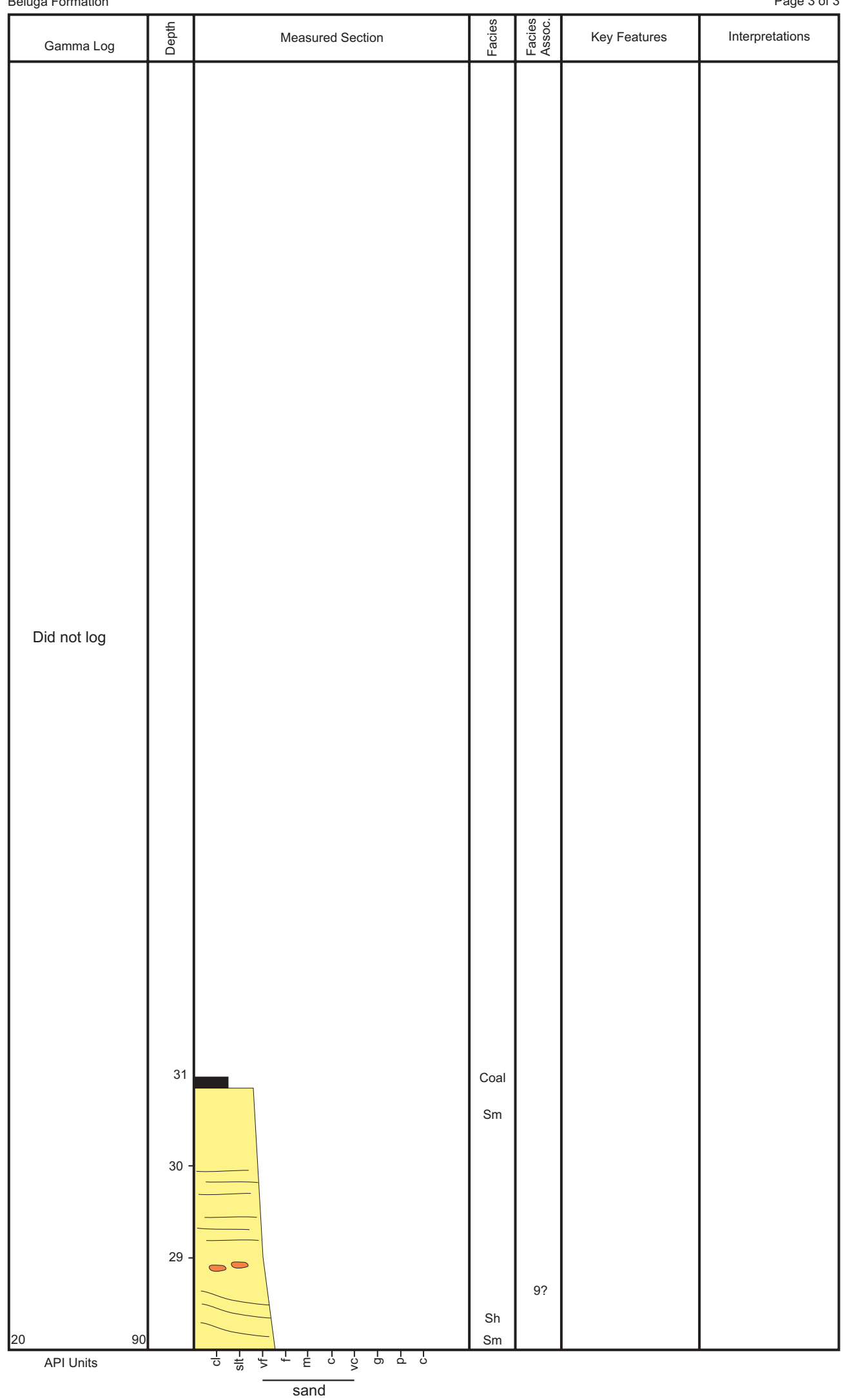


07DL003
Bluff Point

FIGURE A6

N59.65944 W151.66624

Beluga Formation

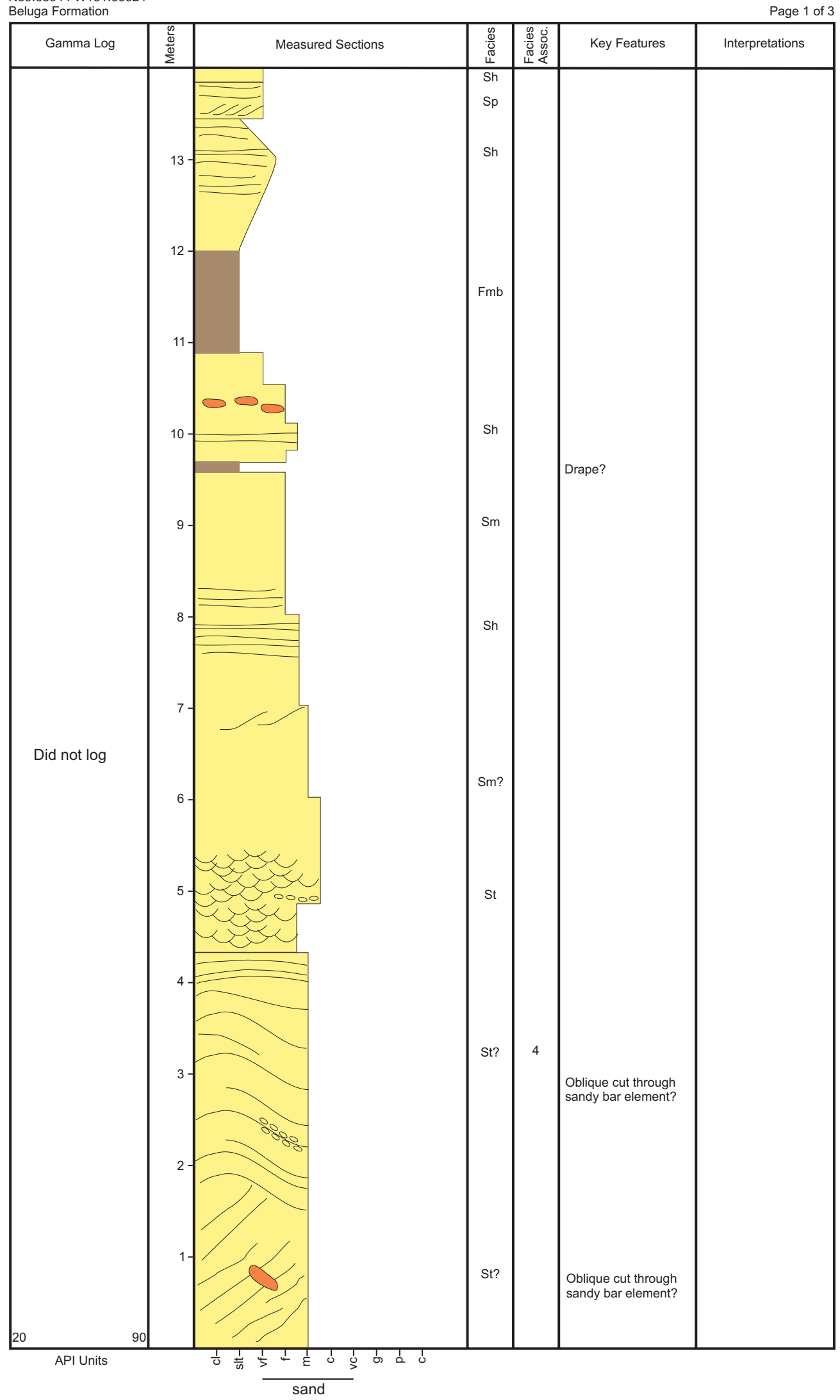


07DL003

Bluff Point

FIGURE A6

N59.65944 W151.66624

Beluga Formation

Page 2 of 3

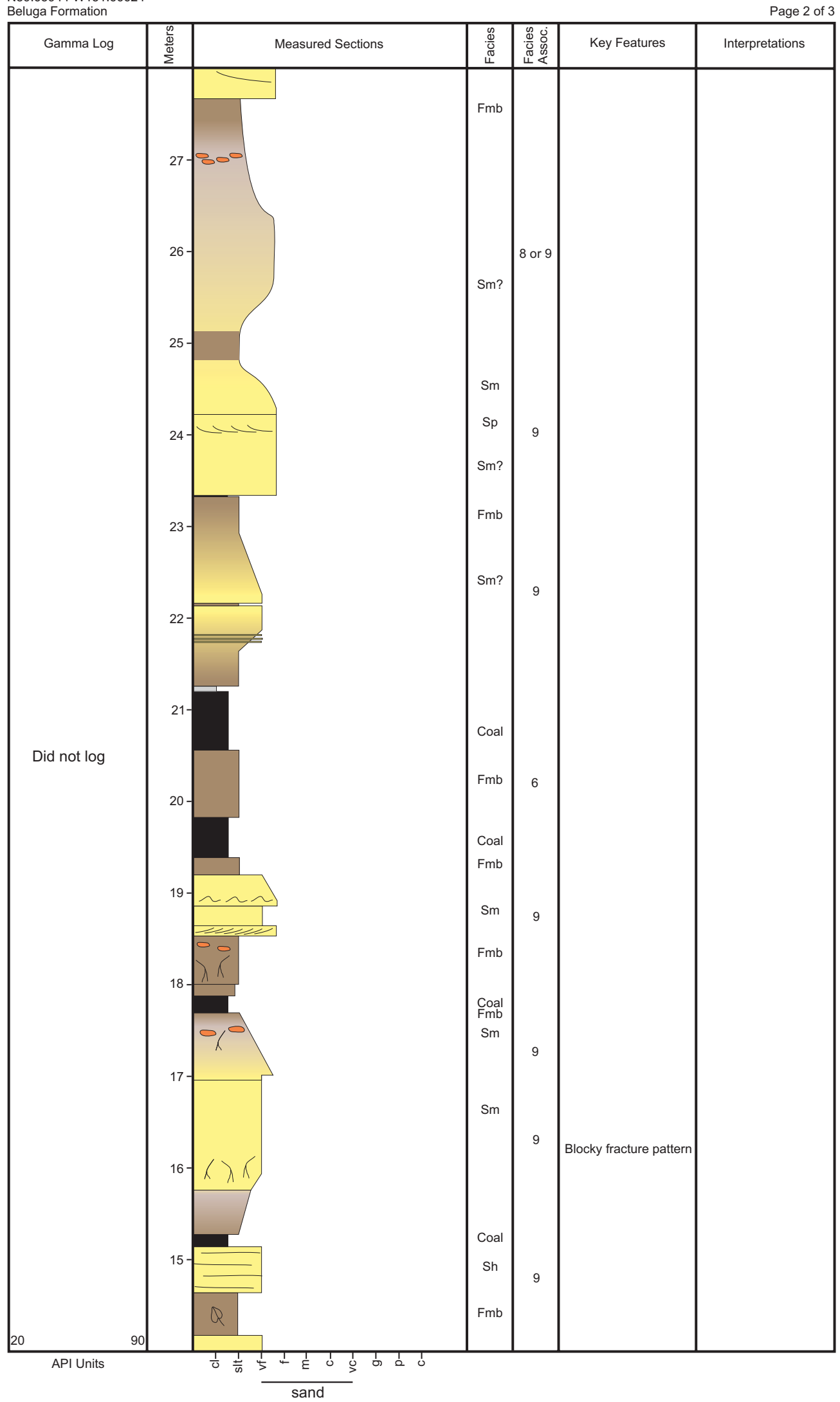


N59.65944 W151.66624

Beluga Formation

Page 3 of 3

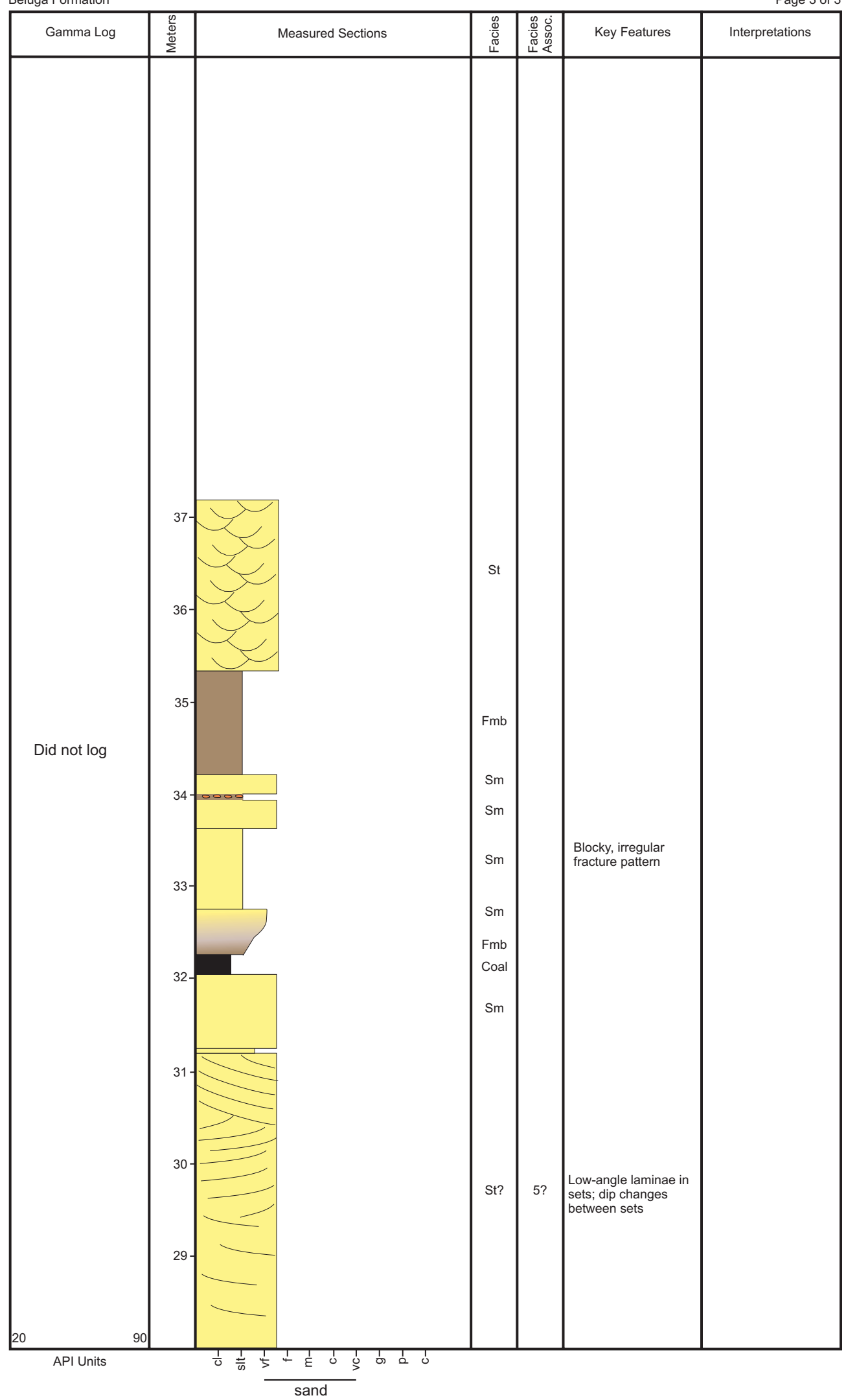


07DL004

Diamond Gulch

FIGURE A7

N59.65964 W151.66736

Page 1 of 1

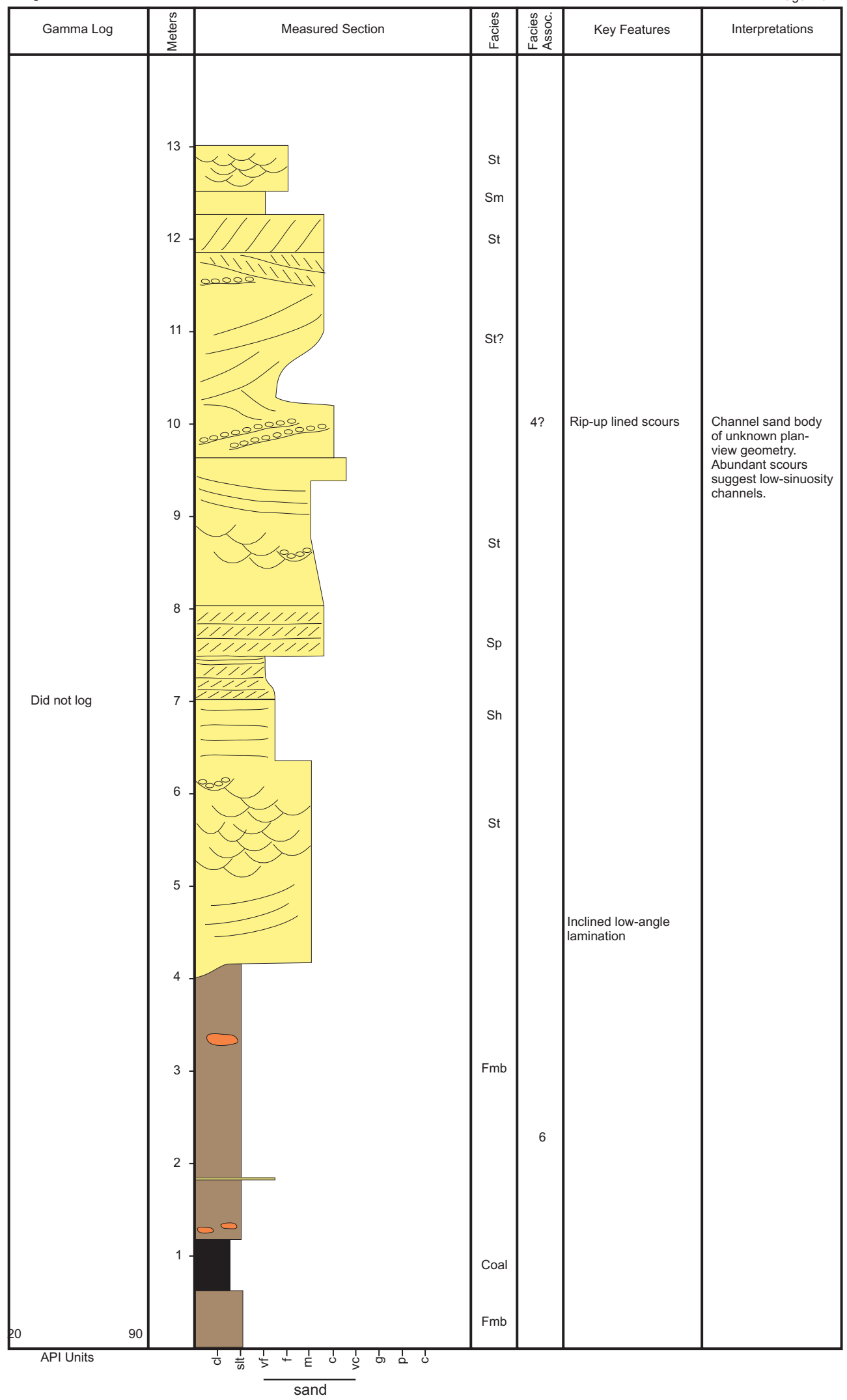


07JRM001

Fritz Creek, Kachemak Bay

FIGURE A8

N59.69343 W151.31347

Beluga Formation

Page 1 of 2

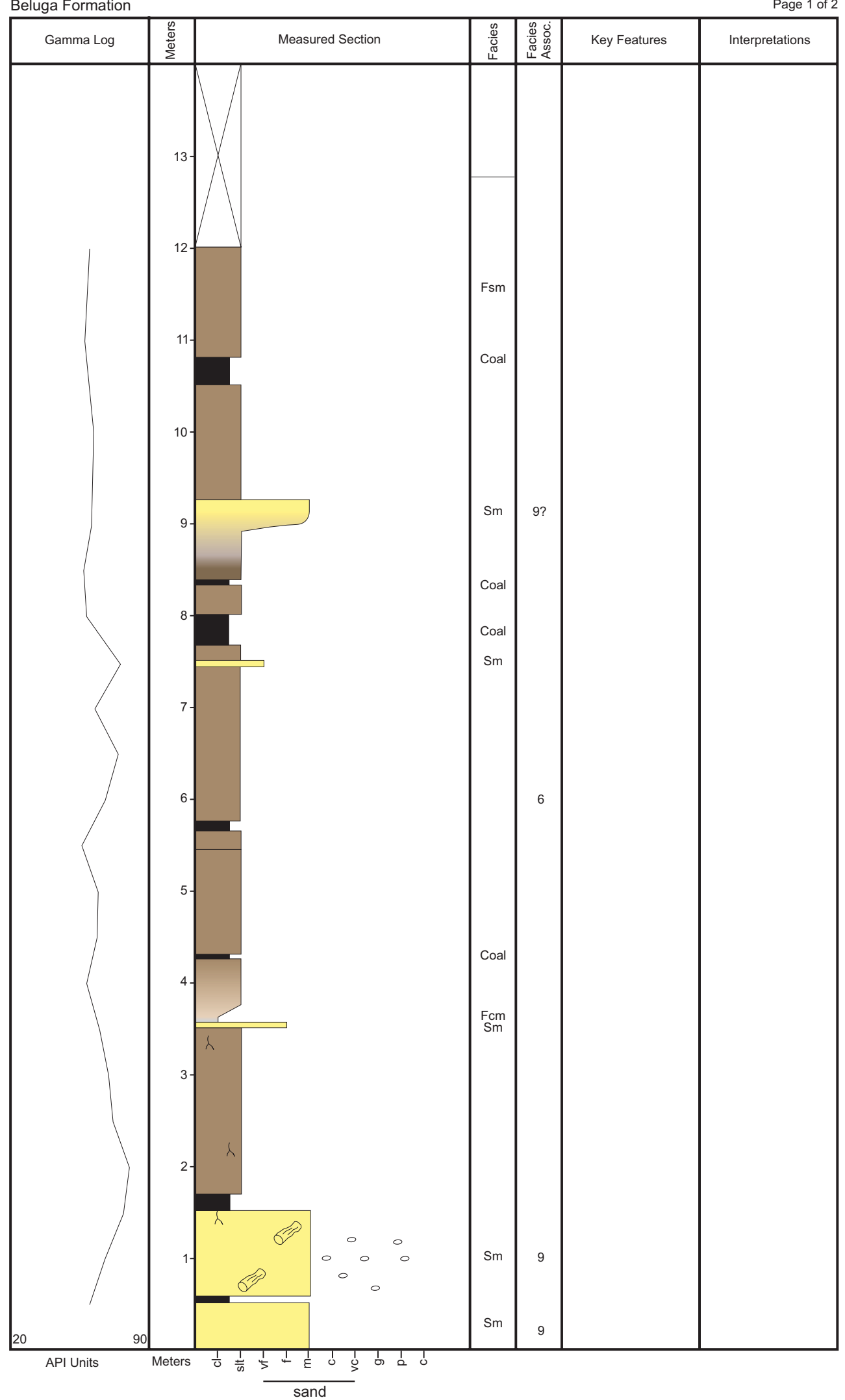


07JRM001

Fritz Creek, Kachemak Bay

N59.69343 W151.31347

Beluga Formation

FIGURE A8

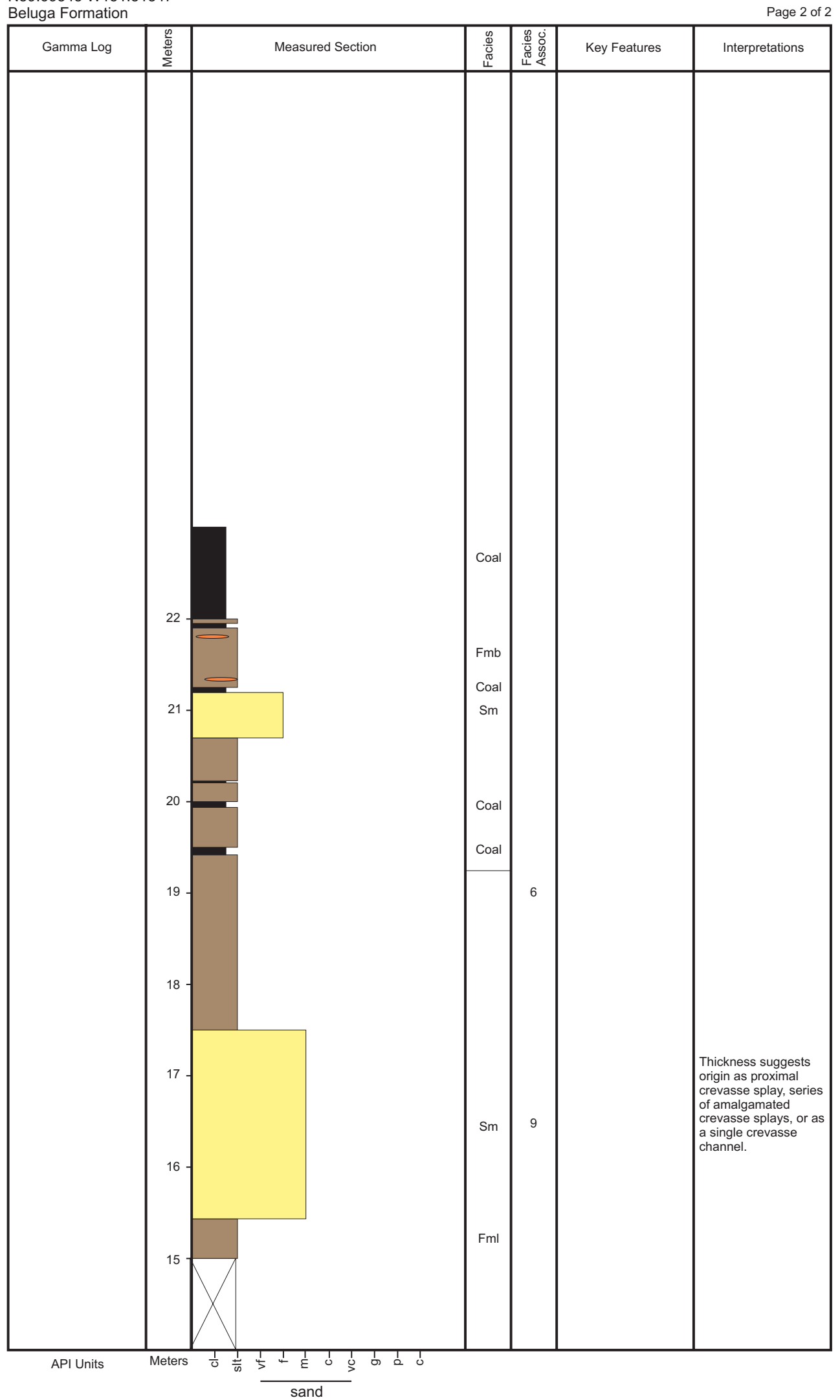


07JRM002

Fritz Creek, Kachemak Bay

N55.69365 W151.3128

FIGURE A9

Beluga Formation

Page 1 of 2

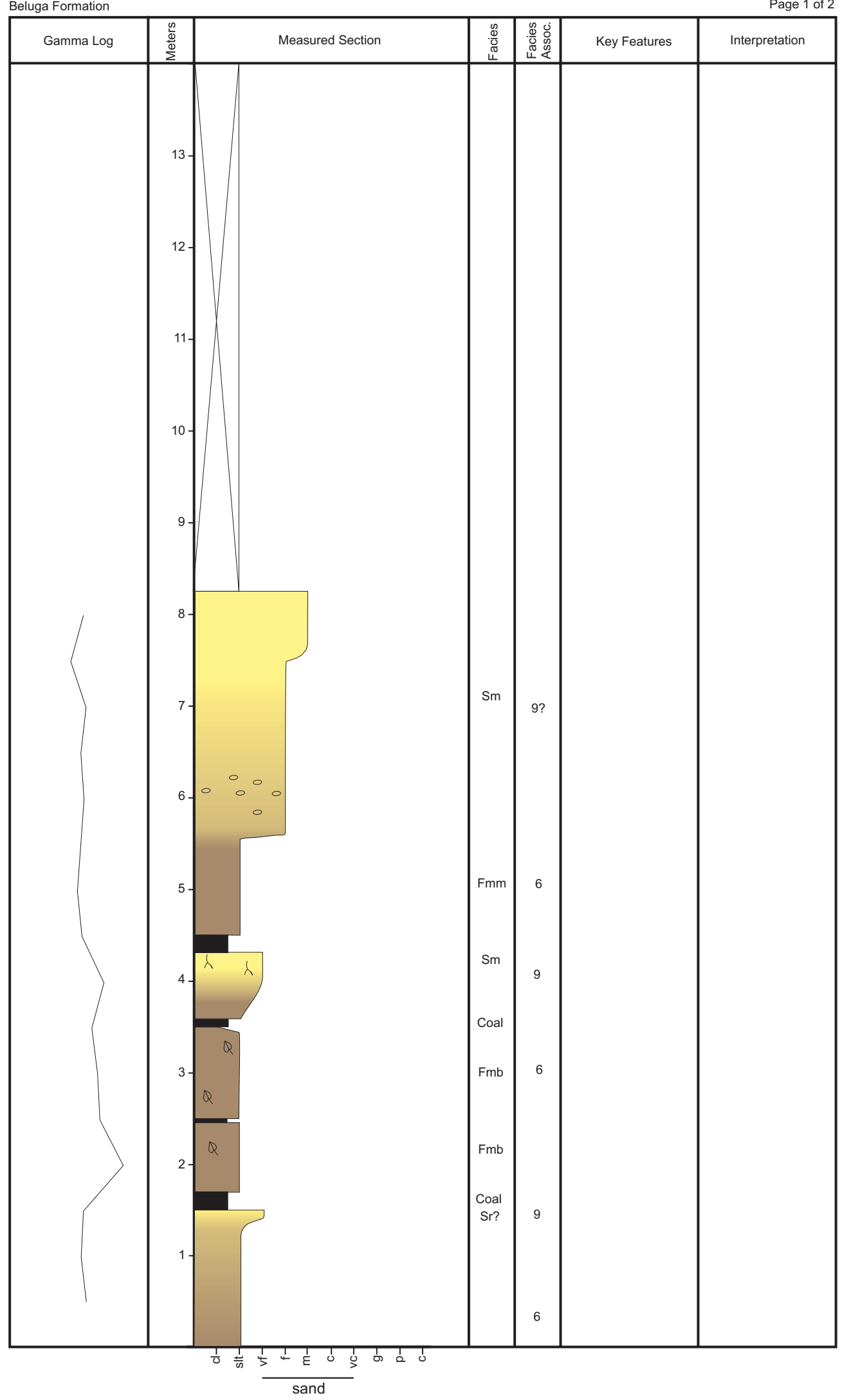


07JRM002

Fritz Creek, Kachemak Bay

N55.69365 W151.3128

Beluga Formation

FIGURE A9

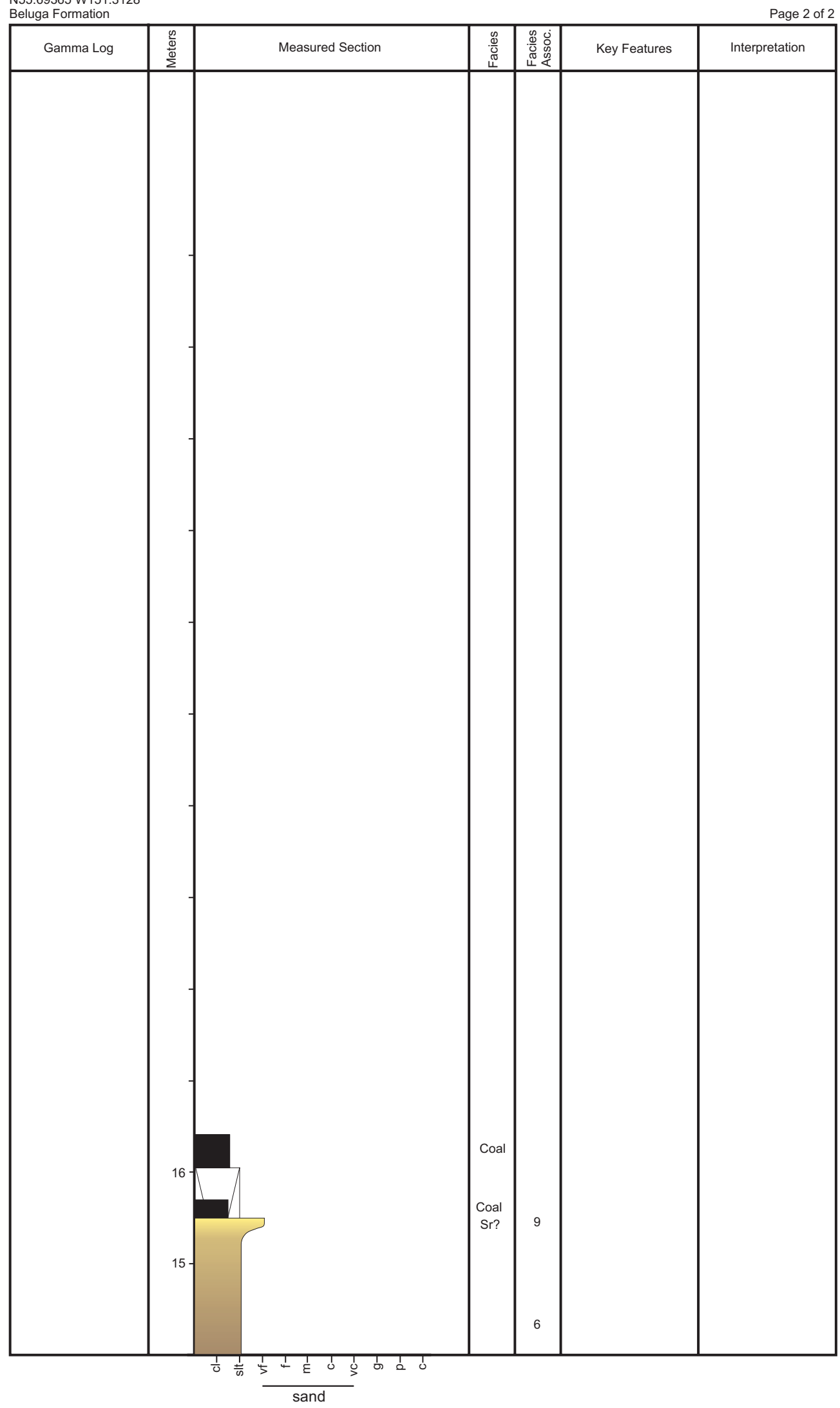


07JRM003

FIGURE A10

Fritz Creek, Kachemak Bay

N59.6938 W151.31266

Beluga Formation

Page 1 of 1

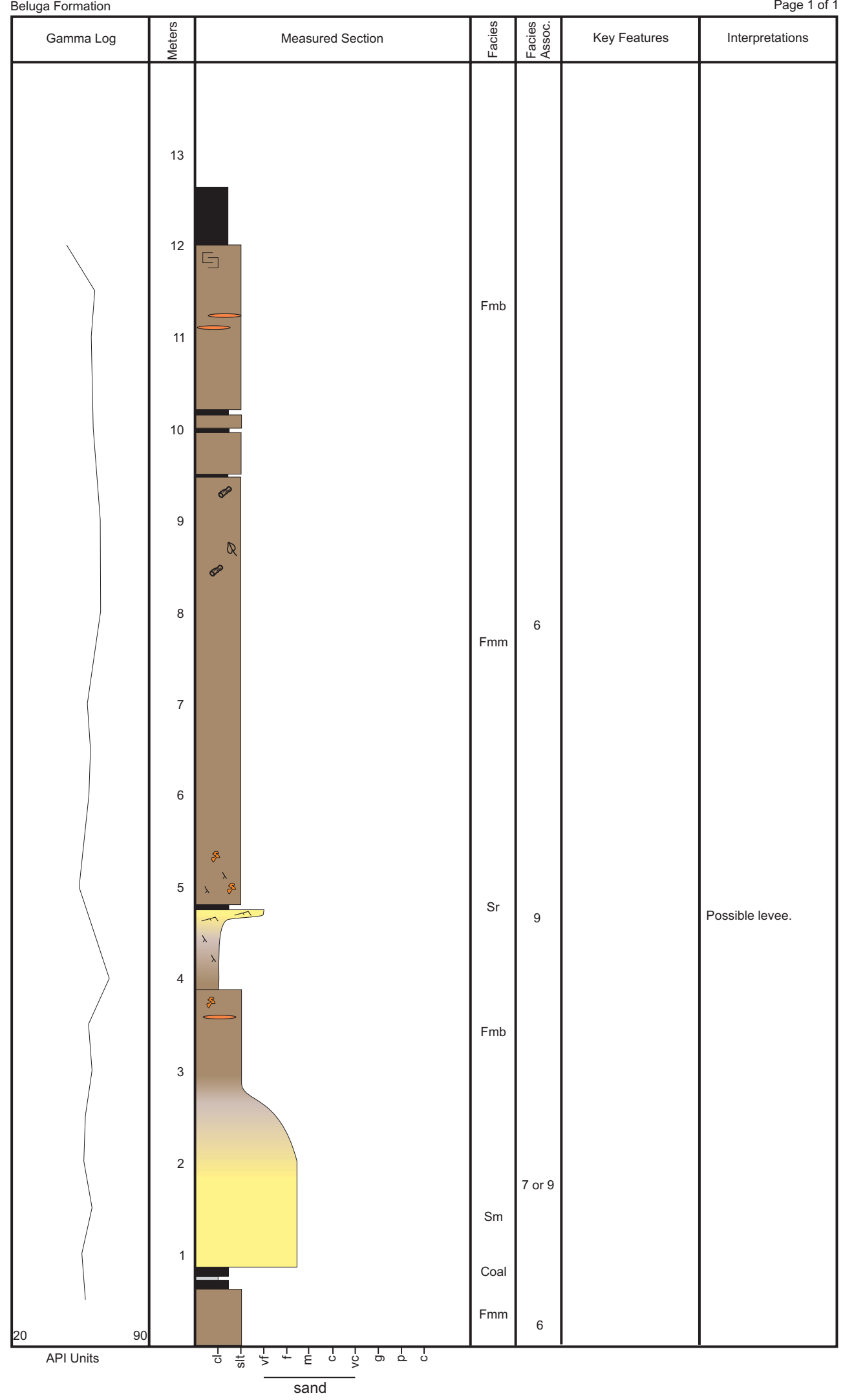


07JRM005

Fritz Creek, Kachemak Bay

N59.69517 W151.30707

Beluga Formation

FIGURE A11

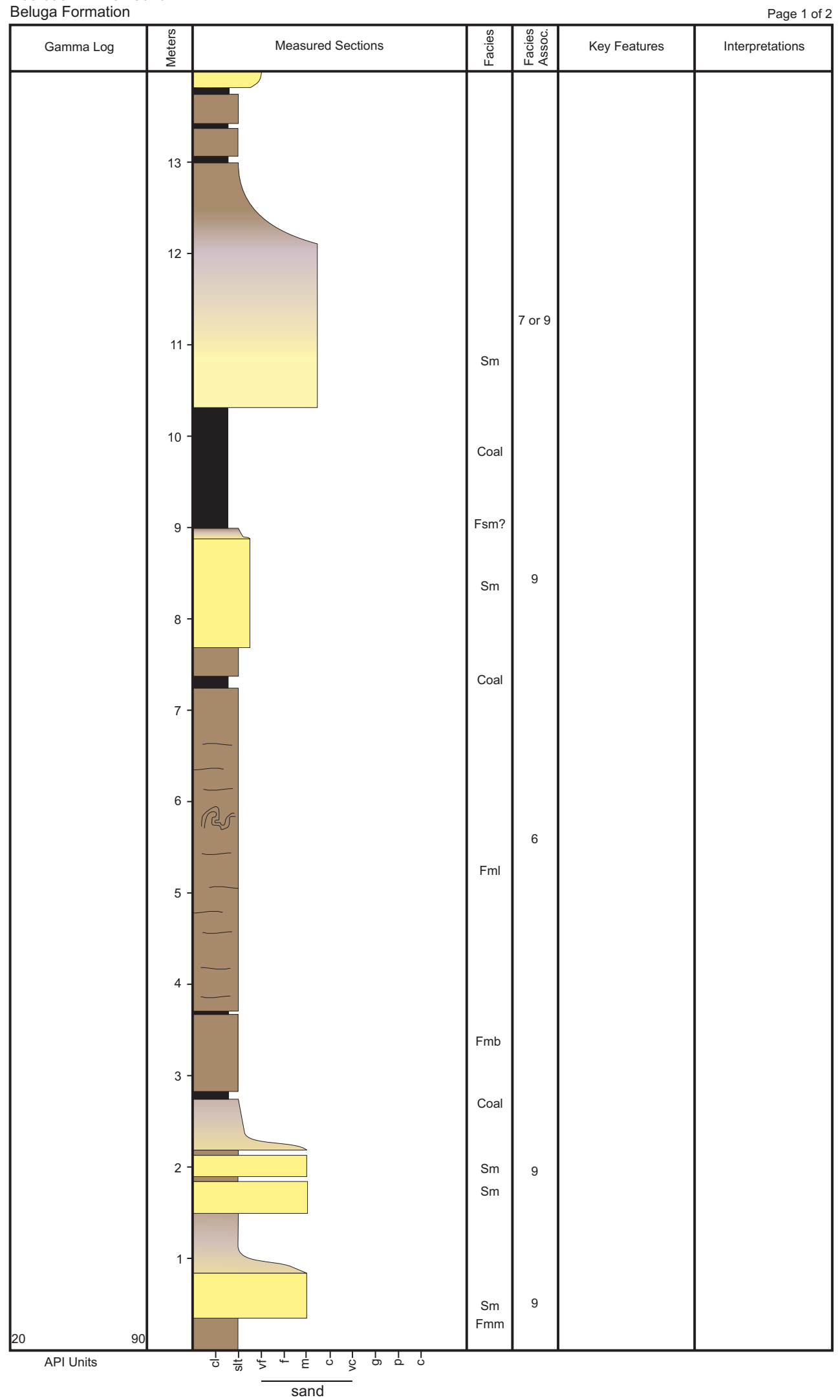


07JRM005

Fritz Creek, Kachemak Bay

N59.69517 W151.30707

Beluga Formation

FIGURE A11

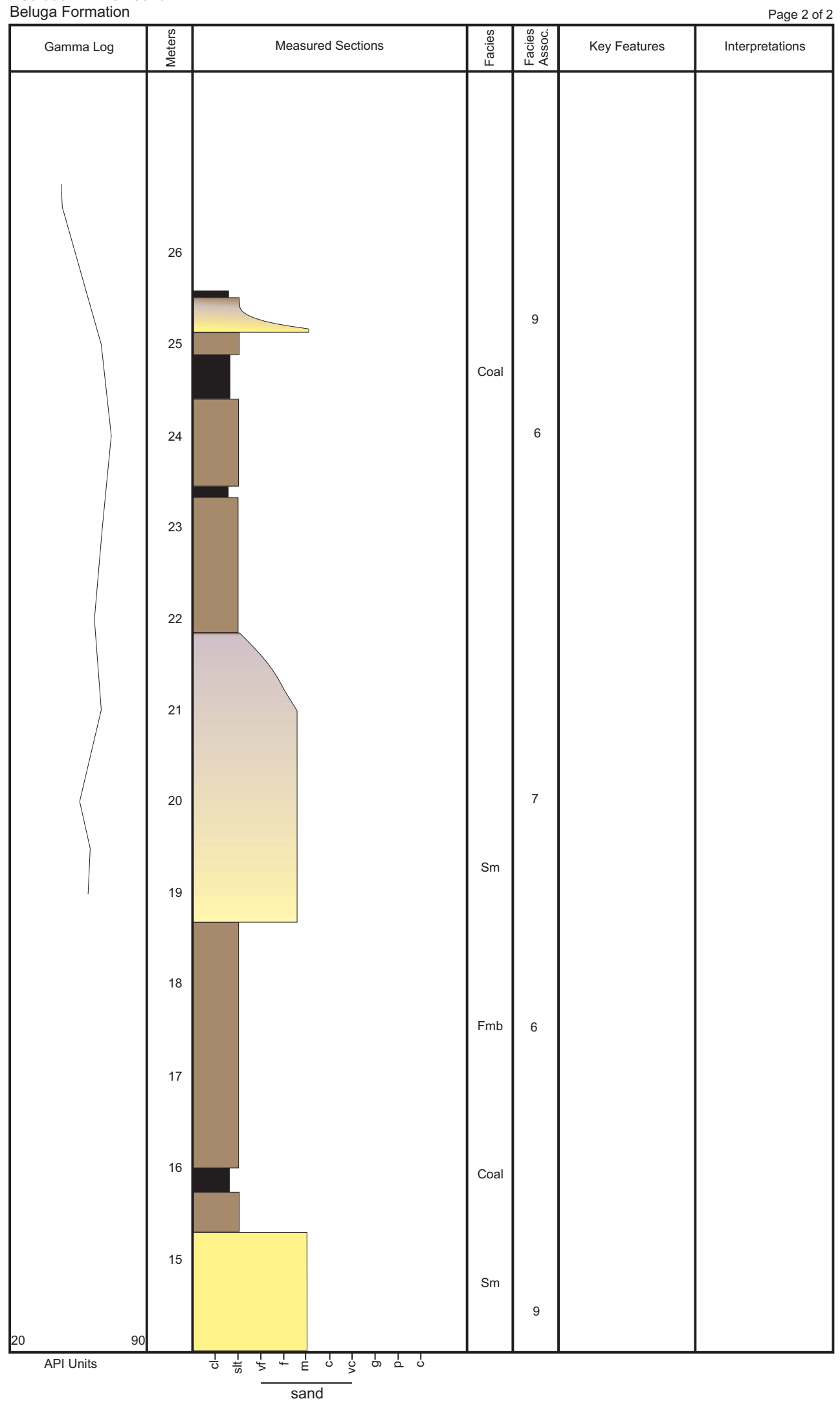


07JRM006

FIGURE A12

Fritz Creek, Kachemak Bay

N59.69522 W151.30672

Beluga Formation

Page 1 of 2

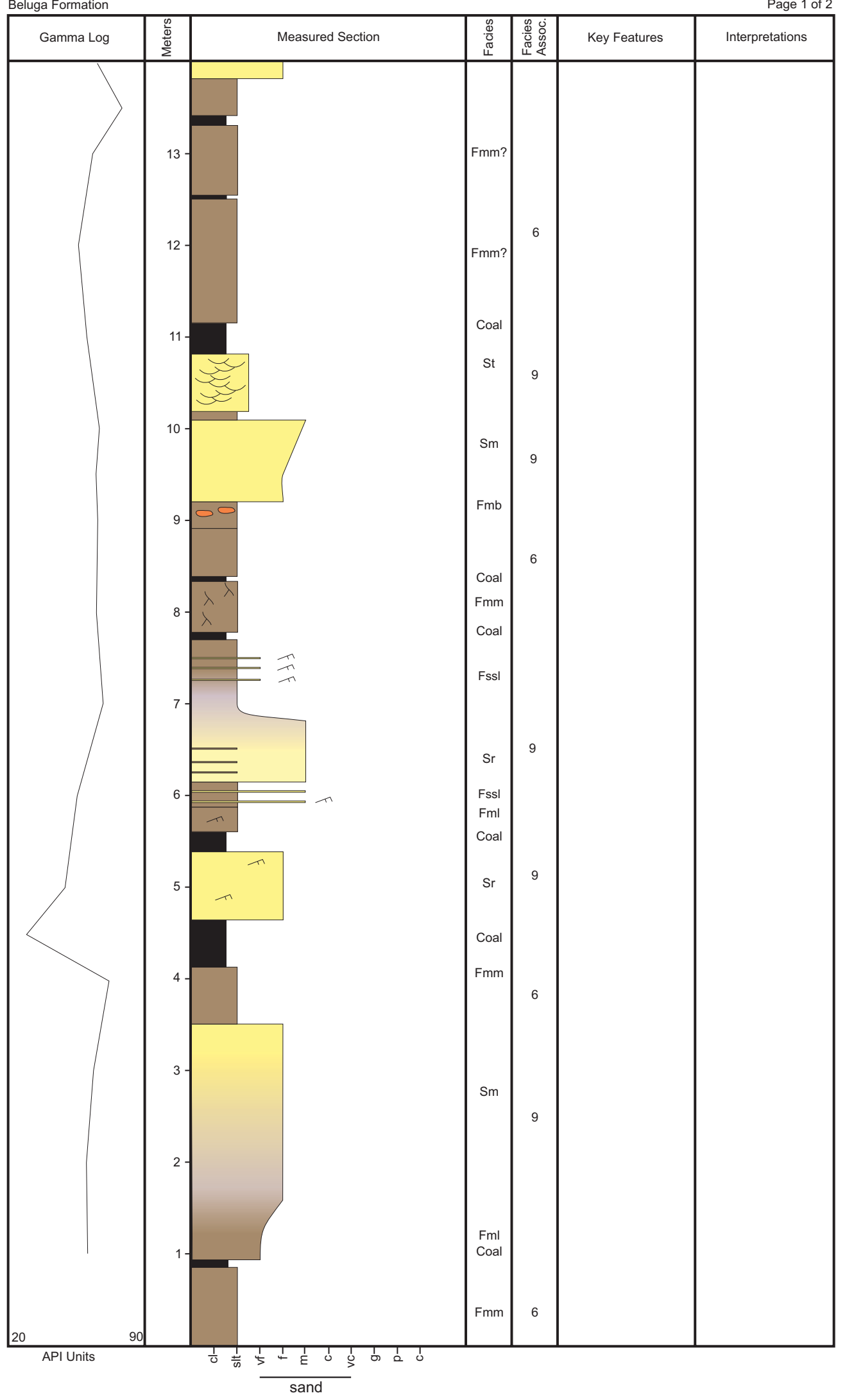


07JRM006

Fritz Creek, Kachemak Bay

FIGURE A12

Beluga Formation

Page 2 of 2

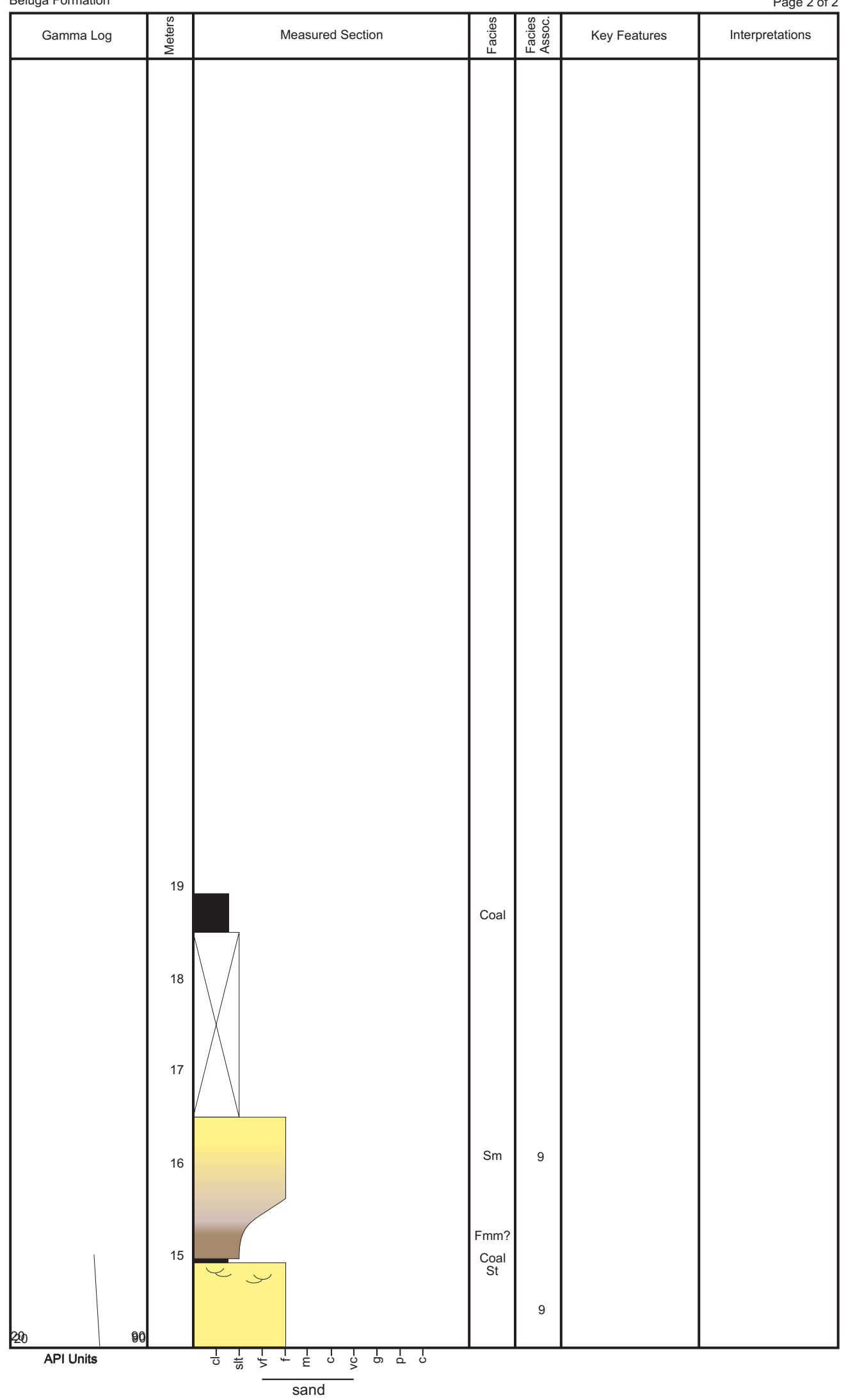


07JRM008

Fritz Creek, Kachemak Bay

FIGURE A13

N59.6962 W151.30368

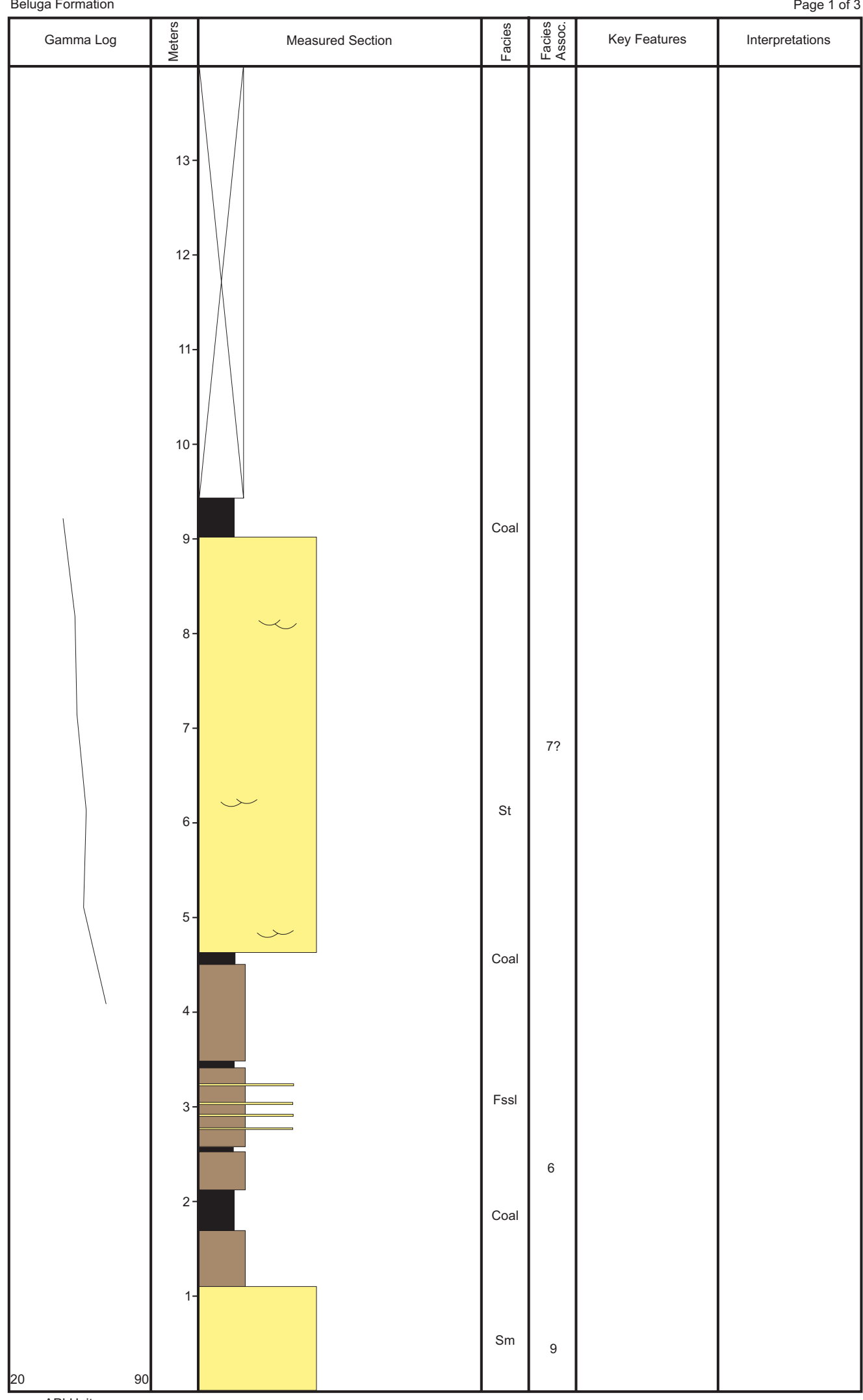

API Units 
07JRM008

FIGURE A13

Fritz Creek, Kachemak Bay

N59.6962 W151.30368

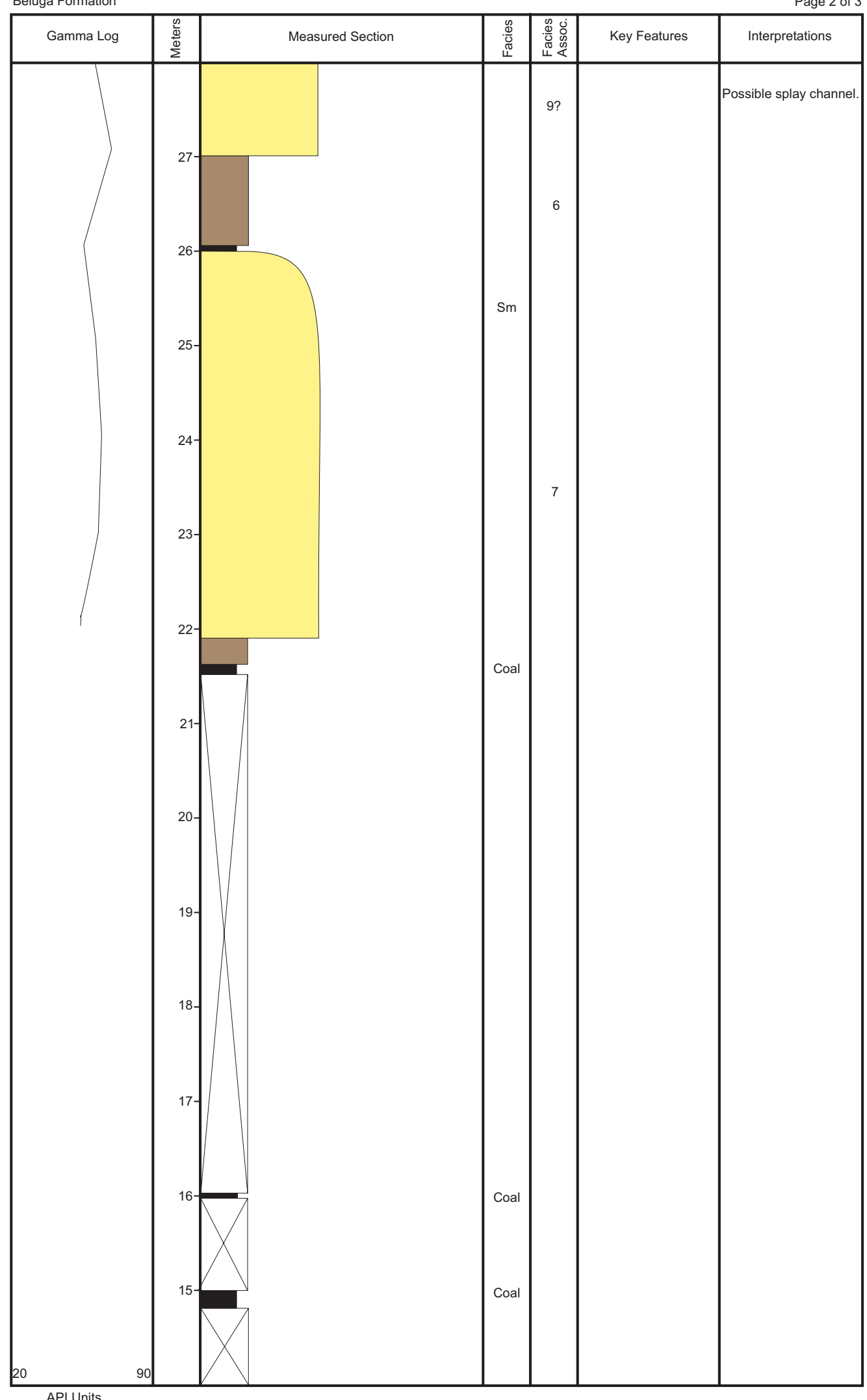


07JRM008

Fritz Creek, Kachemak Bay

FIGURE A13

N59.6962 W151.30368

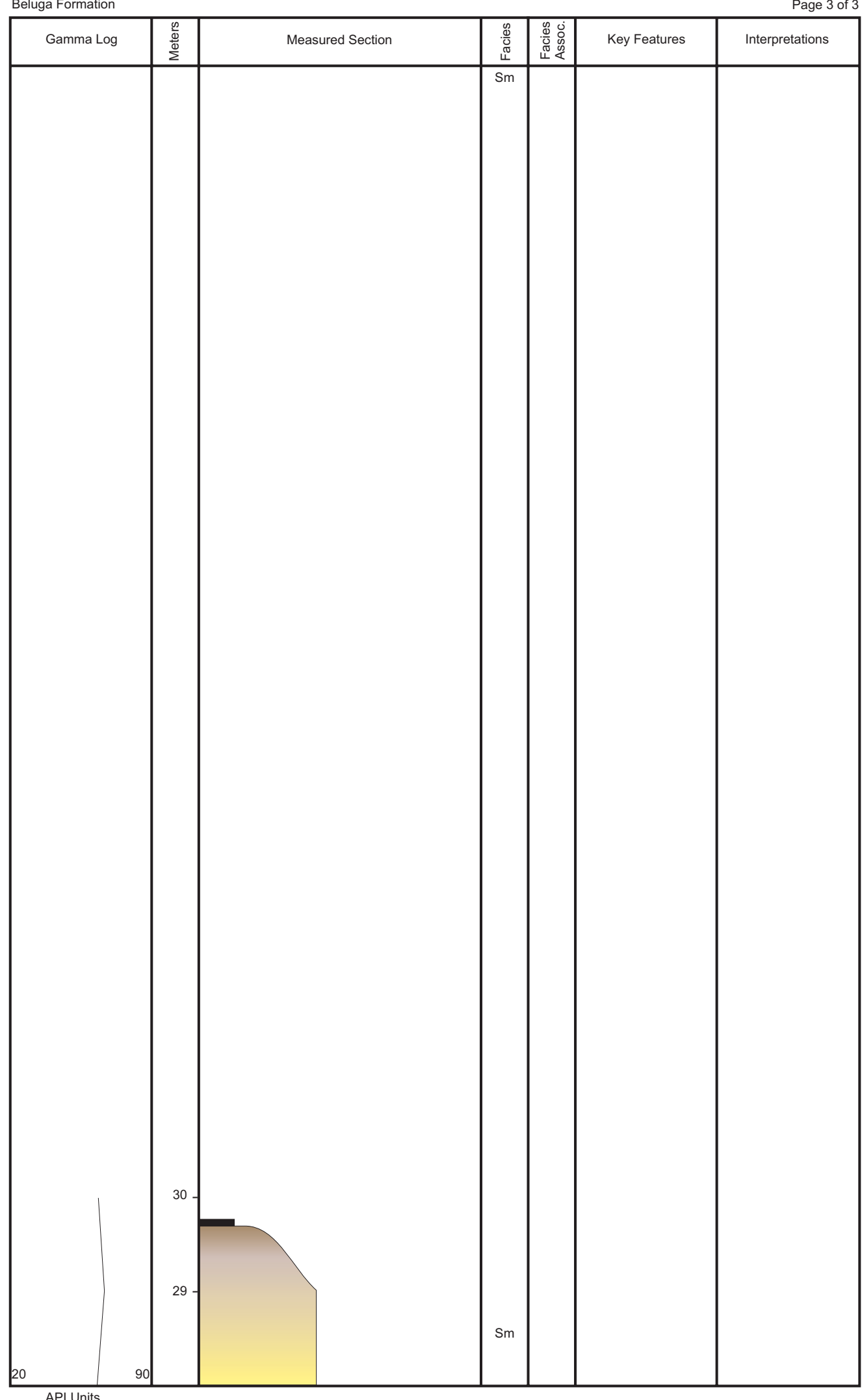

API Units 
N59.70012 W151.29219

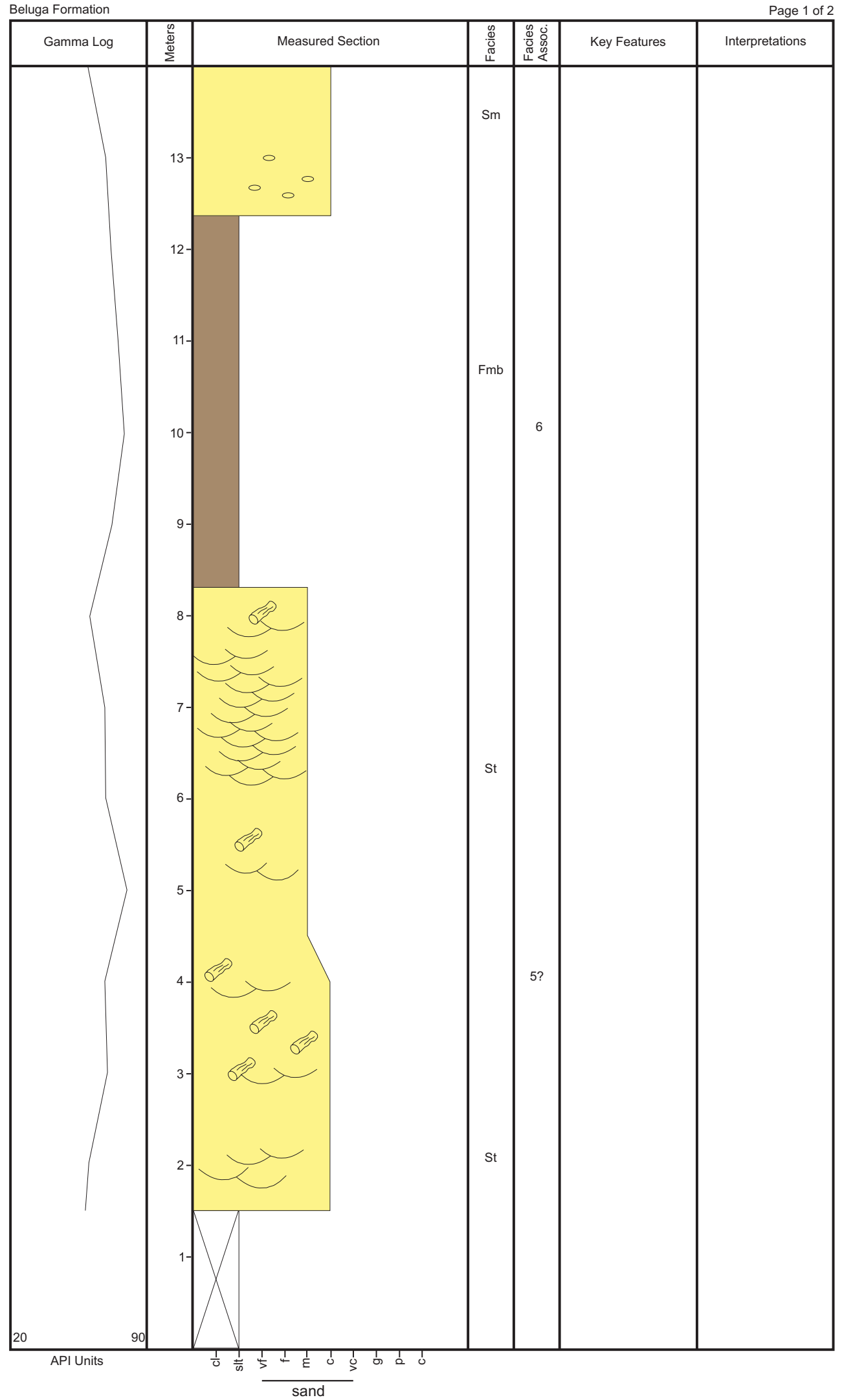


07JRM009

Fritz Creek, Kachemak Bay

FIGURE A14

N59.70012 W151.29219

Beluga Formation

Page 2 of 2

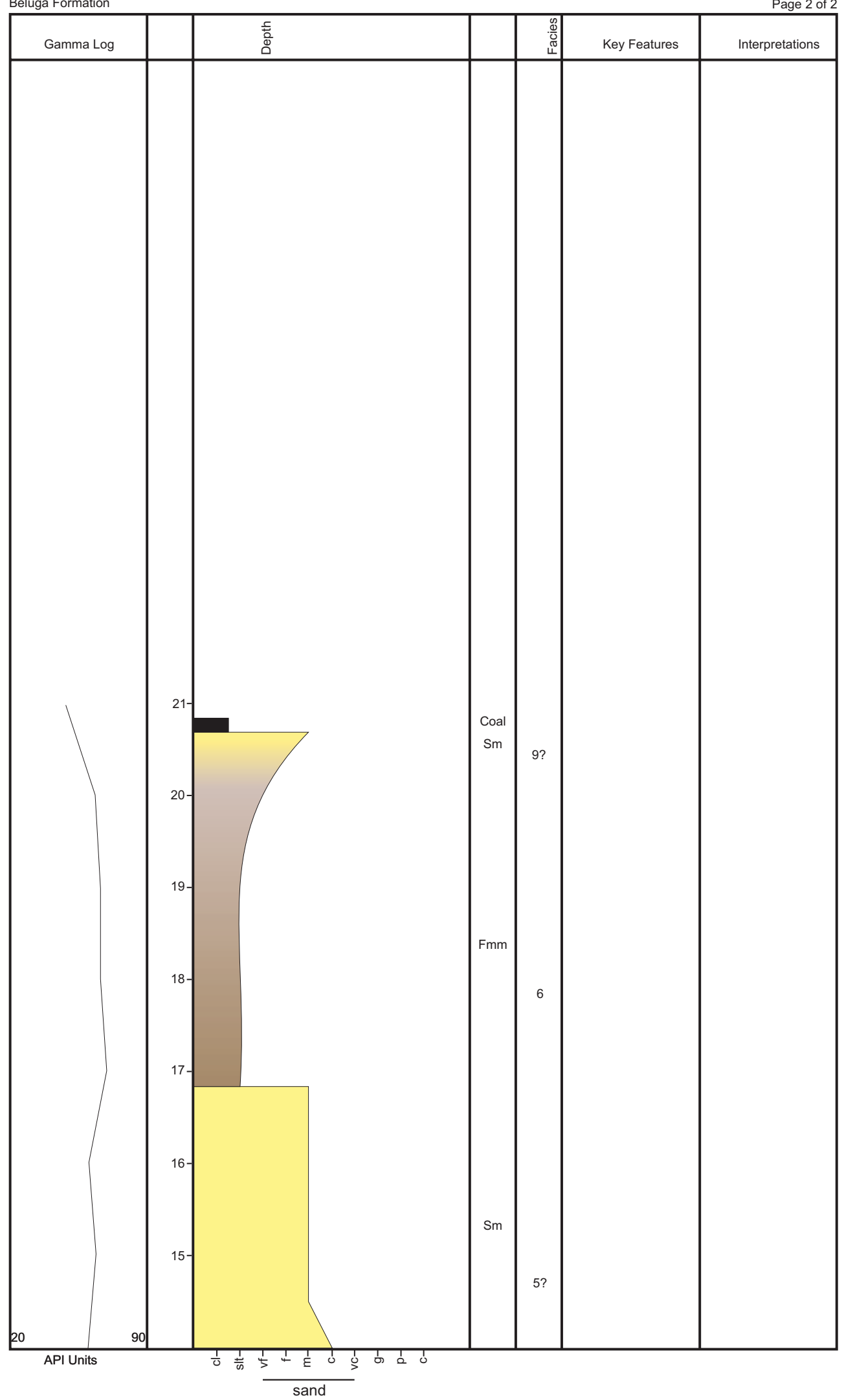


07JRM010

Falls Creek, Kachemak Bay

FIGURE A15

N59.69879 W151.29545

Upper Beluga-Lower Sterling Formation

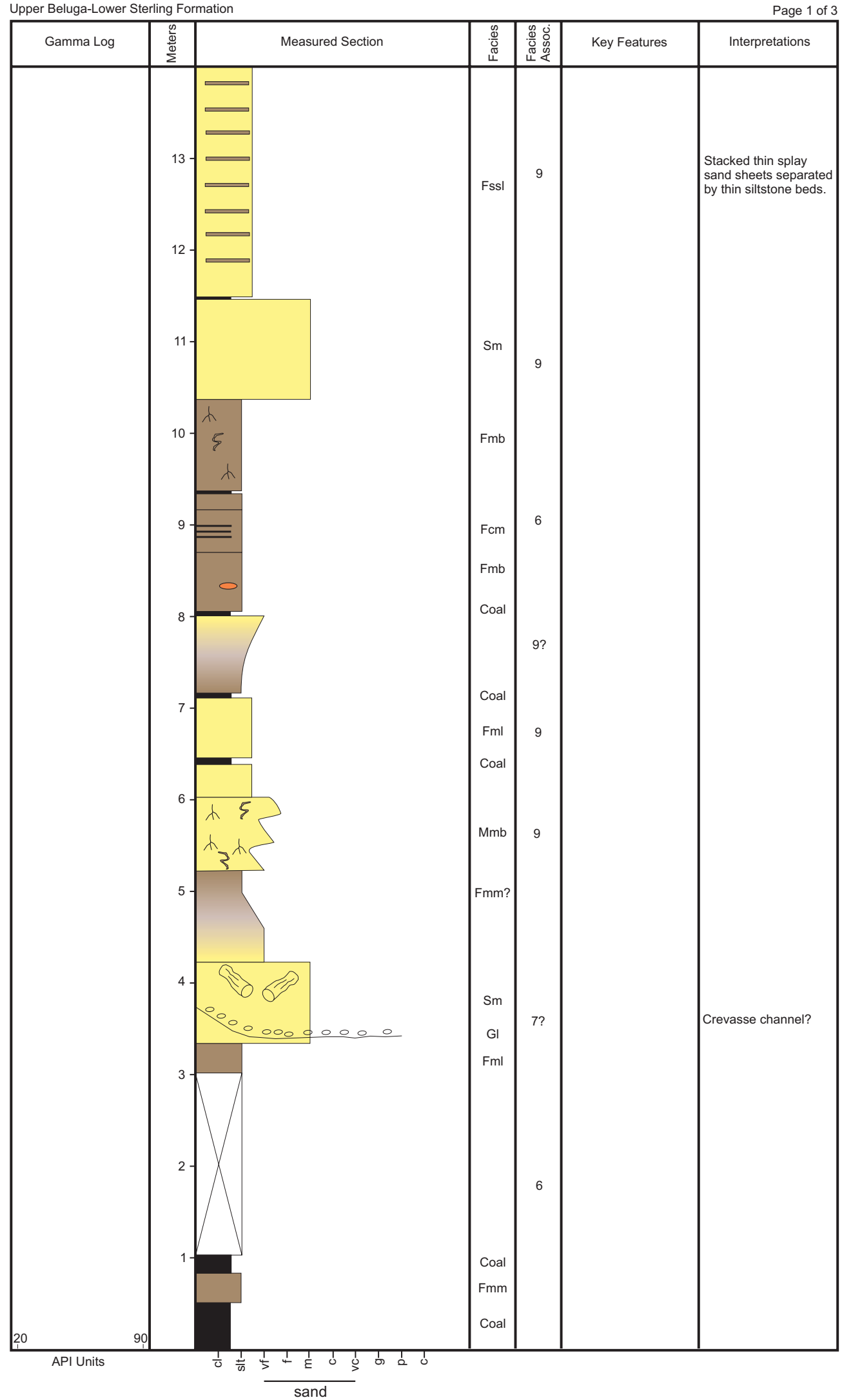


FIGURE A15

07JRM010

Falls Creek, Kachemak Bay

Upper Beluga-Lower Sterling Formation

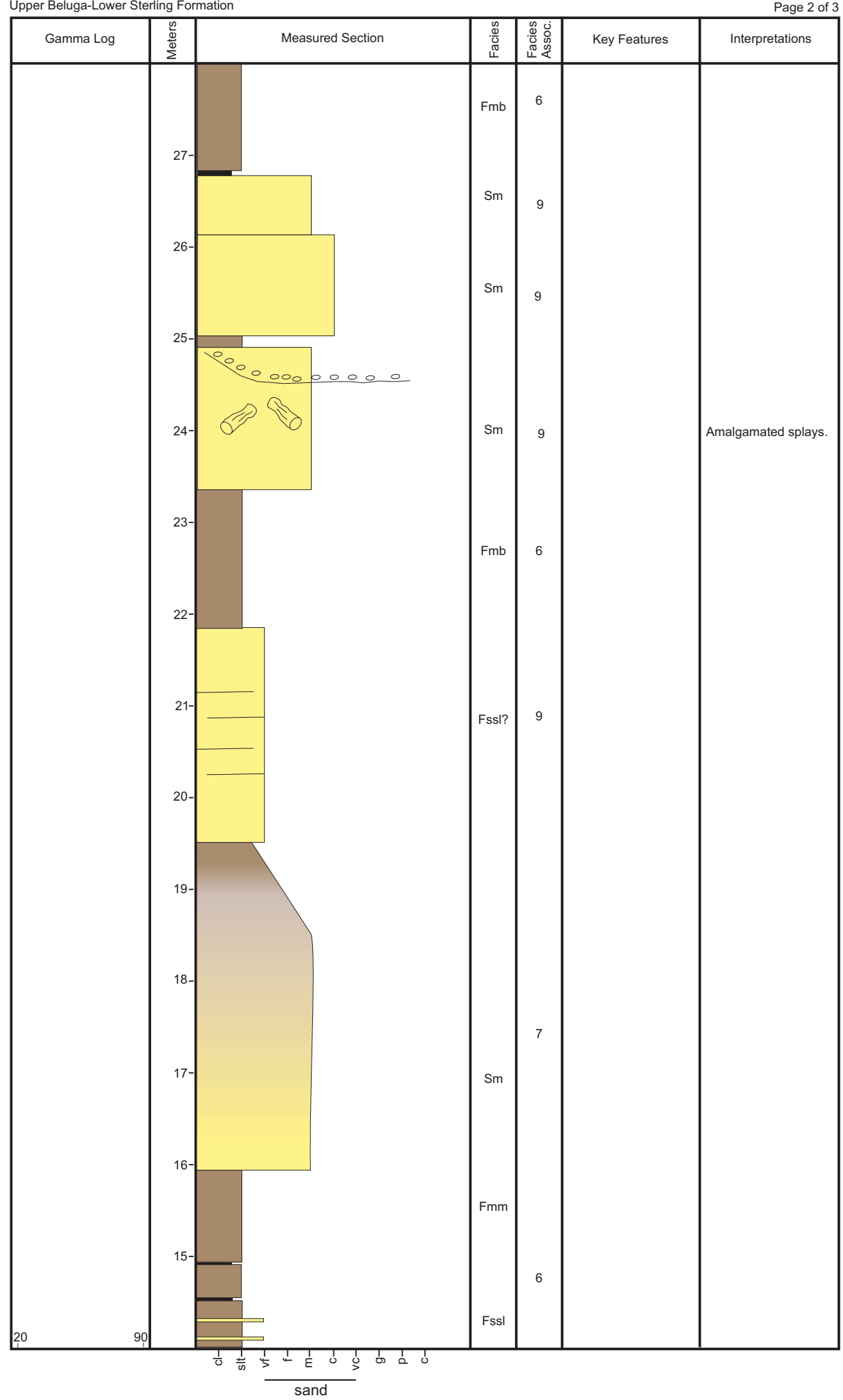


07JRM010

Falls Creek, Kachemak Bay

FIGURE A15

N59.69879 W151.29545

Upper Beluga-Lower Sterling Formation

Page 3 of 3

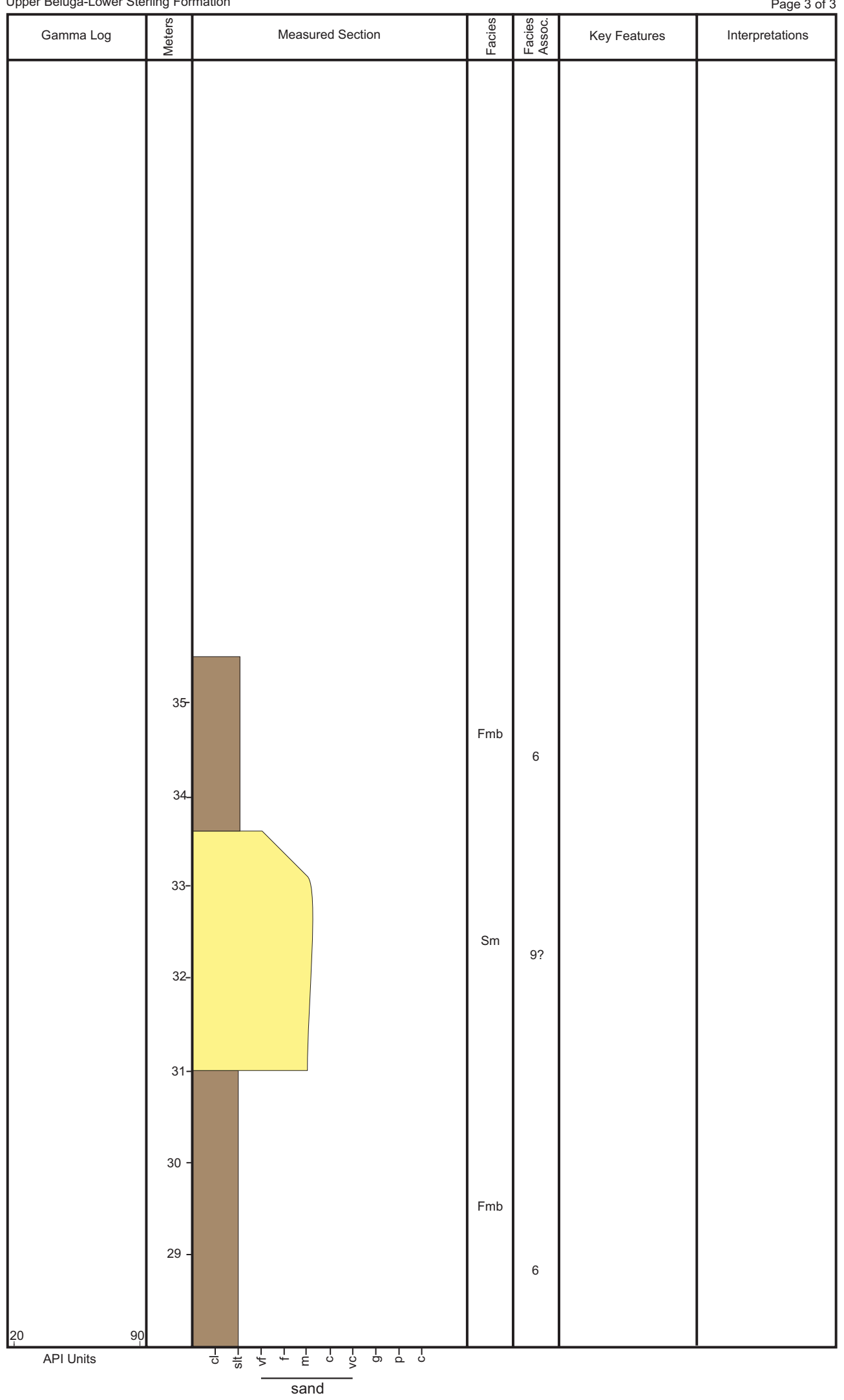


07JRM011

FIGURE A16

Falls Creek, Kachemak Bay

N59.77309 W151.12128

Sterling Formation

Page 1 of 3

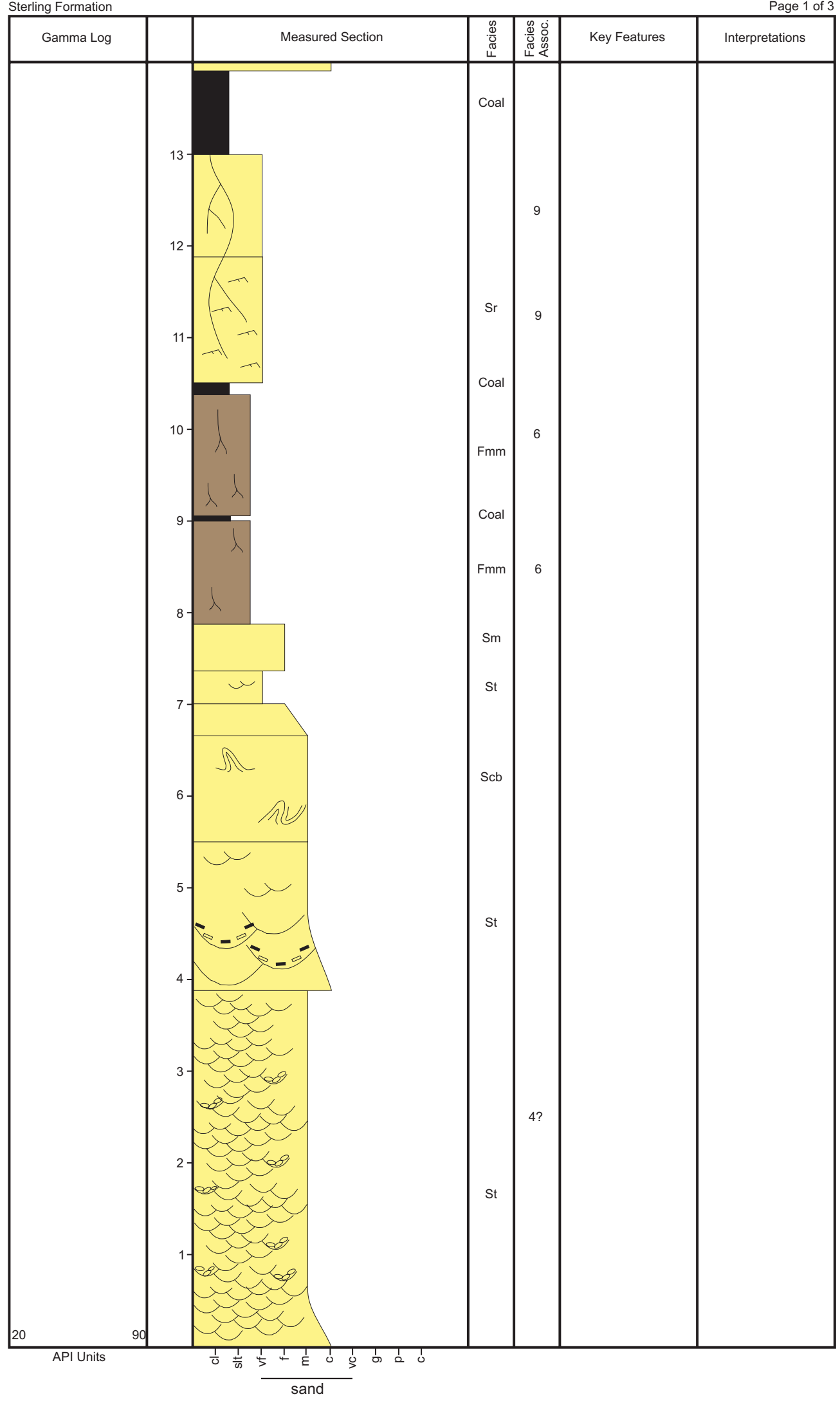


07JRM011

FIGURE A16

Falls Creek, Kachemak Bay

N59.77309 W151.12128

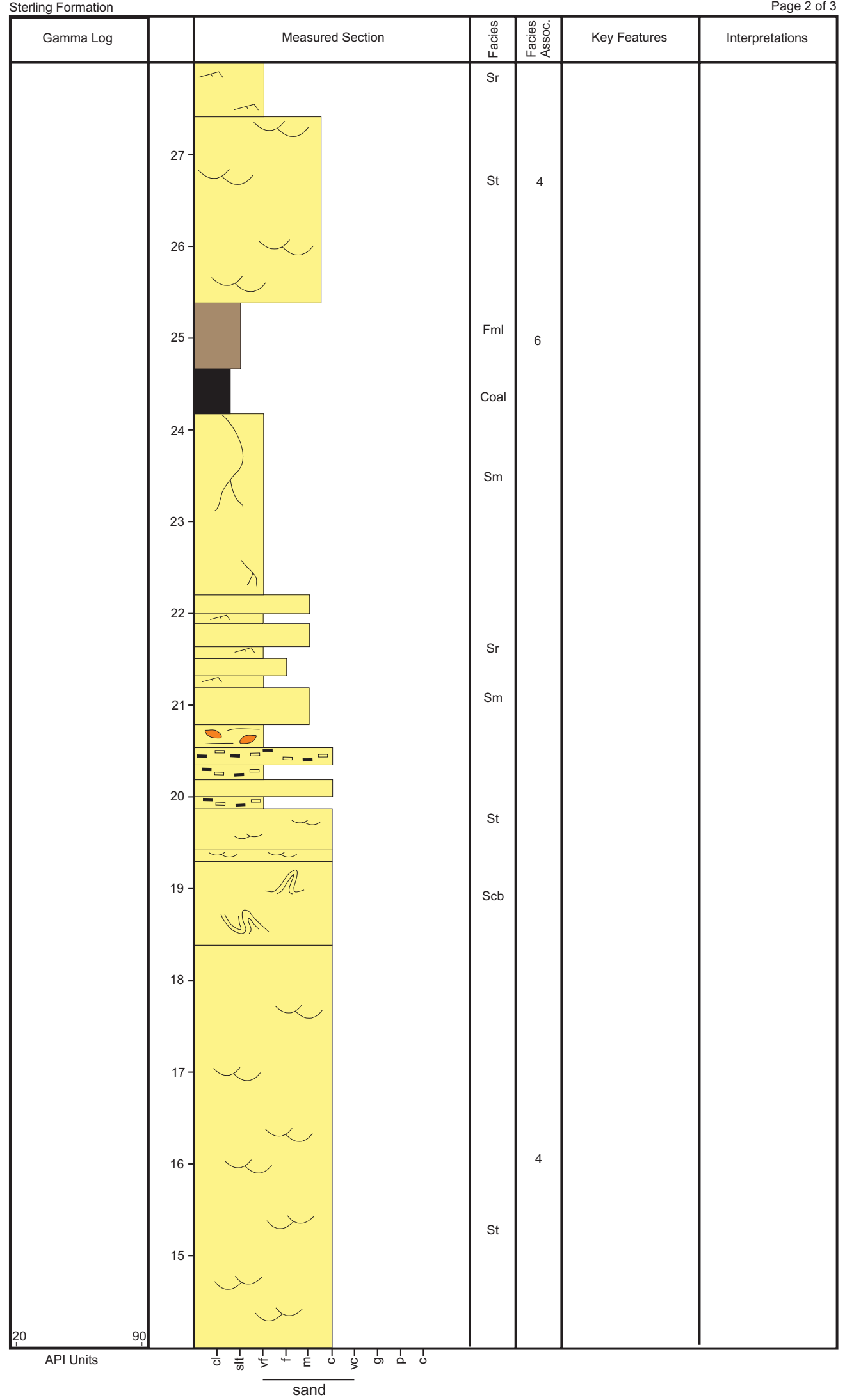


07JRM011

FIGURE A16 Falls Creek, Kachemak Bay N59.77309 W151.12128 Sterling Formation

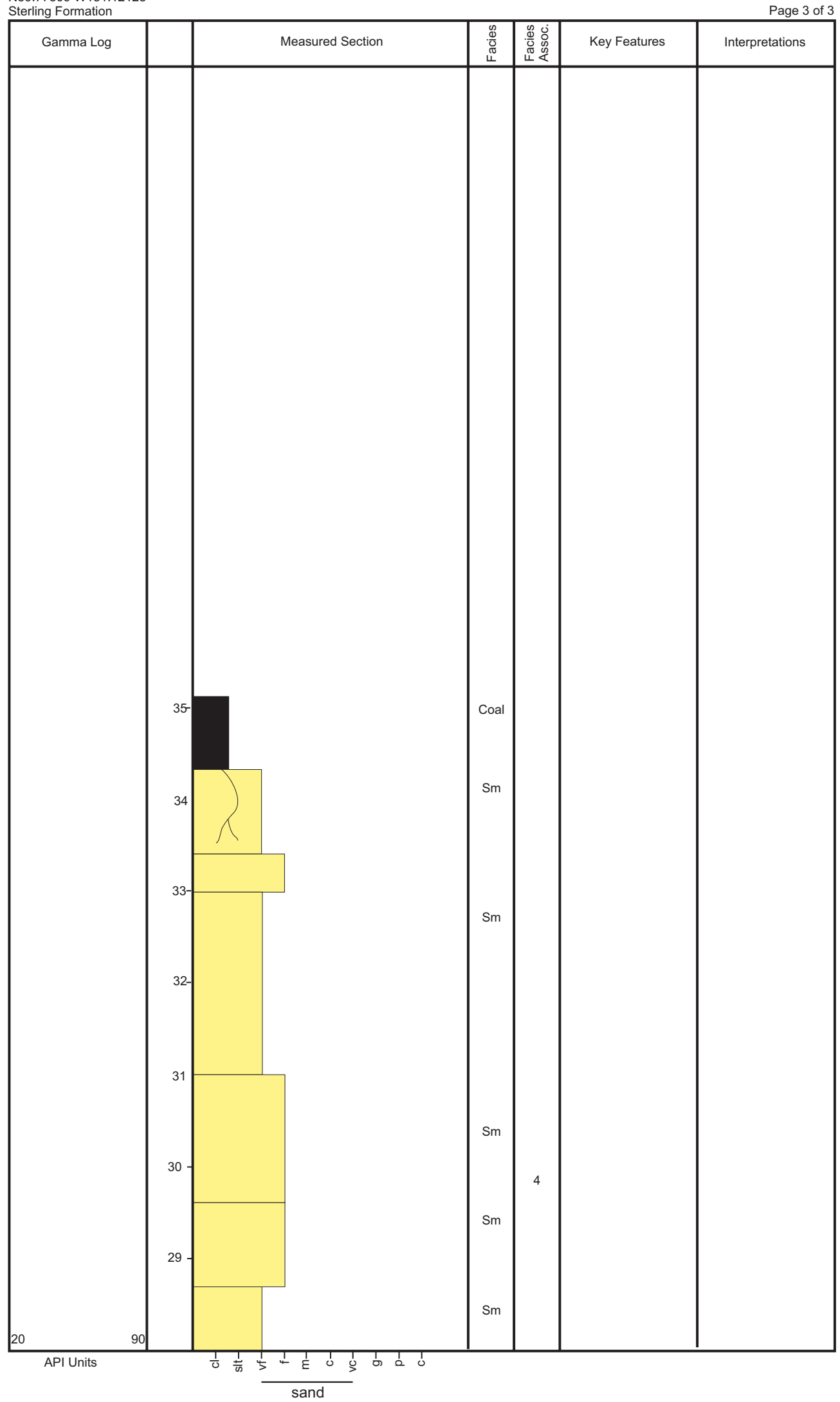


07JRM012

FIGURE A17

Falls Creek, Kachemak Bay

N59.78246 W151.10204

Sterling Formation

Page 1 of 3

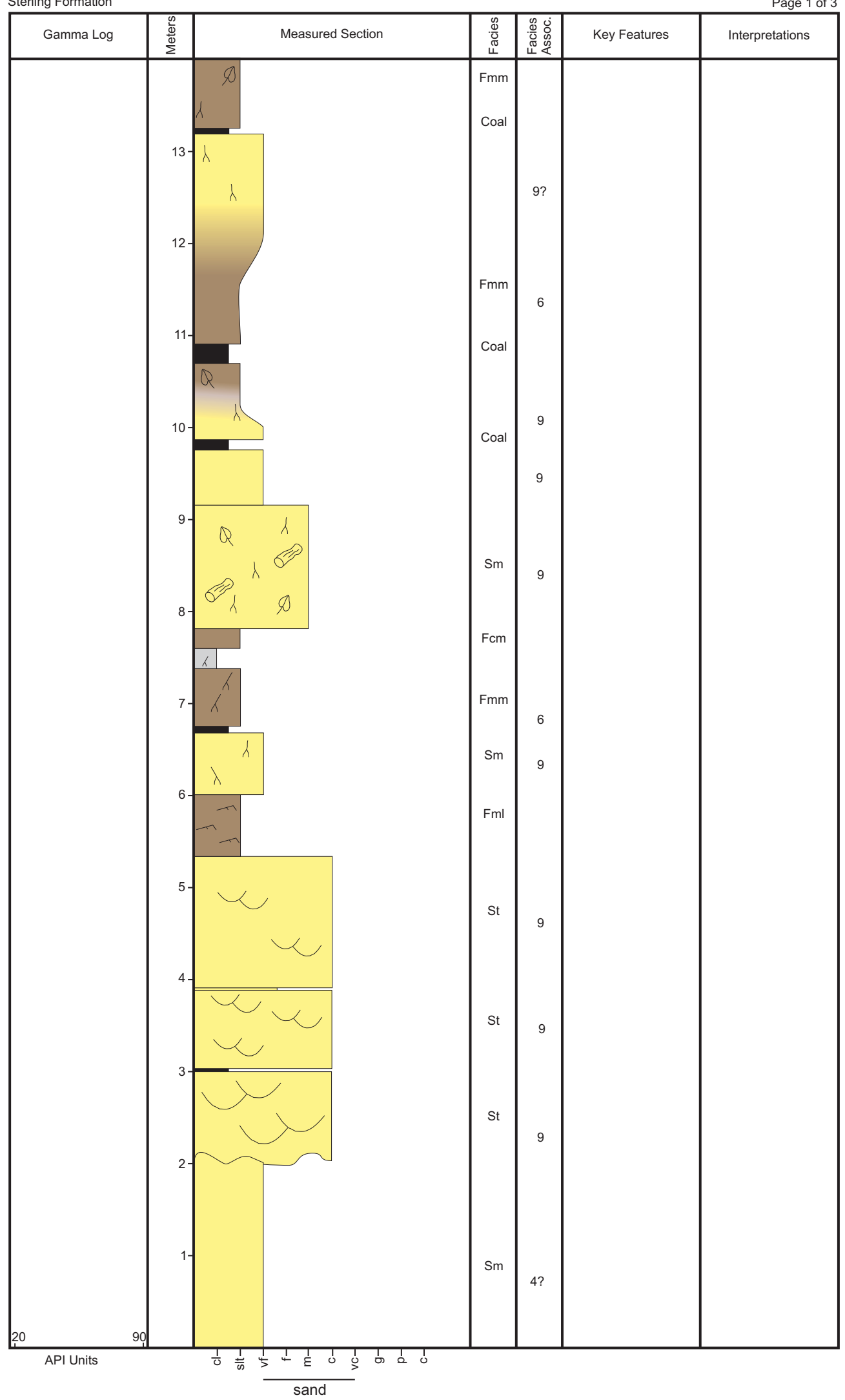


07JRM012

FIGURE A17

Falls Creek, Kachemak Bay

N59.78246 W151.10204

Sterling Formation

Page 2 of 3

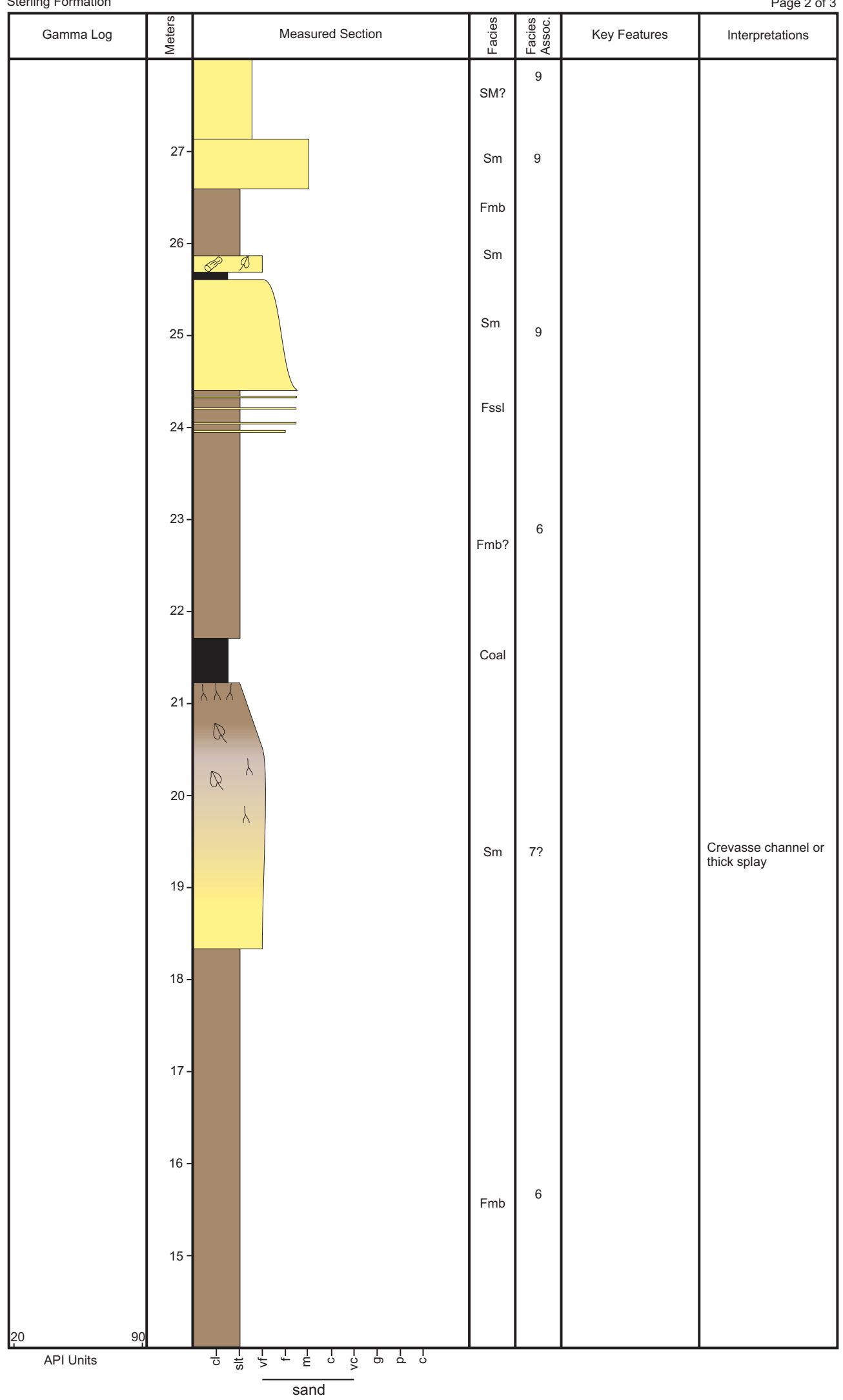


07JRM012

FIGURE A17

Falls Creek, Kachemak Bay

N59.78246 W151.10204

Sterling Formation

Page 3 of 3

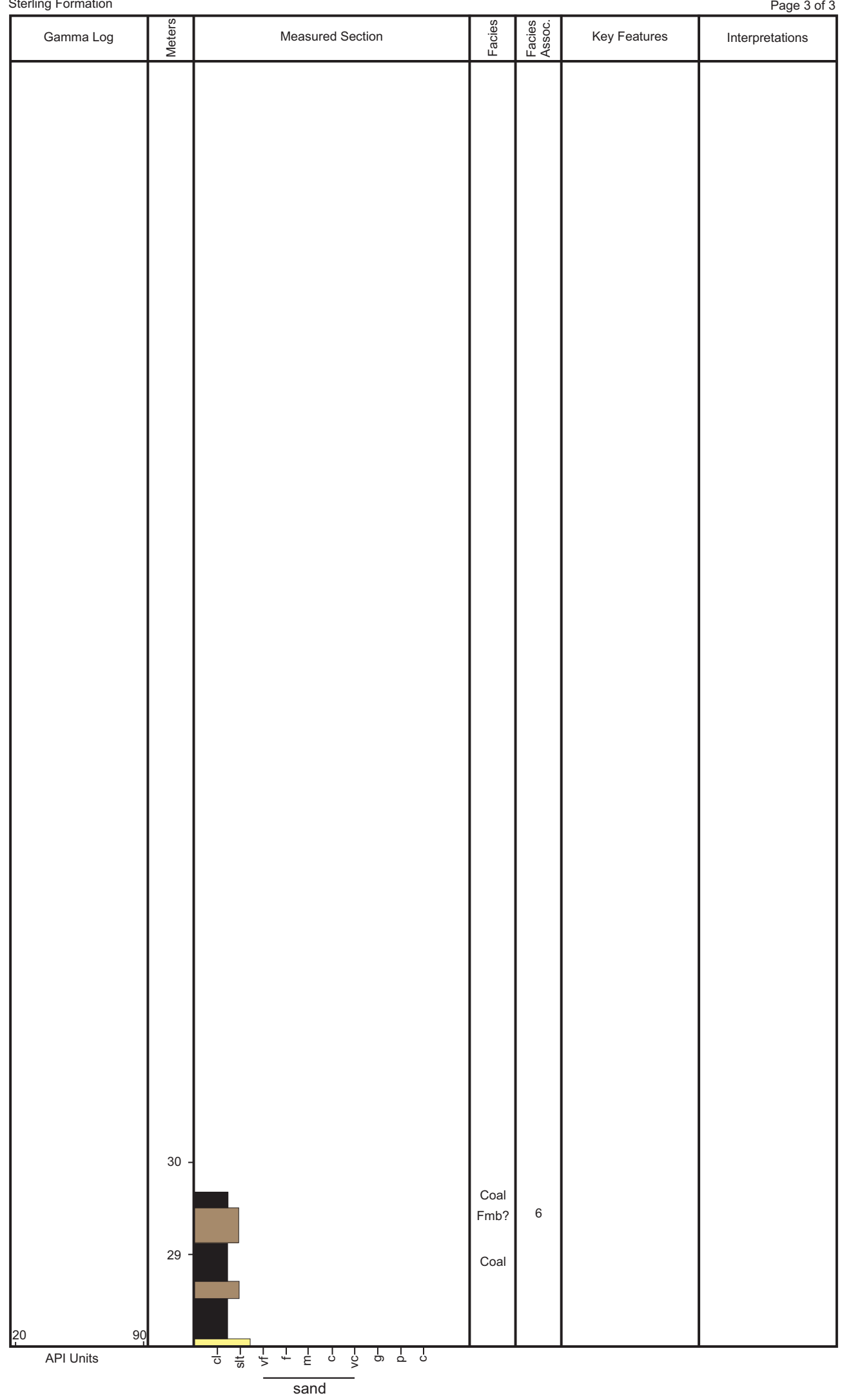


07JRM013

FIGURE A18

Falls Creek, Kachemak Bay

N59.77343 W151.12043

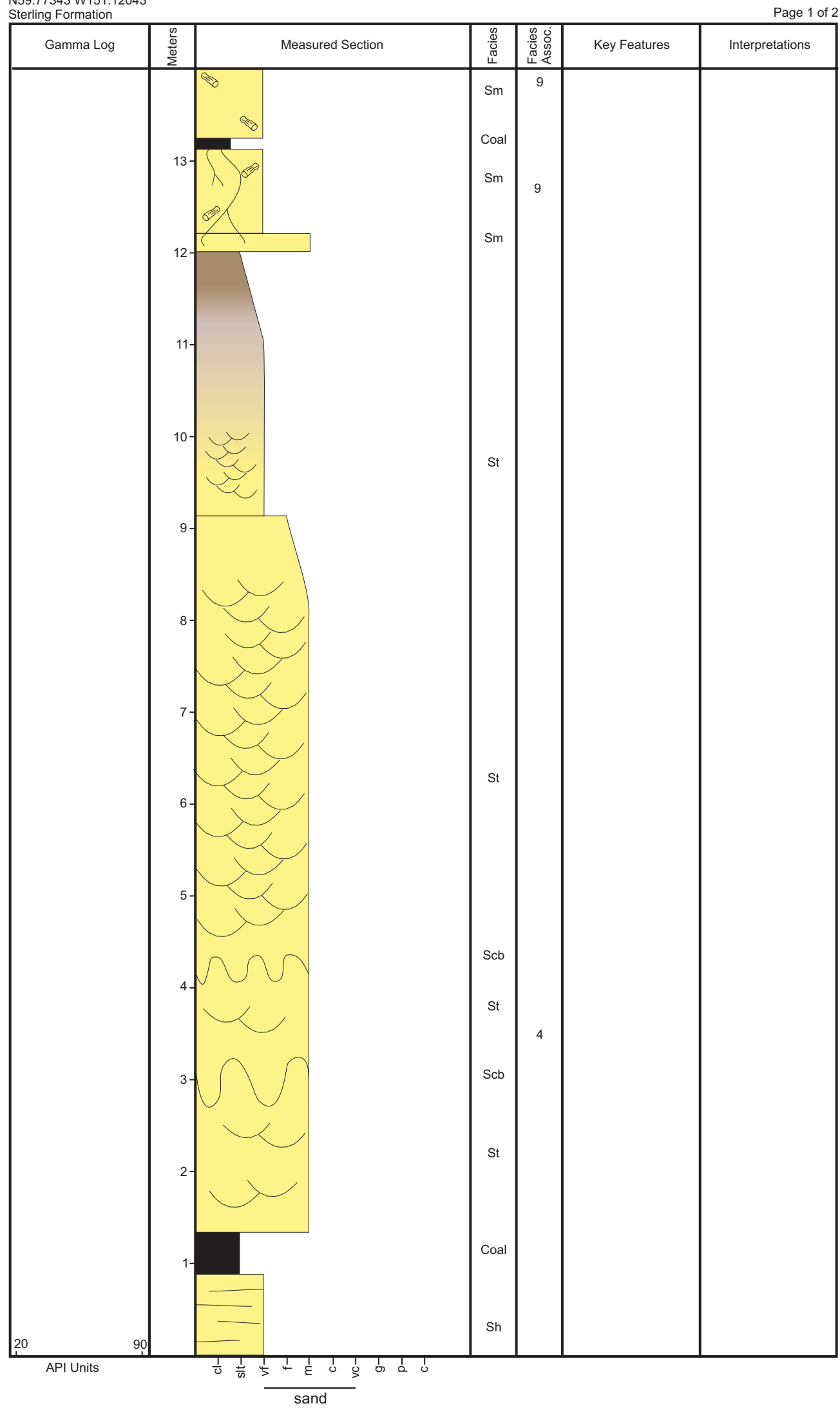


07JRM013

Falls Creek, Kachemak Bay

FIGURE A18

N59.77343 W151.12043

Sterling Formation

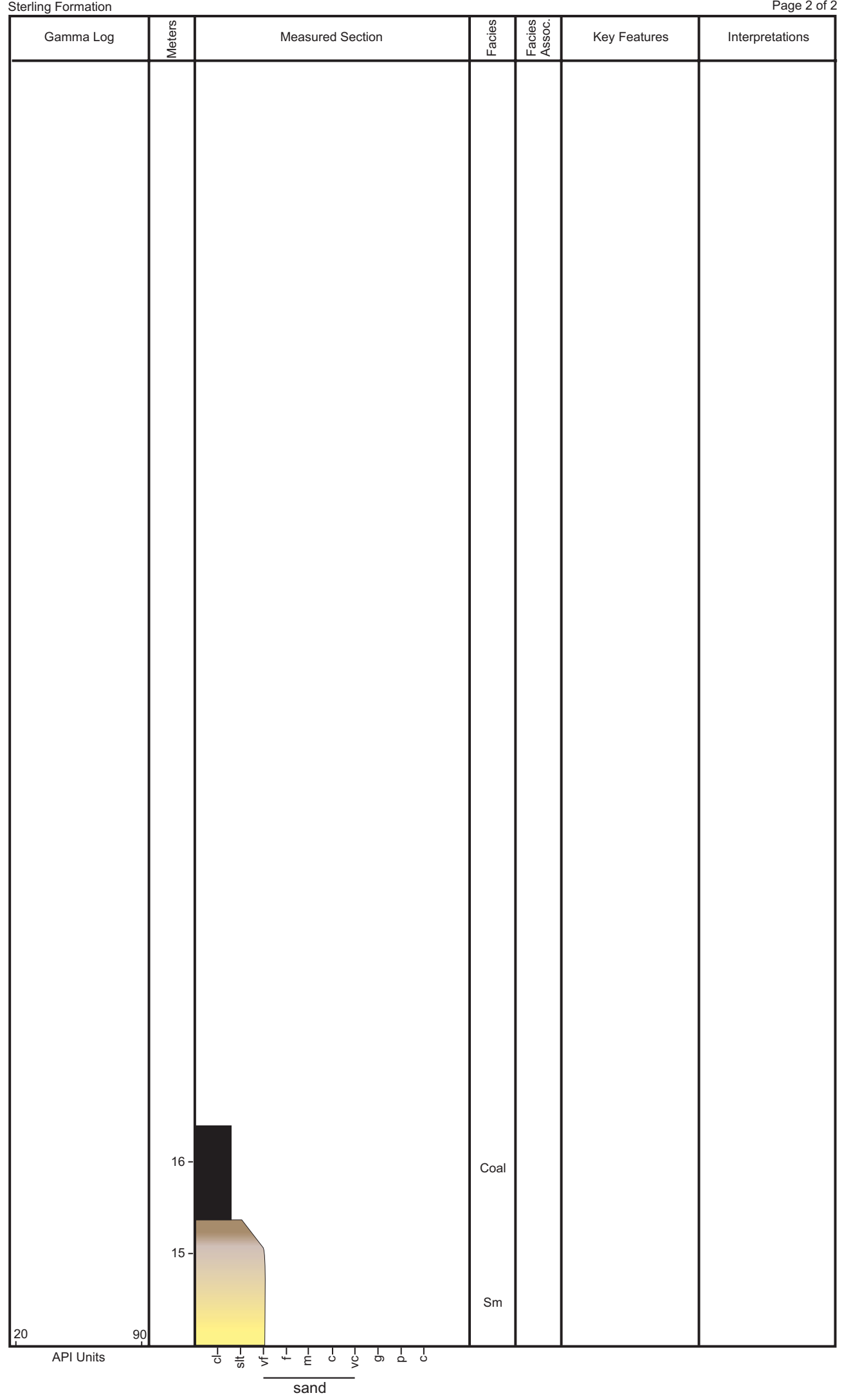


07JRM014

FIGURE A19

alls Creek, Kachemak Bay

N59.77366 W151.12004

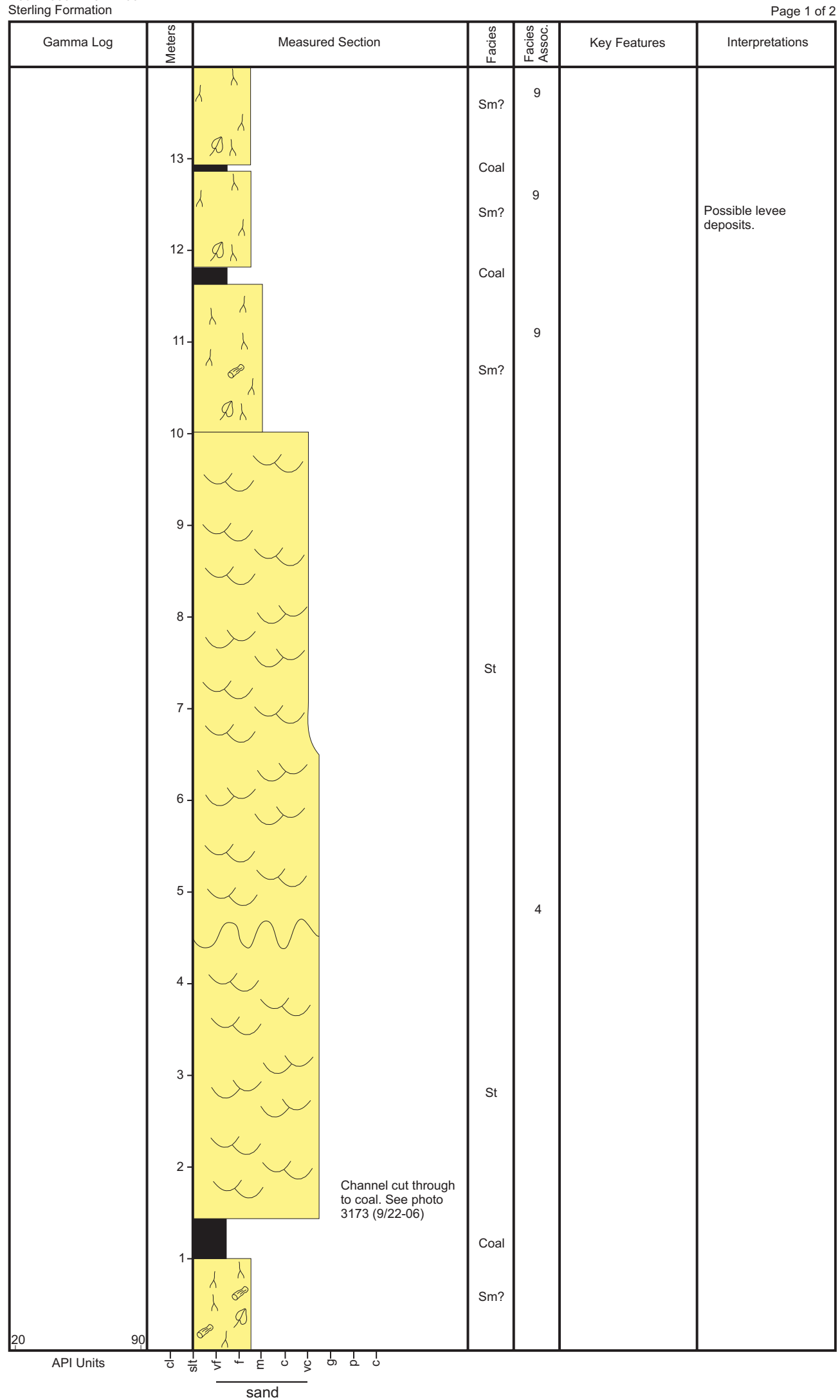


07JRM014

FIGURE A19

Falls Creek, Kachemak Bay

N59.77366 W151.12004

Sterling Formation

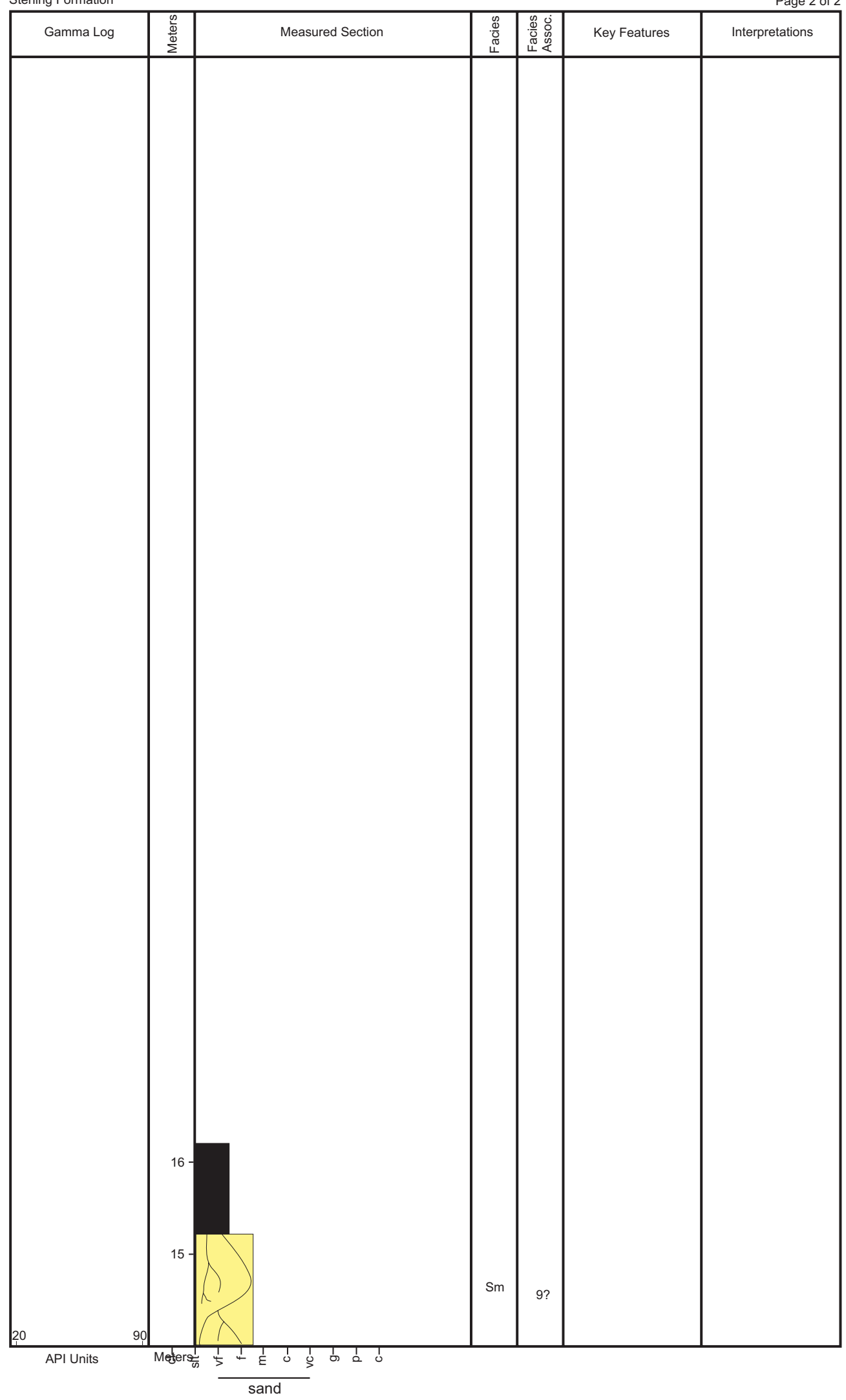


06PD212

Fox River, Kenai National Wildlife Refuge

FIGURE A20

N59.91270 W150.82426

Sterling Formation

Page 1 of 3

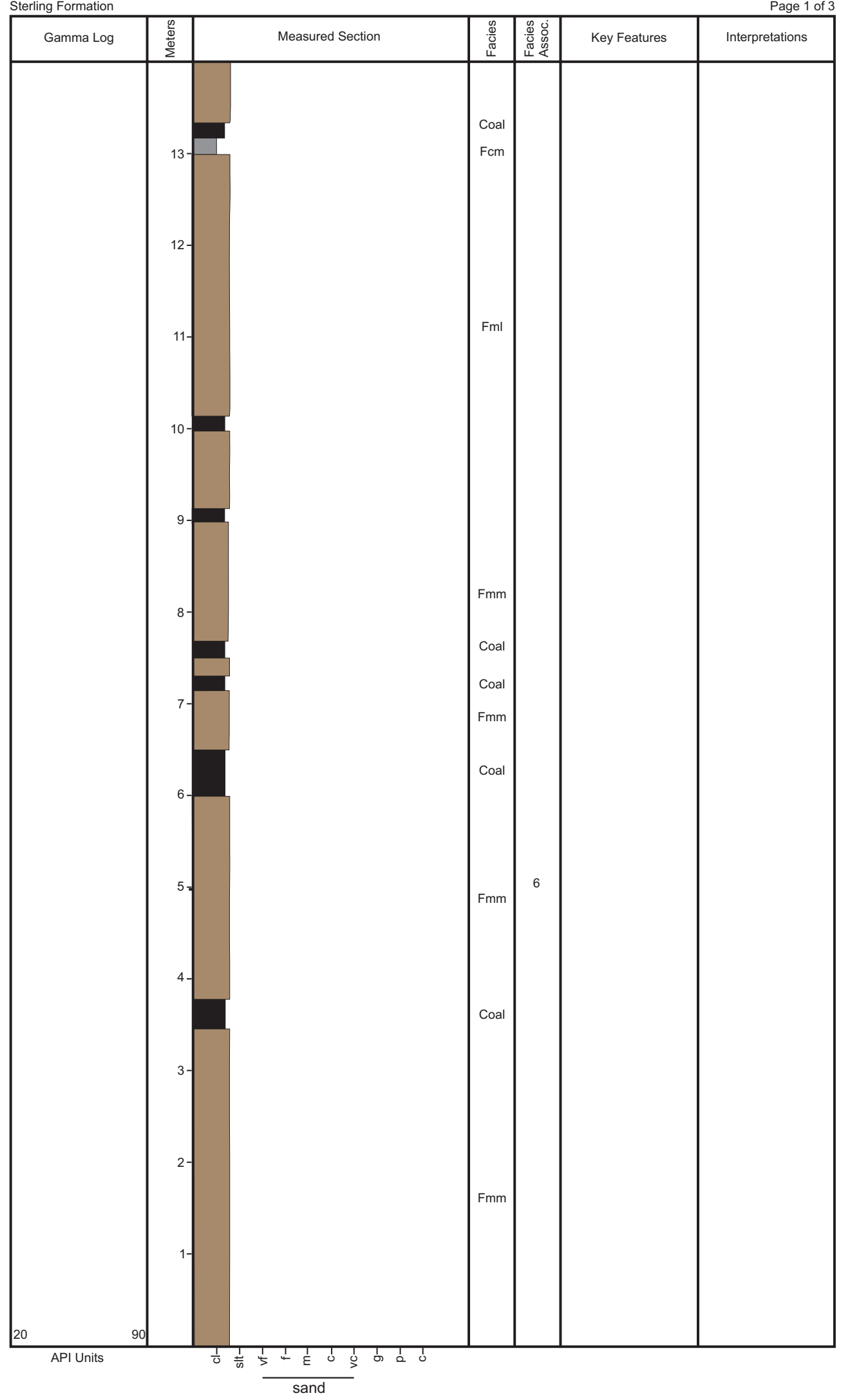


06PD212

Fox River, Kenai National Wildlife Refuge

FIGURE A20

N59.91270 W150.82426

Sterling Formation

Page 2 of 3

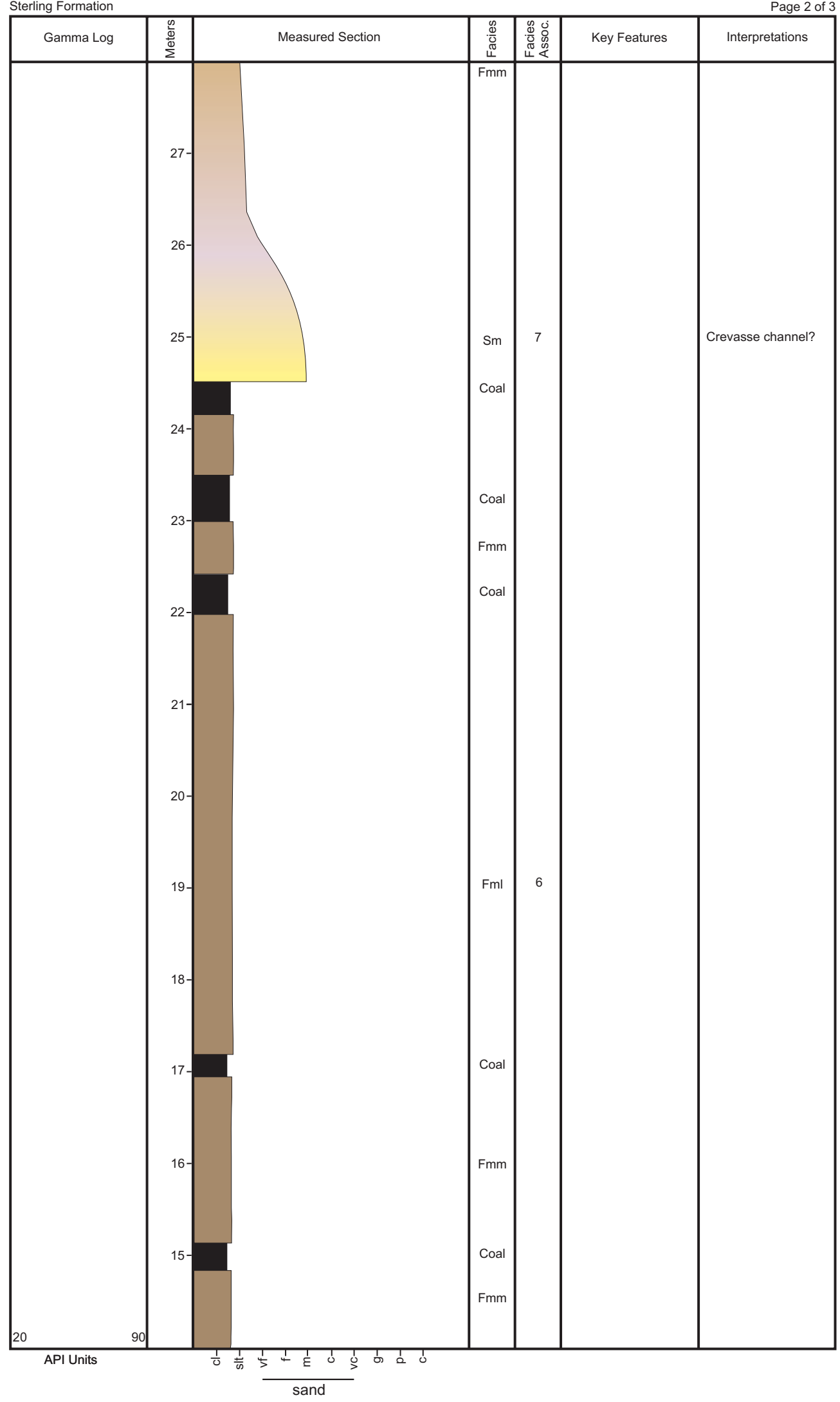


06PD212

Fox River, Kenai National Wildlife Refuge

FIGURE A20

N59.91270 W150.82426

Sterling Formation

Page 3 of 3

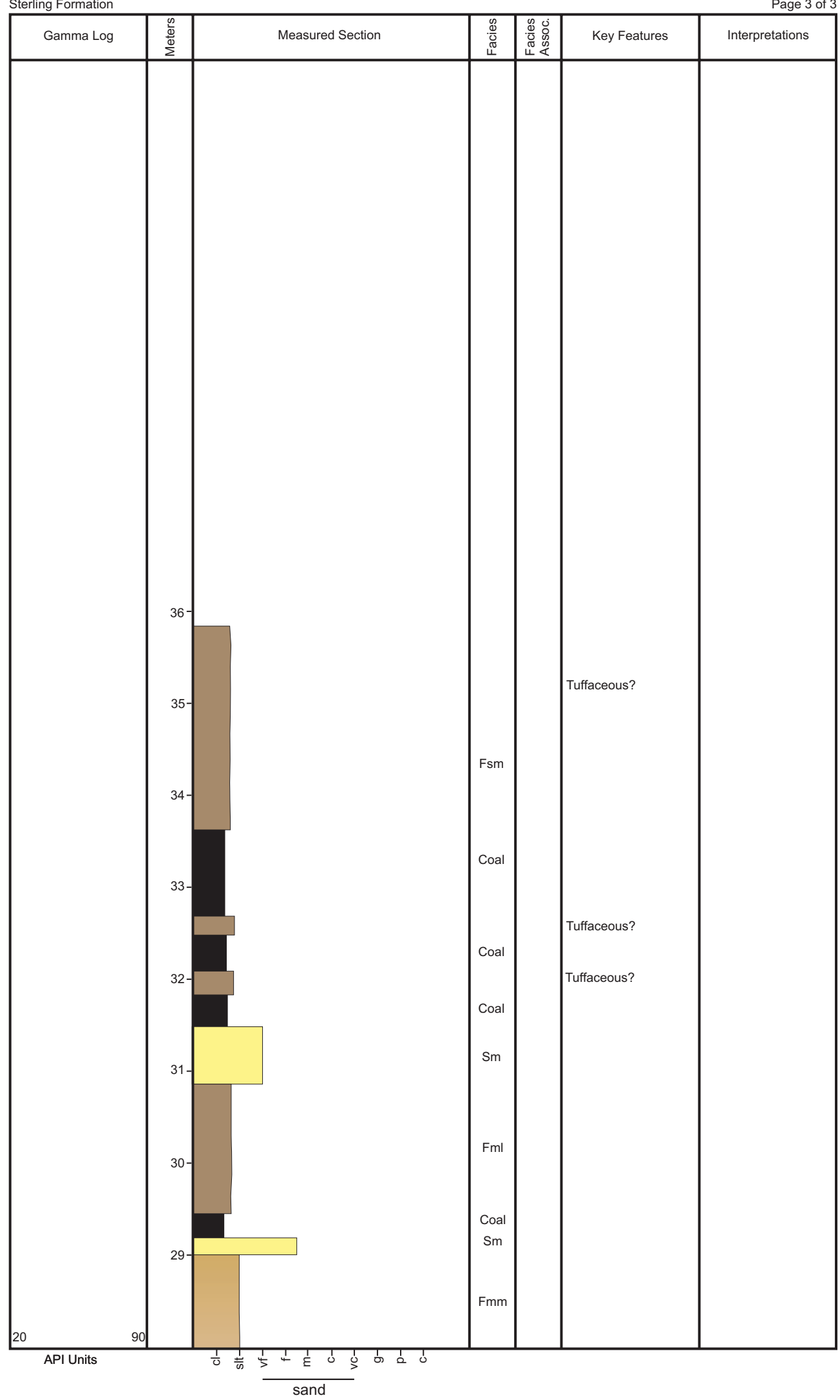


06MAW203

Upper Fox River, Kenai National Wildlife Refuge

FIGURE A21 N59.98066 W150.79642

Sterling Formation

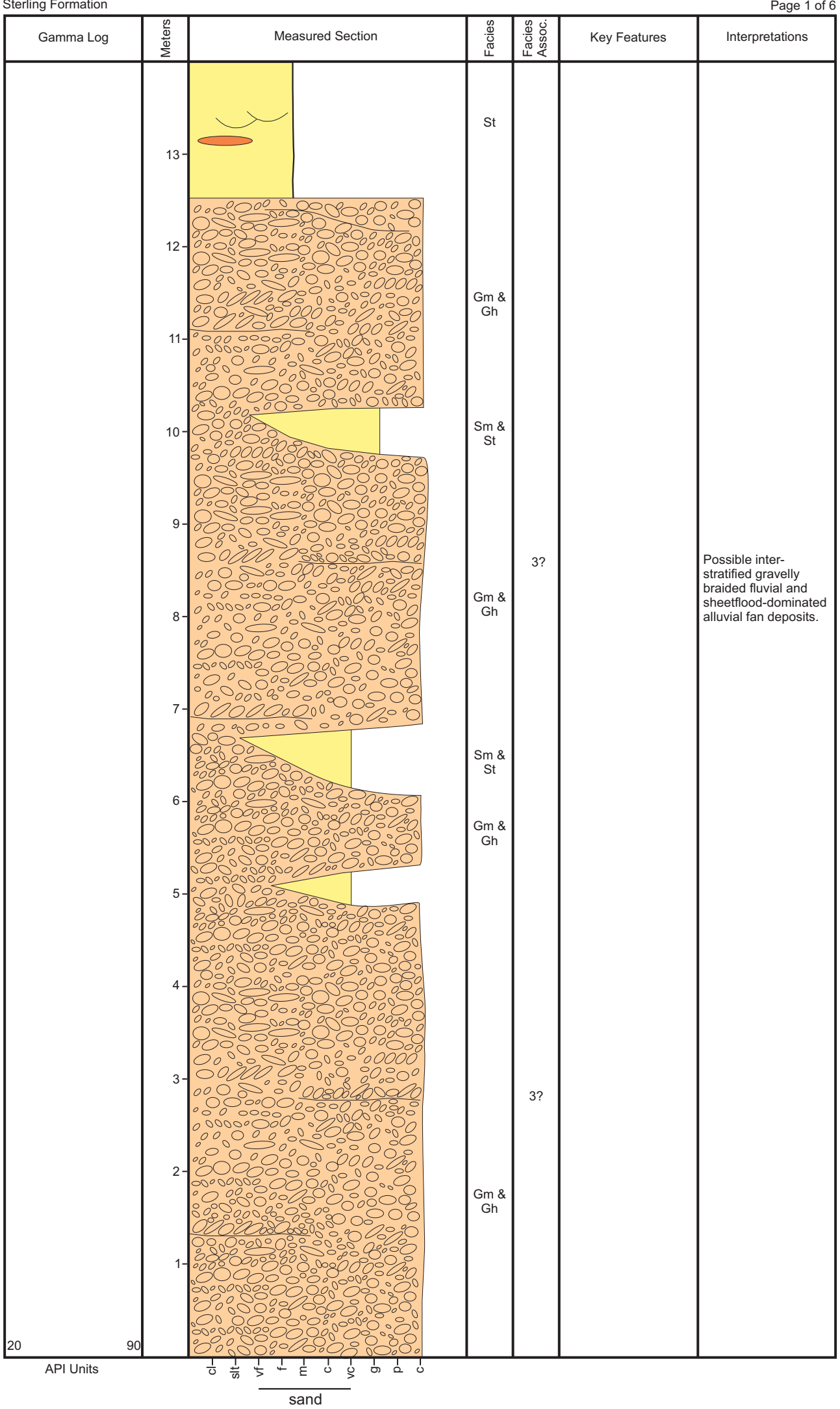


06MAW203

Upper Fox River, Kenai National Wildlife Refuge N59.98066 W150.79642

FIGURE A21 Sterling Formation

Page 2 of 6

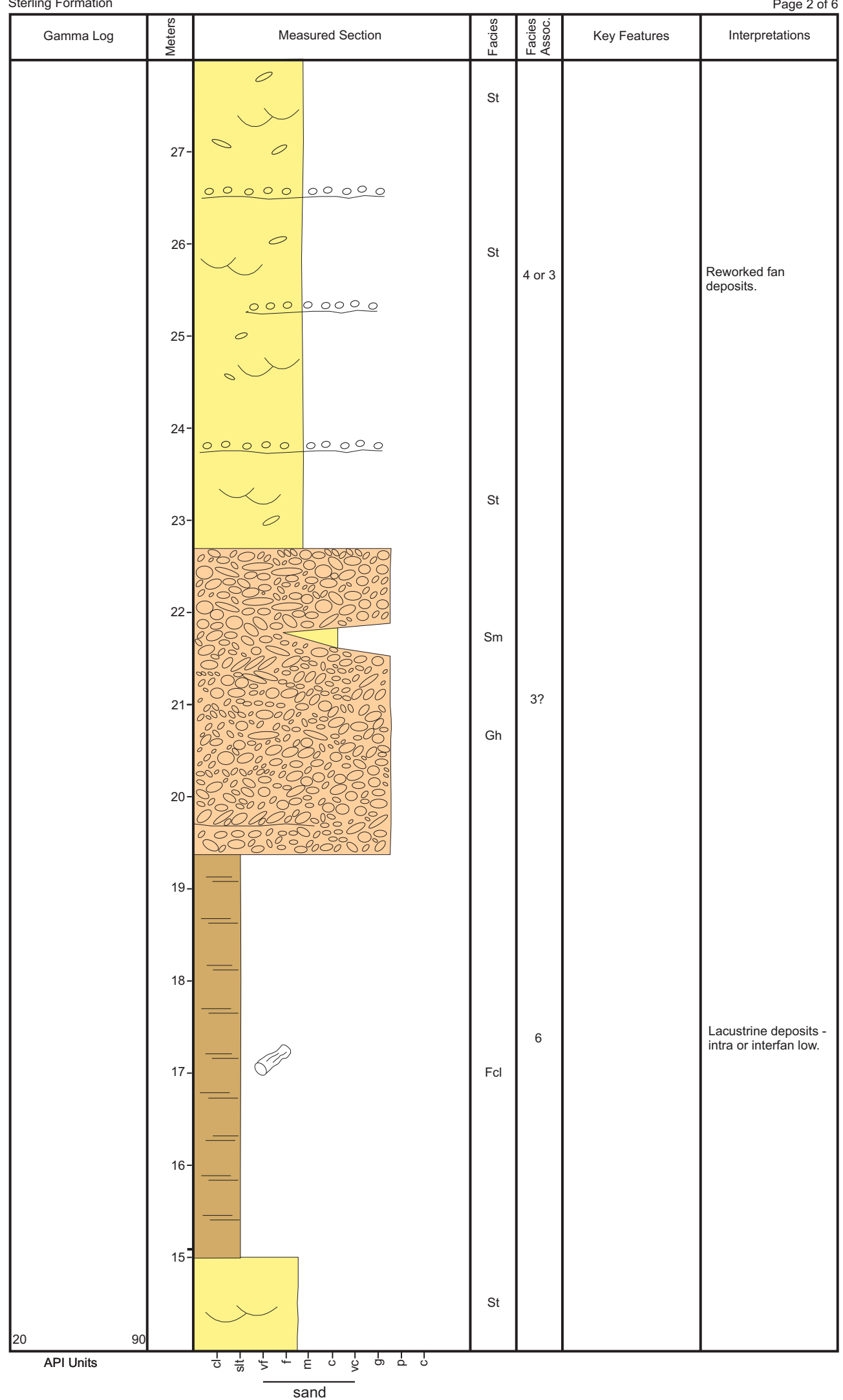


06MAW203

Upper Fox River, Kenai National Wildlife Refuge

FIGURE A21

N59.98066 W150.79642

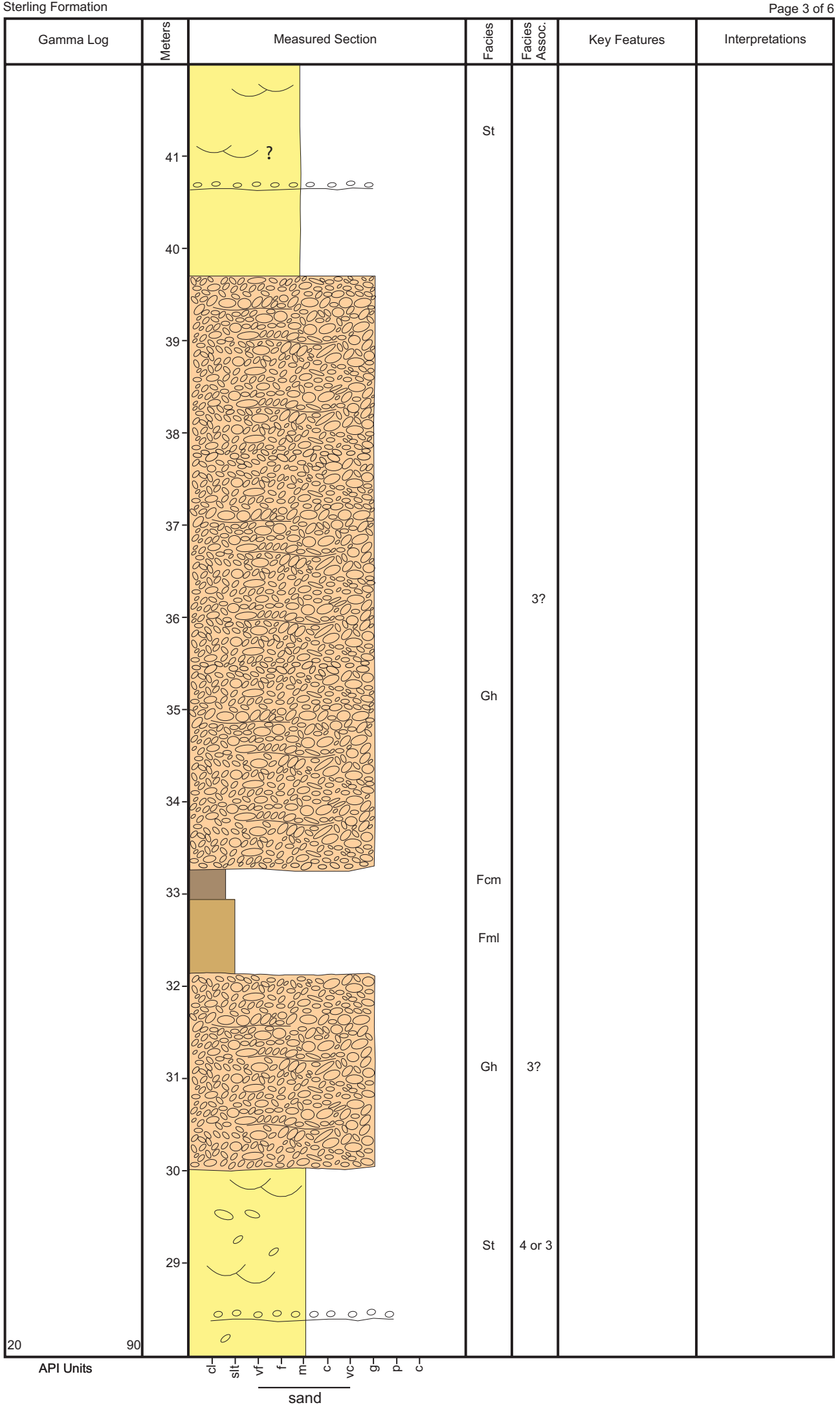


06MAW203

Upper Fox River, Kenai National Wildlife Refuge

FIGURE A21 N59.98066 W150.79642

Sterling Formation

Page 4 of 6

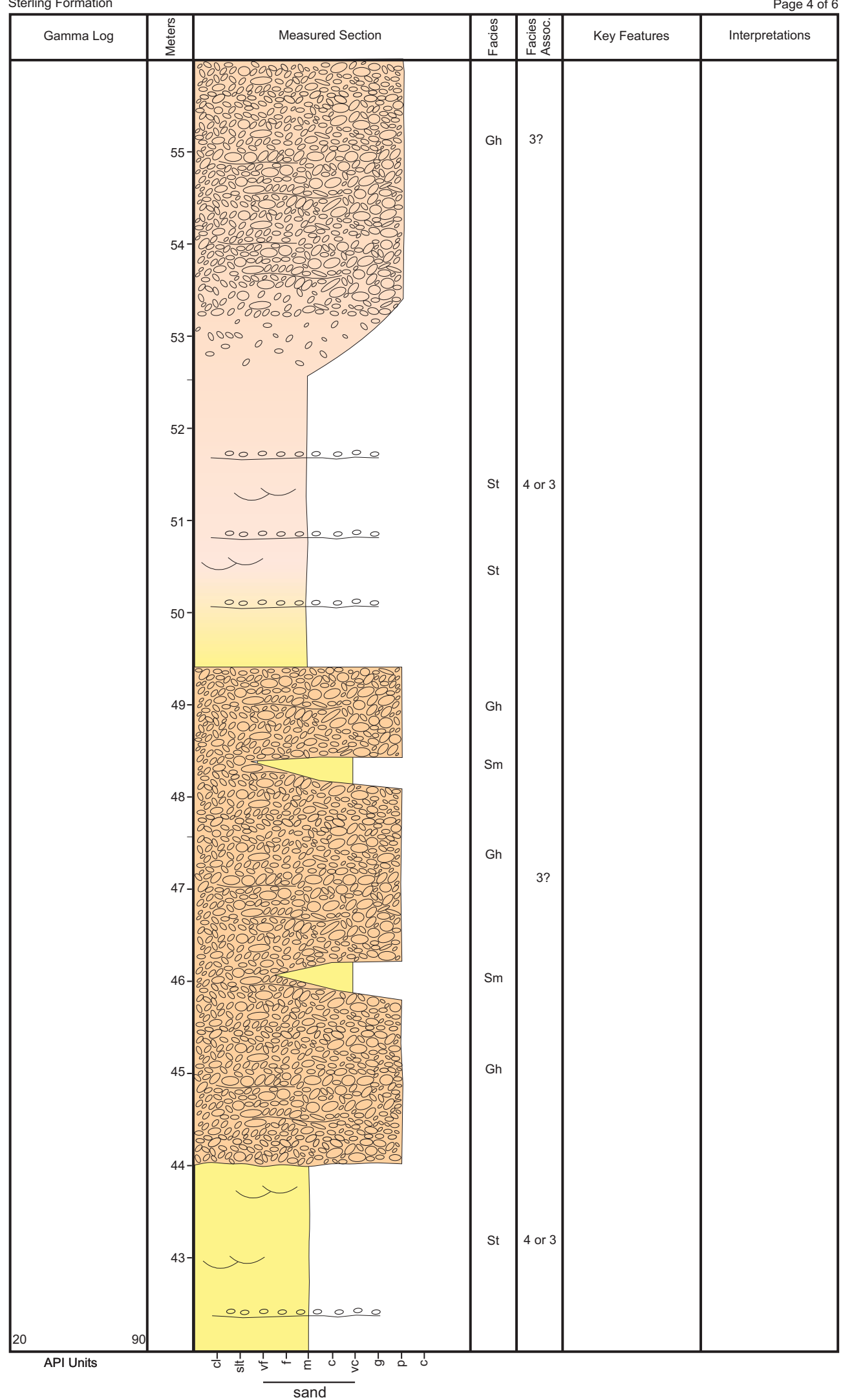


06MAW203

Upper Fox River, Kenai National Wildlife Refuge

FIGURE A21 N59.98066 W150.79642

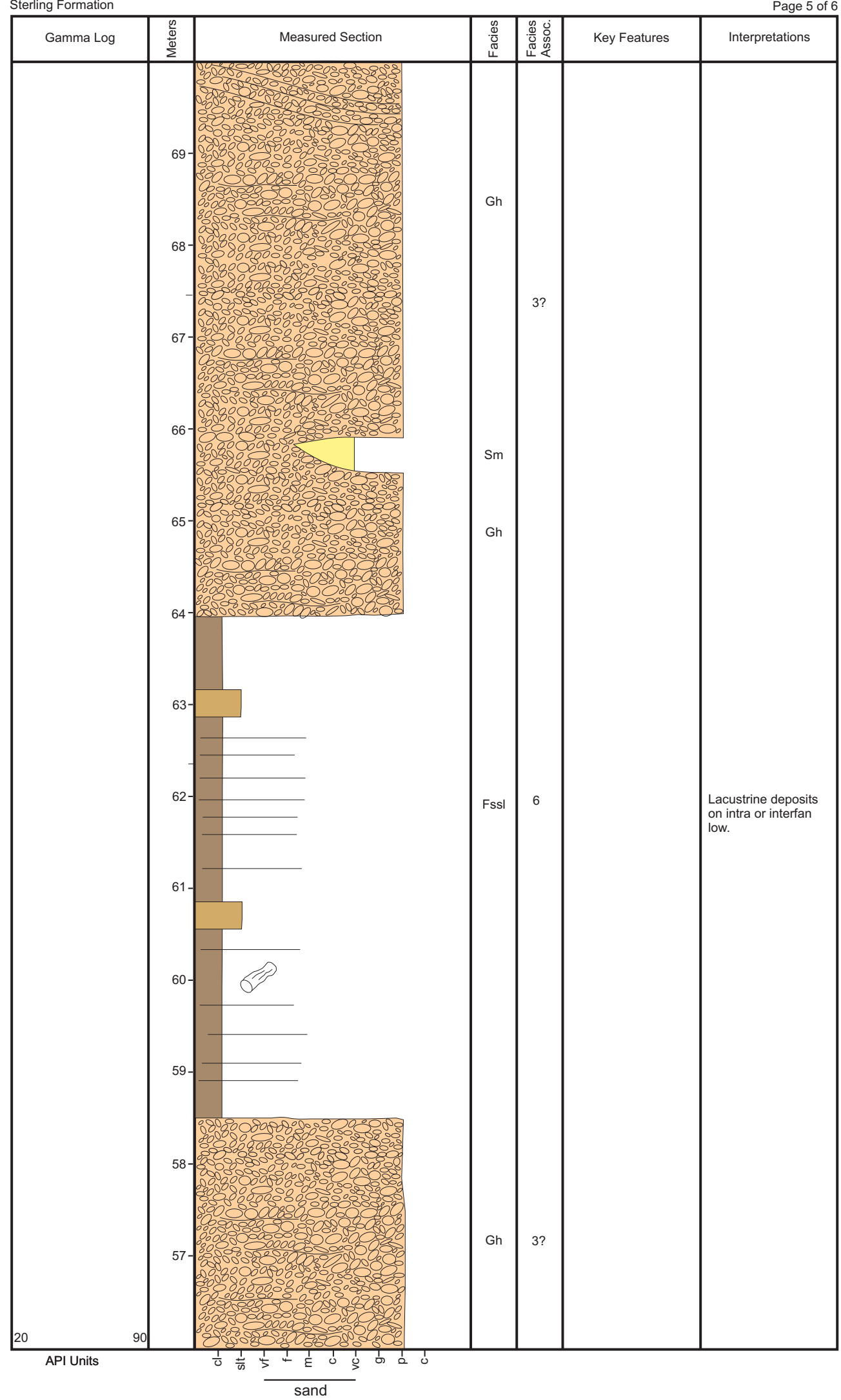


06MAW203

Upper Fox River, Kenai National Wildlife Refuge

FIGURE A21 N59.98066 W150.79642

Sterling Formation

Page 6 of 6

\begin{tabular}{|c|c|c|c|c|c|c|}
\hline Gamma Log & 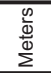 & Measured Section & $\begin{array}{l}\mathscr{\mathscr { d }} \\
\frac{\tilde{\omega}}{\tilde{E}} \\
\ddot{\sim}\end{array}$ & 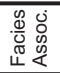 & Key Features & Interpretations \\
\hline 20 & 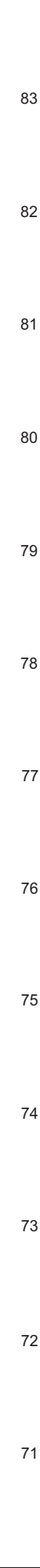 & 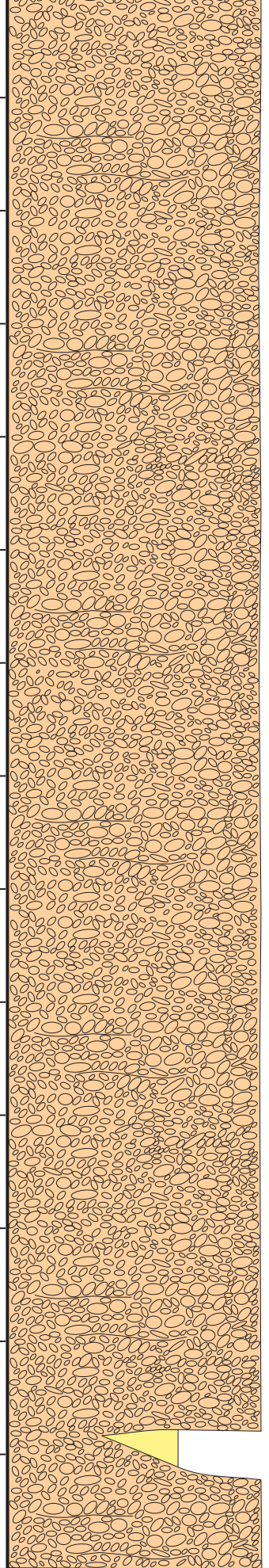 & $\begin{array}{l}\text { Gh } \\
\\
\text { Sm } \\
\\
\\
\\
\end{array}$ & $2 ?$ & & $\begin{array}{l}\text { Large-scale foresets } \\
\text { visible laterally } \\
\text { suggesting streamflow } \\
\text { deposits adjacent to } \\
\text { alluvial fan deposits. }\end{array}$ \\
\hline
\end{tabular}


06PD244

FIGURE A22

Deep Creek, southern Kenai Peninsula

N59.98250 W151.54721

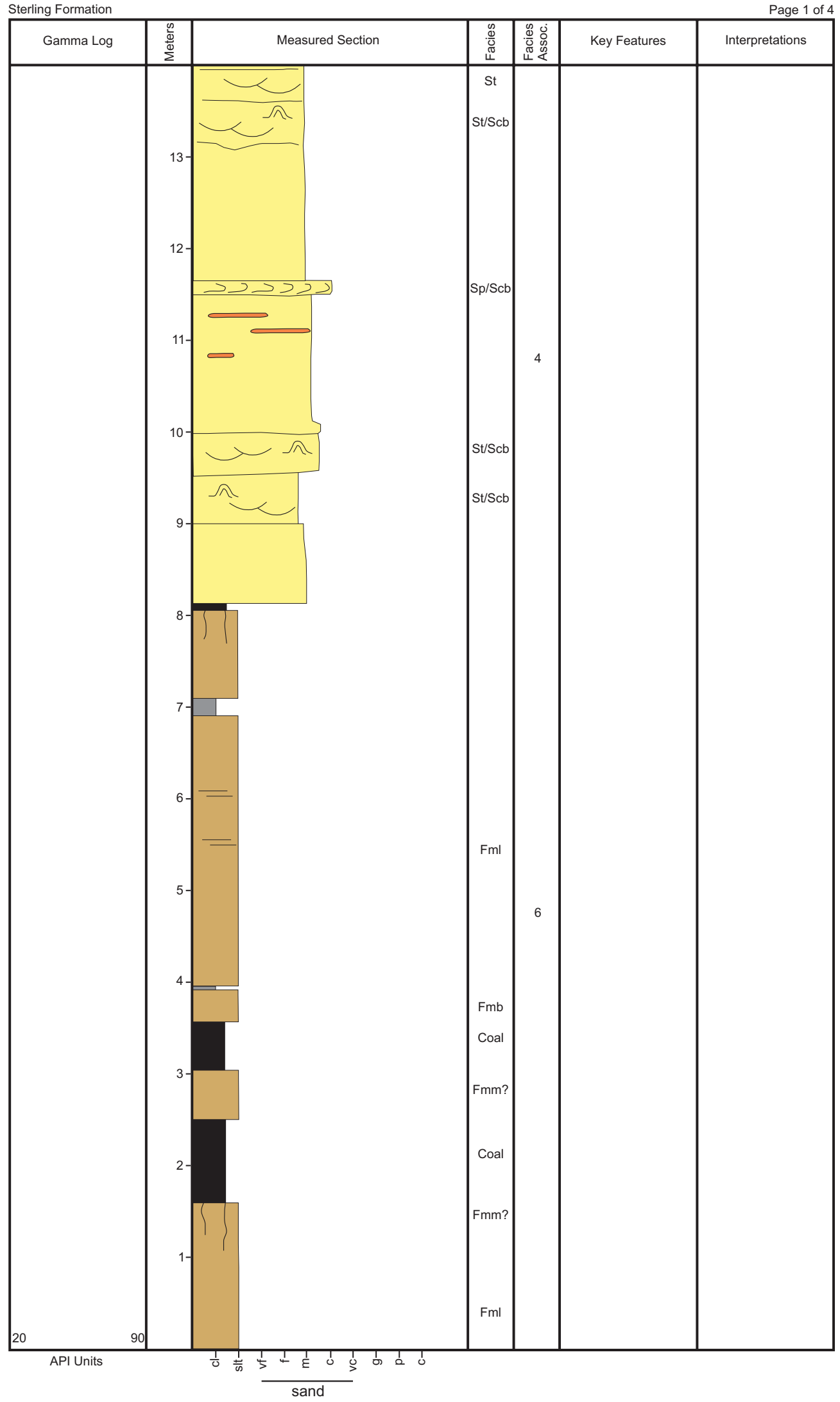


06PD244

Deep Creek, southern Kenai Peninsula

FIGURE A22

N59.98250 W151.54721

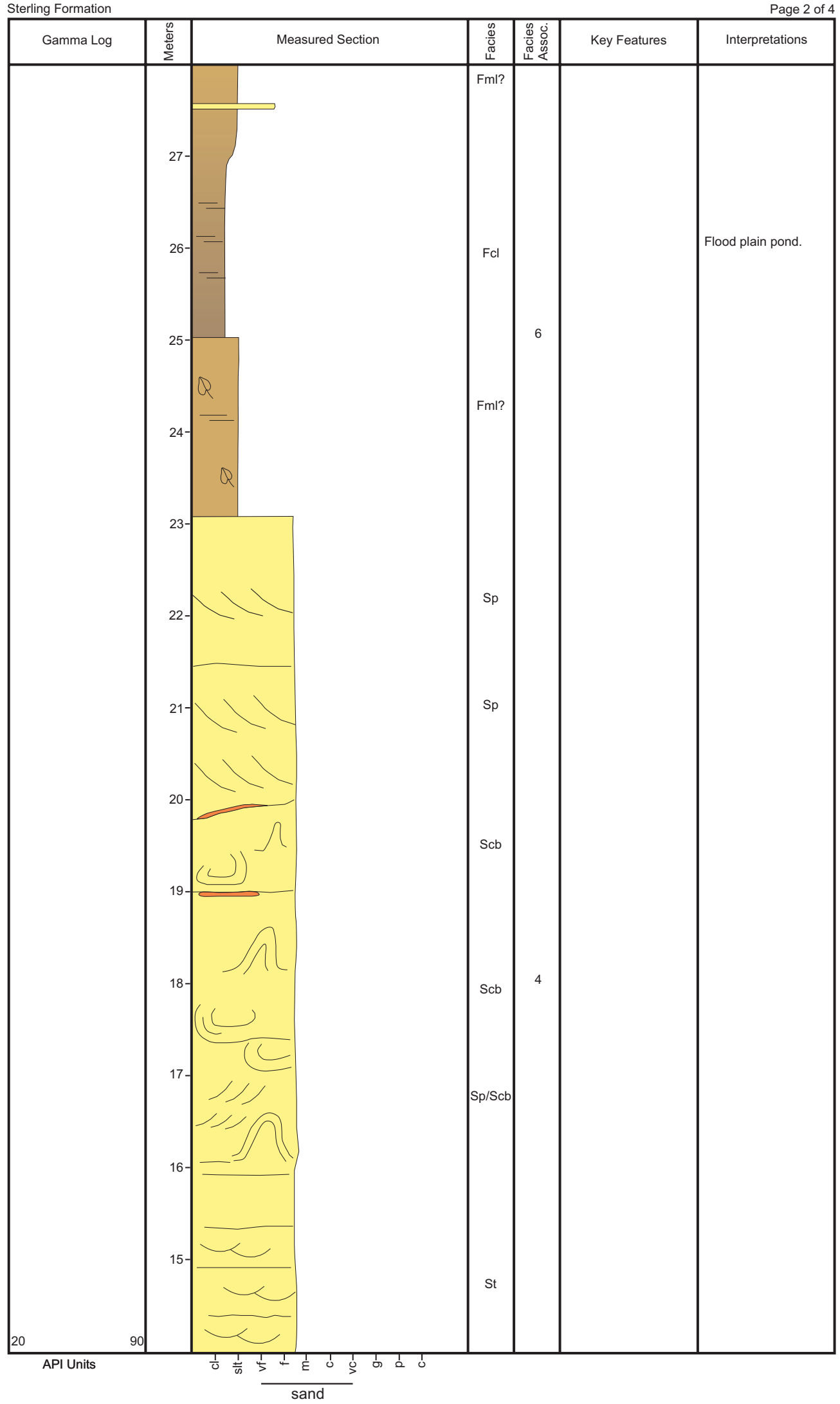


06PD244

FIGURE A22

Deep Creek, southern Kenai Peninsula

N59.98250 W151.54721

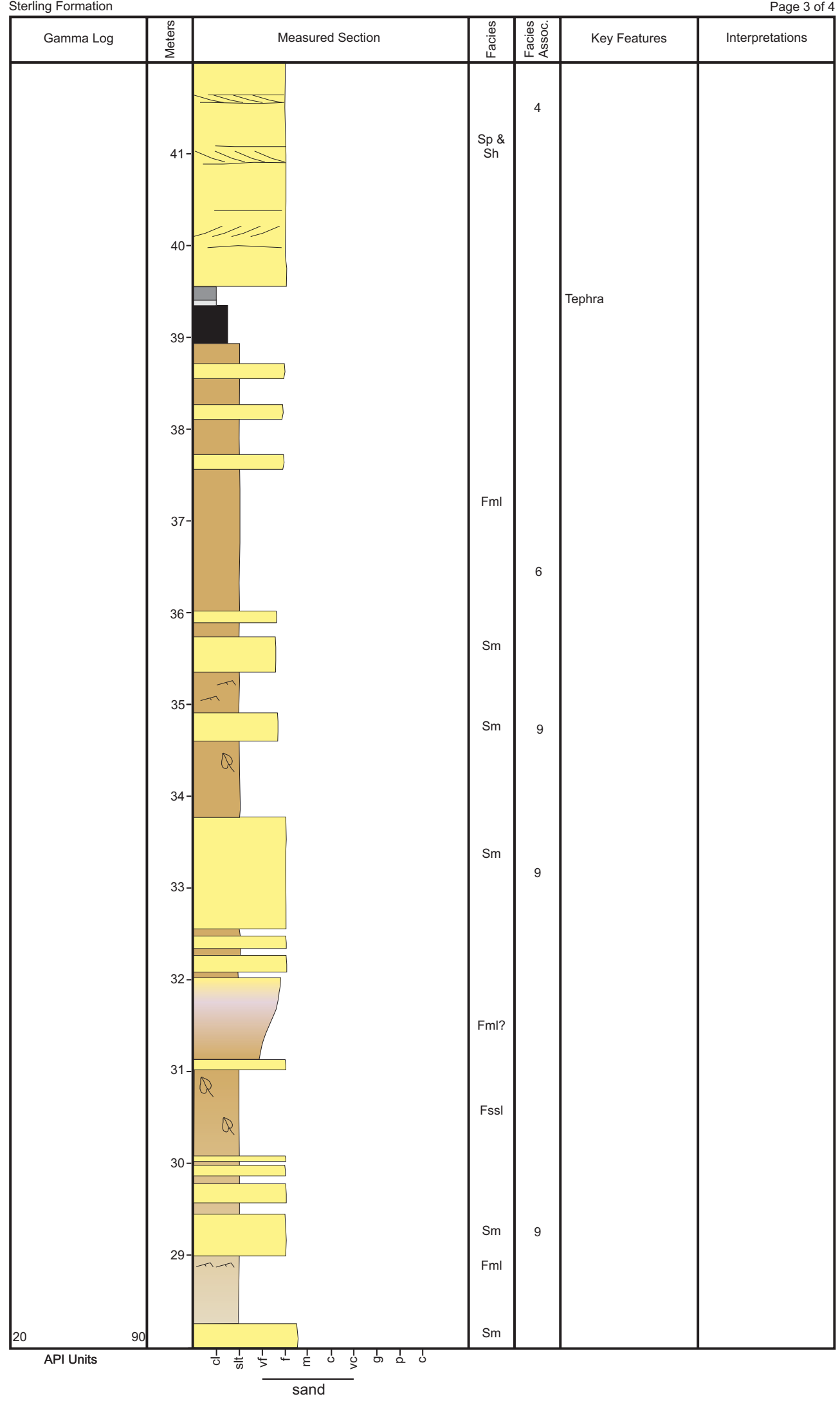


06PD244

Deep Creek, southern Kenai Peninsula

FIGURE A22

N59.98250 W151.54721

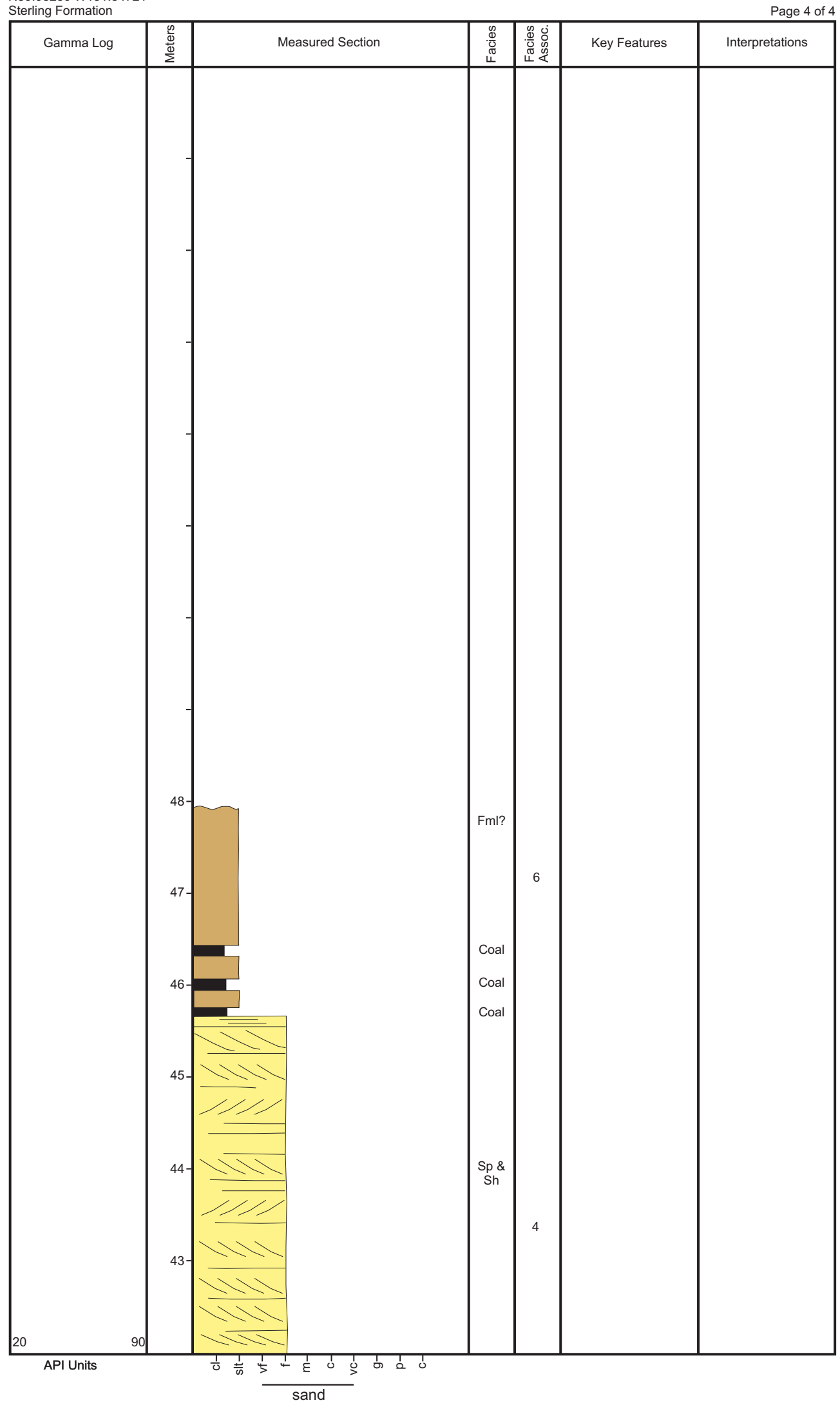


06PD220

FIGURE A23

Clam Gulch, Cook Inlet

N60.24970 W151.39291

Sterling Formation

Page 1 of 4

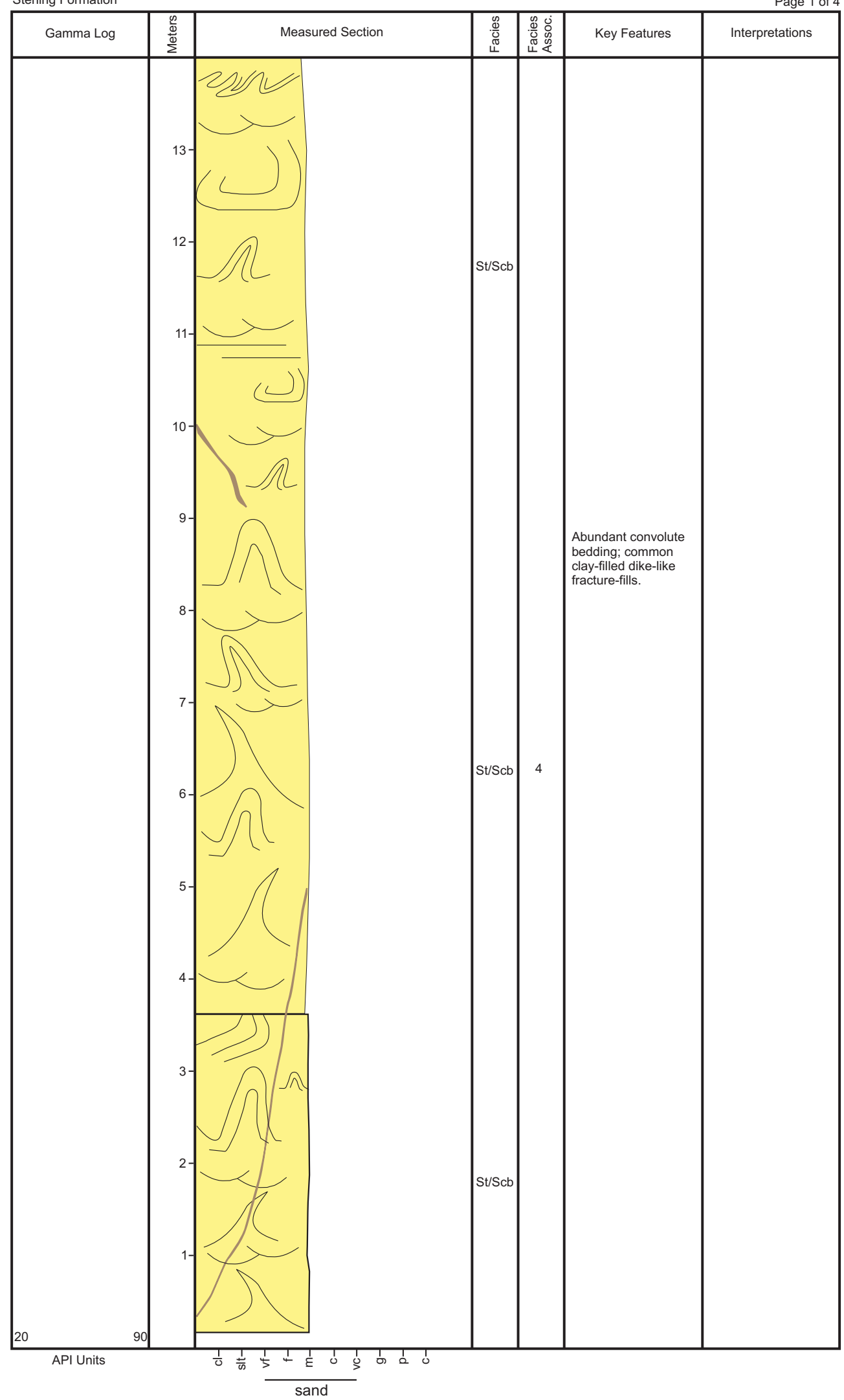


06PD220

FIGURE A23

Clam Gulch, Cook Inlet

N60.24970 W151.39291

Sterling Formation

Page 2 of 4

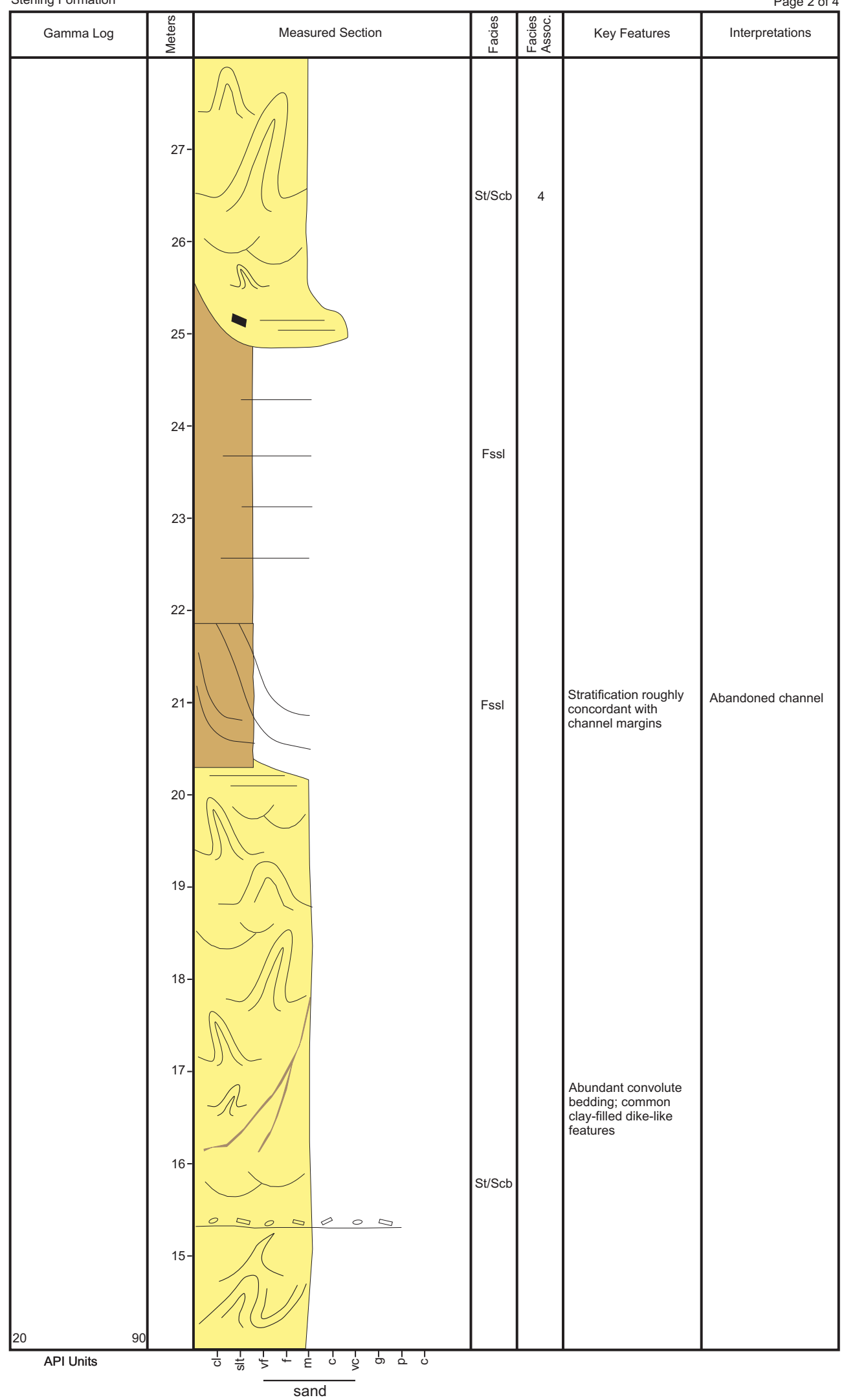


06PD220

FIGURE A23

Clam Gulch, Cook Inlet

N60.24970 W151.39291

Sterling Formation

Page 3 of 4

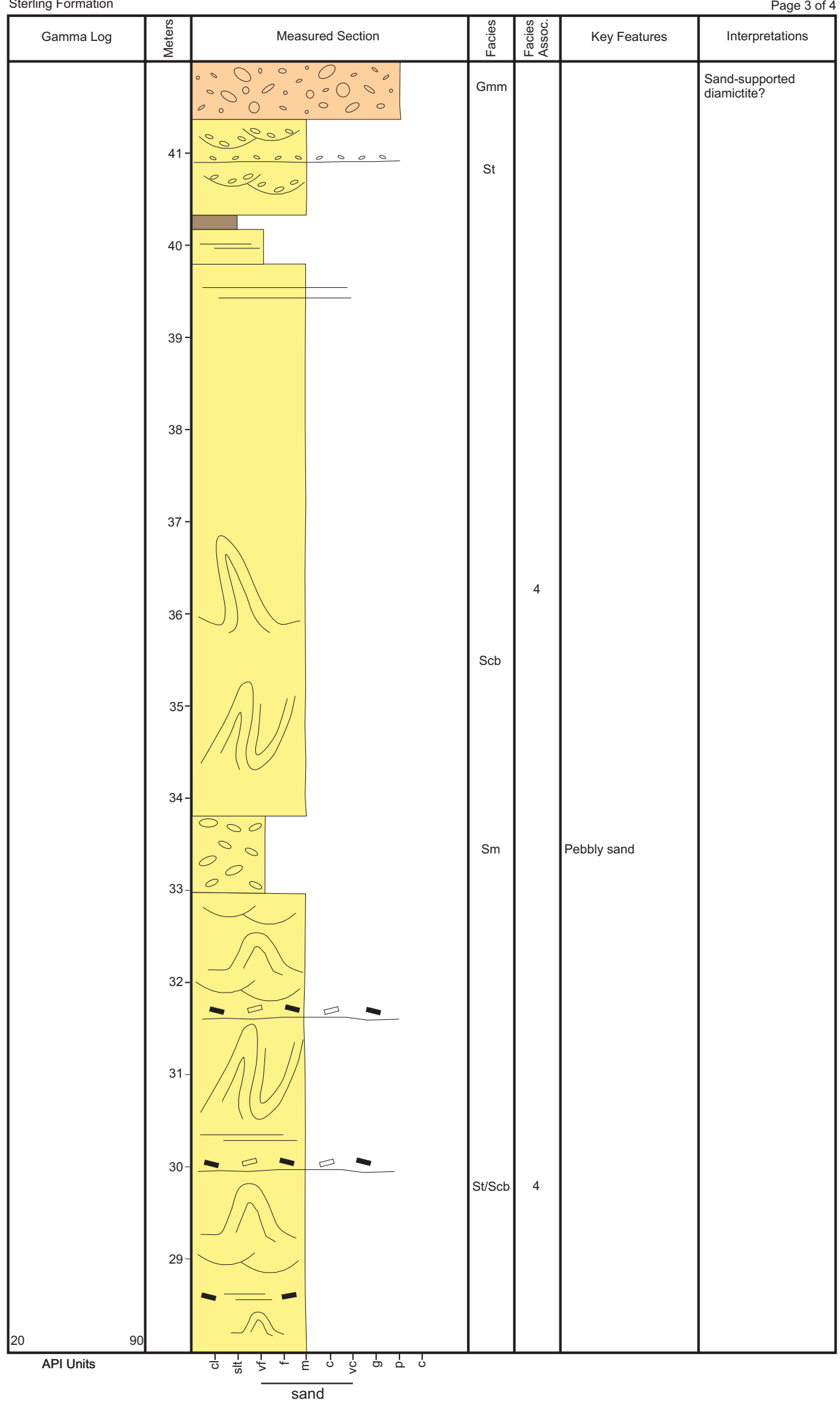


06PD220

FIGURE A23 Clam Gulch, Cook Inlet Sterling Formation

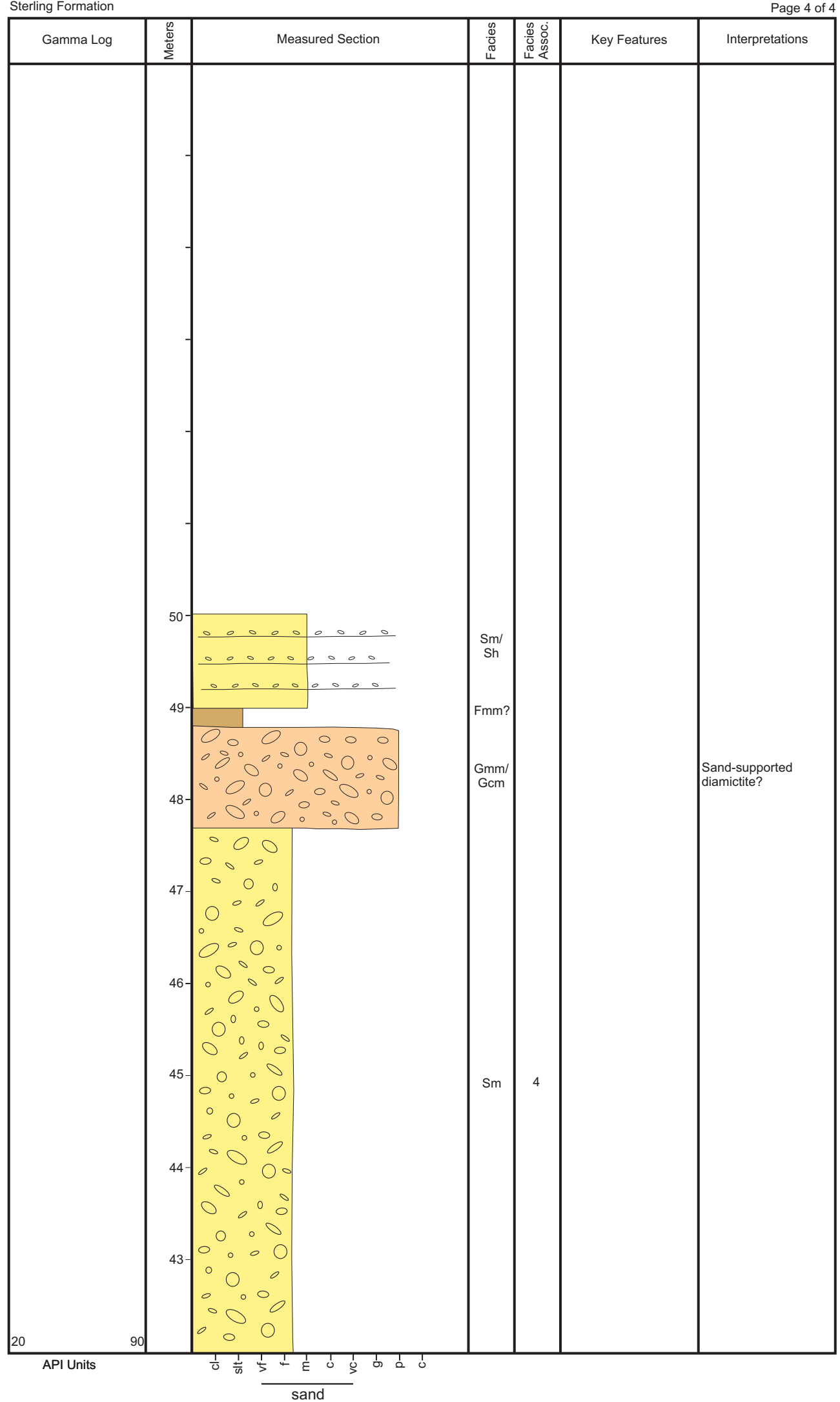


THIS PAGE INTENTIONALLY LEFT BLANK. 


\title{
SEDIMENTOLOGY OF AN OLIGOCENE-MIOCENE INCISED PALEOVALLEY, TYONEK FORMATION, COOK INLET BASIN, ALASKA
}

\author{
by \\ Emily S. Finzel ${ }^{1}$, Kenneth D. Ridgway ${ }^{1}$, and David L. LePain ${ }^{2}$
}

\section{INTRODUCTION}

The Cenozoic Cook Inlet basin is located in the forearc region of the Aleutian-Alaska Peninsula magmatic arc associated with subduction of the Pacific plate beneath the North American plate (fig. 1). A complicated stratigraphy, in part due to the fluvial nature of the depositional systems, was created in the basin by cycles of uplift, denudation, and accommodation related to subduction (Swenson, 1997). Cenozoic depositional systems filled the basin with sediment eroding locally from the exposed accretionary prism to the southeast and the active volcanic arc and southern Alaska Range to the northwest (Crick, 1971; Hartman and others, 1974; Hayes and others, 1976; Hite, 1976; Swenson, 1997). Axial fluvial systems deposited material in the Cook Inlet basin that was transported from eastern Alaska and possibly as far as western Canada (Kirschner and Lyon, 1973; Rawlinson, 1984). The Paleogene and Neogene section is up to 8,500 m thick, but thins dramatically toward the basin margins (Crick, 1971).

The term "Kenai Group" was first applied to the coal-bearing exposures around Cook Inlet (Dall and Harris, 1892). Subsequently, Paleogene and Neogene sedimentary rocks on the Kenai Peninsula were designated the Kenai Formation based on multiple measured sections onshore (Barnes and Cobb, 1959), and were later elevated to group status containing five formations based on subsurface type sections (Calderwood and Fackler, 1972). The Upper Oligocene-Lower Miocene Tyonek Formation is the focus of this study.

The Tyonek Formation (2,316 m) has been described in the subsurface type section in the Pan American No. 2 Tyonek State 17587 well (fig. 2) as fine- to coarse-grained massive sandstone and siltstone with coal beds up to $6.5 \mathrm{~m}$ thick (Crick, 1971). However, Tyonek outcrops (Magoon and others, 1976) examined in this study consist mostly of clast-supported angular conglomerate interbedded with pedogenic siltstone, fine- to medium-grained

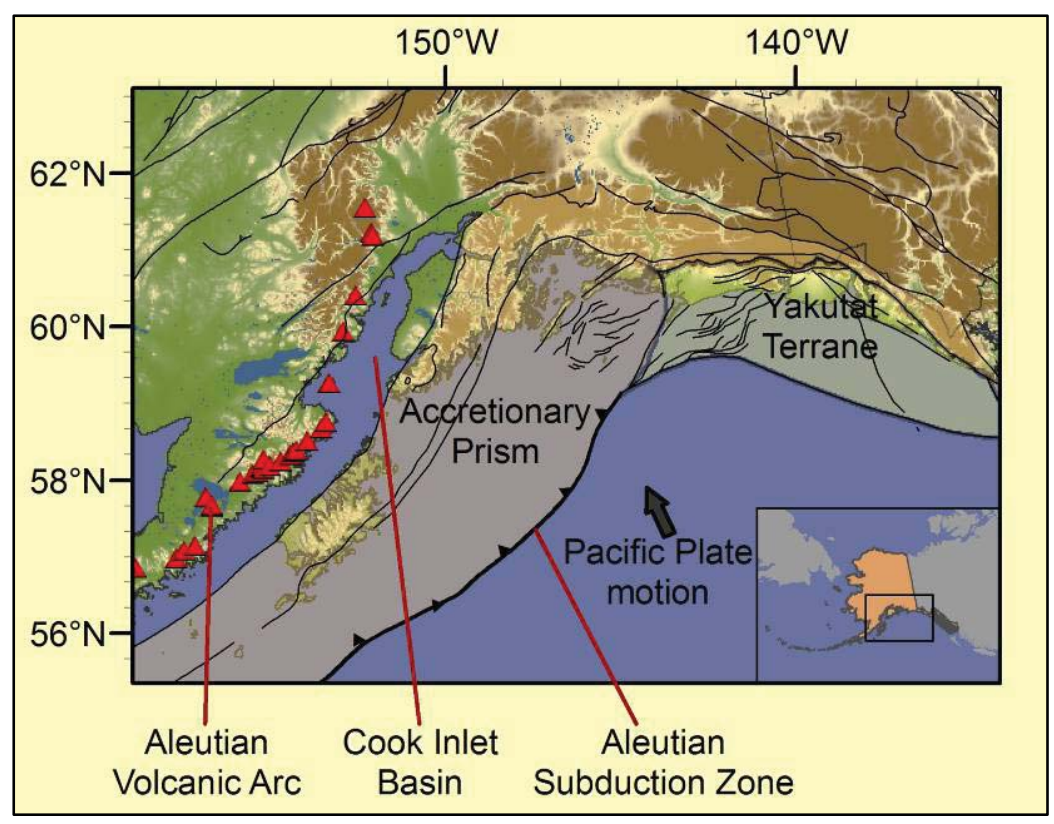

Figure 1. Tectonic map of the southern Alaskan plate margin showing the location of Cook Inlet basin and other important features of the convergent plate margin.

\footnotetext{
${ }^{1}$ Department of Earth and Atmospheric Sciences, Purdue University, West Lafayette, Indiana 47907; Emily Finzel - efinzel@purdue.edu ${ }^{2}$ Alaska Division of Geological \& Geophysical Surveys, 3354 College Rd., Fairbanks, Alaska 99709-3707
} 


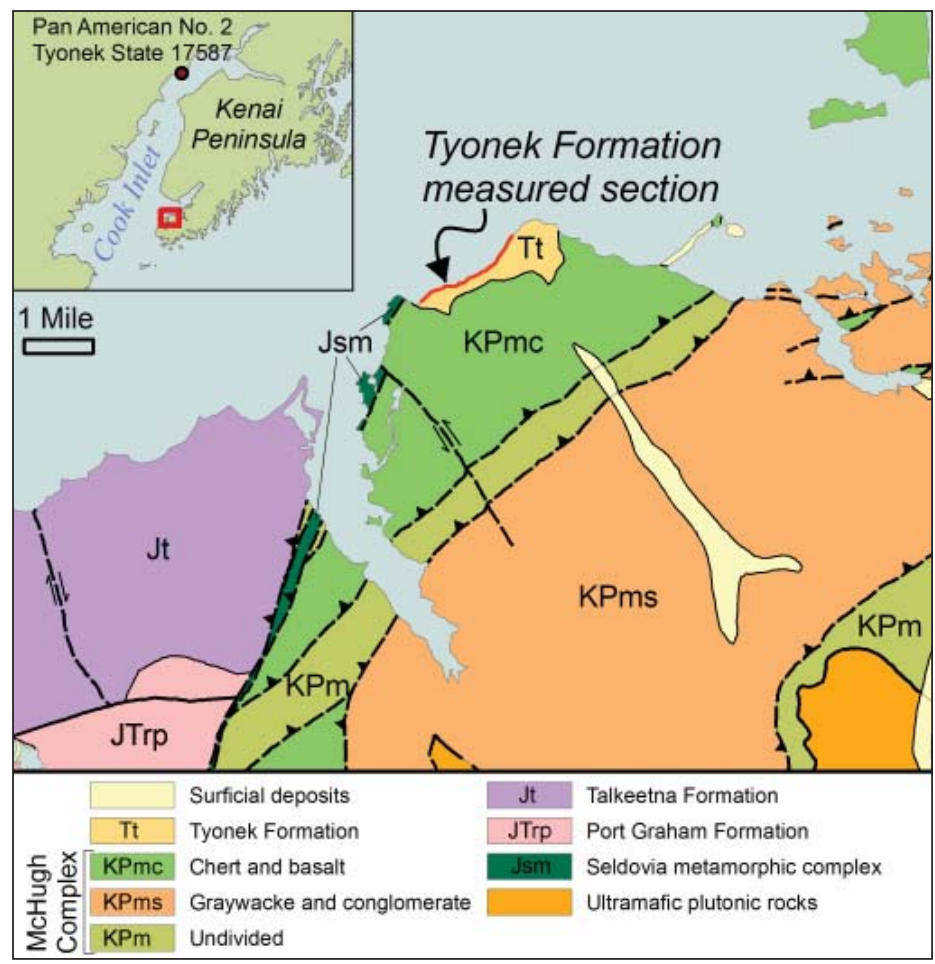

Figure 2. Geologic map of the Barabara Point area showing the location of the measured section (modified from Bradley and others, 1999).

massive and cross-stratified sandstone, and very minor coal. This may be a reflection of the different locations within the basin of the type section and measured section in this study. The section in this study is located near the basin margin; the type section probably reflects the character of the formation away from the basin margins.

\section{METHODS}

One stratigraphic section in the Tyonek Formation was measured near Homer (fig. 2). The lithology, texture, sedimentary structures, and fossil content of the strata were recorded. Samples from mudstone and siltstone were collected for x-ray diffraction (XRD) for compositional analysis and for palynological analysis to determine relative ages; sandstone samples were collected for provenance studies. All analyses are currently underway.

\section{SEDIMENTOLOGY}

The Tyonek Formation measured section is exposed on the southeast coast of Kachemak Bay near Barabara Point (fig. 2). The base of the Tyonek Formation there is unconformable and erosive into the underlying structurally deformed Triassic chert and greenstone. Strata of the gently north-northeast-dipping Tyonek Formation onlap onto the underlying units near the edges of the outcrop. This exposure is interpreted as part of the fill to an incised paleovalley. The lithofacies defined in table 1 have been divided into four facies associations listed in table 2 and described below.

Table 1. Summary of lithofacies.

\begin{tabular}{lll}
\hline Code & \multicolumn{1}{c}{ Description } & Geometry at outcrop scale \\
Gm & Massive, clast-supported conglomerate & Tabular and Lenticular \\
Gp & Planar cross-stratified clast-supported conglomerate & Tabular \\
Sm & Massive sandstone & Lenticular \\
Sh & Horizontally-stratified sandstone & Lenticular \\
Sp & Planar cross-stratified sandstone & Tabular \\
St & Trough cross-stratified sandstone & Tabular \\
Fsb & Angular, blocky siltstone & Tabular \\
Fsm & Massive siltstone & Tabular \\
\hline
\end{tabular}


Table 2. Summary of facies associations.

$\begin{array}{lll}\begin{array}{l}\text { Facies Association } \\ \text { Valley-margin ephemeral debris flows }\end{array} & \begin{array}{l}\text { Lithofacies } \\ \text { Gm, Fsb }\end{array} & \begin{array}{l}\text { Interpretation } \\ \text { Episodic debris flows interbedded with pedogenic } \\ \text { siltstone horizons near the margin of an incised valley } \\ \text { Valley-axis proximal braided streams } \\ \text { axis }\end{array} \\ \begin{array}{lll}\text { Sheet-flow braided stream deposits developed near the } \\ \text { Paludal environment }\end{array} & \text { Fsm, Fsm } & \begin{array}{l}\text { of an incised paleovalley } \\ \text { Isolated fluvial channels laterally adjacent to overbank } \\ \text { and marsh environments interbedded with crevasse } \\ \text { splay deposits }\end{array} \\ \text { Distal braided streams } & \text { St, Sp } & \text { Braided streams constructing a sandy braidplain }\end{array}$

\section{Facies Association 1: Valley-margin ephemeral debris flows}

Description. There are two primary lithofacies in this association: Massive, clast-supported conglomerate $(\mathrm{Gm})$ and massive siltstone (Fsb) (fig. 3). Facies $\mathrm{Gm}$ has dominantly very angular clasts with few sub-rounded types (fig. 4a). The clasts are mostly pebble- $(4-16 \mathrm{~mm})$ to cobble-sized $(1.6-25.6 \mathrm{~cm})$; the mean clast size is 2.9 $\mathrm{cm}$. Clast types identified in hand specimen include variously colored chert, minor quartz, and a predominance of greenstone and metasedimentary types. Individual beds of $\mathrm{Gm}$ average 1-2 $\mathrm{m}$ thick and thicken and thin laterally. Facies Gm frequently has erosive bases, some with very steep relief (fig. 4b). The lateral extent of beds of facies $\mathrm{Gm}$ is on the scale of $10 \mathrm{~m}$.

Facies Fsb is massive, mottled, or angular blocky. Slickensided, clay-lined surfaces, organic detritus, and rooted horizons are prevalent throughout this facies. Beds of Fsb average less than $0.5 \mathrm{~m}$ in thickness and are lenticular laterally. Thin lenses of conglomerate are found locally.

Interpretation. This facies association represents alternating periods of episodic debris flows (Gm) and relatively quiescent soil formation (Fsb) near the margins of an incised paleovalley. The angularity of the clasts suggests that they have not traveled far from their source, lending credence to proximity to a valley margin. Channel axes in this part of the section indicate a general paleoflow toward the northwest or southeast direction, but northwest-directed paleoflow is more reasonable considering the present high topography created by the growing accretionary prism to the southeast was interpreted to be present during deposition of this formation (Magoon and Egbert, 1986). Upright trees appear to be progressively buried by distinct, relatively low energy sedimentation events. Steep, erosive surfaces cut by facies Gm into underlying deposits of Fsm suggest that facies Fsb had been exposed for a long enough period of time to become cohesive (fig. 4d). Mottled textures in facies Fsb are the product of root systems that churn the soil and destroy bedding. Angular, blocky textures result from the swelling and shrinking of the sediments upon wetting and drying (Retallack, 1997). Stress cutans are surfaces that are formed by compressively orienting the clays in the sediments due to swelling, and often display slickensided surfaces as a result (fig. 4c; Bridge, 2003).

\section{Facies Association 2: Valley-axis braided streams}

Description. This facies association consists of five lithofacies present in varying abundance: Massive, clastsupported conglomerate (Gm), planar cross-stratified conglomerate (Gp), horizontally-stratified sandstone (Sh), massive sandstone (Sm), and massive siltstone (Fsm) (fig. 3). Facies Gm is most common at the base of the association, has tabular geometries at the outcrop scale (fig. 5a), and is normally graded and contains imbricated clasts. The cobble-sized clasts are sub-rounded to well rounded (fig. 5b), and generally grain size decreases upsection. The mean clast size near the base of facies association 2 is $7.2 \mathrm{~cm}$, and near the middle and top of the association is $4.4 \mathrm{~cm}$ and $4.3 \mathrm{~cm}$, respectively. Minor interbeds of medium-grained horizontally-stratified sandstone (Sh) occur within facies $\mathrm{Gm}$.

Planar cross-stratified conglomerate (Gp) occurs mostly at the base of the association, and bedding is tabular at the scale of the outcrop and has similar clast characteristics to facies Gm. Facies Sm is medium-grained and typically lenticular over several meters. Facies Fsm is tabular at outcrop scale and contains minor leaf fossils and coaly horizons. Average bed thickness is 1-2 m but beds thicken and thin laterally.

Interpretation. Clasts that are rounded, in combination with normal grading in facies Gm, clast imbrication, and the presence of facies Gp and Sh all suggest tractive transportation of sediment in a fluvial setting (Miall, 2000). 


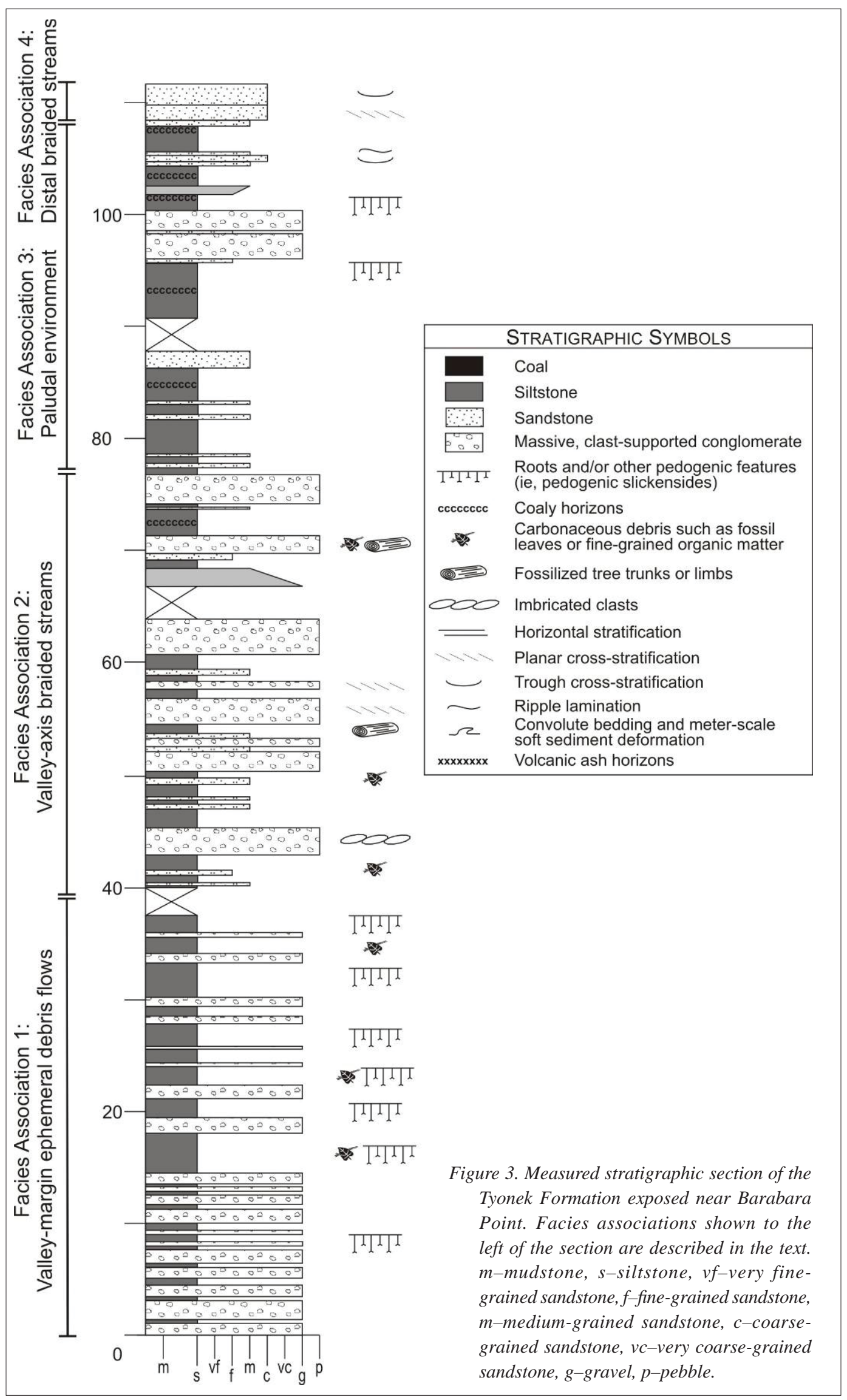




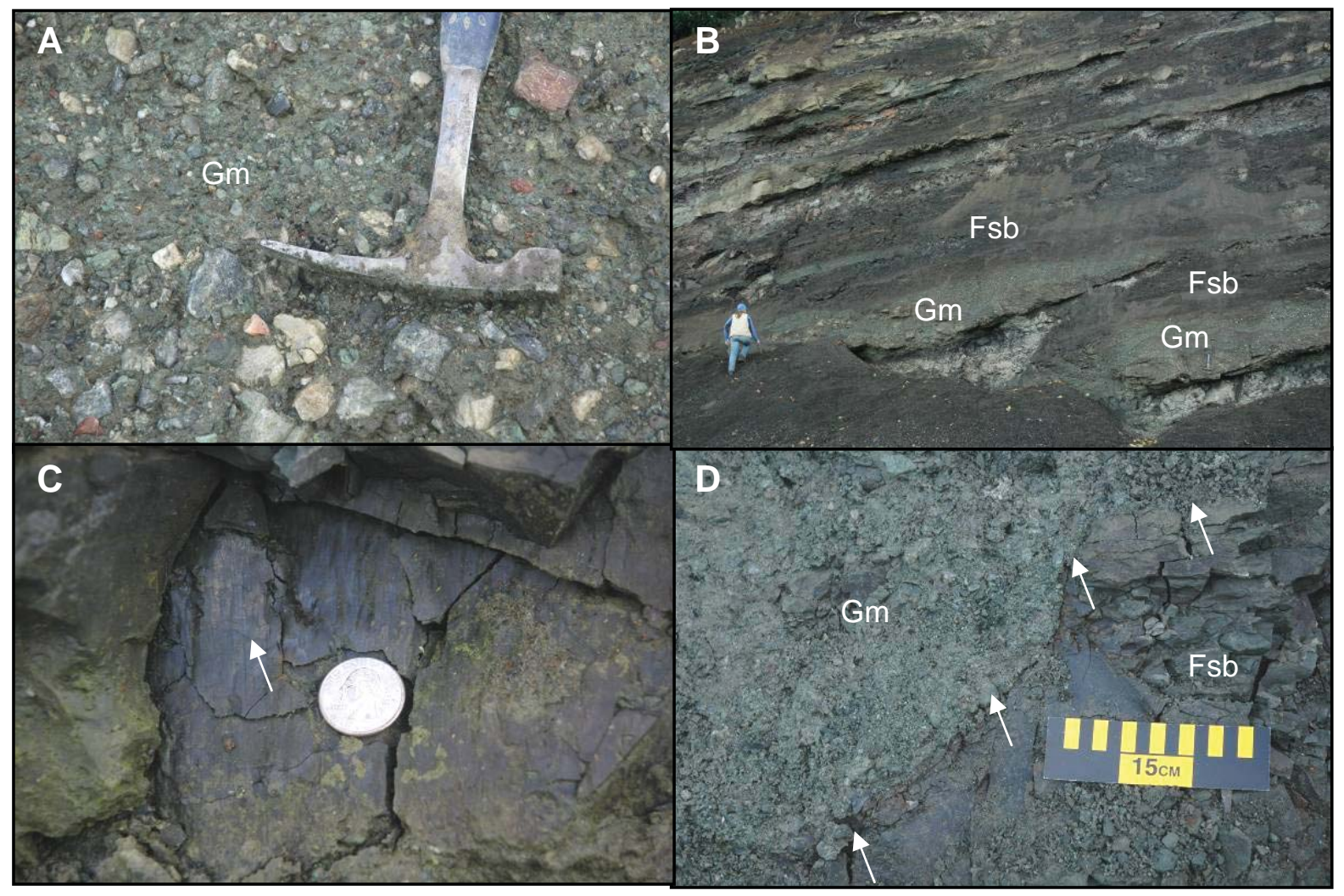

Figure 4. Photographs from facies association 1 valley-margin ephemeral debris-flow deposits. A. Angular clasts dominate the massive conglomerate (Gm) near the base of the section; B. The massive conglomerate (Gm) and siltstone (Fsb) display lenticular geometries in this part of the section; C. Pedogenic features such as stress cutan surfaces with slickensides are common in the siltstone (Fsb); D. The massive conglomerate $(\mathrm{Gm})$ forms steep, erosive cuts into underlying siltstone (Fsb).

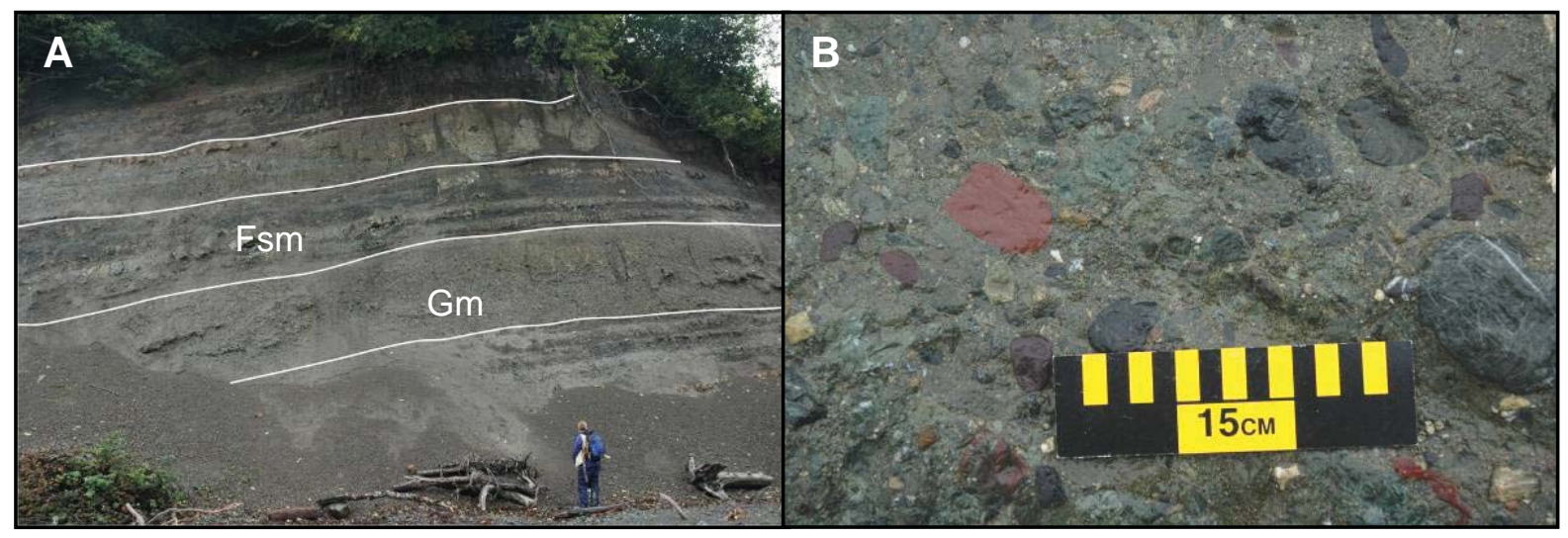

Figure 5. Photographs from facies association 2 valley-axis braided stream deposits. A. The massive clast-supported conglomerate $(\mathrm{Gm})$ has tabular geometries in this part of the section; B. Sub-rounded to rounded clasts of chert, quartz, greenstone, and metasedimentary types dominate the massive conglomerate $(\mathrm{Gm})$ in this part of the section 
The tabular nature of the conglomerate beds implies sheet-like flow similar to that in modern braided systems. Imbricated clasts suggest a paleoflow direction toward the west. The overall upsection reduction in mean clast size suggests that the system is losing transport capacity as it grades into facies association 3 . This facies association is interpreted as braided stream deposits that occupy the axis of a paleovalley.

\section{Facies Association 3: Paludal environment}

Description. The two main lithofacies in this association are massive siltstone (Fsm) and massive sandstone (Sm) (fig. 3). Facies Fsm is the dominant lithofacies but the majority of it is poorly exposed due to slumping and weathering (fig. 6). It is tabular at the scale of the outcrop and trenching revealed several rooted and coaly horizons. A few beds grade from gray siltstone to red clayey siltstone to a rooted surface.

Facies Sm consists of lenticular bodies of massively-bedded fine-grained sandstone that thicken and thin laterally with thicknesses from about 5 to $20 \mathrm{~cm}$. The sandstone is gray to green and appears rich in dark micas in hand specimen. One 4-m-thick bed of lithofacies Gm is present (96 m on fig. 3); clasts within are sub-rounded to well rounded and have a mean clast size of $2.9 \mathrm{~cm}$.

Interpretation. Thick packages of facies Fsm indicate a very low energy depositional environment. Siltstones that grade upward to clayey and rooted horizons may indicate a strongly-developed soil horizon with exposure on the order of 100,000 years (Bridge, 2003). These packages, as well as other rooted and coaly horizons, suggest deposition in overbank and swamp environments. Facies Sm may be the result of floods when laterally adjacent rivers overstepped their banks and deposited coarser material on the surrounding floodplain. The presence of facies Gm indicates minor fluvial channels.

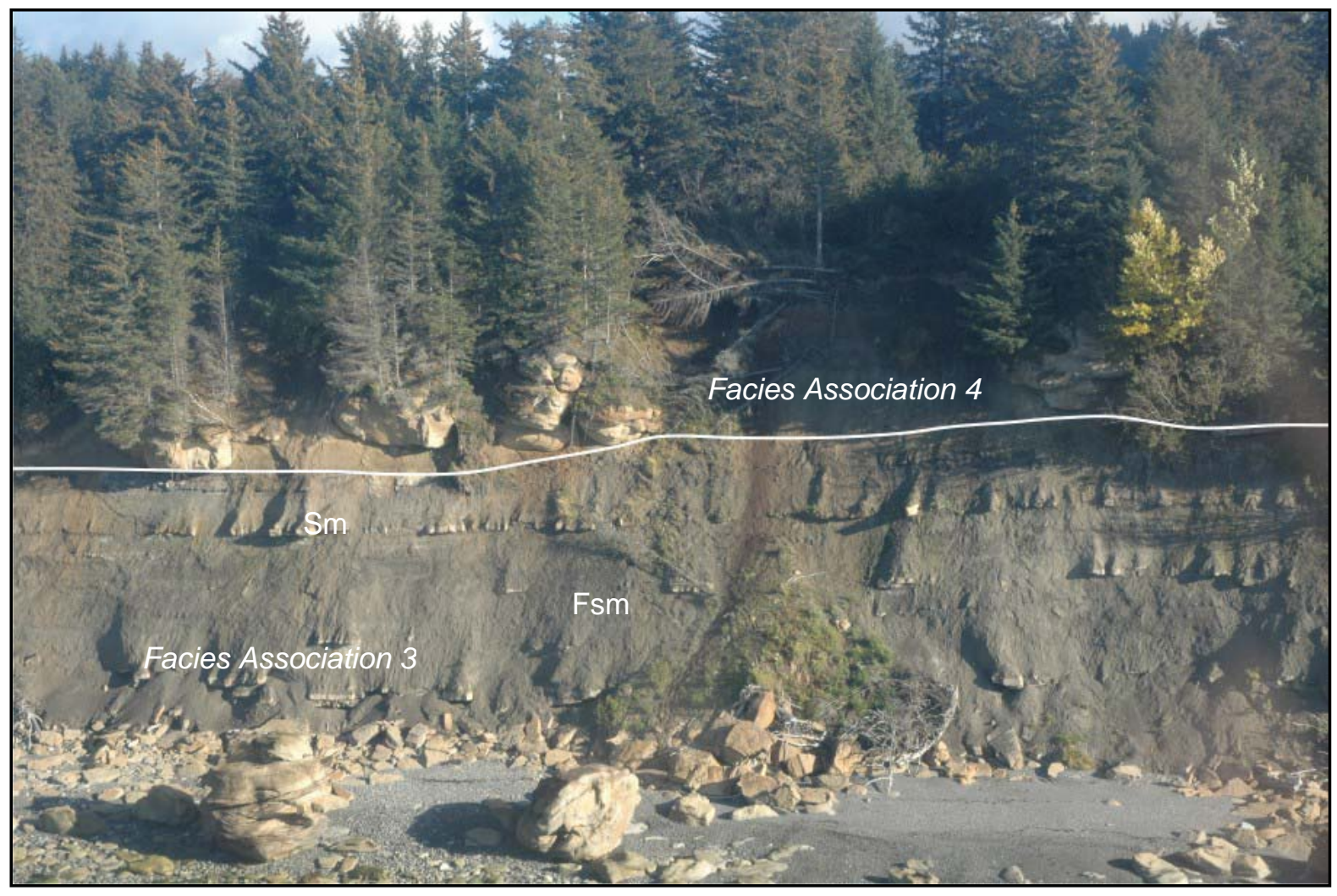

Figure 6. Aerial field photograph from the top part of the measured section showing facies associations 3 and 4 . Weathering of the dominant siltstone facies (Fsm) causes poor exposure in the paludal deposits of facies association 3. Massive sandstone $(\mathrm{Sm})$ forms thin, tabular bodies in this part of the section. Note the thick, light-colored sandstone of facies association 4 exposed at the top of the section. Facies association 4 can be traced to the southeast (right) along most of the top of the 0.3-km-long outcrop. 


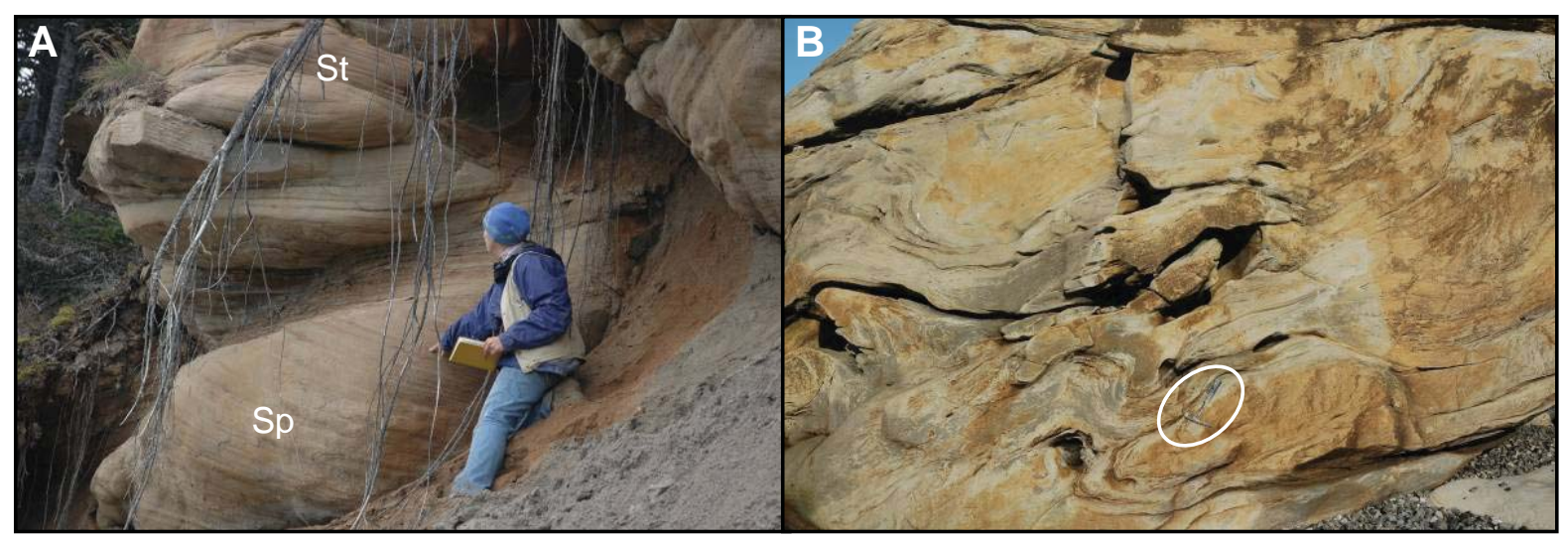

Figure 7. Photographs from facies association 4 distal sandy braided deposits. A. Facies association 4 consists of thick beds of trough cross-stratified (St) and planar cross-stratified (Sp) sandstone; B. Several-meter-scale soft-sediment deformation is common in this association. Hammer in circle for scale.

\section{Facies Association 4: Distal braided streams}

Description. Facies association 4 consists of two lithofacies: trough (St) and planar (Sp) cross-stratified sandstone (fig. 3). This unit is laterally extensive and could be traced across the top of nearly the entire 0.3-km-long exposure (fig. 6). Beds in this facies are 30-40 cm thick on average, but can reach up to $1 \mathrm{~m}$ thick (fig. 7a). Foreset thickness ranges from 5-10 $\mathrm{cm}$ in some of the thicker beds and 1-2 cm in the thinner beds. Large, soft sediment deformation structures deform entire beds on the scale of over a meter (fig. 7b). Organic debris occurs on foresets and bedding planes. The sandstone is dark to light tan and appears rich in white mica in hand specimen.

Interpretation. Facies association 4 may represent deposition in a distal fluvial environment. The sheet-like geometry of the deposit and the evidence of tractive transport (i.e., cross-stratification) suggest deposition on a sandy braid plain. Paleoflow directions measured from facies Sp and St suggest a southerly direction. The composition of this facies looks very different in hand sample from sandstone or conglomerate compositions in the underlying associations, which could indicate a different provenance for this unit. The large-scale convolute bedding may be a sign of tectonic activity, such as subduction-related earthquakes, during deposition.

\section{PRELIMINARY CONCLUSIONS}

The Tyonek Formation exposure on the eastern coast of Kachemak Bay is interpreted as part of the fill to an incised paleovalley. Where exposed in this area, the base of the Tyonek Formation is unconformable and erosive into the underlying structurally deformed Triassic chert and greenstone. Strata of the gently north-northeast-dipping Tyonek Formation onlap onto the underlying units at the margins of the outcrop and fill a present-day topographic low adjacent to the Triassic chert and greenstone.

Facies association 1, consisting of ephemeral debris-flow deposits and pedogenic siltstone, occurs at the base of the inferred paleovalley (fig. 7). This association represents a period when episodic high-energy sedimentation punctuated a primarily low-energy environment. This environment experienced enough subaerial exposure temporally to develop soil characteristics in the siltstone (Fsb), such as stress cutans, and to become cohesive enough that steep erosive surfaces were cut down into these deposits by conglomeratic debris flows (Gm).

Facies association 2 represents the next stage in the paleovalley, when proximal braided streams dominated the system, producing massive (Gm) and planar cross-stratified (Gp) conglomerate (fig. 7). Overbank and floodplain facies are represented by the massive siltstone (Fsm), massive sandstone ( $\mathrm{Sm}$ ), and horizontally-stratified sandstone $(\mathrm{Sh})$ interbeds. Facies association 2 grades upsection to the paludal environment defined by facies association 3 (fig. 7). This marsh and floodplain environment is characterized by thick units of massive siltstone (Fsm) and thin, tabular units of massive sandstone (Sm). Facies Sm may represent crevasse splay deposits associated with isolated fluvial channels represented by lenticular bodies of massive conglomerate (Gm).

Facies association 4 is anomalous in terms of its apparent provenance, lateral extent, and bedforms. Qualitative inspection of hand specimens reveals a mica-rich composition dissimilar to the greenstone- and chert-rich lithologies of the other associations. The lateral extent of facies association 4 is much greater than the others; it extends across the top of the entire exposure and is traceable for more than $0.5 \mathrm{~km}$ before eroding off to the south 
or diving into the subsurface to the north. Thick units of trough and planar cross-stratified sandstone are unique compared to the other conglomerate- and siltstone-dominated facies associations.

The development of a paleovalley during the Late Oligocene-Early Miocene may indicate uplift in the adjacent accretionary prism at that time. Tectonic uplift of the basin margin would lead to incision of streams as relative base level drops and the river systems attempt to maintain their gradient (Bridge, 2003). Uplift of the accretionary prism would also provide a source for sediments deposited in the paleovalley; the predominance of greenstone, chert, and quartz are suitable lithologies that may have been derived from the accretionary prism. If the paleovalley extends into the offshore subsurface, stratigraphic traps commonly associated with such depositional features may exist.

\section{FUTURE WORK}

A major question related to all the Tertiary depositional systems in the Cook Inlet forearc basin is what the provenance for each unit is and how it changes in time and space. For example, can we see a difference in provenance between the axial and marginal fluvial systems? One way to test this is through the use of detrital zircons. Individual zircon grains will be separated from bulk samples collected from the Tyonek, Beluga, and Sterling formations. Ages for each zircon grain will be acquired through LA-MC-ICPMS (Laser Ablation-Multiple-Collection-Inductively Coupled Plasma Mass Spectrometry) U-Th-Pb geochronological analyses. These ages will be compared to published ages obtained from all around southern Alaska in an effort to determine the provenance for each formation. This will also allow a more detailed reconstruction of the depositional systems. Key sediment source areas to focus on will include the Aleutian-Alaska Peninsula volcanic arc, the Alaska Range, the Talkeetna volcanic arc, and the Chugach Mountains (accretionary prism).

In the Seldovia area, this method can be used to analyze the provenance between the unique sandstone observed at the top of the Tyonek section (facies association 4) and that of the underlying strata. Rotation of paleocurrent directions from west- to south-directed from the base to the top of the section, as well as the different sedimentological character and the qualitative discrepancy in provenance, all suggest that the sediment sources for this part of the Tyonek may have changed as it was deposited.

\section{ACKNOWLEDGMENTS}

Field operations for the September 2006 field season were funded by the Alaska Division of Geological \& Geophysical Surveys (DGGS) operating budget. We thank Bob Gillis of DGGS for his helpful review of our manuscript.

\section{REFERENCES}

Barnes, F.F., and Cobb, E.H., 1959, Geology and coal resources of the Homer district, Kenai coal field, Alaska: U.S. Geological Survey Bulletin 1058-F, p. 217-260, 11 sheets, scale 1:2,400.

Bradley, D.C., Kusky, T.M., Haeussler, P.J., Karl, S.M., and Donley, D.T., 1999, Geologic map of the Seldovia quadrangle, south-central Alaska: U.S. Geological Survey Open File Report 99-18, http://pubs.usgs.gov/ of/1999/of99-018/.

Bridge, J.S., 2003, Rivers and floodplains: forms, processes, and sedimentary record: Oxford, U.K., Blackwell Publishing, $491 \mathrm{p}$.

Calderwood, K.W., and Fackler, W.C., 1972, Proposed stratigraphic nomenclature for the Kenai Group, Cook Inlet basin, Alaska: American Association of Petroleum Geologists Bulletin, v. 56, no. 4, p. 739-754.

Crick, R.W., 1971, Potential petroleum reserves, Cook Inlet, Alaska in Cram, I.H., ed., Future petroleum provinces of the United States - their geology and potential: American Association of Petroleum Geologists Memoir, v. 15, no. 1, p. 109-119.

Dall, W.H., and Harris, G.D., 1892, Correlation papers-Neocene: U.S. Geological Survey Bulletin 84, p. 234-238.

Hartman, D.C., Pessel, G.H., and McGee, D.L., 1974, Stratigraphy of the Kenai Group, Cook Inlet: Alaska Division of Geological \& Geophysical Surveys, Alaska Open File Report 49, 7 p., 11 sheets, scale 1:500,000.

Hayes, J.B., Harms, J.C., and Wilson, T.W., 1976, Contrasts between braided and meandering stream deposits, Beluga and Sterling formations (Tertiary), Cook Inlet, Alaska in Miller, T.P., ed., Recent and ancient sedimentary environments in Alaska: Anchorage, Alaska, Alaska Geological Society Symposium Proceedings, p. J1-J27.

Hite, D.M., 1976, Some sedimentary aspects of the Kenai Group, Cook Inlet, Alaska in Miller, T.P., ed., Recent and ancient sedimentary environments in Alaska: Anchorage, Alaska, Alaska Geological Society Symposium Proceedings, p. I1-I22. 
Kirschner, C.E. and Lyon, C.A., 1973, Stratigraphic and tectonic development of the Cook Inlet petroleum province in Pitcher, M.G., ed., Arctic geology: American Association of Petroleum Geologists Memoir, no. 19, p. 396-407.

Magoon, L.B., Adkison, W.L., and Egbert, R.M., 1976, Map showing geology, wildcat wells, Tertiary plant fossil localities, K-Ar age dates, and petroleum operations, Cook Inlet area, Alaska: U.S. Geological Survey Miscellaneous Investigations 1019, 3 sheets, scale 1:250,000.

Magoon, L.B. and Egbert, R.M., 1986, Framework geology and sandstone composition in Magoon, L.B., ed., Geologic Studies of the Lower Cook Inlet COST No. 1 well, Alaska Outer Continental Shelf: U.S. Geological Survey Bulletin 1596, p. 65-90.

Miall, A.D., 1996, The geology of fluvial deposits; sedimentary facies, basin analysis, and petroleum geology: Berlin, Germany, Springer-Verlag, 582 p.

Rawlinson, S.E., 1984, Environments of deposition, paleocurrents, and provenance of Tertiary deposits along Kachemak Bay, Kenai Peninsula, Alaska: Sedimentary Geology, no. 38, v. 1-4, p. 421-442.

Retallack, G.J., 1997, A colour guide to paleosols: Chichester, United Kingdom, John Wiley \& Sons, 170 p.

Swenson, R.F., 1997, Introduction to Tertiary tectonics and sedimentation in the Cook Inlet Basin in Karl, S.M., Vaughn, N.R., and Ryherd, T.J., eds., 1997 Guide to the geology of the Kenai Peninsula, Alaska: Anchorage, Alaska, Geological Society of Alaska, p. 18-27. 


\section{THIS PAGE INTENTIONALLY LEFT BLANK.}




\section{REPORT ON DAY TRIP (5/16/07) TO VISIT MESOZOIC ROCKS EXPOSED IN PORT GRAHAM AND NEAR SELDOVIA, SOUTHERN KENAI PENINSULA}

by

Robert B. Blodgett ${ }^{1}$

Field work was conducted May 16, 2007. We (Dave LePain, Alaska Division of Geological \& Geophysical Surveys; Rick Stanley, U.S. Geological Survey; and myself) departed on the fourth helicopter load leaving from the Ocean Shores Motel in Homer to examine the Upper Triassic in Port Graham and Lower Jurassic west of Point Naskowhak in Kachemak Bay (see fig. 1 for location of stops visited).

\section{Stop 1 - Blodgett station 07RB01 (=07DL005 LePain station)}

\section{Lat. $59.35529^{\circ} \mathrm{N}$, Long. $151.84725^{\circ} \mathrm{W}$}

Small cove (bight) along southwest side of Port Graham (NE1/4 SE1/4 NE1/4 Sec. 31, T9S, R15W, Seldovia B-5 Quadrangle; fig. 1). Cove has small stream (with waterfall above) flowing into it. I had chosen this cove as this is where the earlier GPS coordinates of Andrew Caruther's and George Stanley's Monotis subcircularis locality (their 04AC41) was indicated. In subsequent conversation, it turns out that their locality was situated in the next cove northwest along the shoreline (probably hundred or so meters away).

The exposures at 07RB01 appear to the highly faulted. The southeastern third of the outcrop consists of volcanic-rich conglomeratic sands with locally abundant limestone clasts (most are small, but are up to $1.8 \mathrm{~m}$ across).

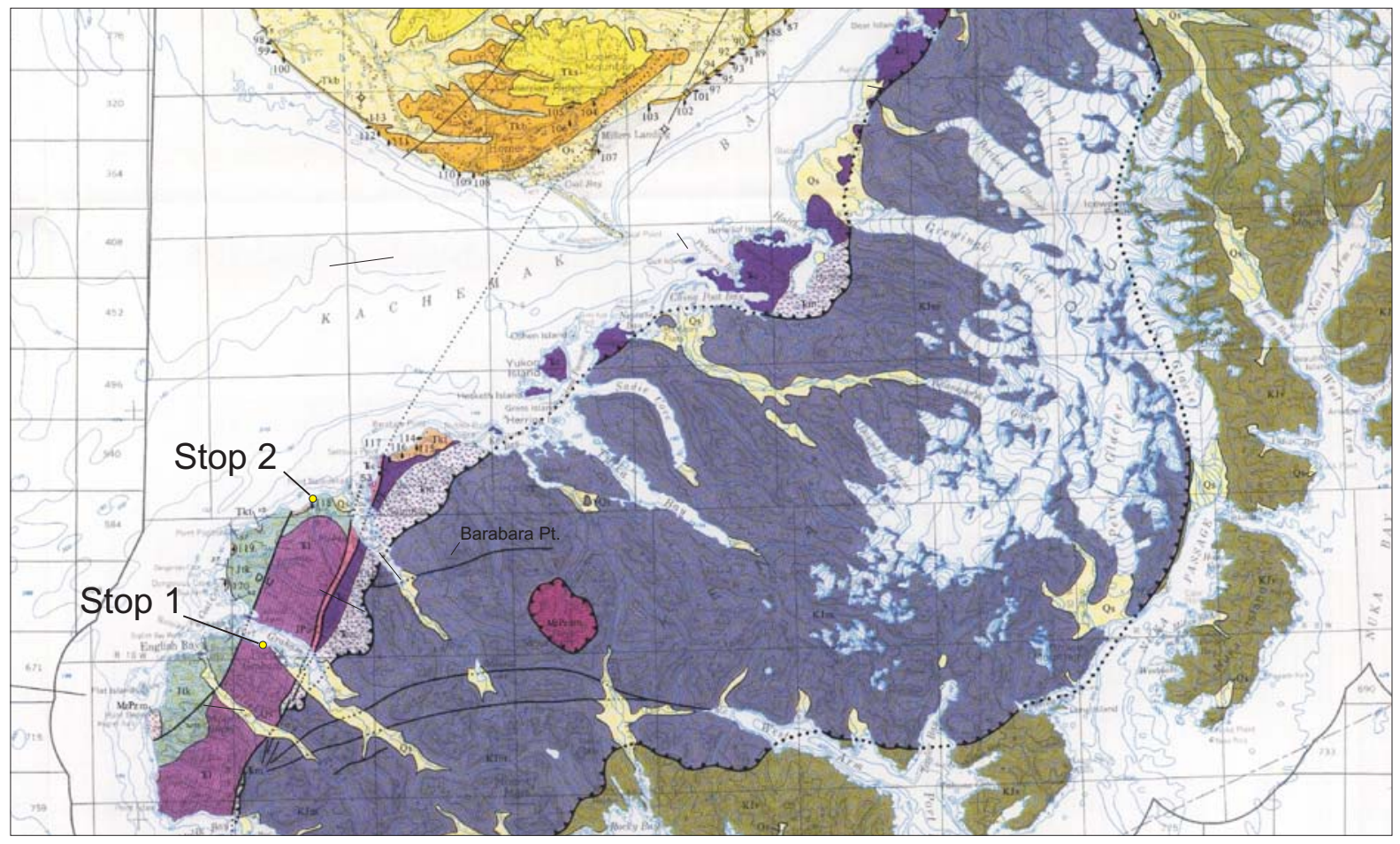

Figure 1 - Map showing two outcrop locations examined on May 16, 2007. Geology from Magoon and others (1976) compilation map. Scale is provided by the 6-mile by 6-mile township-range grid covering on-shore portions of the map. Magoon and others (1976) describe map unit Trl unit is described as Upper Triassic limestone and tuff and unit Jtk as the Lower Jurassic Talkeetna Formation consisting of volcanic breccia, tuff, agglomerate, and aphanitic lava flows. See Bradley and others (1999) for more recent mapping of Mesozoic rocks on the southern Kenai Peninsula.

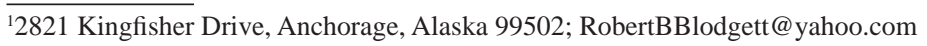


Other clast types, notably volcanic and intrusive? rocks, are present. Conglomerate at the south end weathers green-gray in color. Clasts are angular to subrounded, appear to have been transported, and individual clasts are of various colors. One limestone clast contains a number of recrystallized corals or spongiomorph specimens. We collected a number of lithology samples, and also one conodont sample (07DL005B) that was examined by Andrea Krumhardt (University of Alaska Fairbanks) and found to be barren of conodonts. We observed one mold of a high-spired gastropod reminiscent of the genus Omphaloptychia (see fig. 2). Fossil molds are present here (a few isolated bivalve shells) and in similar rocks on the north side of the cove (in another fault block). These fossils are difficult, if not impossible, to remove. I suggest that any future paleontological work done here include making casts of these molds using latex rubber. A light-green weathering dike is also present at the south end of this exposure.

The central part of the cove (with the stream flowing over it) consists of nearly flat-lying calcareous mudstone/shale with beds ranging from $5 \mathrm{~mm}$ to $5 \mathrm{~cm}$ thick (fig. 3). Beds strike $38^{\circ}$ and dip $14^{\circ}$ to the northwest. No megafossils were observed on bedding planes. The contact between the mudstone/shale section and the southerly adjacent volcanic conglomerate interval is a prominent high-angle fault. The shale beds have a weak drag fold developed in them adjacent to the fault zone.

The northern part of the cove consists of volcanic conglomerate and sandstone similar to that seen at the south end of the cove. Bivalve molds are common here and one resembles Cassianella, suggesting a Late Triassic age. Again, these specimens are difficult to remove, so future work here should include making latex rubber molds of these impressions.

No monotid bivalves were observed here, which were so abundant at Andrew Caruther's nearby locality 04AC41 (see fig. 4). The presence of Monotis subcircularis and Halobia (of the superba species type) in the past was thought to indicate the presence of both Carnian (in the case of Halobia superba) and late Norian (in the case of M. subcircularis). See reports of Martin $(1915,1926)$ and Silberling and others $(1997)$ for previous noted occurrences of these species on both sides of Port Graham. Silberling and others (1997) reexamined the Halobias from older USGS collections at Port Graham and determined them to represent two middle Norian age species, $H$. lineata and $H$. dilitata, rather than $H$. superba. This reassignment indicates that all Upper Triassic fossil collections from this locality can be restricted to the middle and late Norian.

The beds at this locality appear overmature in terms of oil potential.

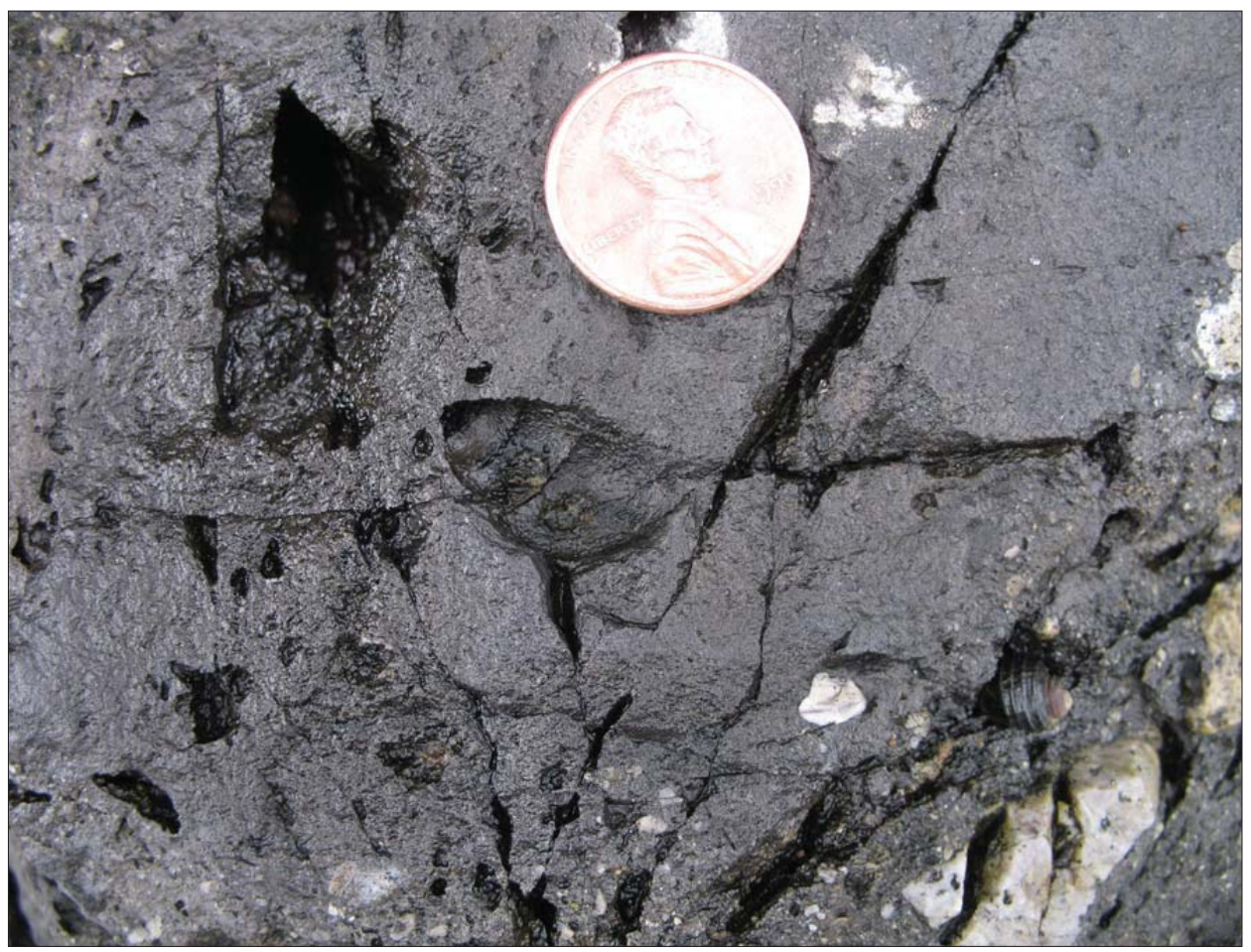

Figure 2. Mold of a high-spired gastropod suggestive of the genus Omphaloptychia (which is rather common in Norian strata of western North America). This specimen was found in the volcanic conglomerate/sandstone interval at the southern end of exposed beds at 07RB01. 


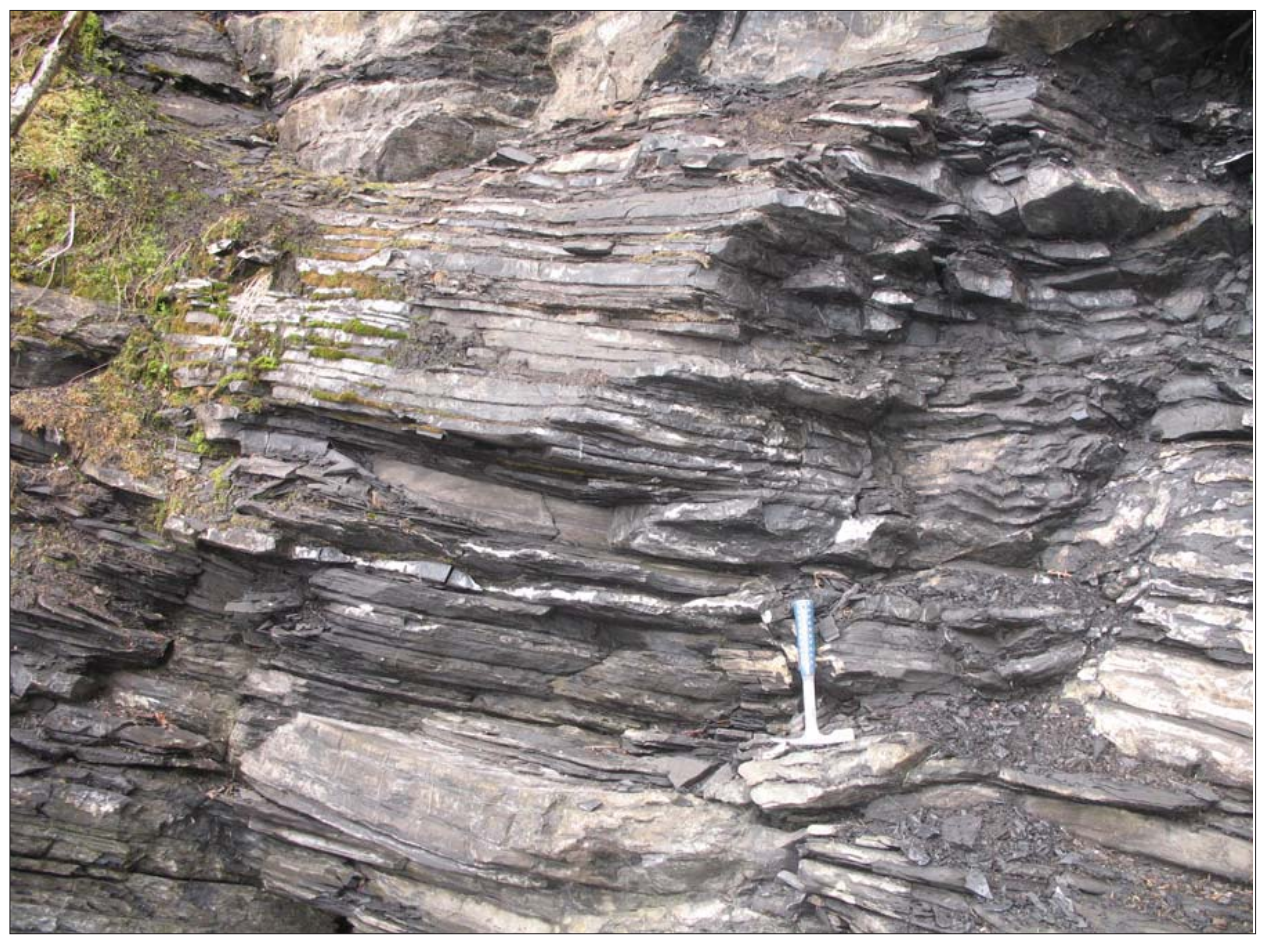

Figure 3. Thin- to medium-bedded shale/mudstone interval that forms central part of exposure of the cove at 07RB01. No visible megafossils observed in the shale.

Figure 4. Photograph showing many specimens of Monotis subcircularis within the folded argillite layers of 04AC41 (visited by Andrew Caruthers, George Stanley, and John Kelley in 2004). My original intent was to visit this locality but Caruthers indicated GPS coordinates were probably off, as it now appears they visited the next cove immediately to the northwest of where we landed by helicopter. Monotis subcircularis is a widespread index bivalve fossil for the early late Norian (late Late Triassic). This species is very widespread in the eastern Panthalassa Ocean and is reported from western North America (both in craton and adjoining accreted terranes),

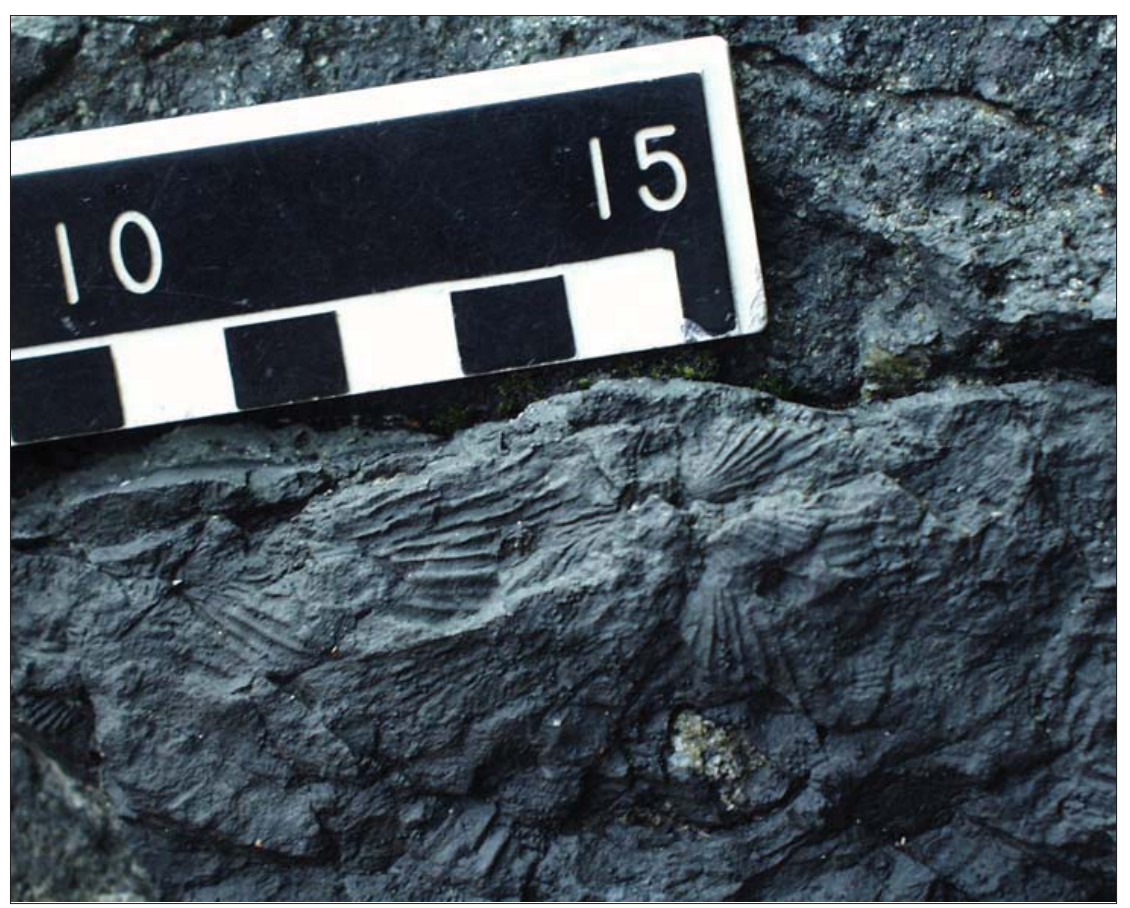
the Canadian Arctic Islands, and Peru. A few occurrences also are now known from eastern Asia (i.e., the Koryak terrane of northeastern Siberia). The monotaxic mass accumulations of this species probably indicate outer shelf depths, below wave-base, in anoxic or dysaerobic conditions. This same species is also extremely abundant and dominates near the entire Norian-age section of Kamishak Formation exposed at Puale Bay on the Alaska Peninsula. The species has previously been reported from Port Graham by Martin $(1915,1926)$ and Silberling and others (1997). 


\section{Stop 2 - Blodgett stations 07RB02 and 07RB03}

Two stations made in Lower Jurassic volcaniclastic rocks that lie immediately east of Tertiary Kenai Group exposures (LePain station 06DL022) along beach approximately $2.9 \mathrm{~km}$ west-southwest of Point Naskowhak (NE1/4 NE1/4 Sec. 35, T9S, R15W, Seldovia B-5 Quadrangle; fig. 1). Tertiary rocks appear to fill a canyon that eroded into underlying Lower Jurassic succession. The lowermost exposed part of the Lower Jurassic section is composed of volcanic flow rock with coarse crystalline fabrics (abundant glass). Most of the Jurassic section is composed of dark greenish-gray weathering coarse volcaniclastic sandstone with mudstone interbeds and conglomeratic lenses. Exposed section is at least $20 \mathrm{~m}$ thick. Fossils are abundant at this section, mostly belonging to the bivalve genus Weyla (indicative of an Early Jurassic age). A few other undetermined bivalve species are present as well as a few undetermined high-spired gastropods. Ammonites collected here indicate an early Sinemurian (Early Jurassic) age (Imlay, 1981). Hettangian-age ammonites were also recognized at nearby localities by Imlay (1981). Martin $(1915,1926)$ provides antiquated faunal lists for this section.

\section{RB02}

Lat. $59.44346^{\circ} \mathrm{N}$, Long. $151.78622^{\circ} \mathrm{W}$

Near the base of sedimentary portion of Jurassic section (west of prominent head; see fig. 5 for outcrop photo). Dave LePain notes that sedimentary structures indicate some down-slope transport here. Numerous specimens of the bivalve Weyla are found here (figs. 6-7), probably representing the species Weyla alata (von Buch, 1838). Many of these are in growth position, suggesting that although the host beds are transported, they have not been displaced great distances. Beds strike $\mathrm{N} 70^{\circ} \mathrm{E}$ and dip $50^{\circ}$ toward the northwest.

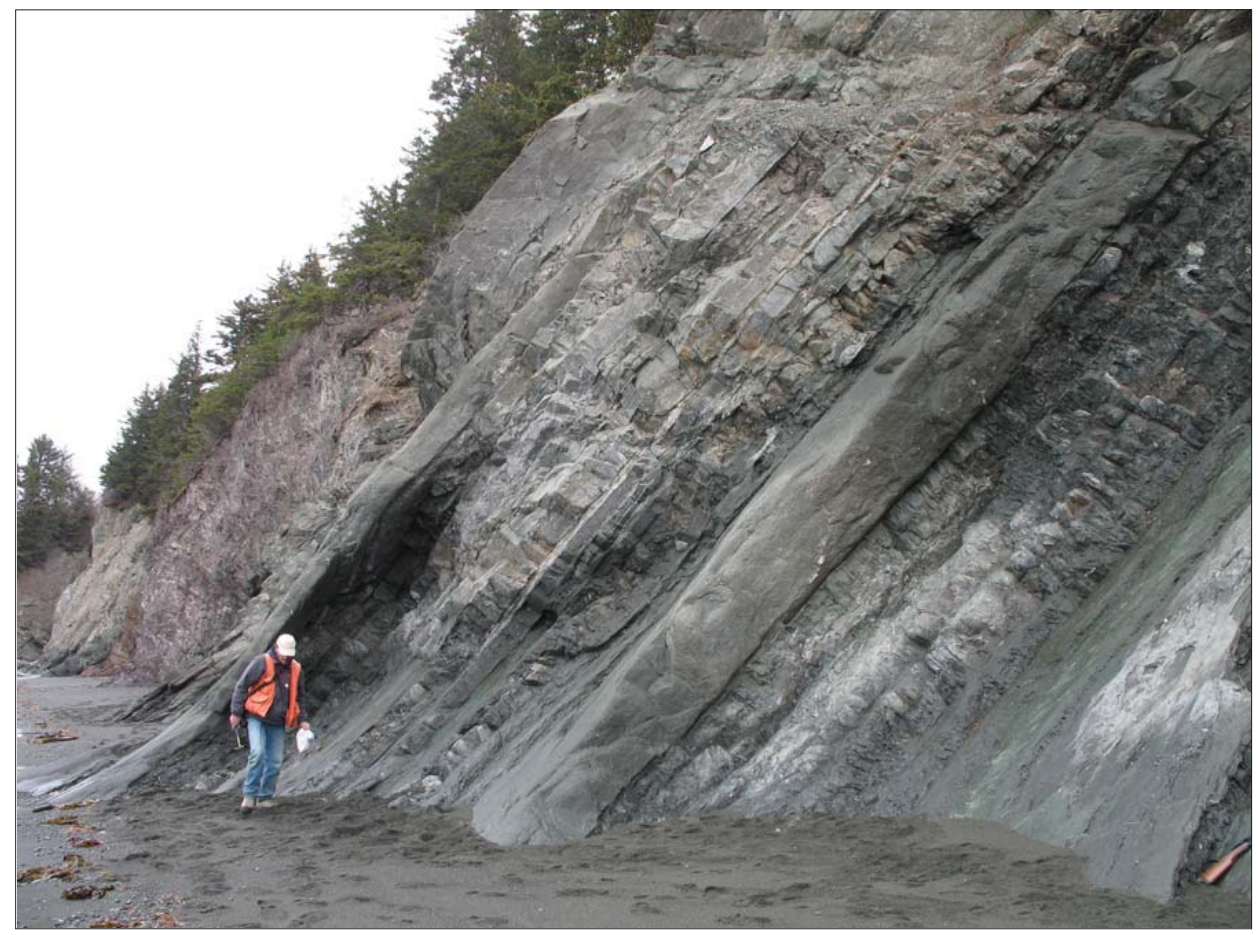

Figure 5. View looking northeast (upsection) from near base of exposed Lower Jurassic section at locality $07 R B 02$. 


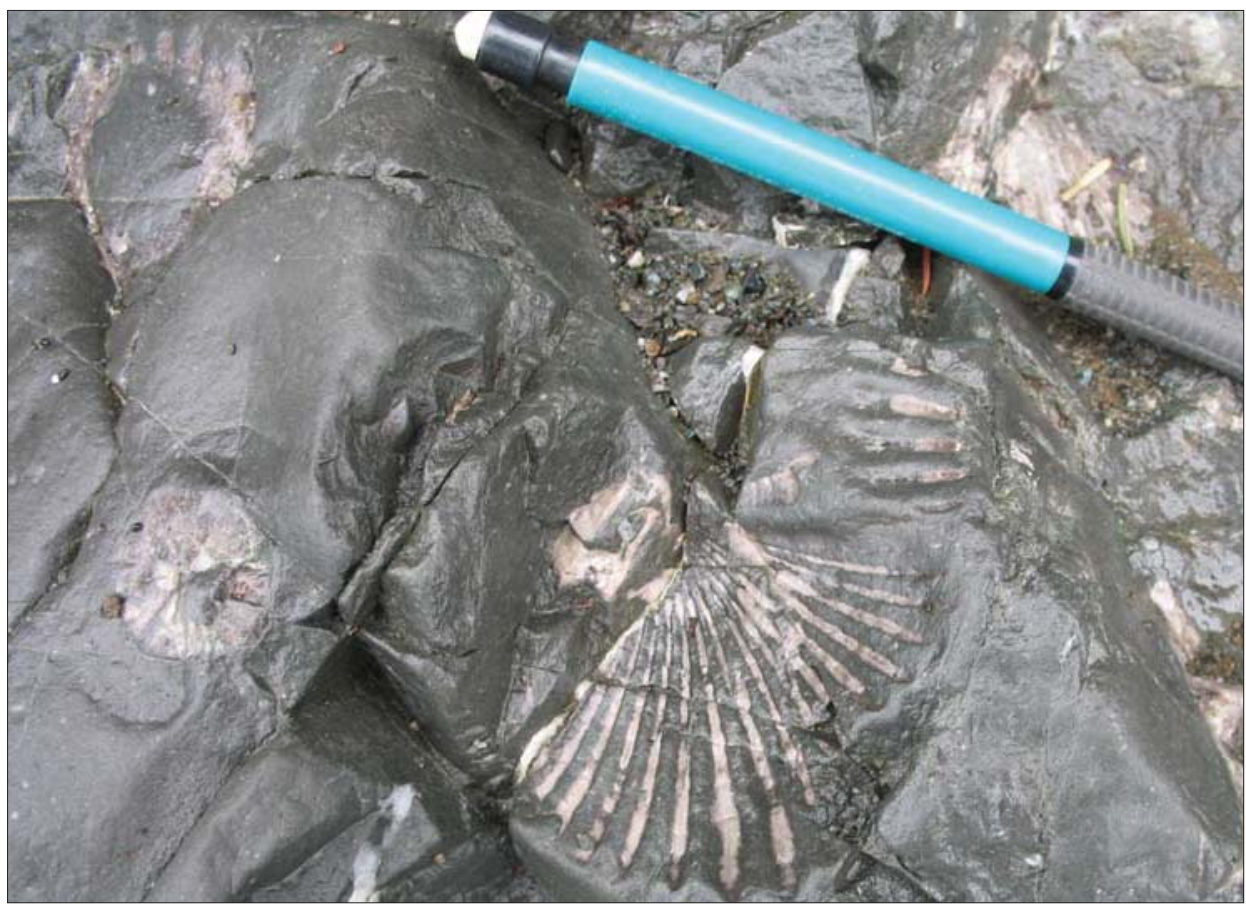

Figure 6. Bedding surface close to locality 07RB02 showing the large bivalve Weyla (probably Weyla alata). The rounded object near the left-center is a solitary scleractinian coral (note septa).

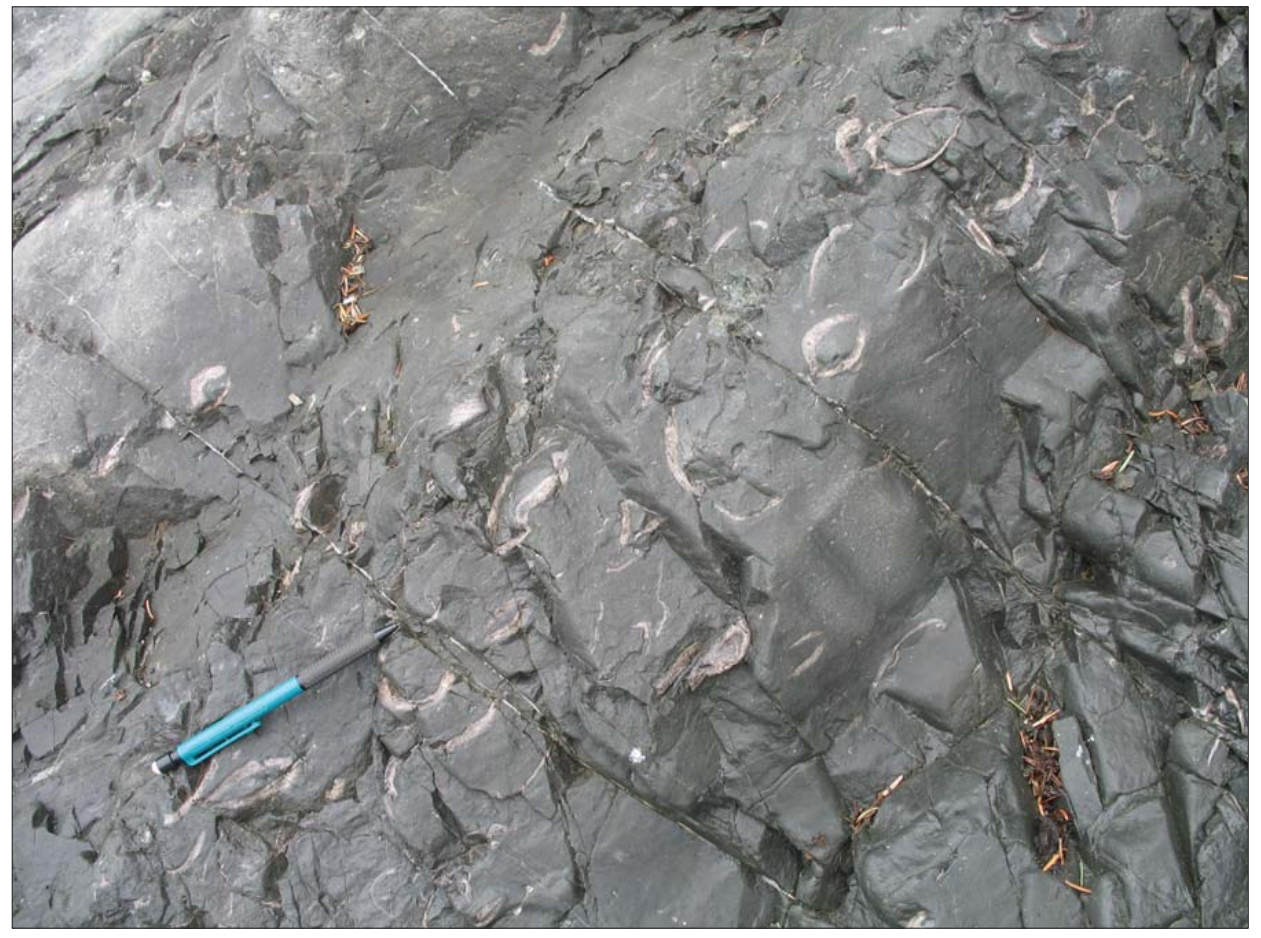

Figure 7. Bank of thick-shelled Weyla specimens between localities 07RB02 and 07RB3. Note that both articulated and disarticulated shells are present. 


\section{RB03}

Lat. $59.44381^{\circ} \mathrm{N}$, Long. $151.78600^{\circ} \mathrm{W}$

Fossils of abundant Weyla found higher in section (above 07RB02). Weyla is by far the most abundant fossil at this locality (fig. 8) as well as throughout the examined section. Occurs in mass accumulations, but also a few large snails observed, and several scattered solitary colonial corals (represented by at least two species). Most beds have horizontal bounding surfaces and are internally massive, but some cross-bedding is present lower in the section. Solitary corals present (figs. 9-11), but one would need a heavy hammer and sledge to recover them. Sands here are coarse grained and appear similar to equivalent age sands seen in the Lower Jurassic section at Puale Bay.

Most of the Weyla occurrences are in monotaxic banks (figs. 6-7), typically in sandstones and siltstone, often articulated, but some specimens are also disarticulated.

The rocks seen at these last two exposures much less altered than those seen in the Upper Triassic at 07RB1.

\section{ACKNOWLEDGMENTS}

I gratefully acknowledge support from DGGS to visit outcrops in the Port Graham area and Dave LePain for reviewing a draft of this manuscript.

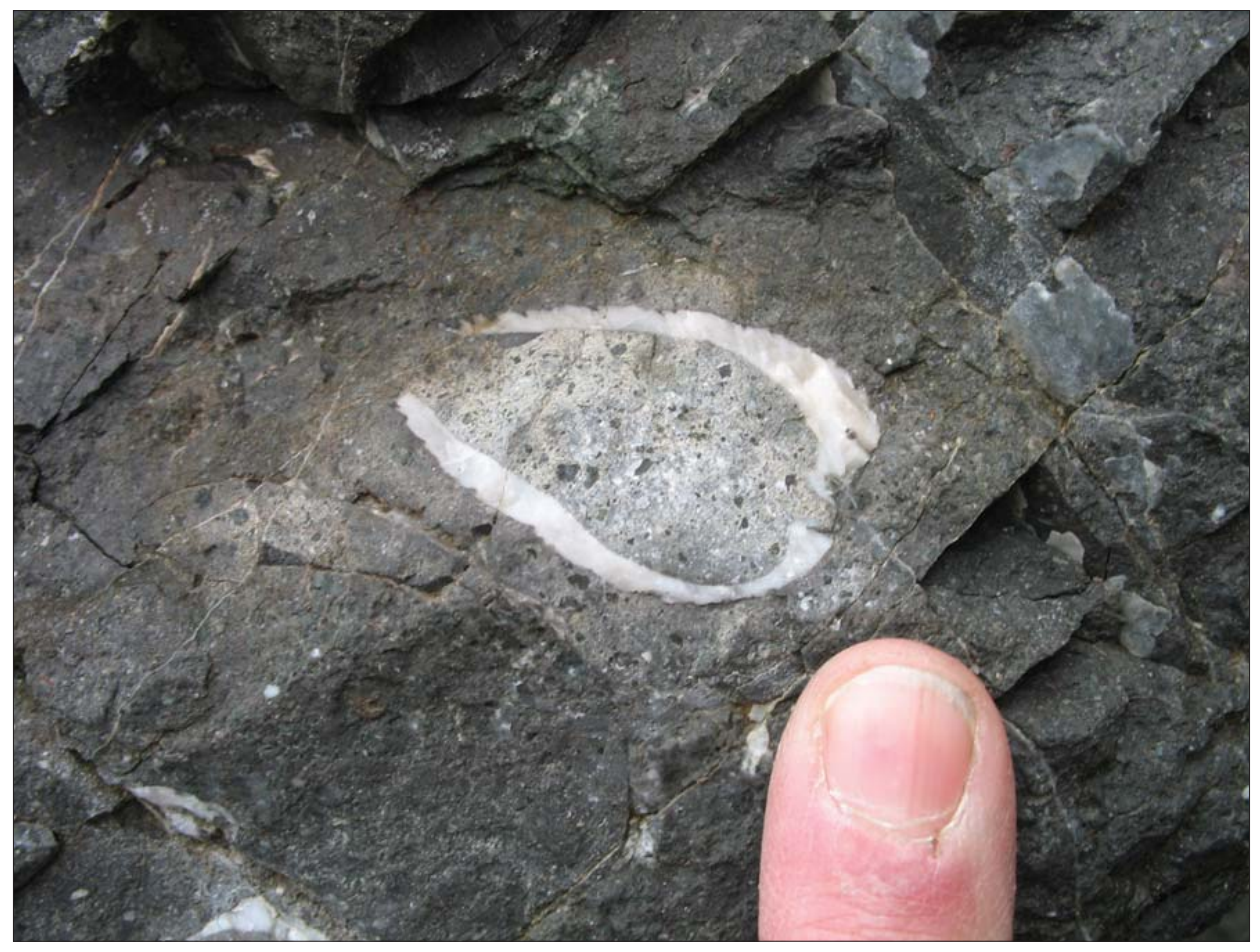

Figure 8. Cross-section of an articulated specimen of Weyla near locality 07RB03. Note angular grain shapes indicative of transport over relatively short distances from source to depositional site. 


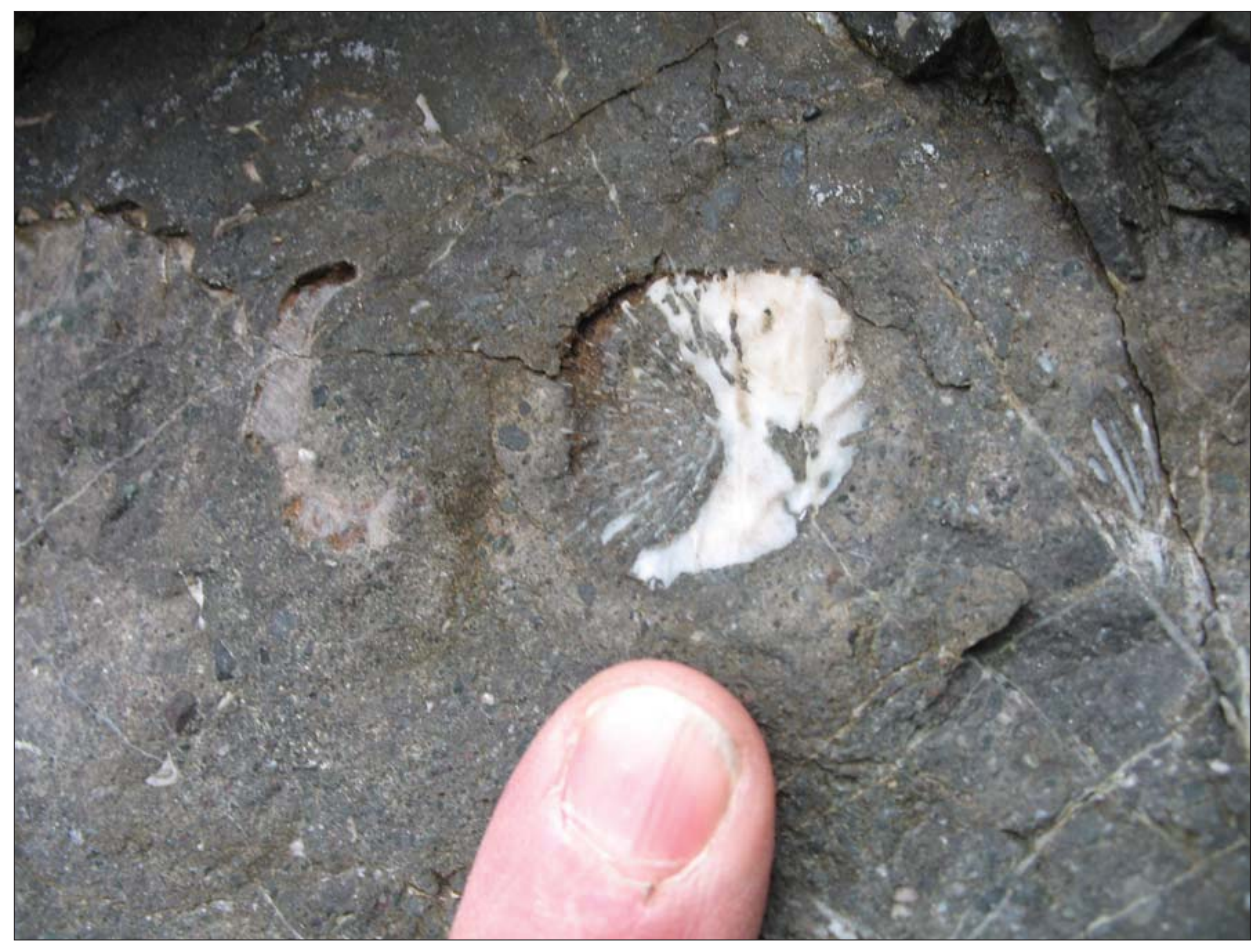

Figure 9. Solitary scleractinian coral in cross-section (note septa). Specimen found just below locality $07 R B 03$.

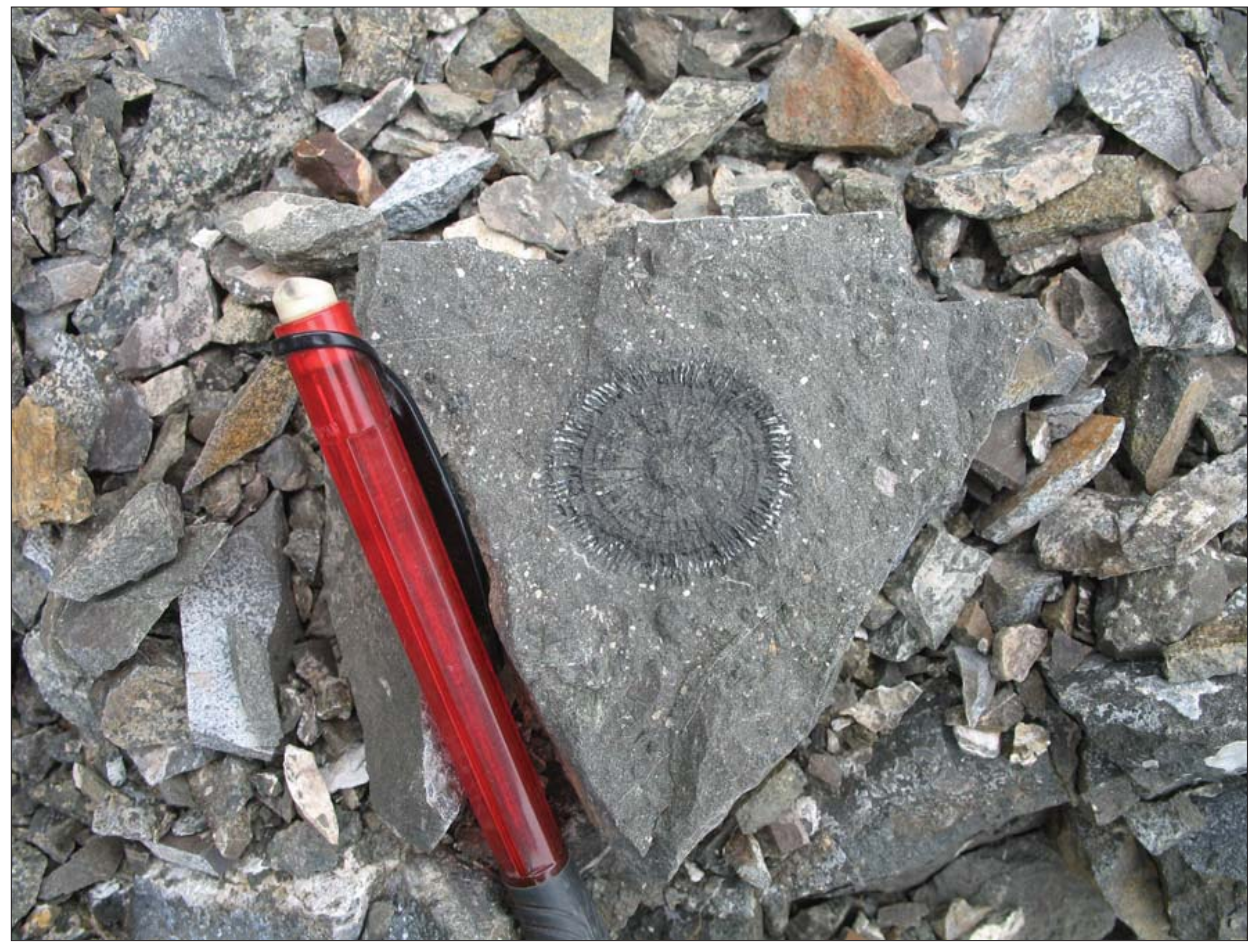

Figure 10. Base of discoidal solitary scleractinian coral from locality 07RB03. Reverse side of sample has numerous impressions of the bivalve Weyla. 


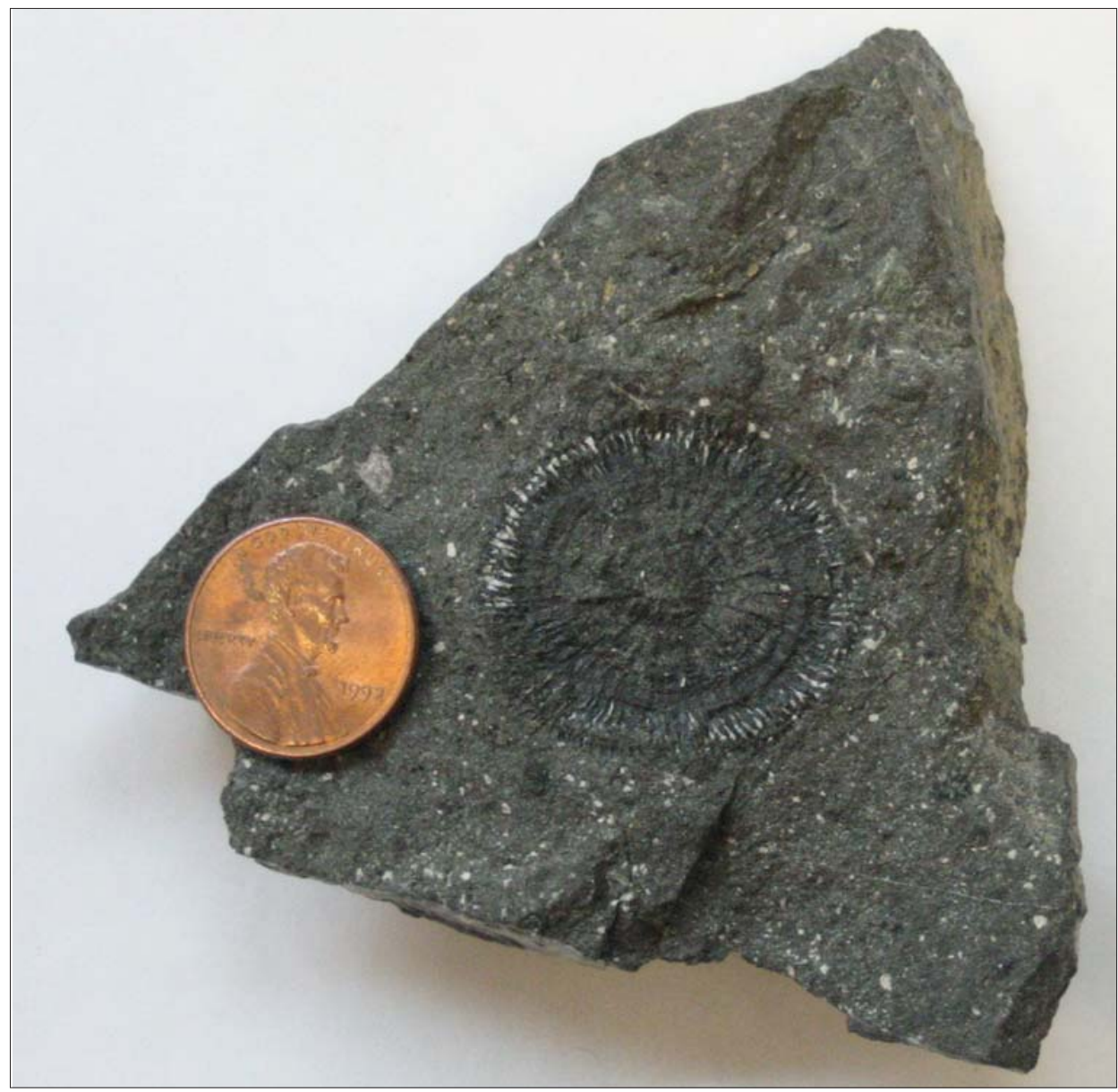

Figure 11. Same solitary scleractinian coral specimen as in fig. 10 (view taken inside under poor lighting)

\section{REFERENCES}

Bradley, D.C., Kusky, T.M., Haeussler, P.J., Karl, S.M., and Donley, D.T., 1999, Geologic map of the Seldovia quadrangle, south-central Alaska: U.S. Geological Survey Open-File Report 99-18, 1 sheet, scale 1:250,000.

Imlay, R.W., 1981, Early Jurassic ammonites from Alaska: U.S. Geological Survey Professional Paper 1148, 49 p., 12 pls.

Kelley, J.S., 1980, Environment of deposition and petrography of Lower Jurassic volcaniclastic rocks, southwestern Kenai Peninsula: Davis, California, University of California, Davis, Ph.D. dissertation, 304 p.

1984, Geologic map and sections of the southwestern Kenai Peninsula west of Port Graham, Alaska: U.S. Geological Survey Open-File Report 84-162, 1 sheet, scale 1:63,360.

Magoon, L.B., Adkison, W.L., and Egbert, R.M., 1976, Map showing geology, wildcat wells, Tertiary plant fossil localities, K-Ar age dates and petroleum operations, Cook Inlet area, Alaska: U.S. Geological Survey Map I-1019, 1 sheet, scale 1:250,000.

Martin, G.C., 1915, The western part of Kenai Peninsula: U.S. Geological Survey Bulletin 587, p. 41-112. 1926, The Mesozoic stratigraphy of Alaska: U.S. Geological Survey Bulletin 776, 493 p.

Silberling, N.A., Grant-Mackie, J.A., and Nichols, K.M., 1997, The Late Triassic bivalve Monotis in accreted terranes of Alaska: U.S. Geological Survey Bulletin 2151, 21 p., 11 pl.

Wilson, F.H., and Hults, C.P., 2008, Geology of the Prince William Sound and Kenai Peninsula region, Alaska: U.S. Geological Survey Open-File Report 2008-1002, 1 sheet, scale 1:350,000. 


\title{
MERCURY INJECTION CAPILLARY PRESSURE RESULTS FROM OUTCROP SAMPLES IN THE HOMER AREA OF COOK INLET
}

by

\author{
Andrea Loveland ${ }^{1}$
}

\section{INTRODUCTION}

This chapter summarizes mercury-injection capillary pressure data for 12 outcrop samples collected from the Beluga and Sterling formations in the vicinity of Homer, Alaska, during the 2007 field season (figs. 1 and 2). All samples are tied to measured stratigraphic sections, which are presented in LePain and others (this volume). Sample numbers correspond to measured section numbers and the sample position (meters above base of section) in a measured section. For example, sample 07JRM002-3.5a was collected 3.5 meters above the base of measured section 07JRM002. Analyses were performed by PetroTech Associates, Houston, Texas.

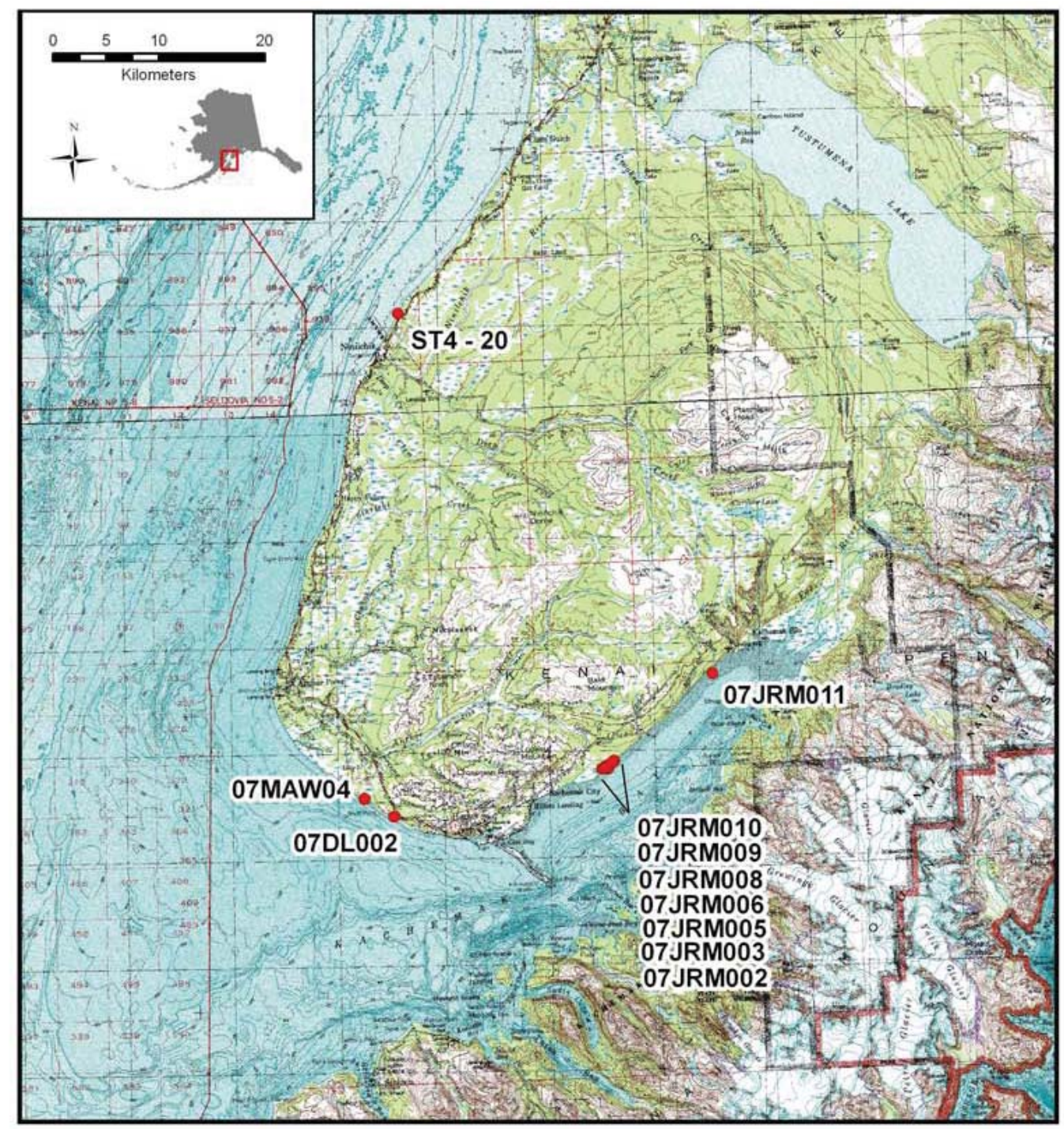

Figure 1. Map showing the Cook Inlet area and the locations of the measured sections from which the MICP samples were collected.

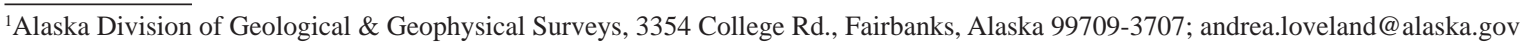


Potential seal capacity data for gas/water and oil/water systems at four different saturation levels are summarized in figures 3a-b and 4a-b, respectively. Figures 5 and 6 illustrate the potential seal capacity for gas and oil, respectively, at $7.5 \%$ seal saturation. Mercury injection capillary pressure and pore aperture curves are presented in figures 7a-20c. Sample collection sites and lithology data are summarized in table 1. The pore system and capillary properties are summarized in table 2 . Oil and gas column heights are summarized in table 3 . Mercury injection capillary pressure data for each sample are presented in tables 4 through 17.

\section{ACKNOWLEDGMENTS}

Funding for this work was provided by Benchmark Oil and Gas, Pioneer Natural Resources, Chevron North American Exploration and Production Company, and the State of Alaska.

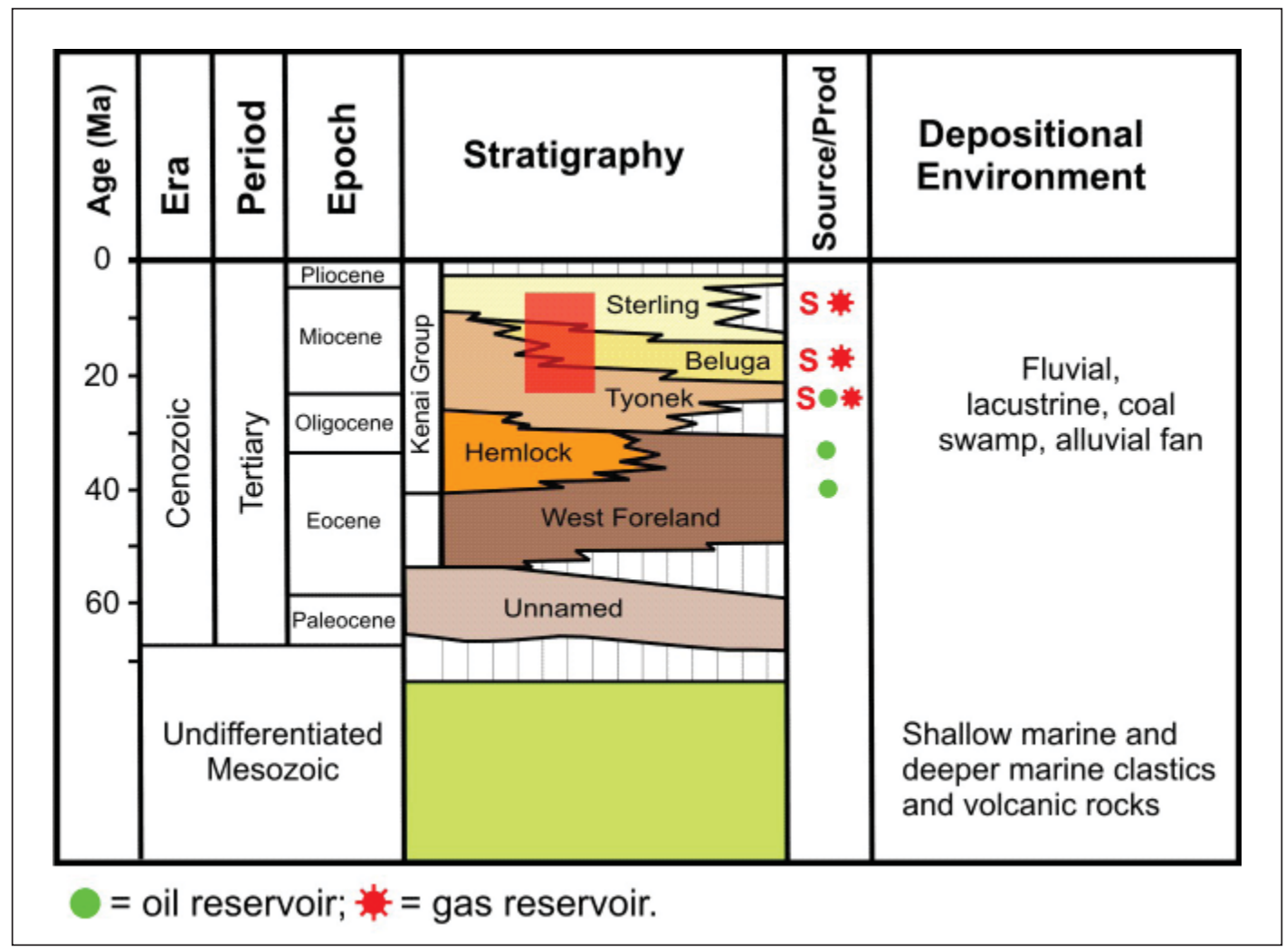

Figure 2. Simplified stratigraphic column showing Tertiary nonmarine formations in Cook Inlet basin. Vertical red bar shows stratigraphic interval where MICP samples were collected. Modified from Swenson (2002). 


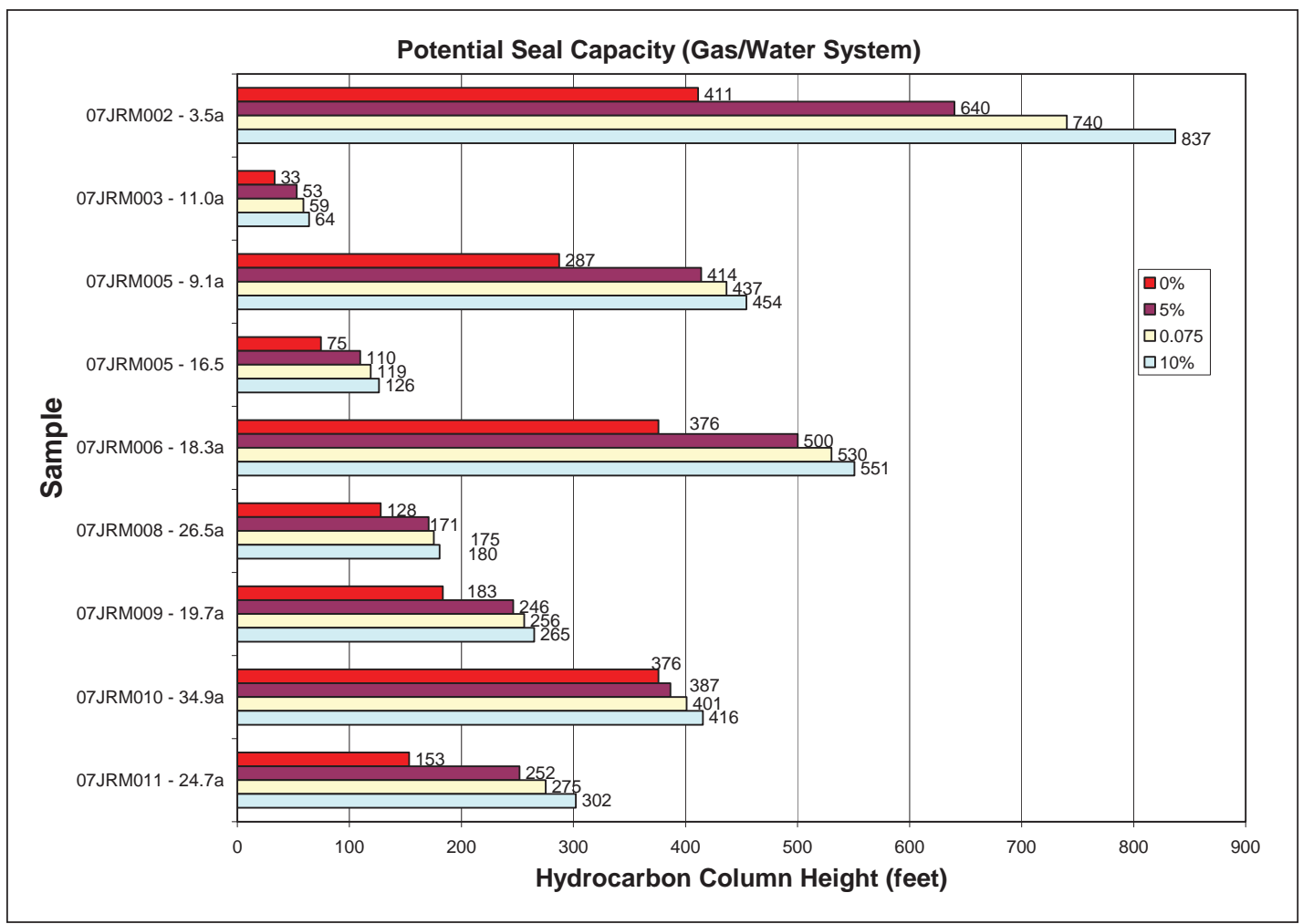

Figure 3a. Potential seal capacity in a gas/water system.

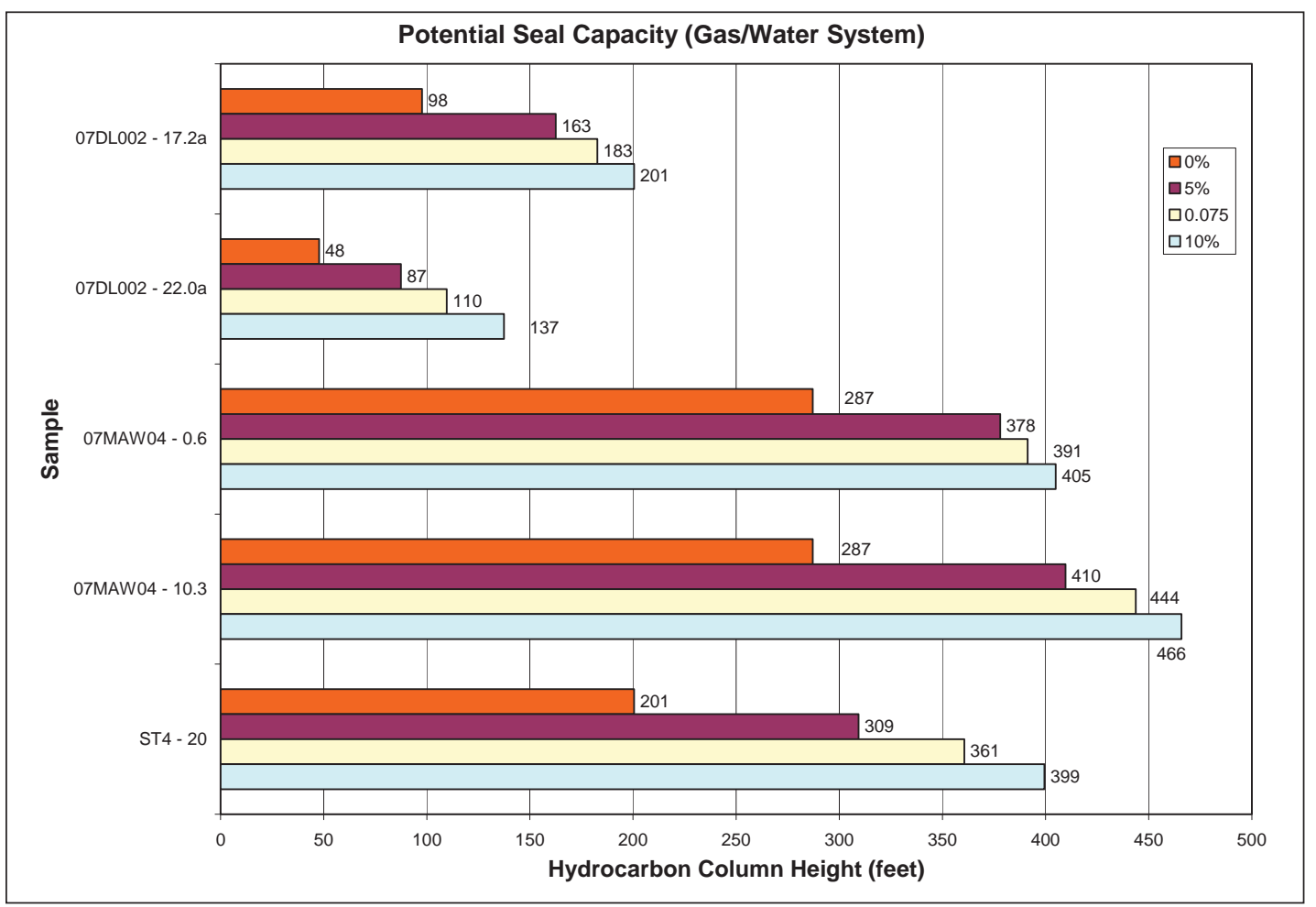

Figure 3b. Potential seal capacity in a gas/water system. 


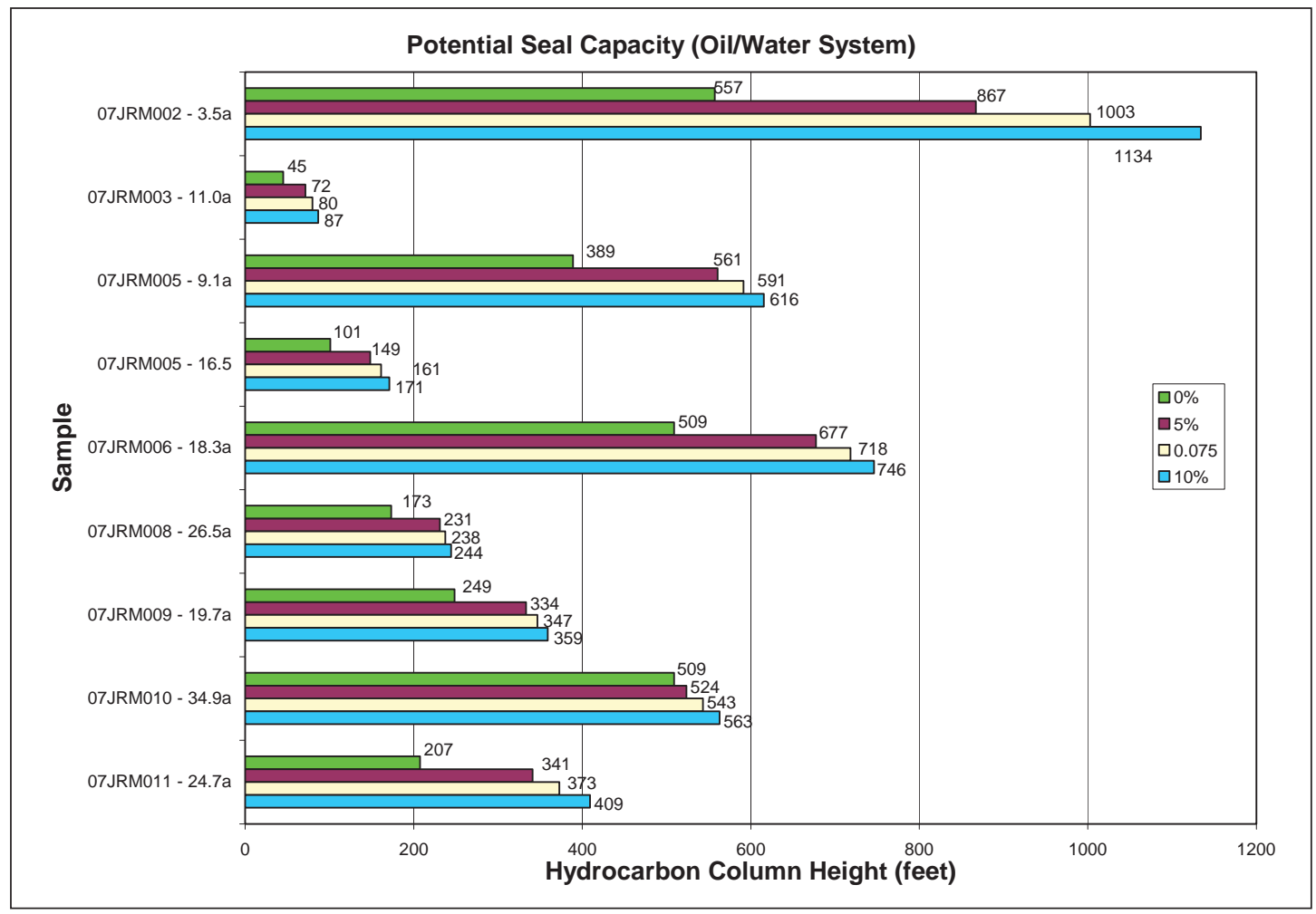

Figure 4a. Potential seal capacity in an oil/water system.

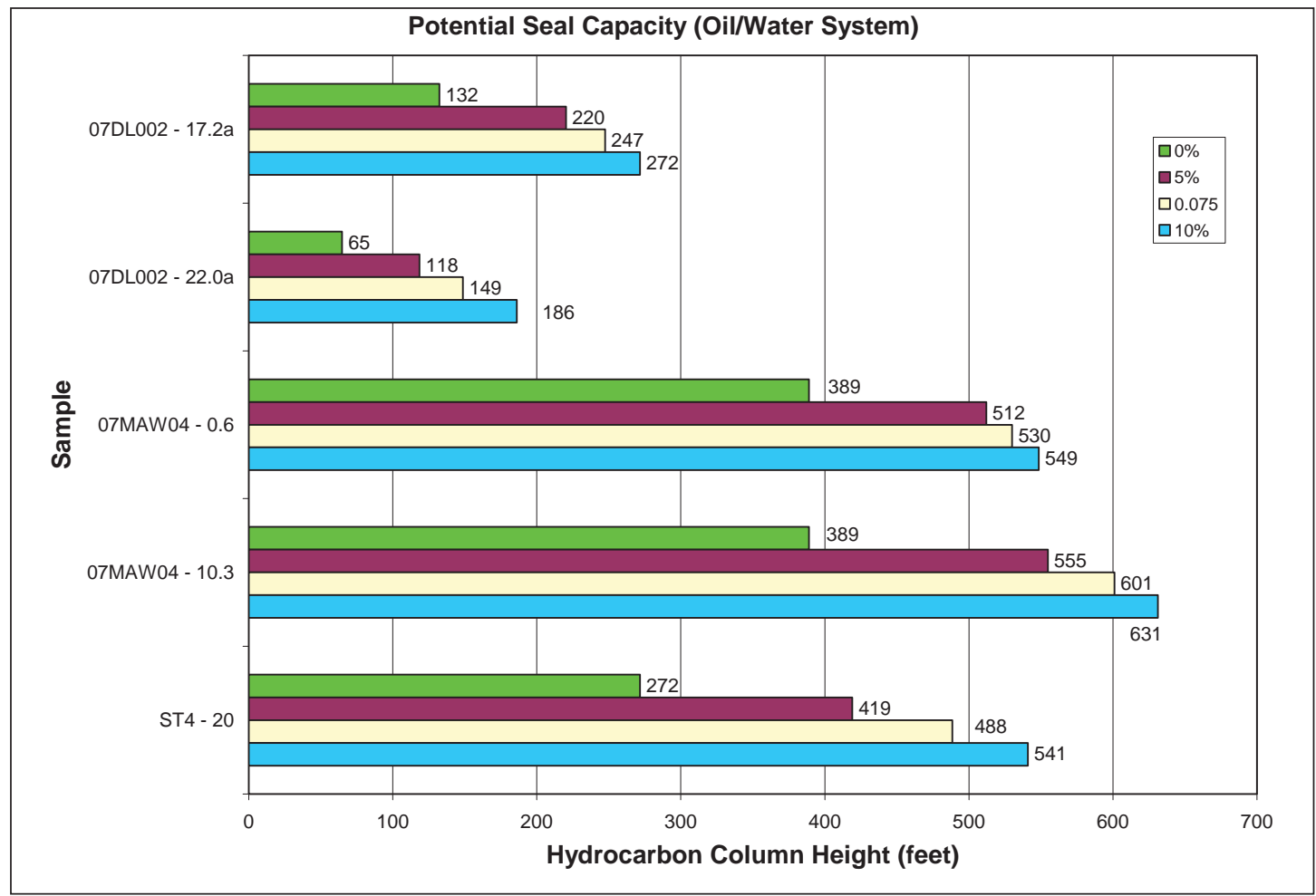

Figure 4b. Potential seal capacity in an oil/water system. 


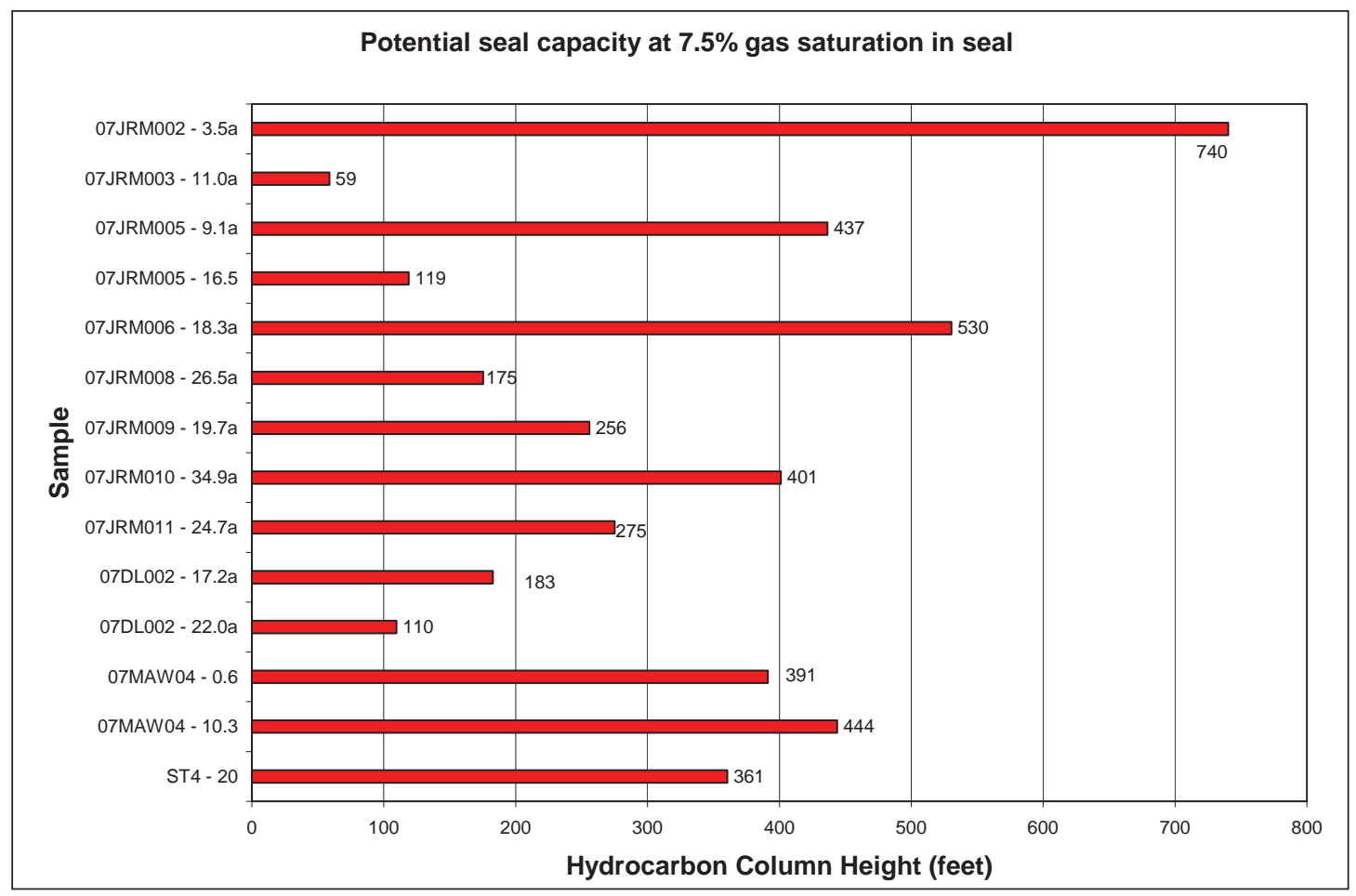

Figure 5. Chart of potential seal capacity at $7.5 \%$ gas saturation in seal for each sample.

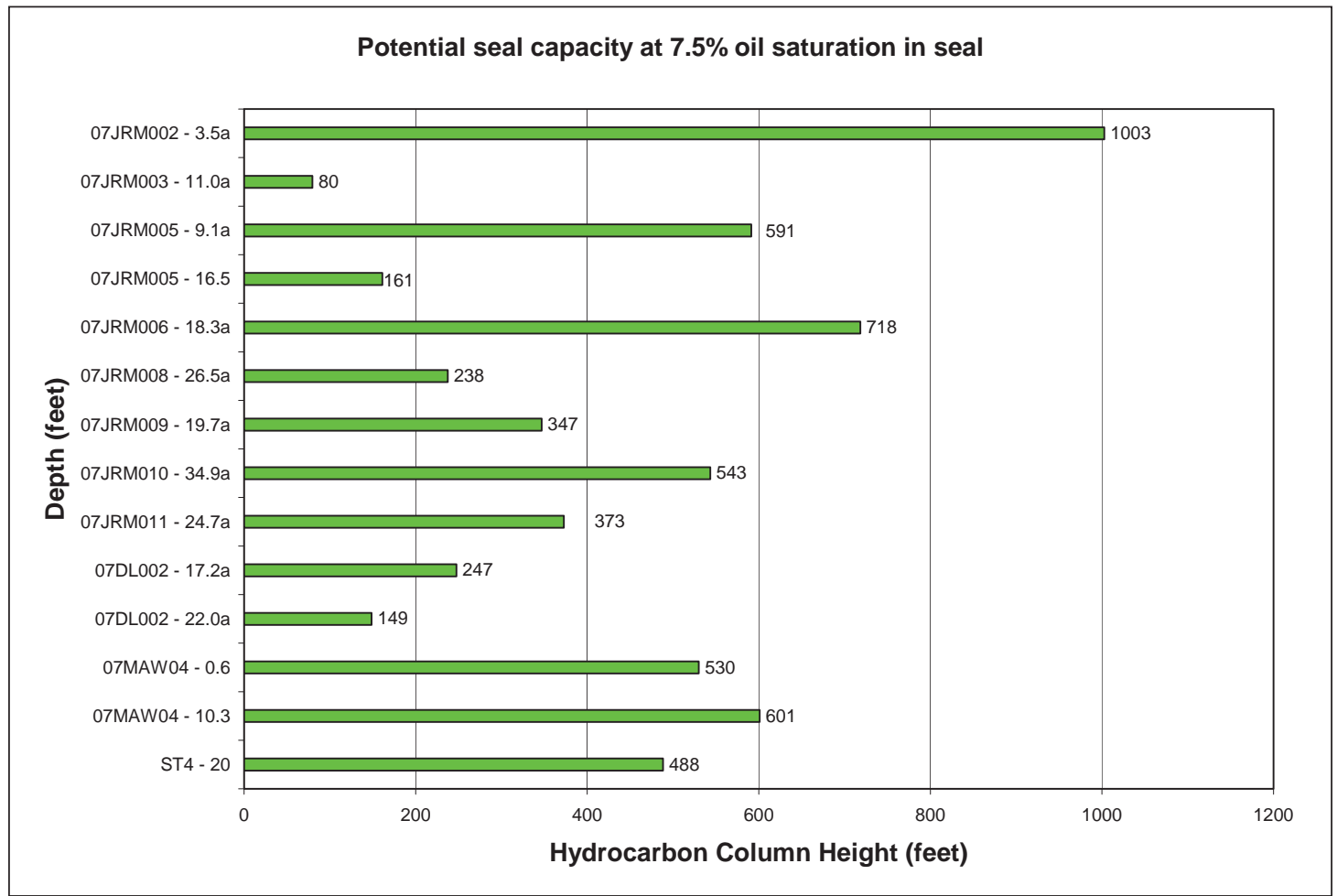

Figure 6. Chart of potential seal capacity at 7.5\% oil saturation in seal for each sample. 

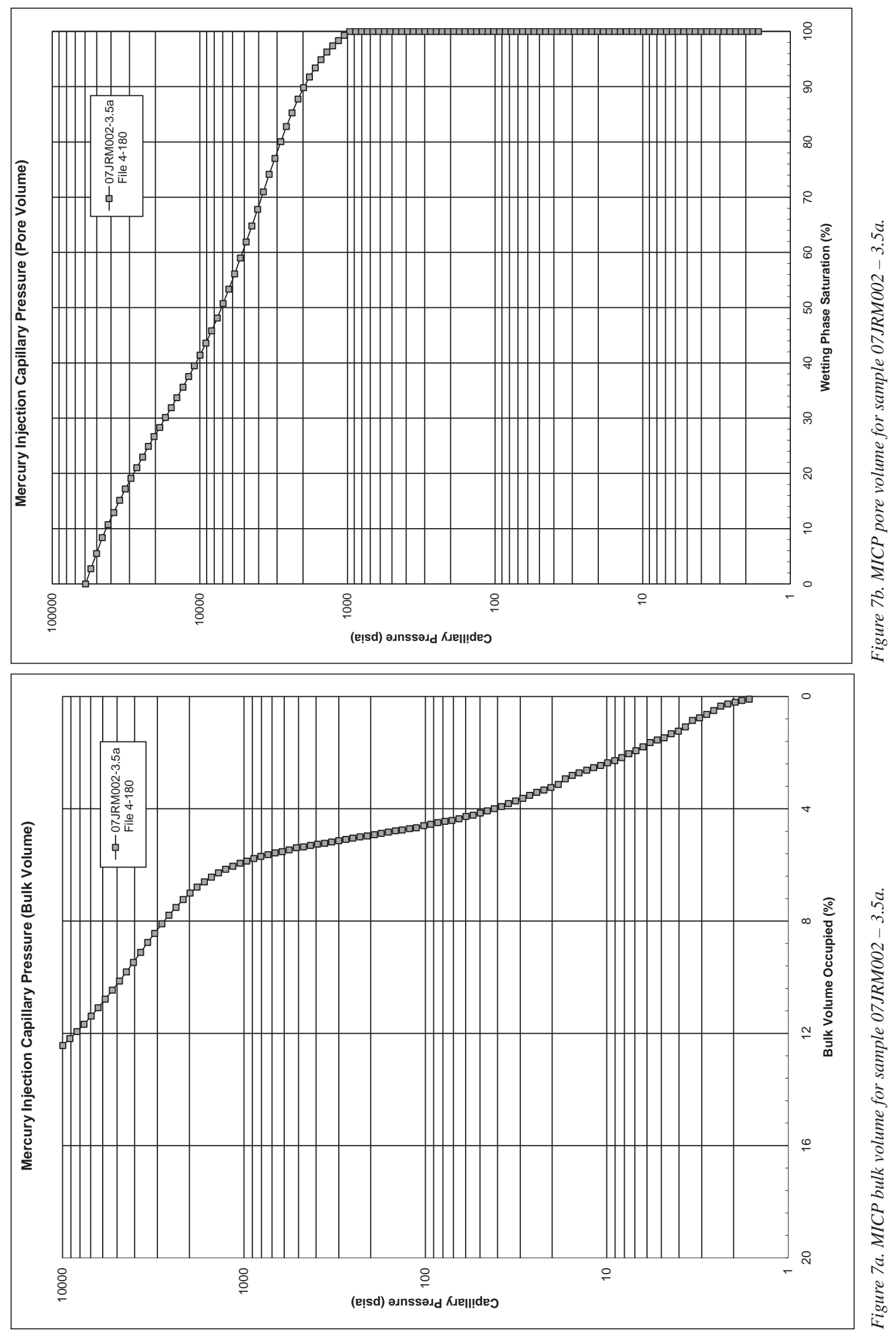


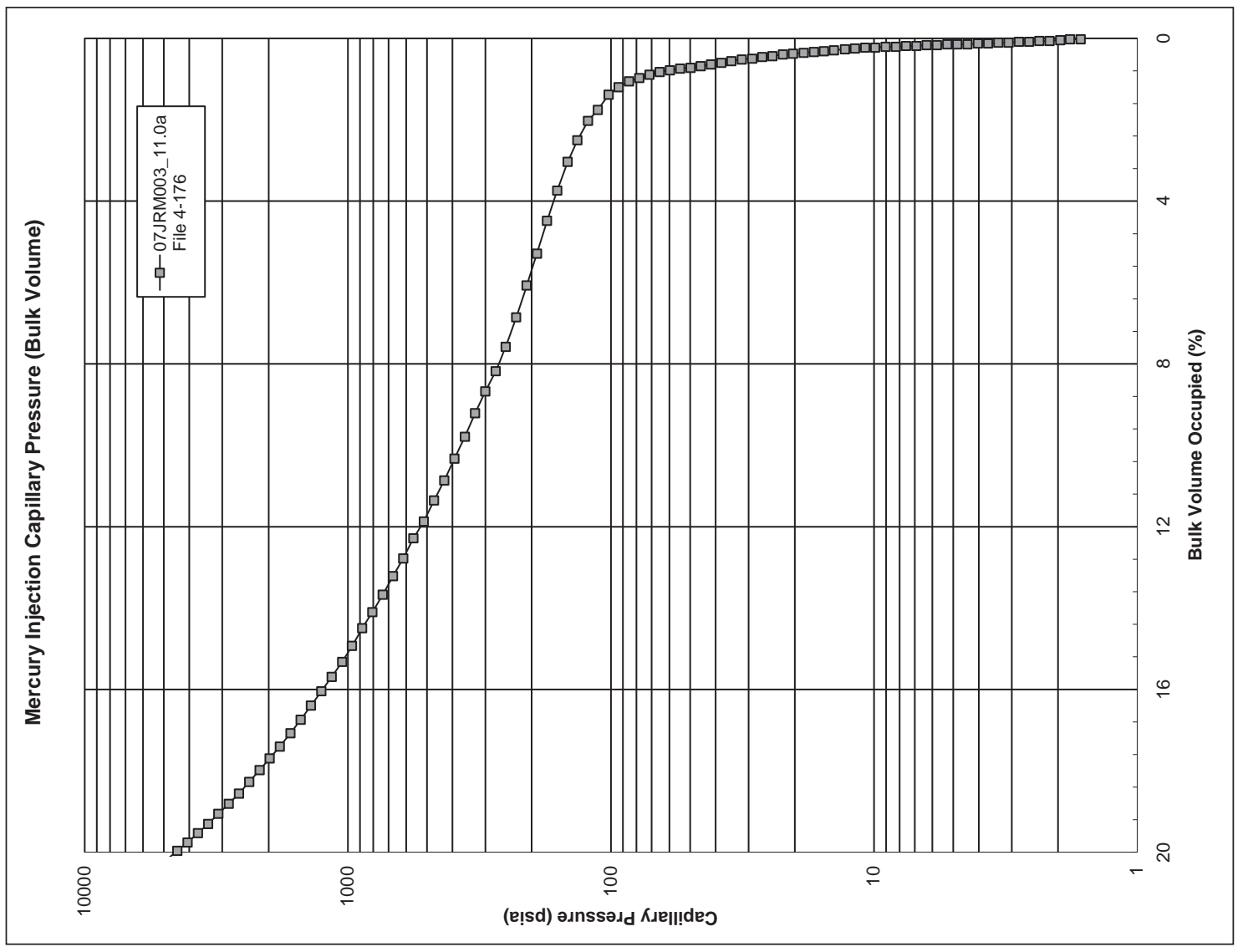

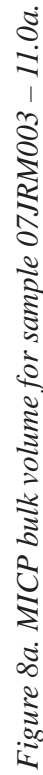

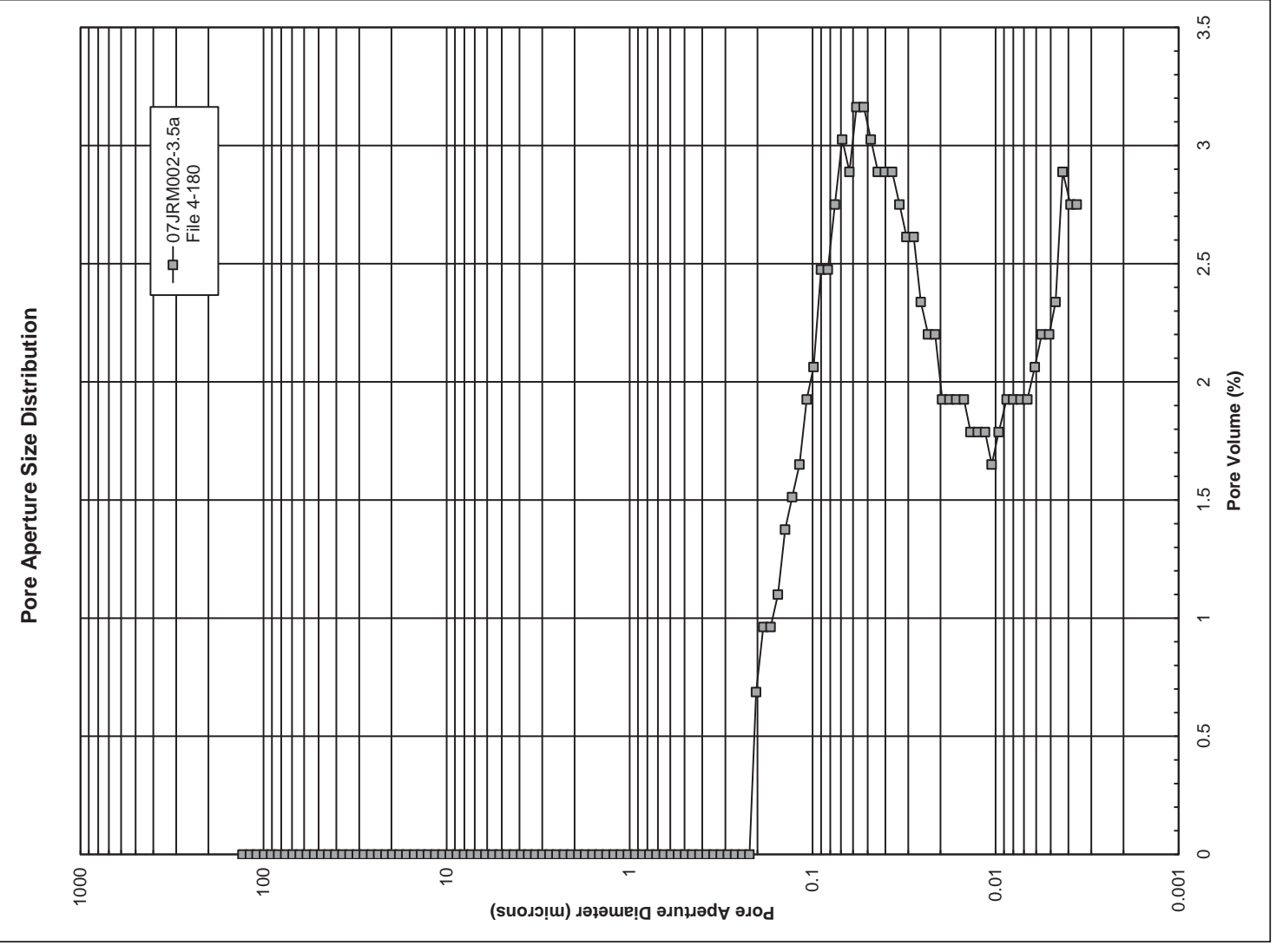

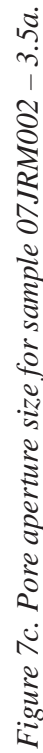



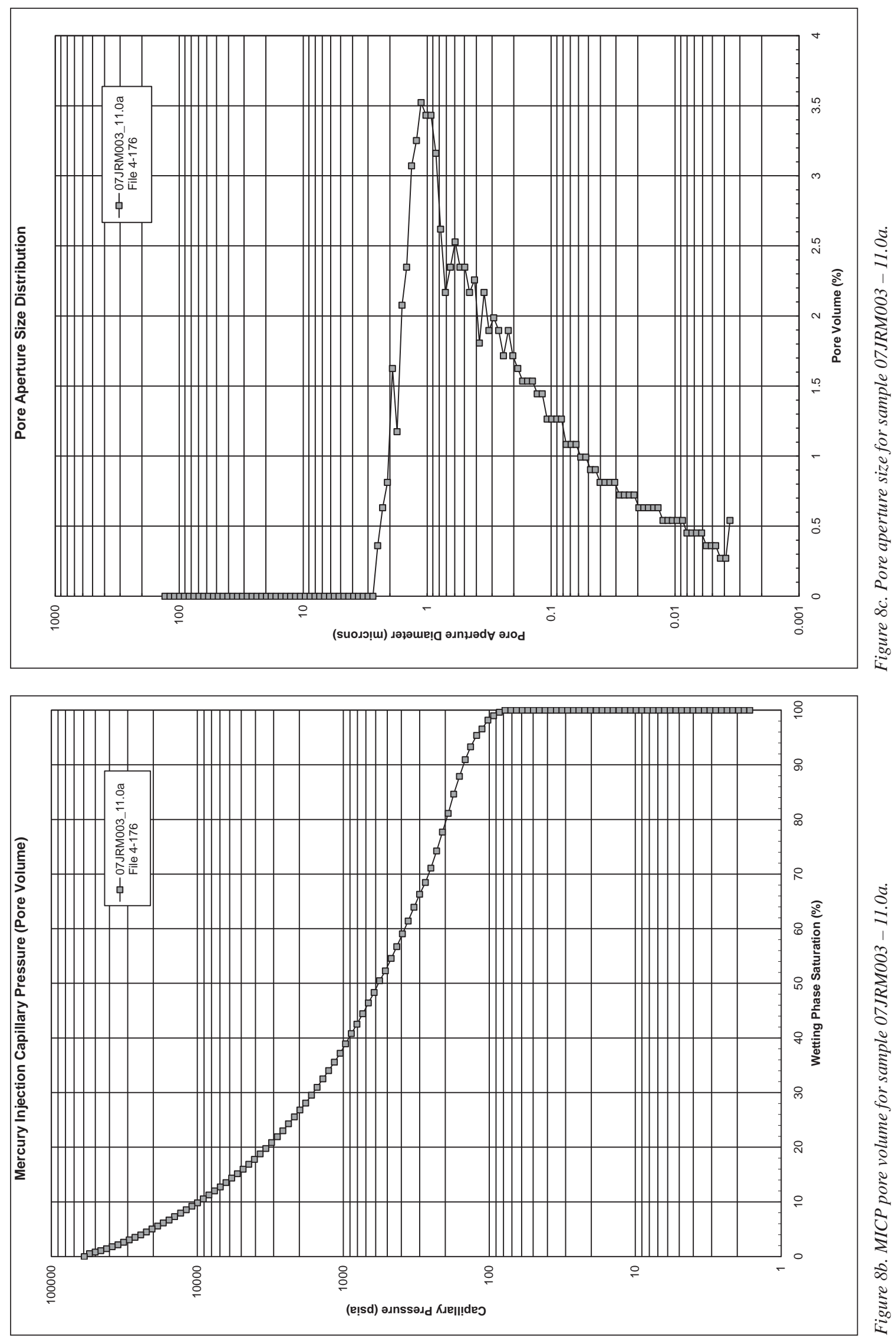


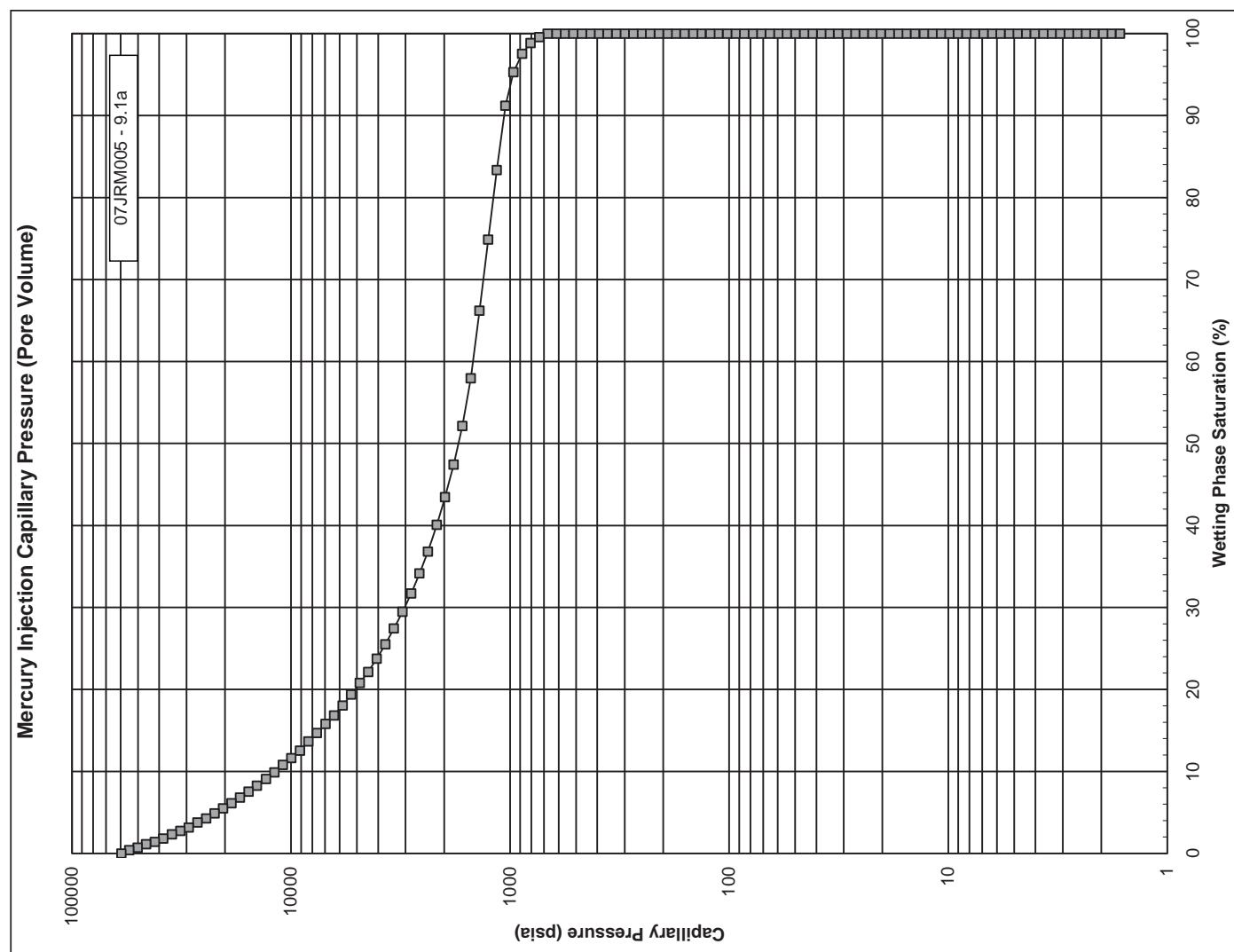

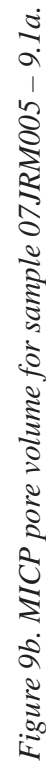

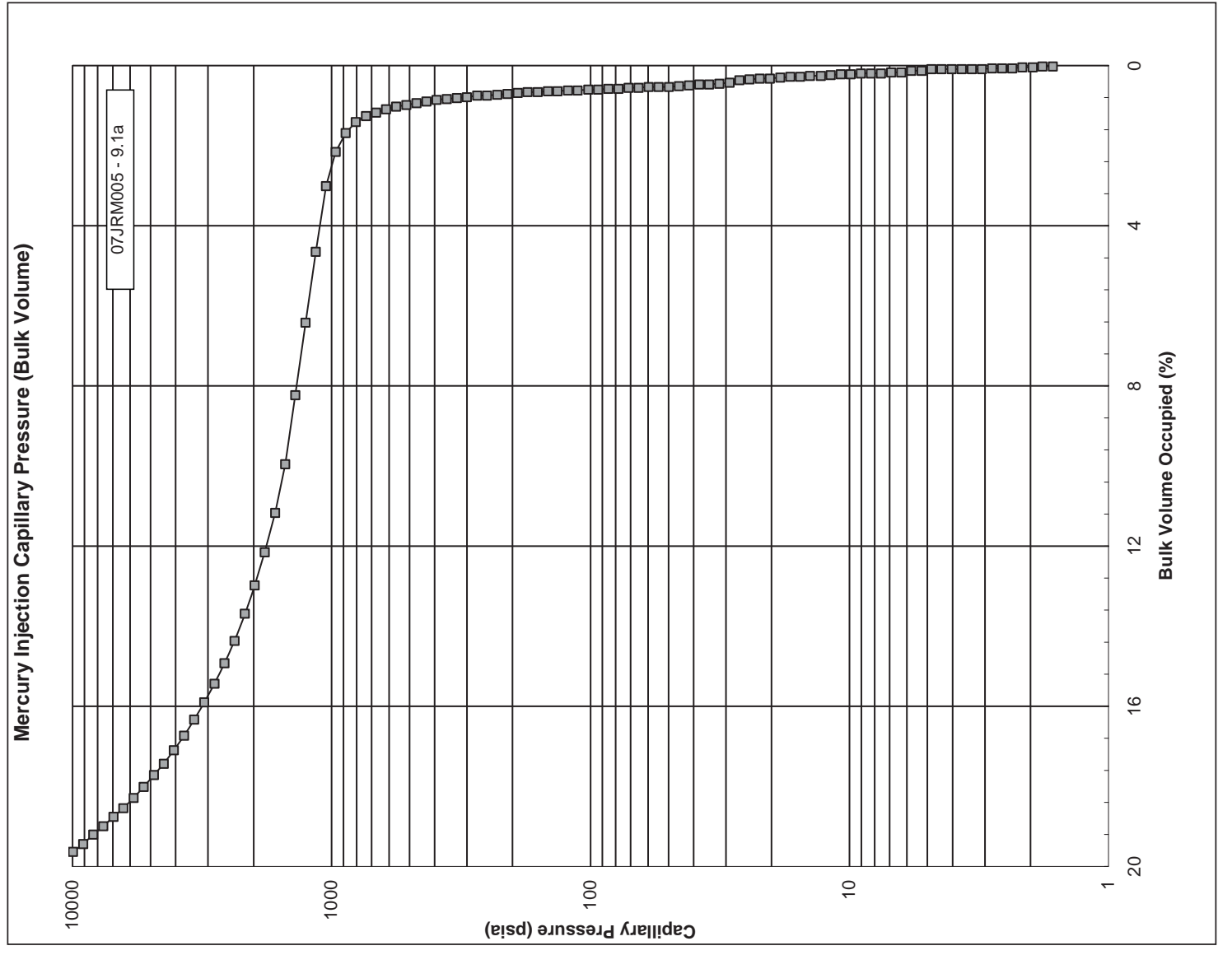

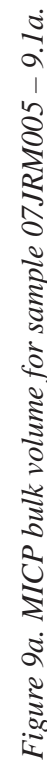



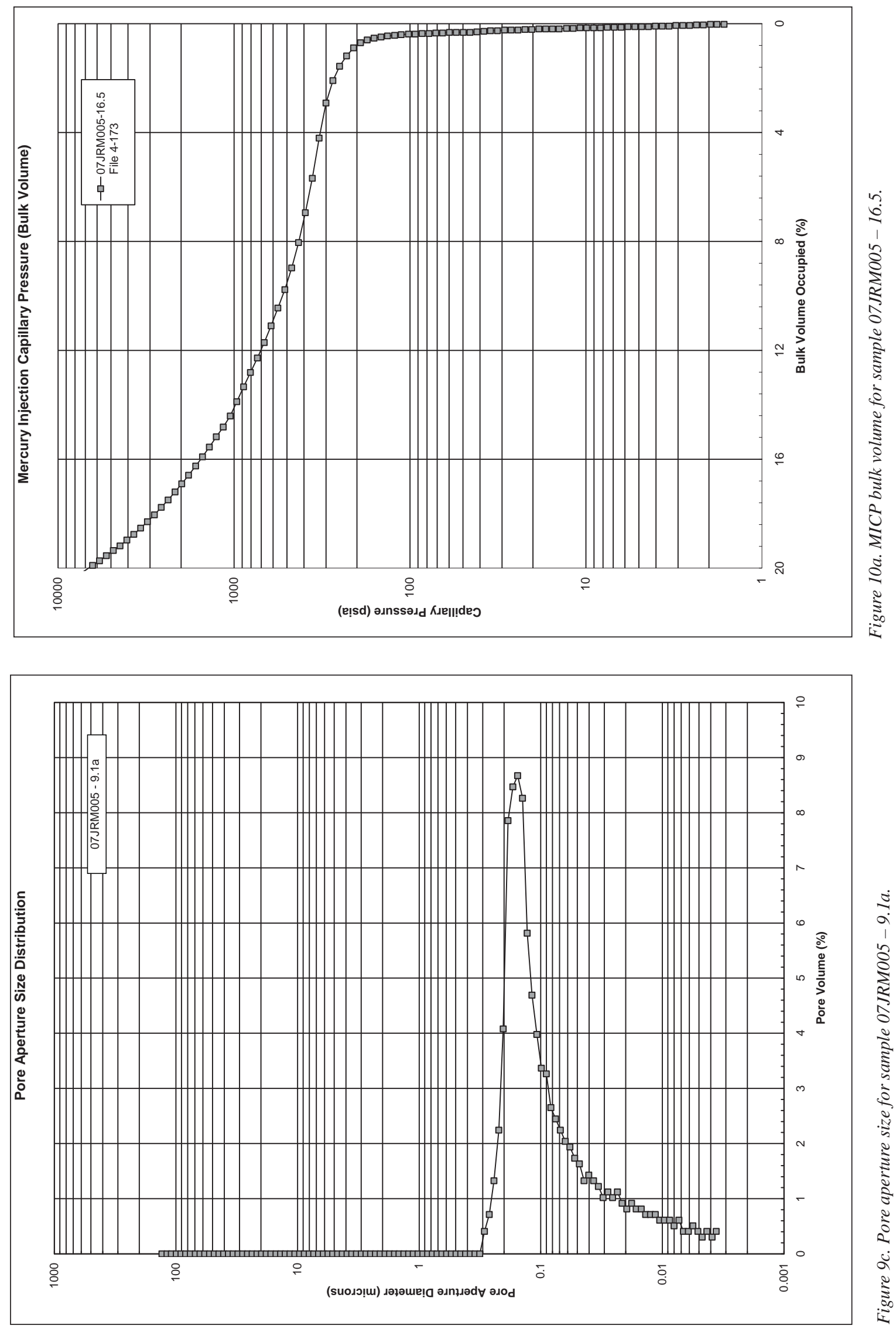


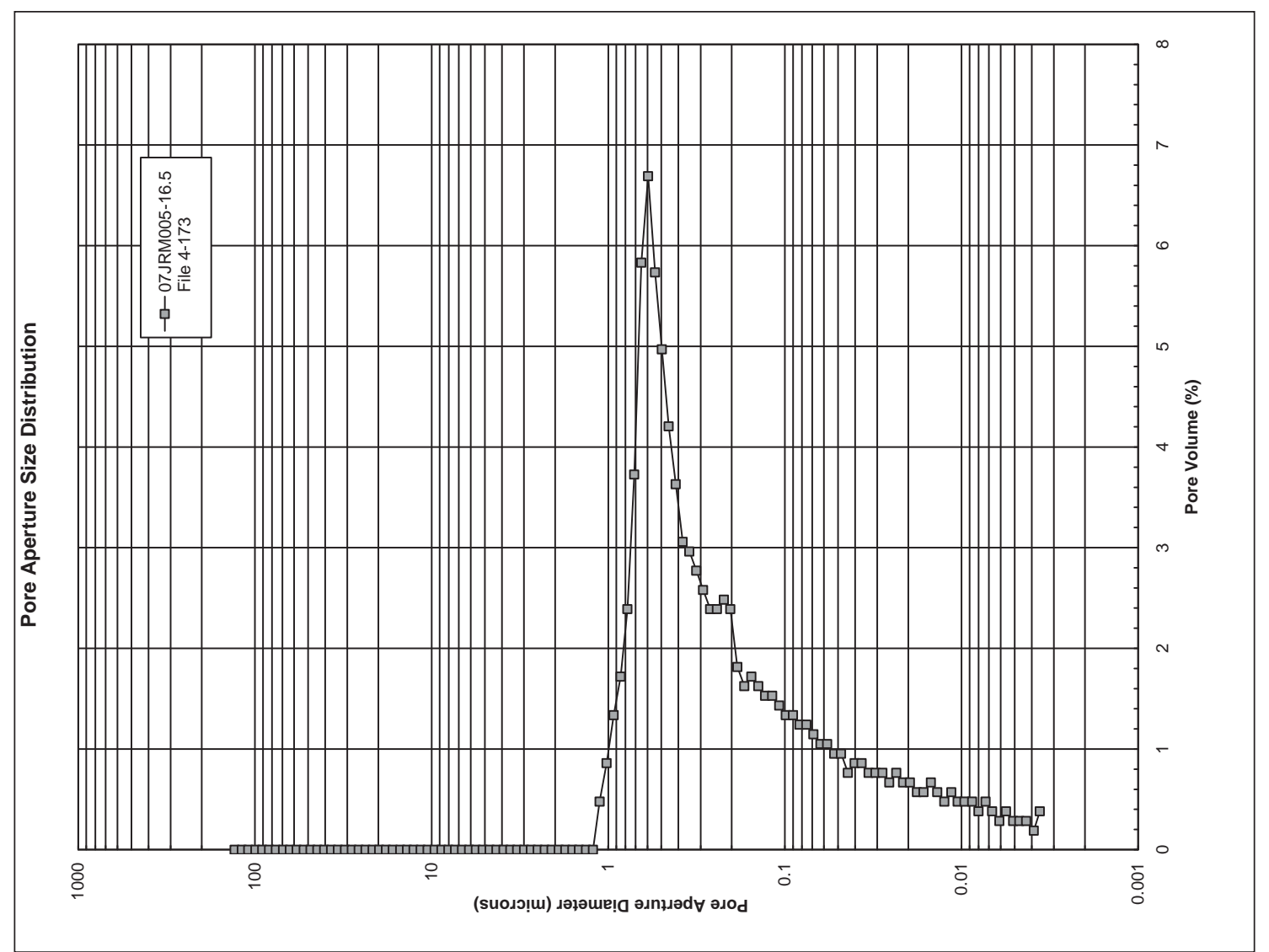

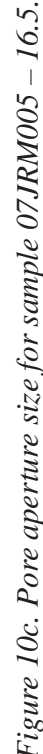

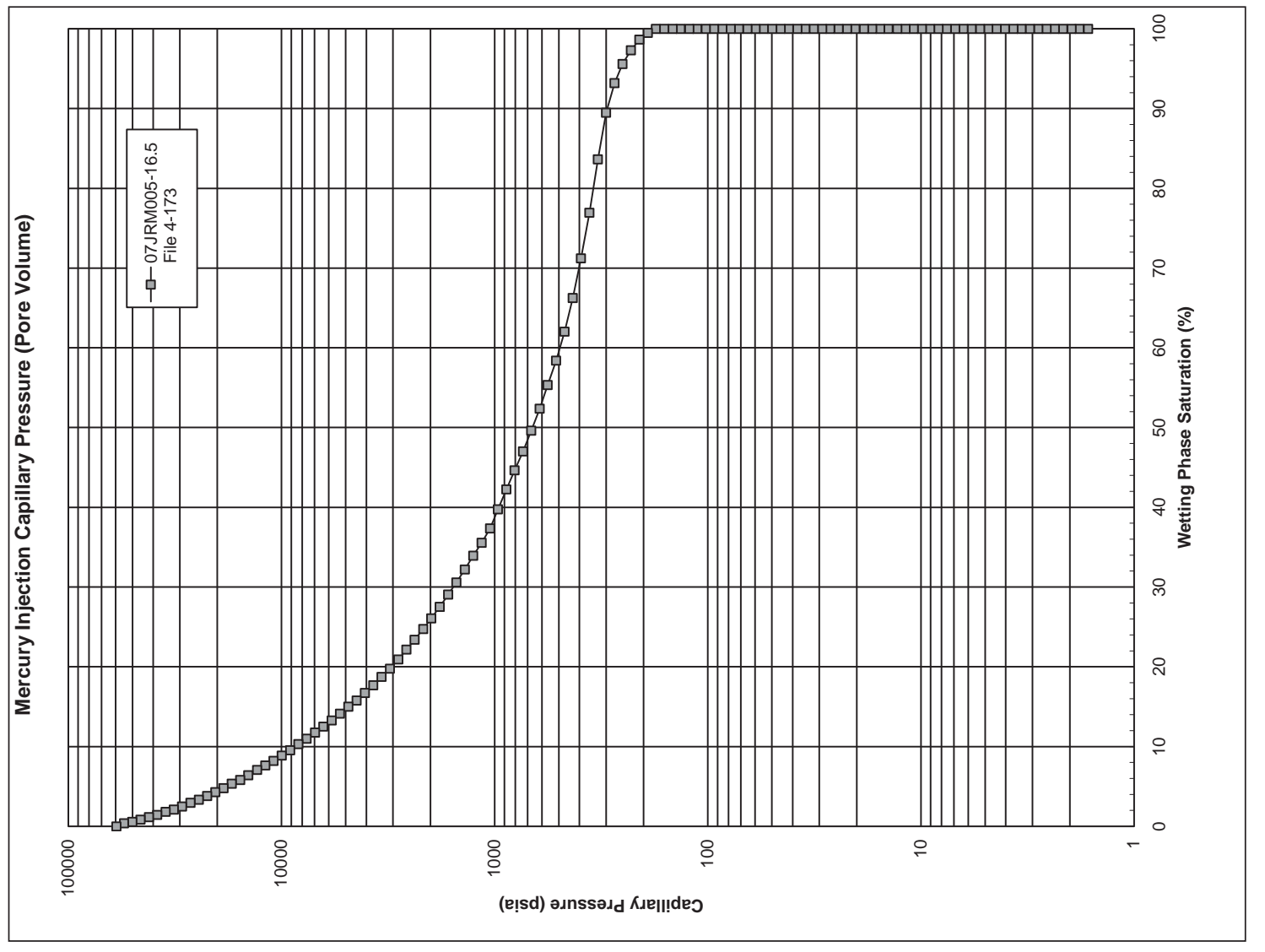

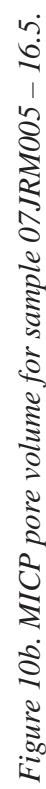



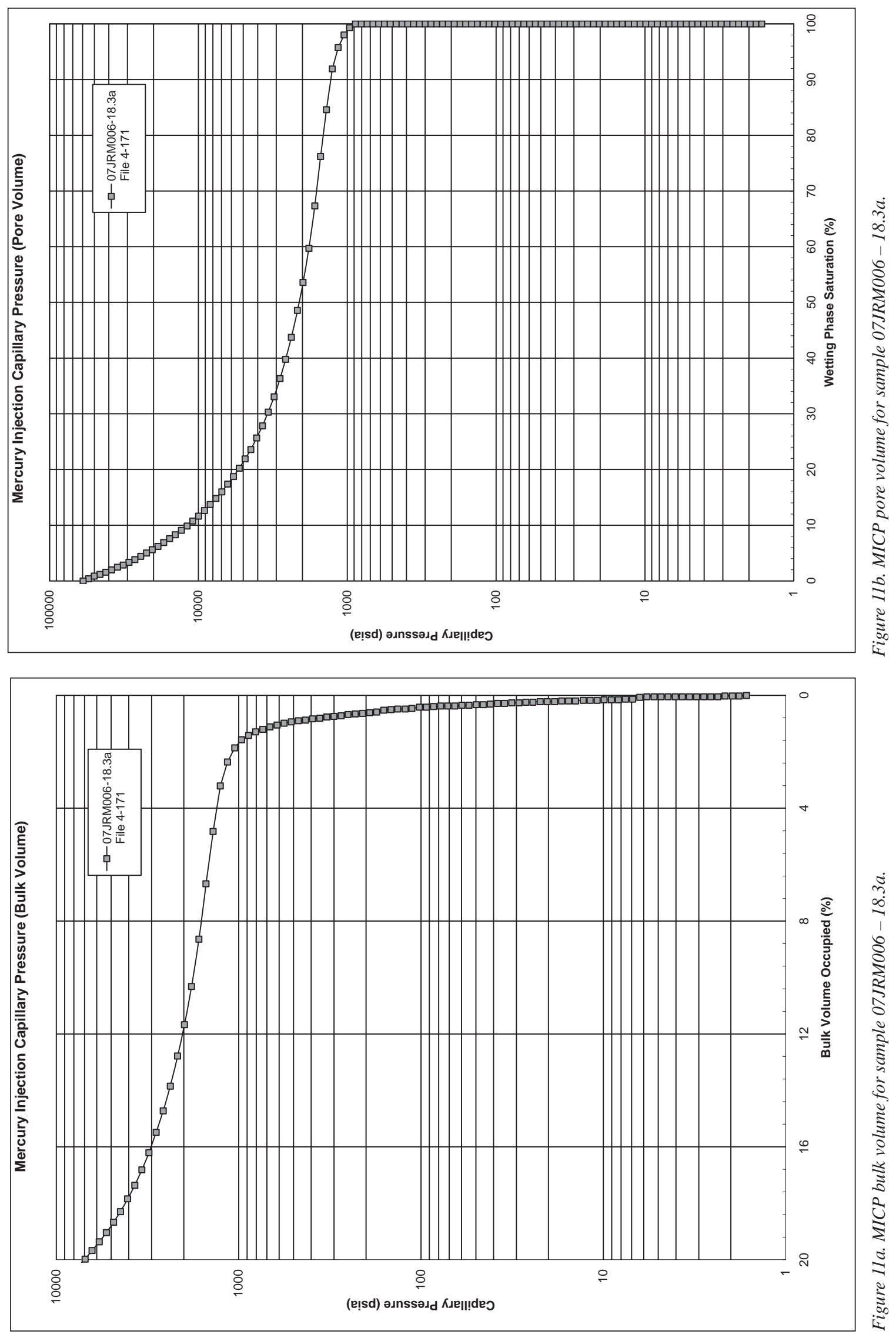


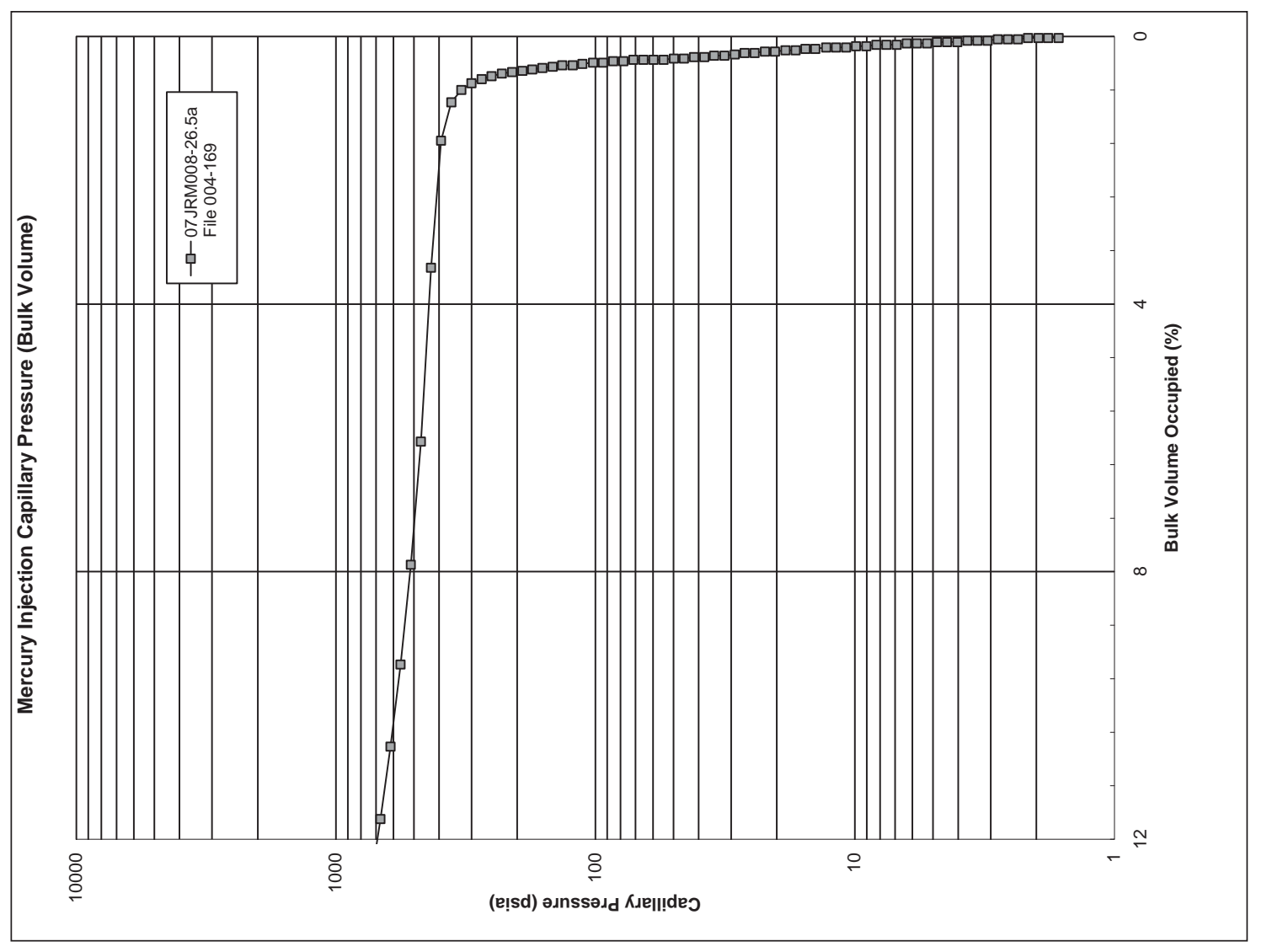

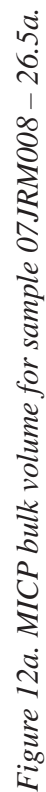

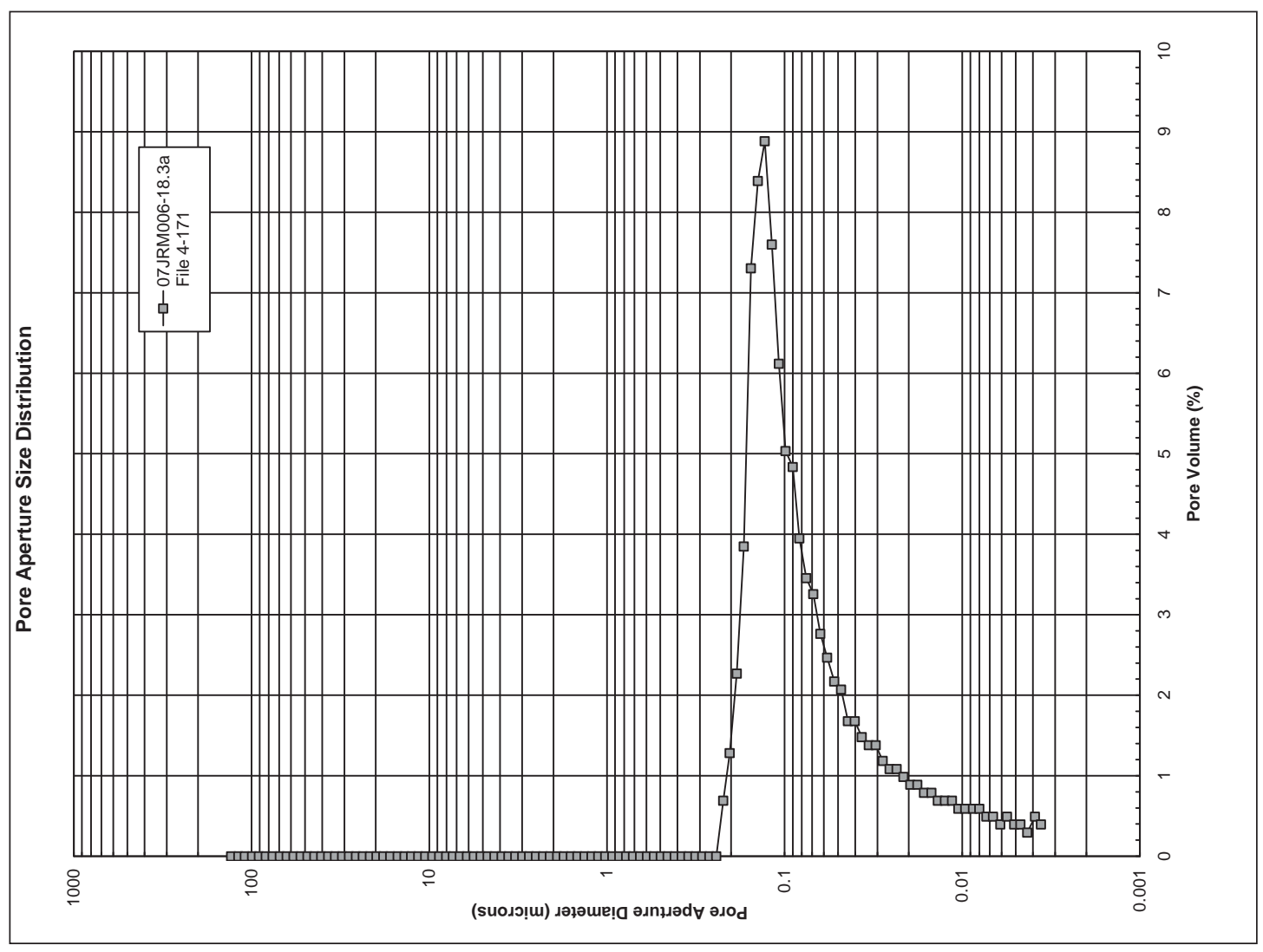

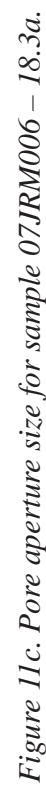



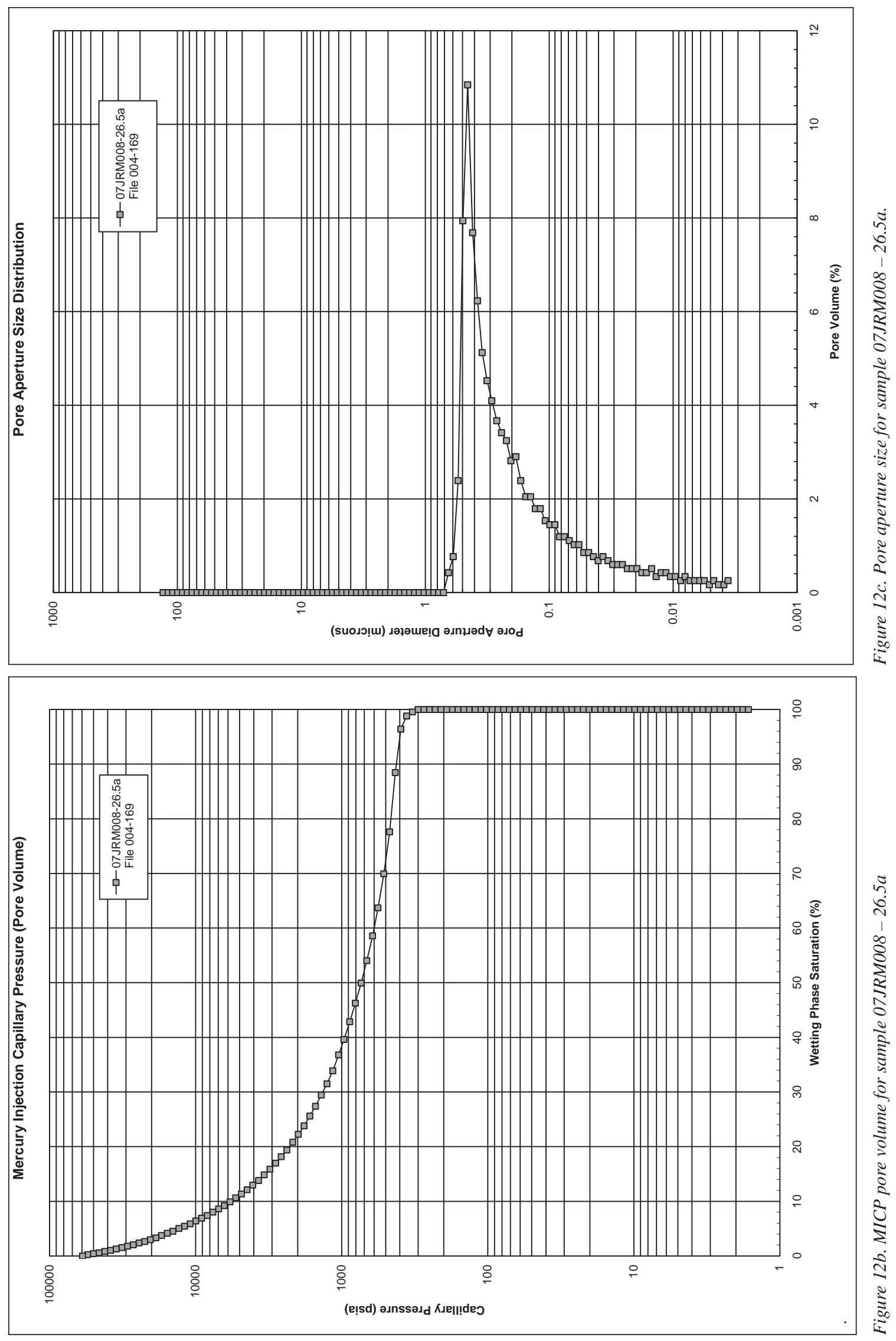


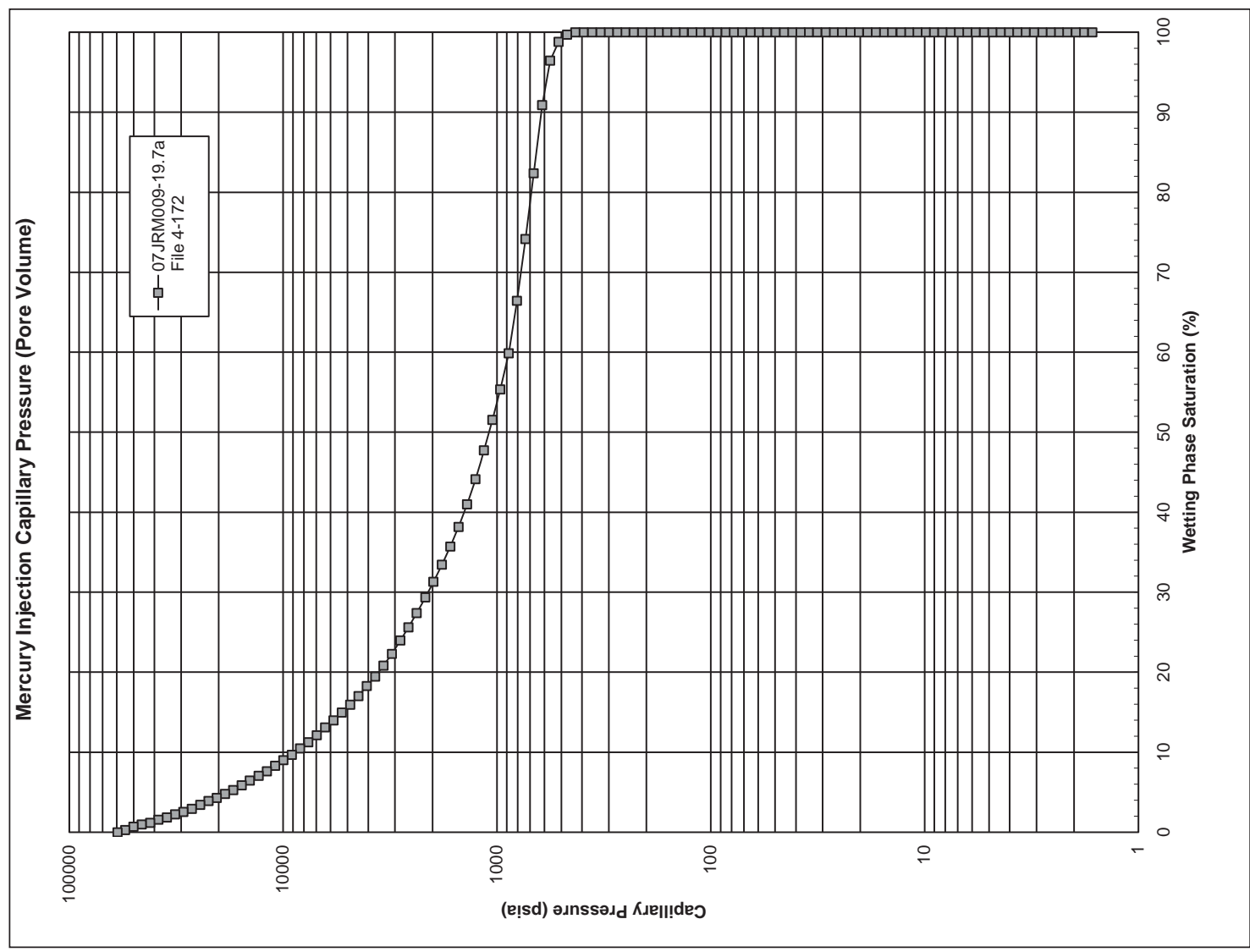

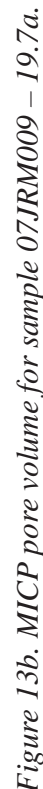

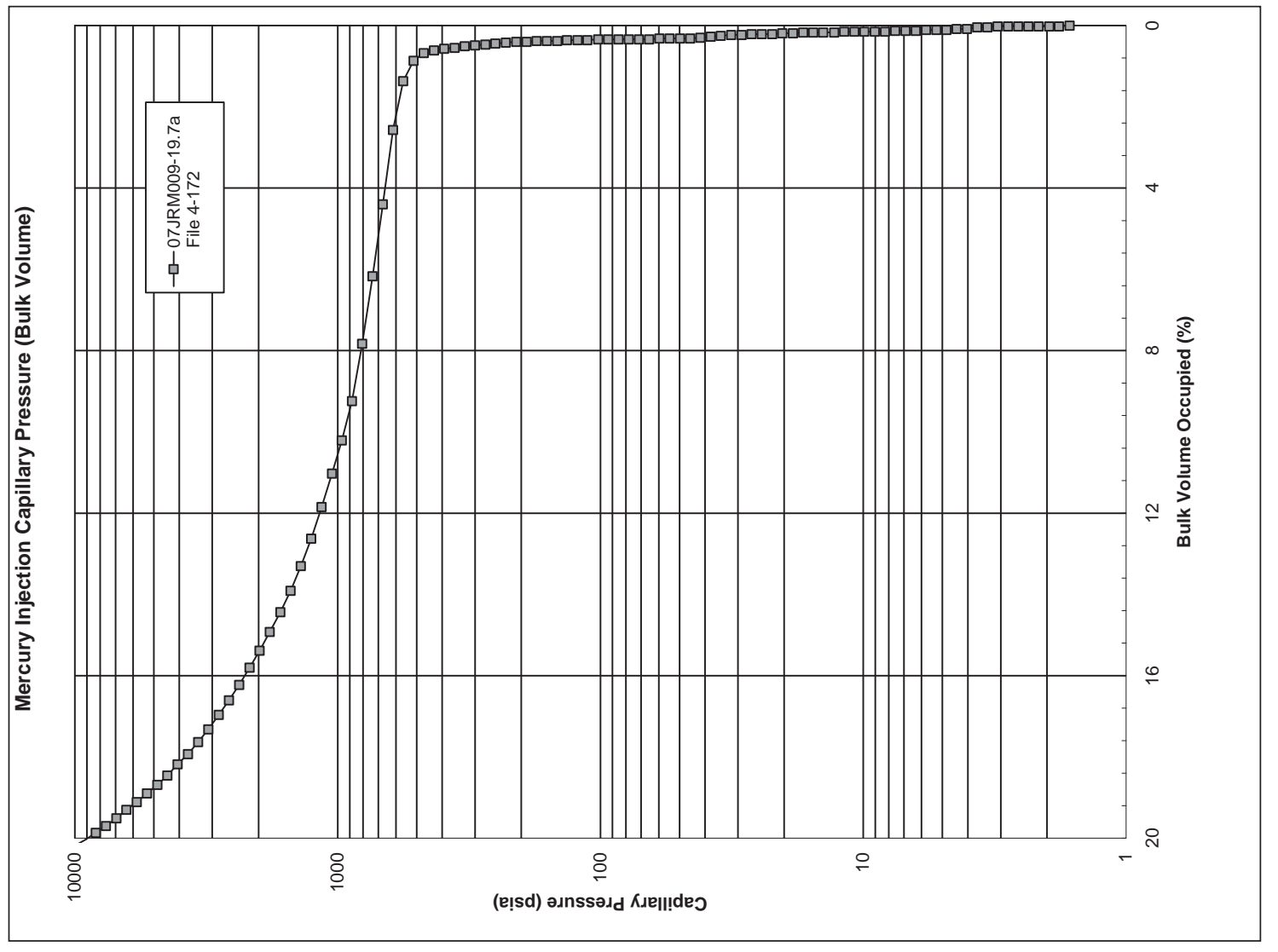

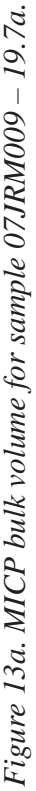



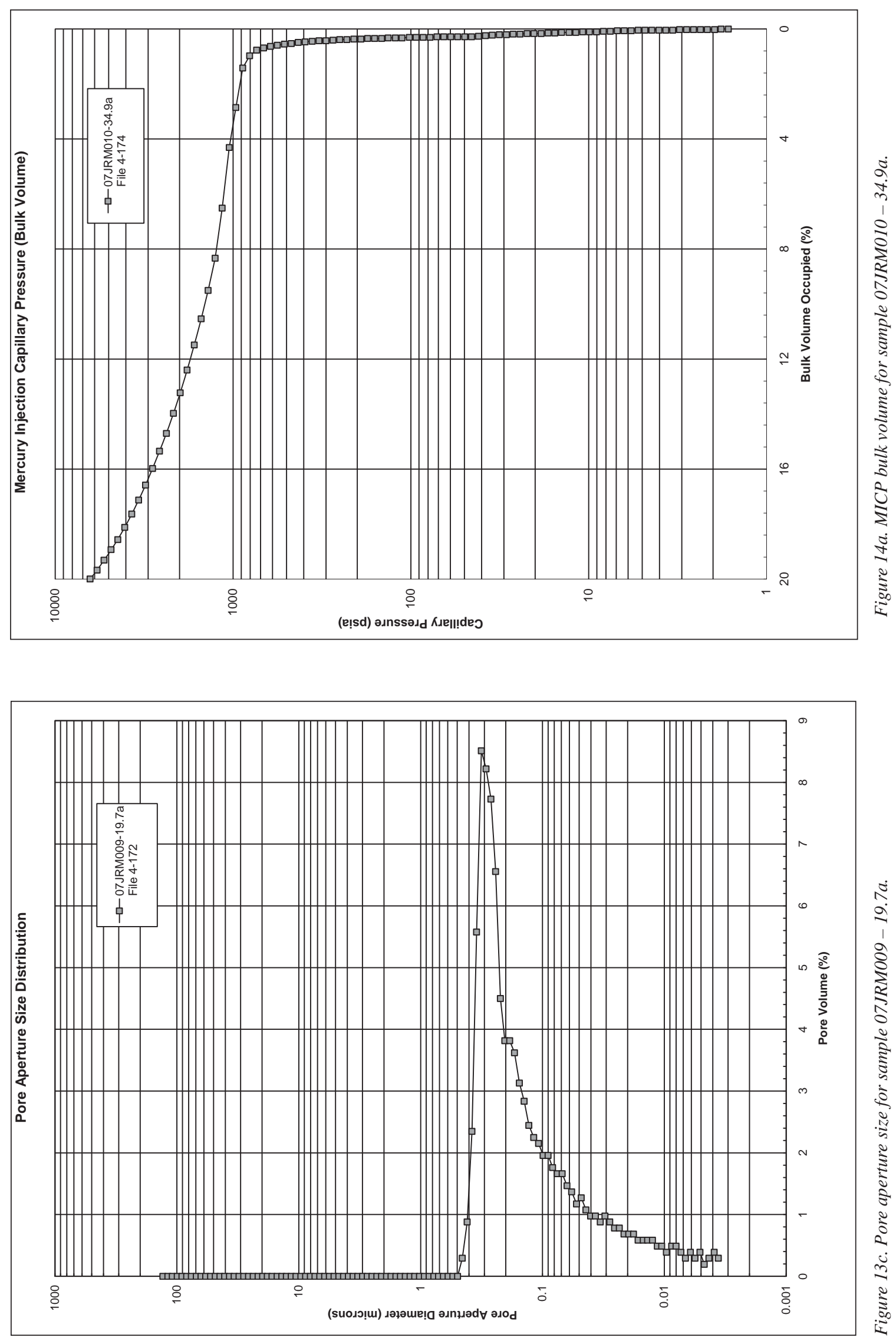


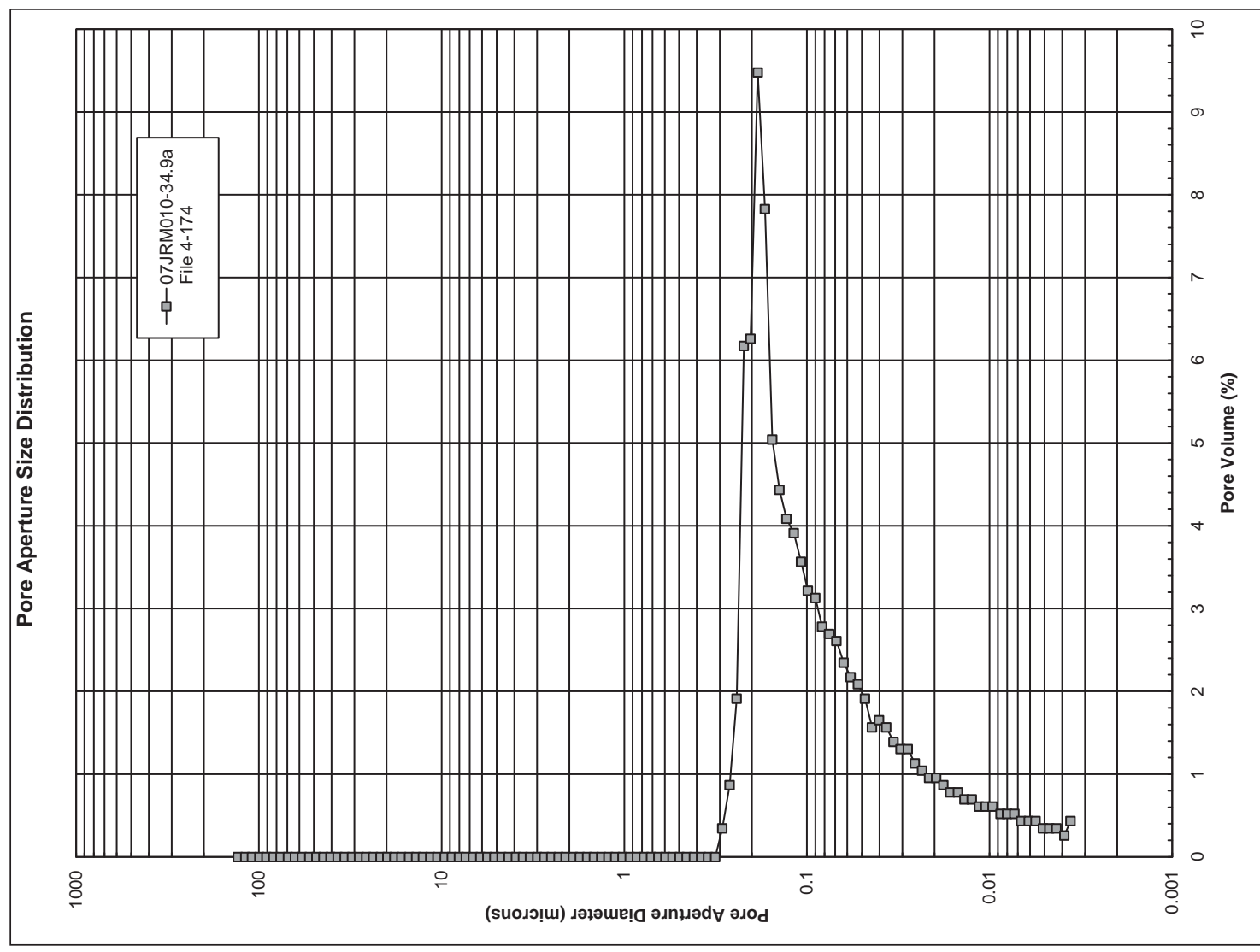

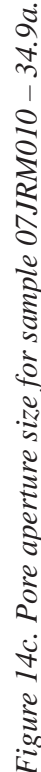

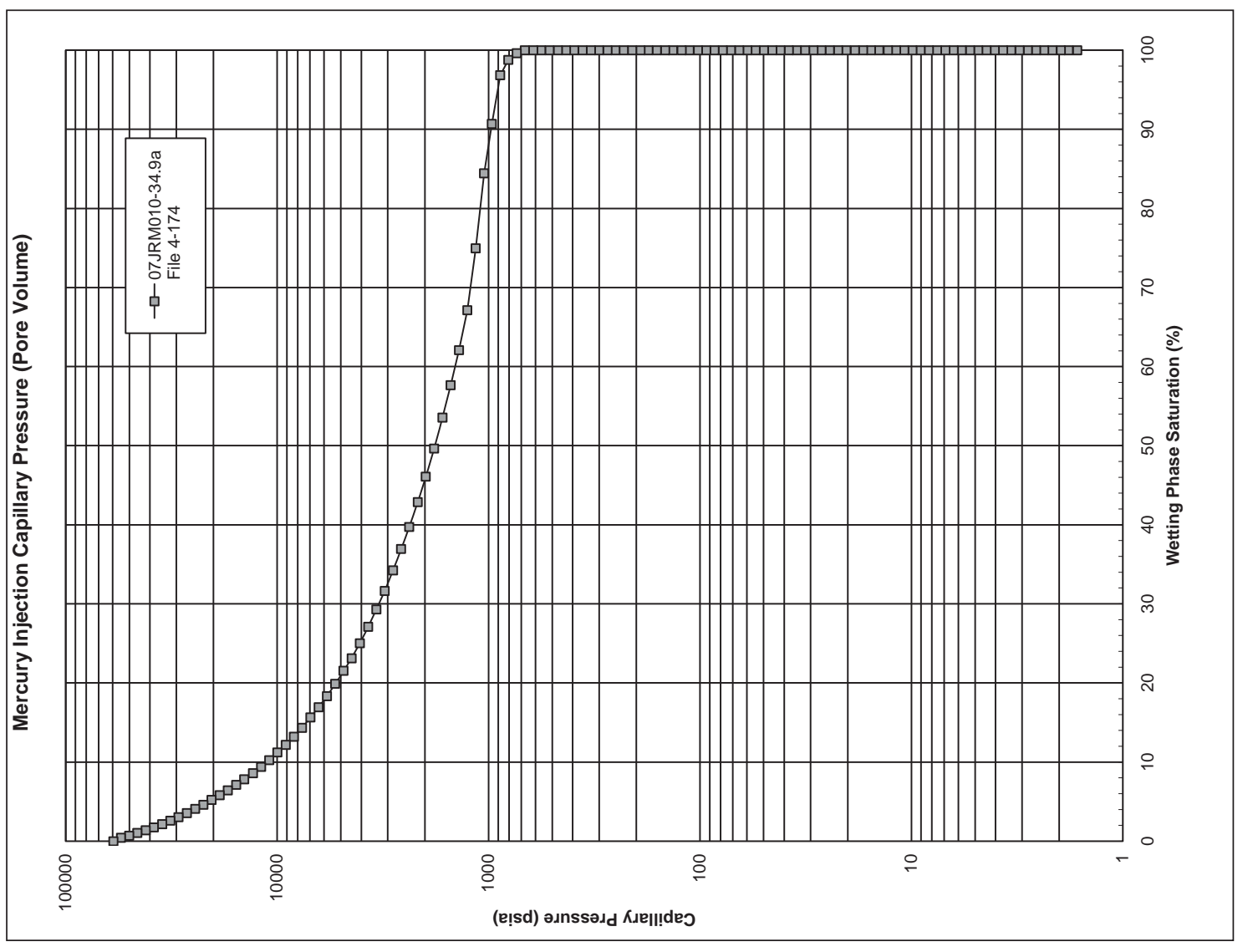

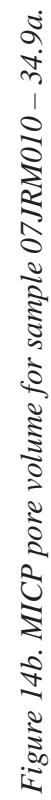




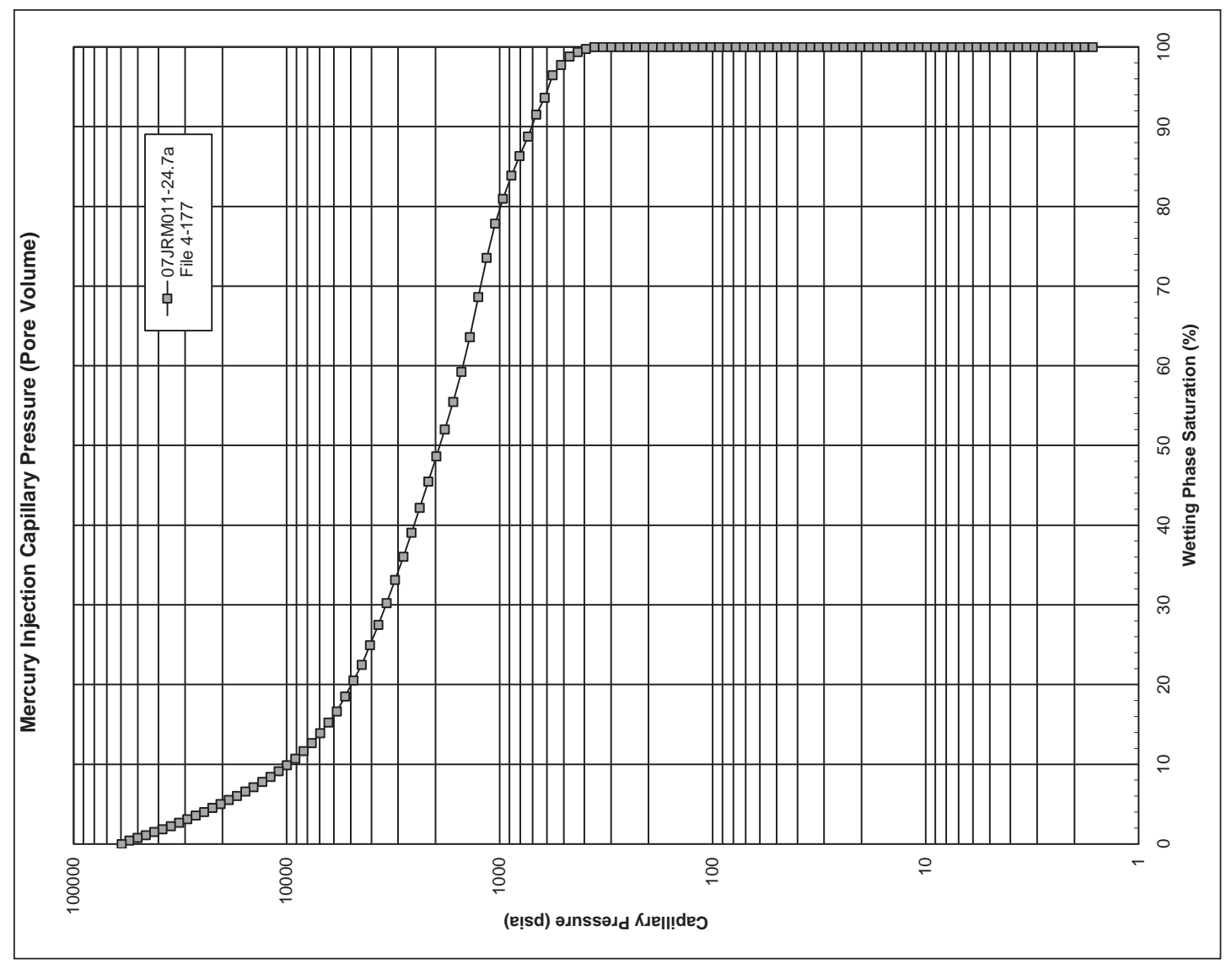

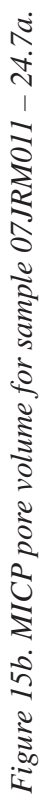

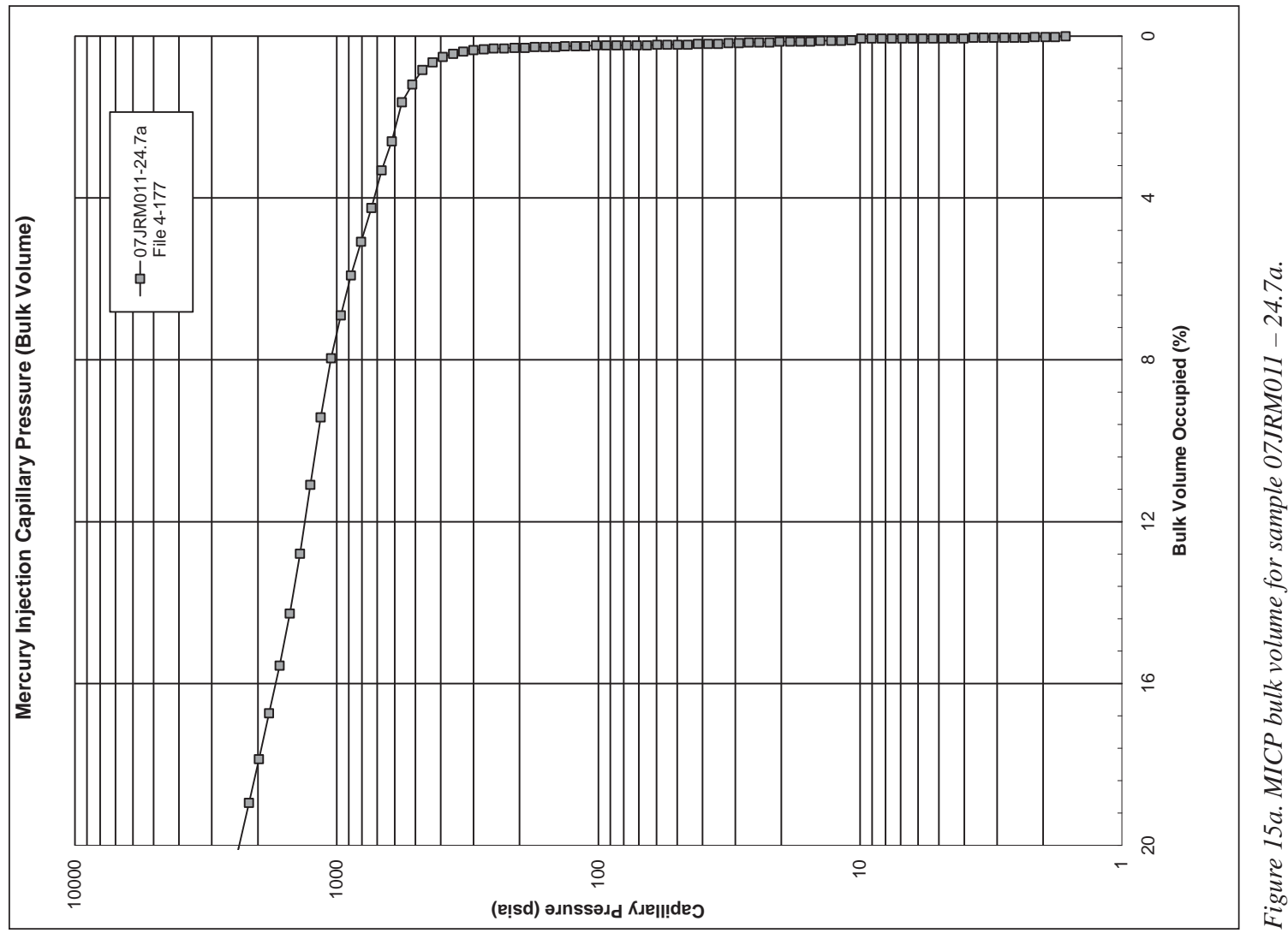



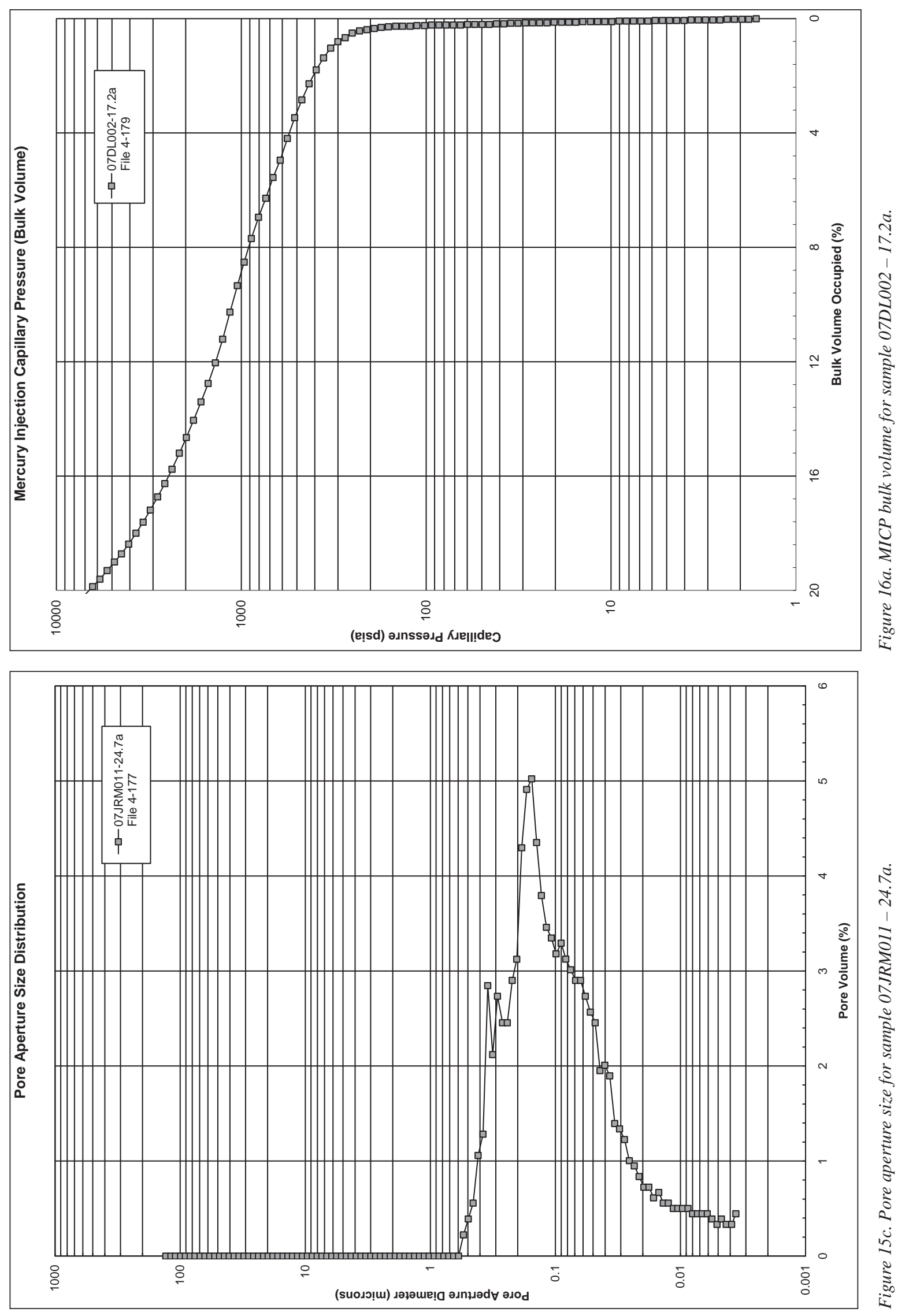

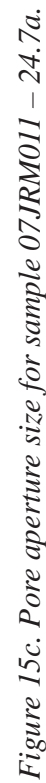



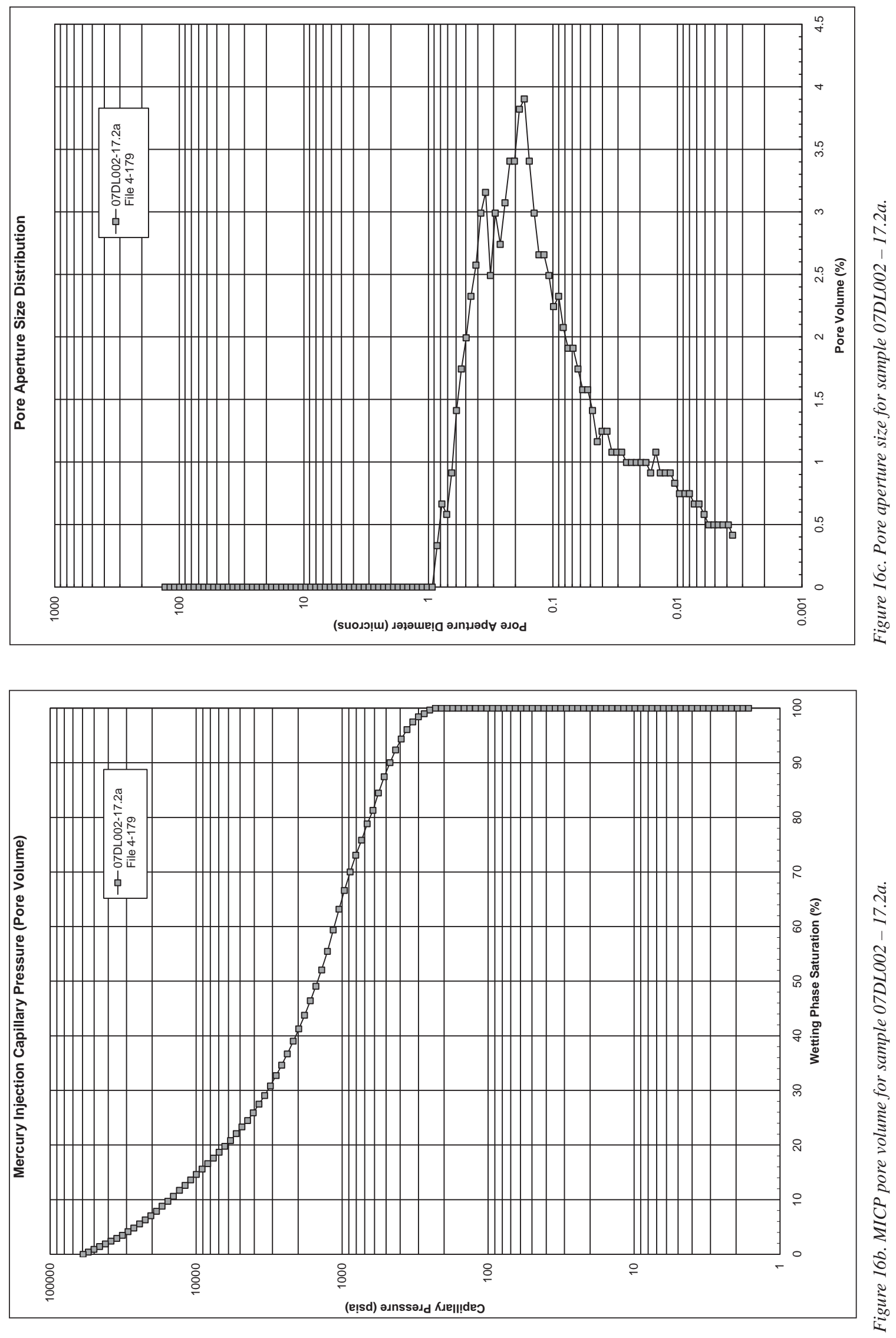


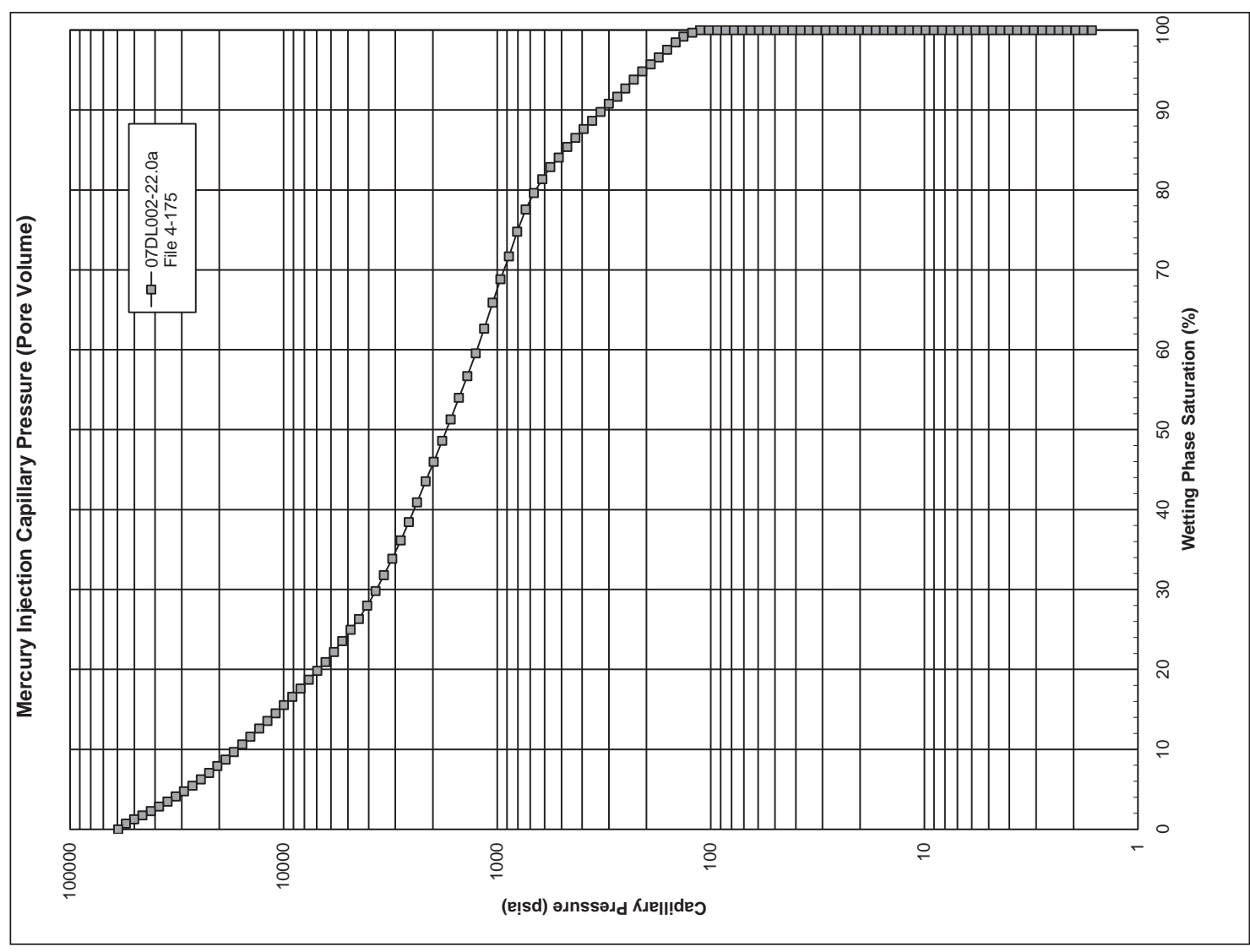

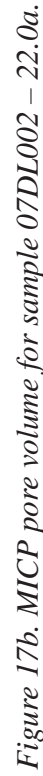

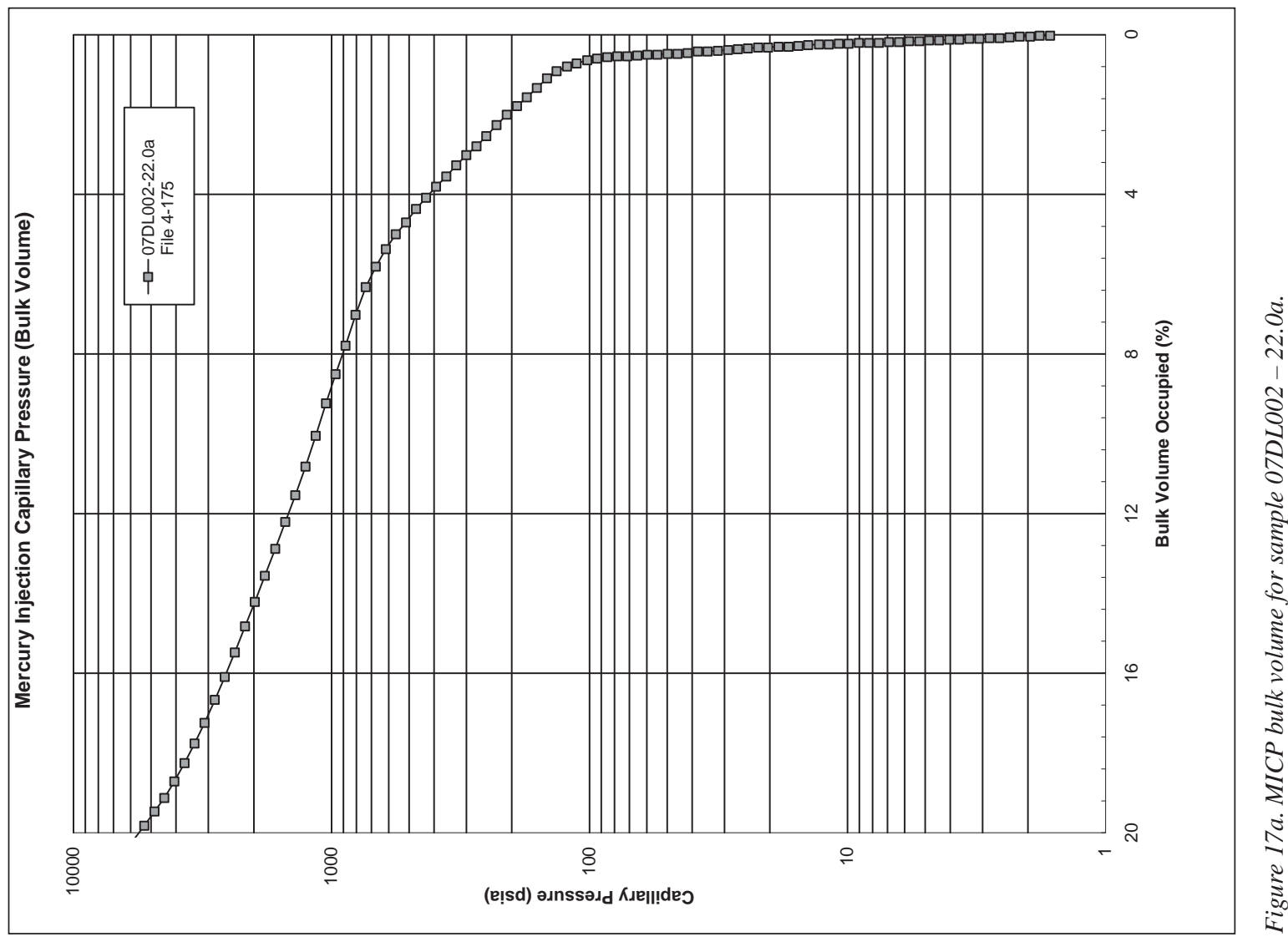




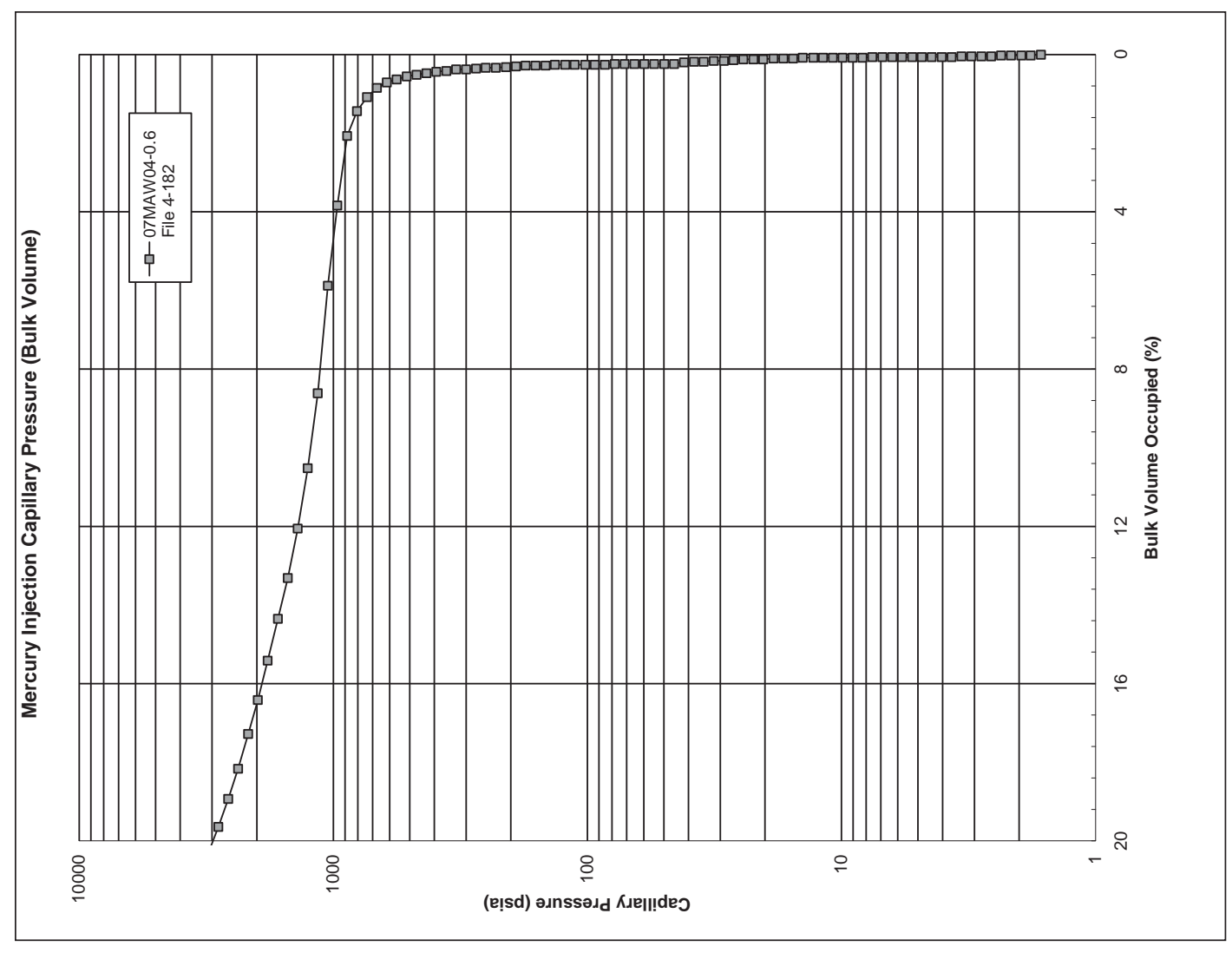

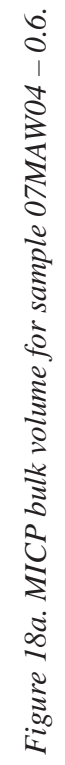

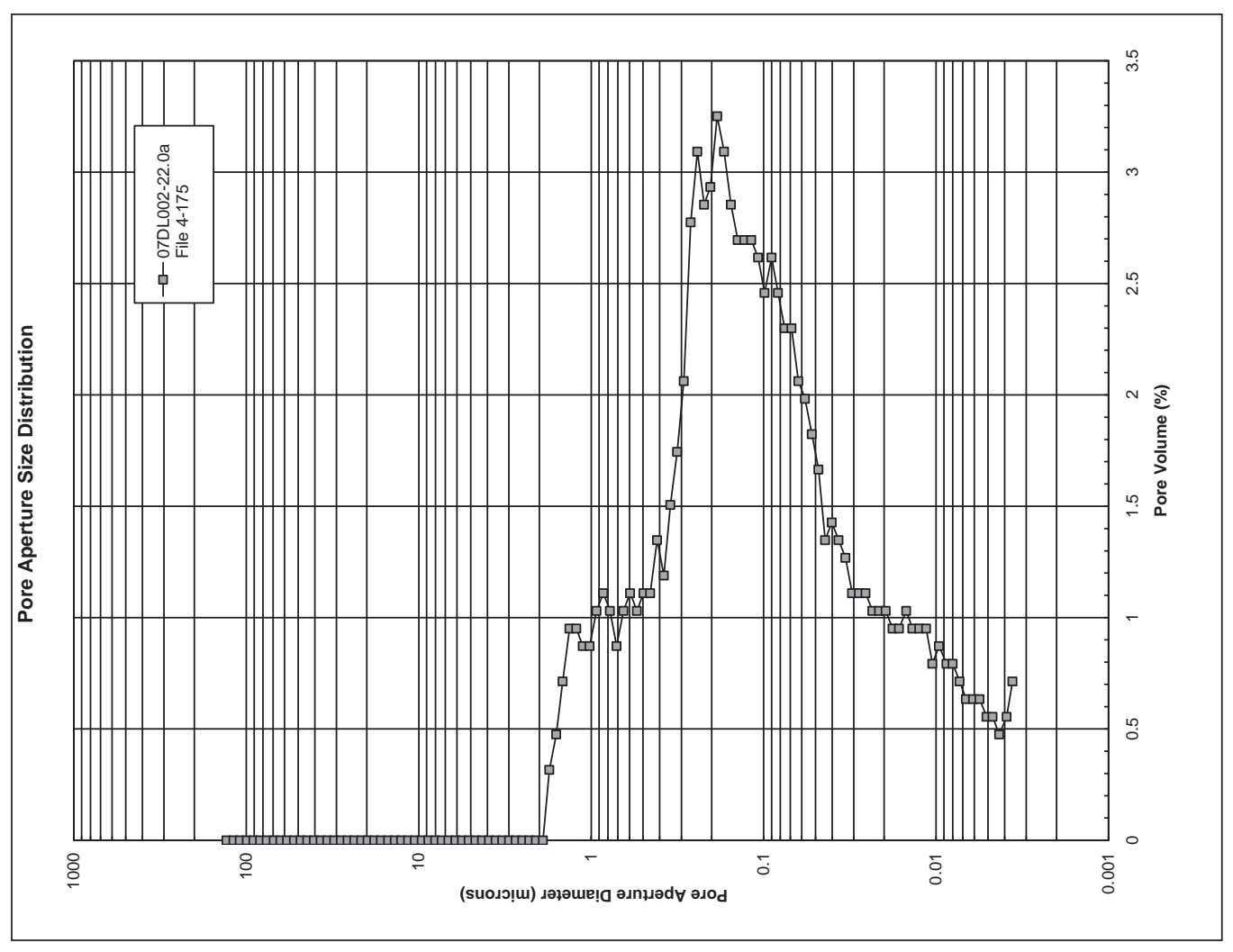

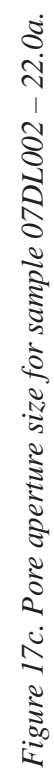




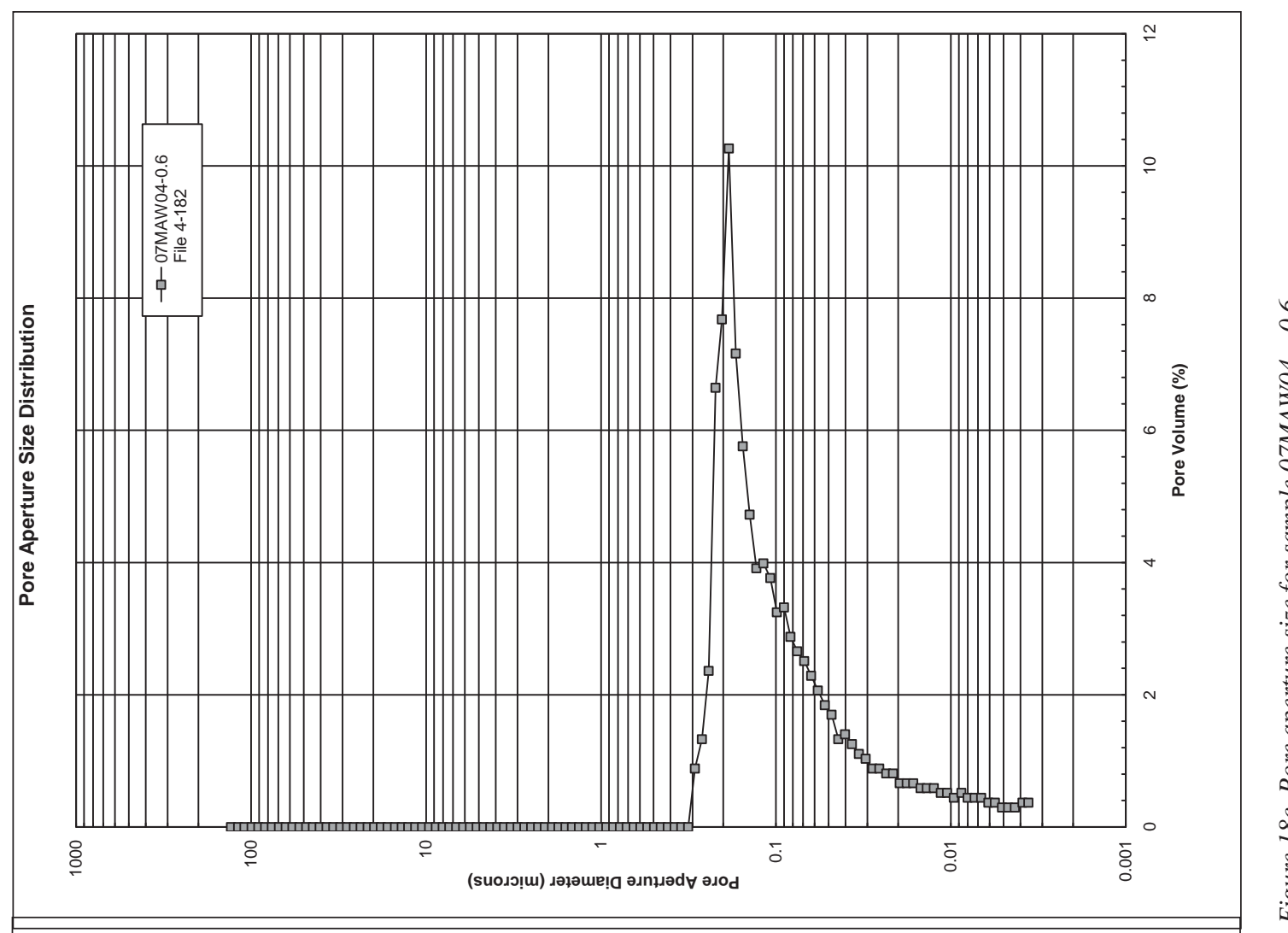

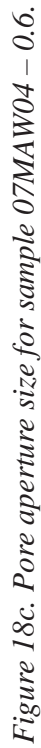

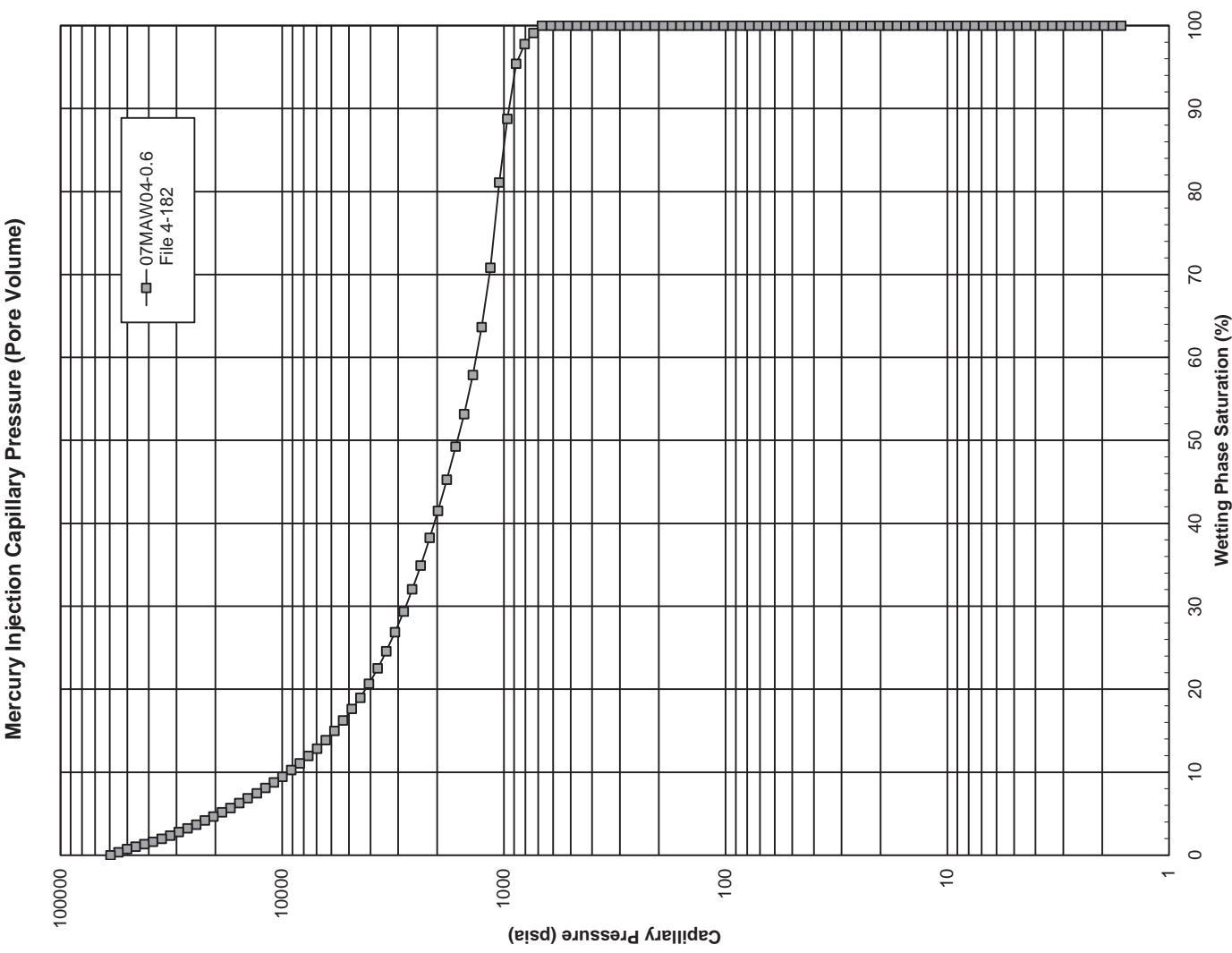

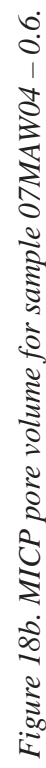



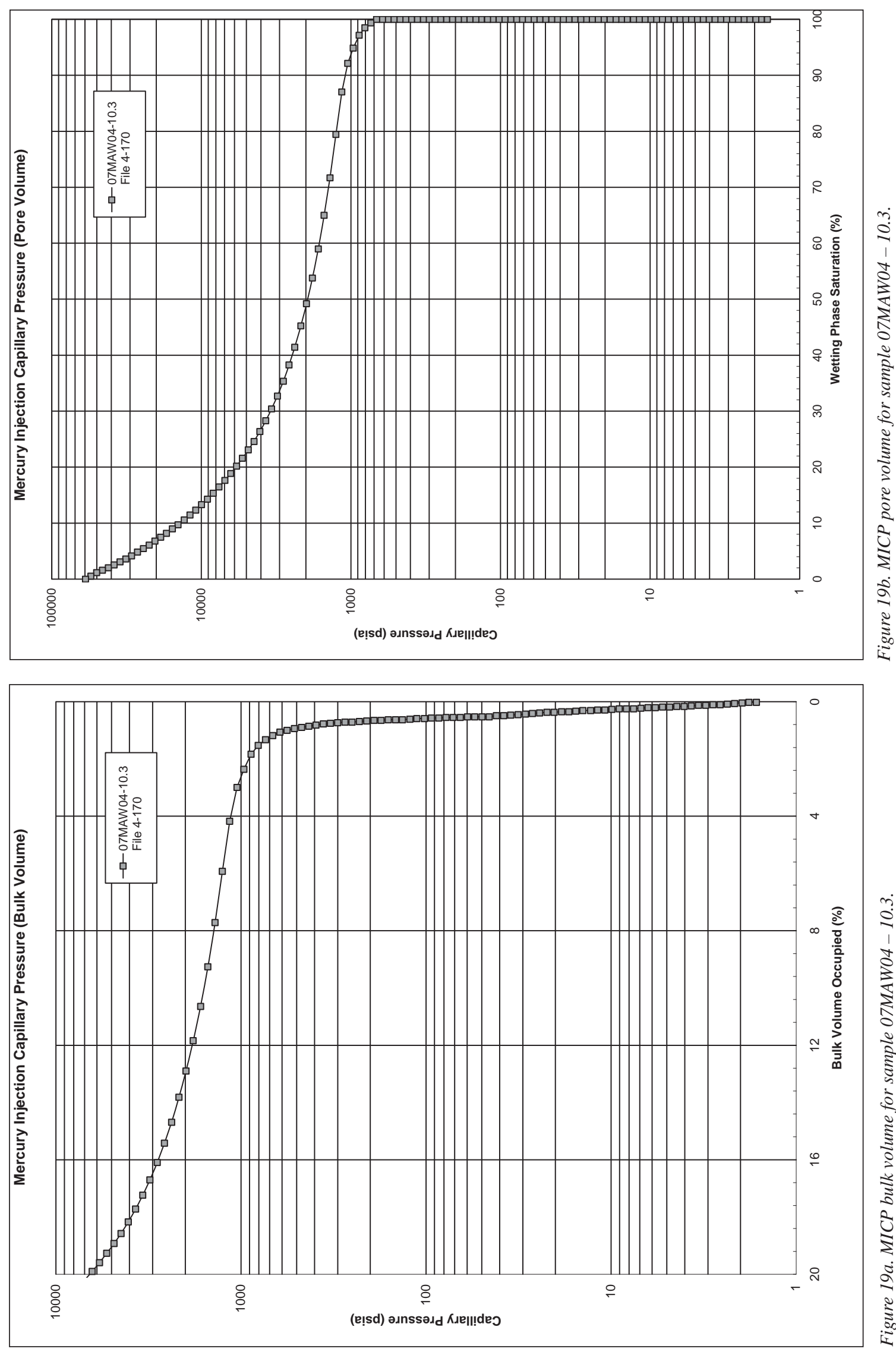

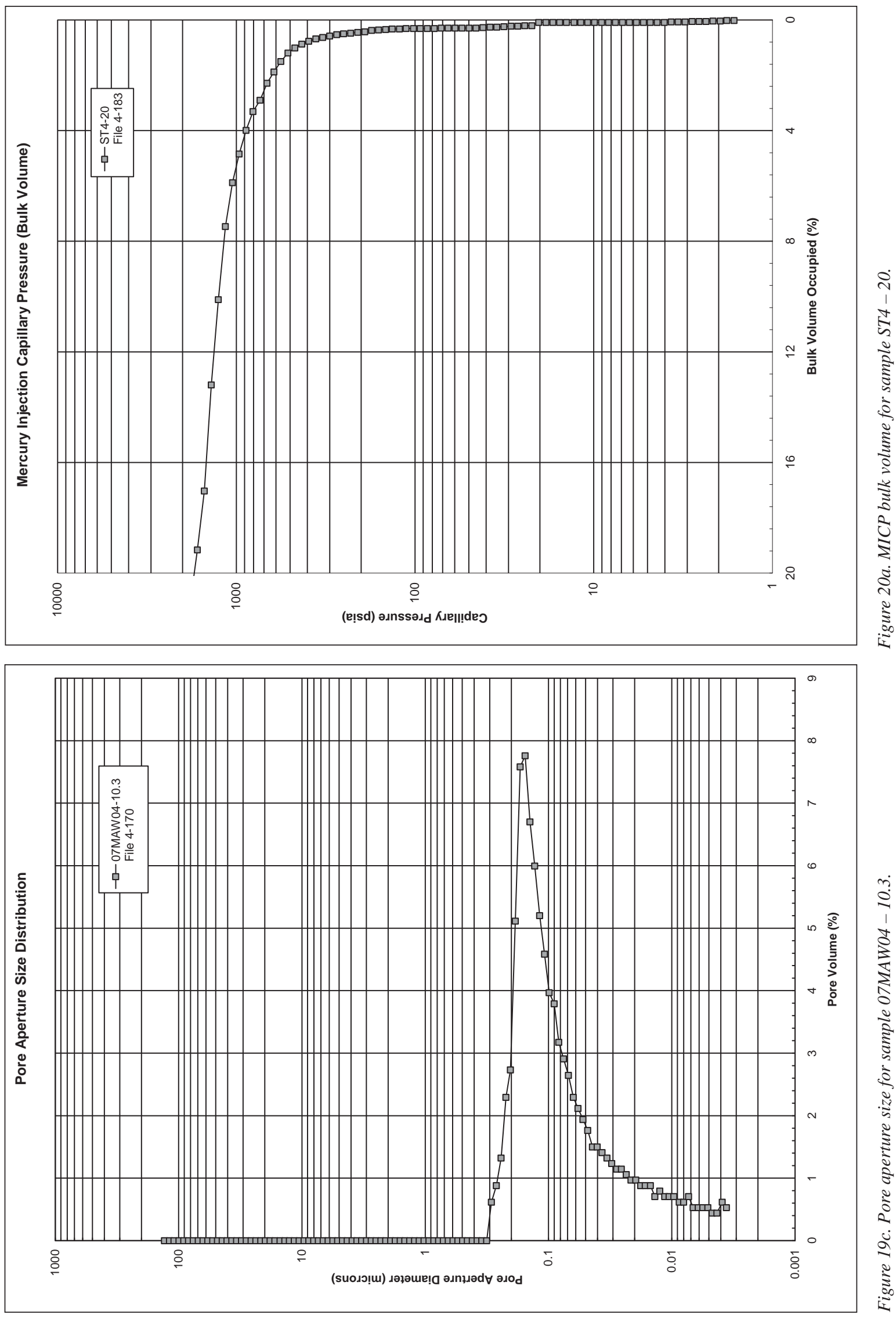

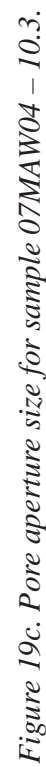



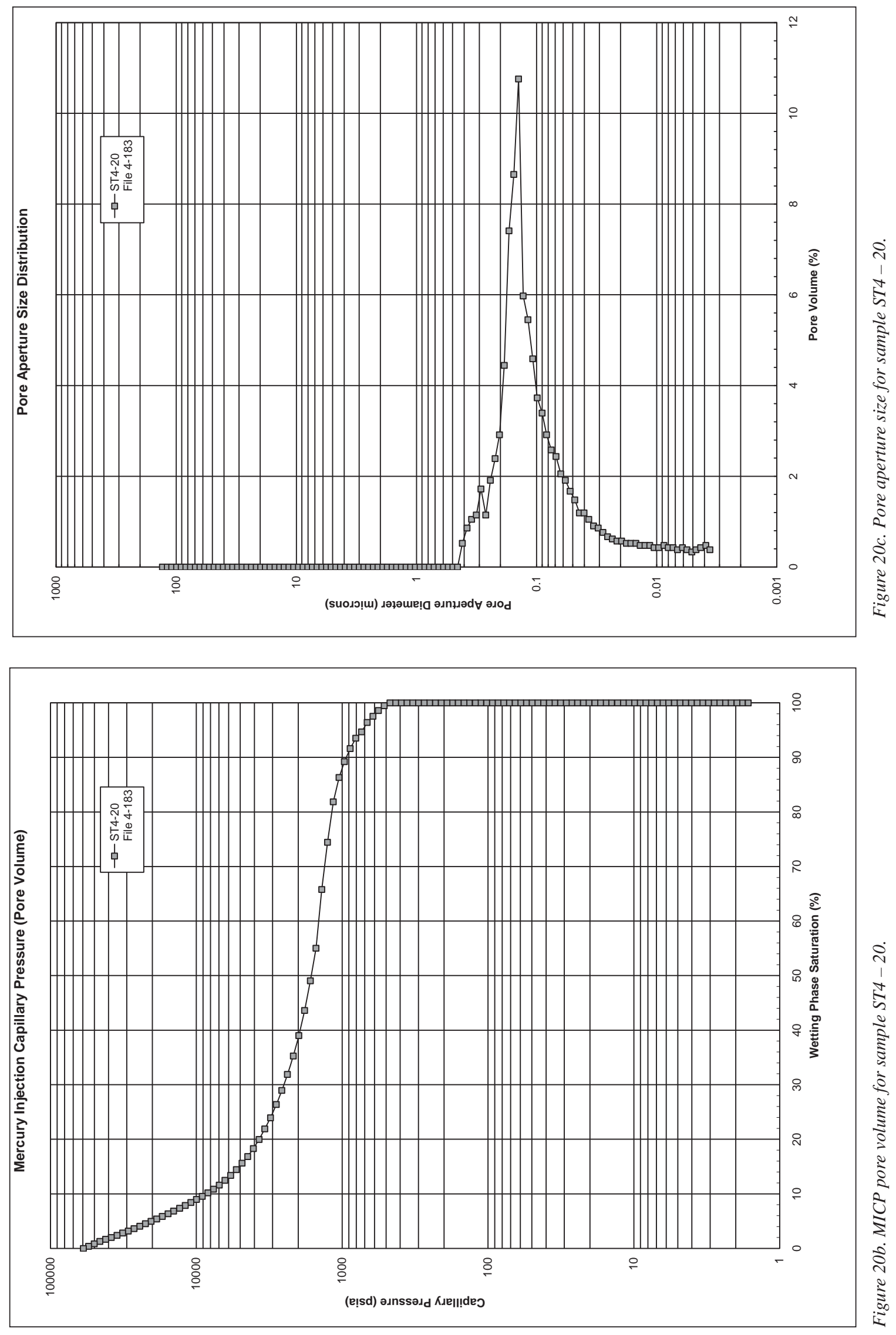


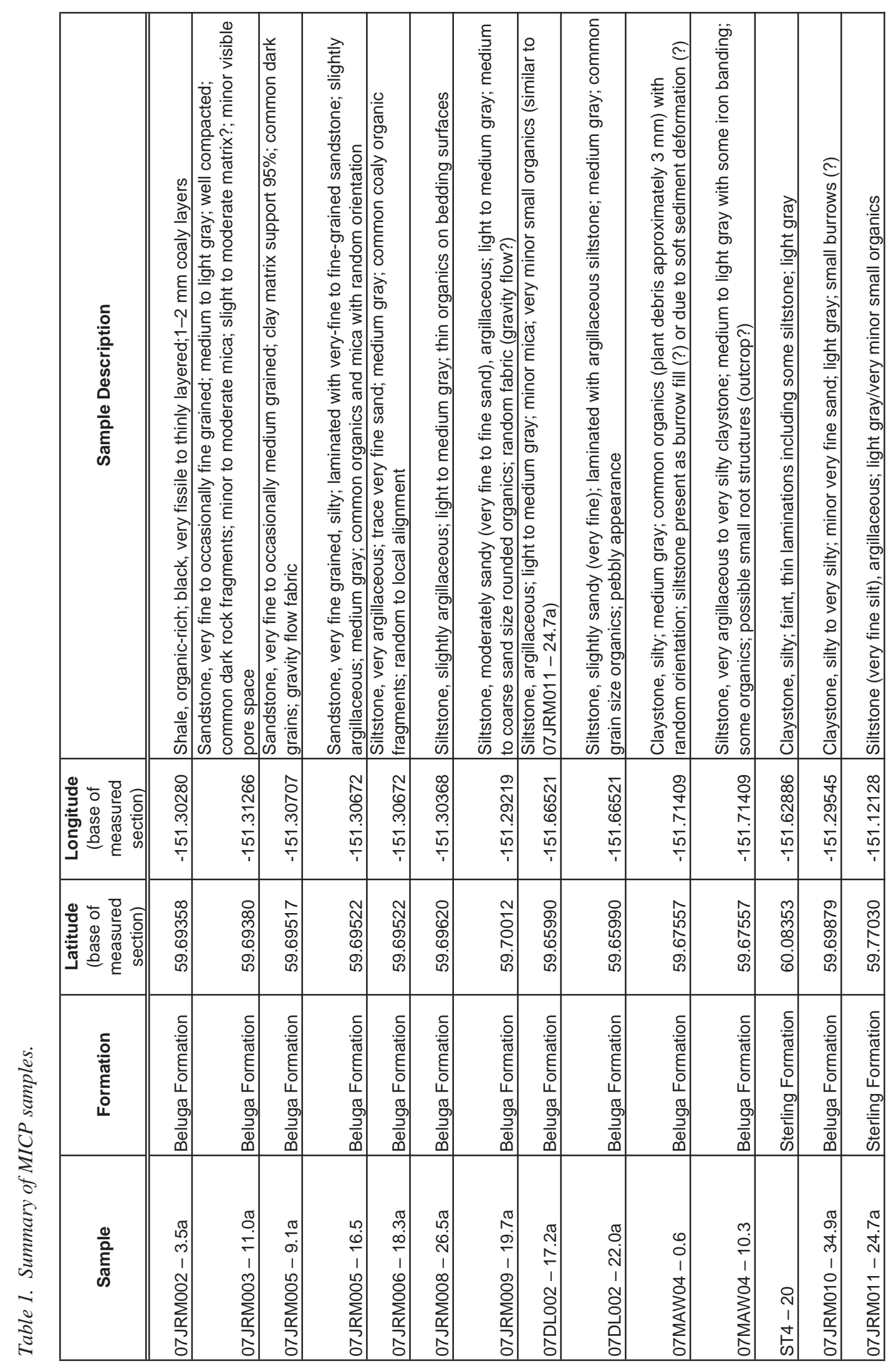


Table 2. Summary of pore system and capillary properties.

\begin{tabular}{|cccccccc}
\hline $\begin{array}{c}\text { Sample } \\
\text { Depth (ft) }\end{array}$ & $\begin{array}{c}\text { Porosity } \\
(\%)\end{array}$ & $\begin{array}{c}\text { Kair } \\
(\mathrm{md})\end{array}$ & $\begin{array}{c}\text { Median } \\
\text { Aperture }\end{array}$ & $\begin{array}{c}\text { apillary } \text { Pressure at Various Mercury Saturatior } \\
\text { entry }\end{array}$ & $5 \%$ & $7.5 \%$ & $10 \%$ \\
\hline \hline 07JRM002-3.5a & 11.3 & 0.0141 & 0.0299 & 964 & 1,500 & 1,735 & 1,962 \\
07JRM003-11.0a & 22.9 & 1.07 & 0.3717 & 78 & 124 & 138 & 150 \\
07JRM005-9.1a & 20.9 & 0.0856 & 0.1242 & 673 & 970 & 1,023 & 1,065 \\
07JRM005-16.5 & 22.1 & 0.494 & 0.3213 & 175 & 257 & 279 & 296 \\
07JRM006-18.3a & 22.1 & 0.0682 & 0.1013 & 881 & 1,172 & 1,243 & 1,291 \\
07JRM008-26.5a & 24.0 & 0.422 & 0.2900 & 300 & 400 & 411 & 423 \\
07JRM009-19.7a & 21.5 & 0.182 & 0.1960 & 430 & 577 & 600 & 621 \\
07JRM010-34.9a & 23.3 & 0.0901 & 0.1188 & 881 & 906 & 940 & 974 \\
07JRM011-24.7a & 34.0 & 0.150 & 0.1117 & 359 & 590 & 645 & 708 \\
07DL002-17.2a & 24.3 & 0.137 & 0.1452 & 229 & 381 & 428 & 470 \\
07DL002-22.0a & 25.0 & 0.171 & 0.1238 & 112 & 205 & 257 & 322 \\
07MAW04-0.6 & 26.6 & 0.134 & 0.1312 & 673 & 886 & 917 & 949 \\
07MAW04-10.3 & 23.1 & 0.0808 & 0.1095 & 673 & 960 & 1,040 & 1,092 \\
ST4-20 & 35.7 & 0.215 & 0.1308 & 470 & 725 & 845 & 936 \\
\hline \hline
\end{tabular}

Permeability calculated at maximum intrusion

Median aperture size is diameter in microns 


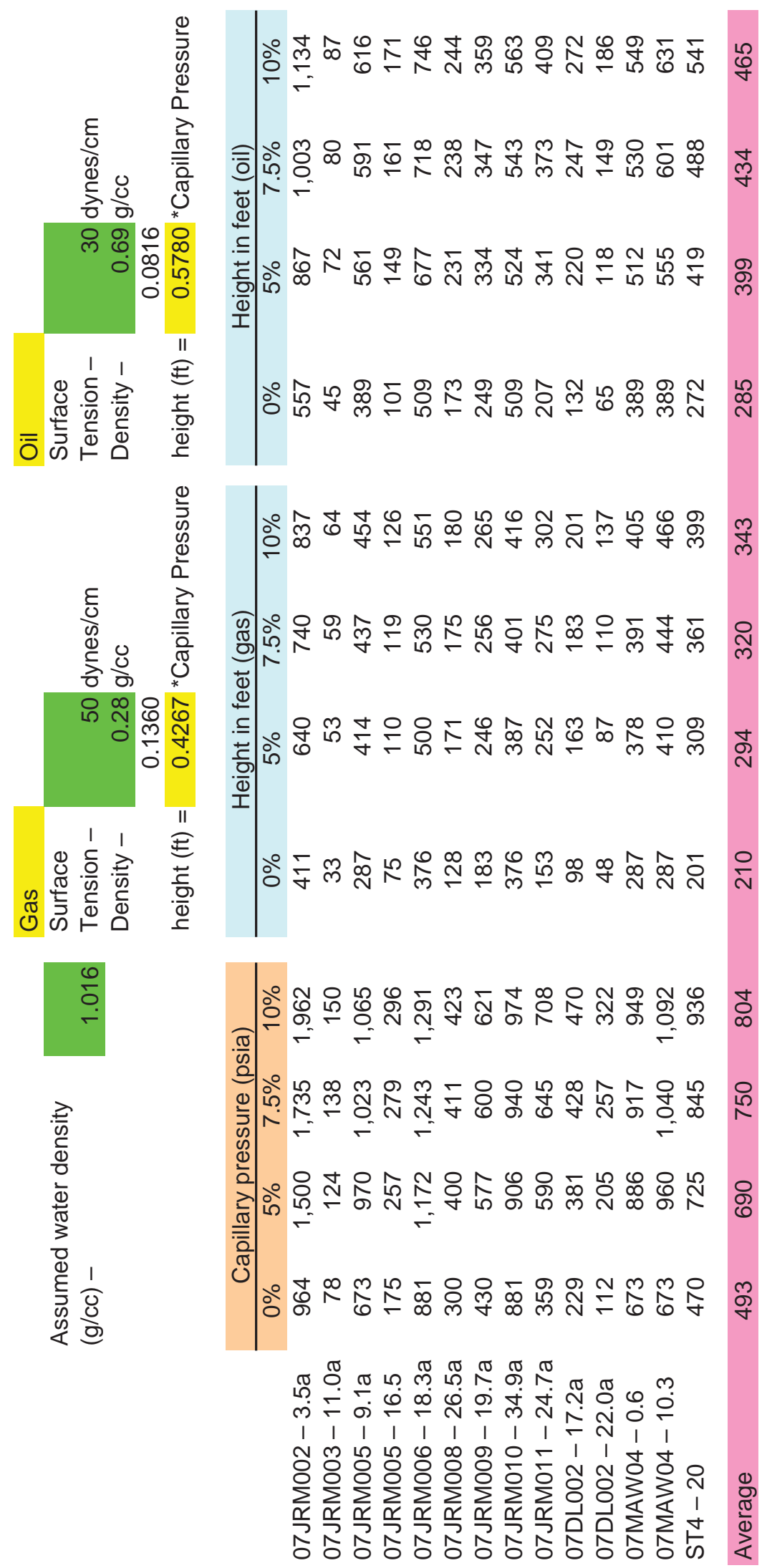


Table 4. MICP data for sample 07JRM002 - 3.5a.

\section{Mercury Injection Capillary Pressure 07JRM002 - 3.5a}

\begin{tabular}{|c|c|c|c|c|c|}
\hline & \multirow{2}{*}{\multicolumn{2}{|c|}{$\begin{array}{ll}\text { Porosity }= & 11.3 \% \text { (mercury) } \\
\text { Permeability }= & \mathrm{na} \\
\text { Median Pore Aperture }= & 0.0299 \mathrm{mi}\end{array}$}} & \\
\hline \multicolumn{3}{|c|}{ 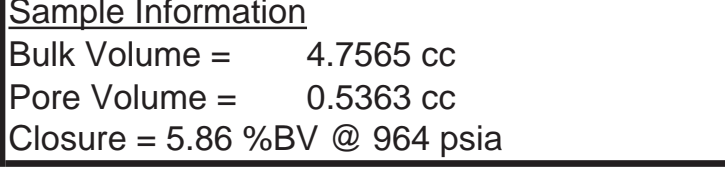 } & & & ns (diameter) \\
\hline $\begin{array}{l}\text { Capillary } \\
\text { Pressure } \\
\text { (psia) } \\
\end{array}$ & $\begin{array}{c}\text { Pore Aperture } \\
\text { Diameter } \\
\text { (microns) } \\
\end{array}$ & $\begin{array}{c}\text { Cumulative } \\
\text { Bulk Vol. (\%) } \\
\end{array}$ & $\begin{array}{l}\text { Wetting Phase } \\
\text { Saturation (\%) }\end{array}$ & $\begin{array}{l}\text { Incremental } \\
\text { Wetting Phase } \\
\text { Change (\%) } \\
\end{array}$ & $\begin{array}{l}\text { Saturation } \\
\text { Change } \\
\text { per psia } \\
\end{array}$ \\
\hline 1.64 & 130 & 0.09 & 100.0 & 0.00 & 0.0000 \\
\hline 1.80 & 119 & 0.14 & 100.0 & 0.00 & 0.0000 \\
\hline 1.96 & 109 & 0.20 & 100.0 & 0.00 & 0.0000 \\
\hline 2.15 & 99.2 & 0.26 & 100.0 & 0.00 & 0.0000 \\
\hline 2.35 & 90.8 & 0.34 & 100.0 & 0.00 & 0.0000 \\
\hline 2.57 & 83.0 & 0.49 & 100.0 & 0.00 & 0.0000 \\
\hline 2.81 & 75.9 & 0.63 & 100.0 & 0.00 & 0.0000 \\
\hline 3.08 & 69.3 & 0.76 & 100.0 & 0.00 & 0.0000 \\
\hline 3.37 & 63.3 & 0.85 & 100.0 & 0.00 & 0.0000 \\
\hline 3.68 & 58.0 & 1.08 & 100.0 & 0.00 & 0.0000 \\
\hline 4.03 & 52.9 & 1.23 & 100.0 & 0.00 & 0.0000 \\
\hline 4.41 & 48.4 & 1.33 & 100.0 & 0.00 & 0.0000 \\
\hline 4.82 & 44.3 & 1.47 & 100.0 & 0.00 & 0.0000 \\
\hline 5.27 & 40.5 & 1.54 & 100.0 & 0.00 & 0.0000 \\
\hline 5.77 & 37.0 & 1.63 & 100.0 & 0.00 & 0.0000 \\
\hline 6.31 & 33.8 & 1.79 & 100.0 & 0.00 & 0.0000 \\
\hline 6.90 & 30.9 & 1.93 & 100.0 & 0.00 & 0.0000 \\
\hline 7.55 & 28.3 & 2.04 & 100.0 & 0.00 & 0.0000 \\
\hline 8.26 & 25.8 & 2.17 & 100.0 & 0.00 & 0.0000 \\
\hline 9.04 & 23.6 & 2.28 & 100.0 & 0.00 & 0.0000 \\
\hline 9.89 & 21.6 & 2.36 & 100.0 & 0.00 & 0.0000 \\
\hline 10.8 & 19.8 & 2.45 & 100.0 & 0.00 & 0.0000 \\
\hline 11.8 & 18.1 & 2.53 & 100.0 & 0.00 & 0.0000 \\
\hline 12.9 & 16.5 & 2.62 & 100.0 & 0.00 & 0.0000 \\
\hline 14.2 & 15.0 & 2.71 & 100.0 & 0.00 & 0.0000 \\
\hline 15.5 & 13.8 & 2.81 & 100.0 & 0.00 & 0.0000 \\
\hline 16.9 & 12.6 & 2.93 & 100.0 & 0.00 & 0.0000 \\
\hline 18.5 & 11.5 & 3.13 & 100.0 & 0.00 & 0.0000 \\
\hline 20.3 & 10.5 & 3.24 & 100.0 & 0.00 & 0.0000 \\
\hline 22.2 & 9.61 & 3.33 & 100.0 & 0.00 & 0.0000 \\
\hline 24.3 & 8.78 & 3.41 & 100.0 & 0.00 & 0.0000 \\
\hline 26.6 & 8.02 & 3.52 & 100.0 & 0.00 & 0.0000 \\
\hline 29.0 & 7.36 & 3.62 & 100.0 & 0.00 & 0.0000 \\
\hline 31.8 & 6.71 & 3.72 & 100.0 & 0.00 & 0.0000 \\
\hline 34.8 & 6.13 & 3.81 & 100.0 & 0.00 & 0.0000 \\
\hline 38.0 & 5.61 & 3.92 & 100.0 & 0.00 & 0.0000 \\
\hline
\end{tabular}


Table 4 (cont.). MICP data for sample 07JRM002 - 3.5a.

\section{Mercury Injection Capillary Pressure 07JRM002 - 3.5a}

\begin{tabular}{|c|c|c|c|c|c|}
\hline $\begin{array}{c}\text { Capillary } \\
\text { Pressure } \\
\text { (psia) } \\
\end{array}$ & $\begin{array}{c}\text { Pore Aperture } \\
\text { Diameter } \\
\text { (microns) } \\
\end{array}$ & $\begin{array}{c}\text { Cumulative } \\
\text { Bulk Vol. (\%) } \\
\end{array}$ & $\begin{array}{l}\text { Wetting Phase } \\
\text { Saturation (\%) }\end{array}$ & $\begin{array}{c}\text { Incremental } \\
\text { Wetting Phase } \\
\text { Change (\%) } \\
\end{array}$ & $\begin{array}{c}\text { Saturation } \\
\text { Change } \\
\text { per psia }\end{array}$ \\
\hline 41.6 & 5.13 & 3.99 & 100.0 & 0.00 & 0.0000 \\
\hline 45.5 & 4.69 & 4.07 & 100.0 & 0.00 & 0.0000 \\
\hline 49.8 & 4.28 & 4.15 & 100.0 & 0.00 & 0.0000 \\
\hline 54.5 & 3.91 & 4.23 & 100.0 & 0.00 & 0.0000 \\
\hline 59.6 & 3.58 & 4.27 & 100.0 & 0.00 & 0.0000 \\
\hline 65.2 & 3.27 & 4.35 & 100.0 & 0.00 & 0.0000 \\
\hline 71.3 & 2.99 & 4.41 & 100.0 & 0.00 & 0.0000 \\
\hline 78.0 & 2.73 & 4.44 & 100.0 & 0.00 & 0.0000 \\
\hline 85.3 & 2.50 & 4.49 & 100.0 & 0.00 & 0.0000 \\
\hline 93.4 & 2.28 & 4.55 & 100.0 & 0.00 & 0.0000 \\
\hline 102 & 2.09 & 4.60 & 100.0 & 0.00 & 0.0000 \\
\hline 112 & 1.90 & 4.67 & 100.0 & 0.00 & 0.0000 \\
\hline 122 & 1.75 & 4.70 & 100.0 & 0.00 & 0.0000 \\
\hline 134 & 1.59 & 4.75 & 100.0 & 0.00 & 0.0000 \\
\hline 146 & 1.46 & 4.78 & 100.0 & 0.00 & 0.0000 \\
\hline 160 & 1.33 & 4.83 & 100.0 & 0.00 & 0.0000 \\
\hline 175 & 1.22 & 4.87 & 100.0 & 0.00 & 0.0000 \\
\hline 191 & 1.12 & 4.92 & 100.0 & 0.00 & 0.0000 \\
\hline 209 & 1.02 & 4.97 & 100.0 & 0.00 & 0.0000 \\
\hline 229 & 0.932 & 5.00 & 100.0 & 0.00 & 0.0000 \\
\hline 251 & 0.850 & 5.04 & 100.0 & 0.00 & 0.0000 \\
\hline 274 & 0.779 & 5.09 & 100.0 & 0.00 & 0.0000 \\
\hline 300 & 0.711 & 5.14 & 100.0 & 0.00 & 0.0000 \\
\hline 328 & 0.650 & 5.18 & 100.0 & 0.00 & 0.0000 \\
\hline 359 & 0.594 & 5.23 & 100.0 & 0.00 & 0.0000 \\
\hline 393 & 0.543 & 5.26 & 100.0 & 0.00 & 0.0000 \\
\hline 430 & 0.496 & 5.31 & 100.0 & 0.00 & 0.0000 \\
\hline 470 & 0.454 & 5.35 & 100.0 & 0.00 & 0.0000 \\
\hline 514 & 0.415 & 5.38 & 100.0 & 0.00 & 0.0000 \\
\hline 563 & 0.379 & 5.46 & 100.0 & 0.00 & 0.0000 \\
\hline 615 & 0.347 & 5.52 & 100.0 & 0.00 & 0.0000 \\
\hline 673 & 0.317 & 5.57 & 100.0 & 0.00 & 0.0000 \\
\hline 736 & 0.290 & 5.63 & 100.0 & 0.00 & 0.0000 \\
\hline 806 & 0.265 & 5.69 & 100.0 & 0.00 & 0.0000 \\
\hline 881 & 0.242 & 5.77 & 100.0 & 0.00 & 0.0000 \\
\hline 964 & 0.221 & 5.86 & 100.0 & 0.00 & 0.0000 \\
\hline 1050 & 0.203 & 5.94 & 99.3 & 0.69 & 0.0080 \\
\hline 1150 & 0.186 & 6.05 & 98.3 & 0.96 & 0.0096 \\
\hline 1260 & 0.169 & 6.15 & 97.4 & 0.96 & 0.0088 \\
\hline 1380 & 0.155 & 6.28 & 96.3 & 1.10 & 0.0092 \\
\hline 1510 & 0.141 & 6.43 & 94.9 & 1.38 & 0.0106 \\
\hline 1650 & 0.129 & 6.60 & 93.4 & 1.51 & 0.0108 \\
\hline
\end{tabular}


Table 4 (cont.). MICP data for sample 07JRM002 - 3.5a.

\section{Mercury Injection Capillary Pressure 07JRM002 - 3.5a}

\begin{tabular}{|c|c|c|c|c|c|}
\hline $\begin{array}{c}\text { Capillary } \\
\text { Pressure } \\
\text { (psia) } \\
\end{array}$ & $\begin{array}{c}\text { Pore Aperture } \\
\text { Diameter } \\
\text { (microns) } \\
\end{array}$ & $\begin{array}{c}\text { Cumulative } \\
\text { Bulk Vol. (\%) }\end{array}$ & $\begin{array}{l}\text { Wetting Phase } \\
\text { Saturation (\%) }\end{array}$ & $\begin{array}{c}\text { Incremental } \\
\text { Wetting Phase } \\
\text { Change (\%) }\end{array}$ & $\begin{array}{c}\text { Saturation } \\
\text { Change } \\
\text { per psia } \\
\end{array}$ \\
\hline 1810 & 0.1179 & 6.79 & 91.7 & 1.65 & 0.0103 \\
\hline 1980 & 0.1077 & 7.00 & 89.8 & 1.93 & 0.0113 \\
\hline 2160 & 0.0988 & 7.23 & 87.8 & 2.06 & 0.0115 \\
\hline 2370 & 0.0900 & 7.51 & 85.3 & 2.48 & 0.0118 \\
\hline 2590 & 0.0824 & 7.79 & 82.8 & 2.48 & 0.0113 \\
\hline 2830 & 0.0754 & 8.10 & 80.1 & 2.75 & 0.0115 \\
\hline 3100 & 0.0688 & 8.44 & 77.0 & 3.03 & 0.0112 \\
\hline 3390 & 0.0629 & 8.76 & 74.1 & 2.89 & 0.0100 \\
\hline 3710 & 0.0575 & 9.12 & 71.0 & 3.16 & 0.0099 \\
\hline 4060 & 0.0525 & 9.47 & 67.8 & 3.16 & 0.0090 \\
\hline 4440 & 0.0480 & 9.81 & 64.8 & 3.03 & 0.0080 \\
\hline 4850 & 0.0440 & 10.13 & 61.9 & 2.89 & 0.0070 \\
\hline 5310 & 0.0402 & 10.46 & 59.0 & 2.89 & 0.0063 \\
\hline 5810 & 0.0367 & 10.78 & 56.1 & 2.89 & 0.0058 \\
\hline 6360 & 0.0335 & 11.09 & 53.4 & 2.75 & 0.0050 \\
\hline 6950 & 0.0307 & 11.38 & 50.8 & 2.61 & 0.0044 \\
\hline 7610 & 0.0280 & 11.68 & 48.1 & 2.61 & 0.0040 \\
\hline 8320 & 0.0256 & 11.94 & 45.8 & 2.34 & 0.0033 \\
\hline 9100 & 0.0234 & 12.18 & 43.6 & 2.20 & 0.0028 \\
\hline 9960 & 0.0214 & 12.43 & 41.4 & 2.20 & 0.0026 \\
\hline 10900 & 0.0196 & 12.65 & 39.5 & 1.93 & 0.0020 \\
\hline 11900 & 0.0179 & 12.86 & 37.6 & 1.93 & 0.0019 \\
\hline 13000 & 0.0164 & 13.08 & 35.6 & 1.93 & 0.0018 \\
\hline 14300 & 0.0149 & 13.29 & 33.7 & 1.93 & 0.0015 \\
\hline 15600 & 0.0137 & 13.50 & 31.9 & 1.79 & 0.0014 \\
\hline 17100 & 0.0125 & 13.70 & 30.1 & 1.79 & 0.0012 \\
\hline 18700 & 0.0114 & 13.90 & 28.3 & 1.79 & 0.0011 \\
\hline 20400 & 0.0105 & 14.08 & 26.7 & 1.65 & 0.0010 \\
\hline 22300 & 0.0096 & 14.28 & 24.9 & 1.79 & 0.0009 \\
\hline 24400 & 0.0087 & 14.50 & 23.0 & 1.93 & 0.0009 \\
\hline 26700 & 0.0080 & 14.71 & 21.0 & 1.93 & 0.0008 \\
\hline 29300 & 0.0073 & 14.93 & 19.1 & 1.93 & 0.0007 \\
\hline 32000 & 0.0067 & 15.15 & 17.2 & 1.93 & 0.0007 \\
\hline 35000 & 0.0061 & 15.38 & 15.1 & 2.06 & 0.0007 \\
\hline 38300 & 0.0056 & 15.62 & 12.9 & 2.20 & 0.0007 \\
\hline 41900 & 0.0051 & 15.87 & 10.7 & 2.20 & 0.0006 \\
\hline 45800 & 0.0047 & 16.13 & 8.4 & 2.34 & 0.0006 \\
\hline 50100 & 0.0043 & 16.46 & 5.5 & 2.89 & 0.0007 \\
\hline 54800 & 0.0039 & 16.76 & 2.8 & 2.75 & 0.0006 \\
\hline 59500 & 0.0036 & 17.07 & 0.0 & 2.75 & 0.0006 \\
\hline
\end{tabular}


Table 5. MICP data for sample 07JRM003 - 11.0a.

\section{Mercury Injection Capillary Pressure 07JRM003 - 11.0a}

\begin{tabular}{|c|c|c|c|c|c|}
\hline $\begin{array}{l}\text { Sample Information } \\
\text { Bulk Volume }= \\
\text { Pore Volume }= \\
\text { Closure }=0.97 \% \mathrm{BV}\end{array}$ & $\begin{array}{l}4.8422 \text { cc } \\
1.1077 \text { cc } \\
0 \text { psia }\end{array}$ & & $\begin{array}{l}\text { Porosity }= \\
\text { Permeability = } \\
\text { Median Pore Apertu }\end{array}$ & $\begin{array}{l}22.9 \% \text { (mercury) } \\
72 \mathrm{md} \text { (mercury } \\
.3717 \text { microns }\end{array}$ & meter) \\
\hline $\begin{array}{l}\text { Capillary } \\
\text { Pressure } \\
\text { (psia) } \\
\end{array}$ & $\begin{array}{l}\text { Pore Aperture } \\
\text { Diameter } \\
\text { (microns) }\end{array}$ & $\begin{array}{l}\text { Cumulative } \\
\text { Bulk Vol. (\%) }\end{array}$ & $\begin{array}{l}\text { Wetting Phase } \\
\text { Saturation (\%) }\end{array}$ & $\begin{array}{l}\text { Incremental } \\
\text { Wetting Phase } \\
\text { Change (\%) }\end{array}$ & $\begin{array}{c}\text { Saturation } \\
\text { Change } \\
\text { per psia }\end{array}$ \\
\hline 1.64 & 130 & 0.02 & 100.0 & 0.00 & 0.0000 \\
\hline 1.80 & 119 & 0.02 & 100.0 & 0.00 & 0.0000 \\
\hline 1.96 & 109 & 0.04 & 100.0 & 0.00 & 0.0000 \\
\hline 2.15 & 99.2 & 0.06 & 100.0 & 0.00 & 0.0000 \\
\hline 2.35 & 90.8 & 0.06 & 100.0 & 0.00 & 0.0000 \\
\hline 2.57 & 83.0 & 0.08 & 100.0 & 0.00 & 0.0000 \\
\hline 2.81 & 75.9 & 0.08 & 100.0 & 0.00 & 0.0000 \\
\hline 3.08 & 69.3 & 0.10 & 100.0 & 0.00 & 0.0000 \\
\hline 3.37 & 63.3 & 0.10 & 100.0 & 0.00 & 0.0000 \\
\hline 3.68 & 58.0 & 0.12 & 100.0 & 0.00 & 0.0000 \\
\hline 4.03 & 52.9 & 0.12 & 100.0 & 0.00 & 0.0000 \\
\hline 4.41 & 48.4 & 0.14 & 100.0 & 0.00 & 0.0000 \\
\hline 4.82 & 44.3 & 0.14 & 100.0 & 0.00 & 0.0000 \\
\hline 5.27 & 40.5 & 0.14 & 100.0 & 0.00 & 0.0000 \\
\hline 5.77 & 37.0 & 0.17 & 100.0 & 0.00 & 0.0000 \\
\hline 6.31 & 33.8 & 0.17 & 100.0 & 0.00 & 0.0000 \\
\hline 6.90 & 30.9 & 0.19 & 100.0 & 0.00 & 0.0000 \\
\hline 7.55 & 28.3 & 0.19 & 100.0 & 0.00 & 0.0000 \\
\hline 8.26 & 25.8 & 0.21 & 100.0 & 0.00 & 0.0000 \\
\hline 9.04 & 23.6 & 0.21 & 100.0 & 0.00 & 0.0000 \\
\hline 9.89 & 21.6 & 0.23 & 100.0 & 0.00 & 0.0000 \\
\hline 10.8 & 19.8 & 0.23 & 100.0 & 0.00 & 0.0000 \\
\hline 11.8 & 18.1 & 0.25 & 100.0 & 0.00 & 0.0000 \\
\hline 12.9 & 16.5 & 0.27 & 100.0 & 0.00 & 0.0000 \\
\hline 14.2 & 15.0 & 0.29 & 100.0 & 0.00 & 0.0000 \\
\hline 15.5 & 13.8 & 0.31 & 100.0 & 0.00 & 0.0000 \\
\hline 16.9 & 12.6 & 0.33 & 100.0 & 0.00 & 0.0000 \\
\hline 18.5 & 11.5 & 0.35 & 100.0 & 0.00 & 0.0000 \\
\hline 20.3 & 10.5 & 0.37 & 100.0 & 0.00 & 0.0000 \\
\hline 22.2 & 9.61 & 0.39 & 100.0 & 0.00 & 0.0000 \\
\hline 24.3 & 8.78 & 0.43 & 100.0 & 0.00 & 0.0000 \\
\hline 26.6 & 8.02 & 0.45 & 100.0 & 0.00 & 0.0000 \\
\hline 29.0 & 7.36 & 0.50 & 100.0 & 0.00 & 0.0000 \\
\hline 31.8 & 6.71 & 0.52 & 100.0 & 0.00 & 0.0000 \\
\hline 34.8 & 6.13 & 0.56 & 100.0 & 0.00 & 0.0000 \\
\hline 38.0 & 5.61 & 0.60 & 100.0 & 0.00 & 0.0000 \\
\hline
\end{tabular}


Table 5 (cont.). MICP data for sample 07JRM003 - 11.0a.

\section{Mercury Injection Capillary Pressure 07JRM003 - 11.0a}

\begin{tabular}{|c|c|c|c|c|c|}
\hline $\begin{array}{c}\text { Capillary } \\
\text { Pressure } \\
\text { (psia) } \\
\end{array}$ & $\begin{array}{c}\text { Pore Aperture } \\
\text { Diameter } \\
\text { (microns) } \\
\end{array}$ & $\begin{array}{c}\text { Cumulative } \\
\text { Bulk Vol. (\%) } \\
\end{array}$ & $\begin{array}{l}\text { Wetting Phase } \\
\text { Saturation (\%) }\end{array}$ & $\begin{array}{c}\text { Incremental } \\
\text { Wetting Phase } \\
\text { Change (\%) } \\
\end{array}$ & $\begin{array}{c}\text { Saturation } \\
\text { Change } \\
\text { per psia } \\
\end{array}$ \\
\hline 41.6 & 5.13 & 0.64 & 100.0 & 0.00 & 0.0000 \\
\hline 45.5 & 4.69 & 0.68 & 100.0 & 0.00 & 0.0000 \\
\hline 49.8 & 4.28 & 0.72 & 100.0 & 0.00 & 0.0000 \\
\hline 54.5 & 3.91 & 0.74 & 100.0 & 0.00 & 0.0000 \\
\hline 59.6 & 3.58 & 0.78 & 100.0 & 0.00 & 0.0000 \\
\hline 65.2 & 3.27 & 0.83 & 100.0 & 0.00 & 0.0000 \\
\hline 71.3 & 2.99 & 0.89 & 100.0 & 0.00 & 0.0000 \\
\hline 78.0 & 2.73 & 0.97 & 100.0 & 0.00 & 0.0000 \\
\hline 85.3 & 2.50 & 1.05 & 99.6 & 0.36 & 0.0495 \\
\hline 93.4 & 2.28 & 1.20 & 99.0 & 0.63 & 0.0781 \\
\hline 102 & 2.09 & 1.38 & 98.2 & 0.81 & 0.0945 \\
\hline 112 & 1.90 & 1.75 & 96.6 & 1.63 & 0.1626 \\
\hline 122 & 1.75 & 2.02 & 95.4 & 1.17 & 0.1174 \\
\hline 134 & 1.59 & 2.50 & 93.3 & 2.08 & 0.1731 \\
\hline 146 & 1.46 & 3.03 & 91.0 & 2.35 & 0.1957 \\
\hline 160 & 1.33 & 3.74 & 87.9 & 3.07 & 0.2194 \\
\hline 175 & 1.22 & 4.48 & 84.6 & 3.25 & 0.2168 \\
\hline 191 & 1.12 & 5.29 & 81.1 & 3.52 & 0.2202 \\
\hline 209 & 1.02 & 6.07 & 77.7 & 3.43 & 0.1907 \\
\hline 229 & 0.932 & 6.85 & 74.3 & 3.43 & 0.1716 \\
\hline 251 & 0.850 & 7.58 & 71.1 & 3.16 & 0.1437 \\
\hline 274 & 0.779 & 8.18 & 68.5 & 2.62 & 0.1139 \\
\hline 300 & 0.711 & 8.67 & 66.3 & 2.17 & 0.0834 \\
\hline 328 & 0.650 & 9.21 & 64.0 & 2.35 & 0.0839 \\
\hline 359 & 0.594 & 9.79 & 61.4 & 2.53 & 0.0816 \\
\hline 393 & 0.543 & 10.32 & 59.1 & 2.35 & 0.0691 \\
\hline 430 & 0.496 & 10.86 & 56.7 & 2.35 & 0.0635 \\
\hline 470 & 0.454 & 11.36 & 54.6 & 2.17 & 0.0542 \\
\hline 514 & 0.415 & 11.87 & 52.3 & 2.26 & 0.0513 \\
\hline 563 & 0.379 & 12.28 & 50.5 & 1.81 & 0.0369 \\
\hline 615 & 0.347 & 12.78 & 48.3 & 2.17 & 0.0417 \\
\hline 673 & 0.317 & 13.21 & 46.4 & 1.90 & 0.0327 \\
\hline 736 & 0.290 & 13.67 & 44.4 & 1.99 & 0.0315 \\
\hline 806 & 0.265 & 14.10 & 42.5 & 1.90 & 0.0271 \\
\hline 881 & 0.242 & 14.49 & 40.8 & 1.72 & 0.0229 \\
\hline 964 & 0.221 & 14.93 & 38.9 & 1.90 & 0.0229 \\
\hline 1050 & 0.203 & 15.32 & 37.2 & 1.72 & 0.0200 \\
\hline 1150 & 0.186 & 15.69 & 35.6 & 1.63 & 0.0163 \\
\hline 1260 & 0.169 & 16.04 & 34.1 & 1.54 & 0.0140 \\
\hline 1380 & 0.155 & 16.39 & 32.5 & 1.54 & 0.0128 \\
\hline 1510 & 0.141 & 16.74 & 31.0 & 1.54 & 0.0118 \\
\hline 1650 & 0.129 & 17.07 & 29.5 & 1.45 & 0.0103 \\
\hline
\end{tabular}


Table 5 (cont.). MICP data for sample 07JRM003 - 11.0a.

\section{Mercury Injection Capillary Pressure 07JRM003 - 11.0a}

\begin{tabular}{|c|c|c|c|c|c|}
\hline $\begin{array}{l}\text { Capillary } \\
\text { Pressure } \\
\text { (psia) } \\
\end{array}$ & $\begin{array}{c}\text { Pore Aperture } \\
\text { Diameter } \\
\text { (microns) } \\
\end{array}$ & $\begin{array}{c}\text { Cumulative } \\
\text { Bulk Vol. (\%) } \\
\end{array}$ & $\begin{array}{l}\text { Wetting Phase } \\
\text { Saturation (\%) }\end{array}$ & $\begin{array}{c}\text { Incremental } \\
\text { Wetting Phase } \\
\text { Change (\%) } \\
\end{array}$ & $\begin{array}{c}\text { Saturation } \\
\text { Change } \\
\text { per psia } \\
\end{array}$ \\
\hline 1810 & 0.1179 & 17.40 & 28.1 & 1.45 & 0.0090 \\
\hline 1980 & 0.1077 & 17.69 & 26.8 & 1.26 & 0.0074 \\
\hline 2160 & 0.0988 & 17.98 & 25.6 & 1.26 & 0.0070 \\
\hline 2370 & 0.0900 & 18.27 & 24.3 & 1.26 & 0.0060 \\
\hline 2590 & 0.0824 & 18.56 & 23.0 & 1.26 & 0.0057 \\
\hline 2830 & 0.0754 & 18.81 & 22.0 & 1.08 & 0.0045 \\
\hline 3100 & 0.0688 & 19.06 & 20.9 & 1.08 & 0.0040 \\
\hline 3390 & 0.0629 & 19.30 & 19.8 & 1.08 & 0.0037 \\
\hline 3710 & 0.0575 & 19.53 & 18.8 & 0.99 & 0.0031 \\
\hline 4060 & 0.0525 & 19.76 & 17.8 & 0.99 & 0.0028 \\
\hline 4440 & 0.0480 & 19.96 & 16.9 & 0.90 & 0.0024 \\
\hline 4850 & 0.0440 & 20.17 & 16.0 & 0.90 & 0.0022 \\
\hline 5310 & 0.0402 & 20.36 & 15.2 & 0.81 & 0.0018 \\
\hline 5810 & 0.0367 & 20.54 & 14.4 & 0.81 & 0.0016 \\
\hline 6360 & 0.0335 & 20.73 & 13.6 & 0.81 & 0.0015 \\
\hline 6950 & 0.0307 & 20.91 & 12.7 & 0.81 & 0.0014 \\
\hline 7610 & 0.0280 & 21.08 & 12.0 & 0.72 & 0.0011 \\
\hline 8320 & 0.0256 & 21.24 & 11.3 & 0.72 & 0.0010 \\
\hline 9100 & 0.0234 & 21.41 & 10.6 & 0.72 & 0.0009 \\
\hline 9960 & 0.0214 & 21.57 & 9.8 & 0.72 & 0.0008 \\
\hline 10900 & 0.0196 & 21.72 & 9.2 & 0.63 & 0.0007 \\
\hline 11900 & 0.0179 & 21.86 & 8.6 & 0.63 & 0.0006 \\
\hline 13000 & 0.0164 & 22.01 & 7.9 & 0.63 & 0.0006 \\
\hline 14300 & 0.0149 & 22.15 & 7.3 & 0.63 & 0.0005 \\
\hline 15600 & 0.0137 & 22.30 & 6.7 & 0.63 & 0.0005 \\
\hline 17100 & 0.0125 & 22.42 & 6.1 & 0.54 & 0.0004 \\
\hline 18700 & 0.0114 & 22.54 & 5.6 & 0.54 & 0.0003 \\
\hline 20400 & 0.0105 & 22.67 & 5.1 & 0.54 & 0.0003 \\
\hline 22300 & 0.0096 & 22.79 & 4.5 & 0.54 & 0.0003 \\
\hline 24400 & 0.0087 & 22.92 & 4.0 & 0.54 & 0.0003 \\
\hline 26700 & 0.0080 & 23.02 & 3.5 & 0.45 & 0.0002 \\
\hline 29300 & 0.0073 & 23.12 & 3.1 & 0.45 & 0.0002 \\
\hline 32000 & 0.0067 & 23.23 & 2.6 & 0.45 & 0.0002 \\
\hline 35000 & 0.0061 & 23.33 & 2.2 & 0.45 & 0.0002 \\
\hline 38300 & 0.0056 & 23.41 & 1.8 & 0.36 & 0.0001 \\
\hline 41900 & 0.0051 & 23.49 & 1.4 & 0.36 & 0.0001 \\
\hline 45800 & 0.0047 & 23.58 & 1.1 & 0.36 & 0.0001 \\
\hline 50100 & 0.0043 & 23.64 & 0.8 & 0.27 & 0.0001 \\
\hline 54800 & 0.0039 & 23.70 & 0.5 & 0.27 & 0.0001 \\
\hline 59500 & 0.0036 & 23.82 & 0.0 & 0.54 & 0.0001 \\
\hline
\end{tabular}


Table 6. MICP data for sample 07JRM005 - 9.1a.

\section{Mercury Injection Capillary Pressure 07JRM005 - 9.1a}

\begin{tabular}{|c|c|c|c|c|c|}
\hline \multicolumn{3}{|c|}{$\begin{array}{ll}\text { Sample Information } & \\
\text { Bulk Volume }= & 8.2263 \mathrm{cc} \\
\text { Pore Volume }= & 1.7183 \mathrm{cc} \\
\text { Closure }=1.17 \% \text { BV @ } 317 \mathrm{psia} \\
\end{array}$} & \multicolumn{3}{|c|}{$\begin{array}{lc}\text { Porosity }= & 20.9 \% \text { (mercury) } \\
\text { Permeability }= & 0.0856 \text { md (mercury) } \\
\text { Median Pore Aperture }=0.1242 \text { microns (diameter) }\end{array}$} \\
\hline $\begin{array}{l}\text { Capillary } \\
\text { Pressure } \\
\text { (psia) } \\
\end{array}$ & $\begin{array}{l}\text { Pore Aperture } \\
\text { Diameter } \\
\text { (microns) } \\
\end{array}$ & $\begin{array}{l}\text { Cumulative } \\
\text { Bulk Vol. (\%) } \\
\end{array}$ & $\begin{array}{l}\text { Wetting Phase } \\
\text { Saturation (\%) }\end{array}$ & $\begin{array}{l}\text { Incremental } \\
\text { Wetting Phase } \\
\text { Change (\%) } \\
\end{array}$ & $\begin{array}{l}\text { Saturation } \\
\text { Change } \\
\text { per psia } \\
\end{array}$ \\
\hline 1.64 & 130 & 0.02 & 100.0 & 0.00 & 0.0000 \\
\hline 1.80 & 119 & 0.02 & 100.0 & 0.00 & 0.0000 \\
\hline 1.96 & 109 & 0.04 & 100.0 & 0.00 & 0.0000 \\
\hline 2.15 & 99.2 & 0.04 & 100.0 & 0.00 & 0.0000 \\
\hline 2.35 & 90.8 & 0.06 & 100.0 & 0.00 & 0.0000 \\
\hline 2.57 & 83.0 & 0.06 & 100.0 & 0.00 & 0.0000 \\
\hline 2.81 & 75.9 & 0.06 & 100.0 & 0.00 & 0.0000 \\
\hline 3.08 & 69.3 & 0.09 & 100.0 & 0.00 & 0.0000 \\
\hline 3.37 & 63.3 & 0.09 & 100.0 & 0.00 & 0.0000 \\
\hline 3.68 & 58.0 & 0.09 & 100.0 & 0.00 & 0.0000 \\
\hline 4.03 & 52.9 & 0.09 & 100.0 & 0.00 & 0.0000 \\
\hline 4.41 & 48.4 & 0.09 & 100.0 & 0.00 & 0.0000 \\
\hline 4.82 & 44.3 & 0.09 & 100.0 & 0.00 & 0.0000 \\
\hline 5.27 & 40.5 & 0.13 & 100.0 & 0.00 & 0.0000 \\
\hline 5.77 & 37.0 & 0.13 & 100.0 & 0.00 & 0.0000 \\
\hline 6.31 & 33.8 & 0.17 & 100.0 & 0.00 & 0.0000 \\
\hline 6.90 & 30.9 & 0.17 & 100.0 & 0.00 & 0.0000 \\
\hline 7.55 & 28.3 & 0.19 & 100.0 & 0.00 & 0.0000 \\
\hline 8.26 & 25.8 & 0.19 & 100.0 & 0.00 & 0.0000 \\
\hline 9.04 & 23.6 & 0.19 & 100.0 & 0.00 & 0.0000 \\
\hline 9.89 & 21.6 & 0.21 & 100.0 & 0.00 & 0.0000 \\
\hline 10.8 & 19.8 & 0.21 & 100.0 & 0.00 & 0.0000 \\
\hline 11.8 & 18.1 & 0.23 & 100.0 & 0.00 & 0.0000 \\
\hline 12.9 & 16.5 & 0.26 & 100.0 & 0.00 & 0.0000 \\
\hline 14.2 & 15.0 & 0.26 & 100.0 & 0.00 & 0.0000 \\
\hline 15.5 & 13.8 & 0.28 & 100.0 & 0.00 & 0.0000 \\
\hline 16.9 & 12.6 & 0.28 & 100.0 & 0.00 & 0.0000 \\
\hline 18.5 & 11.5 & 0.30 & 100.0 & 0.00 & 0.0000 \\
\hline 20.3 & 10.5 & 0.32 & 100.0 & 0.00 & 0.0000 \\
\hline 22.2 & 9.61 & 0.32 & 100.0 & 0.00 & 0.0000 \\
\hline 24.3 & 8.78 & 0.34 & 100.0 & 0.00 & 0.0000 \\
\hline 26.6 & 8.02 & 0.36 & 100.0 & 0.00 & 0.0000 \\
\hline 29.0 & 7.36 & 0.43 & 100.0 & 0.00 & 0.0000 \\
\hline 31.8 & 6.71 & 0.45 & 100.0 & 0.00 & 0.0000 \\
\hline 34.8 & 6.13 & 0.47 & 100.0 & 0.00 & 0.0000 \\
\hline 38.0 & 5.61 & 0.47 & 100.0 & 0.00 & 0.0000 \\
\hline
\end{tabular}


Table 6 (cont.). MICP data for sample 07JRM005 - 9.1a.

\section{Mercury Injection Capillary Pressure 07JRM005 - 9.1a}

\begin{tabular}{|c|c|c|c|c|c|}
\hline $\begin{array}{l}\text { Capillary } \\
\text { Pressure } \\
\text { (psia) } \\
\end{array}$ & $\begin{array}{c}\text { Pore Aperture } \\
\text { Diameter } \\
\text { (microns) } \\
\end{array}$ & $\begin{array}{c}\text { Cumulative } \\
\text { Bulk Vol. (\%) } \\
\end{array}$ & $\begin{array}{l}\text { Wetting Phase } \\
\text { Saturation (\%) }\end{array}$ & $\begin{array}{c}\text { Incremental } \\
\text { Wetting Phase } \\
\text { Change (\%) } \\
\end{array}$ & $\begin{array}{c}\text { Saturation } \\
\text { Change } \\
\text { per psia } \\
\end{array}$ \\
\hline 41.6 & 5.13 & 0.49 & 100.0 & 0.00 & 0.0000 \\
\hline 45.5 & 4.69 & 0.51 & 100.0 & 0.00 & 0.0000 \\
\hline 49.8 & 4.28 & 0.53 & 100.0 & 0.00 & 0.0000 \\
\hline 54.5 & 3.91 & 0.53 & 100.0 & 0.00 & 0.0000 \\
\hline 59.6 & 3.58 & 0.53 & 100.0 & 0.00 & 0.0000 \\
\hline 65.2 & 3.27 & 0.55 & 100.0 & 0.00 & 0.0000 \\
\hline 71.3 & 2.99 & 0.55 & 100.0 & 0.00 & 0.0000 \\
\hline 78.0 & 2.73 & 0.58 & 100.0 & 0.00 & 0.0000 \\
\hline 85.3 & 2.50 & 0.58 & 100.0 & 0.00 & 0.0000 \\
\hline 93.4 & 2.28 & 0.60 & 100.0 & 0.00 & 0.0000 \\
\hline 102 & 2.09 & 0.60 & 100.0 & 0.00 & 0.0000 \\
\hline 112 & 1.90 & 0.62 & 100.0 & 0.00 & 0.0000 \\
\hline 122 & 1.75 & 0.62 & 100.0 & 0.00 & 0.0000 \\
\hline 134 & 1.59 & 0.64 & 100.0 & 0.00 & 0.0000 \\
\hline 146 & 1.46 & 0.64 & 100.0 & 0.00 & 0.0000 \\
\hline 160 & 1.33 & 0.66 & 100.0 & 0.00 & 0.0000 \\
\hline 175 & 1.22 & 0.66 & 100.0 & 0.00 & 0.0000 \\
\hline 191 & 1.12 & 0.68 & 100.0 & 0.00 & 0.0000 \\
\hline 209 & 1.02 & 0.70 & 100.0 & 0.00 & 0.0000 \\
\hline 229 & 0.932 & 0.72 & 100.0 & 0.00 & 0.0000 \\
\hline 251 & 0.850 & 0.75 & 100.0 & 0.00 & 0.0000 \\
\hline 274 & 0.779 & 0.75 & 100.0 & 0.00 & 0.0000 \\
\hline 300 & 0.711 & 0.79 & 100.0 & 0.00 & 0.0000 \\
\hline 328 & 0.650 & 0.81 & 100.0 & 0.00 & 0.0000 \\
\hline 359 & 0.594 & 0.83 & 100.0 & 0.00 & 0.0000 \\
\hline 393 & 0.543 & 0.85 & 100.0 & 0.00 & 0.0000 \\
\hline 430 & 0.496 & 0.90 & 100.0 & 0.00 & 0.0000 \\
\hline 470 & 0.454 & 0.94 & 100.0 & 0.00 & 0.0000 \\
\hline 514 & 0.415 & 0.98 & 100.0 & 0.00 & 0.0000 \\
\hline 563 & 0.379 & 1.02 & 100.0 & 0.00 & 0.0000 \\
\hline 615 & 0.347 & 1.09 & 100.0 & 0.00 & 0.0000 \\
\hline 673 & 0.317 & 1.17 & 100.0 & 0.00 & 0.0000 \\
\hline 736 & 0.290 & 1.26 & 99.6 & 0.41 & 0.0065 \\
\hline 806 & 0.265 & 1.41 & 98.9 & 0.71 & 0.0102 \\
\hline 881 & 0.242 & 1.68 & 97.6 & 1.33 & 0.0177 \\
\hline 964 & 0.221 & 2.15 & 95.3 & 2.24 & 0.0270 \\
\hline 1050 & 0.203 & 3.01 & 91.2 & 4.08 & 0.0475 \\
\hline 1150 & 0.186 & 4.65 & 83.4 & 7.86 & 0.0786 \\
\hline 1260 & 0.169 & 6.42 & 74.9 & 8.47 & 0.0770 \\
\hline 1380 & 0.155 & 8.23 & 66.2 & 8.67 & 0.0723 \\
\hline 1510 & 0.141 & 9.95 & 58.0 & 8.27 & 0.0636 \\
\hline 1650 & 0.129 & 11.17 & 52.1 & 5.82 & 0.0415 \\
\hline
\end{tabular}


Table 6 (cont.). MICP data for sample 07JRM005 - 9.1a.

\section{Mercury Injection Capillary Pressure 07JRM005 - 9.1a}

\begin{tabular}{|c|c|c|c|c|c|}
\hline $\begin{array}{c}\text { Capillary } \\
\text { Pressure } \\
\text { (psia) } \\
\end{array}$ & $\begin{array}{c}\text { Pore Aperture } \\
\text { Diameter } \\
\text { (microns) } \\
\end{array}$ & $\begin{array}{c}\text { Cumulative } \\
\text { Bulk Vol. (\%) } \\
\end{array}$ & $\begin{array}{l}\text { Wetting Phase } \\
\text { Saturation (\%) }\end{array}$ & $\begin{array}{c}\text { Incremental } \\
\text { Wetting Phase } \\
\text { Change (\%) } \\
\end{array}$ & $\begin{array}{c}\text { Saturation } \\
\text { Change } \\
\text { per psia } \\
\end{array}$ \\
\hline 1810 & 0.1179 & 12.15 & 47.4 & 4.69 & 0.0293 \\
\hline 1980 & 0.1077 & 12.98 & 43.5 & 3.98 & 0.0234 \\
\hline 2160 & 0.0988 & 13.68 & 40.1 & 3.37 & 0.0187 \\
\hline 2370 & 0.0900 & 14.37 & 36.8 & 3.27 & 0.0155 \\
\hline 2590 & 0.0824 & 14.92 & 34.2 & 2.65 & 0.0121 \\
\hline 2830 & 0.0754 & 15.43 & 31.7 & 2.45 & 0.0102 \\
\hline 3100 & 0.0688 & 15.90 & 29.5 & 2.24 & 0.0083 \\
\hline 3390 & 0.0629 & 16.33 & 27.4 & 2.04 & 0.0070 \\
\hline 3710 & 0.0575 & 16.73 & 25.5 & 1.94 & 0.0061 \\
\hline 4060 & 0.0525 & 17.09 & 23.8 & 1.73 & 0.0050 \\
\hline 4440 & 0.0480 & 17.44 & 22.1 & 1.63 & 0.0043 \\
\hline 4850 & 0.0440 & 17.71 & 20.8 & 1.33 & 0.0032 \\
\hline 5310 & 0.0402 & 18.01 & 19.4 & 1.43 & 0.0031 \\
\hline 5810 & 0.0367 & 18.29 & 18.1 & 1.33 & 0.0027 \\
\hline 6360 & 0.0335 & 18.54 & 16.8 & 1.22 & 0.0022 \\
\hline 6950 & 0.0307 & 18.76 & 15.8 & 1.02 & 0.0017 \\
\hline 7610 & 0.0280 & 18.99 & 14.7 & 1.12 & 0.0017 \\
\hline 8320 & 0.0256 & 19.20 & 13.7 & 1.02 & 0.0014 \\
\hline 9100 & 0.0234 & 19.44 & 12.6 & 1.12 & 0.0014 \\
\hline 9960 & 0.0214 & 19.63 & 11.6 & 0.92 & 0.0011 \\
\hline 10900 & 0.0196 & 19.80 & 10.8 & 0.82 & 0.0009 \\
\hline 11900 & 0.0179 & 19.99 & 9.9 & 0.92 & 0.0009 \\
\hline 13000 & 0.0164 & 20.16 & 9.1 & 0.82 & 0.0007 \\
\hline 14300 & 0.0149 & 20.33 & 8.3 & 0.82 & 0.0006 \\
\hline 15600 & 0.0137 & 20.48 & 7.6 & 0.71 & 0.0005 \\
\hline 17100 & 0.0125 & 20.63 & 6.8 & 0.71 & 0.0005 \\
\hline 18700 & 0.0114 & 20.78 & 6.1 & 0.71 & 0.0004 \\
\hline 20400 & 0.0105 & 20.91 & 5.5 & 0.61 & 0.0004 \\
\hline 22300 & 0.0096 & 21.04 & 4.9 & 0.61 & 0.0003 \\
\hline 24400 & 0.0087 & 21.17 & 4.3 & 0.61 & 0.0003 \\
\hline 26700 & 0.0080 & 21.27 & 3.8 & 0.51 & 0.0002 \\
\hline 29300 & 0.0073 & 21.40 & 3.2 & 0.61 & 0.0002 \\
\hline 32000 & 0.0067 & 21.49 & 2.8 & 0.41 & 0.0002 \\
\hline 35000 & 0.0061 & 21.57 & 2.3 & 0.41 & 0.0001 \\
\hline 38300 & 0.0056 & 21.68 & 1.8 & 0.51 & 0.0002 \\
\hline 41900 & 0.0051 & 21.76 & 1.4 & 0.41 & 0.0001 \\
\hline 45800 & 0.0047 & 21.83 & 1.1 & 0.31 & 0.0001 \\
\hline 50100 & 0.0043 & 21.91 & 0.7 & 0.41 & 0.0001 \\
\hline 54800 & 0.0039 & 21.98 & 0.4 & 0.31 & 0.0001 \\
\hline 59500 & 0.0036 & 22.06 & 0.0 & 0.41 & 0.0001 \\
\hline
\end{tabular}


Table 7. MICP data for sample 07JRM005 - 16.5.

\section{Mercury Injection Capillary Pressure 07JRM005 - 16.5}

\begin{tabular}{|c|c|c|c|c|c|}
\hline \multicolumn{6}{|c|}{ Sample Information } \\
\hline \multicolumn{3}{|c|}{$\begin{array}{l}\text { Bulk Volume }=5.668 \mathrm{cc} \\
\text { Pore Volume }=\quad 1.2286 \mathrm{cc} \\
\text { Closure }=0.59 \% \mathrm{BV} @ 175 \text { psia }\end{array}$} & \multicolumn{3}{|c|}{$\begin{array}{ll}\text { Porosity }= & 22.1 \% \text { (mercury) } \\
\text { Permeability }= & 0.494 \text { md (mercury) } \\
\text { Median Pore Aperture }=0.3213 \text { microns (diameter) }\end{array}$} \\
\hline $\begin{array}{l}\text { Capillary } \\
\text { Pressure } \\
\text { (psia) }\end{array}$ & $\begin{array}{l}\text { Pore Aperture } \\
\text { Diameter } \\
\text { (microns) }\end{array}$ & $\begin{array}{c}\text { Cumulative } \\
\text { Bulk Vol. (\%) }\end{array}$ & $\begin{array}{l}\text { Wetting Phase } \\
\text { Saturation (\%) }\end{array}$ & $\begin{array}{l}\text { Incremental } \\
\text { Wetting Phase } \\
\text { Change (\%) }\end{array}$ & $\begin{array}{l}\text { Saturation } \\
\text { Change } \\
\text { per psia }\end{array}$ \\
\hline 1.64 & 130 & 0.02 & 100.0 & 0.00 & 0.0000 \\
\hline 1.80 & 119 & 0.02 & 100.0 & 0.00 & 0.0000 \\
\hline 1.96 & 109 & 0.02 & 100.0 & 0.00 & 0.0000 \\
\hline 2.15 & 99.2 & 0.04 & 100.0 & 0.00 & 0.0000 \\
\hline 2.35 & 90.8 & 0.04 & 100.0 & 0.00 & 0.0000 \\
\hline 2.57 & 83.0 & 0.06 & 100.0 & 0.00 & 0.0000 \\
\hline 2.81 & 75.9 & 0.06 & 100.0 & 0.00 & 0.0000 \\
\hline 3.08 & 69.3 & 0.06 & 100.0 & 0.00 & 0.0000 \\
\hline 3.37 & 63.3 & 0.08 & 100.0 & 0.00 & 0.0000 \\
\hline 3.68 & 58.0 & 0.08 & 100.0 & 0.00 & 0.0000 \\
\hline 4.03 & 52.9 & 0.08 & 100.0 & 0.00 & 0.0000 \\
\hline 4.41 & 48.4 & 0.11 & 100.0 & 0.00 & 0.0000 \\
\hline 4.82 & 44.3 & 0.11 & 100.0 & 0.00 & 0.0000 \\
\hline 5.27 & 40.5 & 0.11 & 100.0 & 0.00 & 0.0000 \\
\hline 5.77 & 37.0 & 0.11 & 100.0 & 0.00 & 0.0000 \\
\hline 6.31 & 33.8 & 0.13 & 100.0 & 0.00 & 0.0000 \\
\hline 6.90 & 30.9 & 0.13 & 100.0 & 0.00 & 0.0000 \\
\hline 7.55 & 28.3 & 0.13 & 100.0 & 0.00 & 0.0000 \\
\hline 8.26 & 25.8 & 0.15 & 100.0 & 0.00 & 0.0000 \\
\hline 9.04 & 23.6 & 0.15 & 100.0 & 0.00 & 0.0000 \\
\hline 9.89 & 21.6 & 0.15 & 100.0 & 0.00 & 0.0000 \\
\hline 10.8 & 19.8 & 0.15 & 100.0 & 0.00 & 0.0000 \\
\hline 11.8 & 18.1 & 0.17 & 100.0 & 0.00 & 0.0000 \\
\hline 12.9 & 16.5 & 0.17 & 100.0 & 0.00 & 0.0000 \\
\hline 14.2 & 15.0 & 0.19 & 100.0 & 0.00 & 0.0000 \\
\hline 15.5 & 13.8 & 0.19 & 100.0 & 0.00 & 0.0000 \\
\hline 16.9 & 12.6 & 0.19 & 100.0 & 0.00 & 0.0000 \\
\hline 18.5 & 11.5 & 0.19 & 100.0 & 0.00 & 0.0000 \\
\hline 20.3 & 10.5 & 0.21 & 100.0 & 0.00 & 0.0000 \\
\hline 22.2 & 9.61 & 0.21 & 100.0 & 0.00 & 0.0000 \\
\hline 24.3 & 8.78 & 0.23 & 100.0 & 0.00 & 0.0000 \\
\hline 26.6 & 8.02 & 0.23 & 100.0 & 0.00 & 0.0000 \\
\hline 29.0 & 7.36 & 0.23 & 100.0 & 0.00 & 0.0000 \\
\hline 31.8 & 6.71 & 0.25 & 100.0 & 0.00 & 0.0000 \\
\hline 34.8 & 6.13 & 0.25 & 100.0 & 0.00 & 0.0000 \\
\hline 38.0 & 5.61 & 0.27 & 100.0 & 0.00 & 0.0000 \\
\hline
\end{tabular}


Table 7 (cont.). MICP data for sample 07JRM005 - 16.5.

\section{Mercury Injection Capillary Pressure 07JRM005 - 16.5}

\begin{tabular}{|c|c|c|c|c|c|}
\hline $\begin{array}{l}\text { Capillary } \\
\text { Pressure } \\
\text { (psia) } \\
\end{array}$ & $\begin{array}{l}\text { Pore Aperture } \\
\text { Diameter } \\
\text { (microns) } \\
\end{array}$ & $\begin{array}{c}\text { Cumulative } \\
\text { Bulk Vol. (\%) } \\
\end{array}$ & $\begin{array}{l}\text { Wetting Phase } \\
\text { Saturation (\%) }\end{array}$ & $\begin{array}{l}\text { Incremental } \\
\text { Wetting Phase } \\
\text { Change (\%) } \\
\end{array}$ & $\begin{array}{c}\text { Saturation } \\
\text { Change } \\
\text { per psia }\end{array}$ \\
\hline 41.6 & 5.13 & 0.30 & 100.0 & 0.00 & 0.0000 \\
\hline 45.5 & 4.69 & 0.32 & 100.0 & 0.00 & 0.0000 \\
\hline 49.8 & 4.28 & 0.32 & 100.0 & 0.00 & 0.0000 \\
\hline 54.5 & 3.91 & 0.32 & 100.0 & 0.00 & 0.0000 \\
\hline 59.6 & 3.58 & 0.32 & 100.0 & 0.00 & 0.0000 \\
\hline 65.2 & 3.27 & 0.34 & 100.0 & 0.00 & 0.0000 \\
\hline 71.3 & 2.99 & 0.34 & 100.0 & 0.00 & 0.0000 \\
\hline 78.0 & 2.73 & 0.36 & 100.0 & 0.00 & 0.0000 \\
\hline 85.3 & 2.50 & 0.36 & 100.0 & 0.00 & 0.0000 \\
\hline 93.4 & 2.28 & 0.38 & 100.0 & 0.00 & 0.0000 \\
\hline 102 & 2.09 & 0.38 & 100.0 & 0.00 & 0.0000 \\
\hline 112 & 1.90 & 0.40 & 100.0 & 0.00 & 0.0000 \\
\hline 122 & 1.75 & 0.42 & 100.0 & 0.00 & 0.0000 \\
\hline 134 & 1.59 & 0.44 & 100.0 & 0.00 & 0.0000 \\
\hline 146 & 1.46 & 0.49 & 100.0 & 0.00 & 0.0000 \\
\hline 160 & 1.33 & 0.53 & 100.0 & 0.00 & 0.0000 \\
\hline 175 & 1.22 & 0.59 & 100.0 & 0.00 & 0.0000 \\
\hline 191 & 1.12 & 0.70 & 99.5 & 0.48 & 0.0299 \\
\hline 209 & 1.02 & 0.89 & 98.7 & 0.86 & 0.0478 \\
\hline 229 & 0.932 & 1.18 & 97.3 & 1.34 & 0.0669 \\
\hline 251 & 0.850 & 1.56 & 95.6 & 1.72 & 0.0782 \\
\hline 274 & 0.779 & 2.09 & 93.2 & 2.39 & 0.1039 \\
\hline 300 & 0.711 & 2.91 & 89.5 & 3.73 & 0.1434 \\
\hline 328 & 0.650 & 4.20 & 83.7 & 5.83 & 0.2083 \\
\hline 359 & 0.594 & 5.68 & 77.0 & 6.69 & 0.2159 \\
\hline 393 & 0.543 & 6.94 & 71.2 & 5.74 & 0.1687 \\
\hline 430 & 0.496 & 8.04 & 66.3 & 4.97 & 0.1344 \\
\hline 470 & 0.454 & 8.97 & 62.0 & 4.21 & 0.1052 \\
\hline 514 & 0.415 & 9.77 & 58.4 & 3.63 & 0.0826 \\
\hline 563 & 0.379 & 10.44 & 55.4 & 3.06 & 0.0624 \\
\hline 615 & 0.347 & 11.10 & 52.4 & 2.96 & 0.0570 \\
\hline 673 & 0.317 & 11.71 & 49.6 & 2.77 & 0.0478 \\
\hline 736 & 0.290 & 12.28 & 47.0 & 2.58 & 0.0410 \\
\hline 806 & 0.265 & 12.81 & 44.6 & 2.39 & 0.0341 \\
\hline 881 & 0.242 & 13.34 & 42.3 & 2.39 & 0.0319 \\
\hline 964 & 0.221 & 13.88 & 39.8 & 2.49 & 0.0299 \\
\hline 1050 & 0.203 & 14.41 & 37.4 & 2.39 & 0.0278 \\
\hline 1150 & 0.186 & 14.81 & 35.6 & 1.82 & 0.0182 \\
\hline 1260 & 0.169 & 15.17 & 33.9 & 1.63 & 0.0148 \\
\hline 1380 & 0.155 & 15.55 & 32.2 & 1.72 & 0.0143 \\
\hline 1510 & 0.141 & 15.91 & 30.6 & 1.63 & 0.0125 \\
\hline 1650 & 0.129 & 16.25 & 29.1 & 1.53 & 0.0109 \\
\hline
\end{tabular}


Table 7 (cont.). MICP data for sample 07JRM005 - 16.5.

\section{Mercury Injection Capillary Pressure 07JRM005 - 16.5}

\begin{tabular}{|c|c|c|c|c|c|}
\hline $\begin{array}{l}\text { Capillary } \\
\text { Pressure } \\
\text { (psia) } \\
\end{array}$ & $\begin{array}{l}\text { Pore Aperture } \\
\text { Diameter } \\
\text { (microns) } \\
\end{array}$ & $\begin{array}{c}\text { Cumulative } \\
\text { Bulk Vol. (\%) } \\
\end{array}$ & $\begin{array}{l}\text { Wetting Phase } \\
\text { Saturation (\%) }\end{array}$ & $\begin{array}{c}\text { Incremental } \\
\text { Wetting Phase } \\
\text { Change (\%) } \\
\end{array}$ & $\begin{array}{c}\text { Saturation } \\
\text { Change } \\
\text { per psia } \\
\end{array}$ \\
\hline 1810 & 0.1179 & 16.58 & 27.5 & 1.53 & 0.0096 \\
\hline 1980 & 0.1077 & 16.90 & 26.1 & 1.43 & 0.0084 \\
\hline 2160 & 0.0988 & 17.20 & 24.8 & 1.34 & 0.0074 \\
\hline 2370 & 0.0900 & 17.49 & 23.4 & 1.34 & 0.0064 \\
\hline 2590 & 0.0824 & 17.77 & 22.2 & 1.24 & 0.0056 \\
\hline 2830 & 0.0754 & 18.04 & 20.9 & 1.24 & 0.0052 \\
\hline 3100 & 0.0688 & 18.29 & 19.8 & 1.15 & 0.0042 \\
\hline 3390 & 0.0629 & 18.53 & 18.7 & 1.05 & 0.0036 \\
\hline 3710 & 0.0575 & 18.76 & 17.7 & 1.05 & 0.0033 \\
\hline 4060 & 0.0525 & 18.97 & 16.7 & 0.96 & 0.0027 \\
\hline 4440 & 0.0480 & 19.18 & 15.8 & 0.96 & 0.0025 \\
\hline 4850 & 0.0440 & 19.35 & 15.0 & 0.76 & 0.0019 \\
\hline 5310 & 0.0402 & 19.54 & 14.1 & 0.86 & 0.0019 \\
\hline 5810 & 0.0367 & 19.73 & 13.3 & 0.86 & 0.0017 \\
\hline 6360 & 0.0335 & 19.90 & 12.5 & 0.76 & 0.0014 \\
\hline 6950 & 0.0307 & 20.07 & 11.8 & 0.76 & 0.0013 \\
\hline 7610 & 0.0280 & 20.23 & 11.0 & 0.76 & 0.0012 \\
\hline 8320 & 0.0256 & 20.38 & 10.3 & 0.67 & 0.0009 \\
\hline 9100 & 0.0234 & 20.55 & 9.6 & 0.76 & 0.0010 \\
\hline 9960 & 0.0214 & 20.70 & 8.9 & 0.67 & 0.0008 \\
\hline 10900 & 0.0196 & 20.85 & 8.2 & 0.67 & 0.0007 \\
\hline 11900 & 0.0179 & 20.97 & 7.6 & 0.57 & 0.0006 \\
\hline 13000 & 0.0164 & 21.10 & 7.1 & 0.57 & 0.0005 \\
\hline 14300 & 0.0149 & 21.25 & 6.4 & 0.67 & 0.0005 \\
\hline 15600 & 0.0137 & 21.37 & 5.8 & 0.57 & 0.0004 \\
\hline 17100 & 0.0125 & 21.48 & 5.4 & 0.48 & 0.0003 \\
\hline 18700 & 0.0114 & 21.61 & 4.8 & 0.57 & 0.0004 \\
\hline 20400 & 0.0105 & 21.71 & 4.3 & 0.48 & 0.0003 \\
\hline 22300 & 0.0096 & 21.82 & 3.8 & 0.48 & 0.0003 \\
\hline 24400 & 0.0087 & 21.92 & 3.3 & 0.48 & 0.0002 \\
\hline 26700 & 0.0080 & 22.01 & 3.0 & 0.38 & 0.0002 \\
\hline 29300 & 0.0073 & 22.11 & 2.5 & 0.48 & 0.0002 \\
\hline 32000 & 0.0067 & 22.20 & 2.1 & 0.38 & 0.0001 \\
\hline 35000 & 0.0061 & 22.26 & 1.8 & 0.29 & 0.0001 \\
\hline 38300 & 0.0056 & 22.34 & 1.4 & 0.38 & 0.0001 \\
\hline 41900 & 0.0051 & 22.41 & 1.1 & 0.29 & 0.0001 \\
\hline 45800 & 0.0047 & 22.47 & 0.9 & 0.29 & 0.0001 \\
\hline 50100 & 0.0043 & 22.53 & 0.6 & 0.29 & 0.0001 \\
\hline 54800 & 0.0039 & 22.58 & 0.4 & 0.19 & 0.0000 \\
\hline 59500 & 0.0036 & 22.66 & 0.0 & 0.38 & 0.0001 \\
\hline
\end{tabular}


Table 8. MICP data for sample 07JRM006 - 18.3a.

\section{Mercury Injection Capillary Pressure 07JRM006 - 18.3a}

\begin{tabular}{|c|c|c|c|c|c|}
\hline \multicolumn{3}{|c|}{ Sample Information } & \multirow{2}{*}{\multicolumn{3}{|c|}{$\begin{array}{l}\text { Porosity }=\quad 22.1 \% \text { (mercury) } \\
\text { Permeability }=\quad 0.0682 \text { md (mercury) } \\
\text { Median Pore Aperture }=0.1013 \text { microns (diameter) }\end{array}$}} \\
\hline $\begin{array}{l}\text { Bulk Volume } \\
\text { Pore Volume } \\
\text { Closure }=1.42\end{array}$ & $\begin{array}{c}8.2225 \mathrm{cc} \\
1.8167 \mathrm{cc} \\
\% \mathrm{BV} @ 881 \text { psia }\end{array}$ & & & & \\
\hline $\begin{array}{l}\text { Capillary } \\
\text { Pressure } \\
\text { (psia) } \\
\end{array}$ & $\begin{array}{l}\text { Pore Aperture } \\
\text { Diameter } \\
\text { (microns) } \\
\end{array}$ & $\begin{array}{c}\text { Cumulative } \\
\text { Bulk Vol. (\%) } \\
\end{array}$ & $\begin{array}{l}\text { Wetting Phase } \\
\text { Saturation (\%) }\end{array}$ & $\begin{array}{l}\text { Incremental } \\
\text { Wetting Phase } \\
\text { Change (\%) } \\
\end{array}$ & $\begin{array}{l}\text { Saturation } \\
\text { Change } \\
\text { per psia } \\
\end{array}$ \\
\hline 1.64 & 130 & 0.00 & 100.0 & 0.00 & 0.0000 \\
\hline 1.80 & 119 & 0.02 & 100.0 & 0.00 & 0.0000 \\
\hline 1.96 & 109 & 0.02 & 100.0 & 0.00 & 0.0000 \\
\hline 2.15 & 99.2 & 0.02 & 100.0 & 0.00 & 0.0000 \\
\hline 2.35 & 90.8 & 0.04 & 100.0 & 0.00 & 0.0000 \\
\hline 2.57 & 83.0 & 0.04 & 100.0 & 0.00 & 0.0000 \\
\hline 2.81 & 75.9 & 0.04 & 100.0 & 0.00 & 0.0000 \\
\hline 3.08 & 69.3 & 0.04 & 100.0 & 0.00 & 0.0000 \\
\hline 3.37 & 63.3 & 0.04 & 100.0 & 0.00 & 0.0000 \\
\hline 3.68 & 58.0 & 0.04 & 100.0 & 0.00 & 0.0000 \\
\hline 4.03 & 52.9 & 0.04 & 100.0 & 0.00 & 0.0000 \\
\hline 4.41 & 48.4 & 0.04 & 100.0 & 0.00 & 0.0000 \\
\hline 4.82 & 44.3 & 0.04 & 100.0 & 0.00 & 0.0000 \\
\hline 5.27 & 40.5 & 0.04 & 100.0 & 0.00 & 0.0000 \\
\hline 5.77 & 37.0 & 0.04 & 100.0 & 0.00 & 0.0000 \\
\hline 6.31 & 33.8 & 0.07 & 100.0 & 0.00 & 0.0000 \\
\hline 6.90 & 30.9 & 0.13 & 100.0 & 0.00 & 0.0000 \\
\hline 7.55 & 28.3 & 0.13 & 100.0 & 0.00 & 0.0000 \\
\hline 8.26 & 25.8 & 0.15 & 100.0 & 0.00 & 0.0000 \\
\hline 9.04 & 23.6 & 0.15 & 100.0 & 0.00 & 0.0000 \\
\hline 9.89 & 21.6 & 0.15 & 100.0 & 0.00 & 0.0000 \\
\hline 10.8 & 19.8 & 0.17 & 100.0 & 0.00 & 0.0000 \\
\hline 11.8 & 18.1 & 0.17 & 100.0 & 0.00 & 0.0000 \\
\hline 12.9 & 16.5 & 0.17 & 100.0 & 0.00 & 0.0000 \\
\hline 14.2 & 15.0 & 0.20 & 100.0 & 0.00 & 0.0000 \\
\hline 15.5 & 13.8 & 0.20 & 100.0 & 0.00 & 0.0000 \\
\hline 16.9 & 12.6 & 0.20 & 100.0 & 0.00 & 0.0000 \\
\hline 18.5 & 11.5 & 0.22 & 100.0 & 0.00 & 0.0000 \\
\hline 20.3 & 10.5 & 0.22 & 100.0 & 0.00 & 0.0000 \\
\hline 22.2 & 9.61 & 0.22 & 100.0 & 0.00 & 0.0000 \\
\hline 24.3 & 8.78 & 0.24 & 100.0 & 0.00 & 0.0000 \\
\hline 26.6 & 8.02 & 0.24 & 100.0 & 0.00 & 0.0000 \\
\hline 29.0 & 7.36 & 0.26 & 100.0 & 0.00 & 0.0000 \\
\hline 31.8 & 6.71 & 0.26 & 100.0 & 0.00 & 0.0000 \\
\hline 34.8 & 6.13 & 0.28 & 100.0 & 0.00 & 0.0000 \\
\hline 38.0 & 5.61 & 0.28 & 100.0 & 0.00 & 0.0000 \\
\hline
\end{tabular}


Table 8 (cont.). MICP data for sample 07JRM006 - 18.3a.

\section{Mercury Injection Capillary Pressure 07JRM006 - 18.3a}

\begin{tabular}{|c|c|c|c|c|c|}
\hline $\begin{array}{c}\text { Capillary } \\
\text { Pressure } \\
\text { (psia) } \\
\end{array}$ & $\begin{array}{c}\text { Pore Aperture } \\
\text { Diameter } \\
\text { (microns) } \\
\end{array}$ & $\begin{array}{c}\text { Cumulative } \\
\text { Bulk Vol. (\%) } \\
\end{array}$ & $\begin{array}{l}\text { Wetting Phase } \\
\text { Saturation (\%) }\end{array}$ & $\begin{array}{c}\text { Incremental } \\
\text { Wetting Phase } \\
\text { Change (\%) } \\
\end{array}$ & $\begin{array}{c}\text { Saturation } \\
\text { Change } \\
\text { per psia } \\
\end{array}$ \\
\hline 41.6 & 5.13 & 0.31 & 100.0 & 0.00 & 0.0000 \\
\hline 45.5 & 4.69 & 0.33 & 100.0 & 0.00 & 0.0000 \\
\hline 49.8 & 4.28 & 0.33 & 100.0 & 0.00 & 0.0000 \\
\hline 54.5 & 3.91 & 0.35 & 100.0 & 0.00 & 0.0000 \\
\hline 59.6 & 3.58 & 0.35 & 100.0 & 0.00 & 0.0000 \\
\hline 65.2 & 3.27 & 0.37 & 100.0 & 0.00 & 0.0000 \\
\hline 71.3 & 2.99 & 0.37 & 100.0 & 0.00 & 0.0000 \\
\hline 78.0 & 2.73 & 0.37 & 100.0 & 0.00 & 0.0000 \\
\hline 85.3 & 2.50 & 0.39 & 100.0 & 0.00 & 0.0000 \\
\hline 93.4 & 2.28 & 0.41 & 100.0 & 0.00 & 0.0000 \\
\hline 102 & 2.09 & 0.41 & 100.0 & 0.00 & 0.0000 \\
\hline 112 & 1.90 & 0.46 & 100.0 & 0.00 & 0.0000 \\
\hline 122 & 1.75 & 0.48 & 100.0 & 0.00 & 0.0000 \\
\hline 134 & 1.59 & 0.48 & 100.0 & 0.00 & 0.0000 \\
\hline 146 & 1.46 & 0.50 & 100.0 & 0.00 & 0.0000 \\
\hline 160 & 1.33 & 0.52 & 100.0 & 0.00 & 0.0000 \\
\hline 175 & 1.22 & 0.59 & 100.0 & 0.00 & 0.0000 \\
\hline 191 & 1.12 & 0.61 & 100.0 & 0.00 & 0.0000 \\
\hline 209 & 1.02 & 0.63 & 100.0 & 0.00 & 0.0000 \\
\hline 229 & 0.932 & 0.65 & 100.0 & 0.00 & 0.0000 \\
\hline 251 & 0.850 & 0.68 & 100.0 & 0.00 & 0.0000 \\
\hline 274 & 0.779 & 0.72 & 100.0 & 0.00 & 0.0000 \\
\hline 300 & 0.711 & 0.74 & 100.0 & 0.00 & 0.0000 \\
\hline 328 & 0.650 & 0.76 & 100.0 & 0.00 & 0.0000 \\
\hline 359 & 0.594 & 0.81 & 100.0 & 0.00 & 0.0000 \\
\hline 393 & 0.543 & 0.83 & 100.0 & 0.00 & 0.0000 \\
\hline 430 & 0.496 & 0.87 & 100.0 & 0.00 & 0.0000 \\
\hline 470 & 0.454 & 0.89 & 100.0 & 0.00 & 0.0000 \\
\hline 514 & 0.415 & 0.94 & 100.0 & 0.00 & 0.0000 \\
\hline 563 & 0.379 & 0.98 & 100.0 & 0.00 & 0.0000 \\
\hline 615 & 0.347 & 1.05 & 100.0 & 0.00 & 0.0000 \\
\hline 673 & 0.317 & 1.11 & 100.0 & 0.00 & 0.0000 \\
\hline 736 & 0.290 & 1.20 & 100.0 & 0.00 & 0.0000 \\
\hline 806 & 0.265 & 1.29 & 100.0 & 0.00 & 0.0000 \\
\hline 881 & 0.242 & 1.42 & 100.0 & 0.00 & 0.0000 \\
\hline 964 & 0.221 & 1.57 & 99.3 & 0.69 & 0.0083 \\
\hline 1050 & 0.203 & 1.85 & 98.0 & 1.28 & 0.0149 \\
\hline 1150 & 0.186 & 2.36 & 95.8 & 2.27 & 0.0227 \\
\hline 1260 & 0.169 & 3.21 & 91.9 & 3.85 & 0.0350 \\
\hline 1380 & 0.155 & 4.82 & 84.6 & 7.31 & 0.0609 \\
\hline 1510 & 0.141 & 6.67 & 76.2 & 8.39 & 0.0645 \\
\hline 1650 & 0.129 & 8.64 & 67.3 & 8.88 & 0.0635 \\
\hline
\end{tabular}


Table 8 (cont.). MICP data for sample 07JRM006 - 18.3a.

\section{Mercury Injection Capillary Pressure 07JRM006 - 18.3a}

\begin{tabular}{|c|c|c|c|c|c|}
\hline $\begin{array}{c}\text { Capillary } \\
\text { Pressure } \\
\text { (psia) } \\
\end{array}$ & $\begin{array}{c}\text { Pore Aperture } \\
\text { Diameter } \\
\text { (microns) } \\
\end{array}$ & $\begin{array}{c}\text { Cumulative } \\
\text { Bulk Vol. (\%) } \\
\end{array}$ & $\begin{array}{l}\text { Wetting Phase } \\
\text { Saturation (\%) }\end{array}$ & $\begin{array}{c}\text { Incremental } \\
\text { Wetting Phase } \\
\text { Change (\%) } \\
\end{array}$ & $\begin{array}{c}\text { Saturation } \\
\text { Change } \\
\text { per psia }\end{array}$ \\
\hline 1810 & 0.1179 & 10.32 & 59.7 & 7.60 & 0.0475 \\
\hline 1980 & 0.1077 & 11.67 & 53.6 & 6.12 & 0.0360 \\
\hline 2160 & 0.0988 & 12.78 & 48.6 & 5.03 & 0.0280 \\
\hline 2370 & 0.0900 & 13.85 & 43.7 & 4.84 & 0.0230 \\
\hline 2590 & 0.0824 & 14.72 & 39.8 & 3.95 & 0.0179 \\
\hline 2830 & 0.0754 & 15.49 & 36.3 & 3.46 & 0.0144 \\
\hline 3100 & 0.0688 & 16.21 & 33.1 & 3.26 & 0.0121 \\
\hline 3390 & 0.0629 & 16.82 & 30.3 & 2.76 & 0.0095 \\
\hline 3710 & 0.0575 & 17.36 & 27.8 & 2.47 & 0.0077 \\
\hline 4060 & 0.0525 & 17.84 & 25.7 & 2.17 & 0.0062 \\
\hline 4440 & 0.0480 & 18.30 & 23.6 & 2.07 & 0.0055 \\
\hline 4850 & 0.0440 & 18.67 & 21.9 & 1.68 & 0.0041 \\
\hline 5310 & 0.0402 & 19.04 & 20.2 & 1.68 & 0.0036 \\
\hline 5810 & 0.0367 & 19.37 & 18.8 & 1.48 & 0.0030 \\
\hline 6360 & 0.0335 & 19.67 & 17.4 & 1.38 & 0.0025 \\
\hline 6950 & 0.0307 & 19.98 & 16.0 & 1.38 & 0.0023 \\
\hline 7610 & 0.0280 & 20.24 & 14.8 & 1.18 & 0.0018 \\
\hline 8320 & 0.0256 & 20.48 & 13.7 & 1.09 & 0.0015 \\
\hline 9100 & 0.0234 & 20.72 & 12.6 & 1.09 & 0.0014 \\
\hline 9960 & 0.0214 & 20.94 & 11.6 & 0.99 & 0.0011 \\
\hline 10900 & 0.0196 & 21.13 & 10.8 & 0.89 & 0.0009 \\
\hline 11900 & 0.0179 & 21.33 & 9.9 & 0.89 & 0.0009 \\
\hline 13000 & 0.0164 & 21.51 & 9.1 & 0.79 & 0.0007 \\
\hline 14300 & 0.0149 & 21.68 & 8.3 & 0.79 & 0.0006 \\
\hline 15600 & 0.0137 & 21.83 & 7.6 & 0.69 & 0.0005 \\
\hline 17100 & 0.0125 & 21.99 & 6.9 & 0.69 & 0.0005 \\
\hline 18700 & 0.0114 & 22.14 & 6.2 & 0.69 & 0.0004 \\
\hline 20400 & 0.0105 & 22.27 & 5.6 & 0.59 & 0.0003 \\
\hline 22300 & 0.0096 & 22.40 & 5.0 & 0.59 & 0.0003 \\
\hline 24400 & 0.0087 & 22.53 & 4.4 & 0.59 & 0.0003 \\
\hline 26700 & 0.0080 & 22.66 & 3.8 & 0.59 & 0.0003 \\
\hline 29300 & 0.0073 & 22.77 & 3.4 & 0.49 & 0.0002 \\
\hline 32000 & 0.0067 & 22.88 & 2.9 & 0.49 & 0.0002 \\
\hline 35000 & 0.0061 & 22.97 & 2.5 & 0.39 & 0.0001 \\
\hline 38300 & 0.0056 & 23.08 & 2.0 & 0.49 & 0.0001 \\
\hline 41900 & 0.0051 & 23.16 & 1.6 & 0.39 & 0.0001 \\
\hline 45800 & 0.0047 & 23.25 & 1.2 & 0.39 & 0.0001 \\
\hline 50100 & 0.0043 & 23.32 & 0.9 & 0.30 & 0.0001 \\
\hline 54800 & 0.0039 & 23.42 & 0.4 & 0.49 & 0.0001 \\
\hline 59500 & 0.0036 & 23.51 & 0.0 & 0.39 & 0.0001 \\
\hline
\end{tabular}


Table 9. MICP data for sample 07JRM008 - 26.5a.

\section{Mercury Injection Capillary Pressure 07JRM008 - 26.5a}

\begin{tabular}{|c|c|c|c|c|c|}
\hline \multicolumn{6}{|c|}{ Sample Information } \\
\hline \multirow{3}{*}{\multicolumn{3}{|c|}{$\begin{array}{lr}\text { Bulk Volume }= & 7.0014 \mathrm{cc} \\
\text { Pore Volume }= & 1.6765 \mathrm{cc} \\
\text { Closure }=0.70 \% \mathrm{BV} @ 300 \mathrm{psia} \\
\end{array}$}} & \multirow{3}{*}{\multicolumn{3}{|c|}{$\begin{array}{l}\text { Porosity }=\quad 24.0 \% \text { (mercury) } \\
\text { Permeability }=0.422 \text { md (mercury) } \\
\text { Median Pore Aperture }=0.290 \text { microns (diameter }\end{array}$}} \\
\hline & & & & & \\
\hline & & & & & \\
\hline Capillary & Pore Aperture & & & Incremental & Saturation \\
\hline $\begin{array}{c}\text { Pressure } \\
\text { (psia) }\end{array}$ & $\begin{array}{l}\text { Diameter } \\
\text { (microns) } \\
\end{array}$ & $\begin{array}{c}\text { Cumulative } \\
\text { Bulk Vol. (\%) }\end{array}$ & $\begin{array}{l}\text { Wetting Phase } \\
\text { Saturation (\%) }\end{array}$ & $\begin{array}{c}\text { Wetting Phase } \\
\text { Change (\%) }\end{array}$ & $\begin{array}{l}\text { Change } \\
\text { per psia }\end{array}$ \\
\hline 1.64 & 130 & 0.02 & 100.0 & 0.00 & 0.0000 \\
\hline 1.80 & 119 & 0.02 & 100.0 & 0.00 & 0.0000 \\
\hline 1.96 & 109 & 0.02 & 100.0 & 0.00 & 0.0000 \\
\hline 2.15 & 99.2 & 0.02 & 100.0 & 0.00 & 0.0000 \\
\hline 2.35 & 90.8 & 0.04 & 100.0 & 0.00 & 0.0000 \\
\hline 2.57 & 83.0 & 0.04 & 100.0 & 0.00 & 0.0000 \\
\hline 2.81 & 75.9 & 0.04 & 100.0 & 0.00 & 0.0000 \\
\hline 3.08 & 69.3 & 0.06 & 100.0 & 0.00 & 0.0000 \\
\hline 3.37 & 63.3 & 0.06 & 100.0 & 0.00 & 0.0000 \\
\hline 3.68 & 58.0 & 0.06 & 100.0 & 0.00 & 0.0000 \\
\hline 4.03 & 52.9 & 0.08 & 100.0 & 0.00 & 0.0000 \\
\hline 4.41 & 48.4 & 0.08 & 100.0 & 0.00 & 0.0000 \\
\hline 4.82 & 44.3 & 0.08 & 100.0 & 0.00 & 0.0000 \\
\hline 5.27 & 40.5 & 0.10 & 100.0 & 0.00 & 0.0000 \\
\hline 5.77 & 37.0 & 0.10 & 100.0 & 0.00 & 0.0000 \\
\hline 6.31 & 33.8 & 0.10 & 100.0 & 0.00 & 0.0000 \\
\hline 6.90 & 30.9 & 0.12 & 100.0 & 0.00 & 0.0000 \\
\hline 7.55 & 28.3 & 0.12 & 100.0 & 0.00 & 0.0000 \\
\hline 8.26 & 25.8 & 0.12 & 100.0 & 0.00 & 0.0000 \\
\hline 9.04 & 23.6 & 0.14 & 100.0 & 0.00 & 0.0000 \\
\hline 9.89 & 21.6 & 0.14 & 100.0 & 0.00 & 0.0000 \\
\hline 10.8 & 19.8 & 0.16 & 100.0 & 0.00 & 0.0000 \\
\hline 11.8 & 18.1 & 0.16 & 100.0 & 0.00 & 0.0000 \\
\hline 12.9 & 16.5 & 0.16 & 100.0 & 0.00 & 0.0000 \\
\hline 14.2 & 15.0 & 0.18 & 100.0 & 0.00 & 0.0000 \\
\hline 15.5 & 13.8 & 0.18 & 100.0 & 0.00 & 0.0000 \\
\hline 16.9 & 12.6 & 0.20 & 100.0 & 0.00 & 0.0000 \\
\hline 18.5 & 11.5 & 0.20 & 100.0 & 0.00 & 0.0000 \\
\hline 20.3 & 10.5 & 0.22 & 100.0 & 0.00 & 0.0000 \\
\hline 22.2 & 9.61 & 0.22 & 100.0 & 0.00 & 0.0000 \\
\hline 24.3 & 8.78 & 0.25 & 100.0 & 0.00 & 0.0000 \\
\hline 26.6 & 8.02 & 0.25 & 100.0 & 0.00 & 0.0000 \\
\hline 29.0 & 7.36 & 0.27 & 100.0 & 0.00 & 0.0000 \\
\hline 31.8 & 6.71 & 0.29 & 100.0 & 0.00 & 0.0000 \\
\hline 34.8 & 6.13 & 0.29 & 100.0 & 0.00 & 0.0000 \\
\hline 38.0 & 5.61 & 0.31 & 100.0 & 0.00 & 0.0000 \\
\hline
\end{tabular}


Table 9 (cont.). MICP data for sample 07JRM008 - 26.5a.

\section{Mercury Injection Capillary Pressure 07JRM008 - 26.5a}

\begin{tabular}{|c|c|c|c|c|c|}
\hline $\begin{array}{c}\text { Capillary } \\
\text { Pressure } \\
\text { (psia) } \\
\end{array}$ & $\begin{array}{c}\text { Pore Aperture } \\
\text { Diameter } \\
\text { (microns) } \\
\end{array}$ & $\begin{array}{c}\text { Cumulative } \\
\text { Bulk Vol. (\%) } \\
\end{array}$ & $\begin{array}{l}\text { Wetting Phase } \\
\text { Saturation (\%) }\end{array}$ & $\begin{array}{c}\text { Incremental } \\
\text { Wetting Phase } \\
\text { Change (\%) } \\
\end{array}$ & $\begin{array}{c}\text { Saturation } \\
\text { Change } \\
\text { per psia } \\
\end{array}$ \\
\hline 41.6 & 5.13 & 0.31 & 100.0 & 0.00 & 0.0000 \\
\hline 45.5 & 4.69 & 0.33 & 100.0 & 0.00 & 0.0000 \\
\hline 49.8 & 4.28 & 0.33 & 100.0 & 0.00 & 0.0000 \\
\hline 54.5 & 3.91 & 0.35 & 100.0 & 0.00 & 0.0000 \\
\hline 59.6 & 3.58 & 0.35 & 100.0 & 0.00 & 0.0000 \\
\hline 65.2 & 3.27 & 0.35 & 100.0 & 0.00 & 0.0000 \\
\hline 71.3 & 2.99 & 0.35 & 100.0 & 0.00 & 0.0000 \\
\hline 78.0 & 2.73 & 0.37 & 100.0 & 0.00 & 0.0000 \\
\hline 85.3 & 2.50 & 0.37 & 100.0 & 0.00 & 0.0000 \\
\hline 93.4 & 2.28 & 0.39 & 100.0 & 0.00 & 0.0000 \\
\hline 102 & 2.09 & 0.39 & 100.0 & 0.00 & 0.0000 \\
\hline 112 & 1.90 & 0.41 & 100.0 & 0.00 & 0.0000 \\
\hline 122 & 1.75 & 0.43 & 100.0 & 0.00 & 0.0000 \\
\hline 134 & 1.59 & 0.43 & 100.0 & 0.00 & 0.0000 \\
\hline 146 & 1.46 & 0.45 & 100.0 & 0.00 & 0.0000 \\
\hline 160 & 1.33 & 0.47 & 100.0 & 0.00 & 0.0000 \\
\hline 175 & 1.22 & 0.49 & 100.0 & 0.00 & 0.0000 \\
\hline 191 & 1.12 & 0.51 & 100.0 & 0.00 & 0.0000 \\
\hline 209 & 1.02 & 0.53 & 100.0 & 0.00 & 0.0000 \\
\hline 229 & 0.932 & 0.55 & 100.0 & 0.00 & 0.0000 \\
\hline 251 & 0.850 & 0.59 & 100.0 & 0.00 & 0.0000 \\
\hline 274 & 0.779 & 0.63 & 100.0 & 0.00 & 0.0000 \\
\hline 300 & 0.711 & 0.70 & 100.0 & 0.00 & 0.0000 \\
\hline 328 & 0.650 & 0.80 & 99.6 & 0.43 & 0.0152 \\
\hline 359 & 0.594 & 0.98 & 98.8 & 0.77 & 0.0248 \\
\hline 393 & 0.543 & 1.55 & 96.4 & 2.39 & 0.0703 \\
\hline 430 & 0.496 & 3.46 & 88.5 & 7.94 & 0.2146 \\
\hline 470 & 0.454 & 6.05 & 77.6 & 10.85 & 0.2711 \\
\hline 514 & 0.415 & 7.89 & 69.9 & 7.69 & 0.1747 \\
\hline 563 & 0.379 & 9.39 & 63.7 & 6.23 & 0.1272 \\
\hline 615 & 0.347 & 10.61 & 58.6 & 5.12 & 0.0985 \\
\hline 673 & 0.317 & 11.70 & 54.1 & 4.53 & 0.0780 \\
\hline 736 & 0.290 & 12.68 & 50.0 & 4.10 & 0.0651 \\
\hline 806 & 0.265 & 13.56 & 46.3 & 3.67 & 0.0525 \\
\hline 881 & 0.242 & 14.38 & 42.9 & 3.42 & 0.0455 \\
\hline 964 & 0.221 & 15.15 & 39.6 & 3.25 & 0.0391 \\
\hline 1050 & 0.203 & 15.83 & 36.8 & 2.82 & 0.0328 \\
\hline 1150 & 0.186 & 16.52 & 33.9 & 2.90 & 0.0290 \\
\hline 1260 & 0.169 & 17.10 & 31.5 & 2.39 & 0.0217 \\
\hline 1380 & 0.155 & 17.59 & 29.5 & 2.05 & 0.0171 \\
\hline 1510 & 0.141 & 18.08 & 27.4 & 2.05 & 0.0158 \\
\hline 1650 & 0.129 & 18.51 & 25.6 & 1.79 & 0.0128 \\
\hline
\end{tabular}


Table 9 (cont.). MICP data for sample 07JRM008 - $26.5 a$.

\section{Mercury Injection Capillary Pressure 07JRM008 - 26.5a}

\begin{tabular}{|c|c|c|c|c|c|}
\hline $\begin{array}{c}\text { Capillary } \\
\text { Pressure } \\
\text { (psia) } \\
\end{array}$ & $\begin{array}{c}\text { Pore Aperture } \\
\text { Diameter } \\
\text { (microns) }\end{array}$ & $\begin{array}{c}\text { Cumulative } \\
\text { Bulk Vol. (\%) } \\
\end{array}$ & $\begin{array}{l}\text { Wetting Phase } \\
\text { Saturation (\%) }\end{array}$ & $\begin{array}{c}\text { Incremental } \\
\text { Wetting Phase } \\
\text { Change (\%) }\end{array}$ & $\begin{array}{c}\text { Saturation } \\
\text { Change } \\
\text { per psia }\end{array}$ \\
\hline 1810 & 0.1179 & 18.94 & 23.8 & 1.79 & 0.0112 \\
\hline 1980 & 0.1077 & 19.30 & 22.3 & 1.54 & 0.0090 \\
\hline 2160 & 0.0988 & 19.65 & 20.8 & 1.45 & 0.0081 \\
\hline 2370 & 0.0900 & 20.00 & 19.4 & 1.45 & 0.0069 \\
\hline 2590 & 0.0824 & 20.29 & 18.2 & 1.20 & 0.0054 \\
\hline 2830 & 0.0754 & 20.57 & 17.0 & 1.20 & 0.0050 \\
\hline 3100 & 0.0688 & 20.84 & 15.9 & 1.11 & 0.0041 \\
\hline 3390 & 0.0629 & 21.08 & 14.9 & 1.02 & 0.0035 \\
\hline 3710 & 0.0575 & 21.33 & 13.8 & 1.02 & 0.0032 \\
\hline 4060 & 0.0525 & 21.53 & 13.0 & 0.85 & 0.0024 \\
\hline 4440 & 0.0480 & 21.74 & 12.1 & 0.85 & 0.0022 \\
\hline 4850 & 0.0440 & 21.92 & 11.4 & 0.77 & 0.0019 \\
\hline 5310 & 0.0402 & 22.08 & 10.7 & 0.68 & 0.0015 \\
\hline 5810 & 0.0367 & 22.27 & 9.9 & 0.77 & 0.0015 \\
\hline 6360 & 0.0335 & 22.43 & 9.2 & 0.68 & 0.0012 \\
\hline 6950 & 0.0307 & 22.58 & 8.6 & 0.60 & 0.0010 \\
\hline 7610 & 0.0280 & 22.72 & 8.0 & 0.60 & 0.0009 \\
\hline 8320 & 0.0256 & 22.86 & 7.4 & 0.60 & 0.0008 \\
\hline 9100 & 0.0234 & 22.98 & 6.9 & 0.51 & 0.0007 \\
\hline 9960 & 0.0214 & 23.11 & 6.4 & 0.51 & 0.0006 \\
\hline 10900 & 0.0196 & 23.23 & 5.9 & 0.51 & 0.0005 \\
\hline 11900 & 0.0179 & 23.33 & 5.5 & 0.43 & 0.0004 \\
\hline 13000 & 0.0164 & 23.43 & 5.0 & 0.43 & 0.0004 \\
\hline 14300 & 0.0149 & 23.56 & 4.5 & 0.51 & 0.0004 \\
\hline 15600 & 0.0137 & 23.64 & 4.2 & 0.34 & 0.0003 \\
\hline 17100 & 0.0125 & 23.74 & 3.8 & 0.43 & 0.0003 \\
\hline 18700 & 0.0114 & 23.84 & 3.3 & 0.43 & 0.0003 \\
\hline 20400 & 0.0105 & 23.93 & 3.0 & 0.34 & 0.0002 \\
\hline 22300 & 0.0096 & 24.01 & 2.6 & 0.34 & 0.0002 \\
\hline 24400 & 0.0087 & 24.07 & 2.4 & 0.26 & 0.0001 \\
\hline 26700 & 0.0080 & 24.15 & 2.0 & 0.34 & 0.0001 \\
\hline 29300 & 0.0073 & 24.21 & 1.8 & 0.26 & 0.0001 \\
\hline 32000 & 0.0067 & 24.27 & 1.5 & 0.26 & 0.0001 \\
\hline 35000 & 0.0061 & 24.33 & 1.3 & 0.26 & 0.0001 \\
\hline 38300 & 0.0056 & 24.40 & 1.0 & 0.26 & 0.0001 \\
\hline 41900 & 0.0051 & 24.44 & 0.9 & 0.17 & 0.0000 \\
\hline 45800 & 0.0047 & 24.50 & 0.6 & 0.26 & 0.0001 \\
\hline 50100 & 0.0043 & 24.54 & 0.4 & 0.17 & 0.0000 \\
\hline 54800 & 0.0039 & 24.58 & 0.3 & 0.17 & 0.0000 \\
\hline 59500 & 0.0036 & 24.64 & 0.0 & 0.26 & 0.0001 \\
\hline
\end{tabular}


Table 10. MICP data for sample 07JRM009 - 19.7a.

\section{Mercury Injection Capillary Pressure 07JRM009 - 19.7a}

\begin{tabular}{|c|c|c|c|c|c|}
\hline \\
\hline \multicolumn{3}{|c|}{$\begin{array}{ll}\text { Bulk Volume }= & 7.6051 \mathrm{cc} \\
\text { Pore Volume }= & 1.6356 \mathrm{cc} \\
\text { Closure }=0.61 \% \mathrm{BV} @ 430 \mathrm{psia} \\
\end{array}$} & \multicolumn{3}{|c|}{$\begin{array}{l}\text { Porosity }=\quad 21.5 \% \text { (mercury) } \\
\text { Permeability }=0.182 \text { md (mercury) } \\
\text { Median Pore Aperture }=0.1960 \text { microns (diameter) }\end{array}$} \\
\hline $\begin{array}{l}\text { Capillary } \\
\text { Pressure } \\
\text { (psia) } \\
\end{array}$ & $\begin{array}{l}\text { Pore Aperture } \\
\text { Diameter } \\
\text { (microns) } \\
\end{array}$ & $\begin{array}{c}\text { Cumulative } \\
\text { Bulk Vol. (\%) } \\
\end{array}$ & $\begin{array}{l}\text { Wetting Phase } \\
\text { Saturation (\%) }\end{array}$ & $\begin{array}{l}\text { Incremental } \\
\text { Wetting Phase } \\
\text { Change (\%) } \\
\end{array}$ & $\begin{array}{l}\text { Saturation } \\
\text { Change } \\
\text { per psia } \\
\end{array}$ \\
\hline 1.64 & 130 & 0.00 & 100.0 & 0.00 & 0.0000 \\
\hline 1.80 & 119 & 0.02 & 100.0 & 0.00 & 0.0000 \\
\hline 1.96 & 109 & 0.02 & 100.0 & 0.00 & 0.0000 \\
\hline 2.15 & 99.2 & 0.02 & 100.0 & 0.00 & 0.0000 \\
\hline 2.35 & 90.8 & 0.02 & 100.0 & 0.00 & 0.0000 \\
\hline 2.57 & 83.0 & 0.02 & 100.0 & 0.00 & 0.0000 \\
\hline 2.81 & 75.9 & 0.02 & 100.0 & 0.00 & 0.0000 \\
\hline 3.08 & 69.3 & 0.02 & 100.0 & 0.00 & 0.0000 \\
\hline 3.37 & 63.3 & 0.04 & 100.0 & 0.00 & 0.0000 \\
\hline 3.68 & 58.0 & 0.04 & 100.0 & 0.00 & 0.0000 \\
\hline 4.03 & 52.9 & 0.08 & 100.0 & 0.00 & 0.0000 \\
\hline 4.41 & 48.4 & 0.08 & 100.0 & 0.00 & 0.0000 \\
\hline 4.82 & 44.3 & 0.11 & 100.0 & 0.00 & 0.0000 \\
\hline 5.27 & 40.5 & 0.11 & 100.0 & 0.00 & 0.0000 \\
\hline 5.77 & 37.0 & 0.11 & 100.0 & 0.00 & 0.0000 \\
\hline 6.31 & 33.8 & 0.13 & 100.0 & 0.00 & 0.0000 \\
\hline 6.90 & 30.9 & 0.13 & 100.0 & 0.00 & 0.0000 \\
\hline 7.55 & 28.3 & 0.13 & 100.0 & 0.00 & 0.0000 \\
\hline 8.26 & 25.8 & 0.15 & 100.0 & 0.00 & 0.0000 \\
\hline 9.04 & 23.6 & 0.15 & 100.0 & 0.00 & 0.0000 \\
\hline 9.89 & 21.6 & 0.15 & 100.0 & 0.00 & 0.0000 \\
\hline 10.8 & 19.8 & 0.15 & 100.0 & 0.00 & 0.0000 \\
\hline 11.8 & 18.1 & 0.15 & 100.0 & 0.00 & 0.0000 \\
\hline 12.9 & 16.5 & 0.17 & 100.0 & 0.00 & 0.0000 \\
\hline 14.2 & 15.0 & 0.17 & 100.0 & 0.00 & 0.0000 \\
\hline 15.5 & 13.8 & 0.17 & 100.0 & 0.00 & 0.0000 \\
\hline 16.9 & 12.6 & 0.17 & 100.0 & 0.00 & 0.0000 \\
\hline 18.5 & 11.5 & 0.19 & 100.0 & 0.00 & 0.0000 \\
\hline 20.3 & 10.5 & 0.19 & 100.0 & 0.00 & 0.0000 \\
\hline 22.2 & 9.61 & 0.21 & 100.0 & 0.00 & 0.0000 \\
\hline 24.3 & 8.78 & 0.21 & 100.0 & 0.00 & 0.0000 \\
\hline 26.6 & 8.02 & 0.21 & 100.0 & 0.00 & 0.0000 \\
\hline 29.0 & 7.36 & 0.23 & 100.0 & 0.00 & 0.0000 \\
\hline 31.8 & 6.71 & 0.23 & 100.0 & 0.00 & 0.0000 \\
\hline 34.8 & 6.13 & 0.25 & 100.0 & 0.00 & 0.0000 \\
\hline 38.0 & 5.61 & 0.27 & 100.0 & 0.00 & 0.0000 \\
\hline
\end{tabular}


Table 10 (cont.). MICP data for sample 07JRM009 - 19.7a.

\section{Mercury Injection Capillary Pressure 07JRM009 - 19.7a}

\begin{tabular}{|c|c|c|c|c|c|}
\hline $\begin{array}{c}\text { Capillary } \\
\text { Pressure } \\
\text { (psia) } \\
\end{array}$ & $\begin{array}{c}\text { Pore Aperture } \\
\text { Diameter } \\
\text { (microns) }\end{array}$ & $\begin{array}{c}\text { Cumulative } \\
\text { Bulk Vol. (\%) } \\
\end{array}$ & $\begin{array}{l}\text { Wetting Phase } \\
\text { Saturation (\%) }\end{array}$ & $\begin{array}{c}\text { Incremental } \\
\text { Wetting Phase } \\
\text { Change (\%) } \\
\end{array}$ & $\begin{array}{c}\text { Saturation } \\
\text { Change } \\
\text { per psia } \\
\end{array}$ \\
\hline 41.6 & 5.13 & 0.29 & 100.0 & 0.00 & 0.0000 \\
\hline 45.5 & 4.69 & 0.32 & 100.0 & 0.00 & 0.0000 \\
\hline 49.8 & 4.28 & 0.32 & 100.0 & 0.00 & 0.0000 \\
\hline 54.5 & 3.91 & 0.32 & 100.0 & 0.00 & 0.0000 \\
\hline 59.6 & 3.58 & 0.32 & 100.0 & 0.00 & 0.0000 \\
\hline 65.2 & 3.27 & 0.34 & 100.0 & 0.00 & 0.0000 \\
\hline 71.3 & 2.99 & 0.34 & 100.0 & 0.00 & 0.0000 \\
\hline 78.0 & 2.73 & 0.34 & 100.0 & 0.00 & 0.0000 \\
\hline 85.3 & 2.50 & 0.34 & 100.0 & 0.00 & 0.0000 \\
\hline 93.4 & 2.28 & 0.34 & 100.0 & 0.00 & 0.0000 \\
\hline 102 & 2.09 & 0.34 & 100.0 & 0.00 & 0.0000 \\
\hline 112 & 1.90 & 0.36 & 100.0 & 0.00 & 0.0000 \\
\hline 122 & 1.75 & 0.36 & 100.0 & 0.00 & 0.0000 \\
\hline 134 & 1.59 & 0.36 & 100.0 & 0.00 & 0.0000 \\
\hline 146 & 1.46 & 0.38 & 100.0 & 0.00 & 0.0000 \\
\hline 160 & 1.33 & 0.38 & 100.0 & 0.00 & 0.0000 \\
\hline 175 & 1.22 & 0.38 & 100.0 & 0.00 & 0.0000 \\
\hline 191 & 1.12 & 0.40 & 100.0 & 0.00 & 0.0000 \\
\hline 209 & 1.02 & 0.40 & 100.0 & 0.00 & 0.0000 \\
\hline 229 & 0.932 & 0.42 & 100.0 & 0.00 & 0.0000 \\
\hline 251 & 0.850 & 0.44 & 100.0 & 0.00 & 0.0000 \\
\hline 274 & 0.779 & 0.46 & 100.0 & 0.00 & 0.0000 \\
\hline 300 & 0.711 & 0.48 & 100.0 & 0.00 & 0.0000 \\
\hline 328 & 0.650 & 0.51 & 100.0 & 0.00 & 0.0000 \\
\hline 359 & 0.594 & 0.55 & 100.0 & 0.00 & 0.0000 \\
\hline 393 & 0.543 & 0.57 & 100.0 & 0.00 & 0.0000 \\
\hline 430 & 0.496 & 0.61 & 100.0 & 0.00 & 0.0000 \\
\hline 470 & 0.454 & 0.67 & 99.7 & 0.29 & 0.0073 \\
\hline 514 & 0.415 & 0.86 & 98.8 & 0.88 & 0.0200 \\
\hline 563 & 0.379 & 1.37 & 96.5 & 2.35 & 0.0479 \\
\hline 615 & 0.347 & 2.57 & 90.9 & 5.58 & 0.1073 \\
\hline 673 & 0.317 & 4.40 & 82.4 & 8.51 & 0.1468 \\
\hline 736 & 0.290 & 6.17 & 74.2 & 8.22 & 0.1305 \\
\hline 806 & 0.265 & 7.83 & 66.4 & 7.73 & 0.1104 \\
\hline 881 & 0.242 & 9.24 & 59.9 & 6.56 & 0.0874 \\
\hline 964 & 0.221 & 10.21 & 55.4 & 4.50 & 0.0542 \\
\hline 1050 & 0.203 & 11.03 & 51.6 & 3.82 & 0.0444 \\
\hline 1150 & 0.186 & 11.85 & 47.7 & 3.82 & 0.0382 \\
\hline 1260 & 0.169 & 12.63 & 44.1 & 3.62 & 0.0329 \\
\hline 1380 & 0.155 & 13.30 & 41.0 & 3.13 & 0.0261 \\
\hline 1510 & 0.141 & 13.91 & 38.2 & 2.84 & 0.0218 \\
\hline 1650 & 0.129 & 14.44 & 35.7 & 2.45 & 0.0175 \\
\hline
\end{tabular}


Table 10 (cont.). MICP data for sample 07JRM009 - 19.7a.

\section{Mercury Injection Capillary Pressure 07JRM009 - 19.7a}

\begin{tabular}{|c|c|c|c|c|c|}
\hline $\begin{array}{c}\text { Capillary } \\
\text { Pressure } \\
\text { (psia) } \\
\end{array}$ & $\begin{array}{c}\text { Pore Aperture } \\
\text { Diameter } \\
\text { (microns) }\end{array}$ & $\begin{array}{c}\text { Cumulative } \\
\text { Bulk Vol. (\%) }\end{array}$ & $\begin{array}{l}\text { Wetting Phase } \\
\text { Saturation (\%) }\end{array}$ & $\begin{array}{c}\text { Incremental } \\
\text { Wetting Phase } \\
\text { Change (\%) }\end{array}$ & $\begin{array}{c}\text { Saturation } \\
\text { Change } \\
\text { per psia }\end{array}$ \\
\hline 1810 & 0.1179 & 14.92 & 33.5 & 2.25 & 0.0141 \\
\hline 1980 & 0.1077 & 15.38 & 31.3 & 2.15 & 0.0127 \\
\hline 2160 & 0.0988 & 15.80 & 29.4 & 1.96 & 0.0109 \\
\hline 2370 & 0.0900 & 16.22 & 27.4 & 1.96 & 0.0093 \\
\hline 2590 & 0.0824 & 16.60 & 25.6 & 1.76 & 0.0080 \\
\hline 2830 & 0.0754 & 16.96 & 24.0 & 1.66 & 0.0069 \\
\hline 3100 & 0.0688 & 17.32 & 22.3 & 1.66 & 0.0062 \\
\hline 3390 & 0.0629 & 17.63 & 20.8 & 1.47 & 0.0051 \\
\hline 3710 & 0.0575 & 17.93 & 19.5 & 1.37 & 0.0043 \\
\hline 4060 & 0.0525 & 18.18 & 18.3 & 1.17 & 0.0034 \\
\hline 4440 & 0.0480 & 18.46 & 17.0 & 1.27 & 0.0033 \\
\hline 4850 & 0.0440 & 18.69 & 15.9 & 1.08 & 0.0026 \\
\hline 5310 & 0.0402 & 18.90 & 15.0 & 0.98 & 0.0021 \\
\hline 5810 & 0.0367 & 19.11 & 14.0 & 0.98 & 0.0020 \\
\hline 6360 & 0.0335 & 19.30 & 13.1 & 0.88 & 0.0016 \\
\hline 6950 & 0.0307 & 19.51 & 12.1 & 0.98 & 0.0017 \\
\hline 7610 & 0.0280 & 19.70 & 11.3 & 0.88 & 0.0013 \\
\hline 8320 & 0.0256 & 19.87 & 10.5 & 0.78 & 0.0011 \\
\hline 9100 & 0.0234 & 20.03 & 9.7 & 0.78 & 0.0010 \\
\hline 9960 & 0.0214 & 20.18 & 9.0 & 0.68 & 0.0008 \\
\hline 10900 & 0.0196 & 20.33 & 8.3 & 0.68 & 0.0007 \\
\hline 11900 & 0.0179 & 20.48 & 7.6 & 0.68 & 0.0007 \\
\hline 13000 & 0.0164 & 20.60 & 7.0 & 0.59 & 0.0005 \\
\hline 14300 & 0.0149 & 20.73 & 6.5 & 0.59 & 0.0005 \\
\hline 15600 & 0.0137 & 20.85 & 5.9 & 0.59 & 0.0005 \\
\hline 17100 & 0.0125 & 20.98 & 5.3 & 0.59 & 0.0004 \\
\hline 18700 & 0.0114 & 21.09 & 4.8 & 0.49 & 0.0003 \\
\hline 20400 & 0.0105 & 21.19 & 4.3 & 0.49 & 0.0003 \\
\hline 22300 & 0.0096 & 21.28 & 3.9 & 0.39 & 0.0002 \\
\hline 24400 & 0.0087 & 21.38 & 3.4 & 0.49 & 0.0002 \\
\hline 26700 & 0.0080 & 21.49 & 2.9 & 0.49 & 0.0002 \\
\hline 29300 & 0.0073 & 21.57 & 2.5 & 0.39 & 0.0002 \\
\hline 32000 & 0.0067 & 21.63 & 2.3 & 0.29 & 0.0001 \\
\hline 35000 & 0.0061 & 21.72 & 1.9 & 0.39 & 0.0001 \\
\hline 38300 & 0.0056 & 21.78 & 1.6 & 0.29 & 0.0001 \\
\hline 41900 & 0.0051 & 21.86 & 1.2 & 0.39 & 0.0001 \\
\hline 45800 & 0.0047 & 21.91 & 1.0 & 0.20 & 0.0001 \\
\hline 50100 & 0.0043 & 21.97 & 0.7 & 0.29 & 0.0001 \\
\hline 54800 & 0.0039 & 22.05 & 0.3 & 0.39 & 0.0001 \\
\hline 59500 & 0.0036 & 22.12 & 0.0 & 0.29 & 0.0001 \\
\hline
\end{tabular}


Table 11. MICP data for sample 07JRM010 - 34.9a.

\section{Mercury Injection Capillary Pressure 07JRM010 - 34.9a}

\begin{tabular}{|c|c|c|c|c|c|}
\hline \multicolumn{3}{|c|}{\begin{tabular}{ll}
\multicolumn{2}{l}{ Sample Information } \\
\cline { 1 - 2 } Bulk Volume $=$ & $5.7696 \mathrm{cc}$ \\
Pore Volume $=$ & $1.3428 \mathrm{cc}$ \\
Closure = 0.69 \%BV @ $673 \mathrm{psia}$
\end{tabular}} & \multicolumn{3}{|c|}{$\begin{array}{ll}\text { Porosity }= & 23.3 \% \text { (mercury) } \\
\text { Permeability }= & 0.0901 \text { md (mercury) } \\
\text { Median Pore Aperture }=0.1188 \text { microns (diameter) }\end{array}$} \\
\hline $\begin{array}{l}\text { Capillary } \\
\text { Pressure } \\
\text { (psia) } \\
\end{array}$ & $\begin{array}{c}\text { Pore Aperture } \\
\text { Diameter } \\
\text { (microns) } \\
\end{array}$ & $\begin{array}{l}\text { Cumulative } \\
\text { Bulk Vol. (\%) } \\
\end{array}$ & $\begin{array}{l}\text { Wetting Phase } \\
\text { Saturation (\%) }\end{array}$ & $\begin{array}{l}\text { Incremental } \\
\text { Wetting Phase } \\
\text { Change (\%) } \\
\end{array}$ & $\begin{array}{c}\text { Saturation } \\
\text { Change } \\
\text { per psia } \\
\end{array}$ \\
\hline 1.64 & 130 & 0.00 & 100.0 & 0.00 & 0.0000 \\
\hline 1.80 & 119 & 0.00 & 100.0 & 0.00 & 0.0000 \\
\hline 1.96 & 109 & 0.02 & 100.0 & 0.00 & 0.0000 \\
\hline 2.15 & 99.2 & 0.02 & 100.0 & 0.00 & 0.0000 \\
\hline 2.35 & 90.8 & 0.02 & 100.0 & 0.00 & 0.0000 \\
\hline 2.57 & 83.0 & 0.02 & 100.0 & 0.00 & 0.0000 \\
\hline 2.81 & 75.9 & 0.02 & 100.0 & 0.00 & 0.0000 \\
\hline 3.08 & 69.3 & 0.02 & 100.0 & 0.00 & 0.0000 \\
\hline 3.37 & 63.3 & 0.04 & 100.0 & 0.00 & 0.0000 \\
\hline 3.68 & 58.0 & 0.04 & 100.0 & 0.00 & 0.0000 \\
\hline 4.03 & 52.9 & 0.04 & 100.0 & 0.00 & 0.0000 \\
\hline 4.41 & 48.4 & 0.04 & 100.0 & 0.00 & 0.0000 \\
\hline 4.82 & 44.3 & 0.04 & 100.0 & 0.00 & 0.0000 \\
\hline 5.27 & 40.5 & 0.04 & 100.0 & 0.00 & 0.0000 \\
\hline 5.77 & 37.0 & 0.06 & 100.0 & 0.00 & 0.0000 \\
\hline 6.31 & 33.8 & 0.06 & 100.0 & 0.00 & 0.0000 \\
\hline 6.90 & 30.9 & 0.06 & 100.0 & 0.00 & 0.0000 \\
\hline 7.55 & 28.3 & 0.08 & 100.0 & 0.00 & 0.0000 \\
\hline 8.26 & 25.8 & 0.08 & 100.0 & 0.00 & 0.0000 \\
\hline 9.04 & 23.6 & 0.10 & 100.0 & 0.00 & 0.0000 \\
\hline 9.89 & 21.6 & 0.10 & 100.0 & 0.00 & 0.0000 \\
\hline 10.8 & 19.8 & 0.10 & 100.0 & 0.00 & 0.0000 \\
\hline 11.8 & 18.1 & 0.12 & 100.0 & 0.00 & 0.0000 \\
\hline 12.9 & 16.5 & 0.12 & 100.0 & 0.00 & 0.0000 \\
\hline 14.2 & 15.0 & 0.12 & 100.0 & 0.00 & 0.0000 \\
\hline 15.5 & 13.8 & 0.14 & 100.0 & 0.00 & 0.0000 \\
\hline 16.9 & 12.6 & 0.14 & 100.0 & 0.00 & 0.0000 \\
\hline 18.5 & 11.5 & 0.16 & 100.0 & 0.00 & 0.0000 \\
\hline 20.3 & 10.5 & 0.16 & 100.0 & 0.00 & 0.0000 \\
\hline 22.2 & 9.61 & 0.16 & 100.0 & 0.00 & 0.0000 \\
\hline 24.3 & 8.78 & 0.18 & 100.0 & 0.00 & 0.0000 \\
\hline 26.6 & 8.02 & 0.18 & 100.0 & 0.00 & 0.0000 \\
\hline 29.0 & 7.36 & 0.20 & 100.0 & 0.00 & 0.0000 \\
\hline 31.8 & 6.71 & 0.20 & 100.0 & 0.00 & 0.0000 \\
\hline 34.8 & 6.13 & 0.22 & 100.0 & 0.00 & 0.0000 \\
\hline 38.0 & 5.61 & 0.24 & 100.0 & 0.00 & 0.0000 \\
\hline
\end{tabular}


Table 11 (cont.). MICP data for sample 07JRM010 - 34.9a.

\section{Mercury Injection Capillary Pressure 07JRM010 - 34.9a}

\begin{tabular}{|c|c|c|c|c|c|}
\hline $\begin{array}{c}\text { Capillary } \\
\text { Pressure } \\
\text { (psia) } \\
\end{array}$ & $\begin{array}{l}\text { Pore Aperture } \\
\text { Diameter } \\
\text { (microns) } \\
\end{array}$ & $\begin{array}{c}\text { Cumulative } \\
\text { Bulk Vol. (\%) } \\
\end{array}$ & $\begin{array}{l}\text { Wetting Phase } \\
\text { Saturation (\%) }\end{array}$ & $\begin{array}{c}\text { Incremental } \\
\text { Wetting Phase } \\
\text { Change (\%) } \\
\end{array}$ & $\begin{array}{c}\text { Saturation } \\
\text { Change } \\
\text { per psia } \\
\end{array}$ \\
\hline 41.6 & 5.13 & 0.26 & 100.0 & 0.00 & 0.0000 \\
\hline 45.5 & 4.69 & 0.28 & 100.0 & 0.00 & 0.0000 \\
\hline 49.8 & 4.28 & 0.28 & 100.0 & 0.00 & 0.0000 \\
\hline 54.5 & 3.91 & 0.28 & 100.0 & 0.00 & 0.0000 \\
\hline 59.6 & 3.58 & 0.28 & 100.0 & 0.00 & 0.0000 \\
\hline 65.2 & 3.27 & 0.28 & 100.0 & 0.00 & 0.0000 \\
\hline 71.3 & 2.99 & 0.28 & 100.0 & 0.00 & 0.0000 \\
\hline 78.0 & 2.73 & 0.30 & 100.0 & 0.00 & 0.0000 \\
\hline 85.3 & 2.50 & 0.30 & 100.0 & 0.00 & 0.0000 \\
\hline 93.4 & 2.28 & 0.30 & 100.0 & 0.00 & 0.0000 \\
\hline 102 & 2.09 & 0.30 & 100.0 & 0.00 & 0.0000 \\
\hline 112 & 1.90 & 0.32 & 100.0 & 0.00 & 0.0000 \\
\hline 122 & 1.75 & 0.32 & 100.0 & 0.00 & 0.0000 \\
\hline 134 & 1.59 & 0.32 & 100.0 & 0.00 & 0.0000 \\
\hline 146 & 1.46 & 0.34 & 100.0 & 0.00 & 0.0000 \\
\hline 160 & 1.33 & 0.34 & 100.0 & 0.00 & 0.0000 \\
\hline 175 & 1.22 & 0.34 & 100.0 & 0.00 & 0.0000 \\
\hline 191 & 1.12 & 0.36 & 100.0 & 0.00 & 0.0000 \\
\hline 209 & 1.02 & 0.36 & 100.0 & 0.00 & 0.0000 \\
\hline 229 & 0.932 & 0.38 & 100.0 & 0.00 & 0.0000 \\
\hline 251 & 0.850 & 0.38 & 100.0 & 0.00 & 0.0000 \\
\hline 274 & 0.779 & 0.40 & 100.0 & 0.00 & 0.0000 \\
\hline 300 & 0.711 & 0.42 & 100.0 & 0.00 & 0.0000 \\
\hline 328 & 0.650 & 0.42 & 100.0 & 0.00 & 0.0000 \\
\hline 359 & 0.594 & 0.44 & 100.0 & 0.00 & 0.0000 \\
\hline 393 & 0.543 & 0.47 & 100.0 & 0.00 & 0.0000 \\
\hline 430 & 0.496 & 0.49 & 100.0 & 0.00 & 0.0000 \\
\hline 470 & 0.454 & 0.53 & 100.0 & 0.00 & 0.0000 \\
\hline 514 & 0.415 & 0.55 & 100.0 & 0.00 & 0.0000 \\
\hline 563 & 0.379 & 0.59 & 100.0 & 0.00 & 0.0000 \\
\hline 615 & 0.347 & 0.63 & 100.0 & 0.00 & 0.0000 \\
\hline 673 & 0.317 & 0.69 & 100.0 & 0.00 & 0.0000 \\
\hline 736 & 0.290 & 0.77 & 99.7 & 0.35 & 0.0055 \\
\hline 806 & 0.265 & 0.97 & 98.8 & 0.87 & 0.0124 \\
\hline 881 & 0.242 & 1.42 & 96.9 & 1.91 & 0.0255 \\
\hline 964 & 0.221 & 2.85 & 90.7 & 6.17 & 0.0744 \\
\hline 1050 & 0.203 & 4.31 & 84.4 & 6.26 & 0.0728 \\
\hline 1150 & 0.186 & 6.51 & 75.0 & 9.48 & 0.0948 \\
\hline 1260 & 0.169 & 8.33 & 67.1 & 7.83 & 0.0711 \\
\hline 1380 & 0.155 & 9.50 & 62.1 & 5.04 & 0.0420 \\
\hline 1510 & 0.141 & 10.53 & 57.7 & 4.43 & 0.0341 \\
\hline 1650 & 0.129 & 11.48 & 53.6 & 4.09 & 0.0292 \\
\hline
\end{tabular}


Table 11 (cont.). MICP data for sample 07JRM010 - 34.9a.

\section{Mercury Injection Capillary Pressure 07JRM010 - 34.9a}

\begin{tabular}{|c|c|c|c|c|c|}
\hline $\begin{array}{c}\text { Capillary } \\
\text { Pressure } \\
\text { (psia) } \\
\end{array}$ & $\begin{array}{l}\text { Pore Aperture } \\
\text { Diameter } \\
\text { (microns) } \\
\end{array}$ & $\begin{array}{c}\text { Cumulative } \\
\text { Bulk Vol. (\%) }\end{array}$ & $\begin{array}{l}\text { Wetting Phase } \\
\text { Saturation (\%) }\end{array}$ & $\begin{array}{c}\text { Incremental } \\
\text { Wetting Phase } \\
\text { Change (\%) }\end{array}$ & $\begin{array}{c}\text { Saturation } \\
\text { Change } \\
\text { per psia }\end{array}$ \\
\hline 1810 & 0.1179 & 12.39 & 49.7 & 3.91 & 0.0245 \\
\hline 1980 & 0.1077 & 13.22 & 46.1 & 3.57 & 0.0210 \\
\hline 2160 & 0.0988 & 13.97 & 42.9 & 3.22 & 0.0179 \\
\hline 2370 & 0.0900 & 14.70 & 39.7 & 3.13 & 0.0149 \\
\hline 2590 & 0.0824 & 15.35 & 37.0 & 2.78 & 0.0126 \\
\hline 2830 & 0.0754 & 15.97 & 34.3 & 2.70 & 0.0112 \\
\hline 3100 & 0.0688 & 16.58 & 31.7 & 2.61 & 0.0097 \\
\hline 3390 & 0.0629 & 17.13 & 29.3 & 2.35 & 0.0081 \\
\hline 3710 & 0.0575 & 17.63 & 27.1 & 2.17 & 0.0068 \\
\hline 4060 & 0.0525 & 18.12 & 25.0 & 2.09 & 0.0060 \\
\hline 4440 & 0.0480 & 18.56 & 23.1 & 1.91 & 0.0050 \\
\hline 4850 & 0.0440 & 18.93 & 21.6 & 1.57 & 0.0038 \\
\hline 5310 & 0.0402 & 19.31 & 19.9 & 1.65 & 0.0036 \\
\hline 5810 & 0.0367 & 19.67 & 18.3 & 1.57 & 0.0031 \\
\hline 6360 & 0.0335 & 20.00 & 17.0 & 1.39 & 0.0025 \\
\hline 6950 & 0.0307 & 20.30 & 15.7 & 1.30 & 0.0022 \\
\hline 7610 & 0.0280 & 20.60 & 14.3 & 1.30 & 0.0020 \\
\hline 8320 & 0.0256 & 20.87 & 13.2 & 1.13 & 0.0016 \\
\hline 9100 & 0.0234 & 21.11 & 12.2 & 1.04 & 0.0013 \\
\hline 9960 & 0.0214 & 21.33 & 11.2 & 0.96 & 0.0011 \\
\hline 10900 & 0.0196 & 21.55 & 10.3 & 0.96 & 0.0010 \\
\hline 11900 & 0.0179 & 21.76 & 9.4 & 0.87 & 0.0009 \\
\hline 13000 & 0.0164 & 21.94 & 8.6 & 0.78 & 0.0007 \\
\hline 14300 & 0.0149 & 22.12 & 7.8 & 0.78 & 0.0006 \\
\hline 15600 & 0.0137 & 22.28 & 7.1 & 0.70 & 0.0005 \\
\hline 17100 & 0.0125 & 22.44 & 6.4 & 0.70 & 0.0005 \\
\hline 18700 & 0.0114 & 22.59 & 5.8 & 0.61 & 0.0004 \\
\hline 20400 & 0.0105 & 22.73 & 5.2 & 0.61 & 0.0004 \\
\hline 22300 & 0.0096 & 22.87 & 4.6 & 0.61 & 0.0003 \\
\hline 24400 & 0.0087 & 22.99 & 4.1 & 0.52 & 0.0002 \\
\hline 26700 & 0.0080 & 23.11 & 3.6 & 0.52 & 0.0002 \\
\hline 29300 & 0.0073 & 23.23 & 3.0 & 0.52 & 0.0002 \\
\hline 32000 & 0.0067 & 23.33 & 2.6 & 0.43 & 0.0002 \\
\hline 35000 & 0.0061 & 23.43 & 2.2 & 0.43 & 0.0001 \\
\hline 38300 & 0.0056 & 23.54 & 1.7 & 0.43 & 0.0001 \\
\hline 41900 & 0.0051 & 23.62 & 1.4 & 0.35 & 0.0001 \\
\hline 45800 & 0.0047 & 23.70 & 1.0 & 0.35 & 0.0001 \\
\hline 50100 & 0.0043 & 23.78 & 0.7 & 0.35 & 0.0001 \\
\hline 54800 & 0.0039 & 23.84 & 0.4 & 0.26 & 0.0001 \\
\hline 59500 & 0.0036 & 23.94 & 0.0 & 0.43 & 0.0001 \\
\hline
\end{tabular}


Table 12. MICP data for sample 07JRM011 - 24.7a.

\section{Mercury Injection Capillary Pressure 07JRM011 - 24.7a}

\begin{tabular}{|c|c|c|c|c|c|}
\hline \multicolumn{3}{|c|}{\begin{tabular}{ll}
\multicolumn{2}{l}{ Sample Information } \\
\cline { 1 - 2 } Bulk Volume $=$ & $8.1398 \mathrm{cc}$ \\
Pore Volume $=$ & $2.7671 \mathrm{cc}$ \\
Closure $=0.44 \% \mathrm{BV} @ 359 \mathrm{psia}$ \\
\end{tabular}} & \multicolumn{3}{|c|}{$\begin{array}{lc}\text { Porosity }= & 34.0 \% \text { (mercury) } \\
\text { Permeability }= & 0.150 \mathrm{md} \text { (mercury) } \\
\text { Median Pore Aperture }=0.1117 \text { microns (diameter) }\end{array}$} \\
\hline $\begin{array}{l}\text { Capillary } \\
\text { Pressure } \\
\text { (psia) } \\
\end{array}$ & $\begin{array}{l}\text { Pore Aperture } \\
\text { Diameter } \\
\text { (microns) } \\
\end{array}$ & $\begin{array}{l}\text { Cumulative } \\
\text { Bulk Vol. (\%) } \\
\end{array}$ & $\begin{array}{l}\text { Wetting Phase } \\
\text { Saturation (\%) }\end{array}$ & $\begin{array}{l}\text { Incremental } \\
\text { Wetting Phase } \\
\text { Change (\%) } \\
\end{array}$ & $\begin{array}{l}\text { Saturation } \\
\text { Change } \\
\text { per psia }\end{array}$ \\
\hline 1.64 & 130 & 0.00 & 100.0 & 0.00 & 0.0000 \\
\hline 1.80 & 119 & 0.02 & 100.0 & 0.00 & 0.0000 \\
\hline 1.96 & 109 & 0.02 & 100.0 & 0.00 & 0.0000 \\
\hline 2.15 & 99.2 & 0.02 & 100.0 & 0.00 & 0.0000 \\
\hline 2.35 & 90.8 & 0.04 & 100.0 & 0.00 & 0.0000 \\
\hline 2.57 & 83.0 & 0.04 & 100.0 & 0.00 & 0.0000 \\
\hline 2.81 & 75.9 & 0.04 & 100.0 & 0.00 & 0.0000 \\
\hline 3.08 & 69.3 & 0.04 & 100.0 & 0.00 & 0.0000 \\
\hline 3.37 & 63.3 & 0.04 & 100.0 & 0.00 & 0.0000 \\
\hline 3.68 & 58.0 & 0.04 & 100.0 & 0.00 & 0.0000 \\
\hline 4.03 & 52.9 & 0.06 & 100.0 & 0.00 & 0.0000 \\
\hline 4.41 & 48.4 & 0.06 & 100.0 & 0.00 & 0.0000 \\
\hline 4.82 & 44.3 & 0.06 & 100.0 & 0.00 & 0.0000 \\
\hline 5.27 & 40.5 & 0.06 & 100.0 & 0.00 & 0.0000 \\
\hline 5.77 & 37.0 & 0.06 & 100.0 & 0.00 & 0.0000 \\
\hline 6.31 & 33.8 & 0.06 & 100.0 & 0.00 & 0.0000 \\
\hline 6.90 & 30.9 & 0.06 & 100.0 & 0.00 & 0.0000 \\
\hline 7.55 & 28.3 & 0.06 & 100.0 & 0.00 & 0.0000 \\
\hline 8.26 & 25.8 & 0.06 & 100.0 & 0.00 & 0.0000 \\
\hline 9.04 & 23.6 & 0.06 & 100.0 & 0.00 & 0.0000 \\
\hline 9.89 & 21.6 & 0.06 & 100.0 & 0.00 & 0.0000 \\
\hline 10.8 & 19.8 & 0.09 & 100.0 & 0.00 & 0.0000 \\
\hline 11.8 & 18.1 & 0.11 & 100.0 & 0.00 & 0.0000 \\
\hline 12.9 & 16.5 & 0.11 & 100.0 & 0.00 & 0.0000 \\
\hline 14.2 & 15.0 & 0.11 & 100.0 & 0.00 & 0.0000 \\
\hline 15.5 & 13.8 & 0.13 & 100.0 & 0.00 & 0.0000 \\
\hline 16.9 & 12.6 & 0.13 & 100.0 & 0.00 & 0.0000 \\
\hline 18.5 & 11.5 & 0.13 & 100.0 & 0.00 & 0.0000 \\
\hline 20.3 & 10.5 & 0.13 & 100.0 & 0.00 & 0.0000 \\
\hline 22.2 & 9.61 & 0.15 & 100.0 & 0.00 & 0.0000 \\
\hline 24.3 & 8.78 & 0.15 & 100.0 & 0.00 & 0.0000 \\
\hline 26.6 & 8.02 & 0.15 & 100.0 & 0.00 & 0.0000 \\
\hline 29.0 & 7.36 & 0.17 & 100.0 & 0.00 & 0.0000 \\
\hline 31.8 & 6.71 & 0.17 & 100.0 & 0.00 & 0.0000 \\
\hline 34.8 & 6.13 & 0.19 & 100.0 & 0.00 & 0.0000 \\
\hline 38.0 & 5.61 & 0.19 & 100.0 & 0.00 & 0.0000 \\
\hline
\end{tabular}


Table 12 (cont.). MICP data for sample 07JRM011 - 24.7a.

\section{Mercury Injection Capillary Pressure 07JRM011 - 24.7a}

\begin{tabular}{|c|c|c|c|c|c|}
\hline $\begin{array}{l}\text { Capillary } \\
\text { Pressure } \\
\text { (psia) } \\
\end{array}$ & $\begin{array}{c}\text { Pore Aperture } \\
\text { Diameter } \\
\text { (microns) }\end{array}$ & $\begin{array}{l}\text { Cumulative } \\
\text { Bulk Vol. (\%) }\end{array}$ & $\begin{array}{l}\text { Wetting Phase } \\
\text { Saturation (\%) }\end{array}$ & $\begin{array}{c}\text { Incremental } \\
\text { Wetting Phase } \\
\text { Change (\%) }\end{array}$ & $\begin{array}{c}\text { Saturation } \\
\text { Change } \\
\text { per psia } \\
\end{array}$ \\
\hline 41.6 & 5.13 & 0.19 & 100.0 & 0.00 & 0.0000 \\
\hline 45.5 & 4.69 & 0.21 & 100.0 & 0.00 & 0.0000 \\
\hline 49.8 & 4.28 & 0.21 & 100.0 & 0.00 & 0.0000 \\
\hline 54.5 & 3.91 & 0.21 & 100.0 & 0.00 & 0.0000 \\
\hline 59.6 & 3.58 & 0.21 & 100.0 & 0.00 & 0.0000 \\
\hline 65.2 & 3.27 & 0.23 & 100.0 & 0.00 & 0.0000 \\
\hline 71.3 & 2.99 & 0.23 & 100.0 & 0.00 & 0.0000 \\
\hline 78.0 & 2.73 & 0.23 & 100.0 & 0.00 & 0.0000 \\
\hline 85.3 & 2.50 & 0.23 & 100.0 & 0.00 & 0.0000 \\
\hline 93.4 & 2.28 & 0.23 & 100.0 & 0.00 & 0.0000 \\
\hline 102 & 2.09 & 0.23 & 100.0 & 0.00 & 0.0000 \\
\hline 112 & 1.90 & 0.25 & 100.0 & 0.00 & 0.0000 \\
\hline 122 & 1.75 & 0.25 & 100.0 & 0.00 & 0.0000 \\
\hline 134 & 1.59 & 0.25 & 100.0 & 0.00 & 0.0000 \\
\hline 146 & 1.46 & 0.27 & 100.0 & 0.00 & 0.0000 \\
\hline 160 & 1.33 & 0.27 & 100.0 & 0.00 & 0.0000 \\
\hline 175 & 1.22 & 0.27 & 100.0 & 0.00 & 0.0000 \\
\hline 191 & 1.12 & 0.28 & 100.0 & 0.00 & 0.0000 \\
\hline 209 & 1.02 & 0.28 & 100.0 & 0.00 & 0.0000 \\
\hline 229 & 0.932 & 0.30 & 100.0 & 0.00 & 0.0000 \\
\hline 251 & 0.850 & 0.30 & 100.0 & 0.00 & 0.0000 \\
\hline 274 & 0.779 & 0.32 & 100.0 & 0.00 & 0.0000 \\
\hline 300 & 0.711 & 0.34 & 100.0 & 0.00 & 0.0000 \\
\hline 328 & 0.650 & 0.38 & 100.0 & 0.00 & 0.0000 \\
\hline 359 & 0.594 & 0.44 & 100.0 & 0.00 & 0.0000 \\
\hline 393 & 0.543 & 0.51 & 99.8 & 0.22 & 0.0066 \\
\hline 430 & 0.496 & 0.64 & 99.4 & 0.39 & 0.0106 \\
\hline 470 & 0.454 & 0.83 & 98.8 & 0.56 & 0.0140 \\
\hline 514 & 0.415 & 1.19 & 97.8 & 1.06 & 0.0241 \\
\hline 563 & 0.379 & 1.63 & 96.5 & 1.28 & 0.0262 \\
\hline 615 & 0.347 & 2.60 & 93.6 & 2.85 & 0.0547 \\
\hline 673 & 0.317 & 3.32 & 91.5 & 2.12 & 0.0366 \\
\hline 736 & 0.290 & 4.24 & 88.8 & 2.73 & 0.0434 \\
\hline 806 & 0.265 & 5.08 & 86.3 & 2.46 & 0.0351 \\
\hline 881 & 0.242 & 5.91 & 83.9 & 2.46 & 0.0327 \\
\hline 964 & 0.221 & 6.90 & 81.0 & 2.90 & 0.0350 \\
\hline 1050 & 0.203 & 7.96 & 77.8 & 3.13 & 0.0363 \\
\hline 1150 & 0.186 & 9.42 & 73.5 & 4.30 & 0.0430 \\
\hline 1260 & 0.169 & 11.09 & 68.6 & 4.91 & 0.0446 \\
\hline 1380 & 0.155 & 12.79 & 63.6 & 5.02 & 0.0419 \\
\hline 1510 & 0.141 & 14.27 & 59.3 & 4.35 & 0.0335 \\
\hline 1650 & 0.129 & 15.56 & 55.5 & 3.79 & 0.0271 \\
\hline
\end{tabular}


Table 12 (cont.). MICP data for sample 07JRM011 - 24.7a.

\section{Mercury Injection Capillary Pressure 07JRM011 - 24.7a}

\begin{tabular}{|c|c|c|c|c|c|}
\hline $\begin{array}{c}\text { Capillary } \\
\text { Pressure } \\
\text { (psia) } \\
\end{array}$ & $\begin{array}{c}\text { Pore Aperture } \\
\text { Diameter } \\
\text { (microns) }\end{array}$ & $\begin{array}{c}\text { Cumulative } \\
\text { Bulk Vol. (\%) }\end{array}$ & $\begin{array}{l}\text { Wetting Phase } \\
\text { Saturation (\%) }\end{array}$ & $\begin{array}{c}\text { Incremental } \\
\text { Wetting Phase } \\
\text { Change (\%) }\end{array}$ & $\begin{array}{c}\text { Saturation } \\
\text { Change } \\
\text { per psia }\end{array}$ \\
\hline 1810 & 0.1179 & 16.73 & 52.0 & 3.46 & 0.0216 \\
\hline 1980 & 0.1077 & 17.87 & 48.7 & 3.35 & 0.0197 \\
\hline 2160 & 0.0988 & 18.95 & 45.5 & 3.18 & 0.0177 \\
\hline 2370 & 0.0900 & 20.07 & 42.2 & 3.29 & 0.0157 \\
\hline 2590 & 0.0824 & 21.13 & 39.1 & 3.13 & 0.0142 \\
\hline 2830 & 0.0754 & 22.15 & 36.0 & 3.01 & 0.0126 \\
\hline 3100 & 0.0688 & 23.14 & 33.1 & 2.90 & 0.0107 \\
\hline 3390 & 0.0629 & 24.12 & 30.2 & 2.90 & 0.0100 \\
\hline 3710 & 0.0575 & 25.05 & 27.5 & 2.73 & 0.0085 \\
\hline 4060 & 0.0525 & 25.92 & 24.9 & 2.57 & 0.0073 \\
\hline 4440 & 0.0480 & 26.76 & 22.5 & 2.46 & 0.0065 \\
\hline 4850 & 0.0440 & 27.42 & 20.5 & 1.95 & 0.0048 \\
\hline 5310 & 0.0402 & 28.10 & 18.5 & 2.01 & 0.0044 \\
\hline 5810 & 0.0367 & 28.75 & 16.6 & 1.90 & 0.0038 \\
\hline 6360 & 0.0335 & 29.22 & 15.2 & 1.40 & 0.0025 \\
\hline 6950 & 0.0307 & 29.67 & 13.9 & 1.34 & 0.0023 \\
\hline 7610 & 0.0280 & 30.09 & 12.7 & 1.23 & 0.0019 \\
\hline 8320 & 0.0256 & 30.43 & 11.7 & 1.00 & 0.0014 \\
\hline 9100 & 0.0234 & 30.75 & 10.7 & 0.95 & 0.0012 \\
\hline 9960 & 0.0214 & 31.04 & 9.9 & 0.84 & 0.0010 \\
\hline 10900 & 0.0196 & 31.28 & 9.2 & 0.73 & 0.0008 \\
\hline 11900 & 0.0179 & 31.53 & 8.4 & 0.73 & 0.0007 \\
\hline 13000 & 0.0164 & 31.74 & 7.8 & 0.61 & 0.0006 \\
\hline 14300 & 0.0149 & 31.97 & 7.1 & 0.67 & 0.0005 \\
\hline 15600 & 0.0137 & 32.16 & 6.6 & 0.56 & 0.0004 \\
\hline 17100 & 0.0125 & 32.35 & 6.0 & 0.56 & 0.0004 \\
\hline 18700 & 0.0114 & 32.52 & 5.5 & 0.50 & 0.0003 \\
\hline 20400 & 0.0105 & 32.69 & 5.0 & 0.50 & 0.0003 \\
\hline 22300 & 0.0096 & 32.86 & 4.5 & 0.50 & 0.0003 \\
\hline 24400 & 0.0087 & 33.03 & 4.0 & 0.50 & 0.0002 \\
\hline 26700 & 0.0080 & 33.18 & 3.6 & 0.45 & 0.0002 \\
\hline 29300 & 0.0073 & 33.33 & 3.1 & 0.45 & 0.0002 \\
\hline 32000 & 0.0067 & 33.48 & 2.7 & 0.45 & 0.0002 \\
\hline 35000 & 0.0061 & 33.63 & 2.2 & 0.45 & 0.0001 \\
\hline 38300 & 0.0056 & 33.77 & 1.8 & 0.39 & 0.0001 \\
\hline 41900 & 0.0051 & 33.88 & 1.5 & 0.33 & 0.0001 \\
\hline 45800 & 0.0047 & 34.01 & 1.1 & 0.39 & 0.0001 \\
\hline 50100 & 0.0043 & 34.13 & 0.8 & 0.33 & 0.0001 \\
\hline 54800 & 0.0039 & 34.24 & 0.4 & 0.33 & 0.0001 \\
\hline 59500 & 0.0036 & 34.39 & 0.0 & 0.45 & 0.0001 \\
\hline
\end{tabular}


Table 13. MICP data for sample 07DL002 - 17.2a.

\section{Mercury Injection Capillary Pressure 07DL002 - 17.2a}

\begin{tabular}{|c|c|c|c|c|c|}
\hline \multicolumn{3}{|c|}{ 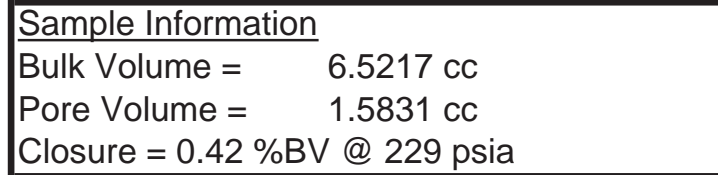 } & \multicolumn{3}{|c|}{$\begin{array}{lc}\text { Porosity }= & 24.3 \% \text { (mercury) } \\
\text { Permeability }= & 0.137 \text { md (mercury) } \\
\text { Median Pore Aperture }=0.1452 \text { microns (diameter) }\end{array}$} \\
\hline $\begin{array}{l}\text { Capillary } \\
\text { Pressure } \\
\text { (psia) }\end{array}$ & $\begin{array}{l}\text { Pore Aperture } \\
\text { Diameter } \\
\text { (microns) }\end{array}$ & $\begin{array}{l}\text { Cumulative } \\
\text { Bulk Vol. (\%) }\end{array}$ & $\begin{array}{l}\text { Wetting Phase } \\
\text { Saturation (\%) }\end{array}$ & $\begin{array}{l}\text { Incremental } \\
\text { Wetting Phase } \\
\text { Change (\%) }\end{array}$ & $\begin{array}{l}\text { Saturation } \\
\text { Change } \\
\text { per psia }\end{array}$ \\
\hline 1.64 & 130 & 0.00 & 100.0 & 0.00 & 0.0000 \\
\hline 1.80 & 119 & 0.02 & 100.0 & 0.00 & 0.0000 \\
\hline 1.96 & 109 & 0.02 & 100.0 & 0.00 & 0.0000 \\
\hline 2.15 & 99.2 & 0.02 & 100.0 & 0.00 & 0.0000 \\
\hline 2.35 & 90.8 & 0.02 & 100.0 & 0.00 & 0.0000 \\
\hline 2.57 & 83.0 & 0.04 & 100.0 & 0.00 & 0.0000 \\
\hline 2.81 & 75.9 & 0.04 & 100.0 & 0.00 & 0.0000 \\
\hline 3.08 & 69.3 & 0.04 & 100.0 & 0.00 & 0.0000 \\
\hline 3.37 & 63.3 & 0.04 & 100.0 & 0.00 & 0.0000 \\
\hline 3.68 & 58.0 & 0.04 & 100.0 & 0.00 & 0.0000 \\
\hline 4.03 & 52.9 & 0.06 & 100.0 & 0.00 & 0.0000 \\
\hline 4.41 & 48.4 & 0.06 & 100.0 & 0.00 & 0.0000 \\
\hline 4.82 & 44.3 & 0.06 & 100.0 & 0.00 & 0.0000 \\
\hline 5.27 & 40.5 & 0.06 & 100.0 & 0.00 & 0.0000 \\
\hline 5.77 & 37.0 & 0.06 & 100.0 & 0.00 & 0.0000 \\
\hline 6.31 & 33.8 & 0.08 & 100.0 & 0.00 & 0.0000 \\
\hline 6.90 & 30.9 & 0.08 & 100.0 & 0.00 & 0.0000 \\
\hline 7.55 & 28.3 & 0.08 & 100.0 & 0.00 & 0.0000 \\
\hline 8.26 & 25.8 & 0.08 & 100.0 & 0.00 & 0.0000 \\
\hline 9.04 & 23.6 & 0.08 & 100.0 & 0.00 & 0.0000 \\
\hline 9.89 & 21.6 & 0.10 & 100.0 & 0.00 & 0.0000 \\
\hline 10.8 & 19.8 & 0.10 & 100.0 & 0.00 & 0.0000 \\
\hline 11.8 & 18.1 & 0.10 & 100.0 & 0.00 & 0.0000 \\
\hline 12.9 & 16.5 & 0.10 & 100.0 & 0.00 & 0.0000 \\
\hline 14.2 & 15.0 & 0.10 & 100.0 & 0.00 & 0.0000 \\
\hline 15.5 & 13.8 & 0.12 & 100.0 & 0.00 & 0.0000 \\
\hline 16.9 & 12.6 & 0.12 & 100.0 & 0.00 & 0.0000 \\
\hline 18.5 & 11.5 & 0.12 & 100.0 & 0.00 & 0.0000 \\
\hline 20.3 & 10.5 & 0.12 & 100.0 & 0.00 & 0.0000 \\
\hline 22.2 & 9.61 & 0.14 & 100.0 & 0.00 & 0.0000 \\
\hline 24.3 & 8.78 & 0.14 & 100.0 & 0.00 & 0.0000 \\
\hline 26.6 & 8.02 & 0.14 & 100.0 & 0.00 & 0.0000 \\
\hline 29.0 & 7.36 & 0.14 & 100.0 & 0.00 & 0.0000 \\
\hline 31.8 & 6.71 & 0.16 & 100.0 & 0.00 & 0.0000 \\
\hline 34.8 & 6.13 & 0.16 & 100.0 & 0.00 & 0.0000 \\
\hline 38.0 & 5.61 & 0.18 & 100.0 & 0.00 & 0.0000 \\
\hline
\end{tabular}


Table 13 (cont.). MICP data for sample 07DL002 - 17.2a.

\section{Mercury Injection Capillary Pressure 07DL002 - 17.2a}

\begin{tabular}{|c|c|c|c|c|c|}
\hline $\begin{array}{c}\text { Capillary } \\
\text { Pressure } \\
\text { (psia) } \\
\end{array}$ & $\begin{array}{c}\text { Pore Aperture } \\
\text { Diameter } \\
\text { (microns) } \\
\end{array}$ & $\begin{array}{l}\text { Cumulative } \\
\text { Bulk Vol. (\%) }\end{array}$ & $\begin{array}{l}\text { Wetting Phase } \\
\text { Saturation (\%) }\end{array}$ & $\begin{array}{c}\text { Incremental } \\
\text { Wetting Phase } \\
\text { Change (\%) }\end{array}$ & $\begin{array}{c}\text { Saturation } \\
\text { Change } \\
\text { per psia }\end{array}$ \\
\hline 41.6 & 5.13 & 0.18 & 100.0 & 0.00 & 0.0000 \\
\hline 45.5 & 4.69 & 0.20 & 100.0 & 0.00 & 0.0000 \\
\hline 49.8 & 4.28 & 0.20 & 100.0 & 0.00 & 0.0000 \\
\hline 54.5 & 3.91 & 0.20 & 100.0 & 0.00 & 0.0000 \\
\hline 59.6 & 3.58 & 0.20 & 100.0 & 0.00 & 0.0000 \\
\hline 65.2 & 3.27 & 0.22 & 100.0 & 0.00 & 0.0000 \\
\hline 71.3 & 2.99 & 0.22 & 100.0 & 0.00 & 0.0000 \\
\hline 78.0 & 2.73 & 0.22 & 100.0 & 0.00 & 0.0000 \\
\hline 85.3 & 2.50 & 0.22 & 100.0 & 0.00 & 0.0000 \\
\hline 93.4 & 2.28 & 0.22 & 100.0 & 0.00 & 0.0000 \\
\hline 102 & 2.09 & 0.24 & 100.0 & 0.00 & 0.0000 \\
\hline 112 & 1.90 & 0.24 & 100.0 & 0.00 & 0.0000 \\
\hline 122 & 1.75 & 0.26 & 100.0 & 0.00 & 0.0000 \\
\hline 134 & 1.59 & 0.26 & 100.0 & 0.00 & 0.0000 \\
\hline 146 & 1.46 & 0.26 & 100.0 & 0.00 & 0.0000 \\
\hline 160 & 1.33 & 0.28 & 100.0 & 0.00 & 0.0000 \\
\hline 175 & 1.22 & 0.30 & 100.0 & 0.00 & 0.0000 \\
\hline 191 & 1.12 & 0.34 & 100.0 & 0.00 & 0.0000 \\
\hline 209 & 1.02 & 0.38 & 100.0 & 0.00 & 0.0000 \\
\hline 229 & 0.932 & 0.42 & 100.0 & 0.00 & 0.0000 \\
\hline 251 & 0.850 & 0.50 & 99.7 & 0.33 & 0.0151 \\
\hline 274 & 0.779 & 0.66 & 99.0 & 0.66 & 0.0289 \\
\hline 300 & 0.711 & 0.81 & 98.4 & 0.58 & 0.0224 \\
\hline 328 & 0.650 & 1.03 & 97.5 & 0.91 & 0.0326 \\
\hline 359 & 0.594 & 1.37 & 96.1 & 1.41 & 0.0455 \\
\hline 393 & 0.543 & 1.79 & 94.4 & 1.74 & 0.0513 \\
\hline 430 & 0.496 & 2.27 & 92.4 & 1.99 & 0.0539 \\
\hline 470 & 0.454 & 2.84 & 90.0 & 2.33 & 0.0581 \\
\hline 514 & 0.415 & 3.46 & 87.5 & 2.57 & 0.0585 \\
\hline 563 & 0.379 & 4.19 & 84.5 & 2.99 & 0.0610 \\
\hline 615 & 0.347 & 4.95 & 81.3 & 3.16 & 0.0607 \\
\hline 673 & 0.317 & 5.56 & 78.8 & 2.49 & 0.0430 \\
\hline 736 & 0.290 & 6.28 & 75.8 & 2.99 & 0.0475 \\
\hline 806 & 0.265 & 6.94 & 73.1 & 2.74 & 0.0392 \\
\hline 881 & 0.242 & 7.69 & 70.0 & 3.07 & 0.0410 \\
\hline 964 & 0.221 & 8.51 & 66.6 & 3.41 & 0.0410 \\
\hline 1050 & 0.203 & 9.34 & 63.2 & 3.41 & 0.0396 \\
\hline 1150 & 0.186 & 10.27 & 59.4 & 3.82 & 0.0382 \\
\hline 1260 & 0.169 & 11.21 & 55.5 & 3.90 & 0.0355 \\
\hline 1380 & 0.155 & 12.04 & 52.1 & 3.41 & 0.0284 \\
\hline 1510 & 0.141 & 12.76 & 49.1 & 2.99 & 0.0230 \\
\hline 1650 & 0.129 & 13.41 & 46.4 & 2.66 & 0.0190 \\
\hline
\end{tabular}


Table 13 (cont.). MICP data for sample 07DL002 - 17.2a.

\section{Mercury Injection Capillary Pressure 07DL002 - 17.2a}

\begin{tabular}{|c|c|c|c|c|c|}
\hline $\begin{array}{c}\text { Capillary } \\
\text { Pressure } \\
\text { (psia) } \\
\end{array}$ & $\begin{array}{l}\text { Pore Aperture } \\
\text { Diameter } \\
\text { (microns) } \\
\end{array}$ & $\begin{array}{l}\text { Cumulative } \\
\text { Bulk Vol. (\%) }\end{array}$ & $\begin{array}{l}\text { Wetting Phase } \\
\text { Saturation (\%) }\end{array}$ & $\begin{array}{c}\text { Incremental } \\
\text { Wetting Phase } \\
\text { Change (\%) } \\
\end{array}$ & $\begin{array}{c}\text { Saturation } \\
\text { Change } \\
\text { per psia }\end{array}$ \\
\hline 1810 & 0.1179 & 14.05 & 43.8 & 2.66 & 0.0166 \\
\hline 1980 & 0.1077 & 14.65 & 41.3 & 2.49 & 0.0147 \\
\hline 2160 & 0.0988 & 15.20 & 39.0 & 2.24 & 0.0125 \\
\hline 2370 & 0.0900 & 15.76 & 36.7 & 2.33 & 0.0111 \\
\hline 2590 & 0.0824 & 16.26 & 34.6 & 2.08 & 0.0094 \\
\hline 2830 & 0.0754 & 16.73 & 32.7 & 1.91 & 0.0080 \\
\hline 3100 & 0.0688 & 17.19 & 30.8 & 1.91 & 0.0071 \\
\hline 3390 & 0.0629 & 17.61 & 29.1 & 1.74 & 0.0060 \\
\hline 3710 & 0.0575 & 17.99 & 27.5 & 1.58 & 0.0049 \\
\hline 4060 & 0.0525 & 18.38 & 25.9 & 1.58 & 0.0045 \\
\hline 4440 & 0.0480 & 18.72 & 24.5 & 1.41 & 0.0037 \\
\hline 4850 & 0.0440 & 19.00 & 23.3 & 1.16 & 0.0028 \\
\hline 5310 & 0.0402 & 19.30 & 22.1 & 1.25 & 0.0027 \\
\hline 5810 & 0.0367 & 19.60 & 20.8 & 1.25 & 0.0025 \\
\hline 6360 & 0.0335 & 19.87 & 19.8 & 1.08 & 0.0020 \\
\hline 6950 & 0.0307 & 20.13 & 18.7 & 1.08 & 0.0018 \\
\hline 7610 & 0.0280 & 20.39 & 17.6 & 1.08 & 0.0016 \\
\hline 8320 & 0.0256 & 20.63 & 16.6 & 1.00 & 0.0014 \\
\hline 9100 & 0.0234 & 20.87 & 15.6 & 1.00 & 0.0013 \\
\hline 9960 & 0.0214 & 21.11 & 14.6 & 1.00 & 0.0012 \\
\hline 10900 & 0.0196 & 21.36 & 13.6 & 1.00 & 0.0011 \\
\hline 11900 & 0.0179 & 21.60 & 12.6 & 1.00 & 0.0010 \\
\hline 13000 & 0.0164 & 21.82 & 11.7 & 0.91 & 0.0008 \\
\hline 14300 & 0.0149 & 22.08 & 10.6 & 1.08 & 0.0008 \\
\hline 15600 & 0.0137 & 22.30 & 9.7 & 0.91 & 0.0007 \\
\hline 17100 & 0.0125 & 22.52 & 8.8 & 0.91 & 0.0006 \\
\hline 18700 & 0.0114 & 22.74 & 7.9 & 0.91 & 0.0006 \\
\hline 20400 & 0.0105 & 22.95 & 7.1 & 0.83 & 0.0005 \\
\hline 22300 & 0.0096 & 23.13 & 6.3 & 0.75 & 0.0004 \\
\hline 24400 & 0.0087 & 23.31 & 5.6 & 0.75 & 0.0004 \\
\hline 26700 & 0.0080 & 23.49 & 4.8 & 0.75 & 0.0003 \\
\hline 29300 & 0.0073 & 23.65 & 4.2 & 0.66 & 0.0003 \\
\hline 32000 & 0.0067 & 23.81 & 3.5 & 0.66 & 0.0002 \\
\hline 35000 & 0.0061 & 23.95 & 2.9 & 0.58 & 0.0002 \\
\hline 38300 & 0.0056 & 24.07 & 2.4 & 0.50 & 0.0002 \\
\hline 41900 & 0.0051 & 24.19 & 1.9 & 0.50 & 0.0001 \\
\hline 45800 & 0.0047 & 24.31 & 1.4 & 0.50 & 0.0001 \\
\hline 50100 & 0.0043 & 24.44 & 0.9 & 0.50 & 0.0001 \\
\hline 54800 & 0.0039 & 24.56 & 0.4 & 0.50 & 0.0001 \\
\hline 59500 & 0.0036 & 24.66 & 0.0 & 0.42 & 0.0001 \\
\hline
\end{tabular}


Table 14. MICP data for sample 07DL002 - 22.0a.

\section{Mercury Injection Capillary Pressure 07DL002 - 22.0a}

\begin{tabular}{|c|c|c|c|c|c|}
\hline \multicolumn{3}{|c|}{\begin{tabular}{ll}
\multicolumn{2}{l}{ Sample Information } \\
\cline { 1 - 2 } Bulk Volume $=$ & $5.0487 \mathrm{cc}$ \\
Pore Volume $=$ & $1.2628 \mathrm{cc}$ \\
Closure $=0.71 \% B V @ 112$ psia
\end{tabular}} & \multicolumn{3}{|c|}{$\begin{array}{l}\text { Porosity }=\quad 25.0 \% \text { (mercury) } \\
\text { Permeability }=\quad 0.171 \text { md (mercury) } \\
\text { Median Pore Aperture }=0.1238 \text { microns (diameter) }\end{array}$} \\
\hline $\begin{array}{l}\text { Capillary } \\
\text { Pressure } \\
\text { (psia) } \\
\end{array}$ & $\begin{array}{l}\text { Pore Aperture } \\
\text { Diameter } \\
\text { (microns) }\end{array}$ & $\begin{array}{c}\text { Cumulative } \\
\text { Bulk Vol. (\%) }\end{array}$ & $\begin{array}{l}\text { Wetting Phase } \\
\text { Saturation (\%) }\end{array}$ & $\begin{array}{l}\text { Incremental } \\
\text { Wetting Phase } \\
\text { Change (\%) } \\
\end{array}$ & $\begin{array}{l}\text { Saturation } \\
\text { Change } \\
\text { per psia }\end{array}$ \\
\hline 1.64 & 130 & 0.02 & 100.0 & 0.00 & 0.0000 \\
\hline 1.80 & 119 & 0.02 & 100.0 & 0.00 & 0.0000 \\
\hline 1.96 & 109 & 0.04 & 100.0 & 0.00 & 0.0000 \\
\hline 2.15 & 99.2 & 0.04 & 100.0 & 0.00 & 0.0000 \\
\hline 2.35 & 90.8 & 0.06 & 100.0 & 0.00 & 0.0000 \\
\hline 2.57 & 83.0 & 0.08 & 100.0 & 0.00 & 0.0000 \\
\hline 2.81 & 75.9 & 0.08 & 100.0 & 0.00 & 0.0000 \\
\hline 3.08 & 69.3 & 0.10 & 100.0 & 0.00 & 0.0000 \\
\hline 3.37 & 63.3 & 0.10 & 100.0 & 0.00 & 0.0000 \\
\hline 3.68 & 58.0 & 0.12 & 100.0 & 0.00 & 0.0000 \\
\hline 4.03 & 52.9 & 0.12 & 100.0 & 0.00 & 0.0000 \\
\hline 4.41 & 48.4 & 0.14 & 100.0 & 0.00 & 0.0000 \\
\hline 4.82 & 44.3 & 0.14 & 100.0 & 0.00 & 0.0000 \\
\hline 5.27 & 40.5 & 0.16 & 100.0 & 0.00 & 0.0000 \\
\hline 5.77 & 37.0 & 0.16 & 100.0 & 0.00 & 0.0000 \\
\hline 6.31 & 33.8 & 0.18 & 100.0 & 0.00 & 0.0000 \\
\hline 6.90 & 30.9 & 0.18 & 100.0 & 0.00 & 0.0000 \\
\hline 7.55 & 28.3 & 0.20 & 100.0 & 0.00 & 0.0000 \\
\hline 8.26 & 25.8 & 0.20 & 100.0 & 0.00 & 0.0000 \\
\hline 9.04 & 23.6 & 0.20 & 100.0 & 0.00 & 0.0000 \\
\hline 9.89 & 21.6 & 0.22 & 100.0 & 0.00 & 0.0000 \\
\hline 10.8 & 19.8 & 0.22 & 100.0 & 0.00 & 0.0000 \\
\hline 11.8 & 18.1 & 0.24 & 100.0 & 0.00 & 0.0000 \\
\hline 12.9 & 16.5 & 0.24 & 100.0 & 0.00 & 0.0000 \\
\hline 14.2 & 15.0 & 0.26 & 100.0 & 0.00 & 0.0000 \\
\hline 15.5 & 13.8 & 0.28 & 100.0 & 0.00 & 0.0000 \\
\hline 16.9 & 12.6 & 0.30 & 100.0 & 0.00 & 0.0000 \\
\hline 18.5 & 11.5 & 0.30 & 100.0 & 0.00 & 0.0000 \\
\hline 20.3 & 10.5 & 0.32 & 100.0 & 0.00 & 0.0000 \\
\hline 22.2 & 9.61 & 0.32 & 100.0 & 0.00 & 0.0000 \\
\hline 24.3 & 8.78 & 0.34 & 100.0 & 0.00 & 0.0000 \\
\hline 26.6 & 8.02 & 0.36 & 100.0 & 0.00 & 0.0000 \\
\hline 29.0 & 7.36 & 0.38 & 100.0 & 0.00 & 0.0000 \\
\hline 31.8 & 6.71 & 0.40 & 100.0 & 0.00 & 0.0000 \\
\hline 34.8 & 6.13 & 0.42 & 100.0 & 0.00 & 0.0000 \\
\hline 38.0 & 5.61 & 0.42 & 100.0 & 0.00 & 0.0000 \\
\hline
\end{tabular}


Table 14 (cont.). MICP data for sample 07DL002 - 22.0a.

\section{Mercury Injection Capillary Pressure 07DL002 - 22.0a}

\begin{tabular}{|c|c|c|c|c|c|}
\hline $\begin{array}{c}\text { Capillary } \\
\text { Pressure } \\
\text { (psia) } \\
\end{array}$ & $\begin{array}{c}\text { Pore Aperture } \\
\text { Diameter } \\
\text { (microns) } \\
\end{array}$ & $\begin{array}{l}\text { Cumulative } \\
\text { Bulk Vol. (\%) } \\
\end{array}$ & $\begin{array}{l}\text { Wetting Phase } \\
\text { Saturation (\%) }\end{array}$ & $\begin{array}{c}\text { Incremental } \\
\text { Wetting Phase } \\
\text { Change (\%) } \\
\end{array}$ & $\begin{array}{c}\text { Saturation } \\
\text { Change } \\
\text { per psia } \\
\end{array}$ \\
\hline 41.6 & 5.13 & 0.46 & 100.0 & 0.00 & 0.0000 \\
\hline 45.5 & 4.69 & 0.48 & 100.0 & 0.00 & 0.0000 \\
\hline 49.8 & 4.28 & 0.48 & 100.0 & 0.00 & 0.0000 \\
\hline 54.5 & 3.91 & 0.50 & 100.0 & 0.00 & 0.0000 \\
\hline 59.6 & 3.58 & 0.50 & 100.0 & 0.00 & 0.0000 \\
\hline 65.2 & 3.27 & 0.52 & 100.0 & 0.00 & 0.0000 \\
\hline 71.3 & 2.99 & 0.54 & 100.0 & 0.00 & 0.0000 \\
\hline 78.0 & 2.73 & 0.54 & 100.0 & 0.00 & 0.0000 \\
\hline 85.3 & 2.50 & 0.55 & 100.0 & 0.00 & 0.0000 \\
\hline 93.4 & 2.28 & 0.59 & 100.0 & 0.00 & 0.0000 \\
\hline 102 & 2.09 & 0.63 & 100.0 & 0.00 & 0.0000 \\
\hline 112 & 1.90 & 0.71 & 100.0 & 0.00 & 0.0000 \\
\hline 122 & 1.75 & 0.79 & 99.7 & 0.32 & 0.0317 \\
\hline 134 & 1.59 & 0.91 & 99.2 & 0.48 & 0.0397 \\
\hline 146 & 1.46 & 1.09 & 98.5 & 0.71 & 0.0595 \\
\hline 160 & 1.33 & 1.33 & 97.5 & 0.95 & 0.0680 \\
\hline 175 & 1.22 & 1.57 & 96.6 & 0.95 & 0.0634 \\
\hline 191 & 1.12 & 1.78 & 95.7 & 0.87 & 0.0545 \\
\hline 209 & 1.02 & 2.00 & 94.8 & 0.87 & 0.0485 \\
\hline 229 & 0.932 & 2.26 & 93.8 & 1.03 & 0.0515 \\
\hline 251 & 0.850 & 2.54 & 92.7 & 1.11 & 0.0505 \\
\hline 274 & 0.779 & 2.79 & 91.7 & 1.03 & 0.0448 \\
\hline 300 & 0.711 & 3.01 & 90.8 & 0.87 & 0.0336 \\
\hline 328 & 0.650 & 3.27 & 89.8 & 1.03 & 0.0368 \\
\hline 359 & 0.594 & 3.55 & 88.7 & 1.11 & 0.0358 \\
\hline 393 & 0.543 & 3.81 & 87.6 & 1.03 & 0.0303 \\
\hline 430 & 0.496 & 4.08 & 86.5 & 1.11 & 0.0300 \\
\hline 470 & 0.454 & 4.36 & 85.4 & 1.11 & 0.0278 \\
\hline 514 & 0.415 & 4.70 & 84.1 & 1.35 & 0.0306 \\
\hline 563 & 0.379 & 4.99 & 82.9 & 1.19 & 0.0243 \\
\hline 615 & 0.347 & 5.37 & 81.4 & 1.51 & 0.0290 \\
\hline 673 & 0.317 & 5.81 & 79.6 & 1.74 & 0.0301 \\
\hline 736 & 0.290 & 6.32 & 77.6 & 2.06 & 0.0327 \\
\hline 806 & 0.265 & 7.02 & 74.8 & 2.78 & 0.0397 \\
\hline 881 & 0.242 & 7.79 & 71.7 & 3.09 & 0.0412 \\
\hline 964 & 0.221 & 8.50 & 68.8 & 2.85 & 0.0344 \\
\hline 1050 & 0.203 & 9.24 & 65.9 & 2.93 & 0.0341 \\
\hline 1150 & 0.186 & 10.05 & 62.6 & 3.25 & 0.0325 \\
\hline 1260 & 0.169 & 10.82 & 59.6 & 3.09 & 0.0281 \\
\hline 1380 & 0.155 & 11.53 & 56.7 & 2.85 & 0.0238 \\
\hline 1510 & 0.141 & 12.21 & 54.0 & 2.70 & 0.0207 \\
\hline 1650 & 0.129 & 12.88 & 51.3 & 2.70 & 0.0193 \\
\hline
\end{tabular}


Table 14 (cont.). MICP data for sample 07DL002 - 22.0a.

\section{Mercury Injection Capillary Pressure 07DL002 - 22.0a}

\begin{tabular}{|c|c|c|c|c|c|}
\hline $\begin{array}{c}\text { Capillary } \\
\text { Pressure } \\
\text { (psia) } \\
\end{array}$ & $\begin{array}{c}\text { Pore Aperture } \\
\text { Diameter } \\
\text { (microns) }\end{array}$ & $\begin{array}{c}\text { Cumulative } \\
\text { Bulk Vol. (\%) } \\
\end{array}$ & $\begin{array}{l}\text { Wetting Phase } \\
\text { Saturation (\%) }\end{array}$ & $\begin{array}{c}\text { Incremental } \\
\text { Wetting Phase } \\
\text { Change (\%) }\end{array}$ & $\begin{array}{c}\text { Saturation } \\
\text { Change } \\
\text { per psia } \\
\end{array}$ \\
\hline 1810 & 0.1179 & 13.56 & 48.6 & 2.70 & 0.0169 \\
\hline 1980 & 0.1077 & 14.21 & 46.0 & 2.62 & 0.0154 \\
\hline 2160 & 0.0988 & 14.82 & 43.5 & 2.46 & 0.0137 \\
\hline 2370 & 0.0900 & 15.48 & 40.9 & 2.62 & 0.0125 \\
\hline 2590 & 0.0824 & 16.09 & 38.5 & 2.46 & 0.0112 \\
\hline 2830 & 0.0754 & 16.67 & 36.2 & 2.30 & 0.0096 \\
\hline 3100 & 0.0688 & 17.24 & 33.9 & 2.30 & 0.0085 \\
\hline 3390 & 0.0629 & 17.76 & 31.8 & 2.06 & 0.0071 \\
\hline 3710 & 0.0575 & 18.25 & 29.8 & 1.98 & 0.0062 \\
\hline 4060 & 0.0525 & 18.71 & 28.0 & 1.82 & 0.0052 \\
\hline 4440 & 0.0480 & 19.13 & 26.3 & 1.67 & 0.0044 \\
\hline 4850 & 0.0440 & 19.46 & 25.0 & 1.35 & 0.0033 \\
\hline 5310 & 0.0402 & 19.82 & 23.6 & 1.43 & 0.0031 \\
\hline 5810 & 0.0367 & 20.16 & 22.2 & 1.35 & 0.0027 \\
\hline 6360 & 0.0335 & 20.47 & 20.9 & 1.27 & 0.0023 \\
\hline 6950 & 0.0307 & 20.75 & 19.8 & 1.11 & 0.0019 \\
\hline 7610 & 0.0280 & 21.03 & 18.7 & 1.11 & 0.0017 \\
\hline 8320 & 0.0256 & 21.31 & 17.6 & 1.11 & 0.0016 \\
\hline 9100 & 0.0234 & 21.56 & 16.6 & 1.03 & 0.0013 \\
\hline 9960 & 0.0214 & 21.82 & 15.5 & 1.03 & 0.0012 \\
\hline 10900 & 0.0196 & 22.08 & 14.5 & 1.03 & 0.0011 \\
\hline 11900 & 0.0179 & 22.32 & 13.6 & 0.95 & 0.0010 \\
\hline 13000 & 0.0164 & 22.55 & 12.6 & 0.95 & 0.0009 \\
\hline 14300 & 0.0149 & 22.81 & 11.6 & 1.03 & 0.0008 \\
\hline 15600 & 0.0137 & 23.05 & 10.6 & 0.95 & 0.0007 \\
\hline 17100 & 0.0125 & 23.29 & 9.7 & 0.95 & 0.0006 \\
\hline 18700 & 0.0114 & 23.53 & 8.7 & 0.95 & 0.0006 \\
\hline 20400 & 0.0105 & 23.72 & 7.9 & 0.79 & 0.0005 \\
\hline 22300 & 0.0096 & 23.94 & 7.1 & 0.87 & 0.0005 \\
\hline 24400 & 0.0087 & 24.14 & 6.3 & 0.79 & 0.0004 \\
\hline 26700 & 0.0080 & 24.34 & 5.5 & 0.79 & 0.0003 \\
\hline 29300 & 0.0073 & 24.52 & 4.8 & 0.71 & 0.0003 \\
\hline 32000 & 0.0067 & 24.67 & 4.1 & 0.63 & 0.0002 \\
\hline 35000 & 0.0061 & 24.83 & 3.5 & 0.63 & 0.0002 \\
\hline 38300 & 0.0056 & 24.99 & 2.9 & 0.63 & 0.0002 \\
\hline 41900 & 0.0051 & 25.13 & 2.3 & 0.56 & 0.0002 \\
\hline 45800 & 0.0047 & 25.27 & 1.7 & 0.56 & 0.0001 \\
\hline 50100 & 0.0043 & 25.39 & 1.3 & 0.48 & 0.0001 \\
\hline 54800 & 0.0039 & 25.53 & 0.7 & 0.56 & 0.0001 \\
\hline 59500 & 0.0036 & 25.71 & 0.0 & 0.71 & 0.0002 \\
\hline
\end{tabular}


Table 15. MICP data for sample 07MAW04 - 0.6.

\section{Mercury Injection Capillary Pressure 07MAW04 - 0.6}

\begin{tabular}{|c|c|c|c|c|c|}
\hline \multicolumn{3}{|c|}{ 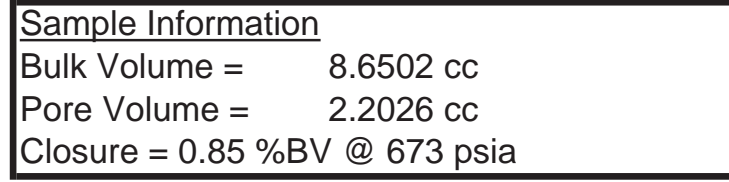 } & \multicolumn{3}{|c|}{$\begin{array}{lc}\text { Porosity }= & 26.6 \% \text { (mercury) } \\
\text { Permeability }= & 0.134 \text { md (mercury) } \\
\text { Median Pore Aperture }=0.1312 \text { microns (diameter) }\end{array}$} \\
\hline $\begin{array}{l}\text { Capillary } \\
\text { Pressure } \\
\text { (psia) } \\
\end{array}$ & $\begin{array}{l}\text { Pore Aperture } \\
\text { Diameter } \\
\text { (microns) } \\
\end{array}$ & $\begin{array}{l}\text { Cumulative } \\
\text { Bulk Vol. (\%) } \\
\end{array}$ & $\begin{array}{l}\text { Wetting Phase } \\
\text { Saturation (\%) } \\
\end{array}$ & $\begin{array}{l}\text { Incremental } \\
\text { Wetting Phase } \\
\text { Change (\%) } \\
\end{array}$ & $\begin{array}{l}\text { Saturation } \\
\text { Change } \\
\text { per psia } \\
\end{array}$ \\
\hline 1.64 & 130 & 0.00 & 100.0 & 0.00 & 0.0000 \\
\hline 1.80 & 119 & 0.02 & 100.0 & 0.00 & 0.0000 \\
\hline 1.96 & 109 & 0.02 & 100.0 & 0.00 & 0.0000 \\
\hline 2.15 & 99.2 & 0.02 & 100.0 & 0.00 & 0.0000 \\
\hline 2.35 & 90.8 & 0.02 & 100.0 & 0.00 & 0.0000 \\
\hline 2.57 & 83.0 & 0.04 & 100.0 & 0.00 & 0.0000 \\
\hline 2.81 & 75.9 & 0.04 & 100.0 & 0.00 & 0.0000 \\
\hline 3.08 & 69.3 & 0.04 & 100.0 & 0.00 & 0.0000 \\
\hline 3.37 & 63.3 & 0.04 & 100.0 & 0.00 & 0.0000 \\
\hline 3.68 & 58.0 & 0.06 & 100.0 & 0.00 & 0.0000 \\
\hline 4.03 & 52.9 & 0.06 & 100.0 & 0.00 & 0.0000 \\
\hline 4.41 & 48.4 & 0.06 & 100.0 & 0.00 & 0.0000 \\
\hline 4.82 & 44.3 & 0.06 & 100.0 & 0.00 & 0.0000 \\
\hline 5.27 & 40.5 & 0.06 & 100.0 & 0.00 & 0.0000 \\
\hline 5.77 & 37.0 & 0.06 & 100.0 & 0.00 & 0.0000 \\
\hline 6.31 & 33.8 & 0.06 & 100.0 & 0.00 & 0.0000 \\
\hline 6.90 & 30.9 & 0.06 & 100.0 & 0.00 & 0.0000 \\
\hline 7.55 & 28.3 & 0.06 & 100.0 & 0.00 & 0.0000 \\
\hline 8.26 & 25.8 & 0.08 & 100.0 & 0.00 & 0.0000 \\
\hline 9.04 & 23.6 & 0.08 & 100.0 & 0.00 & 0.0000 \\
\hline 9.89 & 21.6 & 0.08 & 100.0 & 0.00 & 0.0000 \\
\hline 10.8 & 19.8 & 0.08 & 100.0 & 0.00 & 0.0000 \\
\hline 11.8 & 18.1 & 0.08 & 100.0 & 0.00 & 0.0000 \\
\hline 12.9 & 16.5 & 0.08 & 100.0 & 0.00 & 0.0000 \\
\hline 14.2 & 15.0 & 0.08 & 100.0 & 0.00 & 0.0000 \\
\hline 15.5 & 13.8 & 0.10 & 100.0 & 0.00 & 0.0000 \\
\hline 16.9 & 12.6 & 0.10 & 100.0 & 0.00 & 0.0000 \\
\hline 18.5 & 11.5 & 0.10 & 100.0 & 0.00 & 0.0000 \\
\hline 20.3 & 10.5 & 0.12 & 100.0 & 0.00 & 0.0000 \\
\hline 22.2 & 9.61 & 0.12 & 100.0 & 0.00 & 0.0000 \\
\hline 24.3 & 8.78 & 0.12 & 100.0 & 0.00 & 0.0000 \\
\hline 26.6 & 8.02 & 0.14 & 100.0 & 0.00 & 0.0000 \\
\hline 29.0 & 7.36 & 0.16 & 100.0 & 0.00 & 0.0000 \\
\hline 31.8 & 6.71 & 0.16 & 100.0 & 0.00 & 0.0000 \\
\hline 34.8 & 6.13 & 0.18 & 100.0 & 0.00 & 0.0000 \\
\hline 38.0 & 5.61 & 0.18 & 100.0 & 0.00 & 0.0000 \\
\hline
\end{tabular}


Table 15 (cont.). MICP data for sample 07MAW04 - 0.6.

\section{Mercury Injection Capillary Pressure 07MAW04 - 0.6}

\begin{tabular}{|c|c|c|c|c|c|}
\hline $\begin{array}{c}\text { Capillary } \\
\text { Pressure } \\
\text { (psia) } \\
\end{array}$ & $\begin{array}{c}\text { Pore Aperture } \\
\text { Diameter } \\
\text { (microns) }\end{array}$ & $\begin{array}{c}\text { Cumulative } \\
\text { Bulk Vol. (\%) } \\
\end{array}$ & $\begin{array}{l}\text { Wetting Phase } \\
\text { Saturation (\%) }\end{array}$ & $\begin{array}{c}\text { Incremental } \\
\text { Wetting Phase } \\
\text { Change (\%) } \\
\end{array}$ & $\begin{array}{c}\text { Saturation } \\
\text { Change } \\
\text { per psia } \\
\end{array}$ \\
\hline 41.6 & 5.13 & 0.20 & 100.0 & 0.00 & 0.0000 \\
\hline 45.5 & 4.69 & 0.24 & 100.0 & 0.00 & 0.0000 \\
\hline 49.8 & 4.28 & 0.24 & 100.0 & 0.00 & 0.0000 \\
\hline 54.5 & 3.91 & 0.24 & 100.0 & 0.00 & 0.0000 \\
\hline 59.6 & 3.58 & 0.24 & 100.0 & 0.00 & 0.0000 \\
\hline 65.2 & 3.27 & 0.24 & 100.0 & 0.00 & 0.0000 \\
\hline 71.3 & 2.99 & 0.24 & 100.0 & 0.00 & 0.0000 \\
\hline 78.0 & 2.73 & 0.24 & 100.0 & 0.00 & 0.0000 \\
\hline 85.3 & 2.50 & 0.26 & 100.0 & 0.00 & 0.0000 \\
\hline 93.4 & 2.28 & 0.26 & 100.0 & 0.00 & 0.0000 \\
\hline 102 & 2.09 & 0.26 & 100.0 & 0.00 & 0.0000 \\
\hline 112 & 1.90 & 0.26 & 100.0 & 0.00 & 0.0000 \\
\hline 122 & 1.75 & 0.26 & 100.0 & 0.00 & 0.0000 \\
\hline 134 & 1.59 & 0.26 & 100.0 & 0.00 & 0.0000 \\
\hline 146 & 1.46 & 0.28 & 100.0 & 0.00 & 0.0000 \\
\hline 160 & 1.33 & 0.28 & 100.0 & 0.00 & 0.0000 \\
\hline 175 & 1.22 & 0.28 & 100.0 & 0.00 & 0.0000 \\
\hline 191 & 1.12 & 0.29 & 100.0 & 0.00 & 0.0000 \\
\hline 209 & 1.02 & 0.31 & 100.0 & 0.00 & 0.0000 \\
\hline 229 & 0.932 & 0.33 & 100.0 & 0.00 & 0.0000 \\
\hline 251 & 0.850 & 0.33 & 100.0 & 0.00 & 0.0000 \\
\hline 274 & 0.779 & 0.35 & 100.0 & 0.00 & 0.0000 \\
\hline 300 & 0.711 & 0.37 & 100.0 & 0.00 & 0.0000 \\
\hline 328 & 0.650 & 0.37 & 100.0 & 0.00 & 0.0000 \\
\hline 359 & 0.594 & 0.41 & 100.0 & 0.00 & 0.0000 \\
\hline 393 & 0.543 & 0.43 & 100.0 & 0.00 & 0.0000 \\
\hline 430 & 0.496 & 0.47 & 100.0 & 0.00 & 0.0000 \\
\hline 470 & 0.454 & 0.51 & 100.0 & 0.00 & 0.0000 \\
\hline 514 & 0.415 & 0.55 & 100.0 & 0.00 & 0.0000 \\
\hline 563 & 0.379 & 0.63 & 100.0 & 0.00 & 0.0000 \\
\hline 615 & 0.347 & 0.71 & 100.0 & 0.00 & 0.0000 \\
\hline 673 & 0.317 & 0.85 & 100.0 & 0.00 & 0.0000 \\
\hline 736 & 0.290 & 1.08 & 99.1 & 0.89 & 0.0141 \\
\hline 806 & 0.265 & 1.44 & 97.8 & 1.33 & 0.0190 \\
\hline 881 & 0.242 & 2.06 & 95.4 & 2.36 & 0.0315 \\
\hline 964 & 0.221 & 3.83 & 88.8 & 6.65 & 0.0801 \\
\hline 1050 & 0.203 & 5.88 & 81.1 & 7.68 & 0.0893 \\
\hline 1150 & 0.186 & 8.61 & 70.8 & 10.27 & 0.1027 \\
\hline 1260 & 0.169 & 10.52 & 63.7 & 7.16 & 0.0651 \\
\hline 1380 & 0.155 & 12.05 & 57.9 & 5.76 & 0.0480 \\
\hline 1510 & 0.141 & 13.31 & 53.2 & 4.73 & 0.0364 \\
\hline 1650 & 0.129 & 14.35 & 49.3 & 3.91 & 0.0280 \\
\hline
\end{tabular}


Table 15 (cont.). MICP data for sample 07MAW04 - 0.6.

\section{Mercury Injection Capillary Pressure 07MAW04 - 0.6}

\begin{tabular}{|c|c|c|c|c|c|}
\hline $\begin{array}{c}\text { Capillary } \\
\text { Pressure } \\
\text { (psia) } \\
\end{array}$ & $\begin{array}{c}\text { Pore Aperture } \\
\text { Diameter } \\
\text { (microns) } \\
\end{array}$ & $\begin{array}{c}\text { Cumulative } \\
\text { Bulk Vol. (\%) } \\
\end{array}$ & $\begin{array}{l}\text { Wetting Phase } \\
\text { Saturation (\%) }\end{array}$ & $\begin{array}{c}\text { Incremental } \\
\text { Wetting Phase } \\
\text { Change (\%) } \\
\end{array}$ & $\begin{array}{c}\text { Saturation } \\
\text { Change } \\
\text { per psia } \\
\end{array}$ \\
\hline 1810 & 0.1179 & 15.41 & 45.3 & 3.99 & 0.0249 \\
\hline 1980 & 0.1077 & 16.42 & 41.5 & 3.77 & 0.0222 \\
\hline 2160 & 0.0988 & 17.28 & 38.3 & 3.25 & 0.0181 \\
\hline 2370 & 0.0900 & 18.17 & 34.9 & 3.32 & 0.0158 \\
\hline 2590 & 0.0824 & 18.93 & 32.1 & 2.88 & 0.0131 \\
\hline 2830 & 0.0754 & 19.64 & 29.4 & 2.66 & 0.0111 \\
\hline 3100 & 0.0688 & 20.31 & 26.9 & 2.51 & 0.0093 \\
\hline 3390 & 0.0629 & 20.92 & 24.6 & 2.29 & 0.0079 \\
\hline 3710 & 0.0575 & 21.47 & 22.5 & 2.07 & 0.0065 \\
\hline 4060 & 0.0525 & 21.96 & 20.7 & 1.85 & 0.0053 \\
\hline 4440 & 0.0480 & 22.41 & 19.0 & 1.70 & 0.0045 \\
\hline 4850 & 0.0440 & 22.77 & 17.7 & 1.33 & 0.0032 \\
\hline 5310 & 0.0402 & 23.14 & 16.2 & 1.40 & 0.0031 \\
\hline 5810 & 0.0367 & 23.47 & 15.0 & 1.26 & 0.0025 \\
\hline 6360 & 0.0335 & 23.77 & 13.9 & 1.11 & 0.0020 \\
\hline 6950 & 0.0307 & 24.04 & 12.9 & 1.03 & 0.0018 \\
\hline 7610 & 0.0280 & 24.28 & 12.0 & 0.89 & 0.0013 \\
\hline 8320 & 0.0256 & 24.52 & 11.1 & 0.89 & 0.0012 \\
\hline 9100 & 0.0234 & 24.73 & 10.3 & 0.81 & 0.0010 \\
\hline 9960 & 0.0214 & 24.95 & 9.5 & 0.81 & 0.0009 \\
\hline 10900 & 0.0196 & 25.13 & 8.8 & 0.66 & 0.0007 \\
\hline 11900 & 0.0179 & 25.30 & 8.1 & 0.66 & 0.0007 \\
\hline 13000 & 0.0164 & 25.48 & 7.5 & 0.66 & 0.0006 \\
\hline 14300 & 0.0149 & 25.64 & 6.9 & 0.59 & 0.0005 \\
\hline 15600 & 0.0137 & 25.79 & 6.3 & 0.59 & 0.0005 \\
\hline 17100 & 0.0125 & 25.95 & 5.7 & 0.59 & 0.0004 \\
\hline 18700 & 0.0114 & 26.09 & 5.2 & 0.52 & 0.0003 \\
\hline 20400 & 0.0105 & 26.23 & 4.7 & 0.52 & 0.0003 \\
\hline 22300 & 0.0096 & 26.34 & 4.2 & 0.44 & 0.0002 \\
\hline 24400 & 0.0087 & 26.48 & 3.7 & 0.52 & 0.0002 \\
\hline 26700 & 0.0080 & 26.60 & 3.2 & 0.44 & 0.0002 \\
\hline 29300 & 0.0073 & 26.72 & 2.8 & 0.44 & 0.0002 \\
\hline 32000 & 0.0067 & 26.84 & 2.4 & 0.44 & 0.0002 \\
\hline 35000 & 0.0061 & 26.93 & 2.0 & 0.37 & 0.0001 \\
\hline 38300 & 0.0056 & 27.03 & 1.6 & 0.37 & 0.0001 \\
\hline 41900 & 0.0051 & 27.11 & 1.3 & 0.30 & 0.0001 \\
\hline 45800 & 0.0047 & 27.19 & 1.0 & 0.30 & 0.0001 \\
\hline 50100 & 0.0043 & 27.27 & 0.7 & 0.30 & 0.0001 \\
\hline 54800 & 0.0039 & 27.37 & 0.4 & 0.37 & 0.0001 \\
\hline 59500 & 0.0036 & 27.46 & 0.0 & 0.37 & 0.0001 \\
\hline
\end{tabular}


Table 16. MICP data for sample 07MAW04 - 10.3.

\section{Mercury Injection Capillary Pressure 07MAW04 - 10.3}

\begin{tabular}{|c|c|c|c|c|c|}
\hline \\
\hline \multicolumn{3}{|c|}{$\begin{array}{l}\text { Bulk Volume }=5.7984 \mathrm{cc} \\
\text { Pore Volume }=\quad 1.3388 \mathrm{cc} \\
\text { Closure = 1.18 \%BV @ } 673 \text { psia }\end{array}$} & \multicolumn{3}{|c|}{$\begin{array}{lc}\text { Porosity }= & 23.1 \% \text { (merury) } \\
\text { Permeability }= & 0.0808 \mathrm{md} \text { (mercury) } \\
\text { Median Pore Aperture }=0.1095 \text { microns (diameter) }\end{array}$} \\
\hline $\begin{array}{l}\text { Capillary } \\
\text { Pressure } \\
\text { (psia) } \\
\end{array}$ & $\begin{array}{c}\text { Pore Aperture } \\
\text { Diameter } \\
\text { (microns) } \\
\end{array}$ & $\begin{array}{l}\text { Cumulative } \\
\text { Bulk Vol. (\%) } \\
\end{array}$ & $\begin{array}{l}\text { Wetting Phase } \\
\text { Saturation (\%) }\end{array}$ & $\begin{array}{l}\text { Incremental } \\
\text { Wetting Phase } \\
\text { Change (\%) } \\
\end{array}$ & $\begin{array}{l}\text { Saturation } \\
\text { Change } \\
\text { per psia } \\
\end{array}$ \\
\hline 1.64 & 130 & 0.02 & 100.0 & 0.00 & 0.0000 \\
\hline 1.80 & 119 & 0.02 & 100.0 & 0.00 & 0.0000 \\
\hline 1.96 & 109 & 0.04 & 100.0 & 0.00 & 0.0000 \\
\hline 2.15 & 99.2 & 0.06 & 100.0 & 0.00 & 0.0000 \\
\hline 2.35 & 90.8 & 0.08 & 100.0 & 0.00 & 0.0000 \\
\hline 2.57 & 83.0 & 0.10 & 100.0 & 0.00 & 0.0000 \\
\hline 2.81 & 75.9 & 0.10 & 100.0 & 0.00 & 0.0000 \\
\hline 3.08 & 69.3 & 0.12 & 100.0 & 0.00 & 0.0000 \\
\hline 3.37 & 63.3 & 0.12 & 100.0 & 0.00 & 0.0000 \\
\hline 3.68 & 58.0 & 0.14 & 100.0 & 0.00 & 0.0000 \\
\hline 4.03 & 52.9 & 0.16 & 100.0 & 0.00 & 0.0000 \\
\hline 4.41 & 48.4 & 0.16 & 100.0 & 0.00 & 0.0000 \\
\hline 4.82 & 44.3 & 0.18 & 100.0 & 0.00 & 0.0000 \\
\hline 5.27 & 40.5 & 0.18 & 100.0 & 0.00 & 0.0000 \\
\hline 5.77 & 37.0 & 0.20 & 100.0 & 0.00 & 0.0000 \\
\hline 6.31 & 33.8 & 0.20 & 100.0 & 0.00 & 0.0000 \\
\hline 6.90 & 30.9 & 0.22 & 100.0 & 0.00 & 0.0000 \\
\hline 7.55 & 28.3 & 0.24 & 100.0 & 0.00 & 0.0000 \\
\hline 8.26 & 25.8 & 0.24 & 100.0 & 0.00 & 0.0000 \\
\hline 9.04 & 23.6 & 0.24 & 100.0 & 0.00 & 0.0000 \\
\hline 9.89 & 21.6 & 0.26 & 100.0 & 0.00 & 0.0000 \\
\hline 10.8 & 19.8 & 0.28 & 100.0 & 0.00 & 0.0000 \\
\hline 11.8 & 18.1 & 0.28 & 100.0 & 0.00 & 0.0000 \\
\hline 12.9 & 16.5 & 0.31 & 100.0 & 0.00 & 0.0000 \\
\hline 14.2 & 15.0 & 0.31 & 100.0 & 0.00 & 0.0000 \\
\hline 15.5 & 13.8 & 0.33 & 100.0 & 0.00 & 0.0000 \\
\hline 16.9 & 12.6 & 0.35 & 100.0 & 0.00 & 0.0000 \\
\hline 18.5 & 11.5 & 0.35 & 100.0 & 0.00 & 0.0000 \\
\hline 20.3 & 10.5 & 0.37 & 100.0 & 0.00 & 0.0000 \\
\hline 22.2 & 9.61 & 0.37 & 100.0 & 0.00 & 0.0000 \\
\hline 24.3 & 8.78 & 0.39 & 100.0 & 0.00 & 0.0000 \\
\hline 26.6 & 8.02 & 0.41 & 100.0 & 0.00 & 0.0000 \\
\hline 29.0 & 7.36 & 0.43 & 100.0 & 0.00 & 0.0000 \\
\hline 31.8 & 6.71 & 0.45 & 100.0 & 0.00 & 0.0000 \\
\hline 34.8 & 6.13 & 0.47 & 100.0 & 0.00 & 0.0000 \\
\hline 38.0 & 5.61 & 0.49 & 100.0 & 0.00 & 0.0000 \\
\hline
\end{tabular}


Table 16 (cont.). MICP data for sample 07MAW04 - 10.3.

\section{Mercury Injection Capillary Pressure 07MAW04 - 10.3}

\begin{tabular}{|c|c|c|c|c|c|}
\hline $\begin{array}{c}\text { Capillary } \\
\text { Pressure } \\
\text { (psia) } \\
\end{array}$ & $\begin{array}{c}\text { Pore Aperture } \\
\text { Diameter } \\
\text { (microns) } \\
\end{array}$ & $\begin{array}{c}\text { Cumulative } \\
\text { Bulk Vol. (\%) }\end{array}$ & $\begin{array}{l}\text { Wetting Phase } \\
\text { Saturation (\%) }\end{array}$ & $\begin{array}{c}\text { Incremental } \\
\text { Wetting Phase } \\
\text { Change (\%) } \\
\end{array}$ & $\begin{array}{c}\text { Saturation } \\
\text { Change } \\
\text { per psia }\end{array}$ \\
\hline 41.6 & 5.13 & 0.49 & 100.0 & 0.00 & 0.0000 \\
\hline 45.5 & 4.69 & 0.53 & 100.0 & 0.00 & 0.0000 \\
\hline 49.8 & 4.28 & 0.53 & 100.0 & 0.00 & 0.0000 \\
\hline 54.5 & 3.91 & 0.53 & 100.0 & 0.00 & 0.0000 \\
\hline 59.6 & 3.58 & 0.53 & 100.0 & 0.00 & 0.0000 \\
\hline 65.2 & 3.27 & 0.55 & 100.0 & 0.00 & 0.0000 \\
\hline 71.3 & 2.99 & 0.55 & 100.0 & 0.00 & 0.0000 \\
\hline 78.0 & 2.73 & 0.55 & 100.0 & 0.00 & 0.0000 \\
\hline 85.3 & 2.50 & 0.57 & 100.0 & 0.00 & 0.0000 \\
\hline 93.4 & 2.28 & 0.57 & 100.0 & 0.00 & 0.0000 \\
\hline 102 & 2.09 & 0.59 & 100.0 & 0.00 & 0.0000 \\
\hline 112 & 1.90 & 0.59 & 100.0 & 0.00 & 0.0000 \\
\hline 122 & 1.75 & 0.61 & 100.0 & 0.00 & 0.0000 \\
\hline 134 & 1.59 & 0.63 & 100.0 & 0.00 & 0.0000 \\
\hline 146 & 1.46 & 0.63 & 100.0 & 0.00 & 0.0000 \\
\hline 160 & 1.33 & 0.63 & 100.0 & 0.00 & 0.0000 \\
\hline 175 & 1.22 & 0.65 & 100.0 & 0.00 & 0.0000 \\
\hline 191 & 1.12 & 0.65 & 100.0 & 0.00 & 0.0000 \\
\hline 209 & 1.02 & 0.67 & 100.0 & 0.00 & 0.0000 \\
\hline 229 & 0.932 & 0.69 & 100.0 & 0.00 & 0.0000 \\
\hline 251 & 0.850 & 0.71 & 100.0 & 0.00 & 0.0000 \\
\hline 274 & 0.779 & 0.71 & 100.0 & 0.00 & 0.0000 \\
\hline 300 & 0.711 & 0.73 & 100.0 & 0.00 & 0.0000 \\
\hline 328 & 0.650 & 0.75 & 100.0 & 0.00 & 0.0000 \\
\hline 359 & 0.594 & 0.77 & 100.0 & 0.00 & 0.0000 \\
\hline 393 & 0.543 & 0.81 & 100.0 & 0.00 & 0.0000 \\
\hline 430 & 0.496 & 0.85 & 100.0 & 0.00 & 0.0000 \\
\hline 470 & 0.454 & 0.90 & 100.0 & 0.00 & 0.0000 \\
\hline 514 & 0.415 & 0.94 & 100.0 & 0.00 & 0.0000 \\
\hline 563 & 0.379 & 1.00 & 100.0 & 0.00 & 0.0000 \\
\hline 615 & 0.347 & 1.06 & 100.0 & 0.00 & 0.0000 \\
\hline 673 & 0.317 & 1.18 & 100.0 & 0.00 & 0.0000 \\
\hline 736 & 0.290 & 1.32 & 99.4 & 0.62 & 0.0098 \\
\hline 806 & 0.265 & 1.53 & 98.5 & 0.88 & 0.0126 \\
\hline 881 & 0.242 & 1.83 & 97.2 & 1.32 & 0.0176 \\
\hline 964 & 0.221 & 2.36 & 94.9 & 2.29 & 0.0276 \\
\hline 1050 & 0.203 & 2.99 & 92.2 & 2.73 & 0.0318 \\
\hline 1150 & 0.186 & 4.17 & 87.0 & 5.11 & 0.0511 \\
\hline 1260 & 0.169 & 5.92 & 79.5 & 7.58 & 0.0689 \\
\hline 1380 & 0.155 & 7.71 & 71.7 & 7.76 & 0.0647 \\
\hline 1510 & 0.141 & 9.26 & 65.0 & 6.70 & 0.0516 \\
\hline 1650 & 0.129 & 10.64 & 59.0 & 6.00 & 0.0428 \\
\hline
\end{tabular}


Table 16 (cont.). MICP data for sample 07MAW04 - 10.3.

\section{Mercury Injection Capillary Pressure 07MAW04 - 10.3}

\begin{tabular}{|c|c|c|c|c|c|}
\hline $\begin{array}{c}\text { Capillary } \\
\text { Pressure } \\
\text { (psia) } \\
\end{array}$ & $\begin{array}{c}\text { Pore Aperture } \\
\text { Diameter } \\
\text { (microns) } \\
\end{array}$ & $\begin{array}{c}\text { Cumulative } \\
\text { Bulk Vol. (\%) } \\
\end{array}$ & $\begin{array}{l}\text { Wetting Phase } \\
\text { Saturation (\%) }\end{array}$ & $\begin{array}{c}\text { Incremental } \\
\text { Wetting Phase } \\
\text { Change (\%) } \\
\end{array}$ & $\begin{array}{c}\text { Saturation } \\
\text { Change } \\
\text { per psia } \\
\end{array}$ \\
\hline 1810 & 0.1179 & 11.84 & 53.8 & 5.20 & 0.0325 \\
\hline 1980 & 0.1077 & 12.90 & 49.2 & 4.59 & 0.0270 \\
\hline 2160 & 0.0988 & 13.81 & 45.2 & 3.97 & 0.0220 \\
\hline 2370 & 0.0900 & 14.69 & 41.4 & 3.79 & 0.0181 \\
\hline 2590 & 0.0824 & 15.42 & 38.3 & 3.17 & 0.0144 \\
\hline 2830 & 0.0754 & 16.09 & 35.4 & 2.91 & 0.0121 \\
\hline 3100 & 0.0688 & 16.70 & 32.7 & 2.65 & 0.0098 \\
\hline 3390 & 0.0629 & 17.23 & 30.4 & 2.29 & 0.0079 \\
\hline 3710 & 0.0575 & 17.72 & 28.3 & 2.12 & 0.0066 \\
\hline 4060 & 0.0525 & 18.17 & 26.4 & 1.94 & 0.0055 \\
\hline 4440 & 0.0480 & 18.57 & 24.6 & 1.76 & 0.0046 \\
\hline 4850 & 0.0440 & 18.92 & 23.1 & 1.50 & 0.0037 \\
\hline 5310 & 0.0402 & 19.27 & 21.6 & 1.50 & 0.0033 \\
\hline 5810 & 0.0367 & 19.59 & 20.2 & 1.41 & 0.0028 \\
\hline 6360 & 0.0335 & 19.90 & 18.9 & 1.32 & 0.0024 \\
\hline 6950 & 0.0307 & 20.18 & 17.6 & 1.23 & 0.0021 \\
\hline 7610 & 0.0280 & 20.45 & 16.5 & 1.15 & 0.0017 \\
\hline 8320 & 0.0256 & 20.71 & 15.3 & 1.15 & 0.0016 \\
\hline 9100 & 0.0234 & 20.95 & 14.3 & 1.06 & 0.0014 \\
\hline 9960 & 0.0214 & 21.18 & 13.3 & 0.97 & 0.0011 \\
\hline 10900 & 0.0196 & 21.40 & 12.3 & 0.97 & 0.0010 \\
\hline 11900 & 0.0179 & 21.60 & 11.5 & 0.88 & 0.0009 \\
\hline 13000 & 0.0164 & 21.81 & 10.6 & 0.88 & 0.0008 \\
\hline 14300 & 0.0149 & 22.01 & 9.7 & 0.88 & 0.0007 \\
\hline 15600 & 0.0137 & 22.17 & 9.0 & 0.71 & 0.0005 \\
\hline 17100 & 0.0125 & 22.36 & 8.2 & 0.79 & 0.0005 \\
\hline 18700 & 0.0114 & 22.52 & 7.5 & 0.71 & 0.0004 \\
\hline 20400 & 0.0105 & 22.68 & 6.8 & 0.71 & 0.0004 \\
\hline 22300 & 0.0096 & 22.85 & 6.1 & 0.71 & 0.0004 \\
\hline 24400 & 0.0087 & 22.99 & 5.5 & 0.62 & 0.0003 \\
\hline 26700 & 0.0080 & 23.13 & 4.9 & 0.62 & 0.0003 \\
\hline 29300 & 0.0073 & 23.29 & 4.1 & 0.71 & 0.0003 \\
\hline 32000 & 0.0067 & 23.42 & 3.6 & 0.53 & 0.0002 \\
\hline 35000 & 0.0061 & 23.54 & 3.1 & 0.53 & 0.0002 \\
\hline 38300 & 0.0056 & 23.66 & 2.6 & 0.53 & 0.0002 \\
\hline 41900 & 0.0051 & 23.78 & 2.0 & 0.53 & 0.0001 \\
\hline 45800 & 0.0047 & 23.88 & 1.6 & 0.44 & 0.0001 \\
\hline 50100 & 0.0043 & 23.99 & 1.1 & 0.44 & 0.0001 \\
\hline 54800 & 0.0039 & 24.13 & 0.5 & 0.62 & 0.0001 \\
\hline 59500 & 0.0036 & 24.25 & 0.0 & 0.53 & 0.0001 \\
\hline
\end{tabular}


Table 17. MICP data for sample ST4 - 20.

\section{Mercury Injection Capillary Pressure ST4 - 20}

\begin{tabular}{|c|c|c|c|c|c|}
\hline \multicolumn{3}{|c|}{ Sample Information } & \multirow{2}{*}{\multicolumn{3}{|c|}{$\begin{array}{ll}\text { Porosity }= & 35.7 \% \text { (mercury) } \\
\text { Permeability }= & 0.215 \text { md (mercury) } \\
\text { Median Pore Aperture }=0.1308 \text { microns (diameter) }\end{array}$}} \\
\hline $\begin{array}{l}\text { Bulk Volume }= \\
\text { Pore Volume } \\
\text { Closure }=1.01\end{array}$ & $\begin{array}{r}5.3015 \mathrm{cc} \\
1.8914 \mathrm{cc} \\
\text { oBV @ } 470 \text { psia }\end{array}$ & & & & \\
\hline $\begin{array}{l}\text { Capillary } \\
\text { Pressure } \\
\text { (psia) }\end{array}$ & $\begin{array}{l}\text { Pore Aperture } \\
\text { Diameter } \\
\text { (microns) } \\
\end{array}$ & $\begin{array}{c}\text { Cumulative } \\
\text { Bulk Vol. (\%) } \\
\end{array}$ & $\begin{array}{l}\text { Wetting Phase } \\
\text { Saturation (\%) }\end{array}$ & $\begin{array}{l}\text { Incremental } \\
\text { Wetting Phase } \\
\text { Change (\%) } \\
\end{array}$ & $\begin{array}{l}\text { Saturation } \\
\text { Change } \\
\text { per psia } \\
\end{array}$ \\
\hline 1.64 & 130 & 0.02 & 100.0 & 0.00 & 0.0000 \\
\hline 1.80 & 119 & 0.02 & 100.0 & 0.00 & 0.0000 \\
\hline 1.96 & 109 & 0.03 & 100.0 & 0.00 & 0.0000 \\
\hline 2.15 & 99.2 & 0.03 & 100.0 & 0.00 & 0.0000 \\
\hline 2.35 & 90.8 & 0.05 & 100.0 & 0.00 & 0.0000 \\
\hline 2.57 & 83.0 & 0.05 & 100.0 & 0.00 & 0.0000 \\
\hline 2.81 & 75.9 & 0.05 & 100.0 & 0.00 & 0.0000 \\
\hline 3.08 & 69.3 & 0.07 & 100.0 & 0.00 & 0.0000 \\
\hline 3.37 & 63.3 & 0.07 & 100.0 & 0.00 & 0.0000 \\
\hline 3.68 & 58.0 & 0.07 & 100.0 & 0.00 & 0.0000 \\
\hline 4.03 & 52.9 & 0.09 & 100.0 & 0.00 & 0.0000 \\
\hline 4.41 & 48.4 & 0.09 & 100.0 & 0.00 & 0.0000 \\
\hline 4.82 & 44.3 & 0.09 & 100.0 & 0.00 & 0.0000 \\
\hline 5.27 & 40.5 & 0.09 & 100.0 & 0.00 & 0.0000 \\
\hline 5.77 & 37.0 & 0.09 & 100.0 & 0.00 & 0.0000 \\
\hline 6.31 & 33.8 & 0.09 & 100.0 & 0.00 & 0.0000 \\
\hline 6.90 & 30.9 & 0.09 & 100.0 & 0.00 & 0.0000 \\
\hline 7.55 & 28.3 & 0.09 & 100.0 & 0.00 & 0.0000 \\
\hline 8.26 & 25.8 & 0.09 & 100.0 & 0.00 & 0.0000 \\
\hline 9.04 & 23.6 & 0.09 & 100.0 & 0.00 & 0.0000 \\
\hline 9.89 & 21.6 & 0.09 & 100.0 & 0.00 & 0.0000 \\
\hline 10.8 & 19.8 & 0.09 & 100.0 & 0.00 & 0.0000 \\
\hline 11.8 & 18.1 & 0.09 & 100.0 & 0.00 & 0.0000 \\
\hline 12.9 & 16.5 & 0.09 & 100.0 & 0.00 & 0.0000 \\
\hline 14.2 & 15.0 & 0.09 & 100.0 & 0.00 & 0.0000 \\
\hline 15.5 & 13.8 & 0.09 & 100.0 & 0.00 & 0.0000 \\
\hline 16.9 & 12.6 & 0.09 & 100.0 & 0.00 & 0.0000 \\
\hline 18.5 & 11.5 & 0.09 & 100.0 & 0.00 & 0.0000 \\
\hline 20.3 & 10.5 & 0.09 & 100.0 & 0.00 & 0.0000 \\
\hline 22.2 & 9.61 & 0.20 & 100.0 & 0.00 & 0.0000 \\
\hline 24.3 & 8.78 & 0.20 & 100.0 & 0.00 & 0.0000 \\
\hline 26.6 & 8.02 & 0.22 & 100.0 & 0.00 & 0.0000 \\
\hline 29.0 & 7.36 & 0.22 & 100.0 & 0.00 & 0.0000 \\
\hline 31.8 & 6.71 & 0.24 & 100.0 & 0.00 & 0.0000 \\
\hline 34.8 & 6.13 & 0.26 & 100.0 & 0.00 & 0.0000 \\
\hline 38.0 & 5.61 & 0.26 & 100.0 & 0.00 & 0.0000 \\
\hline
\end{tabular}


Table 17 (cont.). MICP data for sample ST4 - 20.

\section{Mercury Injection Capillary Pressure ST4 - 20}

\begin{tabular}{|c|c|c|c|c|c|}
\hline $\begin{array}{l}\text { Capillary } \\
\text { Pressure } \\
\text { (psia) }\end{array}$ & $\begin{array}{l}\text { Pore Aperture } \\
\text { Diameter } \\
\text { (microns) }\end{array}$ & $\begin{array}{c}\text { Cumulative } \\
\text { Bulk Vol. (\%) }\end{array}$ & $\begin{array}{l}\text { Wetting Phase } \\
\text { Saturation (\%) }\end{array}$ & $\begin{array}{c}\text { Incremental } \\
\text { Wetting Phase } \\
\text { Change (\%) }\end{array}$ & $\begin{array}{c}\text { Saturation } \\
\text { Change } \\
\text { per psia }\end{array}$ \\
\hline 41.6 & 5.13 & 0.27 & 100.0 & 0.00 & 0.0000 \\
\hline 45.5 & 4.69 & 0.29 & 100.0 & 0.00 & 0.0000 \\
\hline 49.8 & 4.28 & 0.29 & 100.0 & 0.00 & 0.0000 \\
\hline 54.5 & 3.91 & 0.29 & 100.0 & 0.00 & 0.0000 \\
\hline 59.6 & 3.58 & 0.29 & 100.0 & 0.00 & 0.0000 \\
\hline 65.2 & 3.27 & 0.29 & 100.0 & 0.00 & 0.0000 \\
\hline 71.3 & 2.99 & 0.29 & 100.0 & 0.00 & 0.0000 \\
\hline 78.0 & 2.73 & 0.31 & 100.0 & 0.00 & 0.0000 \\
\hline 85.3 & 2.50 & 0.31 & 100.0 & 0.00 & 0.0000 \\
\hline 93.4 & 2.28 & 0.31 & 100.0 & 0.00 & 0.0000 \\
\hline 102 & 2.09 & 0.31 & 100.0 & 0.00 & 0.0000 \\
\hline 112 & 1.90 & 0.31 & 100.0 & 0.00 & 0.0000 \\
\hline 122 & 1.75 & 0.32 & 100.0 & 0.00 & 0.0000 \\
\hline 134 & 1.59 & 0.32 & 100.0 & 0.00 & 0.0000 \\
\hline 146 & 1.46 & 0.34 & 100.0 & 0.00 & 0.0000 \\
\hline 160 & 1.33 & 0.36 & 100.0 & 0.00 & 0.0000 \\
\hline 175 & 1.22 & 0.38 & 100.0 & 0.00 & 0.0000 \\
\hline 191 & 1.12 & 0.43 & 100.0 & 0.00 & 0.0000 \\
\hline 209 & 1.02 & 0.44 & 100.0 & 0.00 & 0.0000 \\
\hline 229 & 0.932 & 0.48 & 100.0 & 0.00 & 0.0000 \\
\hline 251 & 0.850 & 0.49 & 100.0 & 0.00 & 0.0000 \\
\hline 274 & 0.779 & 0.53 & 100.0 & 0.00 & 0.0000 \\
\hline 300 & 0.711 & 0.58 & 100.0 & 0.00 & 0.0000 \\
\hline 328 & 0.650 & 0.63 & 100.0 & 0.00 & 0.0000 \\
\hline 359 & 0.594 & 0.68 & 100.0 & 0.00 & 0.0000 \\
\hline 393 & 0.543 & 0.77 & 100.0 & 0.00 & 0.0000 \\
\hline 430 & 0.496 & 0.87 & 100.0 & 0.00 & 0.0000 \\
\hline 470 & 0.454 & 1.01 & 100.0 & 0.00 & 0.0000 \\
\hline 514 & 0.415 & 1.19 & 99.5 & 0.53 & 0.0120 \\
\hline 563 & 0.379 & 1.50 & 98.6 & 0.86 & 0.0176 \\
\hline 615 & 0.347 & 1.88 & 97.6 & 1.05 & 0.0202 \\
\hline 673 & 0.317 & 2.28 & 96.4 & 1.15 & 0.0198 \\
\hline 736 & 0.290 & 2.90 & 94.7 & 1.72 & 0.0273 \\
\hline 806 & 0.265 & 3.31 & 93.5 & 1.15 & 0.0164 \\
\hline 881 & 0.242 & 3.99 & 91.6 & 1.91 & 0.0255 \\
\hline 964 & 0.221 & 4.84 & 89.2 & 2.39 & 0.0288 \\
\hline 1050 & 0.203 & 5.88 & 86.3 & 2.92 & 0.0339 \\
\hline 1150 & 0.186 & 7.47 & 81.9 & 4.45 & 0.0445 \\
\hline 1260 & 0.169 & 10.11 & 74.5 & 7.41 & 0.0674 \\
\hline 1380 & 0.155 & 13.19 & 65.8 & 8.66 & 0.0721 \\
\hline 1510 & 0.141 & 17.03 & 55.0 & 10.76 & 0.0828 \\
\hline 1650 & 0.129 & 19.16 & 49.1 & 5.98 & 0.0427 \\
\hline
\end{tabular}


Table 17 (cont.). MICP data for sample ST4 - 20.

\section{Mercury Injection Capillary Pressure ST4 - 20}

\begin{tabular}{|c|c|c|c|c|c|}
\hline $\begin{array}{c}\text { Capillary } \\
\text { Pressure } \\
\text { (psia) } \\
\end{array}$ & $\begin{array}{l}\text { Pore Aperture } \\
\text { Diameter } \\
\text { (microns) }\end{array}$ & $\begin{array}{c}\text { Cumulative } \\
\text { Bulk Vol. (\%) }\end{array}$ & $\begin{array}{l}\text { Wetting Phase } \\
\text { Saturation (\%) }\end{array}$ & $\begin{array}{c}\text { Incremental } \\
\text { Wetting Phase } \\
\text { Change (\%) }\end{array}$ & $\begin{array}{c}\text { Saturation } \\
\text { Change } \\
\text { per psia } \\
\end{array}$ \\
\hline 1810 & 0.1179 & 21.10 & 43.6 & 5.45 & 0.0341 \\
\hline 1980 & 0.1077 & 22.74 & 39.0 & 4.59 & 0.0270 \\
\hline 2160 & 0.0988 & 24.07 & 35.3 & 3.73 & 0.0207 \\
\hline 2370 & 0.0900 & 25.28 & 31.9 & 3.40 & 0.0162 \\
\hline 2590 & 0.0824 & 26.32 & 29.0 & 2.92 & 0.0133 \\
\hline 2830 & 0.0754 & 27.24 & 26.4 & 2.58 & 0.0108 \\
\hline 3100 & 0.0688 & 28.11 & 24.0 & 2.44 & 0.0090 \\
\hline 3390 & 0.0629 & 28.84 & 21.9 & 2.06 & 0.0071 \\
\hline 3710 & 0.0575 & 29.52 & 20.0 & 1.91 & 0.0060 \\
\hline 4060 & 0.0525 & 30.12 & 18.3 & 1.67 & 0.0048 \\
\hline 4440 & 0.0480 & 30.65 & 16.8 & 1.48 & 0.0039 \\
\hline 4850 & 0.0440 & 31.08 & 15.6 & 1.20 & 0.0029 \\
\hline 5310 & 0.0402 & 31.50 & 14.4 & 1.20 & 0.0026 \\
\hline 5810 & 0.0367 & 31.88 & 13.4 & 1.05 & 0.0021 \\
\hline 6360 & 0.0335 & 32.20 & 12.5 & 0.91 & 0.0017 \\
\hline 6950 & 0.0307 & 32.51 & 11.6 & 0.86 & 0.0015 \\
\hline 7610 & 0.0280 & 32.78 & 10.9 & 0.77 & 0.0012 \\
\hline 8320 & 0.0256 & 33.02 & 10.2 & 0.67 & 0.0009 \\
\hline 9100 & 0.0234 & 33.24 & 9.6 & 0.62 & 0.0008 \\
\hline 9960 & 0.0214 & 33.44 & 9.0 & 0.57 & 0.0007 \\
\hline 10900 & 0.0196 & 33.65 & 8.4 & 0.57 & 0.0006 \\
\hline 11900 & 0.0179 & 33.84 & 7.9 & 0.53 & 0.0005 \\
\hline 13000 & 0.0164 & 34.02 & 7.4 & 0.53 & 0.0005 \\
\hline 14300 & 0.0149 & 34.21 & 6.8 & 0.53 & 0.0004 \\
\hline 15600 & 0.0137 & 34.38 & 6.4 & 0.48 & 0.0004 \\
\hline 17100 & 0.0125 & 34.55 & 5.9 & 0.48 & 0.0003 \\
\hline 18700 & 0.0114 & 34.72 & 5.4 & 0.48 & 0.0003 \\
\hline 20400 & 0.0105 & 34.88 & 5.0 & 0.43 & 0.0003 \\
\hline 22300 & 0.0096 & 35.03 & 4.5 & 0.43 & 0.0002 \\
\hline 24400 & 0.0087 & 35.20 & 4.1 & 0.48 & 0.0002 \\
\hline 26700 & 0.0080 & 35.35 & 3.6 & 0.43 & 0.0002 \\
\hline 29300 & 0.0073 & 35.51 & 3.2 & 0.43 & 0.0002 \\
\hline 32000 & 0.0067 & 35.64 & 2.8 & 0.38 & 0.0001 \\
\hline 35000 & 0.0061 & 35.80 & 2.4 & 0.43 & 0.0001 \\
\hline 38300 & 0.0056 & 35.93 & 2.0 & 0.38 & 0.0001 \\
\hline 41900 & 0.0051 & 36.05 & 1.7 & 0.33 & 0.0001 \\
\hline 45800 & 0.0047 & 36.19 & 1.3 & 0.38 & 0.0001 \\
\hline 50100 & 0.0043 & 36.34 & 0.9 & 0.43 & 0.0001 \\
\hline 54800 & 0.0039 & 36.51 & 0.4 & 0.48 & 0.0001 \\
\hline 59500 & 0.0036 & 36.65 & 0.0 & 0.38 & 0.0001 \\
\hline
\end{tabular}

